(1)

9) .

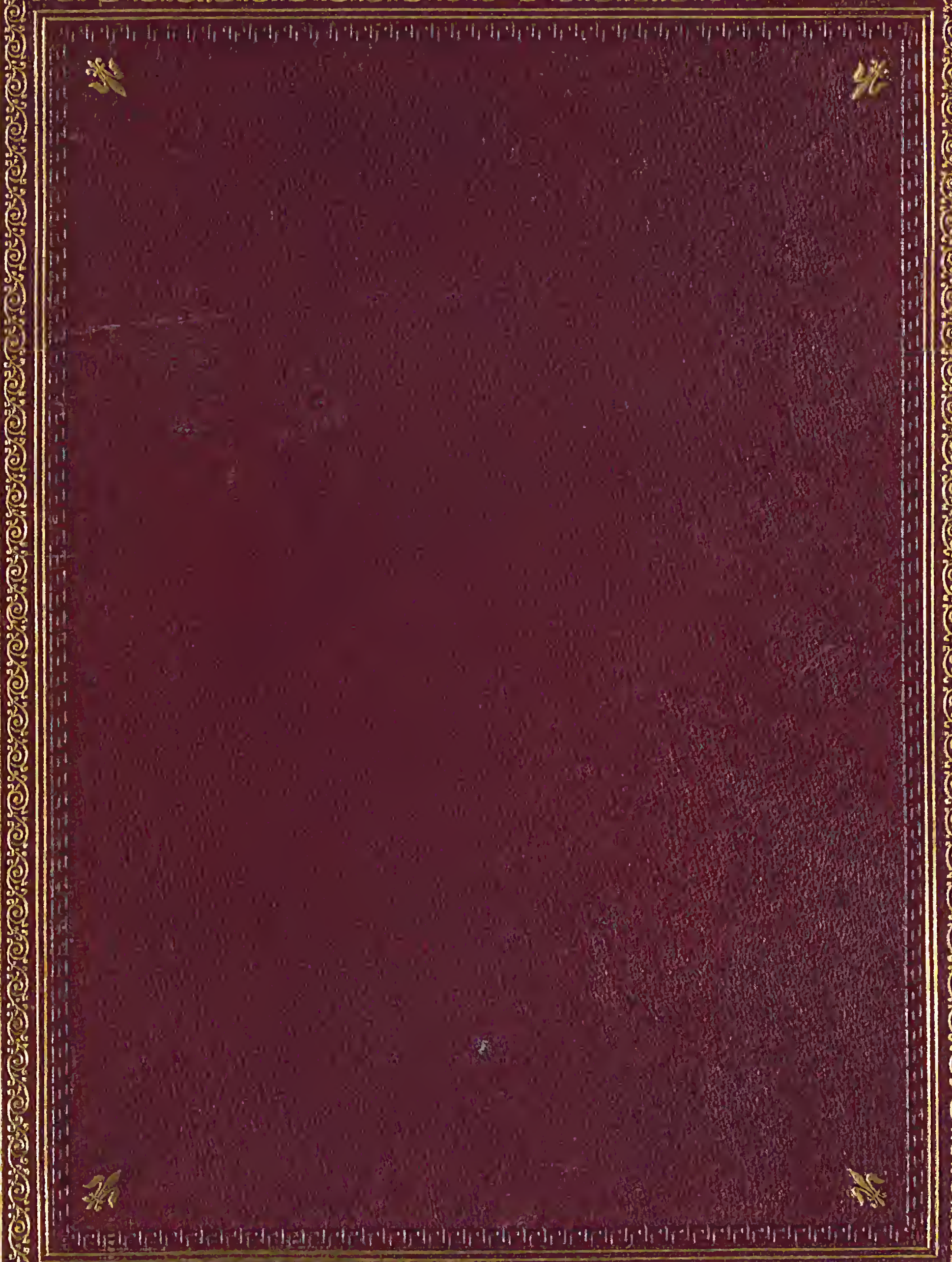





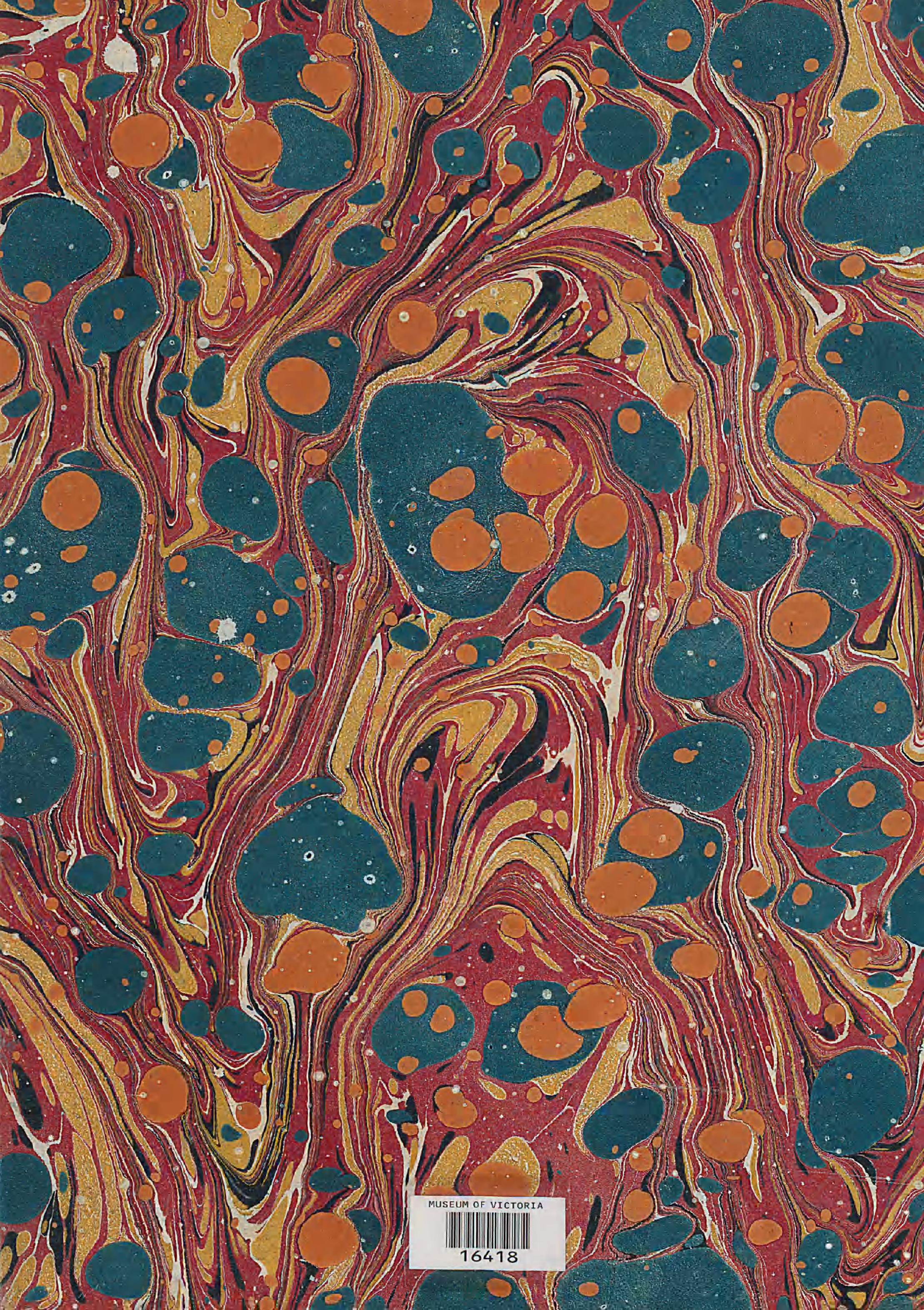


<smiles>C1#CCCC1</smiles> 


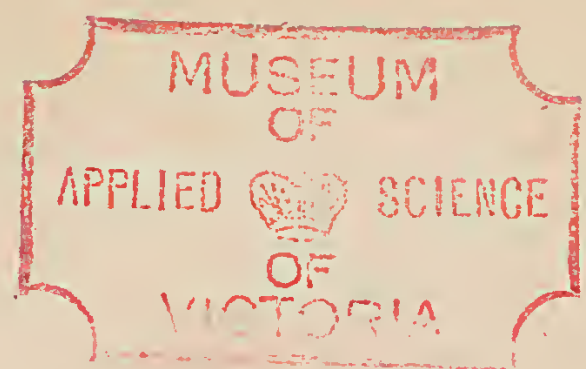





\title{
PLANTS
}

INDIGENOUS TO

\section{THE COLONY OF VICTORIA,}

DESCRIBED BY

\section{FERDINAND MUELLER, PH.D., M.D., F.R.S., F.L.S., F.R.G.S.,}

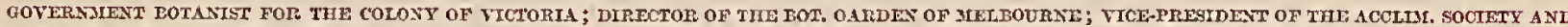

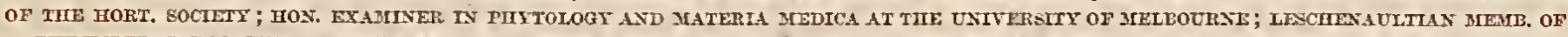

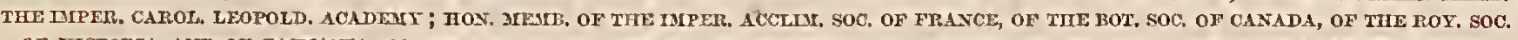

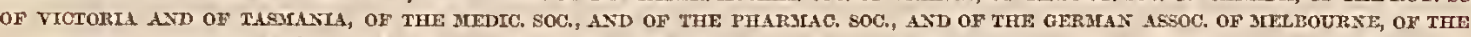
PALITCHAS NATURALISTS' SOC, OF' THE PALATLNATE, OF THE HERCXNIAN AND OF TIE HAJWURGLAN SOC. OF AATURALISIS, OE THE HORT.

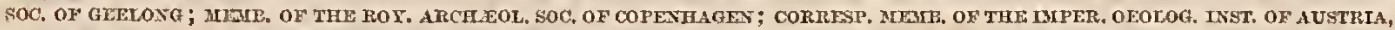

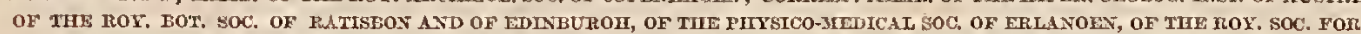
(10TS NATURALISTS' SOC. OF IIALLE, OF TIIE TrORT. SOC. OF PETERSBURO, AND OF SEVERAL OTIER SCIENTITIC UNIONS.
\end{abstract}

VOL. I.

THALAMI F L ORA.

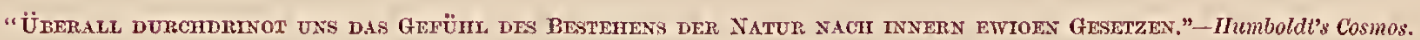

BY AUTHORITY : JOHN FERLES, GOVERNIIEN'T PRINTER, MELBOURNE.

F. F, BAILLIERE, 85, COLLINS-STREET EAST, MELBOURNE ;

I. BAILLIERE, LONDON ; BAILLIERE BROTHERS, NEW YORK; J. B. BAILLIERE, PARIS; BAILLEY BAILLIERE, MADRID.

$1860-1862$. 



\author{
AS A TRIBUTE \\ OF THE AUTHOR'S HIGH REGARD AND GRATITUDE, \\ THESE PAGES ARE DEDICATED
}

To

CHARLES JOSEPH LA TROBE, ESQ., C.B., TO WHOM, AS FORMER LILUTEYANT-GOVERNOR OF VICTORIA, THIS WORK OWES ITS ORIGIN;

To

SIR WILLIAM JACKSON HOOKER, K.H.,

THE NESTOR OF BOTANISTS, WHO, FOR ABOVE HALF A CENTURY, HAS BEEN A LWADTNG STAR IY PHYTOLOGICAL ENQUIRY;

AND TO

SIR 'HENRY BARKLY, K.C.B., GOYEBYOR OF VICTORIA,

UNDER WHOSE UNCEASING EXCOURAGEMIENT THESE VOLUDIES ARE ADVANCING TO COMPLETION. 



\section{SYSTEMATIC INDEX}

OF THE CLASSES, ORDERS, GENERA AND SPECIES DESCRIBED.

\begin{tabular}{|c|c|c|c|c|}
\hline \multicolumn{2}{|l|}{ PoLYCARPOUS THALAMIFLORE } & $\ldots$ & $\ldots$ & $\begin{array}{c}\text { Page } \\
1\end{array}$ \\
\hline Ranunculacere, Juss. & $\ldots$ & $\ldots$ & $\ldots$ & 2 \\
\hline Clematis, $L . \quad \ldots \quad \quad \ldots$ & $\ldots$ & $\ldots$ & $\ldots$ & 3 \\
\hline aristata, R. Br. ... & $\ldots$ & $\ldots$ & $\ldots$ & $i b$. \\
\hline microphylla, Cand. & $\ldots$ & $\ldots$ & $\ldots$ & 4 \\
\hline Myosurus, Dillen. $\quad$... & $\ldots$ & $\ldots$ & $\ldots$ & $i b$. \\
\hline minimus, $\mathrm{L}, \quad \ldots$ & $\ldots$ & $-\ldots$ & $\ldots$ & $i b$. \\
\hline Ranunculus, C. Bauh. ... & $\ldots$ & $\ldots$ & $\ldots$ & 5 \\
\hline aquatilis, $\mathrm{L} . \quad \ldots$ & $\ldots$ & $\ldots$ & $\ldots$ & $i b$. \\
\hline Millani, F. M. ... & $\ldots$ & $\ldots$ & $\ldots$ & 6 \\
\hline anemoneus, F. M. & $\ldots$ & $\ldots$ & $\ldots$ & 7 \\
\hline lappaccus, Smith & $\ldots$ & $\ldots$ & ... & $i b$. \\
\hline rivularis, B. \& S. & $\ldots$ & $\ldots$ & $\ldots$ & 8 \\
\hline parriflorus, L. ... & $\ldots$ & ... & $\ldots$ & 9 \\
\hline Gunnianús, Hook. & $\ldots$ & $\ldots$ & $\ldots$ & $i b$. \\
\hline Caltha, L.... $\quad \ldots . \quad \ldots$ & $\ldots$ & $\ldots$ & $\ldots$ & 10 \\
\hline introloba, F. M. ... & $\cdots$ & $\ldots$ & $\ldots$ & 10,217 \\
\hline Cabombea, Rich. & $\cdots$ & ... & .. & 11 \\
\hline Brasenia, Schreber $\quad$... & $\ldots$ & $\ldots$ & $\ldots$ & 12 \\
\hline peltata, Pursh. ... & $\cdots$ & $\ldots$ & $\ldots$ & 12,217 \\
\hline Dilleniacen, Cand. & $\ldots$ & $\ldots$ & $\ldots$ & 13 \\
\hline Hibbertia, Andr. $\quad$... & $\ldots$ & ... & $\ldots$ & ' $i b$. \\
\hline Billardierii, F. MI. & $\ldots$ & $\ldots$ & $\cdots$ & 17,217 \\
\hline densiflora, F. M. & $\ldots$ & $\ldots$ & $\ldots$ & 15 \\
\hline stricta, R. Br. $\quad \ldots$ & $\ldots$ & $\ldots$ & $\ldots$ & $i b$. \\
\hline humifusa, F. M. ... & $\ldots$ & $\ldots$ & $\ldots$ & 16 \\
\hline acicularis, F. M. & $\ldots$ & $\ldots$ & $\ldots$ & 17 \\
\hline ericifolia, J. Hook. & $\ldots$ & $\ldots$ & $\cdots$ & $i b$. \\
\hline diffusa, $\mathrm{R} . \mathrm{Br} . \quad \ldots$ & $\ldots$ & $\ldots$ & $\ldots$ & 18 \\
\hline angustifolia, Salisb. & $\ldots$ & $\ldots$ & $\ldots$ & $i b$. \\
\hline dentata, R. Br. ... & $\ldots$ & $\ldots$ & $\ldots$ & 217 \\
\hline Magnoliacea, Juss. & $\ldots$ & $\ldots$ & ... & 19 \\
\hline Drimys, Forst. ... ... & $\ldots$ & $\ldots$ & $\ldots$ & 20 \\
\hline aromatica, F. M. & & $\ldots$ & $\ldots$ & 20,218 \\
\hline Anonacee, Juss. ... & $\ldots$ & $\ldots$ & $\ldots$ & 218 \\
\hline Eupomatia, R. Br. & $\ldots$ & $\ldots$ & $\ldots$ & 219 \\
\hline laurina, R.Br. ... & $\ldots$ & $\ldots$ & $\therefore$ & $i b$. \\
\hline
\end{tabular}

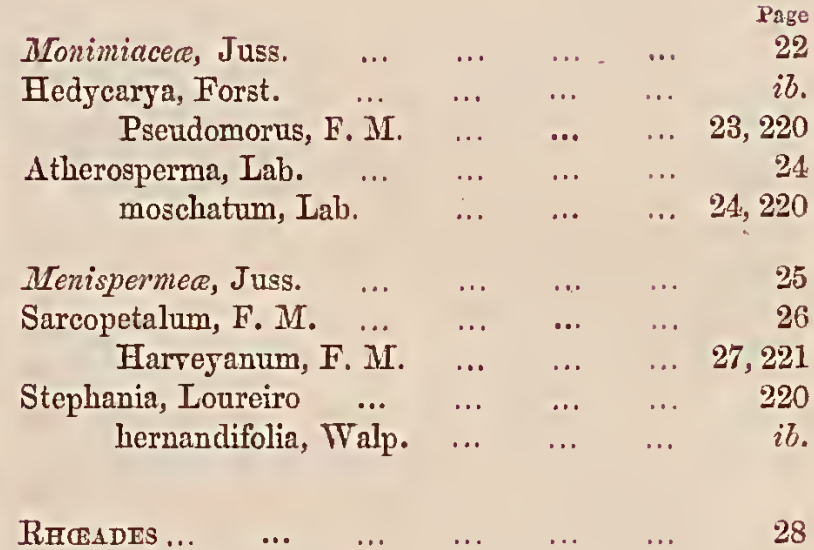

$\begin{array}{llllll}\text { Papaveracer, Venten. ... } & \ldots & \ldots & \ldots & \ldots & i b .\end{array}$

$\begin{array}{llllll}\text { Paparer, Tournef. } & \ldots & \ldots & \ldots & \ldots & 29\end{array}$ horridum, Cand... $\quad \ldots \quad \ldots \quad \ldots . \quad i b$.

$\begin{array}{llllll}\text { Crucifere, Adanson } & \ldots & \ldots & \ldots & \ldots & 30\end{array}$

$\begin{array}{llllll}\text { Nasturtium, R. Br. } & \ldots & \ldots & \ldots & \ldots & i b .\end{array}$ $\begin{array}{llllll}\text { terrestre, } \mathrm{R} . \mathrm{Br}, \ldots & \ldots & \ldots & \ldots & \\ & \ldots & \ldots & \ldots & 31\end{array}$

$\begin{array}{llllll}\text { Barbarea, R. Br. } & \ldots & \ldots & \ldots & \ldots & 32\end{array}$ $\begin{array}{llllll}\text { vulgaris, } \mathrm{R} . \mathrm{Br} . & \ldots & \ldots & \ldots & \ldots & \\ & \ldots & \ldots & \ldots & \ldots & i 6 .\end{array}$

$\begin{array}{llllll}\text { Turritis, Dillen. } & \ldots & \ldots & \ldots & \ldots & 33\end{array}$ $\begin{array}{llllll}\text { glabra, } \mathrm{L} . \quad \ldots & \ldots & \ldots & \ldots & 33,221\end{array}$

$\begin{array}{rrrrr}\text { Cardamine, Tournef. } \quad \ldots & \ldots & \ldots & \ldots & 34\end{array}$

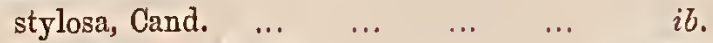
dictyosperma, Hook. $\ldots . \quad \ldots \quad \ldots \quad 35,221$ laciniata, F. M. ... $\quad \ldots \quad$.. $\quad \ldots \quad$.. 35 $\begin{array}{llllll}\text { parviflora, } L . & \ldots & \ldots & \ldots & \ldots & 36\end{array}$ $\begin{array}{llllll}\text { eustylis, F. M. } & \ldots & \ldots & \ldots & \ldots & 37\end{array}$

$\begin{array}{lllllll}\text { Sisymbrium, } L . & \ldots & \ldots & \ldots & \ldots & \ldots & 38\end{array}$ nasturtioides, F. M. $\quad \ldots \quad \ldots \quad \ldots \quad \ldots$ $\begin{array}{lllll}\text { trisectum, F. M.... } & \ldots & \ldots & \ldots & i b .\end{array}$

$\begin{array}{llllll}\text { Blennodia, } \mathrm{R} . \mathrm{Br} . & \ldots & \ldots & \ldots & \ldots & 40\end{array}$ $\begin{array}{lllll}\text { lasiocarpa, F. M. } & \ldots & \ldots & \ldots & i b .\end{array}$ brevipes, F. II. ... … … … 41 curvipes, F.MI. $\quad \ldots \quad$... $\quad \ldots \quad$... 42

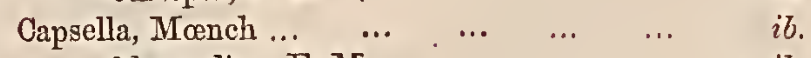
blennodina, F. M. $\quad \ldots \quad$.. $\quad \ldots \quad$ ib. elliptica, C. A. Meyer ... $\quad \ldots \quad \ldots \quad \quad \ldots 3$ 
Capsella antipoda, F. M. pilosula, F. M.

Menkea, Lehım. .. procumbens, $F \cdot \ddot{M}$.

Lepidium, R. Br. zuderale, $\mathrm{I}$ papillosnm, F. M. monoplocoides, F. M. phlebopetalnm, F. M. leptopetalum, F. M.

Stenopetalum, R. Br. lineare, R. Br. ... velntinum, F. M. sphærocarpum, F. M.

Capparidea, Jnss.

Busbeckea, Endl. Mitehellii, F. M...

$\begin{array}{lllr} & & & \text { Page } \\ \ldots & \ldots & \ldots & 44,222 \\ \ldots & \ldots & \ldots & 44 \\ \ldots & \ldots & \ldots & 222 \\ \ldots & \ldots & \ldots & i b . \\ \ldots & \ldots & \ldots & 45 \\ \ldots & \ldots & \ldots & 45,222 \\ \ldots & \ldots & \ldots & 46,222 \\ \ldots & \ldots & \ldots & 47,222 \\ \ldots & \ldots & \ldots & 47 \\ \ldots & \ldots & \ldots & 48,222 \\ \ldots & \ldots & \ldots & 48 \\ \ldots & \ldots & \ldots & 49 \\ \ldots & \ldots & \ldots & 49,223 \\ \ldots & \ldots & \ldots & 50 \\ \ldots & \ldots & \ldots & 51 \\ \ldots & \ldots & \ldots & 52 \\ \ldots & \ldots & \ldots & 53 \\ & & & \end{array}$

Parietine

Droseracere, Salisb.

Drosera, I. glanduligera, Lehm. pygmea, Cand. Whittakerii, Planch. Arcturi, Hook. .

Indica, I.... binata, Lab. spatulata, Lab. peltata, Smith ... Planchoni, J. Hook.

Violacea, Cand. ...

Viola, Tournef. betonicifolia, Smit Caleyana, Don hederacea. Lab. ...

Ionidium, Vent. ... filiforme, F. M. ... Vernonii, F. M. floribundum, Lindl.

Hymenanthera, Banks ... Banksï, F. M.

Pittosporece, R. Br.

Pittosporum, Banks \& Soland. revolutnm, Dryand. undnlatum, Vent. bicolor, Hook. ... philyroides, Cand.

Bursaria, Car. spinosa, Car.

Rhytidosporum, F. M. .. procumbens, F. M.

Cheiranthera, All. Cunn.
Cheiranthera linearis, All. Cunn

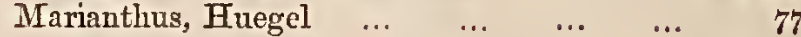

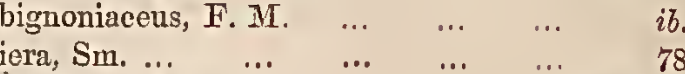
$\begin{array}{llllll}\text { longiflora, Lab. } \ldots & \ldots & \ldots & \ldots & 78,225\end{array}$ scandens, $\mathrm{Sm} . \quad \ldots \quad \ldots \quad \ldots \quad \ldots \quad \ldots, 79$

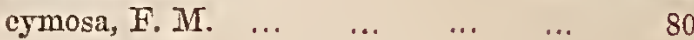

$\begin{array}{lllll}\text { Frankeniacece, St. Hilaire } & \ldots & \ldots & \ldots & 81\end{array}$

$\begin{array}{lllllll}\text { Frankenia, L. } & \ldots & \ldots & \ldots & \ldots & \ldots & 82\end{array}$ $\begin{array}{lllllll}\text { levis, } \mathrm{L} . & \ldots & \ldots & \ldots & \ldots & \ldots & i b .\end{array}$

$\begin{array}{lllllll}\text { SaPINDINI } & \ldots & \ldots & \ldots & \ldots & \ldots & 83\end{array}$

Sapindacea, Juss. $\quad \ldots . \quad \ldots . \quad \ldots \quad \ldots . \quad$ ib.

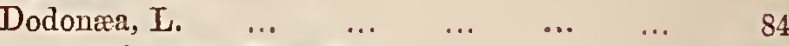

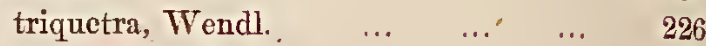
truncatiales, F. M. $\quad \ldots . \quad \ldots \quad \ldots . \quad$ ib. $\begin{array}{llllll}\text { viscosa, } \mathrm{L} . & \ldots & \ldots & \ldots & \ldots & 85\end{array}$ $\begin{array}{lllll}\text { procumbens, } \mathrm{F} . \mathrm{M} . & \ldots & \ldots & \ldots & 86\end{array}$ $\begin{array}{llllll}\text { deflexa, F. M. } & \ldots & \ldots & \ldots & \ldots & 87\end{array}$ bursarifolia, Belir \& Muell. .. $\quad \ldots \quad$ ib. $\begin{array}{lllll}\text { stenozyga, F. M. } & \ldots & \ldots & \ldots & 88\end{array}$ hirtella, Miqn. $\quad \ldots \quad \ldots \quad \ldots \quad \ldots \quad 89,227$

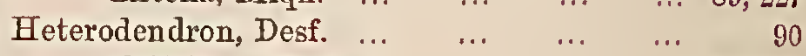
oleifolium, Desf. ... $\quad \ldots \quad \ldots \quad \ldots \quad 90,227$

$\begin{array}{llllll}\text { Spanoghea, Blume } \quad \ldots & \ldots & \ldots & \ldots & 227\end{array}$ S. nephelioides, F. M. ... $\quad \ldots \quad \ldots . \quad$ ib.

$\begin{array}{llllll}\text { Malpighiacece, Juss. } & \ldots & \ldots & \ldots & \ldots & 91\end{array}$

$\begin{array}{llllllll}\text { Nitraria, L. } & \ldots & \ldots & \ldots & \ldots & \ldots & 92\end{array}$ Billardierii, Cand. $\quad \ldots \quad \ldots \quad \ldots, 92,22 \%$

$\begin{array}{lllllll}\text { Vinifere, Juss. } & \ldots & \ldots & \ldots & \ldots & \ldots & 93\end{array}$

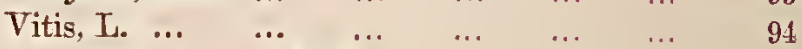
hypoglauca, F. M. $\quad \ldots \quad$.. $\quad \ldots \quad$ ib.

$\begin{array}{llllllll}\text { Rutixis } & \ldots & \ldots & \ldots & \ldots & \ldots & \ldots & 96\end{array}$

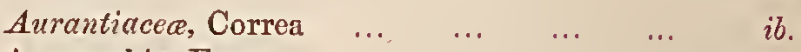
$\begin{array}{llllll}\text { Acronychia, Forst. } & \ldots & \ldots & \ldots & \ldots & i b .\end{array}$ laurina, $\mathrm{F}, \mathrm{M} . \quad \ldots \quad \ldots \quad \ldots \quad \ldots 97,227$

$\begin{array}{lllllll}\text { Zygophyllece, R. Br. } & \ldots & \ldots & \ldots & \ldots & 98\end{array}$

$\begin{array}{llllll}\text { Tribulus, Tournef. } & \ldots & \ldots & \ldots & \ldots & 99\end{array}$ $\begin{array}{llllll}\text { terrestris, } \mathrm{L} . & \ldots & \ldots & \ldots & \ldots & i b .\end{array}$

$\begin{array}{llllll}\text { Zygophyllnm, L, } & \ldots & \ldots & \ldots & \ldots & 100\end{array}$ apiculatum, F. M. $\quad \ldots \quad \ldots \quad \ldots .101$ glauceseens, F. M. $\quad \ldots \quad \ldots \quad \ldots, \quad \ldots 102,227$ crenatum, F. M... $\quad \ldots \quad \ldots \quad \ldots 103,227$

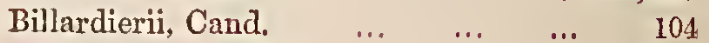
iodocarpum, F. M. $\quad$.. $\quad \ldots \quad \ldots \quad \ldots . \quad 105$

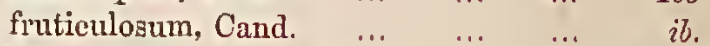

Rutacere, Juss.

$\begin{array}{llllll}\text { Geijera, Schott } & \ldots & \ldots & \ldots & \ldots & 106\end{array}$ $\begin{array}{llll}\cdots & \ldots & \ldots & 108\end{array}$

Boronia, Smith 
Boronia veronicea, F. M. lævigata, F. MT. ... arborescens, F. M. parviflora, Sm. ... polygalifolia, Sm. pinnata, Sm.

clavellifolia, F. M. cœrulescens, F. MI.

Eriostemon, Smith

Crowei, F. M.

trachyphyllus, F. M. myoporoides, Cand. verrucosus, $A$ ch. Rich. .. difformis, All. Cunn. pungens, Lindl. ... lamprophyllus, F. M. Hillebrandii, F. M. umbellatus, Turcz. squamcus, Lab. . lepidotus, Spr.
ovatifolius, F. M. phylicoides, F. M. corræifolius, F. IT. pleurandroides, F. M. ... trymalioides, F. MI.

Correa, Smith alba, Andr. speciosa, Andr. . Lawrenciana, Hook. æmula, F. M.

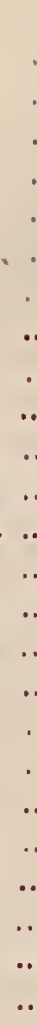

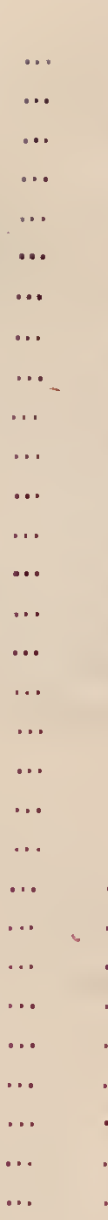

.

Cordanifere

Buettneriacece, R. Br.

Lasiopetalum, Sm fcrrugineum, Sm. parriflorum, Rudge Baucri, Steetz Behrii, F. M. dasyphyllum, Sieb.

Corethrostylis, Endl. Schulzenii, F. M.

Thomasia, Gay petalocalys, F. MI.

Commersonia, Forst. Fraseri, Gay

Rulingia, R. Br. . pannosa, R. Br.

Tiliacece, Juss.

Elrocarpus, I. cyaneus, Ait. holopetalus, F. M.

Sterculiacea, Vent. Brachychiton, R. Br. ... populneum, R. Br.

Malvacea, Juss.

Page

microphyllus, F. M. ...

Sida, L. ... $\quad \begin{array}{llllll} & \ldots & \ldots & \ldots & \ldots & 160\end{array}$ pulchclla, Bonpl. $\quad$... $\quad \ldots \quad$... Lawrcncia, F. M. $\quad$... $\quad \ldots . \quad \ldots . \quad 162$ $\begin{array}{lllll}\text { corrugata, Lindl. } & \ldots & \ldots & \ldots & 163\end{array}$

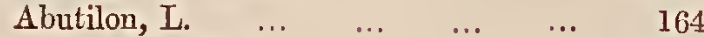
otocarpa, F. M. ... $\quad \ldots . \quad \ldots \quad \ldots . \quad 165$

Laratera, $\mathrm{L}$

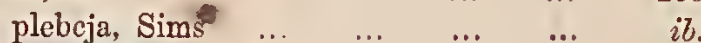

$\begin{array}{lllllll}\text { Horrittia, F. M. } \quad . \quad \ldots & \ldots & \ldots & \ldots & 167\end{array}$ trilocularis, F.M. $\quad \ldots . \quad \ldots \quad \ldots . \quad i l$.

$\begin{array}{llllllll}\text { Groinales } & \ldots & \ldots & \ldots & \ldots & \ldots & 169\end{array}$

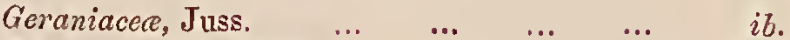

$\begin{array}{lllll}\text { Pclargonium, L'Herit. ... } & \ldots & \ldots & \ldots & \ldots \\ \end{array}$ Australe, Willd. $\quad$... $\quad \ldots . \quad \ldots \quad$ ib.

$\begin{array}{llllll}\text { Erodium, L'Herit: } & \ldots & \ldots & \ldots & \ldots & 171\end{array}$

$\begin{array}{lllll}\text { eygnorum, Nees } & \ldots & \ldots & \ldots & 172\end{array}$

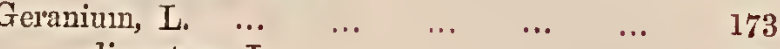
$\begin{array}{llllll}\text { dissectum, L. } & \ldots & \ldots & \ldots & \ldots & i b .\end{array}$

$\begin{array}{llllll}\text { Oxalidea, R. Br. } & \ldots & \ldots & \ldots & \ldots & 175\end{array}$

$\begin{array}{lllllll}\text { Oxalis, L. } & \ldots & \ldots & \ldots & \ldots & \ldots & i b .\end{array}$ Magellanica, Forst. $\quad \ldots \quad \ldots . \quad \ldots \quad 176$ $\begin{array}{llllll}\text { corniculata, L. } & \ldots & \ldots & \ldots & \ldots & 177\end{array}$

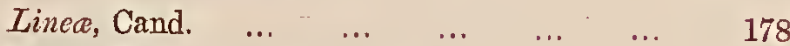

$\begin{array}{lllllll}\text { Linum, } \mathrm{L} . & \ldots & \ldots & \ldots & \ldots & \ldots & i b .\end{array}$ marginale, All. Cunn. $\quad \ldots \quad \ldots, \quad \ldots, \quad \ldots, \quad i b$.

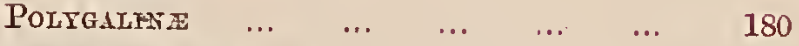

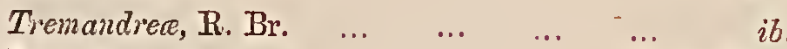

Tetratheca, Sn. ... $\quad \ldots \quad \ldots \quad \ldots . \quad \ldots 181,228$ ciliata, Lindl. $\quad \ldots \quad \ldots \quad \ldots \quad \ldots \quad \ldots . \quad 181$

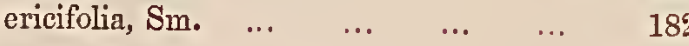

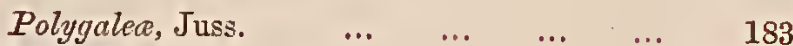

$\begin{array}{lllllll}\text { Polygala, } \mathrm{L} . & \ldots & \ldots & \ldots & \ldots & \ldots & 1.84\end{array}$ $\begin{array}{lllll}\text { Teronicea, } F . M . & \ldots & \ldots & \ldots & i b .\end{array}$

$\begin{array}{llllll}\text { Comespcrma, Lab. } & \ldots & \ldots & \ldots & \ldots & 185\end{array}$

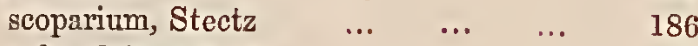
$\begin{array}{lllll}\text { polygaloides, F. M. } & \ldots & \ldots & \ldots & 187\end{array}$ $\begin{array}{llllll}\text { calymega, Lab. } & \ldots & \ldots & \ldots & \ldots & 188\end{array}$ defoliatum, F. M. $\quad$... $\quad$.. $\quad \ldots . \quad 189$ ericinum, Cand. ... $\quad \ldots \quad$... $\quad \ldots \quad 190$

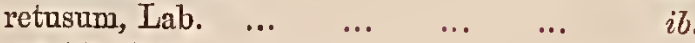
volubile, Lab. $\quad \ldots \quad \ldots \quad \ldots \quad \ldots \quad \ldots \quad 191$

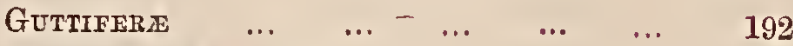

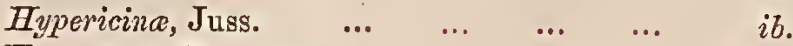

$\begin{array}{llllll}\text { Hypericum, Tournef. } & \ldots & \ldots & \ldots & \ldots & \\ & & \ldots & \end{array}$ 
viii

\begin{tabular}{|c|c|c|c|c|c|}
\hline \multirow{4}{*}{\multicolumn{2}{|c|}{$\begin{array}{l}\text { Elatinece, Cambess. } \\
\text { Elatine, } \mathrm{L} . \\
\text { minima, Fisch. \& Mey. } \\
\text { tripetala, F. M. ... }\end{array}$}} & & & & $\begin{array}{l}\text { Pago } \\
194\end{array}$ \\
\hline & & $\ldots$ & $\begin{array}{l}\ldots \\
\ldots\end{array}$ & $\begin{array}{l}\ldots \\
\ldots\end{array}$ & $\begin{array}{l}194 \\
195\end{array}$ \\
\hline & & $\ldots$ & $\ldots$ & $\ldots$ & $i$ ib. \\
\hline & & $\ldots$ & $\ldots$ & $\ldots$ & 196 \\
\hline CARYOPHYLLINZI... & $\cdots$ & $\ldots$ & ... & ... & 197 \\
\hline Phytolaccer, $\mathbf{R} . \mathrm{Br}$. & & ... & ... & ... & $i b$. \\
\hline Didymotheca, J. Hook. & & $\cdots$ & ... & $\cdots$ & 198 \\
\hline pleiococca, F. M. & & $\cdots \Rightarrow$ & & ... & $i b$. \\
\hline Codonocarpus, All. Cun & & & ... & ... & 199 \\
\hline cotinifolius, F. M & & ... & ... & $\cdots$ & 200 \\
\hline Molluginere, Benth. & $\ldots$ & ... & $\cdots$ & .. & 201 \\
\hline Glinus, Lofl. ... & $\ldots$ & $\ldots$ & ... & $\ldots$ & 202 \\
\hline lotoides, Lœfl. & $\ldots$ & $\ldots$ & $\ldots$ & ... & $i b$. \\
\hline Mollugo, Fenzl & $\cdots$ & ... & .. & $\cdots$, & 203 \\
\hline Caryophyllee, Juss. & $\ldots$ & .. & ... & ... & 204 \\
\hline Polycarpon, Lofl. & & ... & ... & $\ldots$ & 205 \\
\hline tetraphyllum, I. & & & & $\therefore$ & $i b$. \\
\hline Gypsophila, L. ... & $\ldots$ & ... & ... & .. & 206 \\
\hline tubulosa, Boiss. & & ... & $\ldots$ & $\ldots$ & $i b$. \\
\hline Spergularia, Pers. & $\ldots$ & $\ldots$ & ... & $\ldots$ & 207 \\
\hline rubra, Cambess. & $\ldots$ & $\ldots$ & $\ldots$ & $\ldots$ & $i b$. \\
\hline
\end{tabular}

Page $\begin{array}{lll}\cdots & \cdots & \cdots\end{array}$ procumbens, L. ... $\quad \ldots \quad$... $\quad \ldots . \quad i b$. $\begin{array}{llllll}\text { apetala, } L . & \ldots & \ldots & \ldots & \ldots & 209\end{array}$

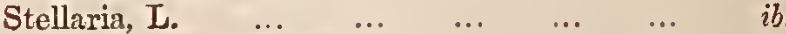
pungens, Brogn.... $\quad$.. $\quad \ldots \quad$... $\quad$ ib.

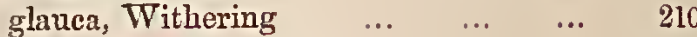
media, Withering $\quad$.. $\quad \ldots . \quad \ldots . \quad 211$ multiflora, Hook. $\quad$ H. $\quad$... $\quad$... 212

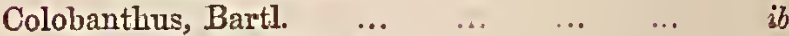
Billardierii, Fenzl $\quad . . * \quad \ldots \quad \ldots . \quad$ ib. $\begin{array}{lllll}\text { pulvinatus, } F \text {. } M \text {. } & \text {. } & \ldots & \ldots & 213\end{array}$

$\begin{array}{llllll}\text { Seleranther, Link. } & \ldots & \ldots & \ldots & \ldots & 214\end{array}$ Scleranthus, L. ... $\quad \ldots \quad$... $\quad \ldots . \quad \ldots, \quad$ ib. biflorus, J. Hook. mniaroides, F. M. $\quad \ldots . \quad \ldots . \quad \ldots \quad 215$

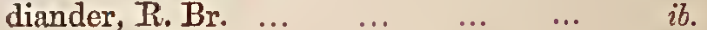
pungens, R. Br. ... $\quad$.. $\quad \ldots \quad \ldots \quad 216$

Total THaLAMIFLorit-

$\begin{array}{lllllll}\text { Orders } & \ldots & \ldots & \ldots & \ldots & \ldots & 35\end{array}$

$\begin{array}{lllllll}\text { Genera } & \ldots & \ldots & \ldots & \ldots & \ldots & 78\end{array}$

$\begin{array}{lllllll}\text { Species } & \ldots & \ldots & \ldots & \ldots & \ldots & 192\end{array}$ 
THE

\title{
PLANTS INDIGENOUS TO THE COLONY OF VICTORIA,
}

DESCRIBED IY

\author{
Dr. FERDINAND MUELLER.
}

I.

PHANEROGAMOUS OR FLOWERING PLANTS.

Plants producing Stamens, Pistills and embryonate Seeds.

\section{I.-EXOGENOUS OR DICOTYLEDONEOUS PLANTS.}

Growth of stem exogenous. Leares gencrally articulated with the branches. Veins of leaves more or less branched. Division of the flowers prevailingly quinary or quaternary. Cotyledons two, opposite or rarely three and more in a whorl, very seldom wanting. Radicle in germination directly lengthened into the root.-Lindley, Veget. Kingdom, edit. iii. p. 239; Torrey \& Gray, Flora of North America, i. 1.

\section{I.-THALAMIFLORE.}

Candolle, Syst. Veget. i. 125.

Calyx consisting of free rarely coherent sepals, in few cases monophyllous or wanting, never connate with the ovary. Petals and stamens hypogynous, inserted on a receptacle; the former free, rarely united, sometimes wanting.

\section{I.-POLYCARPOUS THALAMIFLORE. \\ Endlicher, Gener. Plant.p. 824.}

Ovaries generally numerous, quite distinct, in few instances united; each provided with a separate stigma. Stamens generally unlimited in number, free, rarely united. 
Of the orders of plants belonging to Polycarpous Thalamifloræ, the following have been hitherto observed in Australia:-Ranunculaceæ, Dilleniaceæ, Magnoliaceæ, Monimieæ, Atherospermeæ, Menispermeæ, Cabombeæ, Nelumbiaceæ, Nymphæaceæ, and Myristicer. The three latter occur, however, only in the tropical portion of this country. Berberidere, which are arrayed with most of the preceding ones by De Candolle, may possibly yet be found on the higher unexplored mountains of north-east Australia. Eupomatieæ, referred by R. Brown to Anonaceæ, an order of this series, are to be placed amongst Calycifloræ.

\section{ORDER RANUNCULACE巴.}

Jussieu, Mem. Acad. Paris, 1773, 214.

Sepals 3-15, but usually 5, distinct, liypogynous, deciduous, in præflorescence mostly imbricated. Petals equal in number to the sepals, or numerous, free, imbricated in æestivation, sometimes deformed or diminutive, or missing. Stamens hypogynous, free, indefinite rarely definite in number. Anthers adnate, extrorse, (except in Pæoniex, which may be regarded as a separate order,) bursting lengthwise. Pistils generally numerous, inserted to a torus, free or sometimes connate. Ovules anatropal. Carpels one-celled, with one or several seeds. Arillus none. Albumen large, lorny. Embryo minute, straight, lodged in a groove at the base of the albumen.

Herbs, or more rarely shrubs, with a limpid juice often of volatile acridity. Petioles vaginate. Leaves often divided, without proper stipules. Hair, when present, simple.-DC. Prodr. i. 2; Henfrey's Elem. Course of Botany, p. 220; Wight \& Arnott, Prodr. Flor. Ind. i. 1.

All the genuine tribes of the Ranunculacere are found represented in Victoria: but of the genus Anemone, which is widely distributed chiefly over the colder regions of the globe, no species is known in continental Australia, although one, Anemone crassifolia (Hook. Icon. Plant. cclvii.), inhabits the Alps of Tasmania. No plant of this order lias been observed in any of those parts of tropical Australia traversed by the author of this work, but several of our southern species extend as far as the tropic of Capricorn.

Tribe I. CLEMATIDEÆ, Cand. Syst. i. 134.

Calyx colored, with valvate or induplicate præeflorescence. Petals none, or shorter than the sepals, and flat. Carpels one-seeded, indehiscent, terminated by an often feathery style. Seeds pendulous. 


\section{CLEMATIS.}

Linné Gen. Plant. n. 696.

Sepals petaloid, 4-8. Stamens 6, or more and indefinite. Ovaries numerous, free. Carpels many, sessile, with persistent gradually lengthened naked or bearded style.

Showy, often climbing, herbs or shrubs, inhabiting the temperate zone, or the higher mountains within the tropics, with opposite generally divided or compound leaves, often tendril-like leaf-stalks, a mostly compound inflorescence and ebracteolate or sometimes bibracteolate flowers.

The three or four Australian species of Clematis are endemic.

\section{Sect. Flanniula, Cand. Syst. i. 133.}

Bracteoles and petals wanting. Styles lengthened, plumose.

Clematis aristata, R. Br. in Cand. Syst. i. 147; C. coriacea, Cand. l.c.; C. stenosepala, Cand. l.c.; C. gentianoides, Cand.l. c.; Deless. Icon. scl. i. 5; C. blanda, Hook. Journ. Bot. i. 241.

A woody diœcious climber; leaves divided into three glabrous segments, occasionally some of them simple, generally on long petioles; segments stalked, almost leathery, cordate-ovate or narrow- or ovatelanceolate, almost three-nerred, net-veined, often acute, either entire or particularly below the middle crenate-serrated, above shining; peduncles axillary and terminal, with one or several cymose or fastigiate pedicels, which are frequently longer than the flowers; sepals four, oblong- or linear-lanceolate, outside downy or glabrous, along the margin slightly tomentose, twice or three times as long as the stamens; anthers oblong-linear, with a terminal subulate appendage, which is longer or shorter than the cells, or rarely shortened to a mere point; carpels ovate or ovate-lanceolate acute, not wrinkled, generally downy; finitstyle long, feathery, except at the base and apex.

In moist forest localities, chiefly along banks of rivers and rivulets, as far west as the Grampians, through the whole of the colony of Victoria. It occmrs likewise throughout Tasmania, and in the more southern parts of New Sonth Wales.

A tall evergreen climber, sometimes reaching to the summits of large trees, possessing the general acridity of its congeners. Branches furrowed, snooth in age. Branchlets generally more or less downy. Leaflets 1-4 inches long, $\frac{1}{3}-2$ incles broad, often purplish beneath, prominently veined, variegated in a young. state. Pedicels generally longer than the pednncles; the latter at times very short. Lower bracts leaf-like, upper ones gradually smaller, at last diminntive. Pedicels 4 inches long, or varionsly shorter. Sepals $\frac{1}{2}-1$ inch long, 1-3 lines broad, pure or yellowish white, occasionally five in number. Filaments linear, some surrounding the female flower. Anthers pale, $\frac{3}{4}-1 \frac{1}{2}$ line long; their appendix acute, rarely blunt, varying greatly in length sometimes even in the same flower, their measurement being between $\frac{1}{8}-1 \frac{1}{2}$ line. Carpels $1 \frac{1}{2}-2 \frac{1}{2}$ lines long. Fruit-styles $1-1 \frac{1}{2}$ inch long.

Nothing can be more beautiful than the graceful festoons formed by this climber when loaded with its flowers in spring, or when producing its plumose fruit in summer.

Clematis glycinoides, $D C$., which differs only in generally entire leaves, smaller florrers, oblong'-oval anthers with very short appendage and in narrow lauceolate carpels, is not yet found in Victoria, but extends along the east coast as far north as the Dawson River. Dr. Hooker refers very justly, in the Flora Tasmanica, i. p. 3, to the probability of Clematis pubescens, Hueg. (Cl. indivisa, Steud. non W., Cl. discolor and Cl. cognata, Steud.), belonging to the species above described. Although I found no distinct character by which it could be discriminated from $\mathrm{Cl}$. nristata, I have hesitated to unite them, because the latter is a forest plant which only, with numerous other Tasmanian species, makes its appearance in Victoria, not extending to any part of the colony of South Australia hitherto explored, whilst Clematis pubescens is 
restricted to Western Australia, where scarcely any Tasmanian plants exist beyond those common to almost the whole southern coast.

Clematis microphylla, Cand. Syst. Veg. i. 147; Cl. linearifolia, Stend. in Lehm. Pl. Preiss, i. 262 ; J. Hook. Fl. Tasm. i. 3, tab. i.

A woody diœcious climber; leaves with double- rarely simply- or threefold-térnate divisions; segments glabrous, herbaceous, oblong- or ovate-lanceolate, or oblong-linear, rarely narrow-linear, frequently blunt, always entire; peduncles axillary and terminal, with a solitary or several cymose pedicels, which are generally about as long as the flowers; sepals four, linear-oblong, rather blunt, slightly downy outside, nearly three times as long as the stamens; anthers small, ovale, without appendage; carpels rhomboid- or lanceolate-orate, acute, with a thickened wrinkled margin; fiuit-styles from considerably above the base to nearly the summit plumose.

Not rare in the colony of Victoria, along the coast and on the banks of rivers near the sea; much less fiequent inland. It extends also to the northern parts of Tasmania, to South Australia, Wéstern Australia, and the Moreton Bay district. Sir Th. Mitchell brought it from the Maranoa (Conf. Trop. Austr. p. 368). A slender climber, with numerous intricate branches, which are furrowed and smooth in age. Branchlets often downy: Petioles from a half to several inches long. Segments of leaves variable in size and shape, from a few lines to $1 \frac{1}{2}$ inch long; from 1 to 10 lines broad, generally stalked, sometimes confluent at the base. Bracts usually small, oblong or linear, at the base of the pedicels. Sepals $\frac{2}{3}$ to 1 inch long, 1-2 lines broad, cream-colored. Carpels $1_{1} \frac{1}{2}-2$ lines long, brown, attenuated at the base and apex. Fruit-style $1-1 \frac{1}{2}$ inch long, as far as three lines above the base merely short-downy.

In saline localities the leaves become occasionally flesliy, like those of almost all other plants growing. on such places. A curious variety, with very narrow and smaller leaflets, may be distinguished as leptophylla or stenophylla. It trails over granite rocks on the Snowy River and Mitta Mitta. This species bears flowers early in the spring.

Tribe II. ANEMONEE, Cand. Syst. i. 168.

Sepals often petaloid, with imbricate æstivation. Petals none or flat. Carpels indehiscent, with a solitary pendulous seed.

\section{MYOSURUS,}

Dillen. Nov. Gen.p. 106, t. 4.-Mouse-tail.

Sepals generally 5 , extended below their point of insertion. Petals absent, or about 5, very minute, with a tubular elongated claw, and with an almost cylindrical nectar-groove. Stamens 5-20. Carpels arranged in a dense spike along a subulate elongated receptacle.

Small glabrous annual herbs, occurring in Europe, Asia, America, Australia, and New Zealand. Leaves all radical, linear or very narrow-spathulate, entire. Peduncles thread-like or setaceous, with a single small upright flower.

Inyosurus minimus, Linné, Sp. Pl.407; Lam. Eneycl.t. 221; M. Australis, T. MI. in Trans. Phil. Soc. Victor. i. 6.

Sepals long-spurred; petals lanceolate or spathulate; style threc times shorter than the carpel, or obliterated; fruit-spike long-cylindrical; carpels very numerous, closely imbricated.

On moist places, near permanent waters, or on the open plains where rain-water lodges from time to time; in the vicinity of the rivers Hopkins, Emu Creek, Avoca, Western Avon, Richardson, Murray, Darling, and Murrumbidgee, sometimes gregarious. 
Leaves numerons, $\frac{1}{2}-2$ inches long, $\frac{1}{6}-1$ line broad, somewhat fleshy, one-nerved, rather blunt, tapering into petioles of nearly their own-length. Flower-stalks several, or very many arising from each root, finely streaked, 1-5 inches long, thickened towards the summit. Sepals concave, lanceolate or ovate-lanceolate, without the basal appendage 1-2 lines long; spreading; deciduous, of a pale color; appendage half or nearly as long as the sepals, linear-subulate, membranous. Petals deciduous; their lamina much shorter than the sepals, cream-colored; their claw capillary, $\frac{3}{4}-\frac{1}{2}$ line long: Filaments narrow-linear, abont half as long as the calyx. Anthers oblong-linear, blunt, in age narrow-linear and tristed, $\frac{1}{2}-\frac{2}{3}$ line long. Number of ovaries always considerable, sometimes more than 300 , occasionally reduced to less than fifty. Fruit-spike generally 1-2 inches long, singularly resembling a mouse-tail, whence the generic name. Receptacle thin-filiform, uneven, persistent. Carpels trigonous-ovate, at the back rhomboid, pointed at the apex by the style, abont half a line long, with a dorsal rib, thickened at the outer margin, at their inner angle acute, in age bent at the base slightly outward, at last decidnous. Seeds oblong-ovate, slightlly compressed, brown, streaked._Smitl's Engl. Flora, ii. p. 124; Hook. Lond. Joum. of Bot. vi. 459.

The only other known species of this genus, MI. aristatus, nnay be recognised by its less numerous long-rostrate lax carpels, and may yet be found in Australia. J. Hooker (Flor. of New Zealand, i. 8) states it to be destitute of petals, as originally mentioned by Gay (Flor. of Chili, i. 31, t. 1, f. 1), whilst Sir Will. Hooker and G. Bentham found the corolla to be present in the American specimens. This character therefore seems subject to variation. The notes by which.I once distinguished the Australian plant from the European seen not to afford the means of clear specific distinction.

M. minimus flowers early in the spring. It is not at all improbable that the plant may have been introduced from abroad.

TrIBE III. RANUNCULE $Æ$, Cand. Syst. i. 228.

Calyx imbricate in æstivation. Petals generally with 1 rarely 2-3 nectar-pits. Carpels indehiscent, with a solitary elect seed.

\section{RANUNCULUS.}

C. Bauh. Pin. 180; Cand. Syst. i. 231.-Crowfoot, Spearwort.

Sepals $3-7$, deciduous. Petals generally 5 , sometimes numerous, very rarely wanting, inside with 1 rarely 2-3 nectar-pits. Stamens and pistils several or numerous, rarely very few. Carpels one-celled.

Herbs with few exceptions acrid, dispersed over the whole globe, except through low tropical regions, copious in the colder zone, varied in aspect and in leaves, the majority of the species with yellow, some with white, few with purple or red, none with blue flowers.

\section{Sect. I. Batrachiuzi, Cand. Syst. i. 233.}

Petals white, with a yellow claw. Nectar-pit neither covered with a scale nor surrounded by a prominent margin. Carpels in exsiccation transversely wrinkled.

Glabrous swamp or water plants. Submersed leaves generally divided into numerous capillary segments; roots fibrous; peduncles one-flowered, opposite to the leaves.

Ranunculus aquatills, Linné, Sp. Plant. 781.-Water Crowfoot.

Stems perennial, submersed or creeping; leaves stalked, either all repeatedly divided into chiefly trichotomous numerous spreading hair-like segments, or the floating ones kidney-shaped, 3-5-lobed or notched; lobes of the latter wedge-shaped and cut in fiont, or deeply and varionsly cleft; petals obovate- or. 
orbicular-cuneate or round, longer than the calyx ; receptacle globose, hairy; carpels oblique-ovate, with a short or an obliterated style.

In lakes, swamps and rivers, as well of fresh as of brackish water, over the greater part of the world. Within our colony in Bacchns Marsh, the Murray, Mitta Mitta, \&e. Not found in tropical Anstralia.

Stem obtusangular, branched, when submersed throwing ont long' fibrous roots from its lower joints. Floating leaves generally less rarely more than one inch broad; sometimes peltate, with blunt rarely stalked divisions. Subnersed leaves $\frac{1}{2}-2$ inches long. Petioles, particularly of the ripper leaves, dilated at the base into broad adnate, often hairy, membranes, which are sometimes filly half an inch long. Peduncles measuring 1-3 inches. Flowers from $\frac{1}{3}$ to rather more than 1 inch in diameter. Petals tender, with a tubular nectary about the middle of the claw. Calyx smooth, of one-third or lialf the length of the corolla, very soon dropping. Stamens many, sometimes reduced to about one dozen, short. Anthers oblong. Pollen-grains sphæroid. Carpels $\frac{1}{2}-\frac{3}{4}$ line long; glabrous or hispid; at times as few as 10.-Conf. Smith's English Flora, ecl. ii. vol. iii. p. 54-56.

After watching for nearly twenty years the numerous varieties of this plant, I know of no species belonging to the section Batrachium, except perhaps $R$. hederaceus and $R$. circinnatus, which have any claim on specific distinction from $R$. aquatilis. In most instances, as Sir James Smith justly observed, the canses of aberration from the more common forms in this polymorphous plant are at once explained by the conditions of the localities in which they are produced.

\section{Sect. II. Hecatonia, Cand. Prodr. i. 30.}

Petals yellow or white, with one rarely two nectar-pits, which are generally covered by a scale. Carpels naked.

Ranunculus Mrillani, Fr. MI. in Hook. Kew Miscell. vii. 358; Transact. Phil. Soc. Tict. i. p.97.

Drarf, stemless; root annual, fasciculate-fibrous; leares pinnati-sected, glabrous or together with the upper part of the petioles scantily downy; segments of leaves ferv, Tinear, undivided or bi-or tri-sected, terminated by a gland; peduncle one-flowered, spreading-downy, of the lengtlı of or shorter or rarely longer than the petioles; sepals appressed, glabrous; pctals white, $5-10$, obovate- or oblong-cuneate, almost twice as long as the calyx; nectar-pit distant from the base, margined, covered by a hardly perceptible scale; receptacle hairy; carpels rather few, glabrous, broad-ovate, slightly compressed, acuminate by the
recurved style.

In gravelly places, chiefly such as form slight depressions in the alpine meadows, irrigated by the melting snow, on most of the summits of the Australian Alps.

A neat little plant, 1-3 inches high, generally growing gregariously, accidentally only producing a very short creeping sten. Root large for the size of the plant, consisting of a bundle of fibres, often 2-3 inches long. Leares $\frac{1}{2}-1$ inchl long, on a conspicuous petiole; their segments rather acute. Peduncle from a fer lines to two inches long, bractless or with one or two linear bracts, often solitary. Sepals oral, with membranous margin. Petals $3-4$ lines long, witl a hyaline base, rarely cream-colored. Stamens not very numerous. Filaments mostly longer than the oblong-oval anthers. Carpels about $\frac{2}{3}$ line long, forming a globular head.

'This species was named in acknowledgment of much aid which the author received during his botanical exploration of the Australian Alps, from Angus McMillan, Esq., the discoverer of Gipps Land, it being originally found on Mount Wellington, a montutain which that generous gentleman first named and ascended.

Ran. Millani flowers in the latter part of the spring and in the beginning of summer.

This and the following are the only endemic white flowering species of Crowfoots found in Anstralia; they are curions as repeating here one of the alpine types of the genus as occur'ing in the northerm hemi- 
sphere, characterized by white flowers, whilst all the Ranunci known as peculiar to New Zealand, Tasmania, and the antarctic regions, are, without exception, described as yellow-flowered.

Ranunculus anemoneus, F. M. in Transact. Phil. Soc. Tict. i. 97.-Anemone Crowfoot.

Hirsute or glabions; root perennial; its fibres fasciculate or crowded on a short creeping rhizome; stems simple, erect, 1-3-flowered, lenfless to above the middle, scaly at the base, and surronnded by the bristly remains of leaf-stalks; radical leaves on long petioles, nearly orbicnlar, almost to the base divided into 3-5 lobes, these deeply three- or five-cleft, overlapping each other, their lobes variously cut into generally narrow-lanceolate acute lobnles; stem-leates only at the base of the flower-stalks, large, in outline cordateorbicular, dissccted, sessile, clasping; peduncle bractless, or more frequently with a dissected bract; sepals $5-7$, ovate, appressed, slightly villons; pctals large, whitc, gencrally numerous, twice or three times as long as the calyx, almost constantly narrow oblong-cnneate; nectar-pit margined; receptacle ovate, slightly downy; carpels numerous, in a globose-ovate head, turgid, smooth; their style hooked at the extremity.

On springs near the summits of the Munyang Mountains.

One of the most ornamental and rare plants of the Australian Alps, varying in lieight from $\frac{1}{2}$ to 2 feet, resembling, cliefly on account of its involucre-like stem-leaf, greatly an Anemone. Fibres of root often many inches long. The radical leaves $1 \frac{1}{2}-4$ inches long and broad, provided with a petiole, which is often longer than half a foot. Peduncles streaked, 2-6 inches long, rather thick. Diameter of corolla between 1 and 2 inches. Anthers scarcely one line long, oblong. Fruit-head ovate or ovate-globose, about half an inch long. Carpels nearly one line long, ovate, with a conspicuous style.

It flowers late in the spring or in the beginning of the summer.

It differs from R. nivicola (Hook. Icon. 5\%1) already in its white petals, which are obliquely pointed and not emargined at the apex.

PL. I. 1 and 2 , petals; 3 , anthers; 4, receptacle; 5, carpel; 6, longitudinal, and 7 , transverse section of carpel: all exccpt 1 magnified.

Ranunculus Iappaceus, Smith, in Rees' Cycl.n.61; R. pimpinellifolius, Hook. Jou'n. of Bot. i. 243; Icon. Plant. cclx; R. nanus, Hook. Journ. of Bot. i. 243; R. cuneatus, Hook. l. c.; R. colonorum, Schlccht. Linncea, xx. 627; R. multiscapus, J. Hook. Fl. of $N$. Zcal. i. p. 9, t. 5; R. scapigerus, J. Hook. Fl. Tasm. tab. ii. A.

Perennial, erect, rarely diffised or procumbent, downy with spreading or appressed hair; radical lcaves long-stalked, rarely quite entire lanceolate and ovate, generally divided into 3-5 lobes, which are mostly ovatc-or rhomboid-cuneatc, either all pinnately distinct or, particularly the mpper ones, confluent, with varied broad or more rarely narrow lobnles and teeth; stem-leaves few, or one or wanting, either undivided lanceolate and linear or cleft in several lobes; stems with one or several flowers; its lower part leafless; peduncles long, furrowcel; sepals spreading or appressed, one-third or half as long as the corollas; petals generally 5, rarely 6-10, yellor, obcordate- or cmneate- or orbicular-oborate, with a nectar-pit at or above the base; receptacle orate or conical, hairy; carpels round- or broad-orate, compressed, rarely very turgid, smooth, nith a recurved scldom straight style.

In grassy places, fiom the low land to the limits of eternal snow, here and there also in boggy and swampy localities. Occurs throughout almost the whole of extratropical Anstralia and in New Zealand.

An herb, varying from 2 inches to 2 feet in height. Copiousness, length, and direction of its indument variable, which geneially, however, is soft and spreading. Root fasciculate-fibrous. The bristle-like partial remains of the radical leaf-stalks often surrounding the recent ones. Leaves $\frac{1}{2}-3$ inches long and broad, rarely glabrous, sometimes nearly heart-shaped and trilobed to about the middle, in alpine varieties quite undivided and covered with more rigid appressed hair. Upper stem leaves to be regarded as bracts. Sepals often hairy, not reflexed. Petals 2-6 lines long, occasionally purple outside. Anthers oblong. Fruit-head globose. Carpels $\frac{3}{4}-1 \frac{1}{2}$ line long, with a more or less elongated style. 
This species is in flower principally during the spring season.

The Ranunculus hirtus, Banks \& Solander (R. plebejus, R. Br.; R. scapigerns, Hook,; R. colonorum, Endl.; R. discolor, Steud.), differs only from R. lappaceus in reflexed sepals, and forms most probably a mere variety of this species. It occurs in Victoria on the Moe Swamp and the Snowy River, and a form of it, with very flaccid stems, and scarcely to the middle cleft radical 3-lobed leares, has been observed at South Port, in Tasmania. It does not appear that the position of the nectar-gland can be relied on for distinction of species in this genns. The R. lappaceus approaches very closely to the European $R$. repens, $L$., from which it differs chiefly and perhaps not specifically in not producing creeping scions. In the absence of specinens of Ranunc. geranifolius in our public herbarium, I have not ventured to refer that species to R. lappacens, although its description and figure (Fl. of N. Zealand, i. p. 9, t. iii.) would point to such a reduction.

Ranunculus rivularis, Banks \& Solander, in Cand. Syst. i. 270; R. acaulis, B. \& S. loc. cit.; J. Hook. Fl. Antarct. i. p. 4, t. 2; R. inundatus, R. Br. in Cand. Syst. 7.c.; R. glabrifolius, Hook. Journ. Bot. i. 243; R. nacropus, J. Hook. Teon. Plant, t. cdxxxiv.; R. incisus, J. Hook. Flor. of N. Zeal. i, p. 10, t. iv.; R. inconspicuus, J. Hook. Fl. of Tasm. i. p. 9, t. ii. B.-Rivulet Crowfoot.

Glabrous, rarely scantily appressed-hairy, perennial; stems creeping or stoloniferous, or in part flaccidly erect; leaves small on long' petioles, some rarely kidney-shaped and crenate, the majority deeply divided into three rarely five or more primary segments, which are simply or repeatedly cleft into several lanceolate or oblong- or lanceolate- or narrow-linear, or cuneate or' even rhomboid lobes, or are perfectly entire or toothed; peduncles radical, or opposite to the stem-leaves, one-flowered; sepals spreading, three times or less shorter, rarely longer, than the corolla; petals yellow, cuneate-oblong, 5-12; receptacle short-hairy; carpels round or oblique-ovate, rather turgid, somewhat fleshy, suddenly terminated in a slender almost straight style.

In swamps, rivulets, marshes, or inundated places, or amongst river-reeds, from the coast to the higher Alps, as well in brackish as in fresh water, scattered throughout the colony of Victoria. It is also ascertained to extend from Moreton Bay to the Darling and St. Vincent's Gulf, althougll the plant is rare in most parts of South Australia. Dr. Hooker found it in Lord Auckland's Group and in New Zealand; and if, as seems more than probable from the figures in Hook. Icon. t. 677 and 497, and in J. Hook. Flor. Antarct. ii., t. 81, R. stenopetalus, R. biternatus and R. crassipes are belonging to our R. rivularis, then this species extends to Chili, Magellan's Strait, the Falkland Islands, and Kergnelen Land. If so, the name R. biternatus, given by Sir James Smith, would claim priority. That plant is certainly described by Candolle as a white-flowered species in the Batrachium section; but J. Hooker already transfers it to that of Hecatonia, and points out its close affinity to R. crassipes, thus leading to suppose that it is yellow-flowered (Conf Flor. Antarct. ii. p. 224). Nodes of the creeping rhizome enlarged at times to small globular tubercles; fibres of root occasionally much thickened at the extremity. Remnants of leaf-staiks bristle-like. Stems, when erect, from $1 \frac{1}{2}$ inch to several feet high, according to their growth in shallow or deep water, and varying like the peduncles and petioles much in thickness; both the latter occasionally, particularly when the plant occurs in drier localities, at the apex downy or appressed-liairy. Leares from a few lines to 2 inches loug, showing an endless play of modifications, often resembling the more dissected floating leaves of R. aquatilis, generally smootl, rarely and then scantily clothed with appressed hairs. Sepals 5, or (according. to J. Hook. Fl. Antarct. i. 5) occasionally 3, orbicular-orate or roundisl, in age reflexed. Petals 1-7 lines long; their claw long or short, and accordingly the nectar-pit, which is rariable in form, more or less distant from the base of the petals. Stamens several or numerous. Anthers orate or didyinons. Carpels $\frac{3}{4}-1 \frac{1}{2}$ line long, in drying longitudinally or transversely corrugated, with a more or less elongated rarely recurred style.

It is most probable that several other supposed distinct Ranunculi, particularly Anierican ones, are to be reduced to this species. Its luxuriant forms much resemble the smaller varieties of the R. lappaceus. It Howers throughout the year. 
Sect. III. Echinelda, Cand. Prodr. i. 41.

Petals generally yellow, with a scaly nectar-pit. Carpels scabrous or prickly.

Ranunculus parviflorus, Linné, Sp. Pl.780; R. sessiliflorus, R. Br. in Cand. Syst. i. 302; R. Pumilio, R. Br. l. c. i. 271; R. pilulifer, Hook. Icon.600; R. leptocaulis, Hook. Joum. Bot. i. 244.-Smallflowered Crowfoot.

Stems annual, erect or procumbent, as well as the leaves villons, rarer smooth; leaves small, simply or doubly three-lobed or three-toothed or bi- and tri-ternately dissected; lobes or segments ovate, lanceolate, cnneate or linear, generally with a few acute teeth; flowers opposite to the leares on a thin peduncle or sessile; sepals at last reffexcd, small, not, or but little, rarely considerably, shorter than the yellow petals; stamens few; receptacle smooth; carpels compressed, with a smooth edge, covered, with short hair, minute tubereles, or short hooked bristles; finit-style recurred at the summit.

On moist pastures and banks of rivers and lagoons, not rare. Distributed over nearly the whole of extratropical Australia and throughout Tasmania. Found also in New Zealand, Middle and South Europe, North and South Africa, and North America.

A flaccid herb, varying in length between 1 inch and $1 \frac{1}{2}$ foot. Stems often numerous, either fewbranched or simple; their upper part sonetimes appressed-lairy. Root consisting of a bundle of fibres. Leaves mostly $\frac{1}{2}-1 \frac{1}{2}$ inch long, the lower on longer, the upper ones on shorter petioles; their segments not rarely stalked. Flowers more frequently stalked than sessile. Peduncles very short or upwards of an inch long, very slender, furrowed. Calyx hairy. Petals oblong; yellow, five, or occasionally only $3-4$, measuring 1-1 $\frac{1}{2}$ line. Anthers oval. Carpels brown, never quite smootl, generally not numerous, still occasionally so, forming a globular head, $\frac{2}{3}-1 \frac{1}{2}$ rarely 2 lines long, noderately or slightly turgid, or less commonly flatcompressed, oblique ovate or nearly orbicular, sometimes with a conspicuous flat acumen, formed by the enlarged base of the style, but in other instances with an inconspicuous apex, all intermediate forms occurring.

If, as may be presumed, this species is a cosmopolitan one, then many others yet described from various countries will be combinable with it. The close affinity of Ranunculus sessilifforus and Pumilio to R. parviflorus has already been pointed out by Candolle (Syst. Veg. i. 271 and 302), and by J. Hooker (Flora Tasmanica, i. 10); but their real identity had long been manifest to me, when observing the manifold varieties of this species in various parts of this country. The European specimens which I compared lave rather larger carpels.

The Ranunculus muricatus, $L$., not being indigenous here, although now wild around Melbourne, has been omitted in this enumeration. It differs but slightly, perhaps not even specifically, from $\mathrm{R}$. parviflorus, cliefly in general smoothness and in larger size of all its parts. I find its sepals in the fresh state perfectly reflexed, and occasionally its carpels smooth.

Sect. IV. Pseudadonis, $F$. $M$.

Petals yellow and purplish, with three naked nectar-pits above the base. Carpels smooth.

Ranunculus Gunnianus, Hook. Jormn. of Bot. i. p. 245, t. cxxxiii.

Stemless, perennial, erect; fibres of root thick, fasciculate, rarely in a creeping rhizome detached; petioles generally much longer than the leaves, at the base shagged-silky, surrounded by the bristly remains of decayed leaf-stalks; leaves glabrous or scantily hairy, simply or oftener double-pinnatisected; segments rather fleshy, short, narrow-lanceolate or linear, acute, entire or again cleft, with a terminal gland; peduncles one- rarely two-flowered, bractless, rarely witl a solitary linear bract, silky-hairy, smooth in age, except the summit; petals 5-10, oblong- or rarely obovate-cuneate, inside yellow, outside purplish, generally not much 
longer than the glabrous appressed calyx ; receptacle smooth; carpels ovate or globose-ovate, turgid, smooth, terminated conspicuously into an angular generally straight style.

On grassy places throughout the greater portion of the Australian Alps, at an elevation from 4500 to 7000 feet; Mount Buller, Mount Wellington, Munyang Mountains, \&c. Found also on the highlest mountains of Van Diemen's Iand as far south as Mount Lapérouse.

A beautiful, slightly acrid herb. Fibres of root from one to several inches long. Leaf-stalks 1 to 6 inches long; leaves $\frac{1}{2}-1 \frac{1}{2}$ inch long; the segments of the latter carnulent, shining, seldom longer than half an inch, often much shorter. Peduncles rather stout, 1-10 inches long, extending frequently beyond the leaves. Sepals oblong, 4-6 lines long, often purplish outside like the corolla. Petals $\frac{1}{2}-1$ inch long, occasionally of twice the length of the calyx. Stamens short. Anthers oblong-oval. Fruit-head nearly globose. Carpels and style together about $1 \frac{1}{3}$ line long; the latter sometimes hooked at the extremity.

Tribe IV. HELLEBORE无, Cand. Syst. i. 306.

Sepals generally petaloid, imbricate in restivation. Petals wanting, or $5-10$ of irregular form, in many instances two-lipped. Carpels generally free, bursting longitudinally along their inner side, containing more than one seed. Seeds horizontal.

\section{CALTHA.}

Linné Gen. 703.-Marsh-Marygold.

Sepals 4-8, petaloid. Petals none. Stamens 5, several, or numerous. Carpels 3-10, or numerous, compressed, free, spreading, one-celled, arranged in a single whorl, few- or many-seeded. Seeds ovate. Chalaza fungous,-Endl. Gen. 4786 .

Smooth perennial plants, growing in swamps or lhumid localities, chiefly of the colder zones; roots fibrous; leaves entire, toothed or rarely lobed ; flowers terminal, yellow or white, rarely dicecious.

\section{Sect. Psychrophila, Cand. Syst. i. 307.}

Leaves all radical, with appendages at the base. Peduncles one-flowered, bractless.

The species of this section are dispersed over the colder parts of South America, the Antarctic Islands, and the Alps of New Zealand and Australia.

Caltha introloba, F. M. in Transact. Phil. Soc. Vict. i. 98.

Dwarf; leaves on long petioles, hastate-ovate, with a notch at the apex, perfectly entire, shining, enlarged at the base by two long lobes, which are generally nearly oblong-linear, bent upwards, at their origin dilated, very rarely wanting; peduncles one-flowered, very short; sepals white, 5-8, deciduons, lanceolate-linear, acuminate; carpels free, $5-9$, with a long' straight at the apex reflexed style, $3-4$-seeded.

On gravelly places in the Australian Alps, irrigated during the summer by melting snow; at Mount Hotham, Mount La Trobe, and the Mrunyang Mountains.

A remarkable little plant, with the habit of an Alisma. Root perennial, producing one or several stems, descendent, $\frac{1}{2}-2$ inches long, with numerous stoutish fibres. Stems none; but the broad membranous truncate vaginæ form, by involving each other, a stem-like cylinder, to the length of from $\frac{2}{3}$ to $2 \frac{1}{2}$ inches, which gives the appearance as if the leaves arise from it in a whorl. Petioles 1-4 inches long, comparatively thick; their sheath reacling nearly to the niiddle. Leaves more or less turning black in drying, vividly green when fresh, $\frac{2}{3}-1 \frac{1}{2}$ inch long exclusive of the appendages, nearly coriaceous, beautifully shining, finely veined, hastate-ovate or occasionally somewhat more oblong or cordate; their two basal 
appendages turn inward, either horizontally towards the centre of the plant, or assume a more or less erect position, or are perfectly accumbent to the lamina, frequently lying across each other, sometimes almost equal in length to the lamina, whilst in other specimens they are more or less shorter, or become even, in rare instances, perfectly obliterated. The structure of the appendages is quite leafy; their form varies from a dimidiate-hastate one to that of a dimidiate-cordate or semi-sagittate. Peduncles furrowed, bnt little or hardly protruding beyond the vaginæ of the leaves. Flowers $\frac{1}{2}$ to nearly 1 inch in diameter, only seen in a nearly decayed state, but evidently white, and certainly not merely bleaclied in age. Stamens unknown. Carpels compressed, rhombeo-deltoid, about $1 \frac{1}{2}$ line long, terminated by a comparatively straight style of half or less than half their length, arranged in a single circle on the torus. Seeds ellipsoid-ovate, affixed to the ventral side of the carpel, some distance from the sutural margin.

This species differs from Caltha Novæ Zelandire, which, as the author of the Flor. of New Zealand justly observes (v. i. p. 12, t. vi.), is almost intermediate between the Fuegian C. sagittata and C. appendiculata, in white, not yellow, flowers, in generally longer appendages of the lenves and a straighter style. Yet since Dr. Hooker saw the New Zealand species only in a dried state, it is very possible that his description of the flowers, as regards their color, requires alteration, and that the Australian and New Zealand species may prove identical, since moreover they are accompanied on some localities by other alpine species common to botl countries; viz., Veronica tetragona, Drosera Arcturi, Pentachondra pumila, \&c.

The tendency of this singular plant and its allies to turn the lower lobes or appendages of its leaves upwards in so singular a manner, is an admirable provision of nature by which the whole leaf of the plant is preserved against the current of icy water into which the lower part of the plant is immersed, and which would annihilate the healthy function of the former. Whilst the direct contact of the water with the leaves would destroy them, the lower and exposed part of the plant is protected by the slimy envelope which the decay of the old leaf-stalks forms around them.

It flowers, notwitlistanding the high elevation of its localities, already early in the spring.-Conf: F. M. in Hook. Ken Iriscell. vii. p. 234.

Besides those mentioned in the preceding pages no other clearly limited species of this order seems to exist in any part of Australia hitherto botanically examined.

\section{ORDER CABOMBEA.}

Rich. Anal. Fr. 68; Hydropeltideæ, Schleid. in Wiegm. Archiv. v. 230.

Sepals 2-4, distinct, hypogynous, persistent, imbricate in præflorescence, petaloid or inside colored. Petals persistent, 2-4, alternate with the sepals, hypogynous, free, with imbricate æstivation. Stamens free, definite or indefinite, hypogynous, alternate with and opposite to the petals. Anthers extrorse (in Cabomba), introrse (in Brasenia), bursting lengthwise. Torus inconspicuous. Pistils 2-18, free, verticillate. Ovules orthotropous, pendulous, 2-3, affixed along the ventral suture. Carpels indehiscent, 1-2- rarely 3-seeded. Arillus wanting. Seeds ovate or globose. Embryo minute, external, at the base of an abundant albumen, inclosed in a vitellus. Radicle pointing from the hilum.

Perennial aquatic herbs. Petioles not distinctly vaginate. Stipules wanting. Floating leaves centrally peltate, undivided or with a single sinus; submersed leaves, when present, dissected into numerous hair-like segments, at least partially opposite 
or ternate. Peduncles axillary or lateral, one-flowered. Flowers hermaphrodite, white, yellowish or sordid-purple. Seeds often rough or streaked.-Torrey \& Gray, Flora of North Anerica, i. p. 54; Endlicher, Genera, p. 901 ; Lindley, Vegetable Kingdom, ed. iii. p. $4: 12$.

The plants forming the small order of Cabomber are only to be found in tropical and in northern temperate America, and in eastern extratropical and subtropical Australia. They establish a transit from Ranunculaceæ to Nymphæaceæ, and seeming also to Ceratophyllex, and have indeed been referred to the former, after the suggestion of Jussieu, by Batsch and G. Gardner (Hook. Tcon. Plant. 641). The species of Cabomba resemble in habit the Ranunculi of the Batrachium section, and also to some extent those of Ceratophyllum, whilst those of Brasenia may, in external resemblance, be compared to Caltha. Were it not for the structure of the seeds, fully elucidated by Schleiden, the view of Gardner, that they should form a tribe intermediate between Ranunculex and Helleboreæ, could be readily adopted.

\section{BRASENIA.}

Schreber, Gen. p. 372.

Sepals 3-4, colored within. Petals 3-4, not auriculate. Stamens 12-36. Anthers introrse linear. Ovaries 4-18, with a sessile compressed cylindrical not terminal minute stigma.

An American and Australian water plant, with epidermis of stem, peduncle and lower page of leaves thickly gelatinous, with long-stalked uniformly oval leaves and dull purplish flowers.-Cand. Syst. Veg. ii. p. 37 ; Asa Gray, Popular Flora, 121.

Brasenla peltata, Pursh, Flor. Bor. Americ. ii. p. 389; A. Gray \& Sprague, Gen. Flor. Amer. Bor. 39 ; B. Hydropeltis, Rafin. Medic. Flor. of Unitcd States, t. 17; Hydropeltis purpurea, L. C. Richard, in Michaux' Flor. Bor. Amer. i. 324, t. 29 ; Lamarck, Encycl. Meth. t. 967; Sims, Bot. Mag. t. 1147; Turpin, Dictionnaire des Sciences Naturelles, t. 81; Annal. Nat. Hist. 1853, t. 3.

In the Campaspe River, according to Mr. Walter Hill. Extends to the tropic of Capricorn, along the east coast of Australia, and is also a native of North America.

Stems long, terete. Leaves oval or elliptical, perfectly entire, $2-4$ inches long, $1 \frac{1}{2}-2$ inches broad, with radiating beneath prominent nerves, net-reined, on very long petioles. Peduncles generally shorter than the petioles, inserted aside the base of the latter. Sepals oblong-lanceolate, of the flower about 4 lines, of the finit about 6 lines long. Petals of the flower nearly $\frac{1}{2}$ inch, of the fruit almost 1 incli long, more spreading than the sepals, generally more acnte and of a deeper purple. Filaments capillary, about as long as the antlers, the latter oblong-linear, dark purple, 2 lines long. Polleu-grains ovate-globose, with a longitudinal fissure. Ovaries narrow. Stigma lining the capillary style, nearly 2 lines long, and when fresh $\frac{1}{3}$ line broad, persistent. Carpels $2-3$ lines long, turgid, gradually tapering into the base and apex, $2-3$ lines long, more frequently with one than two seeds. Seeds nearly $1 \frac{1}{2}$ line long, ovate-globose.

The occurrence of this American species forms, notwithstanding the ascertained extensive range of many water plants, still a curious instance of the geographical distribution of many plants over the world, inasunuch as it has not yet been noticed in any intermediate country. There appear to be no specific differences between the Australian and American plant, nor can we assume that it is of American origin and accidentally introduced into this country. 


\section{ORDER DILLENIACEA.}

Salisbury, Parad. Lond. 73.

Sepals persistent, seldom deciduous, 5, rarely more, very rarely numerous, distinct, hypogynous, imbricate in præflorescence. Petals 5, rarely 6, free, imbricate in restivation. Stamens hypogynous, free or connate, 3, several or numerous. Anthers introrse, or rarely with marginal dehiscence, bilocular; cells adnate, bursting lengthwise or rarely with a terminal pore. Pistils generally few, sometimes solitary or numerous. Ovaries free or coherent. Ovules frequently more than one, anatropical, fixed to the inner and sutural edge of the ovary. Carpels one-celled, with one or several seeds. Secds with rarely without an arillus. Albumen large, fleshy. Embryo minute, erect, lodged at the base of the albumen.

Trees, or more frequently shrubs, rarely suffiuticose plants, never annual herbs, without aroma or acridity. Leaves alternate or fasciculate rarely opposite, simple. Stipules very rarely present and then early deciduous. Hair, when present, simple and radiate-branched.-Cand. Syst. Veg. i. p. 395; Endl. Gen. 839; Lindl. Veg. Kingdom, ed. iii. 423.

This order is closely allied to the preceding one, indeed scarcely claims a higher rank than that of a suborder. It counts members in all equinoctial countries, but scarcely reaches beyond the tropic in the northern hemisphere, whilst in Australia the extratropical species are far more numerous than those occurring within the tropics. Of the tribe Delimeæ, distinguished by broad anther-cells, disunited by a dilated connective, no indigenous genus has been noticed in this part of the globe; yet it is not unlikely that in the unexplored ranges and jungles of North-East Australia delimeous genera will be discovered, since Tetracera occurs as far south as New Caledonia. In a collection of several hundred plants, gathered during $\mathrm{Mr}$. Babbage's expedition into the country north-west of Spencer's Gulf, not a single dilleniaceous plant occurred.

Tribe I. DILLENE无, Cand. Syst. i. 411.

Anther-cells narrow: Connection not dilated.

HIBBERTIA.

Andr. Bot. Repos. t. 126; Pleurandra et Candollea, Labill. Nov. Holl. Plant. Specim. ii. 5 \& 33, t. 143, 144, \& 176; Cand. Syst. i. 415, 423, \& 425; Adrastæa, Cand. Syst. i. 424.

Sepals 5, coriaceous or membranous. Petals 5, deciduous. Stamens 3 or more, persistent, all fertile, either surrounding the ovaries or unilateral. Filaments free, all or partially united into 1-5 bundles. Anthers oval or oblong, bursting by longitudinal introrse or marginal slits, connective more narrow than the linear or filiform-linear filaments. Styles capillary or rarely subulate. Stigma minute. Ovaries generally few, rarely one or numerous, free or coherent, with few or several ovules. 
Carpels membranous or coriaceous, dehiscent at their inner side along the ventral suture, with a few or one rarely many arillate seeds.

Shrubs or suffruticose plants dispersed throughout Australia and Tasmania, of erect procumbent or climbing habit, smooth or with a variable indument often of starry hairs, with coriaceous or herbaceous leaves of various forms, often revolute seldom toothed at their margin, with short or obliterated petioles; with solitary rarely crowded or racemose hermaphroditic at last dropping flowers, which are articulated with the persistent often uni-bracteate and not rarely obliterated peduncle, with tender yellow obcordate or obovate-cuneate glabrous petals, with small mostly ovate carpels, with brown or blackish shining seeds and a cupular truncate jagged or fimbriate generally membranous arillus.

The genus Pachynema, of which the only known species has been observed more recently on Macadam Range, differs from Hibbertia-as limited on this occasion-scarcely except in habit, thick filaments and solitary ovules, Hemistemma only in having part of the filaments deprived of anthers, and Wormia in anther-cells bursting by terminal pores and in producing stipules, whilst Ochrolasia, according to Turczaninow's description, is distinguished by petals connate at the base and in lateral styles. This latter genus is, however, in all probability, referable to Hibbertia. Between the genera here drawn together under the name of Hibbertia no clear limitation exists, nor are their respective species separable upon habitual differences. Hemistemma shows, according to recent discoveries, the same inconstancy in regard to the arrangements of its stamens as Hibbertia.

\section{Sect. I. Pleurandra, Labill., R. Brown, Cand. l. c.}

Stamens unilateral

Fribbertia Billardierii.-Pleurandra ovata; Labill. Nov. Holl. Plant. Specim. ii. 5, t. 143; P. parvitora, R. Br. l. c.; P. astrotricha, Sieber in Spreng. Syst. Veg. iv. 191, according to J. Hooh. Fl. Tasm. i. 16 ; P. scabra, R. Br. in Cand. Syst. i. 419.

Stems erect or nearly climbing; leaves obovate or oblong-cuncate, rarely linear-oblong, with recurred margin, ghabrous or scantily stellate-hairy or densely tomentose, above frequently asperons; peduncles of the length of or longer than the flowers, witl a solitary terminal linear-subulate bracteole; ovaries two, tomentosevelutinous; carpels 1-2-seeded; arillus truncate or lacerated, membranous, of more than half the length of the seed.

On forest-ridges, in swamps replete witl scrub and in rocky or sandy wooded vallies scattered orer the southern part of the colony; near Rivoli Bay, at Sealer's Core, on MLount Hunter, the Snowy River, the Broadrib Ranges, \&c. It extends to the Glasshouse Mountains of MIoreton Bay, and is known also in one locality at Spencer's Gulf.

A shrub varying from 1 to 10 feet in height, strictly erect or flaccid and accumbent to other plants, rarely prostrate. Branches clothed with minute floccous or with scattered starry downs, or with strigose or copious long and soft hair. Leares blunt, coriaceous or subherbaceous, one-nerved, distinctly reined, $\frac{1}{4}-1$ inch long, $1 \frac{1}{2}-6$ lines broad, on short petioles, either on both pages smooth or above corered with little rough tubercles and deciduous simple hair, or on both sides tomentose or clothed with simple and starry hair, their margin sometimes almost flat. Peduncles $1-1$ inch long, downy, slender, axillary and terminal, solitary, persistent as in the other species, but after the lapse of the calyx assuming a tendril-like appearance, bearing at the summit a persistent bracteole, which varies in length from 1-4 lines. Sepals scabrous and hairy, or strigose, or hirsnte; the onter ones lanceolate-ovate, acuminate or cuspidate, $1 \frac{1}{2}-3$ lines long; inner ones often longer, nearly orbicular, blunt or pointed, with broad membranous margin; all united at the base. Petals obcordate-cuneate, or broad-obcordate, as long as the calyx, or of twice or three times its length, with 
deep terminal sinus. Stamens 3-25, with filaments either almost free, or beyond the middle united. Anthers oblong, equal to or exceeding the length of the filaments with evidently introrse dehiscence. Styles comparatively short. Carpels 1-2, outward somewhat downy, inward glabrous, nearly as long as the calyx. Seeds oblique ovate-globose, shightly compressed, 1 line long, nearly black, shining, often for the greater part enclosed in the arillus.

P. nitida, $R$. Br., which extends perhaps to the eastern part of Gipps Land, differs cliefly from $P$. ovata in sessile flowers and in the form and smoothness of the sepals.

Some marked forms of $\mathrm{P}$. ovata may be distinguished as varieties; for instance, a small flowering one, growing in swamps, producing but few stamens and small generally velvety leaves; a rouglı-leaved more glabrous trailing variety, occurring in the underwoods of forests; and a large-leaved form, more frequently to be found on or near the coast, remarkable for its conspicuous flowers witl monadelphous numerous stamens. A copious set of specimens in omr collection shows, however, the above notes as of no avail for specific discrimination. Dr. Hooker's researches in this genus liave realized similar results.

Iribbertia densiflora.-Pleurandra sericea, R. Br. in Cand. Syst. i. 416; P. cinerea, R. Br. l.c.; P. densiflora, Hook. Journ. of Bot. i. 245.

A low strictly erect or ascending shrub; leaves linear-or cuncate-or laneeolate-oblong, with recurved or revolute margin, and a strong midrib, lirsute, pubescent, velvety or scantily downy, or above glabrous, floral ones crowded; flower's hardly as long as the leares, sessile or on very short peduncles, scveral at the summit of the branehlcts, rarely solitary; sepals hirsute-silky; ovaries 2, velntinons; carpels 2-3-seeded; arillus flcshy, less than half as long as the seed, hardly sinuate.

In sandy heatly plains, on bar'en scrubby ridges, and occasionally on rocky ranges; from the Glenelg to the Murray River and its tributaries, and thence to Port Plillip; on Futter's Range, on granite ranges on the Broken River, \&c. Found also in the south-eastern part of the colony of South Australia and in Tasmania.

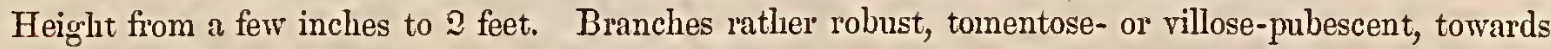
the summit more silky or hirsute. Leaves coriaceons, rarely ovate, subsessile, $1-1$ incl long, 1-2 lines broad, scarcely acnte, the floral ones often increased in breadth; their nerve above impressed, beneatli strongly prominent and rarely touched by the recurved margin of the leaf. Peduncles stout, 1 line long or obliterated. Flowers several or solitary, terminal, witlout scent. Sepals $3-4$ lines long; outer ones lanceolate, inner ones ovate with petaloid margin, the former outside densely, the latter only along the middle part silky-liirsute. Petals obcordate-cuneate, about twice as long as the calyx. Stamens 7-20. Filaments shorter than the anthers, connate at the base. Anthers oblong, nearly 1 line long, with distinctly introrse deliscence. Styles $1 \frac{1}{2}$ line long, incurved. Carpels about 3 lines loug: Seeds brown, oblique ovate-globose, 1. line long: Arillus livid, cupular, subsinuate or repand, not or only towards the margin menbranous.

The description of the fruit is furnished from a specimen grown on granite rocks at the Broken River.

This species is generally well recognized, but there exist certain forms of it which render its discrimination from Hibbertia stricta somewhat difficult.

Neitler of the specific names adopted by R. Brown for this species applies well to its normal form.

Fibbertia stricta, R. Br. in Cand. Syst. i. 422; Pleurandra ericifolia, Cand. Syst. i. 420; P. empetrifolia, Cand.l.c.; P. intermedia, Cand.l.c.; P. enervia, Cand.l.c.; P. stricta, Cand.l.c., Sehlecht. Linnaa, 1847, 625; P. calycina, Cand. l.c.; P. riparia, R. Br. l. c., J. Hook. Flor. Tasm. i. 17; P. incana, Lindl. in Mitehell's Three Exped.; P. cistoidea, Hook. in Mitchell's Trop. Austr. 363.

An erect, spreading or prostrate slirub; leaves linear, rather blunt, scabrous, smooth or velvety or clothed with scattered stary lair; their margin repressed; flowers sessile or short-stalked rarely longstalked bracteate; sepals lanceolate or inner ones ovate; petals obcordate; stamens-5-20; ovaries 2-3, velvettomentose; carpels 1-2-seeded; arillus membranous, about half as long as the seed, lobate or truncate. 
In sandy rocky or heathy localities of the lowlands and hills not rare. It extends also all orer Tasmania and to Spencer's Gulf, and throngh New Sonth Wales, as far as the tropic of Capricorn, and seemingly also to the west coast of Australia.

A bush of variable habit, from a half to several feet high. Branches angular, glabrous or short-downy. Leaves generally spreading, coriaceous or herbaceous, short-stalked, rarely acute, never mucronate, $\frac{1}{6} 1$ inch long, $\frac{1}{2}-1$ line broad; the edges closely revolnte into a narow margin, the interstice between the margin forming a broad flat keel, rendering thereby the lower side of the leaves apparently bistriated; surface nerveless. Cicatrix bearded. Flowers mostly terminal, when sessile bracteate by a few diminutive leaves, when stalked furuished at the summit of the peduncle with a solitary bracteole of the form but not fully of the size of the leaves. Pedincles reflexed in age. Flowers inodorons. Sepals about $\frac{1}{1}$ inch long, generally acite, at last spreading; the outer ones lanceolate, the inner ones ovate, often bearded at the apex, smooth or powdery downy, or less fiequently silky. Petals surpassing but little or half the lengtli of the calyx. Stamens fiee or connected at the base. Anthers oval or oblong, blunt, broader towards the base, $\frac{2}{3}-1$ line long, with decidedly introrse dehiscence. Pollen-grains ellipsoid, with very bhunt extremities, bursting by a longitudinal slit. Styles abont 2 lines long, in age inflexed-uncinate. Carpels varying in length according to their $1111 \mathrm{mber}$ of seeds. The latter ovate-globose, somewhat compressed, dark-brown, shining, hardly 1 line long. Arilhus closely appressed.

Although I enjoyed not the advantage of comparing authentic specimens of those plants which 1 quoted as synonyms of $H$. stricta, I can hardly entertain any doubt about their invalidity as species. P. Iypericoides, $D C$, according to a Preissian specimen, appenrs liardly specifically distinct. On the sterile ranges of the Aron in Gipps Land occnrs a variety well responding to the definition of $P$. calycina, which deserves special notice on account of tall and strict growth, acute leaves and silky calyx; this rariety resembles strongly certain Pultenæas in habit.

Iribbertia humifusa.-Pleurandira Immifusa, F. MI. Second Gen. Repmt, p. 9.

Stems much brancled, procumbent; leares linear, s'ather acute, glaucous, witl revolute margins, as well as the branclilets hirsutc; peduncles not much longer than the cbracteolate floner; sepals large, broadovate, liirsute-pubescent, at last connivent; petals obovate-cuneate, slightly emarginate, liardly as long as the calyx; stanens $6-9$; oraries 2, relntinous, with about 6 ovules ; carpels 4-6-seeded; arillus membranous, truncate or toothed, of less than half the length of the seed.

In barren scrubby plains near Mount Zero.

Stems numerous, spreading in all directions, about 1 foot long. Leaves crowded, 3-5 lines long, tapering into the base and summit, with narrow closely revolute margin, which, however, is not so evidently repressed as in $H$. stricta, although fully or nearly tonching the narrow midrib. Pedincles curved, hirsutepubescent, often below the middle provided with a solitary bract, which is $1 \frac{1}{2}-2$ lines long, but deprived of a terminal bracteole. Sepals 4-5 lines long, rather acnte, inward somewhat velntinous, the onter ones remarkably broad. Petals about 3 lines long, not, as in the generality of the species, cleft by a deep or acute terminal simus, nor considerably upwards dilated. Filaments free, scarcely longer than the linear-oblong anthers. Dehiscence of the latter nearly marginal. Ovaries in coalition, with velutinous carity. Carpels concealed in the connivent calyx, with which they form an almost globular finit. Seeds barely 3 line long, shining-brown, renate-globose. Arillus closely appressed, generally several times shorter than the seed.

Allied to H. stricta and H. hirsita.

Flowers early in tle spring:

Supplemental Plate I. 1, leaves; 2, transverse section of leaves; 3 , flower ; 4, sepals; 5 , petal; 6 , anthers; 7 , pollen-grains; 8 and 9 , ovary, showing relative position of stamens; 10 and 11 , longitudinal section of carpel; 12, seeds : all figures morc or less magnified. 
Iribbertia acicularis.-Pleurandra acicularis, Labill. Nov. Holl. Plant. Spec. ii. p. 6, t. 144.

A small procumbent or diffused shrub; branches furrowed; lcaves glabrous, rigid, linear, acute, mucronulate, with repressed margins; peduncles as long as or longer than the bractcolatc calyx; sepals slightly downy, nearly ovate and orbicular; stamens 5-8; ovaries 1-2, velvet-downy; carpels 1-2-seeded; arillus membranous, obscurely lobed.

On heatly ground, particularly in moist localities near the sea-coast; at Wilson's Promontory, Port Albert, the entrance of the Snowy.River, between La Trobe River and Merriman's Creek. Occurs also in the northern parts of Tasmania, on the islands of Bass's Straits, and in New South Wales as far north as Moreton Island.

A weat little plant, fion a few inches to one foot high, with spreading stems and branches. Root tortuous, not mucl divided. Branches brown, smooth; their bark grey, finally peeling off. Leaves strongly resembling those of some epacrideous plants, stiff, 2-10 lines long, $\frac{1}{3}-\frac{2}{3}$ line broad, on very short stalks, nerreless, shining, smooth or on the upper convex side slightly tubercled, blunt at the base, with narrow closely repressed margins, thus apparently bistriate beneath; their axils bearded. Peduncles axillary and terminal, solitary or rarely twin, glabrous, producing at the summit and occasionally also below the apex a small or diminutive linear-lanceolate or subulate bracteole. Sepals about 2 lines long; the outer ones cuneate- and spathulate-ovate; the inner ones more orbicular and with broader membranous margin; all connate into an attenuate base of the calyx, at the back scantily short-downy, at the top not distinctly mucronate. Length of the obcordate petals equal to or double that of the calyx. Stamens free, or at their base united, hardly longer than the oblong anthers, which measure in length $\frac{1}{2}-\frac{2}{3}$ line, and burst with introrse slits. Ovaries 2 or sometimes 1, velvet-downy. Styles 1-1 $\frac{1}{2}$ line long, capillary. Carpels 1-2-seeded, outside shghtly downy, inside glabrous, almost as long as the calyx. Seeds nearly globose, smooth, shining, dark-brown, 1 line long, half enclosed in the oblique white arillus.

Labillardière's figure does not well express the ordinary state of our plant. The leaves are not gradually attenuated into the base, but abruptly contracted into the stalk; the petals of our specimens are broader and extend considerably beyond the calys.

It flowers during the spring.

On stony mountains at Glen Osmond, in the Bugle Ranges, and towards Mount Remarkable (within the colony of South Australia), occurs a closely allied species, of which the fruit is yet unknown. It differs chiefly in higher erect growtl, sessile flowers, and glabrous sepals. P. acerosa, $R$. Br. in Cand. Syst. i. 422; P. juniperina, Turcz. in Bullet. MLoscou, sxii. 6, and P. mucronata, Turcz. l. c., 1852, 138, rank evidently near to P. acicularis. P. mucronata occurs on West Mount Barren.

\section{Sect. II. Crclandra. .Hibbertia, Andr, $R$. Brown, De Candolle $l . c$.}

Stamens surrounding the ovaries.

Hibbertia ericifolia, J. Hook. Flor. Tasm. i. t. 3.

Stems erect, diffuse or frequently procumbent, much branched; leaves small, linear or ovate-and oblong-linear, with revolute or refracted margin, glabrous, scabrous, or as well as the branches and sepals often liritellous; peduncles as long as or shorter then the calyx, rarely longer; flowers ebracteolate, terminal, solitary; sepals distinctly conmate at the attenuate base, at last spreading; petals obcordate-cuneate; stamens 8-15, irregularly approached in three fascicles or scattered; ovaries thrce, velutinous or tomentose, with 3-4 orules; carpels 1-3-seeded; arillus membranous, of less than half the length of the seeds.

On stony mountains, particularly in the highlands, also on subalpine meadows; for instance, on the Buffalo Ranges, on the ranges along the MIcAllister River, on MLount Wellington, near the Cobboras Mountains, \&c. It is known besides only as a native of Tasmania. 
Stems from a span to 2 feet long. Leares short-stalked, often crowded, $1 \frac{1}{2}-4$ lines long, $\frac{1}{2}-1$ line broad, somewhat acute, generally clothed with short stiff spreading hair arising from points, above nerveless. Peduncles variable in length, generally short, but sometimes obliterated or fully an incl long, townds the base often but not always provided with one or more minute ciliate channelled subulate bracts. Sepals about 3 lines long, generally hairy; the outer ones quite herbaceous, lanceolate or ovate-lanceolate, the inner ones ovate or ovate-orbicular, with membranous margin. Petals but slightly exserted. Anthers about as long as the filaments, oblong; with attenuate base and slightly emarginate apex, their deliscence introrse. Carpels about $1 \frac{1}{2}$ line long. Seeds shining, brown, nearly ovate, and 1 line long; witl a truncate or lobed arillus.

This species produces its flowers during the spring season. All its specimens contained in our collection are trigynous, by which note it differs already from $H$. pedunculata, $H$. serpillifolia, and $H$. aspera, all which species however require a new disquisition.

Eribbertia diffusa, R. Br. in Cand. Syst. i. $429 ;$ H. monogyna, R. Br. l.c.

Stems erect or spreading; leaves alternate or generally fasciculate, herbaccous, flat, obovate- or oblongcuneate, tapering into the petiole, blunt, entire or few-toothed towards the apex, one-nerved, not distinctly veined, either smooth or somewhat downy; on both pages opaque, of equal color, and often glancous; flowers sessile, terminal, solitary, without conspicuous bracts; outer sepals oblong, inner ones ovate, with membranous margin; petals elongate-obcordate; stamens numerons; ovaries 2-4, glabrous; carpels one-seeded; seed spheroid; arillus fringed many-eleft, of less than half the length of the seeds.

On wooded, barren or less fertile mountain ranges, in the enstern part of this colony, viz., from Dandenong to the Upper Yarra, the Rivers Goulbum, Delatite, Ovens, King, and Murray; also in many parts of Gipps Land; thence through New South Wales as far north as Moreton Bay.

A generally dwarf slu'ub, attaining however sometimes the height of several feet. Branches when young tomentose, in age glabrous. Petioles articulated with the prominent lengthened and almost clasping cicatrix, which may be regarded as their persistent base. Leaves $\frac{1}{2}-1 \frac{1}{2}$ inch long, 2-6 lines broad, slightly fleshy, blunt, less commonly notched at the apex, not frequently toothed, often clothed with very short crisp solitar'y and fasciculate evanescent lair. Sepals ciliolate, outer ones $2-3$ lines, inner ones $3-4$ lines long. Bracts minute, lanceolate, deciduous. Petals $\frac{1}{3}-\frac{1}{2}$ inch long, with narrow base. Stamens $20-36$, on one side of the flower more crowded than on the other. Anthers oblong, abont $\frac{2}{3}$ line long, their dehiscence almost marginal. Filaments linear-setaceous, at last fully 2 lines long. Styles $3-4$. Ovaries with two onules. Carpels globose or ovate, or even ovate club-shaped, tardily dehiscent, $1 \frac{1}{2}-2$ lines long. Seeds spherical, shining brown, 1-11 line long; their deeply-cleft arillus lengthened considerably into a somewhat fleshy base.

Iribbertia angustifolia, Salisb. Parad. Londin. 73; Dillenia procumbens, Labill. Nov. Holl. Plant. Specim. ii. 16, t. 156 ; Hibbertia procumbens, Cand. Syst. i. 427 ; H. virgata, R. Br. in Cand. Syst. l. c., Hook. Icon. Plant. 267; H. fasciculata, R. Br. l. c.; H. prostrata, Hook. Jour. Bot. i. 246; H. glandulosa, Schlechtend. Limeaa, xx. 626; Pleurandra camphorosma, Sieber in Spreng. Cur. Post. 191.

Erect, spreading or procumbent, short-downy, silky-hairy, tomentose or glabrous ; leaves alternate or more frequently faseiculatc, linear or setaceous-linear, channelled or. flat, never revolute at their margin, often slightly dilated towards the summit, beneath convex; flowers axillary and terminal, solitary, sessile; bracts 1-3, scarious, broad-ovate or lanceolate or subulatc-lanceolate, cuspidate; outer sepals lanceolate-orate pointed, inner ones broad-ovate 'or roundisl, all with membranous margin; petals obcordate, with slight terminal sinus; stamens 7-24, partially and obscurely connected into bundles; anthers broad-or oblong-orate emarginate, below the middle not or tardily dehiscent; ovaries 3 , rarely $4-5$, glabrous; carpels 1-2- rarely 3-5-seeded; arillus decply and fimbriatcly many-cleft'. 
On sand-ridges, heath-ground, dry barren plains, and stony arid hills, thronghont this colony; common in the southcrn and south-eastern portion of South Australia, as far west as Spencer's Gulf, also in 'Tasmania.

A dwarf, sometimes diminutive slurub, occasionally a few feet lighl. Leares 2 lines to 1 inch long, $\frac{1}{3}-1 \frac{1}{2}$ line broad, often by strong marginal inflexion assuming a terete form, generally crowded, either erect or more or less spreading, the floral ones often membranous at the base, forming a kind of involncre. Bracts ciliate, in one variety conspicuous, $1 \frac{1}{2}-2 \frac{1}{2}$ lines long, passing gradually into the form of sepals, in another variety diminutive. Flowers of disagreeable scent. Sepals 2-4 lines long. Petals mensuring 3-5 lines. Filaments liardly or not much longer than the anthers; the latter $\frac{1}{2}-\frac{2}{3}$ line long, opening by marginal not distinctly introrse deliscence from the summit to about the middle, or at last to the base, often remarkably broad towards the apex. Pollen-grains ellipsoid, very blunt on both extremities, with a longitndinal fissure. Styles about $\frac{2}{3}$ line long. Carpels free, 1-1 $\frac{1}{2}$ line long. Seeds ovate or nearly globose, brown, $\frac{2}{3}-1$ line long. Arillus generally of more than half the length of the seeds.

There exist three forms of this species; the first a prostrate and sinootl one, with polyandrons flowers, which represents the typical H. angustifolia, and occurs in Tasmania and Gipps Land; the second is of more robust and generally erect growtl, produces broader leaves and broad scarious bracts to each flower, thus representing the $H$. virgata, which seems restricted to the northern part of Tasmania, and to the western and north-western portion of Victoria, being known in Gipps Land only on the sand-ridges near the La Trobe River, but occurs abundantly westward as far as Spencer's Gulf. The third rariety, characterized by short and narrow leares and minute narrow bracts, exhibits the normal $H$. fasciculata, which frequents Anstralia felix and Tasmania, but occurs hardly in South Australia. These varieties have at first sight the appearance of well-marked species, yet the analysis demonstrates no valid characters which would render their specific separation possible. Dr. Hooker combines (in Fl. Tasin. i. p. 13) witl H. angustifolia, as synonym, the H. obtusifolia, Cand. A series of numerous specimens from localities between Botany Bay and the Dawson River proves, however, that plant, as already suspected by De Candolle, to be a variety of $\mathrm{H}$. linearis, $R$. $B r$., which may be distinguished by leares more or less recurved at their margin, whilst in $H$. angustifolia a tendency is manifest of turning the margin of its leaves inward. The H. canescens mentioned in Sir Th. Mitchell's Tropical Australia, p. 339, and probably also Sieber's plant of that name, are identical witl H. linearis. Our collection contains no seeds of the normal Hibbertia angustifolia, but except in proportionate length those of $H$. virgata and fasciculata fully accord with Dr. Hooker's description of the former. Labillardière's account of them originated probably from immature specimens.

This plant is in flower during the spring and summer.

\section{ORDER MAGNOLIACE}

Juss. Gen. 280.

Flowers hermaphrodite, rarely polygamous or diœcious. Sepals 2-6, almost always deciduous, rarely wanting. Petals 2 or several, sometimes numerous, imbricate in æstivation, rarely missing. Stamens hypogynous, free, indefinite in number. Anthers introrse or extrorse, two-celled; cells bursting lengthwise, partially or wholly adnate. Ovaries arranged upon a torus either in a cone or in a whorl, rarely solitary, one-celled, with one or more anatropal orules. Style short or wanting. Stigma simple. Carpels distinct or partially connate. Seeds solitary or several, attached to the inner edge of the carpels, with or without an arillus. Embryo minute, at the base of a fleshy solid albumen. 
Trees and shrubs of generally tonic bitterness and conspersed with minute aromatic oil-gland, with evcrgreen or deciduous foliage, with stipules either fugacious or rarely wanting, with alternate or subverticillate never toothed and seldom lobed frequently dotted leaves enclosed in bud by a generally large stipular scale, with solitary seldom umbellate often large scented and showy flower, frequently before expansion spathaceous-bracteate, with sepals and petals in most cases ternate in each rovo, and with dry, baccate or samaroid carpels. The plants of this order are much more copious in North America and tropical Asia than elsewhere, and are not even found yet in Europe and Africa, nor in any other part of continental Australia than in the extra. tropical eastern and in the south-eastern portion.-Endl. Gen. 836; Torrey \&. Gray, Flor. of North Amer. i. 41; Lindl. Veg. Kingdom, ed. iii. p. 417.

This order is morc by the habit of its plants and their aromatic properties distinguished from Ranunculaceæ than by any constant or important morphological characters, but perhaps by the anatomical structure of its wood, which, at least in some species, according to Dr. Lindley and Dr. Hooker, resembles that of pines. The close relationship of this order to Schizandrex and Anonacer is manifest.

\section{DRIMYS.}

Forst. Char. Gen. t. 42; Winterana, Soland. Med. Observ. V. 46; Tasmannia, R. Br. in Cand. Syst. i. 445 \& 547.

Flowers hermaphrodite, polygamous or dicecious. Sepals 2-3, imbricate in æstivation, deciduous. Petals 2-24, in a single or a few rows, deciduous. Stamens extrorse, several or numerous. Filaments broad or thick. Cells of anthers distinct. Ovaries free, 1-10, when several forming a single whorl. Ovules numerous, arrayed along the ventral suture in two rows. Stigma sessile. Berry fleshy or dry, few- or many-seeded. Seeds curved, ovate or renate. Testa brittle, shining. Endopleura netted. Raphe thickened, in part free. Embryo straight. Radicle superior.

Smooth or nearly smooth bitter or pungent-aromatic evergreen shrubs or trees of cold regions, occasionally descending from the Alps to the lowlands, hitherto found over a great part of America, in New Zealand, Tasmania, South-Eastern Australia, and Borneo. Their leaves short-stalked, perfectly entire, ovate, oblong or lanceolate, transparently-dotted without proper stipules; Howers comparatively small, on slender pedicels; berries generally blackish.-Achill. Richard, Sert. d'Astrolabe, 50, t. 19 ; Endl. Gen. 838; Hook. Icon. t. 576 \& 896.

Sect. Tasmannia.

Flowers partially unisexual, generally monogynous. Stigma decurrent.

Drimys aromatica.-Tasmannia aromatica, $R$. Br. in Cand. Syst. i. 445; Deless. Ieon. i. t. 84; Lindl. Bot. Reg. xxxi. t. 43; J. Hook. Flor. Tasm. i. 11; Winterana lanceolata, Poiret, Dietion. viii. 799. - Native Pepper-tree.

Leaves oblong- or ovate-lanceolate, or narrow-oblong; generally blunt at the apex, gradually tapering into the acute base; umbels subsessile, nearly all terminal; flowers polygamous; stigma linear, introrselydecurvent; berries roundish. 
In humid forest-ranges, particularly along shady irrigated ravines, from Mount Disappointment and the Dandenong Ranges through the Western Port district, Gipps Land and the Australian Alps, particularly along the rivulets in higher regions and at the sources of rivers, ascending to an elevation of at least 5000 feet. Found also copiously in Tasmania and the isles of Bass's Straits.

A small tree, sometimes attaining a height of 30 feet, or a shmb of variable size, reduced on the summits of our Alps to very dwarf growth, but then often widely spreading. Branches terete, often subverticillate or fasciculate, covered with red-brown or dull purplish pungent-aromatic bark, with some rery deciduous oblong ovate or roundish scales at their base. Terminal buds, enclosed by caducous generally acuminate scales, from 1-4 lines long. Leaves 1-4 inches long, 3-10 lines broad, flat, generally thick coriaceous, sometimes chartaccous, mole or less distinctly veined, with a conspicuous middle nerve, blunt or somewliat acute, alternate or imperfectly whorled, erect or spreading, either rather opaque on both sides or shining abore, or occasionally glaucous beneatl, often with a reddish tint; their dots pellucid or not, according to the consistence of the leaves. Pcdicels from sereral lines to fully an inch long, few, sereral or numerous, generally forming truly terminal umbels, but by the elongation of the branclilets, or by the obliteration of the latter, the pedicels maj become rerticillate or lateral, surrounded by fast-dropping ovate-oblong or linear blunt or acuminate bracts, which are very short or upwards of half an inch long, and render, after their fall, by their cicatrices, the apex of the branchlets blunt. Unexpanded flower oblique orate-globose and pointed. Sepals dotted, almost constantly two, connected at the base, membranous, brown-reddish, ovate or orbicular, acuminate, $1 \frac{1}{2}-2$ lines long; their margins overlapping each other in præflorescence. Petals oblong- or linear-lanceolate, acute, tapering into the base, 2-8 in number, 2-4 lines long, white, with a red or green middle-streak, male and female organs frequently in the same flowers. Stamens 9-25. Filaments $\frac{1}{4}-1$ line long, ratlier thick, not flat, frequently dilated at the apex, and according to the width of the connective, to which the anther is obliquely outside adnate, the cells of the latter clearly or hardly separated from each other, and finally diverging. Anther-cells yellow, ovate, with extrorse dehiscence, about half a line long. Pollen-grains globose, uneren. Ovaries laterally lined by the adnate stigma, mostly one, but sometimes two or three, which seem to advance

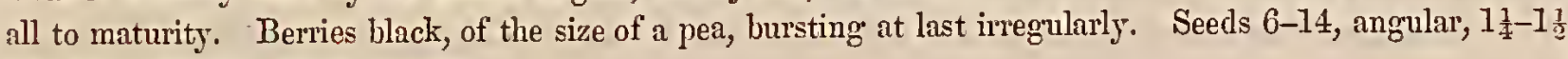
line long, shining, black, smooth.

The discovery of Drimys reticulata (J. Hook. Icon. Plant. 896), which produces declinous flowers and seemingly a lateral stigma, and the occurrence of di- and tri-gynous flowers in Tasmannia aromatica, render the separation of the respective genera untenable, moreover, since already Forster's plate clearly shows the terminal position of the stigma in Drimys axillaris and the lateral one in Drimys Winteri.

The Drimys dipetala (Tasmannia dipetala and insipida, $R . B r$.) occurs sparingly in New South Wales, fiom Mount Lindsay, where it was discovered by Walt. Hill, Esq., at least as far south as Illawarra, and possibly also within the boundaries of this colony near Cape Horre. It differs from D. aromatica in the very blunt base of the leaves, which become almost inflexed-biauriculate, in ovate fruit, with more fleshy pericarp, and perhaps also in the flower. T. monticola (Ach. Rich. Sert. d'Astrolabe, ii. t. 19) appears not to differ from the latter species.

The bark, leaves, and most other parts of Drimys aromatica, are of a strong acrid-aromatic taste, and may be substituted for the officinal Wintera bark. On account of the pungent aroma of the berries the tree received its colonial name.

No other but the two species here alluded to are known to exist in Australia. 


\section{ORDER MONIMIACEA.}

Juss. in Annal. Mus. Paris, xiv. 133.

Caly $x$ monophyllous, four- to many-cleft or operculate and without divisions, its lobes forming one, two or several rows. Petals none. Stamens indefinite, affixed to the base, sides or faux of the calyx. Anthers adnate, two-celled, extrorse or introrse, from the base to the apex opening either by longitudinal fissures or by valves. Staminodia of varied form or wanting. Ovaries inserted to the base or sides of the calyx, free or rarely buried in the succulent walls of the calyx, one-celled, with a solitary erect or pendulous anatropal ovule. Style simple, terminal, lateral or basilar. Stigma undivided. Carpels indehiscent, free, rarely colnerent with the calyx, dry or drupaceous. Embryo straight, in the axis or at the base of a fleshy albumen.

Evergreen generally aromatic trees or shrubs, found in tropical America, Africa and Asia, and in extratropical South America and Australia, and also in New Zealand. Branches opposite or verticillate. Leaves simple, opposite, ternate or quaternate, rarely alternate, frequently dotted with glands, without stipules. Flowers unisexual, rarely hermaphrodite, solitary axiłlary, or cymose-paniculate or racemose, with deciduous bracteoles. Inner lobes of the calyx generally petaloid. Stamens often irritable and gland-bearing.-Endl. Gen. p. 313; Iindl. Veg. King. ed. iii. 298-306; Tulasne, in Archiv. chu Irus. d'Histoire Natur. viii. 273-436; J. Hook. \& Thoms. Flor. Indic. i. 164.

Monimiaceæ are allied both to Magnoliacer and Anonacex through Myristiceæ, and evidently also to Schizandrex and to Laurinex, which latter order, with many others of the monochlamydeous series, would find a more appropriate place amongst Calyciflor:. The tribe Atherospermex, separated as a distinct order by R. Bromn, is connected with the genuine Monimiex through the Indian genus Hortonia, as shown by Hooker and Thomson.

Tribe I. MONIMIE \&, R. Br. Append. to Flinders' Voyage, ii 553 ; Tulasne, Monogr. l.c.

Carpels free, drupaceous.

\section{HEDYCARYA.}

Forst. Char. Gen. t. 64.

Flowers diœcious. Calyx rotate, deeply 6-10-cleft, slightly enlarged and reflexed in age; lobes biseriate. Anther's numerous, inserted to the disk of the calyx, sessile, hairy; their cells parallel, not confluent, bursting by a longitudinal fissure; comective not protruding beyond the cells. Pollengrains four-valved. Ovaries numerous, inserted to the hairy disk of the calyx. Ovule pendulous. Style short or wanting. Stigma blunt. Carpels ovate. Mesocarp fleshy. Endocarp horny or crustaceous. Testa thin. Raphe linear. Chalaza circular. Embryo axillar. Cotyledones flat, elliptical, erect. Radicle long, superior. 
Endemic trees of New Zealand and Eastern and South-Eastern Australia, with smooth toothed opposite leaves, axillary corymbs or racemes of flowers, with a solitary narrow bracteole at the base of the pedicel and sessile or stalked carpels.-Lam. Encycl.t. 827; Ach. Rich. Voy. d'Astrolabe, t. 33; Raoul, Choix des Plant. Nouv. Zel. t. 30 ; J. Hook. Flor. Nov. Zeel. i. 218.

The genus Wilkiea (established in the Transact. of the Plil. Inst. of Vict. vol. ii. 64) differs from Hedycarya in operculate female flowers, and comprises probably the Mollinedia macrophylla, Tul. (Hedycarya macrophylla, A. Cunn.), and MI. Huegeliana, Tul., the only two Australian species referred by Tulasne provisionally to an Anerican genus.

Iredycarya Pseudomorus, F. M. in Transact. Phil. Inst. ii. 63; H. dentata var. Anstralasica, Sond. in Linncen, xxviii. 228.

Stigma depressed, minntely umbonate; carpels small sessile yellow, nearly globose; endocarp ontside densely foveolate.

In moist forest vallies of the fern-tree country, from Cape Otway and Momnt Disappointment, through the Western Port district and Gipps Land to Wilson's Promontory. Probably also in the Blne Mountains and the Cumberland district of New Sontli Wales, and possibly to be found yet in the islands of Bass's Straits and in the northern yet imperfectly explored portion of Tasmania.

A tall shrub, or more generally a small tree. Apex of branchlets and young leaves imperfectly silkydowny. Petioles from $\frac{1}{2}$ inch to rather more than 1 incls long. Leaves thin-coriaceous or chartaceous, lanceolate or ovate-lanceolate, acuminate, $2-6$ inches long, $\frac{3}{4}-2$ inches broad, shining above, paler and almost opaque beneath, abundantly perforated by subtle minute dots, one-nerved, net-veined, smooth in age, with exception of the lower part obscurely or conspicuonsly serrate, their teeth with callous apex. Racemes or corymbs axillary, opposite, few-Hlowered, short-stalked, imperfectly silky. Pedicels 2-4 lines long; opposite or nearly so. Bracteoles 1-2 lines long, linear-canalicnlate, acute, tardily dropping. Calyx without bracteoles, that of the male flowers with a disk about 2 lines in diameter, its teeth almost constantly 8 , more or less lanceolate or deltoid, one-nerved, hardly more than 1 line long, the four outer partially orerlapping the inner ones in præflorescence. Calyx of female flower similar to the male one, nnless rather smaller; its teeth persistent, shrunk in age. Anthers slightly downy, yellow; the outer ones nearly cordate, the inner ones more orate, bursting laterally, $\frac{1}{2}-\frac{2}{3}$ line long. Pollen-grains pale yellow. Style none. Stigma obliqueterminal, centrally umbonate, dilated at the margin into a disk. Ovaries almost glabrous, freqnently all fertile; their cicatix surrounded by vely short dense hair. Drupes scarcely longer than 1 line, nearly globose, densely crowded, thus forming a roundish fiuit, which, according to the number of its carpels, measures $\frac{1}{3}-\frac{1}{2}$ inch across. Pericarp flesly; endocarp brown, throngh innumerable regular minnte impressions densely reticnlate, more or less globose or ovate, slightly pointed at the apex. Albumen soft.

H. dentata, the typical New Zealandian species of this genus, differs, although similar in foliage and flowers to our plant, widely from it in large bright-red short-stalked drupes fully $\frac{1}{2}$ inch long, further in a much thicker and ontside not reticulated endocarp.

Having seen no specimens of $\mathrm{H}$. Pseudomorus from New South Wales, I am left doubtful whether Hedycarya Cunninghami is identical with the species above described; more so, since, in the diagnosis offered from seemingly imperfect material in Trlasne's excellent monograph of the order, the cardinal characters of the Australian plant are not expressed. The embryological notes of the genus are solely derived from $\mathrm{H}$. dentata. The resemblance of the fiuit with that of Morus has induced some settlers to name our tree the "Native Mulberry," a name which I have employed in the specific discrimination of the species.

Supplemental Plate II. 1 and 2, male flowers; 3 and 4, fruit-bearing female flowers; 5 , anther: ; 6 , pollen-grains; 7 , longitudinal, and 8 , transverse section of fruit; 9 , seeds enclosed in the putamen. 
Tribe II. ATHEROSPERMEE, R. Br. Append. to F'inders' Voyage, ii. 553 ; Tulasne, Monogr. Monim. 414.

Carpels free, dry, with a plumose style.

\section{ATHEROSPERMA.}

Labill. Nov. Holl. Plant. Specim. ii. 74, t. 224.

Flowers diøecious. Calyx 8-cleft; lobes biseriate, those of the female flower deciduous. Stamens many, inserted to the bottom of the calyx. Filaments short with two appendages at the base. Anthers with parallel cells, opening by ascendent valves, connective not protruding beyond the cells. Staminodia of the female flowers in several rows around the faux of the calyx. Ovaries numerous, inserted to the long-bearded bottom of the calyx. Style elongate, oblique-terminal, plumose, persistent. Stigma acute. Carpels concealed in the finally enlarged and cup-shaped calyx. Embryo basilar, very minute. Cotyledons flat, diverging.

An Australian and Tasmanian tree, with opposite glandulously serrated leaves, axillary solitary one-flowered peduncles, bibracteolate flowers and minute carpels.

Dr. J. Hooker (Flor. Tasm. i. p. 11) unites with Atherosperma the genera Laurelia, Juss., and Learosa, Reichenb. (Doryphora, Endl., not of zoologists), whilst Tulasne retains their former limitation. Laurelia differs principally in its lagenar fruit, Learosa in hermaphrodite flowers and its very long connective.

A doubtful congener, the Atherosperma micranthum, Tul., which was lately also collected by Mr. W. Hill at Moreton Bay, will modify to some extent the generic limits of Atherosperma, should its hitherto unknown fruit prove its supposed generic position to be correct. R. Brown probably alluded to that plant and to Learosa, when he mentioned, circumspect as ever, already in the appendix to Flinders' work, that two atherospermous genera, distinct from the typical ones in hermaphrodite flowers, occurred in the colony of New South Wales. The occurrence of bisexual flowers amongst the members of this order is very remarkable, since the numerous extra-Australian Monimiex are all declinous.

Atherosperma moschatum, Labill. Nov. Holl. Plant. Spec. ii. $74, t .224$. -Native Sassafras.

Rare in dense swampy forest gullies towards Cape Otway; more frequent at the sources of the Yarra, in the Dandenong Ranges, in the Western Port district, and in the southern part of Gipps Land, forming at Sealer's Core a conspicuous feature in the forest, frequently consociated with fern-trees and Fagus Cunninghami. Common in Van Diemen's Land.

A middle-sized tree, attaining, howerer, sometimes the height of 150 feet. Trunk straight, covered with a greyish very aromatic bark. Branches whorted and spreading. Branchlets covered with a yellowishgrey silky tomentum, at first ang7ular, gradually terete. Leaves rather short-stalked, $1 \frac{1}{2}-4$ inches long, $\frac{1}{2}-1 \frac{1}{2}$ inch broad, thick-coriaceons, penninerved, with spreading veins anastomosing towrerds the margin, in age by secondany veins conspicuously reticulated, lanceolate or ovatc, gradually attenuated into the pointed apex, at the base rather blunt, beneath clothed with an excecdingly thin glancous tomentum, abore smooth and shining, with exception of the generally entire apex and base serrate, rarely quite entire, full of subtle almost pellucid dots, at the margin somewhat thickened and slightly recurved in age, when young somewhat silky. Peduncles opposite, $\frac{1}{3}-\frac{1}{2}$ inch long, rather stont, silky-tomentose. Bractcoles two opposite at the apex of the peduncle, almost coriaceous, one-nerved, pointed, appressed to the calyx, broad cymbco-orate or roundish, 3-5 lines long, outside slighthly velvety, inside silky, at last decidnous, forming a closed valvate involuere to 
the flower-bud. Calyx articulated with the pednncle, attenuated into a very short pedicellar base, cernnous; that of the male flower deeply 8-cleft, spreading; its exterior lobes 4-5 lines long, ovate or orbicular-ovate or lanceolate, either blunt or acute, outside grey-silky, inside glabrous and white, towards the margins membranous; inner lobes about as long as but frequently narrower than the onter ones, or somewhat shorter, alternating with them, silky along the middle dorsal part, nearly petaloid; all veined. Stanens 8-20, rarely more, inserted to the densely silky-downy lower part of the calyx. Filaments thick, $\frac{1}{2}-1$ line long, augmented at the very base with two almost free dimidiate-rhomboid or oblique-lanceolate or somewhat ovate appendages, abont $\frac{1}{2}$ line long; which are often cuspidate, sometines fleshy, sonetines membranous, and are regarded by some botanists as staminodia, whilst part of these perlaps represent undimentary ovaries, connate with the base of the stanens. Anthers quadrate-ovate, $\frac{2}{3}$ line long; with blunt or retuse apex; valves 2 , yellowish, ascendent. Calyx of female flower with a short turgid tube, which is outside densely silky-tomentose; its exterior lobes oblong-lanceolate, ontside silky, inside smootl, inner ones narrow-lanceolate acuminate, all 3-4 lines long. Staminodia lanceolate- or linear-subulate, numerous, 1-3 lines long, long' persistent, except the inner side of the apex silky, exserted after the lapse of the calyx lobes. Cup-shaped indurated portion of the fruit-calyx 3-4 lines long, 5-6 lines broad, inside densely clothed with copious soft brittle more or less intricate grey-brown hair, which become very perceptible after the carpels are ejected, extending conspicuously beyond the orifice of the calyx. Carpels narrow ovate- or oblong-conical, 1-1 $\frac{1}{2}$ line long, passing. gradually into the style, which is setaceous, 4-5 lines long, simple or very rarely bifid and as well as the carpels densely villous with exceedingly soft hair, of which the upper ones are gradually shortened.

The Native Sassafras must be regarded as one of the finest and most useful trees of this part of Anstralia. Its shady crown of horizontal foliage contrasts singularly with the pendulons foliage of the Eucalypti, which characterizes generally the tree vegetation of this country. The powerful tonic property of its bark render the tree of higl medicinal value, whilst its wood is less subject to bursting than most of the other indigenous timber; when polished it much resembles walnut-wood. The flowers are fragrant; and the aromatic scent, which pervades all other parts, reminds of that of nutmeg, inducing Labillardière to apply to the tree its specific name. Leaves and bark are used in infusion and are long retaining their aroma.

\section{ORDER MENISPERME}

Juss. Gen. 284.

Flowers diœcious, rarely monœcious or polygamous or hermaphrodite. Sepals 2-12, rarely 1, free, seldom comnate, valvate or imbricate rarely quincuncial in æstivation, deciduous. Petals usually equal in number to the sepals, distinct or sometimes united, deciduous, not rarely missing. Stamens distinct, or wholly or partially monadelphous, equal in number and opposite to the petals, or in a multiplied number of the latter, rarely fewer than the petals. Anthers 1-2- or 4-celled, extrorse or introrse, vertical or horizontal, opening lengthwise or transversely. Style simple or wanting. Stigna undivided or two- or three-cleft or jagged. Ovaries 1-12, but usually 3 , distinct or rarely united, one-celled or rarely divided into additional lateral cells, the middle one only fertile. Ovule 1, homotropal or campylotropal. Drupes baccate, verticillate or solitary, oblique. Endocarp bony, compressed, kidney- or horseshoeshaped, rarely almost straight, often at its broad back tuberculate. Embryo around the condyle more or less curved. Albumen surrounding the embryo, or wanting. Radicle superior. 
Shrubs or suffruticose plants of climbing habit, of limpid rarely milky juice, of tonic, emetic, narcotic or diuretic properties, dispersed rather copiously over tropical Asia and America, occurring less frequently in Africa, rarely in some parts of both the warm temperate zones, scantily distributed over eastern and northern Australia, not yet found in the southern and western part of the Australian continent, nor in Tasmania, nor in New Zealand, nor in Europe. Their leaves alternate, broad, not unfrequently peltate, always pointed, entire, rarely with a few acute teeth or lobes, without glandular dots, very rarely of different shape in the male and female plant. Stipules none. Flowers minute, racemose, cymose or paniculate. Sepals and petals often in a ternary or quaternary very seldom in a quinary arrangement. Staminodia present in the female flower or wanting. Drupes small, orate, roundish, rarely oblong-cylindrical._Cand. Syst. i. 507; St. Hilaive, Flor. Braz. mer. i. 59 ; Torrey \& Gray, Flor. of North America, i. 46; Miers, in Annal. Nat. Hist. sec. ser. vii. 33; Lindl. Veg. King. ed. iii. 307.

The members of this order are forest plants, but one species of Cocculus extends to the desert of the interior of N.W. and N. Australia. Since the roots of some Brazilian plants of this order are praised as antidotes against snake-bites, it rould be desirable that experiments should be instituted on the perhaps similar effects of those of the Australian species.

The species hitherto observed indigenous to the Australian continent are few in number, one is referable to Stephania (St. hernandiifolia, Walp.), the others, except the new genus here enunciated, are genuine Cocculi.

\section{Tribe PLATYGONE $\mathbb{E}$, Miers, in Lindl. Veg. Kingdom, ed. iii. 309.}

Istivation of sepals imbricate. Stamens united into a central column or free. Embryo nearly of horseshoe form. Cotyledons elongated, flat, incumbent, surrounded by a scanty albumen.

\section{SARCOPETALUM.}

F. $M$.

Flowers diœcious. Sepals 2-5, membranous, free, the outer ones the smallest. Petals 3-5, longer than the calyx, thick-fleshy, unequal, free, ovate, roundish, obcordate or renate. Male flowers: Stamens 2-3. Filaments below the free summit connate. Anthers adnate, oblique-vertical, extrorse, two-celled, opening with longitudinal fissures. Female flowers: Ovaries 3-6. Stigma reflexed, deeply bifid, rarely thrce-cleft. Staminodia few, very minute or wanting. Carpels 1-4, lenticular, one-celled, tapering into a cuneate basc, on each side with an orbicular impression. Pericarp coriaceous. Endocarp cartilaginous, dotted along its broad back with minute tubercles. Imbryo almost hippocrepical.

A gigantic climber, with heart-shaped, smooth, entire, rarely few-toothed, on both sides shining leaves, with lateral or axillary, fasciculate or solitary, simple or partially divided, minutely bracteate racemes, with unibracteolate pedicels subtile glandulous-downy, with small calyces and livid turgid petals. 
The genus here for the first time described would be merely regarded as belonging to a section of Cocculus, according to the definition originally assigned to that genus. From the latter, according to its more recent circumscription, as well as from Pericampylus, Sarcopetalum differs in connate stamens reduced also to a smaller number, and besides, like from most genera of Menispermex, in remarkably carnose petals, which surpass the length of the calyx. It approaches, in regard to its corolla, therefore, and in at least partially connate filaments, to Stephania, thus forming an intermediate link between the tribes Cissampelideæ and Cocculeæ, established in J. Hook. \& Thoms. Flora Indica, i. $186 \& 194$.

Sarcopetalum Irarveyanum, $F$. Mr.; Cocculus Harveyanus, $F$. Mr., Seeond Gen. Report on the Plants of Victoria, p. 9.

In the forests near the mouth of the Snowy River. Found also near Parramatta by W. Woolls, Esq., so that this plant probably occupies many localities of the interjacent territory, which botanically is but little known.

A tall liana, with thick terete stems, covered with brownish-grey minutely warted bark. Leaves chartaceous, 3-5 inches long and broad, acuminate or exceptionally witl a terminal sinus and then kidneyshaped, with 7 nerres diverging from the base, with copious netted veins, paler but not glancous beneath. Petiole attached to the more o1 less expanded basal sinus of the leaves, 1-3 inches long, somewhat channelled. Racemes axillary or far distant below the leaves lateral, nearly from the base or only towards the summit many-flowered, 1-3 inches long: Peduncles slender, with many alternate lanceolate or subulate bracts, which are about 1 line long, rather persistent, alternate along its upper part and crowded towards its base. Bracteoles at the base of the pedicel solitary, similar to the bracts, clothed outside with the same minute brown almost powdery down which covers the pedicels, peduncles and sepals. Pedicels 1-2 lines long during. anthesis, when fruit-bearing generally twice as long, occasionally bearing a second flower at or near the summit. Sepals lanceolate-orate or lanceolate or ovate-cordate, always acuminate, only $\frac{1}{3}-\frac{3}{4}$ line long, appressed, deciduous. Petals in a single irregular row, smooth, $\frac{3}{4}-1$ line long, quite blunt, hardly bent in ward. Column of filaments very short, smooth. Anthers about $\frac{1}{4}$ line long, with two ovate cells, obliquely aftixed to the outer side of the divergent free apex of the filaments, in age conspiciously distant from each other. Style rather rigid, brownish, almost persistent; its divisions curved, subulate and divergent. Carpels seated on a minute receptacle, 3-4 lines long, thickened and slightly carinate at the back, in age black; its apex in gradual maturation of the fruit drawing downward until finally brought almost in contact with the base of the fiuit. Endocnip wrinkled. Seeds compressed, almost kidney-shaped, but too much shrivelled in our herbarium to admit of precise description. The testa as usually membranous, and the albumen apparently but very scanty, if at all developed.

This plant, which produces its flowers during the spring and beginning of summer, is dedicated to my esteemed and learned friend Professor Harvey, M.D., of the Dublin University, to whose indefatigable zeal we owe mainly the elucidation of our marine vegetation. This plant is interesting as offering, with several others within the eastern part of our colony and as far south as the latitude of Melbourne, the commencement of the tropical jungle flora; which in eastern Australia bears so much resemblance to that of India.

The nature of the floral envelopes of Menispermex las received in some instances a varied interpretation. What in describing Sarcopetalum has been assumed as external sepals, would, according to the views held by Wight and Arnott on the floral structure of some Menispermex, be regarded as bracteoles.

Supplemental. Plate III. 1, male flowers, with bracteoles; 2 , side view of flower; 3 , expanded male flower; 4 , calyces; 5 , side view of stamens; 6 , stamens seen from above; 7 , pollen-grains; 8 , female flower seen from abore; 9 , side view of female flower; 10 , staminodia; 11 , pistils; 12 , side view of carpels; 13 , front view of carpel; 14, transverse section of pericarp; 15 , longitudinal section of carpel; 16 , seed : all except fig. 16 and part of fig. 12 more or less magnified. 


\section{II.-RHEADES.}

Endlicher, Gen. Plant. p. 854.

Division of flower nearly always quaternary. Stamens free, rarely united, Ovary compound, solitary. Placentre sutural or parietal.

Of the four natural orders referable to this series, Fumariaceæ are not yet found to be represented in Australia by any indigenous species, although a few Fumarix have accidentally been introduced from Europe and Soutl Africa.

\section{ORDER PAPAVERACER. \\ Venten. Tabl. iii. 89.}

Sepals two, rarely $3-4$, distinct, hypogynous, deciduous, imbricate or valvate in æstivation. Petals 4, cruciate, rarely $6,8,12$, or none, free, hypogynous, in æstiration mostly plicate. Stamens free, 4 or more, in a quarternary definite number or indefinite, often crowded at the base of the petals. Anthers 2-celled, bursting lengthwise. Ovary free, one- rarely two- or many-celled, composed of two several or numerous consolidated very rarely almost free carpels. Styles short or none. Stigmas of equal number with the carpels. Valves of capsule two, several or many. Seeds numorous, rarely few or one, and very seldom provided with a cupular pulpy arillus or a mem. branous strophiole. Albumen large, amygdaloid. Embryo straight, turgid, very minute, located at the base of the albumen. Cotyledons 2 , rarely 1,3 or 4 , sometimes divided.

Herbs, or rarely suffruticose or shrubby plants, with narcotic milky or colored, in some cases limpid, juice. Leaves alternate, very seldom opposite or ternate, simple, variously cleft or toothed, very seldom entire, often dilated at the base, always without stipules. Flowers hermaphrodite, symmetrical, pedrunculate, generally at first cernuous. Petals very fugacious, varied in color, but never blue. Capsules narrow and elongated or more ellipsoid ovate or globose. Seeds often kidney-shaped. -Cand. Syst. Veg. ii. 67; Bernhardi, in Linncea, xii. 659; Endl. Gener.854; Lindl. Teg. Kingd. iii. 430.

The distribution of papaveraceous plants is chiefly over Europe, the Orient and temperate Nortl America; in other parts of the globe few species exist; in extratropical Australia as yet but a single specics is found; in tropical Australia, New Zealand and Tasmania, none have been noticed.

The plants of this order form a clear transit to Crucifere and Fumariacex in one direction, whilst in another they approach to the Ranunculaceous order. 
PAPAVER.

Toumefort, Institutiones Rei Herb. 119.-Poppy.

Sepals 2 or 3, imbricate in æstivation. Petals normally 4-6, by metamorphosis of the stamens numerous. Anthers terminal, with marginal deliscence. Stigmas 4 or more, adnate to the orbicular or broad-conical summit of the ovary, linear-filiform, radiating. Placentas opposite to the stigmas, intervalvular. Ovules very numerous, anatropal. Capsule opening under the terminal disk, either by the short free apex of the otherwise indehiscent valves or by the terminal recess of the latter, imperfectly septate by the placental laminæ. Seeds copious, small, ovate- or globular-kidneyshaped. Testa netted-veined. Strophiole none. Cotyledons undivided-Linné, Gen. 648; Gcertn. de Fruet. et Semin. i. 289, t. 60.

Annual, less frequently biennial or perennial herbs, dispersed over the temperate and the colder zone of Europe and Asia, rare in North America and extratropical Africa and Australia; their juice white or yellow; leaves often hispid and glaucous, pinnati-lobed or jagged; flowers pedunculate, white, yellow, purplish, red or variegated, or in intermediate shades, in bud drooping; capsules globtilar, ovate, oblong or even broad-clavate, truncate at the apex.

Papaver horridum, Cand. Syst. ii. 79 ; Sneet, Brit. Flower Gard. ii. 173; Elkan, Tentam. Monograph. Gen. Papav. 32.

Stem annual, leafy, few-or many-flowered; leaves jagged-pinnatifid, as well as the stem, branches, peduncles and sepals armed nith short rigid spreading bristles; lobes of leaves short, comparatively broad, acutely toothed; petals miniate, about triee as long as the fulvous upwards capillary filaments; anthers subcordate-ovate, yellowish; teeth of the stigmatiferous disk 5-9, minute, semi-orbicular; margin of disk slightly undulate, not plicated; capsule glabrous, truncate-ellipsoid; placentas extending scarcely half way towards the centre of the capsule; seeds brownish-black.

In sandy localities along the Murray and Snowy River. Found also in the neighborhood of the Flinders Ranges and of Moreton Bay, and by Dr. Herm. Becklar near Warwick.

An herb, varying in height from $\frac{1}{2}-5$ feet, with simple or strictly branched stems, everywhere except the petals and organs of fiuctification more or less copiously covered with almost straight bristles, which are pale yellowish, generally from about $\frac{2}{3}-1 \frac{1}{2}$ line long; those towards the apex of the peduncles being the smallest and closest. Root simple or branched, almost without fibres. Radical leares several inches long; elongatelanceolate in outline, tapering into a petiole; stem-leaves in circumscription rhomboid-or ovate- or narrowlanceolate, sessile or even somewhat clasping, 2 inches long, 1 incli broad, or more or less smaller, distinctly veined, glaucous, lacerated into acutely tootleed lobes, the apex and the teeth terminated by a bristle, and somewhat callous and revolute at the upper margin. Peduncles gradually lengthened, simple or little divided, at last sometimes more than $\frac{1}{2}$ foot long, without bracts. Flower-bud ovate. Sepals, particularly towards the summit, hispid, ovate, very thin, $\frac{1}{3}-\frac{1}{2}$ inch long, truncate at the base, with a very tender upwards gradually dilated membrane along the inner margin. Petals pale-scarlet or rather brick-colored or of red-lead color; mucl alike to those of Papaver dubium, turning, like those of Papav. Rhous, dubium; Argemone and allied species, purple in drying, about $\frac{1}{2}$ inch long, nearly ovate. Filaments linear-capillary, $3-4$ lines long. Anthers $\frac{1}{3}-\frac{1}{2}$ line long, witl slightly enarginate base; cells adnate to the very narrow connective. Pollen-grains ovate-globose. Stigmas 5-9. Stigmatiferous disk as broad as the capsule, at first pyramidal, at last flat. Capsule 6-10 lines long. Intervalvular septa or placental laminæ $\frac{1}{2}-\frac{2}{3}$ line broad, meeting at the centre of the disk. Valves bursting only at the apex, leaving openings of less than 1 line in length. Seeds scarcely $\frac{1}{4}$ line long, opaque, oblique ovate-kidney-shaped.

This species flowers in the spring. 
The question is yet open for discussion, whether $P$. horridum is really specific distinct from the only known South African Poppy, P. aculeatum, Thunb. Prodr. Flor. Cap. 431 (P. Gariepinum, Burch.), which, according to the diagnosis of Candolle and Elkan, and according to the figure and description furnished by Sir Will. Hooker (Bot. Magaz. 3623), as already stated by the last-mentioned eminent botanist, seems not to differ from the Australian species, unless in the seeds or placentæ. Should their identity be finally proved, my opinion, that the Paparer horridum is an introduction from abroad, would be greatly strengthened.

The marks of distinction separating onr species from the common red Poppy of England, Paparer Rhœas L., which occasionally occurs in the corn fields of Australia, are obvions, consisting in much more rigid and less copious not hair-like bristles, in the placentre not reaching to near the middle of the capsule, in not dark-purplish filaments of less than half the lengtl of the petals, in the less saturated red color and minor size of the latter, in the teeth of the stigmatiferous disk not overlapping each other and being considerably smaller, and in some other notes. Less marked are its differences from the European Paparer dubium, consisting in rigid nowhere appressed indument, and not violet anthers. To $P$. setigerum, with which it has been compared by Candolle, it has but remote affinity.

\section{ORDER CRUCIFER丑.}

Adanson, Familles des Plantes, ii. 409.

Sepals 4, free, deciduous, imbricate, rarely valvate in restivation, the two outer ones generally narrower. Petals 4, alternate with the sepals, placed crosswise, free, rarely wanting. Stamens six, tetradynamous; the two shorter ones in front of the lateral sepals, the four longer ones facing pairwise the anterior and posterior sepal, 2 or 4 rarely missing, all free or occasionally some connate, very seldom numerous. Anthers two-celled, introrse, with longitudinal dehiscence. Style simple or obliterated. Stigmas 2, very rarely 4, somctimes confluent, always in a line with the placentx. Silique or silicle two-valved, by a spurious dissepiment two-celled, rarely one-celled or valveless, or transversely septate and breaking across, very rarely four-valved. Replum often persistent. Seeds one, two or more in each cell, without albumen, affixed to the intervalvular narrow placentæ. Embryo curved, oily. Cotyledons 2, bent or folded on the cylindrical radicle, very rarely 4 and almost spiral.

Herbaceous sometimes suffruticose plants of volatile often antiscorbutic acridity, some highly valuable as culinary vegetables, distributed over evcry country, except some lowlands of the intertropical zone. Their juice limpid. Leaves simple, entire or variously toothed or divided, alternate, very rarely in part opposite. Racemes opposite to the leaves or terminal, occasionally corymbose or spicate, in derelopment centripetal, sometimes leafy-bracteate. Bracteoles and stipules wanting. Petals white, yellow, pink, less frequently red or purple, rarely blue.-Cand. Sysst. ii. 137; Endl. Gen. 861; Lindl. Veg. Kingdom, iii. p. 351; Henfrey's Elem. Cour'se of Bot. 233; Schnizlein's Analysen, 44.

Crucifcræ arc frequent throughout Europe, extratropical Asia and North America, less numerous at and towards the northern and southern extremes of Africa 
and in extratropical South America, rare however anywhere except on high mountain tracts within the tropics; they are, with exception of Cardamine hirsuta L., totally wanting in the whole botanically-known portions of tropical Australia, even in the northern desert interior, notwithstanding their slightly augmented number in the southern desert; otherwise they are also comparatively scarce as well in extratropical Australia as in Tasmania and New Zealand, even in alpine elevations. The identity of several of our indigenous Cruciferæ, although they seem not to be introduced, with European species appears singular.

Tribe I. PLEURORHIZÆ, Candolle, Syst. i. 146.

Radicle facing the commissural line of the cotyledons.

\section{NASTURTIUM.}

R. Brown, in Aiton. Hort. Ken, ed. ii. vol. iv. p. 109.-Water-cress.

Sepals spreading, equal. Petals entire, sometimes wanting. Stamens free, without teeth. Stigmas confluent. Capsule sub-cylindrical or ellipsoid, rarely spheroid, bi-celled. Valves nerveless or imperfectly nerved at the base. Septum broader than the seeds. Seeds in each cell irregularly biseriate, roundish, somewhat flattened, without a border. Cotyledons accumbent, directed with their edges to the placentr.

Branching herbs, generally found in swampy humid or fountainous localities of many parts of the globe, often smooth. Lower branches frequently rooting. Leaves mostly pinnatilobed. Racemes many-flowered. Pedicels spreading. Petals white or more frequently yellow. Silique often curved.Cand. Syst. ii. 187.

This genus is closely connected with Sisymbrium amongst Nothorhizæ, and more so still with Armoracia (the Horse-radish).

Nasturtium terrestre, R. Br. in Hort. Ken, ed. ii. v. iv. p. 110; N. palustre, Cand. Syst. ii. 191; Koch, Synops. Flor. German, ed. ii. vol. i. p. 38; N. semipinnatifidun, Hook. Journ. of Botany, i. 246.Yellow Marsh-cress.

Root annual or biennial, simple or branched; leaves pinnatifid or pinnatisected, sometimes merely toothed, auriculate at the base, lower ones almost lyrate; lobes nearly ovate or oblong, confluent, unequally repand, sinuate or crenate or serrate; petals about as long as the calyx, yellow; style short; siliques turgid, blunt, ellipsoid, about as long as their pedicel; seeds fulvous, densely and minutely dotted-reticulate.

Around swamps, lakes, and along the banks of rivers, in many localities. The identical plant is dispersed not only over almost all extratropical countries of the northern hemisphere, but likewise over parts of the Indian Highland, of temperate South America, New Zealand, Tasmania, and the Colony of South Australia.

An erect or recumbent glabrous or less commonly hairy herb, from a few inches to 2 feet high. Stem and branches leafy, furrowed. Root not creeping. Radical leaves conspicuously stalked, often $\frac{1}{2}$ foot long and cleft to the stout midnerve; stem-leaves more or less deeply divided, upwards gradually shorter; their lobes oval or oblong, unequal, forming several or a few pairs; terminal lobe the largest, cordate ovate or lanceolate, all more or less confluent or separated, not unfrequently a small lobe interjacent. Upper leaves with fewer or no lobes, often jagged only or even merely toothed, elongate lanceolate, occasionally lanceolate- 
linear. Corymbs closely many-flowered, gradually lengthened into racemes. Sepals about 1 line long, pale particularly towards their margin, oblong or oval. Petals pale yellow ovate-spathulate. Stamens about as long as the corolla. Anthers yellow, ovate-cordate. Pollen-grains ellipsoid, bursting longitudinally. Glands at the base of the stamens small. Style persistent, short and stont, in rare instances 1 line long. Stigmas confluent into one, which is orbicnlar and shightly bilobed and soon not thicker than the style. Germen truncate or emarginate at the apex. Silique spreading, generally 2-4 lines long and blunt, ellipsoid, rarely broad ovate and only $1 \frac{1}{2}$ line long, or when more lengthened cylindrical fully 5 lines long, in both cases the fruit-stalk respectively longer and shorter than usual. Fruit-style of $\frac{1}{4}$ line length. Septum $\frac{1}{2}-1$ line broad, pellucid, perfect. Pedicels and rephrm persistent. Seeds mumerous, $\frac{1}{4}-\frac{1}{3}$ line long, pale fulrous, oblique, verging more or less into an ovate round or cordate form. Testa much more closely dotted-reticulate than in N. officinale, also of a paler color. Funicles short, unequal.

On account of its cress-like taste the plant is now and then used as a vegetable. It flowers here throughout the year. That no other Nasturtia shonld range so widedly over the globe seems inexplicable. The closely allied $\mathbb{N}$. amphibium and $\mathcal{N}$. silvestre produce both petals considerably longer than the calyx. The plaut enumerated as an Anstralian one, under the name of $\mathrm{N}$. anplibium, by R. Brown, in the appendix to Flinders' Voyage, is probably referable to $\mathrm{N}$. terrestre.

The gemine white flowering English water-cress (Nasturtium officinale) has been noticed in a ferw streamlets of Australia, but everywhere its importation from lome could be traced.

\section{BARBAREA.}

R. Brown, in Aiton Hort. Ken, ed. ii. vol. iv. 109.-Winter-cress.

Sepals erect, almost equal. Petals undivided. Stamens free, without teeth. Stigmas confluent. Silique bi-valved, linear, almost cylindrical or compressed-tetragonous, few- or many-seeded. Valves strongly one-nerved. Septum not much broader than the seeds. Seeds in each cell uniseriate, dotted-reticulate, without a border. Cotyledons accumbent, with their edges turned to the placentx.

Erect generally biennial or perennial herbs, noticed in moist places of the temperate zone of Europe, Asia and North America, in the mountainous part of India, and likewise in South-East Australia, Tasmania and New Zealand. Leaves partially lyrate-pinnatifid or pinnatisected, partially and in a few species all merely toothed; their stalk auriculate at the base. Racemes terminal. Sepals frequently somewhat petaloid. Petals yellow.-Cand. Syst. ii. 205 ; Endl. Gen. 864.

Barbarea vulgaris, R. Br. in Ait. Hort. Kew, ed. ii. vol. iv. p. 109; Engl. Bot.443; B. Anstralis, J. Hook. Flor. of New Zeal. i. 14; Flor. Tasm. i. 21.-Bitter Winter-cress. Yellow Rocket.

Lower leaves lyrate pinnatisected; their terminal lobe orbicular- or ovate-subcordate; their lateral lobes small oblique orate or oblong or lanceolate or oblong-linear; upper leaves spathulate, oborate, rhomboid or cuneate, toothed or pinnatifid; flower-bearing pedicels crowded; calyx rather large ; siligues crect or slightly spreading, compressed-tetragonous, linear.

On the banks of the Mitta Mitta, the Mitchell and other river's of Gipps Land, chiefly at an elevation of from 1000 to 3000 feet. A native also of New Zealand and Tasmania, of nearly the whole of Europe and parts of Asia, extending to the monntain chains of India, seemingly introdnced into North America.

An erect somewhat mucilaginous lierb, of a bitter and disagreeable taste, attaining the lieight of $1 \frac{1}{2}$ to sevcral fect, glabrons or scantily hairy. Root livid, sending out more ol' less capillary fibres and lateral branches. Stem streaked, simple or generally not much divided. Radical and lower stem-leares long stalked; petiole of the latter dilated into a sagittate-lobed clasping base. Terminal segment of the lower and lowest lenves 1-3 inclies long' and almost as broad, repand, sometimes sinuate veined and penni-nerved; lateral 
segments of the leaves of the indigenous variety often diminutive in a few or several pairs, the upper one howerer often as long as the width of the terminal lobe, with broad base, sessile. Upper leaves about 1 inch long, sessile, bluntly auriculate or acutely sagittate at the base, laciniate or toothed or repand, the lower incisions deepest. Racemes terminal, solitary or several approximated, many-flowered, in age considerably stretched in length. Flowerless portion of peduncle short. Flower-bearing pedicels 2-3 lines long, fruitbearing ones gradually thicker, about 4 lines long, angular, somewhat spreading. Sepals yellowish, about 2 lines long, oblong and linear-oblong. Petals oblong-spathulate, not very considerably longer in the Australian variety, although so in nany European forms of this plant, pale towards the base. Longer stamens about as long as the calyx. Filaments uarrow-linear subulate, one-nerved, as if capillary and membranous-winged. Anthers yellow, cordate-oblong; inserted above the base, in age reflexed. Fruit-style obliterated or about half a line long aud theu conical, in extra-Australian specimens sometines fully 1 line long, terminated by a minute almost undivided circular stigma. Silique in the Australian rariety $1-1 \frac{1}{2}$ inch loug and fully 1 line broad, yet scnrcely less in width in some Europenn specimens; its ralves concavecouvex, prominently one-nerved and distinctly veined. Septum pellucid, perfect, gradually separating from the replum. Funicles scarcely lialf a liue long. Seeds numerous, pendulous, ovate-roundish or orbicular, conpressed, reticulate with innumerable foveoles, pale brown, nearly 1 line long. Testa not distinctly mucilaginous, wrinkled ol even slightly warted.

I cannot point out any specific characters between the Australian and European plant, particularly such by which it could be separated from the variety B. stricta, Andrz., of the northern hemisphere.

The varieties of Cardamine hirsuta prove the length of the petals, compared to that of the calyx, to be a dubious note of distinction in some Crucifere; this leads yet to further reflections in regard to the value of the principal diagnostic of Nasturtium terrestre, and of some supposed species of Barbarea.

\section{TURRITIS.}

Dillen. Nov. Gen. 120, t. 6.-Tower-mustard.

Sepals erect, almost equal. Petals unguiculate, undivided. Stamens free, without teeth. Stigmas united. Silique bivalved, compressed, linear, many-seeded. Valves one-nerved. Septum broader than the seeds. Seeds biseriate in each cell, smooth, compressed-ovate, bordered. Cotyledons accumbent, with their edges turned to the placentæ.

Annual or biennial, erect herbs, often with simple and floccous or furcate hair partially downy, noticed throughout Europe, in the temperate and arctic zone of Asia and North America, very rare in South Africa and in South-East Australia. Stem-leaves clasping, radical leaves tapering into a petiole. Racemes terminal, lengthened. Petals white, rose- or cream-colored. Silique generally elongateGortn. de Fruct. et Semin. t. 143 ; Cand. Syst. ii. 211.

Some American species render the transit from Turritis to the genus Arabis perfect.

Turritis glabra, Linné, Spec. Plant. 930; Engl. Bot. t.777; Smith's Engl. Flora, ed. ii. vol. iii. 215.-Smooth Tower-mustard.

Radical leaves rough-downy; sten leaves from a sagittate base ovate- or oblong-lanceolate, rarely linear-lanceolate, glabrous, glaucous, mostly entire; pedicels of flowers almost erect; petals yellowish-white; siliques strictly erect, many times longer than thcir pedicel; seeds with a very narron border.

On the banks of the rivers Cobongra, Mitta Mitta, Livingstone Creek and Snowy River, at an elevation of from 3000 to 4000 feet.

The identical spccies is known to exist in Europe, in Asia as far soutl as the Himalayan Mountains, and in North America. 
A biennial herb, from 1 to 3 feet high, witls a solitary or several simple or erectly branched cylindrical pruinous stems. Root tapering or almost cylindrical or somewhat branched. Radical leaves 1 or several inches long; toothed or less fiequently sinuate or entire, quickly emarcescent, spreading, oblong-cuneate occasionally almost lyrate, as well as the petioles and the lower part of the stem downy with rather stiff simple and divided hair, the latter more fiequently covering the leaves, the former clothing chiefly the stem copious curved and turned downward. Stem-leaves numerous, erect or slightly patent, 1-3 inches long, $\frac{1}{4}-1$ incli broad, rather acute, as well as the upper parts of the plant smootl. Pedicels slender, mostly numerous, at first densely corymbose and then hardly longer than the flower, soon dispersed in an often foot-long always bractless raceme, and then from 3 to 8 lines long: Sepals about 2 lines long', pale, membranous, three-nerved, veined, narrow-oblong, blunt at the apex, truncate at the base. Petals obovate-cuneate, not much or nearly half longer than the calyx, tapering gradually into the unguis. Stamens tetradynamous; the longest nearly as long as the petals. Filaments pale, linear-subulate. Anthers yellowish, $\frac{1}{2}-\frac{2}{3}$ line long, linear-oblong, bilobed at the base, in age recurved. Pollen-grains blunt ovate-ellipsoid, bursting lengthwise. Germen and stigmas sessile; the latter confluent into a solitary depressed indistinctly bilobed onc. Siliques $1 \frac{1}{2}-2$ inches long, hardly 1 line broad. Valves blunt, thin-chartaceous, somewhat veined. Septun membranous, nerveless. Funicles capillary, shorter than the seeds. Seeds pendulous, forming two rather irregular rows, ovate, by mutual pressure angular, scarcely $\frac{1}{2}$ line long, brown, witlı a darker narrow edge.

\section{CARDAMINE}

Tournefort, Instit. Rei Herb. 109.-Bitter-cress; Lady's Smock.

Sepals erect or somewhat spreading, almost equal. Petals undivided, unguiculate, sometimes wanting: Stamens free, without teeth, 6 or rarely 4 . Stigmas united. Silique bivalved, long-linear, more or less compressed, very rarely lanceolate. Stipes wanting. Valves nerveless or faintly nerred towards the base. Septum nerveless. Seeds in each cell numerous, rarely few, uniseriate, very rarely irregularly biseriate, seldom bordered. Cotyledons flat, accumbent; their edges facing the placentæ.

A cosmopolitan genus, comprising annual, biennial and perennial herbs, which prefer humid localities. Leaves entire or variously divided. Peduncles with racemose rarely a single flower. Petals white or pink.-Cand. Syst. ii. 245; Endl. Gen. 865.

Cardamine radicata (J. Hook. Icon. Plant. t. 882 ; Flor. Tasm. i. 18) differs from most if not all species in producing a leafy bract at the base of each pedicel, in the exactly lanceolate siliques, containing but few seeds in each cell. It offers thus an approach to Dentaria and Pteroneuron, and thence to the tribe Alyssineæ, deserving therefore to be held distinct as a subgenus, to which the name Platyphragma might be given. This species was noticed on the summit of Mount Lapérouse of Tasmania, by Mr. Oldfield, and may possibly be found to extend to the Victorian or New South Wales Alps.

Gardamine stylosa, Cand. Syst. ii. 248; J. Hook. Fl. Tasm. i. 18; Arabis gigantea, Hook. Icon. t. 259.--Long-styled Bitter-cress.

Smooth; stems leafy, generally loug, flaccid, branched; leaves oblong-lanceolate, sessile, tapering into a sagittate entire base, minutely and remotely toothed; racemes in age much elongated; pedicels stout, spreading, three to six times slorter than the silique, bractless; petals rather small, less than half exserted; stamens about as long as the calyx; anthers yellow; siliques very spreading, rostrate; valves towards the base faintly one-nerved; funicles very short, tooth-like; seeds darli-bronn, densely reticulated.

In lumus-soil of moist forest valleys, rarer in open pasture land near the banks of rivers; in various parts of Gipps Land, for instance, near Wilson's Promontory, ou the Jack River, at Sealer's Core; also in the Dandenong Ranges. Beyond Victoria, through New Soutlı Wales, as far nortlı as Mount Linsar, where 
it was found at an elevation of 5000 feet by Mr. W. Hill; occurs likewise throughont the greater part of Tasmania, ascending to alpine elevations, for instance, on Mount Wellington, according to Mr. Oldfield.

A seemingly perennial herb, sometimes less than 1 foot high, generally, lowever, tall, attaining a height of 5 feet. Stems and branclies somewhat angular. Middle and lower stem-leaves 1-5 inches long, 1-11 inch broad, the uppermost smaller, sometimes toothless, all of very tender consistence. Racemes when in fruit always of considerable length, sometimes measuring not less than 3 feet. Pedicels when flowerbearing 1-2 lines long; when fruit-bearing $1 \frac{1}{2}-3$ lines long. Sepals $1 \frac{1}{2}-2$ lines rarely only 1 line long, nearly oblong: Petals white, oborate-cuneate, about $\frac{1}{3}$ longer than the calyx. Anthers oblong-orate, with cordate hase, only $\frac{1}{3}-\frac{1}{5}$ line long. Siliques divaricate, even occasionally beut downward, $\frac{3}{4}-1 \frac{1}{1}$ inch long; about 1 line broad, occasionally some very nuch shortened and then few-seeded, constantly terminated by a style, which varies in length of $3-2$ lines. Valves concare-convex, veined. Funicles from a broad base subulate, generally many times shorter than the seeds. Seeds oval, about $\frac{3}{4}$ line long, occasionally in a minute-flowering rariety considerably smaller.

Allied to no other Australian species than the following, both forming a transit to Arabis; but the New Zealand C. divaricata, according to Dr. Hooker's description, seems nearly allied to, if not identical with the small-flowering variety noticed in Gipps Land.

Cardamine dictyosperma, Hook. Joum. of Bot. i. 246; J. Hook. Fl. Tasm. i. 19; C. nivea, Hook. Comp. Bot. Mlagaz, i. 273.-Net-seeded Bitter-cress.

Smootlı; stem leafy, generally long, flaccid, branched; petioles slightly dilated into a truncate or sagittate base; radical and lower stem-leaves pinnatiscoted, upper stem-lenves lanceolate or almost linear, toothed, undivided $0 r^{2}$ laciniated; lacemes in age much elongated; pedicels very spreading, generally about half as long as the silique, rarely three to four times shorter, rather slender, bractless; petals rather large, more than lialf exserted, stamens not much longer than the calyx; anthers yellow; siliques rostrate; valves below the middle finely one-nerved; funicles abont half as long as the seeds, thread-like; seeds black, grossly reticulated.

On springy slady localities, in damp valleys, from the lowlands to the Alps; for instance, in the Daudenong Ranges, on Mount Disappointment, on Mount Buller and Mount William.

An herb of lax habit, varying in height from $1 \frac{1}{2}$ to 5 feet.

Stems and branches nearly cylindrical. Leaves all distinctly stalked, nucli more variable in form than those of C. stylosa. Segments of the pinnatisected leaves sessile or stalked, finely or grossly dentate, in a few or several or even many pairs, oblong- or ovate-cunente or rhomboid, lateral ones sometimes alternately sinaller, the terminal one larger than the rest, sometimes jagged. Upper stem-leaves either lanceolate and remotely selrate, or laciniated or. even pimnatisected; rppermost lanceolate or linear or liastate-linear, sonetimes elongated, occasionally diminute. Racemes, particularly the terminal one, gaining sometimes fully the length of 3 feet. Pedicels when flower-bearing $3-4$ lines long, when finit-bearing $\frac{1}{2}-1$ inch long; very spreading. Sepals narrow- or ovate- or lanceolate-oblong, about 2 lines long. Petals white, nearly or fully twice as long as the calyx, with an oborate lamina. Stamens more or less shorter than the corolla. Anthers oblong, with cordate base, $\frac{1}{2}-\frac{2}{3}$ line long, uncinate in nge. Pollen-grains ellipsoid, bursting lengthwise. Siliques many-seeded, generally but very slightly, but occasionally also horizontally patent, from 1-2 $\frac{1}{2}$ inclies long, about 1 line broad, sometimes much slortened and few-seeded, even exceptionally some two-seeded minute and then almost spindle-shaped. Frnit-style stout, 1-21 lines long. Valres concave-convex, veined. Septum nerveless. Funicles thread-like. Seeds oval, nearly 1 line long:

Cardamine Iaciniata, F. MI. in Transact. Phil. Soc. Vict. i. 34.-Jagged Bitter-cress.

Glabrous, perennial; leares all stalked, lanceolate or linear-lanceolate or linear, tootlied, laciniated or pinnatifid or pinnatisected, rarely quite entire or orate; lobes linear or narrow-lanceolate, without or with 
very few teeth, sessile; flowers generally tetrandrous, in each raceme not very numerous; stamens about as long as the calyx; anthers yellow; petals small, little or about $\frac{1}{3}$ longer than the ealyx; siliques twice or several times longer than the pedicel; valves nerveless; seeds brown, smooth.

In marshy places, chiefly in rich soil, often indicating somewhat saline ground, not rare; for instance, on the Yarra Yarra, Darebin Creek, Hopkins River, Mount Emu Creek, Creswick Creek, Loddon, Murray, \&c.; also rather frequent in South Australia, viz., at Lake Alexandrinæ, the Gawler River, the Bugle Ranges, the Onkaparinga, Torreus River, \&e.

A rather weak erect or ascending herb, seldom above 1 foot high, generally lower, sometimes stoloniferons. Root stout, almost woody, more or less divided and fibrilliferous, sonetimes producing long running fibres. Stems simple or branched, hollow, leafy or except the base almost leafless. Petioles of lower leaves very long, of upper ones more or less shortened, somewhat dilated and quite entire at the base. Leaves 1-5 inches long, $1 \frac{1}{2}$ line to $1 \frac{1}{2}$ inch broad, grossly or minutely always remotely toothed, or divided into long acute segments, of which the uppermost is the largest and frequently elongate-lanceolate. Racemes with scveral, seldom very numerous flowers. Pedicels slender, in age often remarkably remote, and then more or less spreading, when flower-bearing $1 \frac{1}{3}-3$ lines, when fruit-bearing $3-8$ lines or occasionally even fillty an inch long. Sepals elliptical-oblong or oblong--linear, $\frac{1}{2}-2$ lines long. Petals white, oblong, unguiculate. Stamens about as long as the calyx, in specimens from numerous localities, 4 , rarely 6 . Anthers basifixed, about $\frac{1}{3}$ line long; ovate-oblong, rolled back in age. Filancnts filiform, linear, pallid, alternately broader. Silique $1-2 \frac{1}{2}$ inches long, erect or in varions degrees divergent, about $\frac{2}{3}$ line brond, gradually terminated in a short style. Funicles filiform, of $\frac{1}{1}$ or $\frac{1}{3}$ the length of the seeds. Seeds as broad as the nerreless septun, round-ovate, about 3 line long. Testa when moistened mucilaginous.

This species is in flower throughout the year. The Mrurray natives use it as food. Its flowers are. occasionally viviparous.

Cardamine parviflora, Linné Spee. Plantar. 919; C. hirsuta, L. Spee. Plant. 915; J. Hook. Fl. Antaret. ii. 232; Flor. of New Zeal. i. 13; Flor. Thesm. i. 20; C. pratensis, L. Spec. Plant. 915, according to J. Hook. Fl. Iasm. i. 19; C. delilis, Banks so Solend. in Cand. Syst. ii. 265; C. silvatica, Link. in Hoffim. Phytogr. Blactt. i. 50; C. heterophylla, Hook. Icon. Pl. 58 ; C. lilacina, Hook. Comp. Bot. Magaz. i. 273; C. tenuifolia, Hook. Journ. Bot. i. 247 ; C. corymbosa, J. Hook. Leon. Pl. 686; C. intermedia, Hook. Icon. 258.-Small-flowered Bitter-cress.

Glabrous, rarely short-hairy, annual; leares all petiolate, pinnatisected, with more frequently stalked than sessile cordate roundish rhomboid ovate lanceolate oblong or linear segments, of which the lateral ones are generally smaller than the terninal one or sometimes perfectly undeveloped; petals twice or severnl times longer than the sepals; stamens longer than the calyx; anthers yellow; seeds compressed, bronn, as broad as the septum, smooth, ovate or orate-oblong.

On wet meadows, springs, rivulets, banks of rivers and lagoons dispersed over the whole colonr: common also in many parts of South Australia, at least as far north as the Flinders Ranges; also in New Soutl Wales, Tasmania and New Zealand, from the lowland to the summits of the Alps; seemingly rare in Westem Australia (at least not contained in the rich collections of Dr. Preiss); not found anywhere in North or North-Western Australia; noticed, however, in alnost every otler part of the globe as indigenous, although within the tropics chiefly restricted to mountain tracts. The large-flowered variety occurs in Australin principally on high mountains.

An herb, sometimes very diminutive, sometimes above a foot higln, in this country seldom hairy. Stems slender, weak, in small plants even capillary, in large plants again robust, erect or ascending, sinple or branched, in most instances producing but few leaves, in rare cases, when growing on shady banks of rivers subject to inundations in rich soil, laxly decumbent and several feet long, rooting then at intervals. Root fibrous, sometimes forming a toothed or almost scaly and much divided rlizome. Petioles at the base widened, 
vet not auriculate. Radical leaves numerous, on long stalks, pinnatisected; their lateral segments in single or a few pairs, either very minute or attaining the length of $\frac{1}{2}$ inch, often entire or repand, sometimes toothed, occasionally confluent. Terminal segment sometimes fully 1 inch long. Stem-leares on longer or shorter stalks, consisting either of a few pinnately-disposed segments or a single lobe, entire or toothed and stalked or sessile. The leaves of the large alpine variety not unfircquently sncculent and shining. Flowers in each raceme in most cases not very numerous, although occasionally so, sometimes very few, and rarely even bint a single one produced. Pedicels when flower-bearing 1-3 lines long, when fruit-bearing 3-6 lines long, rarely longer or shorter, by shortened inflorescence rarely corymbose or even fasciculate, or by division of the raceme paniculate. Sepals oblong, elliptical or orate, in the general small-flowered variety about 1 line long, in the large flowered form 2 lines long, blunt, with narrow white membranous margin. Petals white, rarely in alpine regions pink or lilac, in the ordinary state of the plant rather small, oblong-obovate or oblongcuneate, unguiculate, twice or thrice longer than the calyx, rarely in the large variety $4-5$ times longer than the sepals. Stamens in all specimens from very numerous and dissite Anstralian localities 6 in number. Filaments filiform- or subulate-linear, white. Anthers cordate-ovate, $\frac{1}{6} \frac{1}{4}$ line long. Silique erect or moderately spreading, $\frac{3-1}{4}-1$ chch long, $\frac{1}{2}-\frac{3}{4}$ line brond, terminated by a style of 1 line or less rarely 2 lines length or by a sessile stigma. Replum somewhat variable in breadtl. Valres witl an exceedingly faint or an obliterated midnerve. Septem nerveless. Funicles very short, tooth-like or filiform. Seeds ovate or oblong-orate, $\frac{1}{2}-\frac{\pi}{3}$ line, in the large variety 1 line long, as broad as the septum, therefore regularly uniseriate, rather opaque, distinctly compressed, with a very narow edge, sometimes rery indistinctly winkled.

The preceding description of this widely-diffused and consequently polynorphous plant is drawn up entirely from Australian specimens; many of tlem agree in every point with European plants of Cardaunine parvifora, whilst others are not to be distingmislied from those of Cardanine hirsuta, unless by the number of stamens, whilst again other specimens seem to pass by gradations into Cardamine pratensis. Preference is given to the name C. parvifior:a, because it expresses well the ordinary rariety, the larger-flowering ones being comparativcly scarce, whilst the notes of hairiness and tetranduus flowers of $\mathrm{C}$. liirsuta belong to the exceptions in Australian specimens. Cardamine pratensis is by many anthors particularly distinguished from C. lirsuta and C. parviflora by a perennial root, a claracter which I hardly feel justified to admịt for discrimination; for our European herbarium appears to demonstrate that the roots of Cardamine hirsuta and C. pratensis are only different fiom each other according to tlic proportionate sizes of the plants. The cliaracters derived from the leaves of $\mathrm{C}$. resedifolia are certainly also not offering a criterion, as may be proved by any extensive botanical collection, and a considerable number of congener's are either referable to this species, or are to be separated on other character's than those previously pointed out. To the synonymy of C. parviflora might hare been greatly added on this occasion, but it may suffice to quote those supposed species of which illustrations are extant, or which have special reference to the Anstralian vegetation. To Dr. J. Hooker the credit is due of having first of all cstablished this as a cosmopolitan species.

Specimens from Hong Kong, collected by Dr. Hance, show tetradyriamous stamens, and accord fully with some from Australia. C. resedifolia, $L$, seems merely an alpine state of this species. C. pratensis, according to Sir James Sinith, is always provided with a tooth at the claw of the petals. The subject of the specific limitation of the Cardanines is yet open for furtler inquiry, and deserves careful attention, being replete with phytogegraphical interest. C. depressa and C. stellata (J. Hook. Fl. Antarctica, pp. 6, 7, t. iii. and iv.) may possibly be extreme forms of $\mathrm{C}$. parvifiora, the width of the replum, as may be observed in Australian specimens, being sulject to considerable variation.

Cardamine eustylis, F. M. in Transact. Victor. Inst. i. 114.

Glabrous; leaves all pinnatisccted and stalked; their lobes generally sessile, ovate, oblong or rhounboid, few-toothed; floners small, tetrandrous; petioles of stem-leaves anriculate at the base; sepals longer than the petals, narrow-oblong, about as long as the stanens; antliers yellow, very minute; pedicels slightly 
spreading, nearly half as long or several times or many times shorter than the rather small slightly-compressed rostrate silique; seeds very unerous and vory minute, forming almost tno irregular rons in each cell, fulvous or brown, roundish-ovate, turgid, sunooth.

Rare on the sandy and gravelly banks of the Lower Murray River. Besides only as yet found on the rivers flowing into the Gulf of Carpentaria, and there also of very rare occurrence.

An erect or ascending seemingly anvual herb, from $\frac{1}{4}-1$ inch high. Root simple, filiform, descending or casually also horizontal. Stems simple or brauched, leafy or almost leafless. Petioles of the stem-leares dilated at the base into leafy minute blunt appendages. Leares tender, from less than 1 inch to fully 3 inches long, the radical ones long-stalked, the cauline ones on more or less elongated petioles. Segments in few pair, often decurrent, the terminal one the largest. Racemes bractless, few- or many-florrered. Flowerbearing pedicels about 1 line long, fruit-bearing ones generally $1 \frac{1}{2}-2 \frac{1}{2}$ lines long, but the lower ones of the latter sometimes extended to the length of $\frac{1}{2}$ inch, or eren, if singly arising from the base of the stem, attaining the length of 1 inch. Sepals greenish, abont 1 line long. Petals narrow-spathulate or linearoblong, white, very small, slightly or oftener considerably shorter than the calyx. Filaments linear-capillary, pale. Anthers oblong, only about $\frac{1}{8}$ of a line long. Silique not much spreading, $\frac{3}{4}-1$ inch long, $\frac{1}{2}-\frac{3}{4}$ line broad, terminated by a style of $\frac{1}{2}-1$ line lengtll. Valves membranous, very finely veined, nerveless or faintlr one-nerved towards the base. Replum rery narrow. Septum nerveless, considerably broadcr than the seed. Funicles extremely short, either tooth-like or subulate. Seeds only abont $\frac{1}{5}$ line long, without a perceptible border.

At first sight this remarkable species may be mistaken for Curdamine hirsuta, but the analysis reveals at once the decided discrepancy. It lias likewise some labitual aftinity to small forms of Cardamine impatiens, but the foliage is less divided, the stem not remarkably sulcate, the petioles are not protracted into long stipular appendages, the stamens in all flowers which were examined not 6 in number, nor exserted bexoud the calyx, the seeds are not as large nor arrayed into a single row equal to the width of the septun. By this latter note it differs widely from most congeners.

Tribe II. NOTORRHIZE E, Cand. Syst. ii. 438.

\section{Cotyledons straight, with dorsal radicle.}

\section{SISYMBRIUM.}

Linné, Gen. 813.-Hedge-mustard.

Sepals erect or spreading, nearly always equal at their base. Petals undivided, unguiculate. Stamens free, without teeth. Stigmas more or less united. Silique nearly cylindrical or compressedterete, bivalved. Stipes exceedingly short, or generally wanting. Valves three- or one-nerved, or nerveless. Septum without or with two nerves. Seeds in each cell several or numerous, uniseriate or irregularly biseriate, without a border. Funicles free, filiforn. Cotyledons incumbent, with their edges facing the septum.

Anuval, biemial or perennial herbs, or rarely suffruticose plants, extending over most parts of the globe, the intratropical regions excepted. Leares most variable in form. Pedicels racemose, ràrely bractente. Petals yellow or white.-Cand. Syst. ii. 458 ; Endl. Gen. 87.

A gcnus, subdivided by botanical authors into several distinct scctions, on one side rery closely approaching to Arabis and Cardamine, from which alone the embryo distinguishes it; on the other hand very nearly allied to Erysimum, from which it is chiefly discernible in more cylindrical than quadrangnlar siliques. The few Australian species hitherto known belong to the eastem half of the continent; in New Zealand and in Tasmania also none are found. 
Sisymbrium nasturtioides, F. MI. in Transact. Vict. Inst. i. 115; Erysinum Nasturtium, F. M. in Linnea, 1852, p. 368.

Annual, erect or diffuse; leaves pinnatilobch, rarely simply linear; lobes fen, linear, teethless; pedicels slender, spreading, ebracteate, at last about as long as the silique; petals yellow, small, spathulate, not inuch longer than the small spreading yellow sepals; stamens about as long as the corolla; anthers cordate-ovate, silique rather short, linear or oblong-linear, compressed; valves one-nerved, nearly menbranous; seeds ovate, brown, smooth, forming almost an irregular double row in each cell, much narrower than the septum.

On plains at the IInrray River towards the junction of the Darling; in South Anstralia along the Hill, Hutt, and Rocky Rivers.

A glabrous weak herb with the habit of a Nasturtium. Stems several from each root, $\frac{1}{4}-1$ foot long. Root descendent, cylindrical, flexuose, almost simple or sending out lateral fibrillw. Stem-leaves, as well as radical leaves, deeply pimnatilobed or three-sected or some undivided, tapering into a linear exappendiculate conspicuous petiole, with the addition of which 1-3 inches long, or in diminutive specimens still smaller. Lateral lobes opposite or alternate, from $1 \frac{1}{2}$ line to more than $\frac{1}{2}$ inch long, perfectly entire; the terminal lobe also linear, longer than the rest, sometimes fully 1 inch long; all lobes abont I line broad. Pedicels capillary, numerous, at first corymbose, a few lines long and crowded, soon racemose and 3-8 lines long. Sepals nearly ovate, about 1 line long. Stamens 6 . Filaments $\frac{3}{3}-1$ line long, subulate, somewhat thickened at the base. Anthers $\frac{1}{4}-\frac{1}{3}$ line long, yellow. Pollen-grains ellipsoid, smootl, bursting longitudinally. Style short or' very short. Stigmas united into a single orbicular one, impressed in the centre. Silique generally from $\frac{1}{4}-\frac{1}{2}$ inch long, $\frac{1}{3}-\frac{3}{4}$ line broad. Valves very subtle veined. Septum nerveless. Seeds in each cell sereral or numerons, about $\frac{1}{3}$ line long.

Flowers during the spring montlis.

This species is intermediate between the sections Irio and Arabidopsis, and approaches in habit to S. Thalianum. In its minute yellow flowers and size and shape of fruits, it comes nearer to $\mathrm{S}$. canescens, Nuttall. The disposition of the seeds is that of $\mathrm{S}$. glaucmun.

Amongst the plants collected during. Sir Thon. Mitchell's expedition on the Balonne, a Sisyinbrium exists closely allied to the preceding, differing in being clothed with short undivided hair, in having broader and toothed lobes of the leaves, and perhaps petals of different color.

Sisymbrium trisectum, F. I. in Transact. Tict. Inst. i. 114.

Glabrous, stems suffiruticosc; lcaves numerous, triseeted; segments and some leaves simply linearfiliform or bifid; pedicels slender, slightly spreading, ebracteate, at last of $\frac{1}{3}$ or nearly $\frac{1}{2}$ the length of the fruit; petals white, generally orbicular and abruptly unguiculate, as long as or not much longer than the greenish spreading sepals, stamens about as long as the corolla; anthers hastate-linear; silique slightly compressed; valves thinly one-nerved ; seeds oblong-ovate, brown, smooth, forming an irregular simple or half-double row, narrower than the septum.

On sandy clay-soil and on the dry limestone-plains of the Murray River. In New South Wales, on the Darling; in South Australia, near the Flinders Ranges, the Murray River, and in the interior north-west of Spencer's Gulf.-Conf. Report on Plants of Babbage's Expedition, p. 7.

A handsome plant, 1 to several feet high. Branches furrowed. Leaves $\frac{1}{3}-\frac{1}{2}$ inch long, divided into a narrow unappendiculated stalk and rather fleshy segments, by innovation frequently fasciculate, not rarely glabrous; segments generally $\frac{1}{4}-\frac{1}{3}$ line broad, occasionally 1 inch long, frequently considerably shorter. Racemes scented, on a leafless streaked peduncle of 1-3 inches lengtl ; many-Howered, when fruit-bearing sometimes fully 1 foot long, not corymbose even when in flower. Pedicels whilst tlower-bearing $2-3$ lines, whilst fruit-bearing 3-5 lines long, scarcely spreading: Sepals oblong, veined, about $1 \frac{1}{2}$ line long, with white tender margin. Lamina of petals $1-1 \frac{1}{2}$ line long, sometimes more ovate and somewhat tapering into 
the unguis. Stamens 6. Filaments subulate. Anthers yellow, nearly 1 line long, affixed at their sinus, in age very recurved. Pollen-grains ellipsoid, bursting longitudinally. Stigmas nnited into a single depressed roundish one, alnost sessile. Silique erect or somewhat spreading, without a stipes, about 1 inch long, ${ }_{3}^{-}-1$ line broad. Septem nerveless. Seeds $\frac{1}{3}$ line long. Funicles very thin, often cmrved, shorter than the seeds.

Flowers in the spring.

A similar species or remarkable variety has been found by the anthor at Crystal Brook in South Australia; it has been described as S. filifolium (Transact. Vict. Inst. i. 115 ; Erysimmm filifoliun, Linnea, 1852, 368), and differs in having all leaves undivided, the pedicels thicker and very spreading, the siliques shorter and provided with a very short stipes, in having a conspicnous style and smaller stigma, larger seeds, which attain the width of the septum, and perhaps also in flowers, which are unknown yet.

The Sisymbrimm oficinale (Scopoli, Flora Carniolica, ii. 26), here and there occurring in Australia, is omitted in the series of descriptions for this work, being evidently an immigrated species. As a doubtful plant the Sisymbrimm cardaminoides (F. M. in Transact. Phil. Soc. Vict. i. 34) is likewise excluded, its diversity from S. Thalianum (Gaudin, Flora Helvet. iv. 438) having not yet been convincingly proved. The Australian plant seems to differ, however, from the European one in furcate and ramose not simple and furcate hair of the indument, in the leaves being toothed and those of the stem generally stalked, and in shorter and broader siliques, terminated by a manifest style. It occurs in sandy localities near the Rivers Murray and Glenelg.

\section{BLENNODIA.}

R. Br. in Sturt's Central Austr. ii. Append. p. 6r.

Sepals erect, often unequal at the base. Petals equal, undivided, unguiculate. Stamens free, without teeth. Stigmas united. Siliques long-cylindrical or lanceolate-cylindrical, bi-valved. Stipes wanting. Valves convex, one-nerved or almost nerveless. Septum unnerved. Seeds in each cell mumerous or few, smooth, forming one or two irregular rows, withont a border. Testa, when moistened, yielding a very copious fibrous mucus. Funicles short, subulate. Cotyledons incumbent; their edges facing the septum.

Annual herbs, restricted to the extratropical deserts of Australia, downy with short branched hair. Leaves toothed or laciniated, occasionally entire, never clasping. Pedicels racemose, ebracteate. Petals pink or white, less fiequently yellow.

A genus considered by R. Brown nearly related to Matthiola, placed by Walpers (Annal. Botan. Syst. ii. 48) next to Malcolmia, chiefly by the very mucilaginous testa to be distinguished from Erysimum, in habit also similar to Moricandia and Diplotaxis. Blennodia alpestris, now excluded from the genus, forms the transit to Capsella.

Blennodia lasiocarpa, $F$. MI. in Transact. Phit. Soc. of Tict. i. 100; Errsimum blennodes, F. M. in Linncea, 1852, 367.

Leaves nearly lanceolate, toothed or pinnatifid; petals tnice or three times as long as the calyx, pink or white; silique very short, lanceolate-cylindrical, hispidulons, of nearly the sane or of almost the double length of the spreading pedicel, terminated by a short and slender style and a minnte stigma; valres indistinctly one-nerred; seeds few in each cell, narrower thau the lanceolate septmm.

On arid sandy plains at the River Murray and its lower tributaries. Beyond Victoria, towards Lake Alexandrina (Dr. IIillebraul) and on Cooper's Cruek (A. C. Gregrory).

An erect or ascendent herb, fiom a few inches to $1 \frac{1}{2}$ foot high. Root descendent, filiform, often simple. Stems oftener branched than simple, terete. Radical leaves rather numerons, soon decaying, taperiug into a long unappendiculated petiole, generally from 1-3 inches long, grossly toothed or even pimnatifid, with 
triangular lobes; stem-leaves generally few, occasionally rather numerous, mostly short-stalked, frequently smaller than the rest and more minutely toothed: Pedicels when in flower rather corymbose and 1-3 lines long, when in fruit racemose and 3-6 lines long, rarely shorter. Sepals ovate, 1-1 $\frac{1}{2}$ line long, downy; the two lateral ones gibbose at the base. Petals oborate, attenuated into a more or less elongated claw. Stamens six, tetradynamous, somewhat longer than the calyx. Filaments linear-subulate, often considerably dilated towards the base. Anthers cordate-ovate, yellow, $\frac{1}{5}-\frac{1}{3}$ line long. Pollen-grains ellipsoid, bursting longitudinally, when moistened spheroid. Silique patent or ascendent, covered with short mostly simple spreading somewhat rigid hair, 3-6 lines long, 1-1 $\frac{1}{2}$ line broad, slightly curved, turgid, gradually pointed into the base and apex, rarely in what seems a variety of this species rery short-downy. Fruit-style $\frac{1}{3}-\frac{3}{3}$ line long; glabrous. United stigmas almost hemispherical. Valves sometimes more chartaceous, sonetimes more membranous, faintly one-nerved particularly below the middle. Seeds forming an irregular single or double row, occasionally only $1-2$ in each cell, pale-brown, orate, turgid, hardly longer than $\frac{1}{2}$ line, ejecting when wet a copious radiating mucilage from the testa.

Flowers chiefly during the spring.

Plate II. 1, 2, hair; 3, Hower; 4, sepals; 5, petals; 6, stamens and pistil; 7, pollen-grains, dry; 8 , pollen-grains, moistened; 9 , silique; 10 , longitudinal section of silique, showing septum, funicles and arrangement of seeds; 11, seed, dry; 12, seed, moistened, surrounded by mucus; 13, transrerse section of seed; 14, embryo, illustrated with accumbent instead of incumbent cotyledons : all figures more or less magnified.

From this and the following species the typical Blennodia canescens may be easily distinguished by longer sepals, measuring about $2 \frac{1}{2}$ lines, and by longer linear-cylindrical siliques, with probably in each cell uniseriate seeds, crowned by a large almost sessile stigma. B. canescens, according to specimens from Cooper's Creek and from near Lake Torrens, is annual, not suffruticose. I hạd no opportunity to examine its ripe fruit for comparison.

Blennodia brevipes, F. MI. in Transact. Phil. Soc. Vict. i. p. 100 (adnot.); Erysimum brevipes, F. M. in Linnea, 1852, 365 .

Leaves broad- or rhomboid-lanceolate, the lower ones lyrate-pinnatifid or laciniate, the upper ones toothed; petals white, exceeding in length hardly the minute calyx; silique short, narrow, lanceolatecylindrical, four to six times longer than the stout scarcely spreading pedicel, short-downy, terminated by a very short style and a minute stigma; valves indistinctly one-nerved; seeds few in each cell, narrower than the lanceolate septum.

In barren sandy localities on the Murray River and its lower tributaries; also N.W. of Lake 'Torrens, and on the Rocky River in South Australia.

Stems fistulose, branched, terete, 1-2 feet high. Radical leaves quickly emarcescent; lower stem-leaves 1-2 inches long, tapering into a moderately long petiole; the lobes triangular or semi-lanceolate, sometimes in front again toothed. Upper stem-leaves short-stalked, 1 inch and less long, generally sharp-toothed, short-stalked or the uppermost sessile. Flower-bearing pedicels crowded, very short; fruit-bearing ones stout, slightly spreading, 1-1 $\frac{1}{2}$ line long. Sepals oblong, downy outside, scarcely 1 line long. Petals oblong-spathulate, tapering into a claw. Filaments about 1 line long, capillary, dilated gradually at the base. Anthers yellow, nearly ovate, only $\frac{1}{8}$ line long. Siliques almost erect, turgid, 6-9 lines long, attenuated gradually into the base and apex. United stigmas depressed. Valves faintly one-nerved, particularly below the middle. Seeds nearly $\frac{2}{3}$ line long, roundish-ovate, turgid, brown, smooth, disposed in a single or double irregular row in each cell, emitting when moistened largely a turbid mucilage, which inspected under the nicroscope is beautifully radiated. Funicles dilated at the base. Radicle exactly dorsal or sometimes more lateral.

This plant is more robust than either the preceding one or the following. It bears flowers in the spring. 
Blennodja curvipes, F. M. in Transact. Phil. Soc. Vict. i. 100; Erysinum curvipes, F. M. in Linncea, 1852,365 .

Lcaves lanceolate or broad-linear, toothed or some entire; petals ycllow, scarcely longer than the calyx; silique short, tetragonous-lanceolate, about or nearly as long as the spreading-ascendent slender pedicel; ralves distinctly one-nerved; seeds few in eacli cell, narrower than the lanceolate septum.

In sandy localities on the Murray River, towards the junction of the Darling; in South Australia, N.W. of Lake Torrens and Spencer's Gulf, and at Crystal Brook.

An erect or more generally ascendent leerb, about a span high. Root branched into long thin divisions. Stems slender, terete. Radical as well as lower stem-leaves tapering into a rather short petiole, generally about 1 inch long, minutely or grossly few-toothed. Upper stem-leaves from a ferw lines to nearly 1 inch long, sessile or short-stalked. Pedicels when in flower rather corymbose, 1-2 lines long, when in fruit curved-divaricate, 6-9 lines long, thickened at the summit. Sepals outside downy, almost equal at the base, 1-1 $\frac{1}{2}$ line long, ovate. Petals obovate, hardly or short-unguiculate. Anthers yellow, about $\frac{1}{2}$ line long, oblong-ovate. Filaments linear-subulate. Siliques $4-7$ lines long, about $1 \frac{1}{2}$ line broad, narrow lanceolateellipsoid, somewlat curved, acute, terminated by a short rather stout style and a depressed convex stigma. Valves very convex, carinate by a strong' midnerve, rendering the silique nearly tetragonous. Funicles dilated at the base. "Septum membranous. Seeds irregularly biseriate, eradiating when moistened a copious opaque mucilage, ovate, rather turgid, brown, about $\frac{1}{2}$ line long.

It flowers during the spring. No other species of this genus besides those referred to in the preceding pages are hitherto known.

\section{CAPSELLA.}

Moench, Method. plant. stam. situ describ. 271.

Sepals erect or spreading, equal at the base. Petals undivided, equal. Stamens free, without teeth. Stigmas united. Silicle bivalved, deltoid-or ovate-obcordate, or ovate or ellipsoid, turgid or compressed. Valves wingless, one-nerved or almost nerveless, rarely appendiculate at the apex. Seeds subovate, in each cell several or few or only two, without a border. Funicles free. Cotyledons incumbent.

Annual, biennial or perennial herbs, distributed over most of the temperate and colder regions of the globe. Their leaves variable in form. Pedicels racemose or corymbose, ebracteate. Petals white or pink.

This genus includes Hymenolobus of Nuttall, and those species of Hutchinsia which have incumbent cotyledons, whilst those with accumbent cotyledons are clearly transferable to Thlaspi. The approach of the typical Capsella species with many-seeded fruit-cells, through the subgenus Hutchinsia with two-seeded cells of the silicle, to Lepidium, is close in the extreme. In another direction the gradations to Blennodia are also complete.

Capsella blennodina.-Blennodia alpestris, F. M. in Transact. Philos. Soc. Victoria, i. 100.

Perennial, stems downy, robust, often leafless towards the summit; leaves lyrate or rhomboid or lanceolate-spathulate, toothed or nearly entire, glabrous; pedicels puberulous, forming also in age a corgmb or only a very short raceme, then very spreading and as long as or little longcr thun the tragonous-ellipsoid. aeute siticlc; petals orbicnlar-ovate, long-mngruiculate, about twice as long as the sepals; stamens not much longer than the calyx, shorter than the petals; valves nearly chartaccous, strongly one-nerred; septum about as broad as the contrary transverse dianeter of the fruit, lanceolate; sceds several in each cell, shining; dark-brown, reticulate.

In subalpine grassy meadows at the sources of the Murray and Snowy Rivers; also in the ranges near Bathurst, according to W. Wools, Esq. 
Root eitlier forning a woody descendent rhizome or, underground fibrilliferous runners. Stems erect or ascendent, from 2-8 inches long, oftener simple than branched, more or less densely clothed with short crisp branched hair, leafy in its lower portion or occasionally up to the corymb, rarely quite leafless. Radical leaves numerous, tapering into a conspicuous petiole, sometimes blunt, sometimes rather acute, exclusire of petiole $\frac{1}{2}-1$ inch long, rarely longer, minutely or grossly toothed, seldom without, teetl. Stem-leaves similar to the radical ones, but snualler and attenuated into a shorter petiole; the upper ones often diminutive and sessile. Corymb densely many-flowered, in age not lengthened into an extensive raceme. Pedicels when in

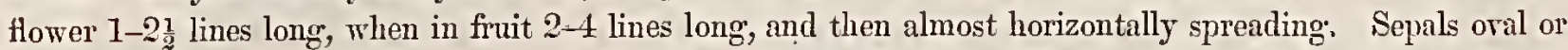
oblong, somewhat patent or ratler erect, glabrous, abont 1-1 $\frac{1}{2}$ line long, not rarely tinged with purple. Petals white or pink, with addition of the narrow often purplish unguis 2-3 lines long:- Stamens 6 . Filaments linear-subulate 1-1 $\frac{1}{2}$ line loug, white or purple. Anthers only $\frac{1}{5}$ or $\frac{1}{4}$ line long, cordate-orate, yellow. Pollen-grains ellipsoid, bursting longitudinally. Silique or silicle turgid, spreading, $2 \frac{1}{2}-3 \frac{1}{2}$ lines long; hardly more than 1-1 $\frac{1}{3}$ line broad, acute at both extremities, terminated by a short style, which is crowned by a small depressed quite confluent pair of stigmas. Valves carinate by the middle nerre, not membranous. Funicles short, subulate. Ovules many. Seeds $3-8$ in each cell, inordinate biseriate, turgid, ovate, about $\frac{1}{3}$ line long. Testa exúding, if softened by moisture, a clear faintly radiating mucus, much less copiously, lowever, than the species of Blennodia. Face of cotyledons turned irregularly towards the septum. Embryo normally notorrhizal.

In flower during the summer.

This plant, one of our very few endemic alpine Cruciferæe, stands undoubtedly in near relationship to the Capsella alpina, $F . M$. (Hutchinsia alpina, R. Br. in Hort. Kew. ed. ii. 4, 82), which delights likewise in cold regions. The comparison shows the Australian plant to be larger and more robust than its contype, the leaves are not deeply divided into many small lobes, the funicles are less rigid, and are, in consequence of the capsule being many- not two-seeded, existing also in the lower part of the fruit, finally the testa is not smooth.

Capsella elliptica, C. A. Meyer, Verzeichn. von Pfanzen des Caucasus, p. 194; Flora Altuica, iii. 199 ; C. procumbens, Fries, Novit. Flor. Suecise, Dlantiss. i. 14; Lepidinm procumbens, Linné, Spec. Plant. 898; Hutchinsia procumbens, Destaux, Journ. iii. 168; Cand. Syst. ii. 391 ; Hymenolobus procrumbens, divaricatus et erectus, Nuttall in Torrey and Gray, Flora of North America, i. 117 ; Hook. Icon. t. $27 \%$; Stenopetalum incisifolium, J. Hook. Icon. Plant. 276.

Annual, glabrous; stems slender, leafy; leaves lanceolate or subovate or the upper ones linear, entire, toothed or pinnatifid; pedicels capillary, at last elongate-racemose, frequently twice as long as the ellipsoid or roundish-ovate blunt silicle; petals minute, obovate-cuneate, havdly longer than the calyx; valves rather turgid, membranous, lightly one-nerved; septum often narrower than the contrary transverse diameter of the fruit, lanceolate; seeds rather numerous in each cell, pale-brown, smooth.

In boggy slightly saline places around Port Phillip Bay, and on the Murray River. Found also at St. Vincent's Gulf and Lake Alexandrinre in South Australia, further in Tasmania and Western Australia; also occurring throughout Europe, in various parts of Asia and Africa, and as well in extratropical North as South America.

A generally ascendent occasionally erect or procumbent herb, 2-9 lines long: Root thin, flexuose, with capillary fibres. Stems from each root several or numerous. Leaves 2 lines to 1 inch long, entire or more frequently acutely and grossly toothed or more or less deeply pinnatifid; the lower ones stalked, the upper ones not rarely sessile; lobes half-lanceolate or triangular or oblong or broad-linear, always few. Pedicels numerous, rarely few, when flower-bearing corymbose and 1-2 lines long, when fruit-bearing racemose, 2-4 even 6 lines long and rather spreading. Pedıncle often flexuose. Sepals oval, pale-green, scarcelv shorter than the stamens. Petals white, hardly longer than $\frac{1}{2}$ line, obovate- or oblong-cuneate. 
Filaments subnlate-linear. Authers very minute, yellow. Silicle $1 \frac{1}{3}-2$ lines long, rounded-blunt or eren truncate or slightly emarginate at the apex, terminated by the minute nnited subsessile or short-stylose stigmas, moderately or slightly compressed in most cases contrary to the often fenestrate septum, nevertheless occasionally also pressed towards the septum. Valves veined, more or less tumid, whereby the width of the dissepiment increases or decreases; thus more frequently silicles occurring in which the valvular diameter of the fruit exceeds its septal width, whilst in other and fewer instances these proportions are reversed, a note which much infringes the limits between the cruciferons tribes of Latiseptre and Angustiseptie in Candolle's System. Seeds ovate or ellipsoid, lightly compressed, in each cell $\breve{5}-14$, occasionally very few, irregularly biseriate, $\frac{1}{4}$ line long. Funicles short or very short, capillary. Testa, when wet, eradiating a limpid homogenous mucilage. Cotyledons invariably truly incumbent, at least foind so in all our specimens examined, and as also well shown in Hooker's Icones Plantarum, t. 276, and remarked by Koch and others, not accumbent, as stated in Candolle's System in the generic note on Hutchinsia, and thence in J. Hooker's Flora Tasmanica, p. 22.-Capsella pauciflora (Koch, Synops. Fl. Germ. ed. secund. i. 79) seems merely a fewflowered variety of this species.

Flowers produced early in the spring.

Capsella antipoda.-Hutchinsia Australis, J. Hook. Fl. Tasm. i. 23, t. 4.

Annual, downy or almost glabrous; stems slender, leafy; leaves lanceolate or spathulate or rarely linear or hastate, tootlred or pinnatifid, or pinnatisected, occasionally entire; pedicels capillary, at last elongate-racemose and generally considerably longer than the ellipsoid silicle; sepals spreading, half as long as the orbicular or ovate-orbicular long-unguiculate patals; valves turgid, membranous, almost nerreless; septum broader than the contrary transverse diameter of the fruit, lanceolate-ovate or lanceolate; seeds in each cell several, pale-brown, smooth.

On Mount Macedon, at the summit of Mount Alexander, and also in the Black Forest. Indigenous likewise to Tasmania.

An herb, variable in height from 1-6 inches, of the appearance of Capsella elliptica, sometimes rather densely pubescent with spreading branched and simple short downs, sometimes but very scantily downy. Root filiform, flexuose, descendent, with more or less thin fibrillæ. Stems many from the root. Leares, except the upper cauline ones, long-stalked, mostly from $\frac{1}{4}-1$ inch long; the ovate, lanceolate or linear lobes, as well as the teeth, acnte. Pedicels capillary, numerous, at first corymbose, 1-2 lines long, soon racemose, in age varying in length from 3-10 lines, rather spreading. Sepals ovate or orbicular-orate, pale-green, patent, with pallid margin. Petals white, about 1 line long. Stamens 6. Filaments linear-subulate, about $\frac{1}{2}$ line long. Anthers yellow, very small, didymous-roundish. Pollen-grains ellipsoid. Stigma nearly sessile. Silicle $1 \frac{1}{2}-2 \frac{1}{2}$ rarely 3 lines long, considerably compressed towards the septum; therefore the latter placed in the broader diameter of the fruit, whilst in many other species the narrower diameter of the fruit is occupied by the septum. Valves veined, nerveless or faintly one-nerved towards the base. Replum very thin. Septum lanceolate or orate, nerveless, sometimes perforated with an irregular foramen. Funicles capillary, about half as long as the seeds. The latter in each cell numbering $3-7$, placed in two irregular rows, nearly $\frac{1}{3}$ line long, ovate, hardly compressed. Mucilage of wet testa limpid, rather copious and slightly radiating. Embryo truly notorrhizal. Edges of cotyledons facing the septum.

In flower early in the spring.

Capsella pilosula, F. M. First Gencral Report, $p .9$; Microlepidium pilosulum, F. M. in Linnea, $1852,371$.

Annual, downy with short simple and divided hair; stems leafy, much branched; leaves lanceolate, obovate or rhomboid, toothed or entire; pedicels stout, half or nearly as long as the cuneate- or orateobcordate compressed siliclc; valves rather chartaceons, boat-shaped, one-nerved, dilated at the apex into a 
minute wing; septum considerably narrower than the transverse contrary diameter of the fruit, lanceolate; seeds few in each cell, smooth.

In the sandy desert on the Minrray River, rare.

An insignificant plant, only a few inches high. Root divided into long thiu fibres. Leaves from a few lines to $\frac{1}{2}$ inch long. Flowers as yet unknown. Fruit-pedicel 1-2 lines long. Stigma subsessile. Silicle measuring $1 \frac{1}{2}-2$ lines, scarcely more than 1 line broad; terminal notch very distinct. Valves not membranous; their cavity not extending to the apex. Funicles very slort. Seeds about $\frac{1}{3}$ line long, somewhat compressed. Embryo exactly notorihizal.

'The conspicuonsly bilobed silicle distinguishes this at once from the preceding species, with which otherwise it agrees in most characters, offering a transit from them to Capsella Bursa pastoris, a now troublesome invader of many parts of Australia, but evidently not an indigenous species. Although the fruitvalves of the latter are likewise protruding at the apex, a remarkable difference consists in their being hollow to the rery summit.

Produces flowers at the end of the rainy season.

\section{LEPIDIUM.}

R. Brown, in Aiton. Hort. Kow. ed. ii. v. iv. 85.-Cress; Pepperwort.

Sepals equal at the base. Petals undivided, equal, sometimes wanting. Stamens 6, or sometimes 4 or 2, free, without teeth. Stigmas united. Silicle bivalved, round or ovate or cordate, often emarginate or bilobed. Valves laterally strongly compressed, rarely turgid, boat-shaped, carinate, wingless or at the apex rarely at their whole dorsal length winged. Septum narrow. Seeds in each cell solitary, very rarely twin, compressed, sometimes nearly trigonous. Funicles free, terminal. Cotyledons incumbent, parallel to the septum, quite exceptionally accumbent, entire, rarely divided, never folded except occasionally at the base, neither channelled.

Herbs or suffruticose plants, generally of strong sometimes cress-like taste, more generally distributed over the extratropical parts of the globe than most other cruciferous genera. Leaves of manifold shape. Flowers small, generally disposed in elongate racemes. Petals white. Silicles often minute.-Cand. Syst. ii. 5227.

Iepidium ruderale, Linné, Spec. Plant. 900; L. hyssopifolium, Desvaux, Journ. Botan. iii. 164 and 179 ; L. ambigum, $F$. M. in Transact. Phil. Soc. Vict. i. 34.

Slightly scabrous by very minute hair or almost smooth; radical leaves generally pinnatisected or pinnatifid, with orate lanceolate or linear toothed or laciniated or pinnatifid lobes; stem-leaves subsessile, linear- or cuneate-lanceolate, entire or toothed or principally the lower ones laciniated or pinnatifid, with nar'ow lobes, subsessile, frequently appendiculate at the base; floners minute gonerally apctalous and diandrous; pedicels slender, not much longer or nearly twice as long as the small roundish- or rhomboidovate slightly-notched silicle; stigma subsessile; valves smooth, very compressed, hardly winged at the apex; seeds subellipsoid; moistened testa sparingly gelatinous; cotyledons undivided.

Throughout the Colony of Victoria in both fertile and sterile localities, but not in alpine elevations. Common also in South Australia, Tasmania, and in East Australia, as far north as the tropic of Capricorn; also in West Australia, and distributed over many other parts of the globe.

An herb of strong somewhat cress-like taste, and of biennial and seemingly here also perennial duration; but already as seedliug producing flowers in the first year of growth. Root simple or branched, sending out more or less numerons often tender fibres. Stems frequently erect or diffuse, sometimes solitary or more generally several from each root, simple or often branched, $\frac{1}{2}-3$ feet long, terete, scarcely upwards angular, always leafy. Leaves $\frac{2}{3}-4$ inches long, very variable in form, minutely ciliolated, divided or 
remotely toothed or rather copiously serrated from considerably above the base, except the upper ones; the basal part narrow-cuneate or linear, constituting a winged stalk, which in large specinens is occasionally fully $\frac{1}{4}$ inch broad, whilst a trine petiole of 1 line or less length is forméd below the acute or blunt generally short occasionally suppressed auricular appendages. Young leaves frequently fasciculate. Racemes terminal and lateral, many-flowered, $1 \frac{1}{2}-8$ inches long, occasionally yet shorter and then contracted into a dense corymb, not rarely several consociated into a sort of panicle. Pedicels depressed, very thin, linear-filiform, when flower-bearing about 1 line long and very crowded, when fiuit-bening $1 \frac{1}{3}-2$ lines long, spreading, even quite horizontal. Sepals erect, oblong or oval, abont $\frac{1}{3}$ line long, witl often sordidly purple back and with white margin. Petals in all specimens examined none, although according to European botanists occasionally developed. Staminodia not very rarely obvious, extremely minute, setaceous-linear, white, aside of the fertile stamens. Stamens in all the Australian specimens exannined two, opposite to the replum, rarely, according to observations in Europe, four. Filaments white, setaceous, hardly longer than the petals. Anthers yellow, very small, didynous-round. Silicle spreading, about 1 rarely in L. ambiguum 2 lines long; the short terminal lobes protruding distinctly beyond the stigma. Back of valres acute. Septum narrow- or linear-lanceolate. Funicles short, terminal. Seeds placed with their edge to the septum, little more than $\frac{1}{2}$ line long, pale brown, or almost rufous, ellipsoid or avate-ellipsoid, somewliat compressed, exuding rather sparingly a liyaline mucus.

Produces flowers in the spring and summer.

Neither the Lepidium Nova Hollandix (Desv. Journ. iii. 177), nor the L. piscidium (Forst. Prodr. 249) seems, according to Candolle's description, to differ essentially from-L. ruderale; and L. puberulun (Bunge, in Lelmann, Plant. Preiss. i. 261) seems also referable to the same. The Lepidium foliosum (Desv. Journ. iii. 164), with which most probably the L. cuneifolium (Cand. Syst. ii. 545; J. Hook. Flor. Tasm. i. 25) concurs, is chiefly from L. ruderale to be discriminated in the normally petaliferous flowers with 6 tetradynamous stamens and in the double size of the silicle. Onr herbarium contains this species from South Port of Tasmania and from Kangaroo Island, and most probably it will also be found yet in the litoral part of the Colony of Victoria.

Lepidium papillosum, $T$. $M$. in Linnaa, 1852, 370 .

Annual; stems densely covered with minute papille; leaves nearly glabrons, sagittate- or hastateoblong or lanceolate or cuneate, sessile, with acute remote teeth; flowers apetalous, tetrandrous, very minute; pedicels flat, rather stont, not much shorter than the broad ovate-obcordate to one-fourth of its length bilobed silicle; stigmn sessile; valves very conlpressed, blnntly winged at the apex; seeds suborate; moistened testa very gelatinous; cotyledons undivided.

In the Murray Desert on several localities gregnrious, for instanee, at Benanee. Also beyond Victoria in great number on the barren lills and plains near Crystal Brook, on the Rocky River and N.W. of Spencer's Gulf.

An lierb of unpleasant scent, $\frac{1}{4}-1 \frac{1}{2}$ foot high, frequently overcast with a purple hne. Root pale, sending out lateral fibrillre. Stems erect or ascendent, as well as the branches and surface of pedicels copiouslr covered with minute spreading almost club-shaped white papillre. Radical leaves fast decaying; stem-leaves generally from $\frac{1}{2}-2$ inches long, $1-5$ lines broad, sometimes scantily papillose-scabrous at the margin, acute. Raccmes terminating the branches, or on short peduncles lateral, rather densely many-flowered, 1-4 inches long. Pedicels mensuring in length $1-1 \frac{1}{2}$ line, depressed-linenr, spreading but not horizontal. Two sepals roundish, two oblong-oval. Stamens exceedingly small. Filaments capillary. Anthers yellow, roundish. Silicles $2-2 \frac{1}{2}$ lines long, with a narrow terminal sinus. Septum lincar-lanceolate. Funicles short, subulate. Seeds about 3 line long; compressed, orate, brown. Gelatine of moistened testn linpid. Cotyledons truly incumbent, semi-cylindrical, of equal height with the radicle.

In flower during the latter part of the rainy season. 
Iepidium monoplocoides, $F$. M. in Transact. Phil. Soc. Vict. i. 35.

Slightly rough with depressed papillæ; stem-leaves linear, entire, their base without appendages ; flowers minute, apetalous, tetrandrous; pedicels flat, ratlier stout, not mucl shorter than the fruit; silicle orbicular, acutely bidentate, quite surrounded by a broad upwards bent margin; terminal sinus extremely narrow, including deeply the style; seeds ovate-orbicular, strongly compressed, surrounded by a very narrow border; moistened testa very gelatinous; cotyledons undivided.

In the Mallee Scrub near the Murray River, towards its junction with the Mnrrumbidgee.

An erect or ascendent herb, producing several branched or simple stems from its probably annual root, from a rery few inches to at least 1 foot high. Root slender, flexuose, but at times stout. Leaves $\frac{1}{4}-1$ incl long, $\frac{2}{3}-1$ line broad, radical ones unknown, being very perishable. Pedicels spreading, yet not horizontal. Sepals oval and oblong, $\frac{1}{2}$ line long: Stamens minute. Filaments from a broad base subulate. Antliers yellow, cordate-roundish. Silicle rigidulous, $1 \frac{1}{2}-2$ lines long and broad, slightly turgid over the space of its cavity; the two terminal teeth forming a short acumen; the sinus extending to near one-fourth the length of the valves, but being by the lateral contact of the valve-teeth generally fully closed up. Funicles very short. Septum narrow-lanceolate. Seeds about $\frac{3}{4}$ line long, brown, smooth. Testa when moistened forming a transparent pearl of tenacious gelatine. Cotyledons semi-cylindrical, without lateral inflexion, but turning: upwards to the radicle, thus their lower portion becoining longitudinally bent. Radicle and cotyledons equally high, but the latter considerably longer than the former.

In flower during the earliest part of the spring.

Iepidium phlebopetalum.-Nonoploca phlebopetala, F. M. ì Limaa, 1852, 369.

Herbaceous ; leaves linear, carnulent, undivided, without basal appendages; pedicels racemose, as long as or shorter than the fruit; petals not much longer than the spreading sepals, oblong; stamens 6 ; anthcrs purplc; silicle large, very compressed, ovate-orbicular, to one-fifth of its length acutely bilobed, wingerl towards the apex; style capillary, free, often exserted; seeds ovate, compressed; moistened testa very gelatinous; cotyledons undivided.

In barren localities on the MIurray. Also in South Australia on the Rocky Creek, and in New Soutl Wales on the Darling.

A seemingly perennial herb, a span or less high. Root flexuose, cylindrical. Stems rigidulous, simple or branched, often many from eacl root, cylindrical, slightly scabrous. Leaves $\frac{1}{2}-1$ incli long, $\frac{3}{4}-1 \frac{1}{2}$ line broad, ratler blunt, one-nerved. Flowers several or many in an at first corymbose, soon lengthened terminal raceme, which, howerer, never exceeds the length of a few inches. Pedicels somewhat flattened and angular, often scabrous, $1 \frac{1}{2}-2 \frac{1}{2}$ lines long, as well as the silicle spreading. Sepals oblong, greenish, with white margin, hardly more than 1 line or $1_{\frac{1}{2}}$ line long. Petals oblong, white, tinged with purple, attenuated at the base, not much longer than the calyx, veined; their midnerve evanescent towards the apex. Stamens, at least the longer ones, reaching the height of the calyx. Filaments capillary-linear. Anthers $\frac{1}{3}$ line long; oblong, with cordate base. Pollen-grains ellipsoid, bursting longitudinally. Germen slightly scabrous. Style capillary, nearly 1 line long. Pair of stigmas very minute. Silicle about $2 \frac{1}{2}$ lines long, by the faint inflexion of its margin above slightly concave, imperfectly scabrous at the margin; the lobes rather acute, about $\frac{2}{3}$ line long, forming a narrow terminal sinus. Replum thick. Septum narrow-lanceolnte. Funicles very short, subulate. Seeds brown, smooth, about $1 \frac{1}{2}$ line long, surrounded by a narrow margin, when thrown into water evolving a copious opaque homogenous gelatine. Cotyledons somewhat longer than the radicle, their sutural line extending around the basis of the seed, rendering the lower part of the exterior cotyledon semicircular and that of the inner cotyledon simply plicate.

In flower during the early part of the spring.

This species approaches evidently not only to the following, but also to Lepidium rotundum (Cand. Syst. ii. 537), MLonoploca rotunda (Bunge, in Lehm. Pl. Preiss. i. 260). 
Iepidium leptopetaium.-Monoploca leptopetala, $F$. MI. in Transact. Phil. Soc. Vict. i. 35.

Fruticulose; branches numerous, finely scabrous; leares semiterete, undivided; their base withont appendages; pedicels corymbose or short-racemose, nearly as long as the fruit; petals scarcely longer than the large spreading sepals, linear-oblong; stamens 6 ; silicle large, ovate, very compressed, with conspicuous rather blunt lobes, winged towards the apex; style elongate, capillary, free; seeds broad-ovate, rery compressed ; moistened testa very gelatinous ; cotyledons undivided.

On the high barren limestone banks of the Murray River and in the surrounding desert.

A rather low shrub. Adult branches brown-black, spreading. Leaves glabrous, opaque, abore slightly convex or channelled, beneath very convex, $\frac{1}{3}-1$ inch long, $\frac{1}{2}-1 \frac{1}{2}$ line broad, acute, in a young state not unfrequently fasciculate. Corymbs terminal, generally few-flowered, in age sometimes lengthened into short racemes, but occasionally also contracted nearly to an umbel. Pedicels rather stont and very spreading, 2-3 lines long, not distinctly flattened. Sepals narrow-oblong, nearly 3 lines long, pallid, membranous, channelled towards the apex. Petals tender, white, tapering towards the base, incurved and concave at the apex, onenerved towards the lower portion. Longer filaments nearly as long as the sepals, filiform. Anthers rellow, $\frac{2}{3}$ line long, oblong-linear, with sagittate base, in age recurved. Germen truncate, bidentate. Style free, a little exceeding 1 line, filiform, exserted. United stigmas minute, hardly thicker than the style, depressed. Silicle $2 \frac{1}{2}-4$ lines long, about 2 lines broad, patent, above by slightly upwards turned margins somewhat hollow, beneath convex, winged towards the apex. Terminal lobes $\frac{1}{2}-\frac{2}{3}$ line long, bluntly triangular, forming a narrow sinus. Replum firm. Septum pellucid, lanceolate-linear or narrow-lanceolate. Funicles tery short, subulate. Seeds $1 \frac{1}{4}-1 \frac{1}{2}$ line long, smootl. Testa when moistened emitting a large quantity of slightly opaque homogenous mucilage. Cotyledons except their base straight, exactly incumbent; but their commissural line stretching around the base of the embryo, ascending for a short distance towards the radicle, which they consequently surpass somewhat in length, never channelled or longitndinally-inflexed. But the seeds exhibit occasionally truly plicate or almost sigmoid cotyledons. To this variability in the direction of the cotyledons also of the preceding species attention has been called ahready in the Linnea 1859, p. 370.

The usual shape of the embryo is in no way different from at least some legitimate Lepidiums; for instance, L. ruderale, in which the division of the cotyledons extends also generally quite around the base of the seed, as easily observable when the testa after maceration is removed. The base of the inner cotyledon becomes naturally in these cases simply plicate.

The genus Monoploca, being founded solely on this embryonic structure, is unhesitatingly here recombined with Lepidinm.

Lepidium leptopetalum is closely allied to the preceding species, but according to our certainly rather imperfect herbarium-specimens not combinable with the same. Iberis linearifolia, Cand. Syst. ii. 40.5 (Monoploca linifolia, Bunge in Lehm. Pl. Preiss. i. 260), is perhaps from it not specifically distinct.

In flower throughout the spring.

STENOPETALUM.

R. Bronn, in Candolle Syst. ii.

Sepals coherent, erect, unequal at the base. Petals terminated by a long very narrow acumen, unguiculate, circinate in æstivation. Stamens free, without teeth. Stigmas united, subsessile. Silicle turgid, linear- or ovate- or globose-ellipsoid, or subglobose. Valves one-nerved or nerveless. Septum broad. Funicles short. Seeds few or many and biseriate in each cell, subovate, without a border. Cotyledons incumbent; their edges facing the septum.

Herbs of frequently if not always annual duration, occurring in the extratropical parts of the Australian continent and rarely in Tasmania. Leaves gencrally narrow, entire or particularly the lower ones divided, none clasping. Pedicels racemose, bractless. Petals white, fulvous, sordidly purple or yellowish, or almost saffron-colored.-Endlicher, Enum. Plant. Hueg. 4. 
The exclusively West-Australian genus Menkea (Lehmann, Hort. Hamb. 1843; Hook. Icon. Plant. t. 610 and 617) differs from Stenopetalum in blunt petals, flat silicles, which by obliteration of the septum are one-celled, in more numerous rough seeds, held by long funicles. Camelina, to which Stenopetalum is still more closely allied, differs only in habit, in clasping leaves, in its equality of the sepals, in blunt petals, and in the very distinct development of a style.

Stenopetalum lineare, $R$. Br. in Cand. Syst. ii. 513; Endl. Plant. Hueg. 4; Hook. Icon. t. 618; J. Hook. Flor. Tasman. i. 22.

Glabrous, rarely pubescent; leaves linear, or occasionally lanceolate, undivided or remotely toothed or pinnatifid or pinnatisected; pedicels shorter than the sepals; petals fulvons, less than half exserted, gradually dilated towards the middle; their unguis and their acumen about as long as the lamina; silicle cllipsoidcylindrical, erect, nearly twice or thrice as long as the not spreading pedicel; valvcs distinctly one-nerved; septum linear-elliptical; moistened testa scantily mucilaginous.

On the sandy and rocky shores of Port Phillip and Wilson's Promontory, in the desert on the Murray River, and in sandy localities near Mount McIvor. To be found also in South Australia, as far nortli as Lake 'Torrens, and in Western Australia, and in a few localities of 'Tasmania and New South Wales.

Stems erect, sometimes diffused, rarely on coast-cliffs quite procumbent, terete, nearly glabrous, or scantily in rare instances densely covered with short more or less branched downs, from a few inches to fully 2 feet high, sometimes in meager specimens capillary-filiform, in large specimens more rigid and robust. Root annual, flexuose, often simple, filform, sometimes, however, stout, several inches long, tortuous, sending ont lateral fibres and being possibly biennial if not even perennial. Leaves $\frac{2}{3}-3$ inches long, $\frac{1}{2}-6$ lines rarely 1 inch broad, sometimes rather numerous, sometimes distant, always carnulent; the upper or all stem-leaves broad- or narrow-linear, much less frequently lanceolate, grossly few-toothed or particularly the lower ones or rarely all to various depths pinnately cleft, gradually tapering into a narrow petiolar base, all over glabrous or nearly so, but like other parts of the plant in the young state often densely downy; lobes linear, oblong or even lanceolate. Radical leaves very early perishing. Racemes spike-like, consisting of few, several, or many flowers. Pedicels stout, when flower-bearing $\frac{1}{2}-1$ line long, when fruit-bearing not much longer, angular, at that period rather remote. Sepals very unequal at the base, $1 \frac{1}{2}-2$ lines long, blunt, oblong-linear, coherent except at the base and apex, finely three-nerved, towards the summit veined, membranous. Petals to about one-third or nearly one-half of their length exserted, 3-4 lines long, about $\frac{1}{3}$ line broad towards the lanceolate middle, sordidly fulvous, tapering gradually into a long unguis and a sometimes still longer linear-setaceous acumen, generally more acute and narrower than in the Hookerian illustration. Stamens 6, tetradynamous. Filaments capillary-linear, 1-1 $\frac{1}{2}$ line long. Anthers oblong, with cordate base, yellow, $\frac{1}{4}-\frac{1}{3}$ line long. Silique or silicle slightly or scarcely compressed, $2 \frac{1}{2}-3 \frac{1}{2}$ lines long, terminated by a small subsessile convex stigma. Valves oblong or oval-oblong, concave-convex, with a distinctly expressed midnerve and two very faint or obliterated side-nerves. Septum lined in the middle with a very narrow longitudinal fold. Funicles very short, filiform. Orules from 9 to 20 in each cell, all or partially developed to seeds, biseriate. Seeds smooth, ovate, rather turgid, fulvous, about $\frac{1}{3}$ line long, when thrown into cold water emitting hardly any mucilage; subjected to the action of tepid water evolving ratler scantily a hyaline homogenous mucus.

In flower chiefly during the early spring time, in favorable localities throughout the year.

Stenopetalum gracile (Bunge, in Lehm. Pl. Preiss.) differs principally in white petals of longer dimensions, in spreading fruit-pedicels, and in obovate or roundish silicles with fewer seeds.

Stenopetalum velutinum, $F$. $M$.

Almost velvet-downy; leares linear, undivided; pedicels as long as the sepals; petals more than half exserted, sordid-yellow, gradually and slightly dilated near the middle, tapering into a very long acumen; 
silique broad ovate-ellipsoid, very turgid, erect, hardly as long or somewhat shorter than the almost erect. pedicel; valves indistinctly one-nerved; septum oval.

In barren localities on the River Murray, rare.

An erect, probably annual plant, about $1 \frac{1}{2}$ foot high, covered on its stem and older leaves more scantily, on its branches, foliage, pedicels and sepals more densely with an ashy velvet of branched short intricate hair. Leaves comparatively numerous, extending to the raceme; the lower ones broad-linear, 1-2 inches long, 1-2 lines broad; upper leaves from a few lines to less than 1 incli long, scarcely 1 line broad. Racemes terminating the branches, producing several or many at first crowded flowers. Flower-pedicels $1_{\frac{1}{2}-2} 2$ lines long; finit-pedicels about twice as long, little spreading. Sepals $1_{\frac{1}{2}-2}$ lines long, towards the middle part at their margin colierent, not very unequal at the base, linear-oblong, inside glabrous. Petals 5-7 lines long, very narrow, gradually tapering as well into the base as into the apex. Stamens 6 . Filaments white, $1 \frac{1}{2}-2$ lines long, linear-capillary. Anthers oblong; witl bilobed base, yellow, about $\frac{1}{2}$ line long, with intronse dehiscence. Pollen-grains ellipsoid, bursting longitudinally. Germen glabrous. Stigmas united into a solitary almost hemispherical one, of rather considerable size. Silicles in not quite mature state about $2 \frac{1}{2}$ lines long, $1 \frac{1}{2}$ line broad; their valvular diameter at least quite as broad as the septal one. Valves with a very faint or obliterated nerve. Septum fenestrate. Funicles slort, filiform. Ovules 10-14. Ripe seeds as yet unknown.

This plant stands evidently in near affinity to Stenopetalum robustum (Endl. Pl. Hueg. 4; Hook. Icon. 620 ; S. croceum and ninus, Bunge, in Lehm. Pl. Preiss. i. 258), which differs in being glabrous, and in more or less drooping rounder silicles. This latter plant ranges, according to Mr. Oldfield's collections, northward near to Shark Bay, and produces varieties with elongated pedicels and intensively orange florers.

- In flower during the spring.

Stenopetalum sphærocarpum, $F$. M. in Transact. Plit. Soc. Vict. i. 35.

Glabrous; stems very slender'; leaves distant, linear'or deeply three-cleft; petals white, about half exserted, rather suddenly dilated towards the middle; pedicels deflexed, nearly as long. as or a little longer than the fruit; silicle spherical, drooping; valves almost nerveless; septum orbicular; moistened testa copiously turbid-ınucilaginous.

In sterile, chiefly humid sandy places on the MIurray River. In South Australia near Lake Alesandrina, the Barossa Ranges, Crystal Brook, and Spencer's Gulf.

An herb of the appearance of Menkea procumbens, Hook., (Stenopetalum procumbens, Hook. Icon. 610). Stems from a few inches to a span long, procumbent, ascendent or erect, simple or fer-branched, slender- or capillary-filiform, arising singly or several from a thin filiform annual root, which produces a few almost capillary fibres. Leaves few, $\frac{1}{4-1}$ inch long, linear, or trisected with linear lobes. Flower-bearing pedicels scarcely longer than 1 line, fruit-bearing ones slender-filiform, $1 \frac{1}{2}-2$ rarely 3 lines long, slightly angular. Sepals oblong, measuring little more than 1 line, membranons, with exception of the very tender margin finely veined. Petals tapering into a very narrow unguis and into a linear-setaceous acumen, dilatel towards the middle. Stamens 6 ; the four longer ones of about the length of the calyx. Filanents linearcapillary, white. Antlers yellow, about $\frac{1}{5}$ line long. Stigma minute, depressed. Silicle scarcely or slightly compressed, about $1 \frac{1}{2}$ line long. Valres faintly vcined. Funicles capillary, rather short. Ovules never very numerous. Seeds $2-8$ in cach cell, forming two not very regular rows, fulvous, opaque, smootl, from $\frac{1}{3}$ to nearly $\frac{1}{2}$ line long, moderately compressed, broad-ovate, yielding already by maceration a large quantity of tenacious mucis.

This species is to be distinguished from the small decumbent forms of St. gracile in sualler comparatively less exserted petals, more turgid seemingly never ovate silicles, which are deprived of a manifest style. St. gracile extends also far northwards in Western Australia.

In flower from August to October. 
In concluding this enumeration of Victorian Crucifere, it may be worth recording, that besides the species alluded to in the foregroing pages but rery few are known as indigenous inhabitants of Australia. Thus the large suborder Orthoplocere seems to possess not a single representative in the whole native Flora, unless perhaps a dubious species of mustard, Sinapis hastata (Desf.). Meniocus serpillifolius (Desv.), occurring in a few localities on the Murray River and St. Vincent's Gulf, can lardly be regarded as indigenous. The number, however, of naturalized species is almost annually angmenting, including amongst other as yet less widely distributed species, Senebiera didyma, Senebiera Coronopus, Sisymbrium officinale, which cannot be extirpated again. The existence of fugitives from gardens is more ephemerous. Draba nemoralis, a plant by no means common in Tasmania, has not yet found its way to these shores, and is in all probability a mere introduction. Draba Pumilio (R. Br.) seems, llowerer, to vindicate for that genus a place in the Australian Flora, although, apparently not refound since the voyage of Robert Brown. Of Thlaspi two species seem to exist, the one T. Tasmanicun (Hook. Icon. t. 848), a rare Tasmanian plant; the other T. cochlearinum (Eunomia cochlearina, F. M. in Linnæa, 1852, p. 369), an equally rare Sonth Australian species. The latter resembles somewliat. Cochlearia Anglica, and has 3-5 seeds in each cell. Menkea numbers but very few, perhaps only two representatives. Some of the Victorian Cruciferæ here adopted have been described from scanty material and require further observation. Thus Capsella antipoda may perhaps be only a large-flowering state of $\mathrm{C}$. elliptica, nor are as yet the distinctions between Lepidium phlebopetalum and leptopetalum perfectly clear.

\section{ORDER CAPPARIDEA.}

\section{Jussieu, Genera Plantarum 242.}

Calyx often tetraphyllous or gamosepalous, sometimes diphyllous, imbricate rarely valvate in restivation, very seldom monophyllous and forming a calyptra, exceptionally octophyllous or five-cleft. Petals hypogynous, 4, sometimes none, rarely 6-8, or 2, free, rarely coherent, symmetrical or unequal. Stamens hypogynous, free or towards the base connate with the stipes of the ovary, 4-7, if 6 rarely or not tetradynamous, or in a multiplied number of the petals or sepals or indefinite. Anthers two-celled, introrse, bursting longitudinally. Ovary free, solitary, sessile or frequently stipitate. Stigmas perfectly united, often scssile. Fruit one-celled, rarely by expansion of the placentre imperfectly two-celled, forming a siliquate capsule or a berry. Placentre intervalvular or parietal. Seeds nearly kidney-shaped, numerous, sometimes few, rarely one. Testa tumid. Albumen none, or very scanty. Embryo arcuate, conduplicate or coiled. Cotyledons compressed.

Herbs, shrubs or trees, with a limpid sometimes pungent juice, more or less numerous within the tropical and subtropical zones, very rare in countries of temperate climates, absent from colder regions. Leares alternate, very seldom opposite, stalked, simple or consisting of ternate or digitate generally quite entire leaflets. Stipules none or spinescent, very rarely foliaceous and adnate. Flowers solitary or collected into bracteate racemes, often showy. Sepals and petals generally deciduous, the latter frequently yellow or white. Style, if present, undivided. Fruit not rarely 
provided with an elongate stipes.-Cand. Prodr. i. 237; Torr. \& Gray, Flor. of North Amer. 1. 120; Wight \& Arnott, Flor. Paninsul. Ind. Orient. i. 21; Endl. Gen. Plant. 889 ; Lindl. Veg. Kingdom, 357.

Capparidere cxtend in a species of Capparis (C. nummularia, Cand.) and in the genus Emblingia as far south as $28^{\circ}$ south latitude in Western Australia, and to $35^{\circ}$ south latitude in Australia Felix, here represented only in a single species (Busbeckea Mitchellii). They become more numerous in the subtropical and intratropical regions of Eastern Australia, and are scattered in a few species over North and NorthWestern Australia. The genus Ropera (F. II. in Hook. Kew Misc. ix. 15) differs from Gynandropsis, which is not yet found in Australia, in solitary flowers, in unequally connate stamens, in a manifest style and perhaps also in strophiolate seeds. The genus Cleomc counts three Australian species, one, C. flava, belonging to the subgenus Polanisia, of wide distribution. Apophyllum (F. MI. in Hook. Kew Misc. ix. 306), referred to this order by $\mathrm{Mr}^{2}$. All. Black, of Kew, is remarkable for polygamous. diœcious flowers and Hakea-like appearance, and differs from the rest of the Austra. lian Capparideæ, Emblingia excepted, in 1-2-seeded berries. Capparis and Busbeckea comprise several species, some of them stately trees. The supposed Capparideous tree mentioned by Allan Cunningham, in the appendix to King's Intratropical Survey of Australia, proved to be a genuine new species of Adansonia, and an antarctic supposed capparideous plant, mentioned in Endlicher's gencra, is evidently identical with the cruciferous Pringlea antiscorbutica.

\section{BUSBECKEA.}

Endl. Prodr. Flor. Norfolk. 64.

Flowers hermaphrodite. Calyx before expansion monophyllous, calyptrate, globose or ovate, acuminate, gradually bursting irregularly into two valves, deciduous from the base. Petals $6-T$, very unequal, imbricate in æestivation, the outer ones sepaloid. Staminodia generally wanting. Stamens numerous, free, inserted to the small hemispherical or depressed receptacle, all fertile. Anthers affixed at their base to the filiform filaments. Ovary long-stalked. Ovules parietal, amphitropal. Stigma sessile, depressed. Berry globose, many-seeded, filled with juiceless pulp.

Erect shrubs or woody climbers or trees of Australia and Norfolk Island, sometimes prickly with stipular thorns. Leaves alternate, broad, flat, entire. Flowers large, showy. Petals white or pale yellowish. Stamens elongate.

Assuming that the outer petals of Busbeckea are true sepals and that the outer part of the calyx is formed by the intimate coalescence of the two exterior sepals, although no suture indicative of regular division is, at least in the Australian species, perceptible, nothing of note will remain to separate this genus from Capparis but the calyptra-like outer part of the calyx. The characteristic offered by Endlicher in regard to the regular valvation of the calyx is slightly at variance witl our plant, and would render the transit from Busbeckea to Capparis still clearer. Morisonia agrees seemingly in the singular structure of the calyx with Busbeckea, differs however in a tetrapetalous corolla, therefore absence of sepaloid petals and more essentially still in connate stamens. 
Busbechea Iritchelli, F. M.; Capparis Mitchelli, Lindley, in IIitchell's Three Exped. i. 315.

A spreading tree; leaves pale ovate or oblong-or lanceolate-elliptical, on both sides or beneath as well as the branchlets and pedicels very thinly grey-velvety; pedicels solitary, thickened towards the apex; petals 6 , imperfectly appressed downy, eroso-denticulate; stipes of ovary downy; berry large, globose, glabrescent.

In the MIallee Scrub, near Eustone, according to Mr. Commissioner Colè. Extending beyond Victoria, from Lake Torrens and Nonnt Nurchison to Cooper's Creek, the Upper Darling and Burdekin River, and their tributaries, and thence fully to the plains of promise on the Gulf of Carpentaria.

A small tree, sometimes attaining a height of 30 feet. Branchlets in youth often flexuose. Stipules recurved, subulate, about 1 line long, frequently wanting. Leares $\frac{1}{2}-3$ inches long, one-nerved, finely or obscurely veined, thickly herbaceous and thus very brittle in exsiccation, beneath glaucous, above particuInrly in age rather smootl. Petioles from 3-5 lines long. Pedicels lateral, axillary or terminal, stout, articulated with the branchlets, curved, 1-2 inches long. Unexpanded calyx globose, short- or longacuminate, perfectly closed or bifid at the apex, outside covered with very thin glaucous velvet, by the gradual development of the flower breaking into two more or less irregular thick nerveless valves and also separating from the receptacle, not however as that of the genus Thylachium transversely bursting'; their lengtl $\frac{1}{2}-\frac{3}{4}$ inch; fracture uneven. The two outer petals, or rather the two inner sepals, obcordate or orbicnlar, from 4-8 lines long, rather thick, inside particularly towards the middle appressed villons, outside with exception of the crenulate margin fulvons-silky. Inner petals obovate- or obcordate-cuneate, tapering into a more or less conspicuous or obliterated claw, fully 1 inch long, slightly carnulent, principally towards the base and middle downy with closely appressed articulated hair. Filaments about 2 inches long, gradually attenuated into the apex, quite glabrous. Sometimes occur one or two deformed stamens, not dissimilar to the staminodium of Cadaba heterotricha and other species, showing strikingly the metamorphosis of petals into stamens, in having an alnost filiform but downy unguis and a petaloid somewhat silky crenulate orbicular or dimidiate-orbicular lamina, in the latter case also a dimidiate anther; the lamina measuring $1 \frac{1}{2}-2$ lines. Anthers oblong, hardly longer than 1 line, introrse, with subcordate base, recurved in age; cells adnate to the slightly protruding connective, bursting lengthwise. Stipes of ovary 2 inches long, beset with short crisp hair. Ovary fusiform-ovate, silky, probably blue when fresh, assuming, at least in tepid water, as well as the upper part of the stalk and the depressed stigma, an indigo color. Berry brown, provided with a firm stalk, spherical, measuring when ripe at least 2 inches, sometimes smooth, sometimes irregularly traversed by amorphous ridges or conspersed with little warts or tubercles, soon glabrous. Pericarp a thick crust. Pulp seemingly not succulent. Seeds 4-5 lines long, roundish- or oblique-ovate, sometrhat renate and slightly compressed. Testa brown, smooth, crustaceous. Endopleura thickish, membranous, white. Embryo of bitter taste, white, coiled up in a double or trifold circle. Cotyledons centripetal, about 2 lines long, either that and complicate in their whole length or cylindrical towards the base. Radicle solid, cylindrical, 8-10 lines long.

Supplemental Plate IV. 1, seedling; 2, side view of flower; 3, front view of flower; 4, 5, 6, valves of calyx ; 7, 8, 9, outer petals; $10,11,12$, inner petals; 13 , unexpanded petals ; 14, petaloid staminodium; 15, semipetaloid staminodium, bearing a dimidiate anther; 16 , stamens unexpanded; all figures natural size; 17, 18, anthers, magnified; 19 , pollen-grains, strongly magnified; 20 , peduncle, stipes and pistil, natural size; 21, ovary, magnified; 22 , fruit, natural size; 23 , transverse section of fruit, natural size; $24-27$, embryo, natural size; 28 , transverse section of seeds, natural size ; 29, 30, embryo, magnified. 


\section{III.-PARIEIINA.}

Division of flower, with few exceptions, quinary. Stamens definite. Ovary solitary. Ovules anatropal. Placentæ generally parietal. Seeds albuminous, indefinite, very seldom without albumen or definite. Embryo straight, erect.

\section{Order DROSERACEA.}

Salisb. Parad. Lond. 95.

Flowers symmetrical, hermaphrodite. Calyx persistent, divided into free sepals, or monophyllous and cleft into lobes, imbricate in restivation. Petals free, alternate with the sepals, hypogynous, very raroly perigynous, persistent, imbricate in astivation. Stamens free, definite in number, always singly opposite to the sepals, none or 1-3 opposite to the petals. Anthers extrorse, terminal, two-celled, opening by longitudinal slits or by pores. Staminodia, if present, opposite to the petals. Styles 1 or 3-5, simple or variously divided, sometimes obliterated. Ovules anatropal. Capsule 2-5-ralved or valveless, 1-5-celled. Arillus none. Seeds numerous, affixed to parietal or less frequently basal placentre, rarely 1-2 in each cell and then affixed to the persistent axis. Albumen copious or wanting. Embryo erect.

Annual, perennial or rarely suffiuticose plants, held deleterious, distributed through all zones. Stipules fringed or wanting. Leaves alternate, often irritable and generally furnished with gland-bearing hairs and long cilia, which are terminated by a dewy gland, rarely glandless, very rarely quite glabrous. Peduncles terminal, lateral or radical, with a solitary or with racemose flowers, frequently as well as the leaves circinate in vernation. Petals white, red, blue, purple, or yellow, as well as the stamens withering and persistent.-Cand. Prodr.i. 317 ; Endl. Gen. 906; Lindl. Veg. Kingd. 433 ; Planch. in Annal. des Scienc. Nat. iii., Ser. ix. 79-309̄.

By this order the transit from Violarinex to Hypericinex is established. In some points of structure it approaches to Pyrolacex.

Tribe I. DROSERE Ex, Arnott, Prodr. Flor. Ind. Or. i. 33.

Staminodia none. Embryo at the base of a copious albumen.

\section{DROSERA.}

\section{Linné, Gen. Plant. 391.-Sundew.}

Calyx generally deeply rarely only to the middle 5-cleft, in some species 4-, 6-, 7-, or 8-cleft. Petals and stumens liypogynous, very seldom perigynous, equal in number to the divisions of the calyx. Anthers erect, longitudinally dehiscent. Styles 3-5 simple or divided. Capsule one-celled, 3-5-valved. Placentoe parietal. Seeds numerous. Testa cellulose. Embryo minute. Radicle pointing to the hilum. 
Tender, sometimes very elegant, cosmopolitan herbs ; leaves generally entire, seldom cleft into segments, beneath very seldom in every part glabrous, above hairy, at the margin fringed; their hair and ciliæ exuding a dew-like fluid. Peduncle one-flowered, or bearing 1 or more minutely and irregularly bracteate racemes. Pedicels solitary. Petals tender, white or pink, less commonly yellow, bright red or purple.-Endl. Gen. 907.

MIore than half the known species of Drosera are of exclusively Australian origin, none, however, is peculiar to the Colony of Victoria, neither any to Tasmania, whilst in New Zealand only the alpine D. stenopetala, which may possibly occur also in our and the Tasmanian Alps, is known to be restricted to that island. Professor Planchon, in his monography of this genus, divided it exquisitely into sections. Since, however, only about one-eightle of the species occur in the territory of this colony, the introduction of the sectional characters into this work was deemed unnecessary. The genus Sondera is justly reunited by Planchon to Drosera. No other genus of this order, except Byblis, is known to exist in Australia. It is recognized by blue flowers, versatile anthers, which open by pores, further by the coalescence of two styles into one, by a two-valved and two-celled capsule and by axil placentæ. The species of Byblis, very few in number, are restricted to Western and Northern Australia. It is, however, not improbable, since many Indian water-plants extend in their geographic range to tropical Australia, that.Aldrovanda may yet be found in the warmer parts of this continent. Finally, it may be worthy of remark, that the lobes of the styles in some species of Drosera are longitudinally, in others only at the apex stiginatose. Hence they may in some cases be regarded entirely as parts of the stigma, their color being moreover generally different from that of the basal part of the style.

Drosera glanduligera, Lehmann, Pugill. viii. 37; Plant. Preissian. i. 252.

Ninute, stemless; root annual, fibrous; leares rosulate, without stipules; petioles linear, about as long as the concave reniform-roundish not peltate lamina, as well as pcduncles and racemes glandulously downy; pedicels about as long as or somewhat longer than the ovate or lanceolate fimbriate sepals; petals crinison; stamens 5 , hypogynous; filaments clavate-linear; styles 3 , very slort, terminated by a comparatively long deeply-bipartite stigma; segments of stigma acute, filiform, undivided or bifid; capsule to the base three-valved, many-seeded; placentæ nearly ovate; seeds ovate-globose, minutely attenuated at the base; testa close, reticulated.

Scattered over the colony, in less fertile pasture land; for instance, at Hobson's Bay, along the lower Yarra Yarra ridges, in the Grampians, near the Glenelg River, Port Albert, \&c.; also in various parts of the Colony of South Australia (viz., near Adelaide, at Lyndoch Valley, the Barossa Range, Bugle Range, Mount Burr, \&c.), and in Western Australia; perhaps also yet to be found in Tasmania.

A minute herb, from 1-3 inches ligh. Root a fascicle of tender fibres. Leaves expanded into a radical rosette; their petiole linear; their lamina tapering somewhat into the petiole, 2-3 lines long, 3-4 lines broad, above downy with short gland-bearing hair, beneath glabrous, at the margin long-ciliated. Peduncles 1 or a few, terminated by a raceme of few or several flowers. Pedicels 1-3 lines long, recurved in age. Sepals of flowers liardly longer than 1 line, of fruit about $1 \frac{1}{2}$ line long, glandulously-downy outside, fimbriate at the margin, spreading in age. Petals bright-red, but dark-red towards the base, obovatecuneate, hardly half exserted. Filaments nearly 1 line long, very acutely tapering at the base. Anthers extremely minute; their cells divergent, yellow, nearly globose. Styles dark-red, very spreading. Lobes of stigma ascending-incurved, pale-red and pellucid, very minutely papillous. Germen globose, green, smooth. Capsule hardly longer than 1-1 $1 \frac{1}{2}$ line, globose, many-seeded. Placentæe considerably smaller than the valves, flat, indistinctly orate. Seeds grey-black, about $\frac{1}{8}$ line long.

In flower during August and September. 
Drosera pygmma, Cand. Prodr. i. 317; Planch. in Annal. des Seiene. Nat. ix. 94; J. Hook. Fl. of New Zeal. i. 20.

Stemless, very minute; root annual, fibrous ; stipules searious, lanceolate- or cuneate-linear, connate below the middle; thence longitudinally cleft into a few linear-setaceous lobes; leaves rosulate, orbicular, concave, peltate, shorter than the very narrow flat petiole; peduncles eapillary one-flonered, not downy, much longer than the leaves; flowers minute, tetramerous; sepals glabrous, entire; petals white or pink; stamens 4, hypogynous; styles 4, undivided, free, each passing into a filiform entire stigma; capsule to the middle four-valved, many-seeded; seeds ovate, minutely attenuated at the base, in age almost smooth and quite shining.

In sandy temporary humid heatl-ground ; for instance, at the base of the Serra Range, at Port Albert; in South Australia, hitherto only found near Encounter Bay; in Tasmania, on several spots, as far south as South Port; in New Zealand, at Cape Maria van Diemen, according to J. Hooker's Flora.

A very remarkable species, smaller than any other Drosera, resembling with its extremely tender red peduncles and with its minute solitary copsule almost a moss. Root consisting of a single or several very tender capillary fibres. Leares forming a tuft of $\frac{1}{2}-1$ incl 1 width. Stipules 1-3 lines long, crowded in the centre of the tuft of leaves around the base of the peduncle, forming a whitish shining brinsh. Petioles 2-5 lines long, attenuated at the apex. Lamina of leaves measuring without the comparatively long cilix only 1-1 $\frac{1}{2}$ line, above glandulously downy, beneath glabrous. Peduncles 1-2 inches long, single or several. Sepals abont 1 line long, ovate or oblong, casually 5. Petals scarcely twice as long as the calyx, ovate, tapering into a narrow one-nerved base, veined. Stamens of the length of the calyx. Filaments linearcapillary. Anthers cream-colored, very minute, didymous-roundish. United styles and stigmas about $\frac{1}{2}$ line long, ascendent, opposite to the petals. Capsule nearly globose, hardly 1 line long. Placentæ rather small and uncertain in form. Seeds about $\frac{1}{8}$ line long, very minutely reticulated, many, although not so numerous as in most other species, in comparison to the capsule rather large, pure-black.

In flower during the spring and the enrly part of the summer.

Drosera Whittakeril, Planch. in Annal. des Scienc. Naturell. ix. 302 ; D. rosulata, Behr, in Linnea, xx. 628.

Stemless ; tuber at the base of the rhizome, spherical; leaves large, rosulate, obovate- or spathulate- or rhomboid-cuneatc, confluent with the broad glabrous rather short petiole; stipules none; peduncles oneflowered, generally as long as the leaves or somewhat longer; scpals acute or acnminate, glabrous; petals white, generally 5 ; stamens 5 , hypogynous, several times shorter than the calyx, many times shorter than the large eorolla; styles 3 , short or almost obliterated; stigmas penicillar-multifid; capsule to the base three-valved; placentæ ovate; seeds large, numerous, blunt at both points; testa close.

Rather frequent in the sonthern parts of the Colonies of Victoria and of South Australia; not yet found in Tasmania.

Rhizome descendent, white or slightly red, about 1 line thick, 1-3 inches long, producing sereral short almost subulate scales, some lateral fibres and a few horizontal white flexuose runners, which are very rarely terminated by a few lenves. Tuber $\frac{1}{3}-1$ inch in diameter, enveloped in some layers of brownish brittle or membranous deciduous scales, outside shining, red-brown or bright red, inside dull or pale red. Leares, including their petiolar base, $\frac{3-2}{4}-2$ inches long, $\frac{1}{3}-1$ inch broad, arranged in a rosette of a few rows, appressed to the soil, green, or more or less tinged witl red, beneath as well as the petiolar cumeate part glabrous, slining and slightly streaked; the laminar portion rhomboid- or obovate-cuneate, $\frac{1}{3}-\frac{5}{3}$ inch broad, above and around the margin clothed witl gland-bearing often red hair, of which those of the margin about 1 line long. Peduncles quite smooth, one or several, occasionally in luxuriant specimens numerous, always one-flowered, cylindrical, when flower-bearing erect, about as long as the leaves, seldom longer, when fruit-bearing prostrate and then somewhat longer than the leaves. Flowers scented. Sepals 5, rarely 4,6 or 7 , if so the 
supernumerary ones in an outer row, twisted-imbricate in æstivation, $\frac{1}{4}-\frac{1}{2}$ inch long, lanceolate, often oblique, acute or acuminate, green or brownish, black in drying, equally membranous, rarely on one or on both edges petaloid, occasionally with one or two acute teeth, closing over the ovary after fecundation, spreading during. anthesis. Petals 5 , rarely $6, \frac{1}{3}-\frac{2}{3}$ inch long, pure-white, glabrous; with an extremely short greenish claw, obovate or obcordate-ovate, or obovate-cuneate, rarely obcordate; the sinus either very shallow or deep and acute, stretching occasionally to $\frac{1}{3}$ of the length rarely to near the base of the petals. Stamens frequently 5 , rarely 3,4 or 6 . Filaments subulate-filiform, white, only 1-1 $\frac{1}{2}$ line long: Anthers cordate, extrorse; their cells ellipsoid, yellow, about $\frac{1}{2}$ line long, free towards the base and at the very apex, above the base adnate to the rather broad white connective, which occasionally is terminated by a subulate appendix, formed by the elongated connective. Pollen-grains globose, three-furrowed, minutely granulated. Seginents of the stigma very numerous (60-80), hyaline, $\frac{1}{2}-\frac{3}{3}$ line long, most of them disconnected, but a few connate even to above the middle, thread-like, blunt, smooth, transparent, a little dilated at the apex, forming a beard at the apex of the ovary. Capsule nearly globose, shorter than the sepals, by which it is enveloped. Seeds reticulate, black when ripe. Testa thick, before maturity cellulose, succulent, equally surrounding the nucleus.

In flower from July to September.

Very near in its affinity to D. bulbosa (Hook. Icon. 375), which differs in generally smaller leaves, shorter than the peduncles. D. rosulata (Lehm. Pugill. viii. 36) approaches still nearer to it; the differences of the latter seem to consist mainly in smaller leaves and flowers, in stamens of nearly the same length as the sepals and in dark-brown anthers.

The tuber of $\mathrm{D}$. Whittakerii is used by the aborigines for coloring various articles. Spirits of wine extracts from it a beautiful red pigment. The tuber, like that of $\mathrm{D}$. porrecta, leaves on paper a purple tinge.

Supplenental Plate VI. 1 , tuber with outer lajers; 2, the same without outer scales; 3 , transierse section of whole tuber; 4 , leaf seen from below; 5 , leaf seen from above; 6 , sepals; 7 , semipetaloid sepals; 8 , petals; 0 , flower seen fiom above; 10 , stamens; 11 , pollen-grains; 12 , styles; 13 , stamens and pistil; 14, styles seen from above; 15 , transverse section of ovary; 16 , vertical section of ovary; 17 , fruit; 18, bursted cupsule; 19, seeds; 20, transverse section of seed; 21, vertical section of seed : all figures except 1-3 more or less magnified.

Drosera Arcturi, Hook. Journ. of Bot. i. 247; Icon. Plant. 56 ; Planchon, in Annal. des Scienc. Natur. ix. 01 ; J. Hook. Flor. of Now Zeal. i. 20; Flor. Tasm. i. 29.

Rhizome perennial, often creeping, passing into a short leafy stem; leaves few or several, alternate, crowded; the upper ones broad- or oblong-linear, blunt, ciliated and above glandulonsly downy; lower leaves smaller, glabrous, almost lanceolate, all tapering into a broad-linear channelled clasping glabrous petiole or vagina; stipules wanting; peduneles one-flonered, stout-filiform, of nearly the same or double the length of the leares, as well as the large generally pentamerous flower glabrous; sepals not much shorter than the white petals; stamens hypogynous, about as loug as the calyx; styles 3, free; stigmas kidney-shaped, papillose; capsule ovate, above the middle three- or four-valved, longer than the calyx, many-seeded; placentæ linear; seeds ovate, margined by the expanded testa.

In places boggy or irrigated by melting' snow, or on the mossy banks of alpine rivulets and ponds, at an elevation from 5000 to 7000 feet; for instance, on Mount Hotham and Mount La Trobe, and on other alps of the Bogong Mountains, also in the Munyang Ranges. In New South Wales, on Mount Kosciusko; in Tasmania, in many of the highest mountains, as far south as Mount Lapérouse (Oldfield); also in the alps of New Zealand.

An erect or ascendent herb, often imbedded in Sphagnum, sending out a flexuose tortnose or straightly descendent or horizontal or creeping rhizome, from which many filiform fibres arise. Stems short, passing gradually into the root, densely covered with the remnants of vaginæ. Leaves $1-4$ inches long, $1 \frac{1}{2}-6$ lines broad, one-nerved, veined, contiguous to the broad petiole. Peduncles 1 or a few to each plant, arising 
solitary from the axis of one of the upper leaves, thus apparently terminal, persistent throughout the year, from 1 to nearly 6 inches long, fistulose, near the apex often furnished with a solitary lanceolate-linear channelled sessile bract, which varies in length from $1-1 \frac{1}{2}$ line. Flowers variable in size, but always rather large. Sepals 3-5 lines long, somctimes more lanceòlate, sometimes more oblong, occasionally oval, always more or less connate at the base, rarely 6 in number, occasionally with a few sharp teeth at the apex. Petals white, ovate in our specimens, but narrow-spathulate or oblong-cuneate according to the descriptions and figure in the works above quoted, to $\frac{1}{4}$ or rarely $\frac{1}{2}$ their length exserted, fully $\frac{1}{2}$ inch or less long. Stamens persistent as in the generality of the species. Filaments white, subulate-linear, one-nerved. Anthers vitellinous, ovate-cordate, $\frac{1}{3}-\frac{1}{3}$ line long. Styles stout, very short, undivided, $3-4$, black in age. Stigmas white when fresh, undivided, renate or occasionally more cordate, incurved, $\frac{1}{3}-\frac{2}{3}$ line long. Germen green. Capsule variable in size according to the size of the plant. Seeds nearly ovate, $\frac{1}{2}-\frac{3}{4}$ line long, blackish, bluntly winged by the expansion of the testa, somewhat wrinkled, tapering at the base; the expansion almost as broad as the nucleus.

Nearest to the also alpine D. stenosepala of New Zealand, which differs in truly radical leaves on longer and narrower stalks, in not even to the middle five-cleft calyces and in divided stigmas, and according to Dr. Hóolzer's description in perigynons insertion of petals and stamens.

Flowers produced in December and January.

Drosera Indica, Linné, Flor. Zeylan. p. 51; J. Hook. ct Thomson, in Proceedings of Linnean Society, ii. 82; D. hexagyna, Blanco, Flor. Filipin. ed. ii. 159, according to Planehon; D. Finlaysoni, Wallieh, in Wight. Illustr. of Ind. Bot. i. 44; D. serpens, Planch. in Annal. des Sciene. Nat. ix. 204; D. angustifolia, F. MI. in Iransact. Phil. Soc. Vict. i. \%.

Root annual, fibrous; stem ascendent or decumbent, scantily downy; stipules wanting; leaces all alternate, long-linear, undivided, long contracted into the very acute apex, sessile or much longer than the continuous puberulous fringeless petiole; peduneles lateral, solitary, as well as the simple raceme slightly glandulous-pubescent; pedicels longer than the deeply 5-cleft calyx; petals white or red, or purple, rather large; styles 3, bifid to near the basc, with incurved stigmatose capillary lobes; capsule to below the middle 3-valved; placentæ oblong; testa close; seeds minute, nearly ovate, reticulated.

In moist gravelly localities around the fresh-water lakes near Eustone on the Murray River, rare; beyond Victoria, scattered over North Australia (for instance, on the River Victoria, Hooker's Creek, Sturt's Creek, towards the Gulf of Carpentaria, \&c.); also in the Indian continent and archipelago, and according to Planchon in Western tropical Africa.

Root subfasciculate- or alternate-fibrous, descendent, 1 inch or less long. Stem from 2 inches to nearly 1 foot long, rarely longer, generally simple, according to various descriptions also branched, lax, gradually tapering at the base, which is foliate with closely approximated and shorter leaves, yet not producing a leafverticille. Leaves rather crowded along the stem, not dissinnilar in form to those of $\mathrm{D}$. filifornis (Raf.), without any true petiole, although the basal portion to the length of $\frac{1}{2}-1$ inch is sometimes denuded of the marginal fringes, little or not tapering into the base, $2-6$ inches long; the upper ones the longest; the lorer oftened shortened to 1 inch; all, exclusive of fringes, from $\frac{3}{4}-1 \frac{1}{2}$ line broad, long-pointed into a linearsetaceous apex, which is remarkably coiled in vcruation, above and at the margin glandulously downy, beneath glabrous, in age longitudinally flat-replicate. Racemes fow- or many-flowered, in exceptional cases reduced to a singlc flower, lateral, either almost oppositc to a leaf or alternate with the leaves, from 1-8 inches long. Peduncles varying in length between $\frac{1}{2}$ and 6 inches; but the greatest dimensions stated here of peduncles and racemes occur not sinultaneously in the samc inflorescence: Bracts 1-1 $\frac{1}{2}$ line long, solitary at or near the base of some of the pedicels, linear-subulate or setaceous. Pedicels sprending, slender, when flower-bearing 3-6 lines long, when fruit-bearing nearly twice as long, the lowermost often longer than the rest. Segments of calyx $1 \frac{1}{2}-2$ lines long, not rarely toothed with a few irregular serratures towards 
the apex, lanceolate, acute, as well as the pedicels and peduncles scantily hairy with short gland-bearing downs. Petals generally obovate-cuneate, twice as long as the calyx, or even longer, sometimes in size and color resembling $\mathrm{D}$. cistitlora, white or pale rose-colored, or more saturated purplish-red, tapering into the unguiculate base. Stamens hardly longer than the calyx, rarely in luxurious specimens transformed into petals. Anthers yellow, $\frac{1}{3}-\frac{1}{2}$ line long. Filaments very narrow linear, one-nerved. Segments of style considerably bent outward of the stamens, arched-uncinate, towards the apex longitudinally stigmatose. Capsule rather membranous, $1 \frac{1}{2}-2 \frac{1}{2}$ lines long, not much longer or as long or somewhat shorter than the calyx. Seeds many-seriate on the placentre, very numerous, about $\frac{1}{6}$ line long, black, opaque, at the base attenuated into a very short point, by seriate foveoles densely reticulated.

-In flower at all seasons, although chiefly here during spring.

Specimens transmitted from Amoy by Dr. Hance fully accord with the Murray plant, although this species is more variable in North Australia than in the South. Sir Will. Hooker (Kew Miscell. viii. p. 5) pointed out its probable identity with $D$. serpens.

Drosera binata, Labillardière, Nov. Holl. Plant. Speeim.i. 78, t.105; Hook. Bot. Magaz. 3082; T. Hook. Flor. Ner Zeal. i. 20; D. pedata, Persoon, Synops. Plant. 336; D. intermedia, A. Cunningh. in Annal. of Nat. History, iv. 109.

Stemless; root fasciculate-fibrous; stipules in front fimbriate, longitudinally connate; leaves on very long glabrons petioles, to the base divided into two elongate simply linear or deeply bipartite or dichotomons gradually long-aenminated segments; peduncles very elongated, longer than the leares, bearing at the summit 2-4 racemes; sepals acute, glabrous, hardly as long as the stamens; petals large, white, generally more than half exserted; styles often 3, penicillar-multifid; capsule globose, generally three-ralred to the base, shorter than the calyx; seeds very numerous, hnear-filform; nucleus several times shorter than the testa.

In boggy springy localities, often growing in moss; for instance, in the Western Port district, at Wilson's Promontory, in the Buffalo Ranges, the Granpians, at the Mnddy Creek and King Parrot Creek, \&c. In Sonth Austrahia, on the upper cataracts near Mount Lofty, and also at Encounter Bay; further, thronghout Tasmania, and in several tracts of New Zealand, and in New South Wales, as far north as Moreton Bay.

One of the most showy plants of this genus, varying in lieight from $\frac{1}{2}-2$ feet. Root seemingly perennial, consisting of long fasciculate fibres, which exceed in thickness occasionally 1 line. Stipules membranous,

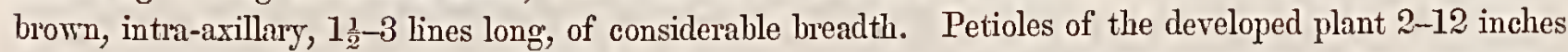
long, compressed-terete, often 1 line thick. Leaves consisting of two primary segments, which are either simply linear and rather erect, or deeply bifid or dichotomous, 1-4 inches long, hardly more than 1 line broad, long-ciliated by red gland-bearing hair, beneath glabrous, above glandulous-downy. Peduncle solitary, terete, glabrous, from $\frac{1}{2}-1 \frac{1}{2}$ foot long, erect, not much thicker than the petioles. Inflorescence consisting of united racemes, imitating in division that of the leaves; the racemes all arising from the summit of the peduncle, drawn into a spurious cyme or panicle, few-flowered or with several more or less crowded or distant flowers, and with about as many bracts, which are standing singly opposite to the pedicels or removed from them, and are 1-1 $\frac{1}{2}$ line long, somewhat fringed, the lower ones ovate or lanceolate, the upper ones more linear or subulate. Pedicels 2-12 lines long, moderately patent, glabrous. Sepals ovate or lanceolate, frequently acuminate, $2-4$ lines long, generally 5 , occasionally 1 , more or less in number, at the apex irregularly lacerated into acute teeth or finged, connate towards the base. Petals generally about three times as long as the calyx, obovate, according to some descriptions also sometimes obcordate, shortand broad-unguiculate, veined, yellowish towards the base. Filaments subulate-linear, one-nerved, almost white. Anthers cordate, orange, at last yellow, when dry $\frac{1}{2}-\frac{3}{4}$ line long. Styles about 1 line long, according. to Labillardière also sometimes $4-5$ in number, divided into numerous unequal capillary segments, which are 
often upwards again cleft, and stigmatose at the truncate apex. Capsule laxly enclosed in the calyx, covered by the marcescent petals, about $1 \frac{1}{2}$ line long. Placentæe sometimes narrower and more elevated, sometimes broader and more depressed. Seeds, inclusive of the expansion of the sordid-brown cellulose testa, nearly 1 line long, extremely narrow. Nucleus minute, narrow-ellipsoid, not laterally but at both extremities long appendiculate by the contiguous testa.

In flower during December and January.

Drosera spatulata, Labill. Nov. Holl. Plant. Specim. i. 79, t. 106, 1; Planch. Annal. des Scienc. Nat. ix. 193; D. propinqua, A7l. Cunn. in Annal. of Nat. Hist. iv. 109.

Stemless; root fibrous; stipules connate, deeply longitudinally dissccted; leaves spathulate, rosulate, tapering into a rather short glabrous linear petiole; peduncles many times longer than the leares; slender towards the summit, as well as the solitary or geminate raceme glandulous-puberulous; pedicels unilateral, mostly shorter than the small acutely five-cleft at last rigidulous calyx; petals white or red, generally less than half exserted; stylcs 3, bipartite, with simple filiform rarely semi-bifid lobes; capsule turbinate-ovate, much shorter than the calyx, deeply three-valved, rigidulous; placentre oval, flat; seeds many, ellipsoid, minute; testa not expanded.

In boggy soil towards Brighton (Dr. Howitt), on Mount Abrupt (C. Wilhelmi); also in extratropical Eastern Australia, in Tasmania, as far south as South Port, in New Zealand, and according to Planchion in the Plilippine Islands.

The whole plant frequently tinged red, reminding in appearance of the British D. longifolia. Root probably perennial, sending out filiform fibrillæ. Leares, with addition of the confluent petiole, from about $\frac{1}{2}$ inch to nearly 1 inch long, $1 \frac{1}{2}-4$ lines broad, fimbriate, beneath glabrous, above glandulous-hairy, by decay of the successive layers of old ones forming a kind of cushion. Stipules 2 lines or less long, scarious, fulvous, with linear-setaceous segments. Peduncle solitary or a few to each individual plant, 1-6 inches long, slender-filiform, from an ascending base erect, casually twining or bifid. Raceme few-or many-flowered, $\frac{1}{2}-1 \frac{1}{2}$ rarely $2 \frac{1}{2}$ inches long, sometimes reduced to two flowers only, spike-like, occasionally geminate or bifid, very rarely, however, even imperfectly dichotomous. Bracts linear-setaceous, about 1 line long, at or near the base of the pedicels solitary, often less in number than the flowers. Pedicels generally $\frac{1}{2}$ rarely $1-1 \frac{1}{2}$ line long, sometimes almost obliterated. Calyx 1-1 $\frac{1}{2}$ line long, to the middle or deeply never to the base slit, with lanceolate or linear-lanceolate appressed at the apex spreading lobes. Petals generally broad obovate-cuneate, occasionally with a stalked terminal gland. Stamens about as long as the calyx. Filaments hinear-filiform. Anthers yellow, cordate, about $\frac{1}{4}$ line long. Styles confluent at the base, greenish, except the hyaline ramifications. Capsule somewhat less than 1 line long. Seeds measuring approximately $\frac{1}{5}$ line, ellipsoid, black, reticulate, with a testa except at the pointed base closely surrounding the nucleus.

The relationship of this species to the D. longifolia, $L$., of the northern hemisplere, is erident; in that plant, howerer, the leaves are tapering into a much narrower and longer petiole, thereby reaching to about half the height of the peduncle, the raceme is smooth, the capsule excecds the length of the calyx, is ovate, considerably larger and membranous, the seeds are also larger, and the testa is widely expanded beyond the nucleus. Amongst the Australian species, D. spatulata comcs nearest to D. Burmanni (Vahl, Srmbol. iii. 50), which species, however, not extends to the southern latitudes of Australia, occurring scattered throughront the tropics, for instance, on the Victoria River, near Hooker's Creek, on Macadan Range, the Nicholson River, Moreton Bay, \&c., sometimes on sandy occasionally luumid localities, sometimes in mossy places near springs or cataracts. It differs in more dilated leaves, in finit-pedicels as long as the calyx, in less rigid and less ' acute divisions of the calyx, in 5 styles with radiating stigmas, in somewhat larger and membranous capsules, in linear prominent placentre and in more numerous seeds. The Australian specimens accord fully with Ceylon ones communicated by Mrr. Thwaites.

Principally in flower from November until January; in favorable places throughout the year. 
Drosera peltata, Smith, in Willd. Spec. Plant. 1546 ; Exotic Bot. i. t. 51 ; Cand. Syst. i. 319 ; Planchon, in Annal. des Scienc. Nat. ix. 296; J. Hook. Flor. Tasm. i. 30 ; D. lunata, Hook. Icon. t. 54 ; D. gracilis, J. Hook. and D. foliosa, J. Hook. in Planch. Droser. p. $297 \& 298$; Flor. Tasmanica, i. 30 ; D. sulphurea, Behr, in Linncea, xx. 629.

Rhizome at the base with a spherical tuber; stem erect, leafy, glabrous, simple or branched; stipules wanting; radical leaves kidney-shaped or cordate-kidney-shaped; stcm-7caves pcltate, broadly semiorbicularcrcscent-shapcd, alternate or laterally ternate; petioles of the latter filiform, longer than the leaves; racemes terminal; pedicels longer than the calyx; sepals c7oscly appresscd to the finit, fimbriate, glabrous or pubescent, disconnected; petals white or pink, as well as the stamens 5 , hypogynous; styles short, generally 3 ; stigmas penicillar-many-cleft; capsule to the base 3-rarely 4-or 5-valred; seeds ovate; testa close, at the base attenuated.

In fertile pastures and meadows; not rare in the Colony of Victoria; also in South Australia, Tasmania and New South Wales, at least as far north as $26^{\circ} \mathrm{S}$.

An herb from a few inches to 1 foot high. Rhizome 1-3 inches long, descendent, filiform. Tuber measuring $\frac{1}{2}-\frac{3}{4}$ incl, covered with dark dry scales; the surface of its 'solid portion beautifully shining red and smooth; the inside livid. Stems solitary or several from each root, flexuose. Petioles of radical leaves, which generally early perish, linear, 3-8 lines long; lamina 3-5, lines broad, 2-3 lines long. Petioles of stem-leaves spreading, from a few lines to $\frac{3}{4}$ inch long, two generally in the axis of a longer third one, and generally the shortest and sometimes witl an imperfect leaf. Lamina measuring without the comparatively long cilix 2-4 lines, smooth beneath, glandulous-hairy above. Raceme $1 \frac{1}{2}-4$ inches long, provided with a peduncle of generally 1-2 inches length, sometimes very reduced in the number of flowers, usually furnished with small linear-subulate bracts opposite to or near the base of the pedicel. Fruit-pedicels 2-8 lines long. Sepals ovate or lanceolate, fringed, frequently downy, outside with blackisll-green somewhat appressed straight hair, sometimes glabrous. Petals oborate-cuneate, generally about half exserted, but in a smallflowered variety very short. Stamens nearly half as long as the petals. Anthers yellow. Stigma dissected into capillary lyyalinous at the apex dilated smootlı seginents. Capsule $1 \frac{1}{2}-2$ lines long, nearly globose or ovate-globose. Placentre ovate, flat, occupying the greater portion of the inner face of the valves. Seeds about $\frac{1}{5}$ line long, black, reticulated, blunt at the apex; the testa protracted at the base into a minute stipes.

In flower during September and October.

Drosera auriculata, Backhousc, in Planch. Droserce,295; D. peltata, Labill. Nov. Holl. Spccim. i. p. $79, t .106$ (according to description).

Rhizome at the base with a spherical tuber; stem erect, leafy, glabrous, simple or branched; stipules wanting; radical leaves kidney-shaped or cordate-kidney-shaped; stem-learcs peltate, Iroadly semiorbicularcrcscent-slaped, alternate or laterally ternate; petioles of the latter filiform, longer than the leaves; racemes terninal; pedicels longer than the calyx; sepals glabrous, flexuose, laxly appressed to the fruit, disconnected; petals white or pink, as well as the stamens 5 , hypogynous; styles short, generally 3 ; stigmas penicillarmany-cleft; capsule to the base 3-rarely 4- or 5-valved; sceds cylindrical-subulate; testa long protruding beyond the nuclens.

In sandy soil, poor pasture land and on sterile ridges; not rare in the Colony of Victoria; also in South Anstralia, Tasmania, New South Wales and New Zealand.

In every respect, except the differential notes pointed out, so nearly allied to D. peltata, as to render a detailed description almost needless. Stems $\frac{1}{2}-1 \frac{1}{2}$ foot high. Racemes generally on longer peduncles than those of D. peltata, sometimes paniculate. Sepals about 2 lines long, at the summit often irregularly toothed; with their edges towards the base distant from each other. Petals tapering like those of D. peltata into a very short yellow unguis. Filaments subulate, white. Anthers cordate-round, $\frac{1}{4}$ line long; yellow, pale in age. Stigmas with addition of the style nearly 1 line long; the lobes clavate-filiform, occasionally more 
flabellate than penicillar in their arrangement. Capsule turbinate- or depressed-globose, $1 \frac{1}{2}-2$ lines long. Seeds, compared in shape to file-dust by Planchon, blackish, reticulated, about 1 line long, on account of the testa protruding on the base and apex extremely narrow in proportion to their length.

The resemblance of this species to the Indian D. lunata (Hamilt.) is very great; it differs from it as well as from D. peltata chiefly in the shape of the seeds.

In flower during September and October, and in higher mountainous localities in November.

Drosera Planchoni, J. Hook. in Planch. Dros., Annal. Scienc. Nat. ix. 295; Fr. Tasm. i. 29; D. Menziesii, Hook. Comp. Bot. Mag. 274; Icon. Plant. 53.

Rhizome enveloped in copious membranes, tuberous at the base ; stems weak, generally simple, slender, decumbent or somewhat scandent, below leafless and glabrous, towards the summit scantily hairy; stipules and radical leaves wanting; stcm-leaves pcltate, orbicular, cup-shaped, or some transversely elliptical, laterally ternate, rarely geminate or solitary, shorter than the setaceous-filiform petiole; racemes terminal, solitary or twin; few flowered, subsessile or short pedunculate; pedicels as long as or longer than the calyx; sepals hairy, fringed; petals large, white; stamens about as long as the calyx; style rcpeatedly di-or trichotomous, with decompound capillary lobes of the stigma; capsule to the base 3-valved; placentæ elliptical; seeds constricted at the middle, with broadly and bluntly expanded tcsta at the cxtremities.

In many localities within the boundaries of the Colony of Victoria, extending to the Murray; also throughout the greater part of South Australia, as far north as the Flinders Ranges; not common in Tasmania; not yet found in New Zealand or New South Wales.

A perennial plant, amongst the most handsome of the genus, generally leaning on other plants for support. Rhizome a few inches long, cylindrical, simple, descendent, densely enveloped in several layers of scarions membranes. Stems filiform, 1-2 feet long, at first often erect but soon decumbent by the weight of the developed plant, sometimes trailing, occasionally even climbing, always more or less flexuose, leafy from the apex to below the middle, towards the base provided with distant linear-subulate scales, which are about 1 line long. Lower leaf of each fascicle on a longer petiole; the two other leaves axillary; petiole of the former $\frac{1}{2}-1 \frac{3}{4}$ inch long, of the latter $3-8$ lines long, and still more slender; all spreading, often recurred, glabrous or scantily hairy. Leaves measuring without their long cilix 2-4 lines, above covered with short crisp glandular irritable hair, beneath glabıous. Number of flowers in the generally corymb-like raceme always few, occasionally reduced to two. Pedicels $\frac{1}{4}-1$ inch long, scantily producing short gland-bearing hair. Bracts spathulate- or lanceolate-cuneate or obovate or linear, generally 2-3 lines long, hairy and fringed. Sepals 3-5 lines long, not rarely unequal, lanceolate or ovate, acute or obtuse, lacerate-fringed towards the apex, hairy at the back. Petals 5 , rarely 6 , brond-or cordate-obovate, contracted from a cunente base into a short unguis, often fully $\frac{1}{2}$ inch long or even somewhat longer. Filaments linear-filiform, about 2 lines long. Anthers cordate, intensely yellow, about $\frac{3}{4}$ line long; ; their cells divergent towards the base. Style with addition of the stigma about $1 \frac{1}{2}$ line long, from the base branched into numerons repentedly very tender segments, of which the upper ones are stigmatose, not dilated at the apex, forming a long-bearded stigma. Capsule globose, about 2 lines long. Placentre flat, stretching over the greater part of the valve. Seeds about 1 line long, numerous, although.not quite as many as in several other species, black, cylindrical towards the middle, where the testa is closely appressed to the nucleus, at both extremities dilated to a double width by the ovate or roundish expansion of the testa.

D. Menziesii (R. Br. in Cand. Prodr. i. 319; D. filicaulis, Endl. in Hueg. Enum. p. 6; Lelm. Pl. Preiss. i. 255) differs in totally glabrous stems and racemes, generally smaller leaves, also somewhat smailer and often more copions flowers, but chiefly in having its style divided from the base into simple or simply divided at least not repeatedly decompound lobes. Its fruit, not available on this occasion for examining, may also offer marks of discrimination.

In flower during the rainy season. 


\section{Order VIOLÁCE王.}

Cand. Flor. Franc. iv. 801.

Flowers unsymmetrical, less frequently symmetrical. Sepals 5, persistent, imbricate in astivation. Petals 5, convolute rarely imbricate in æstivation, free. Stamens 5, alternate with the petals, free or coherent. Filaments upwards extended beyond the anthers, broad, flat; the two lower ones often appendiculate. Anthers introrse, two-celled, free or coherent, bursting lengthwise. Stylc 1. Stigma simple, oblique, rarely 2-5-cleft. Ovary one-celled. Ovules anatropal. Fruit capsular, less commonly baccate, few- or many-seeded, rarely one-seeded. Placentæ 3, rarely 1, 2 or 4, parietal. Seeds generally strophiolate. Chalaza usually conspicuous. Embryo straight, erect, in the axis of a fleshy albumen.

Herbs, suffruticose plants or shrubs, extending to almost every part of the globe, not numerous in any part of Australia. Thcir root not rarely of emctic property. Leaves simple, frequently with an involute vernation. Stipules generally persistent, sometimes leafy, sometimes obliterated. Flowers hermaphrodite, rarely polygamous or diœcious; their disposition and color various. Petals marcescent or deciduous. Style often declinate.-Ging. in Cand. Prodr. i. 287; Endl. Gen. 909; Lindl. Veg. Kingd. 338.

This order stands in close relation to Pittosporeæ, to which the genus Hymenanthera is also similar in aspect. Citriobatus, referred by J. Hooker to this order, perfects the unison.

Petals unequal.

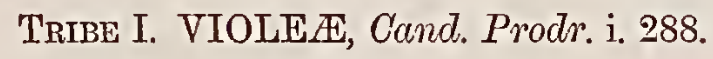

VIOLA.

Tournef. Instit. Rei Herb. 419.-Violet.

Sepals generally lengthened at the base beyond the point of insertion. Petals unequal; the lower one hardly larger than the rest, gibbose or calcarate at the base. Stamens touching each other at their margin. Filaments flat, membranous, continued beyond the anthers into a terminal arid appendage; the two lower filaments usually appendiculate. Style clavate or subulate, often bent. Capsule three-valved, many-seeded. Seeds more or less ovate or globose, generally strophiolate.

Herbs, rarely suffiuticose plants, dispersed over most countries of the globe, but generally wanting in low tropical regions, numerous especially in the temperate zone of the northern hemisphere. Leaves permanently stipulate, all radical, otherwise alternate. Peduncles one-flowered, generally angular, bibracteolated, reflexed at the apex. Lastly developed flowers occasionally apetalous. Color of petals various, often violet, blue or white, sometimes yellow. Stamens closely accumbent to the ovary. Appendage of each of the lower stamens frequently calcarate and concealed within the concave base of the lower petal. Valves of the bursted capsule very spreading.-Ging. in Cand. Prodr. i. 291; Endl. Gen. 909; Torr. \& Gray, Flor. of North Amer. i. 36; Wight \& Am. Prodr. Flor. Peninsul. Ind. Orient. i. 33 ; Erpetion, Cand. in Sweet Flow. Gard.t. 170. 
It has been deemed unnecessary to introduce the subdivisions of the genus Viola, as promulgated by Gingins, Koch and other authors, into this work, since the whole Flora of Australia possesses, as far as ascertained, no other than the here enumerated species.

Viola betonicifolia, Smith, in Recs'Cycl.7; J. Hook. Fl. Tasman.i. 27; V. phyteumifolia, Cand. in Don Gen. Syst. i. 322 ; V. longiscapa, Cand. l. c.

Stemless; root perennial, without stolons; leaves ovate or oblong, with a hastate or cordate rarely attenuated base, repand-crenulate, rarely serrate; stipules adnate to the petiole, scarious, seldom toothed; their lanceolate-subulate apex free; peduncles elongated; bracteoles hinear-subulate, teethless; sepals bluntly appendiculate; petals violet; the four upper ones bearded; the lower one entire, with a slort saccate spur; lower stamens with nearly subulate spur's; style clavate; stigma truncate; seeds brownish, about four times longer than the ovate fleshy strophiole; cotyledons orbicular.

On grassy moist ridges and irrigated plains, sparingly scattered over the southern and eastern part of the Colony of Victoria, ascending from the lowlands to the Alps. 'This species occurs likewise in Tasmania, and rarely in South Austrakia, there for instance near Rivoli Bay and in the Bugle Ranges; it is not rare in East Australia and extends there northward as far as $25^{\circ}$ S.L.

A glabrous or sometimes lispidulous-downy lierb. Root descendent, emitting rather stout fibrillæ. Leaves all radical, more frequently blunt than acute, penninerved, $\frac{3}{4}-3$ inches long, $\frac{1}{2}-1$ line broad, either tapering into the petiole or terminated more or less abruptly at the base. Stipules 2-6 hines long, rarely toothed at the apex, forming linear wings to the base of the petiole, not free as described by Candolle. Petioles varying in length between 1 and 6 lines. Peduncles 1-8 lines long, near the middle or towards the base bibracteolate, angular. Brácteoles alternate or nearly opposite, 1-3 lines long. Sepals ovate- or narrơmlanceolate, acute, 2-3 lines long; their basal appendage about 3 line long. Petals violet, whitish towards the base, dark-veined, 4-6 lines long; upper ones generally scantily bearded, obovate, tapering into a rather short unguis, generally about as loug as the rest, occasionally shorter; lateral ones obovate-cuneate, conspicuously white-bearded; lower one glabrous or towards the centre ver'y scantily puberulous, seemingly never emarginate, obovate-spathulate, with a blunt spur; the latter pale; its length $1_{\frac{1}{2}}$ line or less. Stamens very minutely ciliolated. Anthers about $I$ line long, yellowish-white; their terminal membranous appendage $\frac{1}{2}-1$ line long, orange, often semi-ovate. Spur of the lower stamens $\frac{1}{2}-1$ line long, penetrating into the saccate base of the corolla, divergent, curvate, terminated with a minute gland at the apex. Style 1 line long. Stigma concare, - angular. Capsule 4-5 lines long. Seeds several or many, ovate, filly 1 line long, smootl. Strophiole pale-yellow. Testa crustaceours. Endopleurn very tender membranous. Embryo as long as the albuminous part of the seed. Cotyledons flat, hardly longer, but much broader than the cylindrical radicle.

In flower during the spring.

จiola Caleyana, Don, Gen. Syst. of Dichlam. Pl. i. 329; J. Hook. Fl. Tasm. ii. $35 \%$.

Root perennial; stem erect or decumbent; leaves cordate or cordate-renate, repand- or serrate-crenulate; stipules herbaccous, free, orate- or narrow-lanceolate, l'emotely toothed; bracteoles subulate- or lanceolate. linear, teetlless; sepals short-appendiculate; petals white, glabrous, or the lateral ones very slinghtly bearded; the lower onc obcordate-cuneatc, with a short saccate spur'; lover stamens with gibbous appendages; style clavate; stigma emarginate; seeds brown-black; strophiole less than half as long as the seed, nearly mem. branous; cotyledons orbicular.

On banks of rivulets subject to inundation, on springrs and in wet forest-gullies of Gipps Land; for instance, on the Livingstone, Dargo, Wentworth, Broadribb and Snowy Rivers, nowhere common; thence at least as far as Illawarra into New South Wales; very rare in Tasmania.

Root descendent, either somewhat cylindrical or divided into short branches, always emitting numerous rather tender fibres, sometimes producing short stolons. Stems from a few inches to upwards of 2 feet long, 
angular, laxly erect or quite decumbent. Petioles rather distant, varying from $\frac{1}{2}-3$ inches in length; a few radical. Leaves nearly membranous, more acute than blunt, glabrous or somewhat scabrous, mensuring 1-2 inches, sometimes broader than long; their base with a deep or shallow sinus, occasionally quite truncate, not or but slightly tapering: into the petiole; their lateral nerves originating at the base, thence dirergent and branched upwards into veins. Stipules 3-6 lines long, $\frac{3}{4}-1 \frac{1}{2}$ line broad, acute, slightly. ciliated, with a few remote serratures, or almost teethless. Peduncles axillary, $1 \frac{1}{2}-4$ inches long, furnished near or above the middle with two almost opposite ciliolate bracteoles, which are 1-2 lines long. Sepals measuring about 2 lines, lanceolate, acute, entire, three-nerved; their free base only about $\frac{1}{2}$ line long; blunt. Petals 4-6 lines long; upper ones obovate-spathulate; lateral ones curved- and cuneate-oblong; lower one short- and bluntbilobed, streaked with violet reins; spur of the latter about 1 line long. Anthers cream-colored, hardly 1 line long, their terminal appendage orange, nearly deltoid or semiovate, dilated at the base, about $\frac{2}{3}$ line long. Glandular appendages at the back of the two lower stamens $\frac{1}{2}$ line long, gibbons below, fulvons, very minutely puberulous. Style 1 line long; twisted at the base, glabrous. Stigmn oblique terminal; its npper lobe broadest. Capsule 3-4 lines long, short cuspidate; valves lanceolate-cymbiforn. Seeds not very numerous, ovate, nearly $\frac{2}{3}$ line long; when well matured almost black, marked witl minute white spots. Strophiole whitish, almost lanceolate. Embryo as long as the albuminous part of the seed. Cotyledons of equal length with the cylindrical radicle.

In flower during the spring.

Viola hederacea, Labill. Nov. Holl. Pl. Sp. i. 66 t. 91 ; V. Sieberinna, Spreng. Syst. Append. 96 ; Hook. Comp. Bot. DLagaz. 274; Erpetion reniforme, Sweet Fl. Gard.170; E. hederaceun, Cand. in Don Gen. Syst. i. 335 ; E. petiolare, Don, 7. e.; E. spathulatum, Don, l.e.

Perennial, stoloniferous, rarely canlescent; leares kidney-shaped or rhomboid, or verging into a semilunate or cunente or orbiculate form, repand-crenulate or dentate; stipules fimbriolate, rarely entire, scarious, free, semilanceolate-subulate; bracteoles lanceolate- or subulate-linear, teethless; sepals scareely appendiculate; corolla without a spur; petals more or less blue; the lateral ones bearded; the lower one emarginate; lower stamens without appendages; style cylindrieal; stigma very minute ; seeds without strophiole, black; eotyledons ovate.

Dispersed over the whole Colony of Victoria, with the exception of the north-western quarter; occurring in sandy moist heath-soil, on rivulets, in boggy places, from the lowlands to the summits of our Alps (6000-7000 feet elevation). Frequent in Tasmania, and also in East Australia, where it extends to latitude $26^{\circ} \mathrm{S}$. Comparatively of rare occurrence in South Australia, where it has been noticed near Mount Barker, on the Onkaparinga, in the Barossa Ranges and near Rivoli Bay.

A creeping or tufted herb, extremely variable in form, sometimes in all parts very minute, forming. patches only 1 inch high, with short intricately interwoven stolons; sometimes, on favorable localities along. torrents, producing very long stolons, which from node to node occasionally measure fully a foot, and in rare instances produce a weak flaccid but not rooting stem upwards of 2 feet long and then alternately folinte. Forms intermediate between these extreme varieties exist in abundance. Stolons furnished with alternate stipular scales, in early-Howering seedling-plants wanting. Leaves in fascicles at the joints of the creeping stem, eren when well developed often reduced to the length of 2 lines, although generally larger, sometimes in gigantic specimens attaining a breadth of $1 \frac{1}{2}$ inch and a length of nearly 1 inch, either equally green on botl pages or much paler below, either membranous or somewhat carnulent, either glabrons or slightly hispidulous, toothed or repand in front, entire towards the base. Petioles generally longer than the leaves, attaining in luxurious growth a length of 3 inches. Stipules brownish, $1 \frac{1}{2}-3$ lines long; their teeth glandbearing. Peduncles slender, capable of varying in length between $\frac{3}{4}$ and 9 inches, towards or below the middle bracteolate, glabrous or densely hispidulous; the hair in the latter case white, short and spreading. Bracteoles generally opposite, 1-3 lines long, tipped with a minute gland. Flower as in most Violets nodding. 
Sepals subulate- or linear- or ovate-lanceolate, $1 \frac{1}{3}-2 \frac{1}{2}$ lines long, showing barely a trace of a basal appendage, although the lower extremity is blunt and thickencd. Petals 2-6 lines long, either of an equal blue, or blue and towards the margin whitish, beautifully dark-veined, rarely quite white; upper ones spathulate-obovate, glabrons; lateral ones oblique obovate- or oblong-cuneate, thinly white-bearded towards the margin of the upper side, occasionally ahmost smooth; lower one obovate, tapering into the slightly turgid base. Stamens ciliolate; their appendage lanceolate or somewhat deltoid, abont $\frac{1}{2}$ line long, orange, bleaching; their base beneath the anthcrs short, attenuated. Anther-cells white-yellow, about as long as the appendix. Style $\frac{1}{2}-1$ line long; bent at the base, hardly increasing in thickness towards the apex. Lower tooth of the stigma extremely minute. Capsule 2-4 lines long, trigonous-ovate; valves cymbiform-ellipsoid. Seeds few or several, ovate, about $\frac{2}{3}$ line long, smooth. Strophiole not manifestly developed. Embryo chub-shaped, as long as the albuminons portion of the seed. Cotyledons bnt slightly broader than the cylindrical radicle, with which they are equal in length.

In flower during the spring, on favorable places throughout the year.

The New Zealand and Tasmanian Viola Cunninghami, which according to J. Hooker is at once distinguished from V. hederacea by the development of a corolla-spur, may perhaps yet be found in the Australian Alps.

Viola hederacea may well be separated from its congeners as a subgenus, to which the name of Erpetion should be assigned, and which, by the spurless corolla, the absence of the dorsal appendages of the anthers and the obliteration of the strophiole, is well characterized, although seemingly this subgems would embrace but a solitary species.

\section{IONIDIUM.}

Venten. Malmais. $t .27$.

Sepals scarcely or not protracted into a free base. Petals unequal; the lower one much the largest; its unguis slightly concave or saccate at the base. Stamens touching each other at the margin. Filaments flat, continued beyond the anthers into a membranous apex; the two anterior ones generally appendiculate. Style curved, clavate. Capsule 3-valved, few- or many-seeded. Seeds ovate or subglobose, strophiolate.

Herbs, less frequently shrubby plants, principally dispersed through tropical and subtropical regions. Stems leafy. Leaves alternate or opposite. Stipules small, sometimes almost obliterated. Flowers racemose, cymose or solitary. Pedicels frequently articulated and bibracteolate. Petals purple, blue, white or orange.-Endl. Gen. 909.

It seems very doubtful whether the genus Ionidium can be retained as distinct from Viola. The above characters have been adopted from the works quoted under Viola. A careful investigation of all Ionidia, will, we may anticipate, lead to their reunion with the preceding genus.

Ionidium filiforme.-Pigen filiformis, Cand. Prodr. i. 307; Ionidium linaroides, Presl, Bot. Bemerk. p. 12.

Herbaceous, glabrous; stems simple or not much branched, slender; lower leaves alternate, linear or some oblong; upper leaves opposite, linear; all entire; stipules minute, entire, deltoid- or orate- or subulate-lanceolate; racemes long-stalled; Zraets opposite, minute; pedicels ebracteolate, distant in age; sepals narrow-lanceolate, acuminate; paired petals acuminate, longer than the calyx ; lateral ones dimidiatesubcordate; upper ones lanceolate; all many times shorter than the blue ovate-orbicular unguiculate labellum; anthers terminated by two rery minute linear-subulate lobes; stigma ovate, blunt; capsule fewr-seeded; seeds blackish, closely and very minutely dotted; strophiole almost obliterated; embryo nearly as long as the albumen; cotyledons ovate, as long as the radicle. 
On dry grassy or scrubby ridges near the Avon and Mitchell River of Gipps Land ; extending through Eastern Australia as far north as Moreton Bay; noticed by Dr. Beckler on the summit of Ben Lomond, in New England, at a height of 5000 feet.

Root perennial, flexuose or tortuose, pale, filiform or thickened with few fibres, producing a solitary or several stems. The latter cylindrical, finely streaked, from a span to 3 feet long, sometimes slightly scabrous. Leaves acute, 1-3 inches long, 1-2 lines broad, tapering into the base; their margin generally narrowrevolute. Stipules frequently $\frac{1}{2}$ line long. Peduncles axillary and terminal, filiform, geuerally $2-4$ inches long, occasionally shorter, bearing a raceme of at last alinost equal length. Flowers few or sereral. Bracts ovate-lanceolate, resembling. the stipules. Pedicels alternate, when flower-bearing. 1 line long, recurved and 2-3 lines long when fruit-bearing, jointed at or near the base. Sepals glabrons, aciminate, 1-1 $\frac{1}{2}$ line long; the lateral ones a little longer than the rest; all a little thickened at the base, not appendiculate. Upper two petals pallid, about $1 \frac{1}{3}$ line long, witl a'cyaneous dorsal line; lateral petals yellowisli-grcen, about 2 lines long, streaked with dork blue lines, glabrous on their pages, hardly perceptibly ciliolated at their margin. Lamina of the labellum orbicular or broad-ovate, never truncate, very slightly emarginate, indistinctly bearded towards the base of the upper page, green-yellowish at the base, with a dark limbus, generally 3-5 lines, rarely not fully 2 lines long, flabellate-veined; the claw $2-3$ lincs long, protruding in to a very sliort blunt saccate spur. Filaments violet, pale at last, slightly bearded towards the base, terminated by a semiovate orange appendix, which measures about $\frac{1}{2}$ line. Anthers about $\frac{2}{3}$ line long, extremely faintly bearded at the apex and terminated by two very minute pale appendages. The two staminal glands small and depressed. Style I line long, ascendent from a reclined base, dilated at the summit. Stigma white, concave, not pointed, about $\frac{1}{2}$ line long, with a minute marginal papilla. Ovary glabrous. Capsule globoseovate, $2-3$ lines long, at maturity with very spreading valves. Seeds globose-ovate, abont 5 line long; barren ones livid; fertile ones with an extremely subtile meshwork of veins. Raphe slightly enlarged at the hilum into a hivid narrow strophiole. Cotyledons twice as broad as the cylindrical radicle.

There exists no difficulty in recognizing this well-1narked species. I. glancum (Pigea glauca, Endl. Enum. Pl. Hueg. 5; Vlamingia Australasica, Vriese in Lelım. Pl. Preiss. i. 899), to which also most probably Pigea calycina, Cand. Prodr. i. 307 (Solea calycina, Spr. Syst. Veg. i. 804), is referable, differs chiefly in having all its leaves alternate, in longer narrower bracts, in sepals so large that they extend a little beyond the paired petals, the latter moreover being blunt and less unequal in form, and in a somewhat more rhomboid labellun; ; otherwise it agrees with $\mathrm{I}$. filiforme both in habit and inflorescence. I. monopetalum (Rœem. and Schult. Syst. Veg. v. 400; Pigea monopetala, Ging. in Cand. Pr. 307 ; Solea monopetala, Spr. Syst. Veg. i. 804) most likely belongs to this species, but its diagnosis applies equally to other Australian congeners. Since I. filiforme hardly ever occurs in a downy state, it seems likely that Pigea Banksiann (Ging. in Cand. Prodr. i. 307) does not belong to this species, but to I. suffruticosun, of which the monographer of the Violarinæ had no specimen, when introdncing it into Candolle's work. This supposition appears yet more likely, since I. suffruticosum has even a wider range over Australia than I. filiforme, extending as a by no means local plant from $32^{\circ}$ south latitude in Eastern Australia to Arnhem's Land. The Australian specimens agree fully with Ceylon ones communicated by Mr. Thwaites, and are also identified with the Indian one by Dr. Hooker. The plant is at first sight recogmized, wherever by the anthor of this work it was noticed in Anstralia, by its purple labellum; it may be further distinguished by its often downy state and more diffuse habit, by always alternate not rarely denticulated generally broader leaves, by its linear-subulate stipules, short always one-flowered peduncles, anthers without bristles and whitish exactly ovate streaked seeds.

That Candolle's Pigea filiformis is to be regarded as identical with our plant will admit scarcely of doubt, although the diagnosis characterizes the leaves only as alternate, inasmuch as this species is the only one described by Candolle which sufficiently accords witl the common Port Jackson plant, one that not 
likely could have remained unknown to the illustrious Genève botanist. A glabrous Ionidium, very similar to I. suffiruticosum, differing chiefly in blunt pairs of petals, has been collected near Parramatta by W. Woolls, Esq. This may prove a mere variety of I. filiforme, which exceptionally is found with short one-flowered peduncles, the fruit of this plant being as yet unknown. An Ionidium, remarkable for its orange corolla, is of no rare occurrence in tropical Australia, and was also found by Aug. Gregory, Esq., on Cooper's River. Whether it is a variety of I. suffiuticosum or' a definite species future observations will decide. From the latter plant is neither specifically to be distinguished the I. ramosissimum, Throait. Enum. Pl. Zeyl. i. 21.

Tonidium floribundum, Lindl. in Mitch. three Exped. ii. 165; Annal. Seiene. Nat. xv. 57; Walp. Repert. Bot. Syst. ii. 767 ; I. Australasiæ, Behr in Linnca, xx. 629.

Shrubby or suffruticose, glabrous; leaves alternate, linear or lanceolate-linear, entire, recurved-pointed; stipules very minute or obliterated; peduneles short, cymosely few-flowered or two-flowered, rarely oneflowered; bracts minute, ovate-lanceolate, opposite; sepals subovate, short-acuminate; paired petals orate, subtruncate, nearly half as long as the obcordate-cuneate pale-blue or white labellum, about as long as the calyx; staminal glands blunt; anthers without a furcate appendage; stigma horizontal, ovate, laterally short-acuminate; capsule few-sceded; seeds blackish, slightly tubercled; stropliole about half as long as the seed; embryo cylindrical, shorter than the albumen; cotyledons semiterete.

On barren ridges and low stony or rocky ranges in the vicinity of the Murray River and of its lower tribntaries; originally found by Sir Th. Mitchell towards the Australian Pyrenees. Not rare through the scrubby lowland and mountain tracts of the Colony of South Australia from Guichen Bay to Spencer's Gulf; seemingly local in Western Australia, where it exists near King. George's Sound, and where it was found by Mr. A. Oldfield near the Rivers Harvey and Mrurchison.

An everflowcring slurub, attaining a height of 5 feet, although remaining generally more dwarf, often flowering already as a yearly seedling. Branches angular, somewhat spreading or ascendent. Leaves rather crowded, one-nerved, generally from $\frac{3}{4}-1 \frac{1}{2}$ inches long, $\frac{2}{3}-3$ lines broad, sessile, slightly thickened or revolute at the margin. Stipules linear-subulate, generally shorter than $\frac{1}{2}$ line. Primary peduncles often less than 3 lines long, never conspicuously elongated, bearing, as well as the secondary peduncles at the apex, a pair of concave-lanceolate acuminate bracts, which are about 1 line long. Pedicels, with the addition of the secondary peduncle, 1-21 lines long. Flowers all verging in the same inflorescence to one side, in their arrangement more or less corymbose- or racemose-cymose. "The two inferior sepals deltoid- or rhomboid-

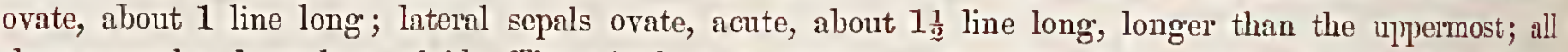
three-nerved and nearly petaloid. The paired petals almost quadrate-obovate; the lateral ones hardly longer than the upper ones; lower one 3-5 lines long; riolet-veined; its claw bicarinate, slightly bearded at the surface, protracted into a short blunt saccate spur; lamina yellow at the base, with a dark violet limbus. Staminal glands verging from a cubic to subglobose form, opposite to the ridges of the lower petal, yellowishgreen. Filaments measuring about 1 line, below very faintly downy; their appendage cordate- or ovateorbicular, orange-colored. Pollen-grains ellipsoid, with longitudinal slits. Style white, filiform, turgid towards the middle and apex, about 1 line long. Capsule 3-4 lines long; ; its valves navicular-ovate, in age very divergent. Fertile seeds ovate or nearly ovate-globose, hardly longer than 1 line; sterile seeds pale and smooth. Strophiole fleshy, senilanceolate, turgid towards the base.

Supplemintal Plate VIII. 1, leaves and stipules; 2 , side view of Hower; 3 , frout view of flower; 4, lower petal; 5, paired petals ; 6, upper sepal; 7, lateral sepals ; 8, lower sepals; 9, staminal glands; 10 , genitalia; 11, back view of an anther; 12 , front view of an anther; 13, pollen-grains; 14, pistil; 15 , unexpanded capsule; 16, half-expanded capsule; 17 , transverse section of capsule; 18 , seeds ; 19, transverse section of a seed; 20, longitudinal section of a seed: all analytical figures more or less magnified. 
TrIBe II. ALSODINE Petals equal.

\section{HYMENANTHERA.}

Banks, according to $R$. Br: l.c.

Sepals without appendages, imbricate in præflorescence. Petals equal. Filaments bearing a dorsal seale, coherent towards the base, continued beyond the anthers into a terminal arid appendage. Style short. Stigma bifid. Ovary one-celled, with 2-4 ovules. Berry 1-4-seeded.

Shrubs of South-Eastern Australia, Tasmania, New Zealand and Norfolk Island. Leaves scattered or fasciculate, minutely stipulate. Pedicels axillary or lateral, solitary or fasciculate. Flowers small, hermaphrodite or polygamous. Petals yellow or green.-Ging. in Mem. Genev. ii. t. 2 f. g.; Endl. Prodr. Flor. Norf. 70 ; Endl. Iconograph. 108; J. Hook. Flor. of New Zeal. i. 19, t. vii.

This genus establishes, according to $\mathbf{R}$. Brown, the affinity between Violarinæ and Polygalex. It is the only known Australian one of the Alsodineous tribe, and approaches, as ingeniously pointed out by Jos. Hooker, nearest to Melicytus, a genus only noticed in New Zealand and Norfolk Island, which differs principally in a 3-5-cleft stigma and corresponding number of placentæ. Its habitual resemblance to certain Pittosporeæ is easily recognized.

Irymenanthera Banirsil, F. M. First Gen. Report, p. 9; H. angustifolia, R. Br. in Cand. Prodr. i. 315 ; J. Hook. Fl. Tasm. i. 27 ; H. dentata, R. Br. l. c.; Hook. Bot. MIagaz. 3163.

Leares generally oblong- or cuneate-linear and short-stalked; pedicels solitary or twin, rarely fasciculate; dorsal appendage of the stamens cuneate-linear, emarginate; terminal one involute at the sides, jagged at the apex.

On the sliady banks of rivers, creeks and rivulets; not rare in the sonthern and south-eastern part of the Colony of Victoria, from the marshy lowlands to the highest summits of the Australian Alps, where it generally occurs in fissures of rocks. Further dispersed through many parts of Tasmania and through Eastern Australia as far north as New England.

A stout shrub, many feet high, except when occurring in alpine localities, where its growth and habit are diminutive and depressed. Branches rigid, almost cylindrical, sordidly brown or pale-grey, minutely lenticellated. Branchlets spreading, not unfrequently spinescent, in young plants often subulate or even acicular, occasionally downy-scabrous. Leaves coriaceous, shining, generally $\frac{1}{2}-1 \frac{1}{2}$ inch long and 1-4 lines broad, tapering gradually into a very short petiole, blunt, one-nerved, conspicuously veined, perfectly entire or remotely and callously denticulated, sometimes of uniform color above and below, sometimes paler beneath, occasionally verging into a lanceolate or ovate form. Saplings produce exceptionally leaves of a thinner texture, fully 3 inches long and $\mathbf{1}_{2} \frac{1}{2}$ inch broad, with long petioles and coarse unequal notches. Stipules generally less than $\frac{1}{2}$ line long, membranons, at first semilanceolate, at a later period more deltoid, very slightly fringed. Pedicels decurred, forming often a spurious leafy unilateral raceme, varying in length from $\frac{1}{2}-2$ inches, provided towards the middle with two alternate or opposite nearly ovate bracteoles, which are generally about $\frac{1}{2}$ line long, and with similar bracts at the base. Sepals ovate-orbicular, very finely or hardly visibly ciliolated; the three outer ones about $\frac{3}{4}$ line long; the two inner ones about 1 line long, as well as the pedicels not rarely pruinose. Petals ovate-oblong, one-nerved, outside pale- inside full-yellow, $1 \frac{1}{2}-2$ lines long, broader below than above; the upper fourtl-part reflexed; the lower portion hardly divergent. Filaments but slightly extending below the anthers; their posterior scale free, glabrous, 
appressed to the connective of the anthers, of about equal length with the anther-cells. 'Terminal appendage of the stamens orange, from a dilated base upwards attenuated, about $\frac{1}{2}$ line long. Anthers yellow, subovate, abont $\frac{7}{2}$ line long. Pollen-grains ellipsoid, bursting lengthwise. Style glabrous, filiform, less than $\frac{1}{2}$ line long; persistent. Lobes of stigma flat, very short, spreading, nearly semiovate. Ovary attenuated into the style, with 2-4 parietal ovules, of which generally only one or two are advancing to fertility. Berry ovate-globose, of about the size of a pea, without pulp, of a purplish color. Seeds $1 \frac{1}{2}-2$ lines long; of an exactly ovate form, if only one becomes developed; or when two are fertile assuming an oblique-ovate form, in being turgid at the back and flat at the commissural face, suspended from very short funicles, black, smooth, livid before ripe. Testa crustaceous. Embryo not much shorter than the albumen. Radicle cylindrical, as long as the thin-laminar ovate-orbicular cotyledons.

In flower during the spring.

This plant seems to perfect male and female flowers on separate plants, although they are hermaphrodite. The male flowers are longer stalked, and have larger petals and anthers, whilst the ovary is almost suppressed and the lobes of the stigma remain united. The female flowers are provided with shorter anthers and smaller staminal appendages, whilst the ovary soon enlarges, and the stigma spreads with comparatively conspicuous lobes. Endlicher described most accurately analogous floral disparities of the H. latifolia.

Leaves quite as large as those delineated by Baner in his iconography may exceptionally be seen in the Australian species. The figure of $\mathrm{H}$. crinssifolia, furnished by Fitch, shows more acute dorsal scales of the stamens and a cylindrical embryo to form the main distinctions of the New Zealand congener.

L. Becker directs attention to the lasting purple pigment of the berries. No Violaceous plants, beyond those alluded to in these pages, are as yet known from any part of Australia hitherto explored.

\section{ORDER PITTOSPOREA.}

\section{R. Br. in Flinders' Voyage, ii. 542 .}

Flowers exactly or nearly symmetrical. Sepals and petals 5 , rarely 4 , deciduous, imbricate in restivation, free or coherent. Stamens 5, rarely 4, hypogynous, distinct, alternate with the petals. Anthers introrse, terminal, opening by two slits or pores. Style 1. Stigma faintly or distinctly 2-5-lobed. Ovary 2-5-celled. Orules anatropal. Fruit capsular or baccate, many-seeded, rarely two-seeded. Seeds attached to the margin of the dissepiments, albuminous. Enbryo extremely minute, next to the hilum.

Elegant trces or shrubs, rarely herbs, occurring sparingly in Africa, Oceania, the warmer parts of Asia and tropical Australia, more frequently in the extratropical part of the Australian continent, some ascending to alpine elevations. Leares simple, alternate, undivided, rarely pinnatifid. Stipules wanting. Flowers hermaphrodite, rarely polygamous or diœcious; their disposition and eolor various.-Cand. Prodr. i. 345; Putterl. Synops. Pitlosporear. 1.

This order stands amongst Thalamifloræ next in its relationship to Violacex, whilst amongst Calyciflore it closely approaehes to Celastrineæ. The genuine genera of the order, not represented within the Colony of Vietoria, are Citriobatus, Sollya, Homalosporum and Hymenosporum. 


\section{PITTOSPORUM.}

Banks and Solander, according to Gartn. de Fruct. et Sem.pl. i. 286, t. 59.

Sepals free, seldom unequally united. Petals equal; their claws more or less coherent into a tube. Stamens free, straight. Anther-cells bursting lengthwise. Style filiform. Stigma imperfectly 2-5-lobed. Capsule thich-coriaceous or bony, 2-5-valved, with imperfect dissepiments. Seeds enveloped in a viscid pulp, wingless, few or many in each cell, turgid or somewhat angular-compressed.

Trees or shrubs, rarely of epiphytal growth, scattered in a scanty number of species over Continental Australia, comparatively frequent in New Zealand, rather rare in Polynesia, Africa, and the warmer parts of Asia. Leaves alternate or those situated at the summit of the branchlets crowded into whorls, generally coriaceous and entire, rarely toothed. Flowers hermaphrodite, seldom poly gamous, axillary and terminal, solitary, corymbose, umbellate or paniculate, often fragrant. Capsules frequently verging towards an ovate or globose form, rarely cylindrical. Seeds commonly conglutinated to a somewhat compact mass, rarely distant and pendulous.-Putt. Syn. 5; Wight \& Arn. Prodr. 153; Endl. Gen. 1082 ; Blume DIus. Bot. Lugd. Bat. 159; J. Hook. Flor. of Nerv Zeal. i. 21.

Pittosporum undulatum, Ventenat Hort. Cels. t.76; Andr. Bot. Rcp. t. 383; Schrad. Gon. Nov. Emend. t. 4 ; Delaun. Hert. Amat. t. 86; Ker Bot. Reg. t. 16; Dict. Class. t. xv.; Duham. Traité des Arbres, iv. $62 ;$ Puttcrl. Syn. Pittosp. 6.

Branchlets verticillate, spreading; leaves on conspicuons petioles, thin-coriaceous, lanceolate or ovatelanceolate, acnte or acuminate, grlabrous, spreading-nerved, finely net-reined, undulate at the margin, above shining, beneath paler and opaque, at the summit of the branchlets nearly verticillate, otherwise scattered; petioles at first, as well as the young branchlets, the peduncles and the pedicels, shightly downy; corymbs or compound umbels terminal; bracts and bracteoles linear-subulate; sepals unequally connate, lanceolate, with a long acumen; petals white, narrow spathulate-oblong, blunt; anthers oblong-sagittate, about half as long as the filaments; orary outside everywhere appressed-downy; capsules pearshaped-globose, fulvous, smooth, turgid, 2- rarely 3-valved; valves thick-coriaceous; funicles rery short; seeds many, angular, brownish-rubiginous.

On the banks of rivers in humid forest districts or on rocky places, about Western Port, on the Buchan River, the Tambo, the Broadribb and Snowy River; thence through Eastern Australia as far north as the Hastings River.

A bushy umbrageous tree of noble aspect, highly recommendable for arenue plantations in this country, attaining in favorable situations a height of 40 feet, although in barren exposed places it may remain of shrubby habit. Branchlets terete, soon perfectly glabrous. Leaves mostly from $2-5$ inches long, 1-1 $\frac{1}{2}$ inch broad, teethless. Primary pednncles solitary, or more frequently several, from $\frac{1}{2}-2$ inches long. Pedicels from $1 \frac{1}{2}$ line to $I$ inch long, slender-filiform, furnished at the base with a solitary deciduous bracteole, which is 1 or a few lines long, and occasionally accompanied by a few diminutire accessorial bracteoles. Flowers very fragrant. Sepals almost glabrous or particularly at the margin downy, united below into a nearly unilateral or somewhat bilabiate calyx, 2-3 or occasionally 4 lines long. Petals glabrous, 4-6 lines long; above the middle $1-1 \frac{1}{2}$ line broad. Filaments subulate,-smooth. Anthers $1-1 \frac{1}{2}$ line long, yellow, at the termination of the basal sinus fixed to the filament. Style glabrous, 1-2 lines long. Lobes of stigma almost semiovate, about $\frac{1}{3}$ line long, with a slight middle-furrow. Capșle $5-8$ lines long, before quite ripe of a strong odor reminding of that of orange-peel, finally valvate to the base. Dissepinent very imperfect. Seeds forming two irregular rows, being densely conglutinated by their viscid envelope, angular by mutual pressure, 1-1 $1 \frac{1}{2}$ line long, verging into a more or less globose, orate or rhomboid form.

Amongst Australian congeners P. revolutum comes nearest to this species, from which it differs in shorter petioles, still more regularly subverticillate leaves, which are clothed beneath with short rust-brown 
finally greyish downs, and are above wrinkled by the impressed nerves and veins, in glandulous-downy larger bracteoles, in a more contracted often drooping inflorescence, in free sepals, in yellowish longer coherent petals, in more ovate tardily glabrescent not rarely 3-valved capsules, which are bright yellow or almost orange-colored inside, in longer orange funicles, and in less angular more globose seeds. P. revolutum occurs through Eastern Australia as far north as Moreton Bay, and may possibly exist on the eastern frontiers of this colony. The New Zealandian P. umbellatum is to be distinguished already by its not undulated leares, by its broader bracts, umbellate longer pedicels, free sepals and granulate somewhat tetragonous capsules. P. rhombifolium, which ranges from the NcLeay to the Burnett River, is the only other Australian species producing white petals; it differs, however, widely already in its toothed leaves, small copious paniculate flowers, less downy ovaries and minute capsules.

Bears flowers in open localities during the spring; in the dense forest during the summer.

Pittosporum bicolor, Hook. Journ. of Bot. i. 249; Putt. Syn. Pittosp. 17; J. Hook. Flora Tasmaniae, i. 38.

Leaves coriaceous, on short petioles, oblong- or lipear- rarely ovate-lanceolate acute or rather blunt, entire, indistinctly veined, generally recurved at the margin, beneath silliy-or velvety-donmy, as well as the branchlets, pedicels and sepals, above scantily downy or glabrescent; pedicels axillary and terminal, solitary or umbellate, surrounded at the base with several or. numerous imbricated small bracts; sepals narrow- or ovate-lanceolate, about three times shorter than the corolla; petals purple and yellow, narrow spathulateoblong; anthers nearly thrice shorter than the filaments; ovary outside everywhere silky-tomentose; capsule roundish, thick-coriaceous, bivalved, somewhat compressed and downy; funicles short; seeds angular, brownish-red.

In the ferm-tree gullies from Wilson's Promontory to the Delatite, the Dandenong Ranges and Mount Disappointment; also in the ranges towards Cape Otway and Apollo Bay, and on Nount Tambo; ascending to subalpine elevations. Not rare in the damp forest ranges of Tasmania.

A small tree, which, however, in favorable spots assumes a height of 40 feet, whilst it retains in exposed localities and higher mountain regions mostly a bushy habit. Branchlets leafy, corered, like the lower page of the lenves and the pedicels and sepals, with a thin fulvous or ferruginous in age more or less canescent toment. Leaves resembling those of certain Grevillea more than those of most Pittospora, 1-3 inches long, $2-8$ lines broad, exceptionally larger, often of considerable stiffness, not narrowly pointed; their surface shining; their margin much more frequently recurved or even revolute, than flat; their lateral nerves thin; their veins merely observable in age. Outer bracts from orbicular gradually ovate, $\frac{3}{4}-1 \frac{1}{2}$ line. long; inner ones from an elliptical form verging gradually into a linear-oblong one, $1 \frac{1}{2}-3$ lines long; innermost generally almost linear; all either perfectly silky-downy at the back, or only ciliated torards the margin. Pedicels varying in length from $\frac{1}{6}-1$ inch, rather slender, bearing occasionally a subulate- or linear-lanceolate bracteole near its middle. Flowers faintly odorous. Sepals $1 \frac{1}{2}-2$ rarely 3 lines long, somewhat unequal, reflexed in age. Petals glabrous, colored by a mixed tint of yellow and purple, soon longitudinally disjoined, more blunt than acute, above the middle reflexed. Filaments linear-filiform, about $2 \frac{1}{2}$ lines long, glabrous. Anthers yellow, sometimes from a saggitate base nearly linear, sometimes from a cordate base oblong, $2^{2}-1$ line long. Style either silky or with exception of its base glabrous, 1-2 lines long, filiform. Stigma slightlly bilobed, depressed. Capsules measuring 4-5 lines, outward blackish-brown in age. Seeds conglomerated by their viscid pulp.

This tree exudes like several of its congeners a pale useful gum.

Pittosporum phylliræoides, Cand. Prodr. i. 317; Putterl. Syn. Pitt. 16; Lehm. Pl. Preiss. i. 192 ; P. ligustrifolium, All. Cunn. in Loud. Hort. Brit. Suppl. i. 597; P. oleæfolium, All. Cunn. in Putt. Syn. Pitt. 17; P. Roeanum, Putt. l. c.; P. longifclium, Putt. l. c.; P. acacioides, All. Cunn. in 
Annal. of Nat. Hist. iv. 109; P. angustifolium, Lodd. Bot. Cabin. t. 1859; P. salicinum, Lindl. in Miteh. Trop. Austr. 97.

Branchlets slender, generally dependent or cernuous; leaves glabrous, broad-or lanceolatc- or falcatelinear, pointed into an uncinate apex, indistinetly veined, scarcely paler beneath, perfectly entire, flat, .tapering into the petiole; pedicels axillary, lateral and terminal, solitary or forming few-flowered umbels; sepals free, membranous, subovate, several times shorter than the smooth yellow oblong-spathulate longcolerent petals; anthers cordate-oblong, scarcely laalf as long as the filaments; ovary imperfectly downy; capsules considerably compresscd, bony, yellowish, ovate- or cordate-roundish or quite ovate, 2- rarely 3 -valved; funicles very short; seeds few or several, dark- or orange-red, angular, ovate-globose.

On sandy or barren stony declivities and plains, chiefly with limestone subsoil, dispersed through the desert from the Mrurray River to South-Western Australia, to the MIurchison River, to Sturt's and Hooker's Creek, to the Burdekin and Darling River and their tributaries.

A small, exceedingly graceful tree or slender shrub, resembling in habit and foliage more.Eremophila bignoniflora, Myoporum Cunninghami or some plyyllodineons Acaciæ than its congeners, of bitter taste in all its parts. Bark of the trunk sordidly brownish-black, rimose and wrinkled; that of the branches grey and smooth. Branches erect or ascendent. Branchlets terete, flexible, bent more or less downward, generally except in very early age smooth, sometintes, however, densely grey-downy. Leaves scattered, not much crowded on the extremities of the branchlets, when well dereloped 2-5 inches long, and as many lines brond, occasionally, however, of greater and lesser dimensions; the margin rarely in age reflexed; the middle nerve never very prominent. Pedicels 2-10 lines long, forming not rarely along the branches an interrupted more or less leafy raceme. Bracts ninute, almost ovate, slightly fringed, fast dropping. Bracteoles, if present, fixed near the middle of the pedicel, lanceolate or linear-subulate, 1-2 lines long. Flowers very fragrant.

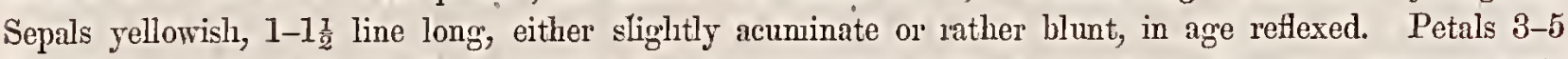
lines long, to about the iniddle counected into a broad tube, reflexed towards the summit. Stamens little protruding beyond the tube. Filaments linear-filiform. Anthers $\frac{3}{4}-1$ line long, golden-yellow. Style of 1 line length or shorter. Stigma peltate, slightly emarginate. Capsules of an unpleasant odor, outward sordidly orange, inward bright yellow or vitellinous, 5-8 lines long, tardily dehiscent. Septum evanescent above the middle of the valve, forming a low ridge below. Seeds $1 \frac{1}{2}-2$ lines long, sometimes only very few or even a solitary one developed in the cell.

This tree exudes in the warmer season rather copiously a transparent pale insipid gum. Cattle are fond of the leaves. Water extracts the bitter principle of the plant. Alcohol dissolves the resinous-viscid covering of the seeds, forming thèreby a yellow tincture.

In flower during the spring.

Our collections establish as well-marked additional Australian species of this genus only the following, P. revolutum, P. rhombifolium, P. melanospermum and P. ovatifolium, the two latter to be further compared, when their flowers are known, with some Asiatic species. P. parviflorum, of South-Western Anstralia, may possibly not belong to this genus. P. flavum constitutes the genus Hymenosporum.

\section{BURSARIA.}

Cavan. Icon. et Descr. Pl. iv. 30; t. 350.

Sepals free. Petals equal, divergent, not unguiculate. Stamens unconnected. Anther-cells bursting lengthwise. Style short, filiform. Stigma extremely minute, hardly lobed. Capsules much compressed, short-stalked, thin-parchmentous, two-celled, exceptionally three-celled, with terminal loculicidal dehiscence. Septum exceedingly narrow. Seeds 1-3, vertical in each cell, flat, surrounded by a very narrow border, wingless, dry, smorth. 
A tree or shrub of the extratropical and of the eastern and north-eastern intratropical parts of Australia and of Tasmania. Branchlets not rarely spinescent. Leaves alternate or fasciculate, chartaceous, entire, very rarely toothed. Racemes paniculate. Sepals minute, dropping before the expansion of the corolla. Petals small, almost white. Capsules obcordate- or renate-orbicular, rather small.-Cand. Prodr. i. 347.

This genus mediates the transit from Pittosporum to Rhytidosporum; it differs, however, from both in the plane-compressed seeds. The paucity and the vertical not horizontal position of the latter, and the form of the corolla, distinguish it principally from Homalosporum and Hymenosporum. Habitually, however, Bursaria bears in its small state much more resemblance to Citriobatus than to any other Pittosporaceous genus. Putterlick, Endlicher and J. Hooker comprehend under Bursaria also Rhytidosporum.

Bursaria spinosa, Cavan. Tcon. et Descr. iv. 30, t.530; Bot. Mag.t. 1767; Putterl. Syn. Pittosp. 19; J. Hook. Fl. Tusm. i. 39; B. incana, Lindl. in Mitch. Thrce Exp. 224; Itea spinosa, Andr. Bot. Rep. t. 314; Cyrilla spinosa, Spreng. Nov. Provent. Hort. Hal. \& Berol. 15.

Common as well in the lowland as in the mountain districts of Victoria, particularly in stony places, ascending to the Australian Alps; distribnted thence over the southern part of the Continent, at least as far as the Darling River and Streaky Bay, and over the eastern part of Australia as far as the Gulf of Carpentaria, being, however, rare within the tropics. Abundant throughout Tasmania. Apparently absent from North-Western and Sonth-Western Australiâ, although reappearing towards the Mrurchison River, where it was at first noticed by J. Diummond.

A small tree, attaining: occasionally a height of fully 40 feet, often, however, particularly in barren and exposed localities, remaining of shrubby habit, in a young state generally producing nnmerous solitary subulate or acicular thorns of the length of a few or several lines. Bark almost black, wrinkled and fissured. Branches spreading. Branchlets almost cylindrical, generally covered with short downs, sometimes spinescent. Petioles very short or not developed. Leaves subject to great rariations according to the age of the plants and the places of their growth, obovate or oblong, tapering into a cuneate base, flat, entire, seldom irregularly serrated, glabrous or covered beneath with an exceedingly thin grey or rarely fulvous velvet, blunt or minutely pointed, not rarely having a terminal notch, slightly or manifestly shining above, paler and opaque beneath, one-nerved, with more or less distinct veins, from 2 lines to 3 inches long, $1 \frac{1}{2}-8$ lines broad, flat, seldom revolute at the margin. Panicle often several or many inches long, provided with but a very short general peduncle, consisting of several or numerous spieading oftener compound than simple racemes, freguently forming an ample somewhat pyramidal mass of flowers. Peduncles and pedicels glabrous or downy. The latter when flower-bearing 1-3 lines long, when fruit-bearing about double as long; patent, slender, fliform, hardly angular. Bracteoles similar to the sepals, exceedingly figaceous, solitary at the base and apex or occurring also at the middle of the pedicel, appressed. Flowers fragrant. Sepals semilanceolate, only $\frac{1}{2}-\frac{9}{3}$ line long; slightly puberulous. Petals 5, exceptionally 4 , accidentally even $6-9$, meinbranous, 2-3 lines long, glabrous, lanceolate-oblong, rather blunt or scarcely acute, very finely three-nerved, often with a greenish or red tint. Stamens abont as long as the petals. Filaments glabrous, subulate, white, not compressed. Anthers oscillating, yellow, subcordate, about $\frac{1}{2}$ line long, affixed to the filaments at the apex of their basal sinus. Pollen-grains ellipsoid, bursting lengthwise. Style generally less than $\frac{1}{2}$ line long, or almost obliterated. Stigma a mere point, not broader than the apex of the style. Stipes of the ovary dark grceu, stont, about $\frac{1}{2}$ line, rarely 1. line long, hardly lcngthened in age. Germen ellipsoil, acute, glabrous, rarely short-dorny. Ovules several or many, affixed in two rows to ench sidc of the septum. Capsulc $2-1$ lines long, a little broader than its length, grey- or pale-brown, smooth, bursting in front, never spontaneously towards the base, in age separating imperfectly from the apex along the dissepiment into its two carpels, which are 
easily separable by pressure. Funicles very short. Seeds brown, smooth, opaque, nearly kidney-shaped, 11-13 line long, extremely finely reticulated. Hilum lateral.

The lower page of the leaves and the ovary are almost constantly clotlied with subtle down, wherever the plant occurs in the dry tropical or the southern desert tracts. In this colony it may be seen also beyond the desert in this state on the Snowy River. The Bursaria spinosa passes here amongst colonists in some districts under the very inappropriate names of Native Myrtle and Box-tree.

In flower chiefly during the summer, although some flowers may be gathered at all seasons.

\section{RHYTIDOSPORUMI.}

\section{F. Mr. First Gen. Report on the Veg. of Vict. $p .10$.}

Sepals free. Petals equal, divergent, not unguiculate. Stamens uncomnected. Anther-cells bursting lengthwise. Style short, filiform. Stigma minute, bilobed. Capsule slightly compressed, sessile, thin-parchmentous, two-celled, exceptionally three-celled, bursting to the middle by loculicidal and septicidal dehiscence. Seeds turgid, dry, wrinkled, wingless, several almost horizontally arrayed in each cell.

A small herb or low suffruticose never climbing plant, to be found in Eastern extratropical and South-Eastern Australia, as also in Tasmania. Leaves alternate, chartaceous or coriaceous, often toothed at the apex. Flowers small, axillary and terminal, solitary, less frequently twin or ternate. Petals white, not rarely tinged with red. Capsule didymous- or kidneyshaped-orbicular, rather small, nodding.

Rhytidosporum, although as regards its flowers referable to Bursaria, differs essentially in its fruit, by which to a certain degree the contact with Pittosporum, and with that section of Marianthus designated as Oncosporum, is effected. In habit it differs totally from any of the known Pittosporaceous genera.

Rhytidosporum procumbens, F. M. First Gen.Rep. p. 10; Pittosporum procumbens, Hook. in Comp. to the Bot.MIag. i. 275; P. nanum, Hook. l.e.; Busaria procumbens, Putt. Syn. Pitt. 20; J. Hook. Fl. Tasm. i. 39; B. diosmoides, Putt. Syn. Pitt. 20; B. Stuartiana, Klatt in Linncea, xxviii. 568 ; Pronaya ericoides, Lindl. in Nitch. Three Exped. ii. $22 \%$.

On barren forest-ridges and heath-ground, by no means common in the Colony of Victoria; noticed on Mount William, in the Black Forest, near Forest Creek, around Port Albert, on the Rivers La Trobe and Tarwin and in the Bogong Ranges. Further known from many parts of Tasmania and New South Wales, advancing northward, according to Dr. Beckler's observations, as far as the tributaries of the Clarence River.

An erect, diffuse, ascendent or procumbent plant, from 2 inches to 1 foot high, producing a solitary or several or many stenis from each root. 'The latter, according to the age of the plant, slender, flexuose and simple, or thick and aroody. Branches spreading, sparingly clothed with white crisp downs. Leares rather crowded, subsessile, linear- or cuneate- or oblong- or ovate-lanceolate, promiscuonsly entire and with a few either faint or coarse serratures toothed towards the summit, flat or more fiequently recurved or revolute at the margin, acute and minutely cuspidate, 2-7 lines long, 1-2 lines broad, shining above, hardly paler beneath, somewhat downy in a young state, glabrous in age; the middle nerve barely visible at their surface. Peduncles none. Pedicels filiform, downy, when flower-bearing 1-2 lines long; when fruit-bearing somewhat longer and very recurved. Bracteoles solitary, situated generally towards the base of the pedicel, linear-subulate, 1-2 lines long, slightly downy. Sepals lanceolate- or linear-subulate, $1-1 \frac{1}{2}$ occasionally 2 lines long, dropping simultaneously with the corolla. Petals oblong-lanceolate, acite, glabrous, 2-3 lines long; one-nerved, finely veined, membranous. Filaments white, 1-11 line long, subulate, attenuated at the 
base. Anthers cordate-ovate, about $\frac{1}{4}$ line long, yellow or red. Pollen-grains ellipsoid, bursting lengthwise, occasionally red. Style $\frac{1}{4}-\frac{1}{2}$ line long. Stigma very small. Ovary glabrous. Capsule pale-brown, $2-3$ lines long, 3-4 lines broad, smooth. Valves inside streaked by transverse veins. Funicles minute, tootl-like. Seeds attached in a double row within each cell to the dissepiment, dark-brown, opaque, kidneyslaped-ovate, glabrous, about 1 line long. Hilum lateral.

Specimens communicated by W. Woolls from Parramatta, from.whence Putterlick receired his Bursaria diosmoides, accord fully with our plant. Specimens from the Argyle county have their flowers somewhat larger and ternate.

\section{CHEIRANTHERA.}

All. Cunn. in Bot. Regist. 1719.

Sepals free. Petals equal, spreading, neither coherent nor unguiculate. Stamens unilateral. Filaments short. Anthers opening at the apex with two pores, free or at first coherent. Pollen-grains ellipsoid, bursting lengthwise. Ovary reclined. Style filiform. Stigma minute, slightly bilobed. Capsule parchmentous, ellipsoid-cylindrical, perfectly two-celled, with loculicidal dehiscence to the middle and septicidal dehiscence to near the base. Seeds many in each cell, dry, subglobose, vingless.

Small erect suffruticose plants, inhabiting sparingly extratropical tracts of Australia. Leaves linear or filiform, alternate or fasciculate. Flowers erect, mostly terminal and corymbose, rarely solitary. Petals blue.-Putt. Syn. Pitt. 24; Planch. in Annal. Scienc. Natur. iv. 266, t. 2.

Sollya differs from Cheiranthera in anthers cohering conically around the pistil and in truly baccate fruit, and agrees with it in the corolla and in anthers opening by pores. The latter character removes these genera from all other Pittosporeæ. Our extensive botanical collections from almost every explored part of Australia contain of this genus only two other species, namely, C. brevifolia and C. tortilis (Fragm. Phyt. Austr. i. 97 and ii. 75), the genus being therefore probably not one of numerous species. C. Preissiana (Putt. in Lehm. Pl. Preiss. i. 201), of which the flowers and ripe fruits are not described, may possibly not belong to the genus. Putterlick remarks, that in its climbing habit the latter agrees with two South-Western Australian undescribed congeners.

Cheiranthera linearis, All. Cunn. in Bot. Reg. 1719; Hook. Icon. Plant. i. t.47; Putterl. Syn. Pittosp. 24; Schlechtend. Linncea, xx. 636; Planch. in Houtte Fl. de Serres, viii. 291, with plate; Regel Gartenfl. i. 227, t. 22; F. M. Fragm. Phytogr. Austr, i. 97 ; C. cyanea, Brogn. Voy. Coquille, t. 77.

Leaves fasciculate or alternately-crowded, long-linear, acute, somewhat channelled, entire, rarely lanceolate-linear, flat and remotely toothed; anthers about four times shorter than the large corolla, free, subcordate at the lyase.

On barren stony ridges and hills; thus on Mount McIvor and near the Ovens River; thence to the vicinity of the Flinders Ranges, Spencer's Gulf and St. Vincent's Gulf, and to the Upper Lachlan River.

A handsome plant, from a few inches to $1_{\frac{1}{2}}$ foot high. Rhizome woody. Stems often simple and somewhat flexuose, or provided with strict branches, either glabrous or very scantily clothed with short spreading downs. Well developed leaves from $\frac{3}{4}-2$ inches long and as many lines broad, one-nerved, minutely ciliolate, otherwise almost glabrous, of equal color on both pages; serratures, if present, seldom extending. below the middle of the leaves, generally only occurring near the apex, very minute or fully 1 line long. Primordial leaves cordate. Corymb few-flowered, occasionally reduced to one flower, not often axillary. General peduncle $\frac{3}{4}-1 \frac{1}{2}$ inch long. Pedicels neasuring fiom $\frac{1}{4}-2$ inches, thickened towards the apex, bearing below the middle two generally alternate linear-subulate bracteoles, which measure 1-2 lines, furnished at the base with a bract somewhat larger than the bracteoles. Sepals $\frac{1}{2}-2 \frac{1}{2}$ lines long, lanceolate, gradually 
acuminate, sometimes linear-subulate, finely ciliolated, pale at the margin. Petals cyan-blue, very rarely pink or white, glabrous, oblong- or elliptical-obovate, tapering into a cuneate base, minutely cuspidate at the apex, three-nerved along the middle, veined, $\frac{1}{2}-1$ inch long. Filaments $1-1 \frac{1}{2}$ line long; subulate, considerably thickened towards the base, glabrons, often blue. Anthers not oscillating, affixed at their basal sinus to the filament, $1 \frac{1}{2}-2 \frac{1}{2}$ lines long, oblong with cordate base, bending to that side of the flower opposite to the pistil. Style thin-filiform, at first about 1 line, finally nearly 2 lines long, slightly curved or uncinate. Ovary glabrous, tapering into an extremely short stipes. Capsule subsessile, $\frac{1}{2}-\frac{3}{4}$ inch long, grey-fulvous, opaque outside, polished inside, bursting in age half downward along the middle nerve of the valves and separating also finally along the septum almost completely into its carpellar portions. Funicles very short. Seeds brown, shining.

In flower during the spring.

\section{MARIANTHUS.}

Hueg. Enum. Plant. Nov. Holl. austro-occid. p. 8.

Sepals free. Petals more or less coherent into a tube, unguiculate. Filaments elongate, surrounding the pistil. Anthers free, bursting longitudinally. Style generally long, setaceous. Stigma minute, bilobed. Capsule parchmentous, two-celled, slightly compressed, with loculicidal and sometimes also septicidal dehiscence. Seeds several or many in each cell, dry, turgid or somewhat compressed, wingless.

Elegant climbers, all; with exception of $\mathbf{M}$. bignoniaceus, natives of Western and South-Western Australia. Leaves alternate, herbaceous or subcoriaceoü, entire, sometimes partially toothed, never very narrow; flowers terminal and axillary, cymose, less frequently solitary, twin or ternate. Petals white, yellowish, orange or red, sometimes beautifully streaked or dotted.-Putt. Syn. Pitt. 22 ; Calopetalon, Dmumm. in Hook. Kew Misc. vii. 52.

Marianthus is brouglit through the analogous structure of its fruit into close relationship with Cheiranthera, from which in general the habit and more especially the corolla and stamens render it distinct. Homalosporum may either be regarded as a subgenus of Marianthus, or, chiefly on account of its perfectly flat seeds, as generically distinct. Billardiera agrees with Marianthus in the flowers, but differs widely in its baccate fruit.

Irarianthus bignoniaceus, F. MI. Transact. Plit. Soc. Vict. i. 6; Billardiera latifolia, Klatt in Linnea, xxviii. $5 \% 0$.

Branches downy, at first silky, at last snooth; petioles rather short; leaves herbaceous, ovate, oblong: or lanceolate, with cordate base, above glabrescent, beneath somewhat hairy; pedicels axillary, solitary, twin or ternate, about as long as the calyx or twice as long; flowers pendulous; sepals downy, lanceolate, acuminate, several times shorter than the corolla; petals orange-yellow, coherent to near the apex into a straight cylindrical slightly bcll-shapel corolla, rather blunt, somewhat downy; flaments setaceous; anthers cordate-ovate; ovary silky; capsules narrow-elliptical, downy, many-seeded; seeds globose-ovate, turgid.

On umbrageous rivulets, springs and cataracts, and also in fissures of irrigated rocks in the Serra and Victoria Ranges and the Grampians. Further only known from the shady banks of the Onkaparinga and from the Mount Isofty Ranges in Sonth Australia; nowhere frequent; ascending to elevations of 5000 feet."

Root filiform, tortuous', with distant fibres. Stems often several feet long, slender, covered with a brown membranous periphlæum. Petioles 2-6 lines long, downy. Well-developed leaves $3-3$ inches long, one-nerved, finely veined, somewhat paler and opaque beneath, more densely downy at the margin, which in age is often revolute; the lower one sometimes quite cordate. Bracts several at the base of the pedicels, about 1 line long, ovate- or linear-lanceolate, acuminate, silky-downy at the back. Bracteoles wanting or a 
solitary one similar to the bracts at the middle of the pedicel. Sepals $1 \frac{1}{2}-2$ lines long, narrow- or linearlanceolate, acuminate. Corolla straight, $\frac{2}{3}-1$ inch long, inside glabrous, outside green-yellow towards the base, almost orange-colored towards the middle, yellowish at the apex and throughout inside, consisting of narrow-cuneate petals, which are finely striate-reined, produce a roundish or blunt triangular free lamina of only $1 \frac{1}{2}-2$ lines length, and are early separated at their base. Filaments setaceons, glabrous, as long as the coherent part of the corolla. Anthers oscillating, about $\frac{2}{3}$ line long. Style about as long as the stamens, setaceous, scantily downy towards the base. Stigma slightly dilated and distinctly bilobed. Ovary silky, showing at the base five minute glands. Capsule generally less than 1 inch long, only $\frac{1}{2}-2$ lines broad. Valves of a thinner texture than in most congeners, separating to near the base, seemingly not cleft, appressed-downy. Seeds brown, about 1 line long.

Plate X. 1, corolla ; 2, the same, laid open; 3, complete flower, laid open ; 4, calyx; 5, anthers; 6 , pollen-grains; 7 , pistil; 8 , stigma; 9 , capsule; 10 , valves ; 11 , longitudinal section of capsule; 12 , transverse section of the same; 13 , seeds ; 14, seed entire; 15 , longitudinal section, and 16 , transverse section of the same: all figures, with exception of 13 , in various degrees magnified.

This species holds, as regards its almost tubular corolla, the same position to its congeners as Billardier' longiflora to the other Billardiera.

In flower throughout the whole year, although more copiously during the spring.

\section{BIILARDIERA.}

\section{Smith, Botany of New Holland, i. 1.}

Sepals free. Petals more or less colerent into a tube, unguiculate. Filaments elongate, surrounding the pistil. Anthers free, bursting longitudinally. Style filiform or setaceous. Stigma minute, bilobed. Berry pulpous or holtow, one- or two-celled. Seed several or many in each cell, turgid or compressed, wingless.

Handsome suffruticose or shrubby climbing plants, extending through the greater part of extratropical Australia. Leaves alternate, herbaceous or subcoriaceous, entire, sometimes partially toothed, never extremely narrow. Flowers generally terminal, solitary, fasciculate or cymose. Petals yellowish or more or less violet or purplish._Cand. Prodr. i. 345 ; Putt. Syn. Pittosp. 27 ; Pronaya, Irueg. Bot. Archiv. 6 ; Endl. Enum. Plant. Hueg. 9 ; Putt. Syn. Pittospor. 26 ; Spiranthera, Hook. in Bot. Nlag. 2523 ; Campylanthera, Hook. Icon. Plant. i. 82.

In this genus we find the flowers of Marianthus combined with the fruit of Sollya. All those species of Billardiera, not indigenous to Victoria, were formerly regarded as belonging to a distinct genus, viz., Pronaya. They comprise B. elegans (Pronaya elegans, Hueg. Bot. Archiv. 6; Campylanthera Frazeri, Hook. Icon. i. 82); B. Huegeliana (Pronaya Huegeliana, Putt. in Lehm. Pl. Preiss. i. 204); B. speciosa (Pronaya speciosa, Endl. in Enum. P1. Hueg. 9); and B. Lehmanniana (Marianthus angustifolius, Putt. in Lehm. Pl. Preiss. i. 200; Pronaya angustifolia, Lehm. Index Sem. Hort. Hamb. 1845, Pl. Preiss. ii. 233).

\section{Sect. I. Encorlocarpus.}

Petals bending together into an almost cylindrical corolla. Style long, setaceous. Berry hollow, without pulp, one-celled.

Billardiera longiflora, Labill. Nov. Holl. Plant. Specim. i. 64, t. 89; Bot. MIag. t. 1507; Putt. Symops. Pitt. i. 29; J. Hook. Fl. Tasm. i. 37; B. ovalis, Lindl. Bot. Reg.t. 1719; B. macrantla, J. Hook. Fl. Tasm. i. 37. 
Leaves-ovate- or lanceolate- or linear-oblong; or ovate, smooth, ciliate; pedicels solitary; petals many times longer than the ovate- or narrow-lanceolate sepals, narrowly oblong-cuneate, hardly recurved towards the summit; stamens many times longer than the calyx; style very long; berry one-celled, hollon, destitute of pulp, generally blue.

On shady rivulets and in damp mountain forests; in Gipps Land, in the Western Port district, towards Cape Otway, in the Grampians, in the Dandenong Ranges, on Mount Macedon and Mount Disappointment, in the Buffalo Ranges, around Mount Buller ascending to subalpine elevations. Conmon throughout Tasmania.

A most beantiful climber, attaining in favorable spots a height of about 20 feet, generally, however, smaller in size. Branches slender, scantily silky in youth, glabrous in ag'e. Leaves herbaceous, chartaceous or subcoriaceous, $\frac{1}{4}-2 \frac{1}{2}$ inches long, 1-8 lines broad, entire, seldom few-toothed or even occasionally quite pinnatifid, tapering into a very short petiole or nearly sessile, oftener blunt than acute, flat or somewhat recurved at the margin, shining above, often paler and opaque beneath, one-nerved, faintly reined. Pedicels terminating the branchlets, slender- or capillary-filiform, $\frac{1}{2}-1 \frac{1}{4}$ inch long; bearing at the base a very caducous linear-subulate membranous ciliolate bracteole of 1-2 lines length. Flowers cernuous or pendulous, without fiagrance. Sepals membranous, $1 \frac{1}{2}-3$ lines long, ciliated, more or less acuminate. Petals, except at their very top or towards their base, glabrous, $\frac{2}{3}-1 \frac{1}{2}$ inch long, tapering gradually into the long unguis, introflexed at the lower margin, lined with several alternately more prominent and faint longitudinal veins, pervaded besides with numerous very tender anastomosing veinlets, ronnded-blunt or somewhat acute or rarely short-acuminate, greenish-yellow, striped with purple or changing considerably into a purplish color, soon after fecundation separating from each other. Filaments linear-setaceous, glabrous, fully as long as the petals or about one-third shorter. Anthers $\frac{3}{4}-1$ line long, affixed above the basal sinus, generally placed more horizontally than those of other species, cordate-oblong, accidentally quite as revolute as in B. elegans. Style capillary, 7-15 lines long, glabrous, sometimes short-exserted, articulated near the base, for a long while persistent. Stigma minute, at last dilated, slightly lobed. Orary glabrous or scantily silky, tapering into a very short occasionally obliterated stipes. Berry smooth, shining, cyan- or pale-blue, rarely, according to observations of Tasmanian botanists, greenish or yellowish, ovate or cylindrical-ovate or rarely verging into a spherical form, bluntly quadrangylar, emarginate or subtruncate at the bottom and top, $\frac{1}{2}-1$ inch long, by the enrly rupture of the septum one-celled, the septum being thereby reduced to a narrow ridge, slightly impressed along the dissepiment, provided with no conspicuous stipes. Pericarp spongr-tleshy, $\frac{1}{2}-1$ line thick, inside white. Seeds generally numerous, reduced to about a dozen in diminutive fruits, darkbrown, shining, about 1 line long, nearly round, slightly compressed and angular, very finely reticulated, not enveloped in any pulp, but loosely filling the carity of the firuit, attached in two rows along each rudimentary septum.

\section{Sect. II. Plerocarpus.}

Petals bending together into an almost bell-shaped corolla. Style short, filiform. Berry filled with pulp, two-celled.

Billardiera scandens, Smith Bot.of Nen Holl. i. 1; Bot. Mag.t. 801; Sweet Fl. Austr. t.54; Turp.Dict. Scienc. Nat. t. 130 ; Reichenb. Mag. der. Atst. Bot. 25; B. Canariensis, Wendl. Hort. Herrenh. iii. t. 15 ; B. mutabilis, Salisb. Parad. Londin. i. t. 48; Bot. IIag. t. 1313; J. Hook. Fl. Tasm. i. 37; B. angustifolia, Cand. Prodr. i. 345; B. grandiflora, Putt. in Endl. Stirp. Nov. Decad.53; B. latifolia, Putt. l.c. 52; B. brachyantha, $F . M I$. in Linnea, xxviii. 5 ro.

Leares orate- or oblong- or linear-lanceolate, or broad-linear, beneath silky-downy or smooth, ciliate; pedicels solitary, rarely $2-4$, fasciculate; petals twice or three times as long as the lanceolate- or linearsubulate sepals, narrowly cuneate- or spathulate-lanceolate, acuminate, considerably recurved towards the 
summit; stamens of about equal or double the length of the calyx; style very short; berry livid, tro-celled; seeds enveloped in pulp; compressed.

On stony or rocky declivities, chiefly amongst scrubs along rivers or in moist forest country; through the southern and eastern parts of the colony, ascending to the Alps; extending through Eastern Australia as far north as Wide Bay, westward seemingly not beyond Mount Gambier; noticed also over the whole territory of Tasmania.

A twining shrub or suffruticose plant, generally a few feet ligh. Branches almost terete, glabrous or more or less densely clothed with soft spreading or silky or velvety downs, seldom smooth from the beginning. Leaves herbaceous, tapering into a very short petiole or nearly sessile, flat or in age along the margin recurved and often undulated, sometimes slightly crenulate, generally perfectly entire, one-nerved, finely and copiously veined, rarely blunt, $\frac{3}{4}-2 \frac{1}{2}$ inches long, $3-8$ lines broad, in age always on the upper page nearly or perfectly glabrous, beneath silky or in various degrees pubescent, or sinooth and then of pale color. Pedicels terminating the branchlets, 2-14 lines long, filiform, smooth or downy, provided at the base with one or two bracteoles, which are linear-subulate, very caducous, 1-3 hines long, membranous and finely downy at the back and at the margin. Sepals membranous, 3-5 lines long, generally outside somewhat silky- or villose-downy, inside smooth, occasionally one or the other reduced to the length of only 2 lines, rarely transformed into spurious leaves, which resemble those of the stem, except in size. Petals connivent in their lower part, soon perfectly free, purple, glabrous except at the apex, narrowly cuneate- or spathulate-lanceolate, streaked along near the middle with three fine longitudinal veins, which are laterally ranified. Filaments setaceous, glabrous, sometimes not longer than the sepals, always considerably shorter than the petals. Anthers pale-yellow, riolet according to Sweet's plate, $\frac{1}{2}-\frac{2}{3}$ line long, cordate-oblong, straight, erect. Pollen-g'rains tetraëdrous-spherical, opening by pores. Style about 1 line long, rarely shorter, glabrous, seldom silky, articulated at or above the base. Stigma dilated, $\frac{1}{2}$ line or less broad, faintly lobed. Ovary sessile, silky, gradually less densely hairy, or from the beginning but laxly downy, or even perfectly glabrous. Berry cylindrical- or spherical- or quadrate-ovate, blunt at the base and apex, in various degrees downy or glabrous, $\frac{1}{2}-1$ inch long, slightly compressed. Seeds horizontally disposed in a close double row thronghout ench cell, brown, ovate- or renate-orbicular, very slightly wrinkled, measuring abont, 1 line in diameter.

B. parviflora (Cand. Prodr. i. 346) represents most probably a small-flowered state of this species.

In flower throughout the jear, but principally during the spring season.

Billardiera cymosa, F. ML. in Transact. of the Victor. Inst. i. 29; Klatt in Linnea, xxriii. 571; B. sericophora, F. M. in Iinncea, xxv. 371; B. versicolor, F. II. in Linnea, xxviii. 571 ; B. pseudo-cymosa, Klatt, l. $c$.

Leaves narrow- or broad-lanceolate, sometimes ovate, rarely orbicular, beneath somewhat downy or silky or smooth, ciliate; pedicels cymose-paniculate or fasciculate, rarely solitary; petals three or sereral times longer than the ovate- or subnlate-lanceolate sepals, acuminate, considerably recurved towards the summit; stamens abont twice as long as the calyx; style very short; berry livid, two-celled; seeds enveloped in pulp.

In the desert on the Murray River and its lower tributaries, otherwise within the precincts of the Colony of Victoria only as yet found on scrubby barren ridges in Baechus Marsh. Not rare in the Colony of South Australia on barren plains or stony or scrubby arid ranges, seattered from Guichen Bay to Venus Bay and to Mount Remarkable, ranging to wide distances inland; frequent in Kangaroo Island.

A shrub, attaining sometimes a height of 12 feet, although it generally occurs of less extensire growth and even sometimes quite dwarf. Stem covered with a brown scarions periphloum. Branches climbing, glabrous or clothed with an either more velvety or more silky indument. Leaves subsessile or short petiolate, chartaceous or more or less herbaceous or coriaceous, oftener smooth than downy, one-nerved, very 
finely veined, $1-3$ inches long, generally from $2-8$ lines exceptionally $1 \frac{1}{2}$ inch broad, entire, paler and opaque beneath. Cymes lateral and terminal solitary or several united into a panicle, sessile or pedunculate. Bracts very soon dropping, 3 lines or less long, linear- or lanceolate-subulate. Pedicels $1 \frac{1}{2}-8$ lines long; as well as the calyx silver-silky or smooth. Bracteoles at the base of the pedicels, linceolate-subulate, 1-1 1 line long, ciliated, fugaceous. Flowers fiagrant. Sepals variable in size, commonly about 2 lines long, in some instances, however, reduced to the length of 1 line, in other cases fully 3 lines long, always ciliated. Petals spathulate, most inconstant as regards their color, either greenish- or pale-yellow, or frequently yellow mixed with shades of purple, pink, green and violet, or prevailingly purplish and violet, spathulate, $6-10$ lines long; with the exception of the very apex glabrous, lined with three longitudinal veins; their claws broad-linear, soon separating, about as long as the lamina. Filaments setaceous, glabrous. Anthers yellow, cordate-ovate, about $\frac{1}{2}$ line long, not recurved. Pollen-grains ellipsoid, bursting longitudinally. Style 1 line or less long, glabrous or silky towards the base, jointed. Ovary silky or glabrous. Berry sessile, oblongovate, turgid, slightly quadrangula:; glabrous or somewhat downy, $\frac{1}{2}-1$ inch long, of sweetish taste, yet not without a slight aridity, seemingly harmless, from purplish fading to a livid color. Seeds numerous, brown, imbedded in pulp, about 1 line long, slightly wrinkled, either considerably compressed or rather turgid, roundish or broad-ovate. The leaves of seedlings are generally deeply incised.

If in comparing this plant with B. scandens the inflorescence is disregarded, it becomes difficult to distinguish some of their varieties from each other. In the disposition of the flowers and in most other characters B. cymosa approaches B. elegans; the sepals of that plant are, lowever, in proportion to the petals larger, the latter are smaller and more lanceolate, and the anthers revolute, not straight.

In flower almost the whole year.

\section{ORDER FRANKENIACEA.}

St. Hilaire, in Mrem. IIus. ii. 122.

Flowers symmetrical. Sepals 4-7, united into a furrowed tube, persistent. Petals free, alternate with the sepals, hypogynous, long-unguiculate, often appendiculate, imbricate-twisted in praflorescence. Stamens 3-10, rarely numerous, free or coherent. Anthers extrorse, two-celled, versatile, bursting lengthwise. Style 2-5-cleft, with stigmatose lobes or capitate stigmas. Orules anatropal. Capsule one-celled, 2-5-valved, many- or few-seeded. Placcntæ parietal. Embryo straight, erect, in the axis of the albumen. Radicle short, inferior.

Suffruticose or herbaceous plants, scattered in a few species over Southern Europe, Northern and Southern Africa, Middle Asia, temperate South-Western America, California and the greater part of Australia. Stems and branches articulated. Leaves opposite, verticillate or fasciculate, rarely alternate, without stipules, vaginate. Flowers generally sessile and pink.-Cand. Prodr. i. 349; Endl. Gen. 913; Iindl. Veg. Kingd. 340.

Frankeniæ are amongst those orders of plants, represented in Australia, nearest allied to Violaceæ; otherwise their relationship is 'still closer with Fouquiracex. Some of the characteristics of the order point to an affinity, with Caryophylleæ. Lucid remarks on their systematic relation are offered by Lindley. If the Indian genus 
Anisadenia is to be admitted into this family, then the ordinal characters have to be greatly altered.

\section{FRANKENIA.}

Iinné, Gen. Plant. 445.-Sea-heath.

Sepals 4-7, connate. Petals appendiculate, long-unguiculate. Stamens double or less than double the number of the petals, coherent towards the base. Style cleft into 2-5 stigmatose lobes. Capsule 2-5-valved. Placentæe towards the base parietal. Seeds numerous or few, ascendent. Embryo somewhat mealy.

Annual or perennial or suffruticose plants of saline inland or litoral tracts, represented in many parts of the warm temperate zone both in the northern and southern hemisphere, ranging as far north as Britain, occurring in Australia also within the tropics. Stems and branches jointed. Leaves small, opposite or verticillate, rarely alternate; the younger ones frequently fasciculate. Flowers generally sessile, solitary, often forming a leafy cyme. Corolla usually pink.-Endl. Gen. 914; Schnizlein Analysen, t. 47 .

The genus Beatsonia has apparently no. claim to be distinguished from Frankenia. Hypericopsis differs solely in stamens exceeding about fourfold the number of the petals.

Frankenia levis, Linné, Spec. Pl.473; F. panciflora, Cand. Prodr. i. 350; Bot. Mlagaz.t. 2896; F. fruticulosa, Cand. Prodr. i. 350; Nees, in Lêhm. Pl. Preiss. i. 249; F. serpillifolia, Lindl. in Ifitch. Trop. Axstr. 305; F. scabra, Lindl. l.c.

Suffruticose, leaves opposite or quaternately-verticillate, at first fasciculate, oblong- or: linear-lanceolate, rarely ovate, recurved or revolute at the margin; sepals generally 5, coherent to near the summit; unguis of petals enclosed; stamens 5 or 6 or rarely 4; style 3-rarely 2-cleft; capsule few-seeded.

On many parts of the Victorian const in saline marshes; for instance, at Port Phillip, Port Albert; more common on salty or sandy depressions along the River Murray and its tributaries. Thence extending across the continent through the desert to near the Gulf of Carpentaria, to Sturt's Creek, and along the western and southern coast of Australia; particularly abundant in the northern part of the Colony of South Australia; not yet found in Tasmania, where it however likely exists. Further distributed orer South Europe, part of Asia, North and Sonth Africa.

A dwarf, wiry plant, attaining the height of 3 feet, producing many erect ascendent or recumbent stems. Branclies terete, covered with short grey down or almost glabrons, thickened at the nodes. Leares on rather short or very short petioles, generally somewhat fleshy, blunt or acute, $1 \frac{1}{2}-6$ lines long, $\frac{1}{2}-2$ lines broad, often ciliate at the base; the floral leaves often very short. Flowers forming a leafy cyme or scattered, resembling those of some silenaceous plants. Pedicels none. Calyx $2 \frac{1}{2}-4$ lines long, cylindrical, consisting of generally 5 rarely $4-6$ linear acute sepals, which whilst flower-bearing are to one-fourth or one-fifth of their length counate, by their inflexed margins channelled, thus forming a fiurowed tube, inside glabrous, in age somewhat more separating from each other. Petals glabrous; their claws as long as the calyx and coherent into a narrow angular tube; their lamina white or more frequently pink, $1 \frac{1}{2}-2 \frac{1}{2}$ lines long, obovate- or truncate-cuneate, entire or crenulate in front, veined, tapering gradually into the unguis; appendage situated at the confluence of the lamina and claw, oblong- or narrow-linear, short, entire. Stamens 5-6, glabrous, little shorter than the petals, as far as enclosed within the trube of the corolla like the latter coherent into a filiform tube; the free parts of the filaments pink or pale, capillary, very tender, of unequal length, 1 line or less long, their connate part towards the base winged by a very tender membrane. Anthers dorsifixed, about $\frac{1}{2}$ line long, formed by two narrow-ellipsoid longitudinally bursting parallel cells, red in youth. Pollen-grains yellow, ellipsoid, bursting lengthwise. Style capillary, hardly longer than the stamens, glabrous, cleft to 
about one-half or one-third of its length into 3 rarely 2 exceedingly narrow bluntish stigmatose lobes, which are upwards slightly dilated. Capsule about $1 \frac{1}{2}$ line long, glabrous. Valves 3 rarely 2, parchmentous, linear-lanceolate, bearing the placental ridge along their middle. Funicles setaceous, brown, crowded in the lower part of each valve, erect, slightly twisted, nearly half or one-third as long as the capsule. Seeds narrow-ellipsoid, brown or livid, smooth, about $\frac{1}{2}$ line long, with a longitudinal furrow. Cotyledons planeconvex, elliptical, about three times as long as the very short cylindrical radicle.

From near the locality where Labillardière collected his F. tetrapetala a plant occurs in our collection, benring great resemblance to it in figure, and producing promiscuously flowers with 4 and 5 petals and sepals, but a 2-or 3-cleft style. Neither the coalescence of the sepals is, however, at least during the anthesis, as inperfect as described and illustrated in Labill. Nov. Holl. Plant. Specim. i. 88, t. 114, nor even the style undivided. It seems doubtful whether these notes, pointed out by Labillardière, were not accidental or based on imperfect observation. South African specimens of F. 1ævis, communicated by Sonder, agree sufficiently with certain forms of the Australian plant. It is not within the scope of this work to settle the synonymy of this genus; yet the autlior's persuasion may be expressed, that many of the described Frankeniæ are referable to $\mathrm{F}$. lævis.

\section{IV.-DAPINDINA.}

Flowers often insymmetrical. Stamens definite, very rarely indefinite. Ovary compound. Ovules frequently anatropal. Placentæ axil. Seeds exalbuminous, definite, seldom albuminous or indefinite. Embryo rarely straight.

\section{ORDER SAPINDACEA.}

Juss. Gen. 246.

Flowers insymmetrical. Sepals generally 5 , free or all or only partially connate, imbricate in æstivation. Petals free, hypogynous, often inserted on a hypogynous disk, alternate with the petals; imbricate in præflorescence, not rarely all or one wanting. Stamens generally double, sometimes equal, very rarely fourfold in number to the petals or seldom indefinite, free or connate at the base. Anthers introrse, twocelled, bursting longitudinally. Styles 1 or more and coherent into one. Stigmas 1-4, rarely more. Ovary 2-4- rarely 5-7-celled. Ovules anatropal, generally 1 , less frequently 2 or 3, rarely several in each cell. Cells of the capsule bursting with loculicidal or septicidal dehiscence, or separating into more or less free bivalvate or indehiscent carpels. Albumen none. Embryo curved, plicate, coiled or spiral, rarely straight.

Trees or shrubs, rarely suffruticose or herbaceous plants, sometimes climbing and provided with tendrils, numerous within or near the tropics, also rather copiously dispersed through extratropical Australia, represented almost exclusively by $\mathbb{E}$ sculeæ and Hippocastaneæ in the temperate zone of the northern hemisphere. Leaves simple 
or compound, alternate, rarely opposite, sometimes marked with pellucid lines or dots. Stipules usually wanting. Flowers hermaphrodite or oftener polygamous or diœcious; their disposition various. Petals frequently unguiculate, sometimes provided with a basal appendage, generally white or pink. Disk sometimes glandulous. Fruit-cells predominantly ternary. Seeds not rarely arillate.-Endl. Gen. 1066; Lindl. Veg. Kringd. 382.

In the systematical arrangement Sapindaceæ are touching on Malpighiacex; nor are the lines of demarkation easily drawn between both. Some resemble Meliacex and Anacardiex in habit. Of the numerous noble arborescent Sapindacex, which impart to the humid jungles of Eastern Australia quite an Indian aspect, and which comprise species of Erioglossum, Schmiedelia, Aryteria, Cupania, Harpulia, Atalaya and other genera, none seem to find in Victoria a climate sufficiently genial for their development, unless the almost unexplored eastern tracts of Gipps Land should harbor yet some of these magnificent trees.

\section{DODONAE.}

\section{Linné, Gen. Plant. 855.}

Flowers polygamous or diœcious. Sepals 3-6, almost equal, free or somewhat coherent. Petals none. Disk hardly developed. Stamens double the number of the sepals. Filaments generally short. Anthers two-celled, basifixed. Styles twisted into one, which is long, filiform and deciduous, separating into stigmatose lobes at the apex. Ovary central, sessile or short stipitate. Ovules two in each cell. Capsule membranous or nearly crustaceous, 2-6-valved.' Valves separating from the persistent column. Seeds oblique-sublenticular, exarillate, attached to the middle of the internal angle of the cell. Embryo circinate.

Evergreen often viscid shrubs, rarely small trees, rather copiously to be found in all parts of the Australian continent, scattered in but few species over other tropical and subtropical countries, extending soutliward to New Zealand and Tasmania and northward to China and Florida. Leares subcoriaceous or chartaceous, alternate, simple or pinnate, as well as the leafiets entire or toothed. Flowers small, axillary and terminal, solitary or racemose or corymbose or paniculate or subumbellate. Capsule generally scariously winged. Valves navicular. Column almost constantly winged by the persistent part of the dissepiment. Seeds small, often surrounded by a very tender brittle and perishable pellicle.-Endl. Gen. Plant. 1073; Gray \& Sprague, Gen. Flor. Amer. Bor. Orient. 182.

The genus Distichostemon (Dodonæa hispidula, Endl. Atackt. xxx.) of tropical Australia approaches in its relationship very closely to Dodonæa, from which, at least as a subgenus, the numerous stamens, disposed in two or more rows, distinguish it, although this number of stamens remains normally still double that of the sepals. Habitually it differs considerably in its almost herbaceous leaves and its foliaceous fruit-wings. In respect to the texture of the leaves, Diplopeltis, an allied exclusively Western Australian genus, comes nearer to Distichostemon than to Dodonea, differing from both by producing petals and a conspicuous dimidiate disk, by long and declinate filaments and versatile anthers. The capsule of Diplopeltis Huegelii, which species seems to be the only one of the genus, is glandulous-hairy like that of Dodonæa humilis. 
The genus Dodonæa exhibits, in the permanent marginal coherence of the septa with either column or valves or both, such modifications as are not usually to be found in genera with a similarly constructed fruit. In the majority of the species the navicular valves separate from the septa, to the margin of which they are with their edgeis originally adnate; the dissepiment thus remains standing, forming wings to the column; in these instances it neither separates into plates. The species amongst those, of which the ripe fruits are contained in our collection, responding to the above character are:D. viscosa, $L_{.}$; D. lobulata, $F . M$.; D. cuneata, Rudge; D. triquetra, Wendl.; D. triangularis, Lindl.; D. ceratocarpa, Endl.; D. deflexa, $H . M$. ; D. acerosa, Lindl.; D. pinifolia, Miq.; D. hexandra, $H . M$.; D. hirtella, Miq.; D. vestita, Hook.; D. humilis, Endl.; D. oxyptera, $F$. MI; D. stenozyga, $F$. M.; D. adenophora, MIiq.; D. foliolosa, $F$. $M I$. (D. multijuga, $F$. ML., Fragm. Phyt. Aust. i. 219, non Don); D. polyzyga, $F . M$. ; and D. leptozyga, $F . M$.

In ferwer instances the septa separate from the column, and remain permanently connate at their margin with the valves, separate with truly septicidal deliscence into two plates, forming thereby the axillary part of carpels, which at first cohere and afterwards secede, carrying when falling with them the seed, which finally escape through the fissure along the axillary edge of the carpels. The columna and funicles in this instance alone remain standing. D. bursarifolia, $B . \& M$., and seemingly also D. platyptera, $F . M$., and D. stenophylla, $F$. $M$., belong to this series. In a third modification of the opening of the fruit, which has been only observed in D. physocarpa, the septa seem to separate neither distinctly from the valves nor from the column; the membranous valves, it appears, remain persistent, the seeds being shed by irregular ruptures of the tender valves.

Dodonæa viscosa, Linné, Suppl. 218; J. Hook. Fl. N. Zeal. i. 38; Fl. Tasm. i. 55; D. asplenifolia, Rudge in Transact. Linn. Soc. xi. 296, t. 20; D. oblongifolia, Link, Enuen. i. 381; Bot. Reg. 1051; D. attenuata, A.Cunn. in Field's Non South Wales, 353; Bot. IIag. 2860; D. conferta, Don, Gen. Syst. Dichlam. Plants, i. 674; Schlcchten. Lixncea, 1852, 655; D. umbellata, Don, l.c.; D. Kingii, Don, l. c.; D. longipes, Don, l. c.; D. Preissiana, Miq. in Lehm. Pl. Prciss. i. 226; F. M. Fragm. Phytogr. Austr. i. 72.

Viscid; leaves subchartaceous, lanceolate or ovate- or linear- or spathulate-lanceolate or oblong- or ovate-cuneate, entire or repand or remotely or obscurely denticulated, rarely pinnate with linear-lanceolate almost entire or incised rachis and few or many lanceolate flat leaflets; flowcrs racemose, corymbose or paniculatc, mostly diœcious; sepals generally 4, lanceolate or lanceolate-ovate, about as long as the ovate-oblong anthers; filaments very short; style not much elongated; capsule generally three-valved; valves winged from the sunmit to the base, separating from the septa; wings rounded-blunt on both cxtremities, about as broad as the valves; dissepiments persistent with the columna, dimidiate-ovate or dimidiate-lanceolate; seeds generally opaque, gradually compressed towards the margin; cotyledons considerably longer than the radicle.

On rocky scrubby places, particularly on the banks of watercourses, also on stony or sandy localities on ranges and in the desert; very widely and copiously distributed through Victoria and most other parts of extratropical Australia, restricted in tropical Australia to the eastern tracts; inhabiting also parts of India, Africa, America and the Pacific islands, never advancing to cold regions, yet occurring far south in Tasmania and New Zealand.

A plant variable in the same degree as it accommodates itself to varied localities and climatic influences, sometimes forming a large erect shrub or diminutive tree, attaining a lieight of 16 feet, sometimes in very exposed localities remaining of depressed growth, exuding in all parts, particularly in youth, a more or less copious viscidity, which imparts to the plant a varnished appearance. Branchlets straight, flexuose or crooked, faintly or distinctly angular particularly towards the summit, cylindrical in their lower portion, occasionally slightly downy. Leaves assuming forms of remarkable discrepancy, tapering gradually to the 
base, acuminate, acute or rounded-blunt or truncate or emarginate at the apex, flat or recurved at the margin, $\frac{1}{2}-6$ inches long, $\frac{1}{8}-1 \frac{1}{4}$ inch broad, one-nerved, faintly or prominently veined, the primary veins being almost parallel-divergent from the midrib, glabrous, seldom in a young state downy, more or less distinctly dotted, in rare instances pinnate; the rachis then sometimes similar to the ordinary state of the leaf, the leaflets $\frac{1}{2}-1$ inch long, acute, flat, few or numerous, alternate or opposite. Inflorescence terminating the branchlets, consisting of few or many flowers, short-pedunculate. Pedicels capillary-filiform, when flower-bearing 1 or a few lines long, when fruit-bearing often extending to several lines, provided at or near the base with a short linear deciduous bracteole. Sepals about 1 line long, lanceolate-ovate or lanceolate, rather acute, very slightly downy, viscid, deciduous. Anthers somewhat tetragonous, yellow or reddish-purple, minutely apiculate, glabrous or very slightly bearded at the apex. Pollen-grains globose-ovate, bursting lengthwise. Styles 3 , united into one, which is setaceous, yellowish or brownish-red, $\frac{1}{2}-4$ lines long; the acute apex free, or occasionally the styles deeply separating: Size of fruit subject to considerable variations, measuring, inclusive of the wings, from 4-8 hines across, and almost as much in length. Valves thin-crustaceous or chartaceous, with semiorbicular sides; their edges meeting the margin of the septa. Wings scarious, veined, yellowish or purplish, somewhat narrower towards the base than towards the apex, occasionally nearly twice as broad as the valves. Seeds affixed like in the congeners to very short funicles at the middle of the internal angle of the cell, 1-1 $\frac{1}{2}$ line long, smooth, roundish or lenticular-ovate, opaque, sometimes quite shining, rather turgid, somewhat acute at the edge. Hilum conspicuous, fulvous. Testa subcoriaceous. Endopleura membranous. Embryo cream-colored, coiled up in many windings, circinate. The radicle cylindrical, thickened gradually towards the blunt extremity; the cotyledons about twice as long as the radicle, flat, linear, narrower towards the apex.

The greater part of the described extra-Australian species may be referable to this plant. D. triquetra differs in being. hardly resinous-viscid, having hence its leaves opaque, in more decidedly compressed branchlets, in generally longer pedicels, in male flowers with remarkably short sepals and long anthers, in a very elongate style, in wings hardly as broad as the valves and in always very shining seeds, surrounded by a very tender brittle diaphanous pellicle.

D. cuneata seems only a variety of $\mathrm{D}$. viscosa, characterized by wedge-shaped leaves.

D. lobulata, which extends from Lake Torrens to the Gardiner Ranges in Western Australia, may only be a state of $\mathrm{D}$. viscosa, inclined to produce leaflets, which however are reduced to mere minute teeth; the flowers, however, of this plant are as yet undiscovered.

Beautiful pinnate-leaved specimens of D. viscosa were collected by Dr. Beckler in the warm damp forest valleys of the Hastings River; in this curious rariety, which may be designated megazyga, the valves of the firuit remain small, and the seeds almost constantly undeveloped, whilst the folinge so remarkably luxuriates. To Mr. Woolls we owe a specimen of D. viscosa, found at Parramatta, which exhibits on the same branchlets simple and pinnate leaves and their intermediate forms.

The stout D. Burmanniana is evidently only another state of the polymorphous D. viscosa, being a progeny of the tropical zone, with more vigorously developed almost coriaceous leaves, which are strongly spreading-reined, and with predoninantly hermaphrodite flowers. This variety retains its characters in cultivation. It occurs in forms perfectly analogous to those of India in lumid localities of the warm eastern tracts of Australia.

Dodonæa procumbens, Tr. Mr. in I'ransact. Phil. Soc. Vict. i. 8.

Dwarf, diffiuse or procumbent, hardly viscid ; leaves subchartaceous, cuneate, fiat, generally with a few coarse acute teetl at the apex; pedicels rather short, erect, terninal; those of the female flowers solitary, occasionally geminate or ternate; flowers diocious; sepals generally 5 , lanceolate, about as long as the ovate-oblong anthers; filaments very short; style much elongated; "capsules wingless, 2- or 3-valred; somewhat longer than broad, dissepiments dimidiate lanceolate. 
In subsaline and boggy plains at the base of Mount Sturgeon and Mount Abrupt, also on stony barren ranges near the Snowy River, in the Maneroo district.

A little shrub, as far as known, not exceeding 2 feet in size, generally much smaller. Branches blackbrown, often rooting. Branchlets slender, finely downy. Leaves $\frac{1}{2}-1$ inch long, above the middle $2-4$ lines broad, one-nerved, seldom entire. Pedicels 2-4 lines long, upwards thickened. Sepals 5, rarely 4, often unequal in size, broad- or narrow- or linear-lanceolate, 1-1 $\frac{1}{2}$ line long; sometimes acute, sometimes blunt. Stamens generally 10, at times 8 or 9 . Anthers measuring about 1 line, yellowish, minutely and sharply pointed. Style red, twisted, setaceous, frequently measuring fully 1 inch in length, occasionally shorter, dividing into its two or three constituent parts at the stigmatose apex, deciduous. Capsules 5-7 lines long, seen only in an immature state, chartaceous.

D. procumbens is brought by some of its characters, for instance, the elongated style, the absence of viscidity, next to D. triquetra (Wendl. Bot. Beob. 44), an exclusively Eastern Australian species of tall growth, of which, according to diagnosis, D. laurina (Sieb. in Spreng. Syst. Veg. App. 152) seems a variety. The main differences which distinguish $\mathrm{D}$. triquetra from $\mathrm{D}$. procumbens, are its habit, its large entire lanceolate leaves, its paniculate nale flowers with very small sepals and with long and narrow anthers, and its winged capsule.

Dodonæa deflexa, F. M. in Transact. Phit. Soc. Vict. i. 8.

Somewhat viscid; leaves subcoriaceous, small, roundish or almost ovate, undulate-repand or remotely denticulated, truneate or rounded-blunt at the apex; pedicels short, axillary, solitary or twin, deflexed; flowers dicecious; sepals $4-5$, ovate or roundish, about as long as the oblong-linear anthers; filaments very short; style slightly elongated; capsules small, broader than long, 4-5-valved; valves keeled by a narrow often truncate ring at the back, wingless at the base and apex, seceding from the septa; dissepiments almost semiorbicular.

In the Murray scrub. Beyond the Colony of Victoria found at the Flinders Ranges, Spencer's Gulf and Venus Bay; obtained from the latter locality through Major Warburton.

A dwarf shrub, with spreading branches. Branchlets somewhat downy. Leaves 3-5 lines long, provided with a very short petiole, hardly paler beneath, one-nerved, faintly veined. Pedicels measuring 1-3 lines, with a very minute and narrow bracteole at the base. Sepals about 1 line long or not much longer, shightly downy, tardily dropping. Anthers minutely apiculate. Style a few lines long. Capsule thin-crustaceous, $2-2 \frac{1}{2}$ lines long. Wing somewhat or much narrower than the valves, occasionally dilated upwards.

D. Baneri (Endl. in Hueg. Enum. 13) seems, according to diagnosis, closely allied to this species.

Dodonæa bursarifolia, Behr and IIuell. in Transact. Phil. Soc. Vict. i. 8.

Glabrous, scarcely viscid; leaves coriaceons, small, flat, almost opaque, obovate-cuneate, entire or indistinctly repand, rounded-blunt at the apex, rarely emarginate or apiculate; their veins indistinct; pedicels short, axillary and terminal, solitary, twin or ternate, erect or' spreading; flowers diœcious; sepals 4-5, lanceolate or linear-lanceolate, shorter than the oblong-linear yellowish-white anthers; filaments very short; style somewhat elongated; capsule wingless or very narrowly keeled, chartaceous, 3-4-valved; dissepiments permanently attachcd to the ralves, dimidiate-lanceolate, separating in two plates; columna wingless, filiform, downy; seeds shining, surrounded by a pellicle, gradually compressed towards the margin ; cotyledons nearly twice as long as the radicle.

In the Niurray desert; further known from barren ridges and dry scrubby plains near St. Vincent's Gulf.

A shrub, but few feet high, with spreading branches. Branchlets scarcely angular, glabrous. Leaves 4-10 lines long, 2-4 lines broad, one-nerved. Peduncles very short or obliterated. Pedicels 2 lines long or shorter, thin-filiform. Sepals not much or considerably shorter than the stamens. Anthers not much longer 
than 1 line, with a minute point, of a much paler color than in most other Dodonæa. Styles 3-4 united in to one, viscidulous, about $\frac{1}{2}$ inch long, twisted, free at their acute apex. Capsule inconsiderably longer than broad, 3-4 lines long, subcoriaceous or chartaceous, not so brittle or scarious as in many congeners, remarkable for not throwing the valves off from the septa, but the former, when dropping, carrying the latter and the seeds with them, leaving merely the columna and funicles persistent. Seeds measuring about 1 line, oblique-lenticular, at first brown, at last black, covered with a wrinkled pellicle, often retained in the falling cells of the capsule, inasmuch as the two plates of the dissepiment belonging to each carpel are not generally bursting with a wide fissure along their axil suture.

The species nearest to this seems to be D. trigona (Lindl. in Mitch. Trop. Austr. 236). D. Lindleyana (D. triangularis, Lindl. in Mitch. Trop. Austr. 219; D. mollis, Lindl. 1. c. 212) differs in narrower anthers and in the frnit, which is otherwise very similar, having the septa persistent with the column.

Plate V. 1, male flower; 2, stamen; 3, transverse section of an anther ; 4, pollen-grains; 5 , female Hower; 6 , capsule, seen from above; 7 , separate carpels; 8 , transverse section of fruit; 9 , vertical section of a part of fruit; 10, seed; 11 and 12, sections of seed: all figures more or less magnified.

Dodonæa stenozyga, F. MI. Fragm. Plyt. Austr. i. 98.

Glabrous, slightly viscid; leaves pinnate, rarely a few simple; raehis narron-semiterete, wingless, cliannelled; Teaflets emanating towards the summit of the rachis, few, rarely several, alternate and opposite, remote, short, linear, entire, blunt, concave above, convex beneath; pedicels of the female flowers axillar, solitary, geminate or ternate, about as long as the fruit; sepals oblong-lanceolate; style short; capsule short-stipitate, 4-5-valved; valves seceding from the septa; wings blunt on both extremities, winged from the summit to the base, upwards dilated and broader than the valves; septa dimidiate-ovate; seeds opaque, gradually compressed towards the margin; cotyledons somewhat longer than the radicle.

In the desert near the confluence of the Loddon with the Minuray River. J. Dallachy.

A compact shrub, a few or several feet high, with numerous branches and slender branchlets. Rachis measuring $\frac{1}{2}-1$ inch in length, and less than 1 line or generally only about $\frac{1}{2}$ line in width; its lower part without leaflets, forming a long spurious petiole. Terminal leaflet in most cases diminutive or undeveloped; lateral leaflets either forming a single pair at the apex of the rachis, thus giving to the whole leaf a furcate form, or few or several, never more than about a dozen in number, rather distantly disposed along a machis, in width and consistence similar to the latter, but generally less distinctly channelled, sometimes nearly fat, mostly from 3-9 lines long. Flowers seemingly diœcious; male ones unknown; peduncle of the female ones either very short or wanting; pedicels generally very spreading or deflexed, $\frac{1}{4}-\frac{1}{2}$ inch long, slender-filiform, gradually thickened towards the apex. Sepals slightly dominy, about 1 line long, early dropping. Style $1_{\frac{1}{2}-2}$ lines long, dark-red, filiform. Stipes of fruit always eridently developed, sometimes in smaller fruits only about $\frac{1}{2}$ line long, sometimes in larger fruits even somewhat more than 1 line long, cylindrical, scarcely thicker than the summit of the pedicel, from which it is separated by articulation. Consistence of the capsule that of D. riscosa. Valves 3-6 lines long, with semicircular sides, shining. Wings scarious, often purplish, according to the size of the fruit 1-2 lines broad towards the summit. Seeds hardly 1 line long, rendered by the firmly adnate pellicle opaque, after the removal of which the perfect splendor of the testa becomes ensily perceptible. Einbryo alike to that of $\mathrm{D}$. viscosa.

It is more than probable that this curious plant will prove merely a pinnate-leaved variety of $\mathrm{D}$. acerosa (Lindl. in Mitch. Trop. Anstr. 273; D. filifolia, Hook. 1. c. 241), a question which, however, cannot be set at rest, until the male flowers are available for comparison. D. tenuifolia (Lindl, in Mitch. Trop. Austr. i. 248) is, according to the brief diagnosis, near to our plant if not identical with it. D. adenophora (Miq. in Lehm. Pl. Preiss. ii. 235; 'Thoninia adenophora, Miq. l. c. i. 224) differs, as far as the material within our reach admits judging of, in having, the rachis with regularly opposite and closely approximated leaflets foliate to near the base and in shining seeds. 
Dodonzea hirtella, Miq. in Linncea, xviii. 94.

Downy or almost glabrous, viscid; leaves pinnate; rachis nith dilated joints, producing leaflets to near the base; leaflcts opposite in 3-7 pairs, oblique cuneate- or 1.homboid-ovate, subcoriaceous, toothed from above the middle or at the apex, dotted, hardly recurved at the margin; pedicels of the female tlowers axillary and terminal, solitary, binate or ternate; flowers diccious; sepals ovate or lanceolate, acuminate; style slightly elongate; capsule generally four-valved; valves seceding from the septa, winged from the summit to the base; wings blunt on both extremities, about as broad as the valves; septa dimidiate-orbicular; seeds opaque, very turgid towards the centre, suddenly compressed towards the margin; cotyledons not much longer than the radicle.

On granite rocks of the hills and mountains between the Goulburn and Ovens Rivers. Found also on various granite ranges of New South Wales, as far north as the Maranoa River, where it was noticed by Sir Thos. Mitchell.

A shrub generally of dense growth, varying in height from 2-5 feet, pervaded with strong somewhat balsamic odor, densely foliate. Branchlets almost cylindirical, more densely covered with short grey soft spreading downs, than the leaves, occasionally almost smooth. Leaves, with addition of the short petiolar base of the rachis, 1-2 inches long. Rachis either only about 1 line broad, and thus but slightly dilated along the interstices from leaflets to leaflets, or conspicuously widened, about 2 lines broad, the petiolar base becoming then cuneate; in rare instances confluent with the leaflets into an undivided wedge-shaped or irregularly few-lobed upwards dilated leaf, such leaves being mixed with normally pinnate ones. The apex of the rachis in most cases free of a terminal leaflet, protruding to the length of 1 or 2 lines beyond the uppermost pair of leaftets, or expanding occasionally into a rhomboid or wedge-shaped terminal leaflet, which often exceeds the rest in size. Lateral leaflets sessile, 2-6 lines long, always entire towards the base, generally deeply and bluntly toothed in front or to about the middle downward, seldom almost perfectly entire, sparingly downy or not hairy, slightly viscous or exuding so much clammy substance from their pores, which are particularly conspicuous beneath, as if they were varnished. Distribution of male flowers not yet ascertained. Pedicels of the female flowers either united on a short peduncle, or deprived of the latter, 2-8 lines long, slender-filiform, thickened gradually towards the summit, spreading-downy, provided at the base with a short green canaliculate-linear deciduous bracteole. Sepals generally 4 , about $1_{\frac{1}{2}}$ line long, membranous, somewhat downy, deciduous. Styles contorted into one, about 4 lines long, soon falling, at the stigmatose apex separated. Capsules membranous, sparingly downy, measuring, with the addition of the wings, 4-6 lines. Wings about 1 line broad, very tender. Seeds brownish-black, measuring about 1 line across. Cotyledons oblique-hnear, gradually pointed, coiled up, centripetal, as broad as and hardly one-third longer than the cylindrical centrifugal radicle. The embryo in none of the seeds, examined on this occasion, was well developed; hence the singular form of the seeds may to some extent depend on this circumstance.

The relative characters of D. pinnata (Smith in Rees' Cycl. 7), D. Caleyana (Don, Gen. Syst. i. 674) and D. multijuga (Don, 1. c.) remain to be further traced. D. boronifolia (Don, Gen. Syst. i. 674), as far as it can be recognized from description, seems not to differ from $D$. hirtella.

In the desert on the Lower Murray, on Spencer's Gulf and in various parts of Soutli-Western Australia, occurs the D. humilis (Endl. Nov. Stirp. Decad. 33, Atakta tab. 31), a species not felicitously named, since it attains in favorable places a height of many feet. It will most likely be found yet in the north-western part of the Victorian telritory, and may at once be recognized by its wingless capsule covered with very short gland-bearing bristles, by conspicuous filaments and by anthers terminated by stipitate glands.

In reference to the fecundation of Dodonææ, the singular circumstance may be adduced, that the strictly female plants of $\mathrm{D}$. hexandra, cultivated in the Botanic Garden at Melbourne, whilst male plants of this species are wanting, still produce fertile seeds, from which the genuine species, not hybrid productions, are raised. 


\section{HETERODENDRON.}

Desfont. in Mémoir. du Muséum d'Hist. Natur. iv. 8, t. 3.

Flowers bisexual. Calyx persistent, irregularly short-toothed or truncate, bursting on one side. Petals wanting. Stamens 6-15, indefinite, forming one row. Filaments short, inserted on the surface of a small adnate circular hardly crenulate disk. Anthers basifixed, two-celled, bursting lengthwise. Styles very short, connate into one. Stigmas minute, truncate. Ovary 2-4-celled, supported by a very short gynophor. Ovules solitary at the base of each cell. Capsule somewhat woody or thickcrustaceous, consisting of 2-4 at their inner angle connate valveless irregularly bursting often only partially developed carpels. Seeds exalbuminous, turgid. Avillus large, fleshy. Testa thin-crustaceous. Cotyledons thick, flexuose. Radicle short, pointed.

Shrubs or small trees inhabiting tropical eastern and extratropical Australia, bearing habitually resemblance to Stylobasium and Cneorum. Leaves chartaceous or thin-coriaceous, alternate or fasciculate, simple, quite entire or partially few- and sharp-toothed, finely penninerved. Flowers axillary and terminal, collected into panicles, racemes or cormybs, rarely solitary. Capsule smooth, wingless, with roundish cells. Seeds shining. Arillus bright-red.-Lam. Encycl. t. 959; Kunth in Annal. Scienc. Natur. ii. 365 ; Webb in Hook. Lond. Journ. of Bot. i. 255; F. MI. in Hook. Kew. Nrisc. ix. 197.

The generic character of the embryo has been solely obtained from $\mathrm{H}$. diversifolium.

Desfontaines, in discussing the affinity of Heterodendron, compared it to Cneorum and Stylobasium. Candolle (Prodr. ii. 92) and Endlicher (Gen. 1141) adopt this view. Webb, when establishing for Cneorum a separate order, removed it from Cneoreæ. Planchon (in Mitch. Trop. Austr. p. 398) places it judiciously amongst Sapindaceæ. Its affinity to Spanoghea (an Indian and East Australian genus) is close in the extreme, the discriminating generic character's of the latter being reduced to a calyx with fewer and larger teeth and to pinnate leaves.

Stylobasium, a phytolaccaceous genus, referred to Chrysobalaneæ by previous observers, is more in aspect than in similarity of structure allied to Heterodendron. It is neither an East Australian genus, the typical species, Stylobasium spathulatum, occurring towards Sharks Bay, according to Mr. Oldfield's observations, and unquestionably was found in Baudin's Expedition on the "Baie des Chiens marins," where many plants occur, which like Stylobasium spathulatum are found also on the Murchison River. Turpin's drawing (in Mém. du Muséum, v. t. 2) represents the carpel in figs. 6 and 9 two-seeded. Stylobasium lineare (Macrostigma Australe, Hook. Icon. 412), which extends to near Sharks Bay, shows a one-seeded carpel, although the ovary according to Hooker is biovulate. The fruit is dry, crustaceous and wrinkled. The seed is affixed to the base of the cell; the testa membranous, and the albumen, if not entirely absent, is but scantily developed, as far as could be ascertained from seeds in a shrivelled state. The embryo is arcuate, with an inferior radicle, which is about half as long as the almost flat cuneate-ovate cotyledons; the latter face with their sides the radicle, not with their edge. The external resemblance of Stylobasium to Gyrostemonoid genera is striking, with which the plant participates also in glaucescence.

Ireterodendron oleifolium, Desfont. in MLémoir. du ILus. d'Hist. Nat. iv. 8, t. 3; F. M. Report on Babbage's Plants, $p$. 7 .

Leaves narrow- or lanceolate-oblong, or linear-lanceolate, always entire; ovary generally four-celled; earpels very turgid, nearly globose, normally quaternate. 
In the Mallee scrub on the Rivers Murray, Wimmera and Avoca, particularly in the limestone formation. Thence to the Rivers Darling, Maacquarie and Burdekin, and their desert tributaries, as far north as latitude $19^{\circ} \mathrm{S}$; ; also in the vicinity of Lake Torrens and the Flinders Ranges, and in the north-western parts of the Colony of South Australia, from whence probably it extends through the whole subtropical zone westward, having been found by Mrr. A. Oldfield on the Mrurchison River in Western Australia, consociated with Nitraria, Eremophila maculata, E. longifolia, and other of its eastern companions.

A shrub, generally of tall growth, sometimes forming a small tree, covered, at least in youth, densely with exceedingly short downs, which impart an ashy color to the plant. Branches terete. Leares 2-4 inches long, 2-6 lines broad, seldom broader, thin-coriaceous or chartaceous, more fiequently acute than blunt, flat, tapering into a short petiole, with a strong midrib, with numerous very divergent lateral nerves and more or less conspicuous veins. Peduncles generally few-flowered, sometimes only one-flowered, about I inch long or shorter or obliterated, filiform, mostly axillary, solitary, geminate or ternate, constituting, by the fall of the leaves, often a compound raceme, or crowded into a panicle. Pedicels a few lines to $\frac{1}{2}$ inch long, thickened gradually towards the apex, articulated with generally short secondary peduncles, bearing two very minute bracteoles at the joint. Calyx patellar or cup-shaped, 1-2 lines long; about twice as broad, outside and inside downy; its teeth of uncertain number, very short, triangular, minutely pointed, often confluent or obliterated. Filaments 6-15, short, filiform, glabrous. Anthers yellow, linear-oblong, somewhat four-sided, $\frac{3}{4}-1 \frac{1}{4}$ line long, blunt at the base and apex. Pollen-grains ellipsoid, bursting lengthwise. Ovary short-stipitate, white-velvety. Style very short or obliterated. Capsule woody-coriaceous, with smooth almost spherical carpels, measuring 3-4 lines, which are lined with a very faint dorsal impression, seldom all advancing to maturity, suddenly attenuated at the base into the stipes of the fiuit, which is about 1 line long. Seeds ovate-globose, obtusangular, affixed towards the base at the internal side of the cell, erect, not seen as yet in a perfectly developed state. Arillus dark-scarlet, Heshy, closely enveloping the inner side and the base of the seed, below which it is considerably extended.

H. diversifolium (F. MI. Fragm. Phytogr. Austr. i. 46), the only other known species, may be easily recognized by its partially toothed leaves, two-celled ovary, more or less compressed carpels, which are broader than long.

\section{ORDER MALPIGHIACE $A$. \\ Juss. Gen. Plant. 252.}

Sepals 5, often gland-bearing, quincuncial rarely valvate in præflorescence. Petals 5, equal, almost constantly long-unguiculate, generally convolute in rstivation. Stamens frequently twice the number of the petals, often connate towards the base, sometimes partially sterile. Anthers two-celled, bursting lengthwise. Styles free or connate. Ovaries generally 3 , rarely 2 , 4 or 5 , one-celled, uniovulate, connate or rarely free. Fruit generally consisting of three drupaceous, nucamentaceous or crustaceous frequently winged or cristate free or connate indehiscent carpels, rarely simple. Seed suspended on a funicle, without albumen. Cotyledons straight or variously curved or folded. Radicle short, superior.

Trees or shrubs, the latter sometimes of climbing growth, with very few exceptions restricted to the tropical and subtropical zone, much more numerous in the western than in the eastern hemisphere, rare in Australia. Indument, if present, formed by duplicate hair. Leaves often stipulate, opposite, rarely whorled or scattered, always 
simple, seldom toothed or lobed, with frequently gland-bearing petioles. Flowers hermaphrodite or rarely polygamous; their disposition various. Petals yellow or red, sometimes white, hardly ever blue.-Adr. de Juss. in Endl. Gen. 1057; Monograph. des Malpigh. 1843; Archiv. du IIuséum d'Hist. Natur. iii. 255, 614, t. i.-xxiii.

No infallible characteristic separates Malpighiaceæ from Sapindaceæ, although by collective notes the disquisition of the plants belonging to either order is readily effected. The Australian Malpighiacex hitherto known are besides Nitraria only a Ryssopterys, detected by Mr. Thozet near Rockhampton, Cadellia pentastylis (F. MI. Fragm. Phyt. Austr. ii. 26, t. xii.) from New England, and Tristellateia Australasica (A. Rich. Voy. d'Astrolab. ii. 38, t. 15) from North-Eastern Australia.

NITRARIA.

Linné, Gener. Plant. 602.

Calyx 5-rarely 6-cleft, persistent, glandless. Petals 5 or rarely 6 , hypogynous, alternate with the divisions of the calyx, inflexed at the margin and apex, tapering to the base, implicate-valvate in æstivation, deciduous. Stamens threefold the number of the petals. Filanents free, linear-subulate. Anthers two-celled, with introrse longitudinal dehiscence. Style short, thick. Stigmas 2-6, minute. Ovary 2-6-celled. Ovules solitary, pendulous. Drupe one-celled, with a fleshy pericarp. Putamen bony, acuminate, scrobiculate, valvate above the middle. Seeds without albumen. Funicles elongated. Testa membranous. Embryo straight. Cotyledons elliptical, plane-convex. Radicle short, next to the hilum.

Shrubs inhabiting sparingly the coasts and subsaline desert-tracts of South Europe, of Middle Asia, of the Orient, of extratropical northern and tropical Africa, and of extratropical and subtropical Australia. Branches not rarely spinescent. Leaves fleshy, alternate or fasciculate, minutely stipulate. Flowers cymose, rarely solitary. Petals white. Fruit edible--Pallas, Flor. Ross. i. t. $50 ;$ Lam. Encycl. t. 403; Gartn. de Fruct. \& Semin.t. 58 ; Andr. Repos. t. 529; Lodd. Bot. Cabin.t. 1395; Endl. Gen. 1094; Lindl. Veg. Kingd. 389 ; Jaub. et Spach, Illustration. Plant. Orient. t. 293-295; Schnizl. Analys. t. 60.

Nitraria Billardierii, Cand. Prodi. iii. 456.

Leaves linear- or lanceolate- or cuneate-oblong, entire; flowers spicate-cymose; ovary 2-3-celled; stigmas 2 or 3 , deltoid-ovate, erect; drupe ellipsoid-ovate, without angles.

In saline tracts of the desert on the Murray and in other localities in the north-western part of the Colony of Victoria. Not rare on the Darling and Murrumbidgee plains and in the Colony of South Australia, where it occurs also on the coast, extending northward to the depressions around Lake Torrens; found further on the Murchison River by MIr. A. Oldfield, distributed therefore in all likelilood through a great portion of the intervening country; according to Eyre along the Great Australian Bight.

An amply expanding slurub, 3-6 feet high. Branches more or less divaricate or arched-reclined, in age black-brown. Branchlets at first angular, soon terete, often, as well as the leaves, peduncles, pedicels and calyces, clothed scantily or densely with very short grey sonewhat silk-like dowus. Stipules brown, membranous, glabrons, from a broad base oblique deltoid or lanceolate or lanceolate-subulate, long persistent, generally less than I line long. Leaves scattered or more fiequently fasciculate, glaucons, sueenlent, $\frac{1}{2}-1 \frac{1}{2}$ inch long, $1 \frac{1}{2}-3$ lines broad, Hat above, rather convex beneath, tapering to the base without distinct petioles. Cymes sessile or short pedunculate, frequently formed by two simple or compound divergent scorpoid flesuose 
spikes, with several or numerous unilateral flowers. Pedicels short or none. Calyx hardly 1 linc long, with deltoid-semiovate or semilanceolate lobes. Petals 2-21 lines long; ovate-spathulate, narrowed at the base, yet not exactly unguiculate, glabrous or imperfectly silky at the back; the apex producing- sometimes a slort appendage beyond the inflexed margin. Filaments 1-2 lines long, glabrous, of whitish color. Anthers versatile, yellow, dorsifixed, $\frac{1}{2}-\frac{2}{3}$ line long, subovate, bilobed at the base, emarginate at the apex. Pollengrains smooth, ellipsoid, bursting longitudinally. Stignras $\frac{1}{4}$ or $\frac{1}{3}$ line long, not divergent. Ovary, silky, ovate-conical. Pericarp juicy, of a sweetish yet somewhat salty taste, outside dark-purple or dull-red or yellow, measuring $\frac{1}{2}$ to nearly 1 inch, before drying ellipsoid-ovate. Putamen 4-6 lines long, ellipsoid, tapering and pointed at the apex, grooved with irregular deep large impressions particularly below the middle; three outer semilanceolate-subulate valves free or below adnate, alternate with three narrow subulate ones, which cohere at the apcx; three inner ralves semilanceolate, separated half downward, alternate with the broader outer valves, finally to one-third of their length cleft into two pungent points, lined at the back with an adnate thread, which is the continuation of the opposite narrow outer valves. Seed filling the cavity of the fruit. Embryo yellow. Cotyledons twice as long as the radicle.

In flower towards the end of spring.

Suppeenextal Plate VII. 1, 2, flowers; 3, calyx with pistil after the lapse of stamens and petals ; 4 , back view of petal; 5 , front view of petal; 6 , back view of stamen; 7 , front view of stamen; 8 , pollengrains dry; 9 , pollen-grains moist; 10 , transverse section of ovary; 11 , side view of putamen; 12 , vertical view of putamen; 13 , putamen with some valves forcibly bcnt; 14, narrower outer valve; 15 , broader outer valve; 16 , inner valves; 17 , onter and inner valves; 18 , vertical section of fruit; 19 , transverse section of fruit; 20,21, seeds; 22, 23, embryo : all figures, with execption of 11 and 12 , are to a varied extent magnified.

It is yet an unsolved question, whether the Australian Nitraria is distinct from N. Schøebri, to which it evidently bears the closest resemblance. The diagnosis of most of the species hitherto published should be founded on other than those untenable characters, which have been adopted. Eyre (Expeditions of Discovery, ii. 271) noticed already the value of Nitraria as a fruit plant to the natives.

\section{ORDER VINIFERA.}

Juss. in Mém. du Muséum d’ Hist. Natur. iii. 444.

Flowers symmetrical. Caly $x$ monophyllous, entire or toothed, persistent. Petals 4-5, rarely 6 , inserted on the outer side of a basal disk, alternate with the teeth of the calyx, free, or at the apex rarely at the base coherent, valvate in restivation, deciduous. Stamens singly opposite to the petals. Filaments free. Anthers two-celled, versatile, with longitudinal dehiscence, free, rarely connate. Ovary surrounded by a disk, two-celled, rarely 3-6-celled. Orules 2, rarely 1 , at the base of each cell, erect. Style short, undivided or undeveloped. Stigma simple or slightly lobed. Berry 1- or 2-celled, rarely 3-6-celled. Seeds erect. Epidermis membranous. Testa bony. Endopleura generally plicate or wrinkled. Albumen fleshy, oily, including at the base a minute straight embryo with an inferior radicle.

Shrubs, occasionally trees, rarely suffruticose plants, almost always climbing, with limpid copious sap, indigenous to all intratropical and subtropical countries, inhabiting, within the temperate zone, North America, Middle Asia, South Africa, 
and Eastern Australia, not occurring spontaneously in Europe. Nodes of the stems and branches tumid. Leaves alternate, much less commonly opposite, simple or compound, always stalked. Stipules persistent, deciduous or obliterated. Tendrils very generally developed, as well as the peduncles opposite to the leaves, rarely axillary. Inflorescencc often paniculate. Pedicels frequently umbellulate and at the base freebracteolate. Flowers hermaphrodite, rarely polygamous, almost always small. Color of petals various. Berry often acidulous, sometimes acrid.-Endl. Gen. 796; Lindl. Veg. Kingdom, ed. iii. 439.

Viniferæ approach amongst Thalamifloræ to Meliaceæ and Sapindaceæ, amongst Calycifloræ to Araliaceæ.

\section{VITIS.}

Linné, Gen. Plant. 284.

Calyx truncate or minutely toothed. Petals $4-5$, rarely 6 , with an inflexed margin and apex, free or at the summit coherent. Stamens 4-5, rarely 6. Filaments capillary, straight. Anthers free, introrse. Ovary two-celled, with two collateral ovules at the base of each cell. Disk girt at the base by a ring. Style short or none. Stigma simple or short-lobed. Berry two-celled or by the obliteration of the dissepiment one-celled. Seeds 1 or 2 in each cell. Testa hard. Endopleura penetrating into the folds and wrinkles of the nucleus.

Shrubs, or sometimes trees, rarely suffruticose plants, glabrous or more or less clothed with downs or hair, producing in almost all instances climbing branches, which are articulated at the joints, and provided in most cases with evergreen foliage, found within the intratropical and subtropical zone of both hemispheres, and in some of the countries with a milder temperate clime. Root sometimes thick cylindrical and fleshy. Petioles articulated with the branches. Leaves herbaceous or coriaceous, alternate, simple, and then entire, toothed, lobed or dissected, or with leaflets disposed in a digitate or pedate or impari-pinnate or bipinnate arrangement, sometimes pellucidly dotted and of acidulous or acrid taste. Tendrils simple or divided. Flowers hermaphrodite, sometimes polygamous or diœcious, generally paniculate, with umbellate or fasciculate pedicels. Petals often greenish, sometimes yellow or black-purplish, always small. Stamens deciduous, longer or shorter than the corolla. Berry often black, dark-blue or purplish. - Wight \& Arnott, Prodr. Flor. Penins. Ind. Or. i. 124; Gray \& Sprag. Gen.Fl. Amer. Bor. Or. t. 161; Cissus, Linné, Gen. 147; Ampelopsis, Rich. in Michaux' Flor. Boreal. Americ. i. 159.

The kinds of Vitis hitherto known from Australia amount to twelve species, to which future researches in North-Eastern Australia are likely to add. All, with the exception of Vitis angustissima from subtropical Western Australia, Vitis acetosa (Cissus acetosa, F. MI. Transact. Phil. Instit. Vict. iii. 24, a suffruticose not clinbing acid plant), V. psoralifolia, and a species allied to V. adnata, from Arnhem's Land, are inhabitants of the eastern tracts of Australia, where a few ascend to the mountains of New England, whilst Vitis clematidea extends from New England through Eastern Australia to Arnhem's Land. The Indian Leea sambucifolia is by Dr. J. Hooker recognized amongst Australian plants. It occurs on the islands of Lord Howick's Group.

Vitis hypoglauca.-Cissus hypoglauca, Asa Gray in Wilk. Unit. Stat. Explor. Exped. Bot. 272; Cissus Australasica, F. Mr. in Transact of the Phil. Soc. Vict. i. 8. 
Aborescent; leaves long-petiolate, with generally 5 leaflets; stipules hairy, foliaceous, spathulateovate, rery fugaceous; leaficts on conspicuous radiating stalks, chartaceous or thinly coriaceous, ovate or lanceolate-orate, acuminate, entire or towards the apex acutely toothed, closely net-veined, paler or glaucons beneath; tendrils long, simple or bifid; peduncles bearing a double glabrons panicle witl opposite branchlets ; pedicels stout, short, umbellate; bracteoles very minute and fugacious; flowers hermaplirodite witl 4 petals and stamens; calyx hardly repand, much shorter than the corolla; petals yellow, semilanceolate, longer than the stamens, free; anthers nearly orate, as long as the filaments; style short, conical; stigma very minute, undivided; berry bluish-black, splerical, rather large; seeds subovate, gradually and slightly attenuated at the base.

On the banks of forest streams and rivulets in eastern Gipps Land; for instance, towards the moutl of the Snowy Rivel, on the Broadribb and Cabbagetree River, thus advancing the limits of Ampelider to almost $38^{\circ} \mathrm{S} . \mathrm{L}$. Thence along the eastern tracts of Australia inland as far as New England and northward as far as Moreton Bay.

One of the most robust of all species of vines, attaining when fully developed a lieight of 40 feet, with a stem stout in proportion. Branches valid, chmbing and winding. Branchlets as well as the petioles cylindrical, covered more or less densely with brown appressed hair, sometimes, however, with the exception of their apex, perfectly glabrous. Stipules several lines long, visible only in the innovations. Tendrils opposite to the leares, often several inches long. Primary petioles 1 to 2 inches long; secondary ones generally 5, sometimes $3,4,6$ or 7 , free; the lateral ones longer than the two lower ones and shorter than the terminal one, which measures frequently about 1 inch. Leaflets always of firm consistence, flat, with a strong midrib and many divergent lateral nerves, generally between 2 and 4 inches long and $1-1 \frac{1}{2}$ inch broad, above shining and, at least in age, glabrous, beneath always paler and either liglit-green or glaucous or aslyy-grey, at the midrib and nerres often brown-hairy, otherwise glabrous or nearly so, never decurring in to their stalk. Primary peduncles opposite to the leaves, $1-1 \frac{1}{2}$ inches long, bearing two secondary flowerstalks, each of which is yielding a miany-florered amply-expanding panicle. Bracts and bracteoles very caducous, spathulate or subovate, ciliated in front; the former about 1 line, the latter about $\frac{1}{2}$ line long. Pedicels 1-2 lines long or finally somewhat longer, articulated at the base. Flower-buds ovate-globose. Calyx bluntly and faintly four-lobed in age. Petals hardly longer than 1 line, acute at the apex, truncate at the base. Disk annular, entire. Filaments capillary, glabrous, $\frac{1}{2}-\frac{2}{3}$ line long. Anthers yellow, affixed near the base, almost erect, neasuring about $\frac{1}{2}$ line. Pollell-grains smooth, ellipsoid, longitudinally fissured. Style about $\frac{1}{2}$ he long, subulate- or pyramidal-conical. Stigma blunt. Berry glabrous, two-celled or by evanescence of the septum one-celled, about $\frac{1}{2}$ inch long, of acid pleasant taste. Seeds 2-3 lines long, in a fresh state brown; convex on both sides if only one in the whole berry matures; plane-convex if one in each cell is produced, the flat side then facing the septum; trigonous if two in each cell arrive at maturity, then convex at the back and flat as well towards the septum as on their commissural face. Albumen generally channelled with three irregular longitudinal furrows, besides transversely wrinkled.

This species, which was simultaneously described by Prof. Asa Gray, of Boston, and in the Melbourne Phil. Transactions, has its nearest relation in Vitis sterculifolia, discovered by Dr. Beckler on the Hastings River. The latter plant, of which the flowers are not yet known, may be recognized by leaflets of equal color on both pages, tapering into a short petiolule, being less closely veined, and producing callous elevations on the underside at the junctions of the lateral nerves with the midrib; the berries, moreover, are much larger and the seeds twice as long as those of Vitis hypoglauca.

Supplenental Prate X. 1, flower in bud; 2, flower expanded; 3, calyx, stamen and pistil; 4, petal; 5 , back vier of anther; 6 , front view of anther; 7 , dry pollen-grains; 8 , moist pollen-grains; 9,10 , berry; 11, longitudinal section of the fruit; 12-16, transverse section of the fruit; 17, seed, natural size; 18 , side view of seed; 19 , back view of seed; 20 , longitudinal section of seed; 21 , transverse section of seed: all figures, with the cxception of 17 , in a higher or lesser degrce magnified. 


\section{V.-RUTIN正.}

Flowers generally symmetrical. Stamens definite. Ovary one compound or sereral. Placentre axil. Seeds more frequently with scanty or no albumen then copiously albuminous. Embryo almost always straight.

\section{ORder AURANTIACEA.}

Correa, Annal. IIus. vi. 376.

Flowers symmetrical. Calyx 3-5-cleft, often persistent. Petals 3-5, sessile, as well as the lobes of the calyx imbricate, rarely valvate in restivation, distinct or somewhat coherent, inserted on the outer side of a hypogynous disk, deciduous, in rare instances wanting. Stamens definite in number, free or connate. Anthers twocelled, with longitudinal introrse dehiscence. Style 1, simple, rarely divided. Cells of the ovary 2 or several. Ovules 1, 2 or more in each cell, anatropal or amphitropal. Fruit consolidated, generally pulpy. Seeds pendulous or horizontal, frequently destitute of albumen. Embryo straight. Cotyledons often thick, fleshy. Radicle very short, superior. Plumule developed.

Trees or shrubs, dotted with oil-glands, not rarely thorny, hardly erer scandent, some extending considerably beyond the tropics, almost exclusively restricted to the eastern hemisphere, particularly numerous in the warmer parts of Asia. Ieares alternate, much less frequently opposite, pinnate or reduced to a single leaflet. Sti. pules none. Flowcrs hermaphrodite, seldom unisexual, variously distributed, often fragrant. Petals white, or more or less tinged with red, sometimes yellow. Fruit often with an aromatic-oily rind and a juicy pulp.-Endl. Gen. 1043; Lindl. Veg. Kingd. ed. iii. 457; Romer, Synops. MTonograph. 28-75.

The transit from Aurantiacere to Rutacere is rendered perfect through Xanthoxylex, which differ in prevailingly declinous flowers, in free or coalescent styles, an apocarpic fruit and often largely developed albumen.

In Australia exist plants of this order only in the eastern tracts, along which they occur in species of Citrus, Triphasia, Micromelum, Murraya, Acronychia, and perhaps Glycosmis, Cookia and other genera.

\section{ACRONYCHIA.}

Forst. Char. Gen. t. 27.

Flowers bisexual. Calyx short, four-cleft. Petals 4, valvate in cestivation, distinct. Stamens 8 , free, all fertile. Style simple. Stigma undivided or four-lobed. Ovary sessile, four-celled. Ovules 2 in each cell, amphitropal, inserted below the apex of the cell. Berry fleshy, four-celled. Endocarp 
crustaceous or scarious. Seeds 1 rarely 2 in each cell. Testa bony or crustaceous. Albumen copious. Cotyledons compressed.

Shrubs and trees, noticed throughout Eastern Australia, in the warmer parts of Asia, in Norfolk Island and in New Caledonia. Leaves opposite, rarely alternate, consisting of a single leaflet, rarely trifoliolate. Cymes axillary and terminal. Petals white or yellowish-green.-Schott Rutac. 3,t.2\&3; Cyminosma, Gcertn. de Fruct. et Semin. i. 280, t. 58; Adr. de Juss. Mém. du Muséum, xii. 465, t. 17, f. 11.

This genus stands on the verge of Aurantiaceæ; in the structure of its seeds it agrees fully with Xanthoxyleæ.

Acronychia laurina, F. II. Fragm. Phytogr. Austr. i. 27; Cyminosma oblongifolia, All. Cunn. in Bot. Mag. 3322.

Leaves opposite or some few alternate, consisting of a single rarely of three chartaceous or at length coriaceous ovate-oblong or obovate pellucidly dotted leaflets; cymes nearly glabrous; lobes of calyx almost round, very small; petals deciduous, narrow-oblong, blunt, inflexed at and towards the apex; filaments tomentose at the lower margins and inward above the base; anthers didymous-ovate; style downy below the middle; stigma very ninute, undivided; ovary smooth; dish glabrous, repand; fruit four-seeded; endocarp scarious, separating from the thin pericarp; cells much wider than the seeds; seeds small; testa crustaceous; embryo nearly of the length of the albumen.

Rare in forest-1'avines at Lake King and Lake Tyers, in about $38^{\circ} \mathrm{S}$. latitude; this being the most southern locality attained by any aurantiaceous plant; not rare in humid forest-valleys of Eastern Australia; known northward as far as Keppel Bay.

A noble tree, reaching the height of 60 feet. Bark almost smooth, sordidly grey. Alburnum brownred. Wood pale, rather soft. Branchlets terete, as well as the petioles smooth or very slightly downy. Petioles $\frac{1}{3}-1$ inch long, channelled-cylindrical or semiterete, jointed at the summit. Leaflets $1 \frac{1}{2}-6$ inches long, $\frac{3}{4}-2$ inches broad, in exceptional instances fully 9 inches long and $3 \frac{1}{2}$ inches broad, glabrous, rather acute at the base, blunt and often shightly'emarginate at the apex, spreading-nerved, net-veined, not much paler beneath, more or less shining particularly above, generally with a glassy lustre in age, copiously dotted with very transparent aromatic somewhat lemon-scented oil-glands. Cymes chiefly axillary, occasionally terminal, few- or many-flowered, simple or repeatedly branched. Primary peduncles often shorter than 1 inch, almost terete; secondary one generally more slender, a few lines sometimes many lines long, occasionally reduced to extreme shortness. Pedicels filiform, from 1 to a few lines in length. Bracts and bracteoles at the base of the peduncles and pedicels, very minute, semilanceolate or nearly so, slightly downy, early dropping. Flower-buds lagenar-ovate. Lobes of the calyx $\frac{1}{2}-\frac{3}{4}$ line long; glabrous, persistent. Petals white, deciduous, about $\frac{1}{4}$ inch long, valvate in æstivation, on account of their marginal inflexion narrower towards the apex than towards the base, sessile. Stamens 8; those opposite to the sepals somewhat longer than those in front of the petals. Filaments inserted outside the disk, linear-subulate, coherent at their velvety margin. Anthers yellow, dorsifixed, about $\frac{1}{3}$ line long, with introrse longitudinal dehiscence. Disk narrow, annular. Style 1-1 $\frac{1}{2}$ line long, subulate, decidnous, silky-tomentose or laxly pubescent beneath the middle. Stigma not broader than the style, blunt, slightly four-furrowed. Ovules 2 in each cell, affixed near the middle of its internal angle, descendent. Young fruit yellowish-brown, globose-ovate, with four rather acute longitudinal ridges; ripe one about $\frac{1}{2}$ inch long, of aromatic scent, tetragonous-globose, tinged with red. Dissepiments thin." Endocarp scarions, brittle, nerveless, separable into two valves. Seeds 1 or 2 in each cell, both descendent, the one placed obliquely above the other, immediately attached to the angle of

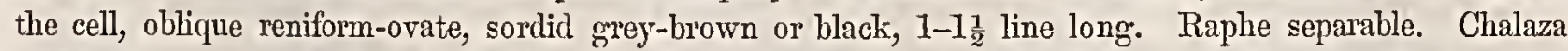
inferior, large, protruding, shining-black. Testa smooth or but slightly tubercled. Albumen rather copious. Cotyledons elliptical, compressed, twice as long as the cylindrical superior radicle. 
From various forest-regions of New South Wales we possess fruit specinnens of an Acronychia, which in every respect seems identical with our plant, except that the sarcocarp and septa become much more fleshy, causing thereby a contraction of the fruit-cells, which are walled with the almost or perfectly persistent endocarp. This plant may prove a mere state of A. laurina.

The closely allied Asiatic Acronychia cyminosma (F. M. Fragm. Phytogr. Austr. i. 27, note; Cyminosma pedunculata, Cand. Prodr. i. 723) differs, according to Wight and Arnott's Prodromus, i. 147, and Adr. de Juss. description and plate in Mémoir. du Muséum d'Hist. Nat. xii. 465, tab. 17, 11, in haring exserted stamens, in the ovary and disk being tomentose, in seemingly less distinctly bearded filaments, in a thick sarcocarp and in a bony endocarp. The scarcely less unlike Acronychia lævis (Forst. Gen. 27; Lawsonia Acronychia, Labill. Sert. Nov. Caled. 66; tab. 65) is to be distinguished in somewhat downy petals, in a lobed disk, a longer style, a broader slightly divided stigma, in tuberculated seeds and in an embryo considerably shorter than the albumen. In Turpin's illustration of the latter plant, the radicle is placed inferior and next to the chalaza, a note which, if not founded on erroneous observation, would be sufficient for generic distinction. The differences between A. laurina in contrast to those of the other Australian species, namely, A. Cunninghami, A. Hilli and A. imperforata, are pointed out in the Fragm. Phytogr. Austr. i. 26 \& 27. Ripe fruit of the latter species is only known of A. Hilli, showing precisely the genuine general characters. The ovary of this plant is, however, occasionally five-celled. Several evidently allied Javanic species are not defined with sufficient accuracy to admit, without comparing specimens, of an exposition of their differential notes.

\section{ORDER ZYGOPHYLLEA.}

\section{R. Brown, in Flind. Voy. ii. 545.}

Flowers hermaphrodite. Sepals $\mathbf{4} \mathbf{- 5}$, convolute, rarely valvate in æstivation. Petals alternate with the sepals, convolute-imbricate in præflorescence, deciduous, seldom wanting. Stamens definite, all fertile or rarely partially sterile. Anthers two-celled, the fertile ones with introrse longitudinal dehiscence. Style 1, rarely several. Stigma simple or lobed. Ovary 4-5- rarely 10-celled, surrounded at the base by a disk or glands or scales. Fruit capsular or rarely carnulent, or consisting of free or coherent carpels. Endocarp permanently connate with the sarcocarp, seldom free. Seeds with or without alloumen. Testa membranous or crustaceous. Cotyledons foliaceous, seldom thick. Radicle superior.

Herbs or shrubs, rarely trees, destitute of oil-glands, scattered over South Europe, Middle Asia, all tropical countrics, Soutl Africa and extratropical Australia. Branches often articulated. Leaves stipulate, opposite, rarely alternate, frequently compound. Flowers in most cases solitary. Petals yellow, less commonly white, red or blue.Adr. de Juss. in IIémoir. du IIuséum d' Hist. Nat. xii. 450; Endl. Gen.1161; Lindl. Veg. Kingdom, iii. 478.

The Rutineous orders of plants are through Zygophyllex brought into contact with Oxalidex and Geraniacex. In Australia the genera are reduced to Tribulus and Zygophyllum, of which the former is principally intratropical, the latter exclusively extratropical. There are many reasons in favor of transferring Nitraria from Malpighiacex to this order. 


\section{TRIBULUS.}

\section{Tournefort, Institut. Rei Herbar. 141.}

Sepals 5, rarely 6 , deciduous or persistent. Petals 5, rarely 6 , as well as the sepals convolute in præflorescence. Stamens generally 10 , sometimes 5, rarely $6-9$ or 12 , all fertile or some sterile. Filaments capillary, those opposite the sepals frequently shorter than those belonging to the petals, provided externally with a basilar gland. Anthers two-celled; fertile ones with introrse longitudinal dehiscence. Ovary five-celled, girt by an hypogynous disk or surrounded at the base with scales. Ovules 1-4 in each cell, inserted to the central angle of the cell, pendulous. Style filiform. Stigma with 5 recumbent adnate lobes. Carpels normally 5 , woody, indehiscent, colierent without a column, at last separating, generally with dorsal thorns, transversely 2-4-celled, or one-celled. Seeds tapering at the hilum. Testa membranous. Endopleura and albumen none. Embryo straight. Cotyledons plane-convex. Radicle conical.

Herbs, dispersed over most tropical and subtropical countries, particularly of the eastern hemisphere, found besides in South Europe, South Africa, and extratropical Australia, frequently prostrate and annual. Leaves opposite or some or all alternate, abruptly pinnate, stipulate, one of each pair of smaller size. Leaflets small, herbaceous, entire. Pedicels solitary, in the axis of the smaller leaf or sometimes lateral. Petals tender, yellow, rarely white or below the middle red. Style often short. Carpels sometimes partially undeveloped, often tuberculate, rarely winged.-Linne, Gen. Plant. 532; Adr. de Juss. in Mémoir. du Muséum d'Hist. Nat. xii. 451-452, t. J4, f. 1 ; Endl. Gen. 1162 ; Tribulopsis, R. Brown in Sturt's Central Australia, ii. Append. p. 70.

The species of Tribulus are readily segregated under two subgeneric divisions. The first of these, which may be designated Eutribulus, comprises all the formerly described species (with exclusion of those already separated as Kallstrœmias), and is characterized by leaves all or mostly opposite, by always fertile anthers and, except in rare cases, transversely celled carpels. The second subgenus, Tribulopsis, comprises Tribulus Solandri (Tribulopsis Solandri, R. Br. in Sturt's Exp. ii. App. p. 10 ; T. angustifolia, R. Br. l. c.), Tribulus Brownii (Tribulopsis pentandra, R. Br. 1. c.) and Tribulus bicolor (Tribulopsis bicolor, F. MI. Fragm. Phytogr. Austr. i. 47), all three species being restricted to tropical Australia, and remarkable for having constantly alternate leaves, fertile and barren anthers in often uncertain proportions, and normally one-celled carpels. These notes would seem clearly sufficient for generic distinction; yet in Tribulus alatus often less than 10 stamens occur, and 5 only in several oriental species, mentioned by Kralick, whilst in Tribulopsis Solandri and T. pentandra not rarely only fertile stamens, 5 in number, may be observed. The other main characteristic, that of the transversely celled carpels, becomes of doubtful value, when we in the North Australian Tribulus ranunculiflorus observe the carpels at least occasionally one-celled. The embryonic notes of Eutribulus and Tribulopsis are the same. The seeds of the former are, however, frequently depressed and placed nearly horizontally, whilst the seed of Tribulopsis is pendulous and more turgid.

Tribulus terrestris, Linné, Spec. Plant. 554; Lamark, Encycl. Mćthodique, t. 346; Kratich, in Annal. des Scienc. Nat. xi. 25; T. lanuginosus, Iinné, Spec. Plant. 553; Wight, Icon. Plant. Ind. Orient. t. 98 ; T. cistoides, Linné, Spec. Plant. 554; T. acanthococcus, F. M. in Transact. Phil. Soc. Vict. i. 9.

Prostrate; leaves opposite or a few alternate, generally longer than the pedicels, consisting of from $4-8$ pairs of leaflets, which are oblique ovate-lanceolate or oblong or rarely ovate, and generally appressedhairy beneath; flowers deeandrous; anthers ovatc, all fertile; sepals almost lanceolate, appressed, deciduous ; 
petals obovate-cuneate, not much longer than the calyx, or extending to twice its length; style frequently longer than the stigma; carpels ningless, depressed, with two dorsal thorns, downy and often tubereulated at the back, generally three-celled.

On the arid plains near the junction of the Murrumbidgee with the Murray River, where it is accompanied by Euphorbia Chamæsyce, Frankenia lævis, Cressa Cretica and a few other plants, extending from South Europe through Asia and the hotter parts of Australia to the northern boundaries of our colony. In South Australia north of Lake Torrens; in Western Australia within the settlements, according to J. Hooker; not rare within the tropics of Australia, Asia and Africa, rarer in America.

Root annual, perhaps occasionally also bi- or triennial, cylindrical, producing some capillary-filiform fibres. Stems $\frac{1}{2}-2$ feet long, nearly terete, streaked, simple or branched, densely covered witl short grey ascending or occasionally spreading downs, and besides beset with scattered longer hair, according to Kralick sometimes quite smooth. Leaves short-petiolate, alternately smaller, $\frac{3}{4}-2$ inches long. Stipules from a broad base ovate- or falcate-lanceolate, sometimes linear-lanceolate or even linear, 1-4 lines long. Leaflets $1 \frac{1}{2}-6$ lines long, $\frac{3}{4}-3$ rarely 4 lines broad, oftener blunt than acute, above soon glabrous or rarely retaining its pubescence in age, beneath and at the margin, as well as the rachis, pedicels and sepals, covered with an indument similar to that of the stem and branches, the upper and lower ones gradually diminishing in size. Pedicels slender-filiform, 4-14 lines long. Sepals measuring in length $1 \frac{1}{2}-3$ lines. Petals smooth, connected at the base with the opposite stamens. Filaments yellow, glabrous, generally $1 \frac{1}{2}-2$ lines long. Anthers $\frac{1}{4}-\frac{1}{2}$ line long, ovate, sometimes verging into a more round or oblong form. Pollen-grains globose, slightly rough. Style green, smooth, sometimes exceedingly short, sometimes more or less elongated, capable of extending to the length of three lines, at last dropping. Rays of the stigma yellowish, about $\frac{1}{2}$ line long. Ovary clothed with appressed white hair. Carpels connected into a starry fruit, 2-5 lines long, glabrous and lacunose at the commissural side, about the middle of the lateral edges armed on both sides with a stout subulate straight slightly down-bent thorn, which is generally less than 3 lines long, prorided besides not rarely at the base with two shorter thorns, which point downward, rarely thornless, covered at the back with downs and with either tubercles or small pungent points, which again are terminated by a short bristle. Seeds placed oblique-horizontally, 1-2 lines long, pointed at the hihm, ovate-cuneate. Testa pale-grey, almost opaque.

Specimens of this species, gathered in South Europe, Ceylon, Bengal, China, Timor and the Islands of Torres Straits, and compared on this occasion, differ in no essential note from the Australian plant, which moreover has been identified by J. Hooker with T. cistoides, and accords with the figures quoted. An allied species, found in the deserts around Lake Torrens, T. Hystrix (R. Br. in Sturt's Exped. ii. App. 69; T. lanatus, Walp. Annal. ii. 243), differs principally in copiously thorny fruit. To Tribulus terrestris belong evidently many of the plants hitherto acknowledged as distinct congeners.

\section{ZYGOPHYLLUM.}

Linné, Gen. Plant. 530.

Sepals 4 or 5 , persistent or deciduous. Petals 4 or 5 , unguiculate. Stamens twice as many as petals and as sepals, opposite to them, all fertile. Filaments free. Anthers two-ccllcd, versatile, with introrse longitudinal dehiscence. Hypogynous disk annular, sinuatc. Ovary 4-5- rarely 2-3celled. Ovules 2 or more, sometimes numerous in each cell, suspended in a double row from the central angle, anatropal. Style setaceous or subulate, furrowed. Stigma very small, furrowed or cleft. Capsule 4-5- rarely 2-3-celled, with loculicidal rarely with septicidal dehiscence. Column persistent. Seeds 1, 2, or several in each cell, pendent. Hilum situate below the apex of the seed. Exterior integument of the seed when moistened mucilaginous; interior one subcoriaceous or 
membranous. Raphe adnate, rarely free. Albumen rather scanty. Embryo straight. Cotyledons plane-convex. Radicle short, superior.

Herbs or half-shrubs or shrubs, known to occur at the Mediterranean Sea, throughout a great part of Africa, particularly the most southern regions, further in South-Western and Middle Asia, in Chili, Mexico and extratropical Australia, chiefly inhabitants of coast and deserts, often succulent and glabrous. Branches often semiterete, seldom spinescent. Stipules free or much more frequently either totally or partially connate into solitary interpetiolar ones. Leaves opposite, consisting generally of a solitary pair, rarely of a few pair of leaflets, seldom reduced to a single leaflet. Petioles not rarely foliaceous-dilated, rarely obliterated, terminated by a small membranous seldom spinescent appendage. Pedicels interpetiolar, ebracteolate, solitary or twin, rarely ternate or racemose. Sepals in age often reflexed. Petals very tender, ephemerous, yellow, rarely white or red or orange, sometimes spotted at the base. Filaments frequently provided with an adnate scale. Sarcocarp more or less fleshy or succulent, sometimes thin. Seeds oblique ovate or ellipsoid.-Candolle, Prodr. i. 705 ; Zygophyllum et Ropera, Adr. de Juss. in Mém. du Mus. xii. 454-456, tab. 15; Endl. Gen. 1163 ; Sarcozygium, Bunge, in Linncea, xvii. $7, t$. 1 .

Besides the species enumerated in the following pages, only two others are known as indigenous to this continent, viz., Z. Australasicum (Miq. in Lehm. Pl. Preiss. i. 165), which, according to its description, differs from all others in racemose flowers, and from most or all Australian congeners besides in being hirtellous-downy and having sessile leaves. The remaining species, Z. prismatothecum (F. M. in Linnæa, xxv. 375), is at once recognized from all other indigenous Australian kinds in having by the confluence of a pair of leaflets simple bilobed leaves. It may be sought in the Murray desert, since it accompanies the other Victorian species in the vicinity of Lake Torrens.

Zygophyllum apiculatum, $F$. MI: in Linnaa, xxv. 373; Rœpera latifolia, J. Hook. Fl. Tasm. i. 60 .

Suffruticose, diffuse, glabrous; branches semiterete; stipules interpetiolar, deltoid or semilanceolate; leaflets geminate, about twice as long as the narrow-winged petiole, oblique broad-ovate, entire, somewhat fleshy; appendage at the apex of the leafstalk ovate- or subulate-lanceolate, nearly membranous; pedicels about as long as the flowers, generally geminate; sepals 5, persistent, lanceolate-ovate, half or more than half as long as the corolla; lamina of petals yellow, spotless, broad-ovate or orbicular or nearly obcordate; stamens 10, about as long as the petals or shorter; scale cuneate, half or more than half as long as the filaments, acutely bidentate at the apex; lypogynous disk repand, slightly velvety at the margin; style short; ovary glabrous; ovules 4-5 above the middle in each cell; capsules drooping, semiovate, acute-pentagonous, at the vertex truncate, at the apex of the angles dilated into a short blunt appendage, otherwise wingless, with loculicidal dehiscence; seeds generally solitary in the cells; raphe adnate.

On the calcarious subsaline plains along the River Murray from its junction with the Murrumbidgee downward; further ascertained to extend to the tropic of Capricorn in Eastern Australia, having, for instance, been collected in Gregory's expedition at the Mackenzie River; noticed likewise on the Broughton River, at the base of the Flinders Ranges and on Spencer's Gulf in South Australia, by Mr. Drummond in SouthWestern Australia, by Mr. Oldfield towards Sharks Bay, and by Mr. Gunn on the islands of Bass's Straits; thus showing a wider range than that of any other Australian species.

An ascendent or spreading much-branched plant, from about 1 to a few feet high. Root livid, flexuose, almost cylindrical, scantily fibrilliferous. Branches lax, faintly margined with two longitudinal lines, streaked when dry. Petioles 3-6 lines long, somewhat channelled, lined with a narrow leafy towards the base dilated margin. Stipules united into interpetiolar ones, which are about 1 line long, entire or very imperfectly frïged, in age often bifid or somewhat lacerated. Leaflets from $\frac{1}{2}-1 \frac{1}{4}$ inch long, 4-8 lines 
broad, less fleshy than in most other Australian species, flat, rather vividly green, in a fresh state shining, blunt; their exterior half the broadest. Terminal appendage of the leafstalk persistent, about 1 line long. Pedicels solitary or more frequently twin, affixed at the axis of the anterior interpetiolar stipules. Flowers without scent. Sepals about 2 lines long, green, reflexed in age, appressed during florescence. Petals gradually contracted into a pale claw. Stamens as long as or longer than the calyx, outside adnate to the very tender below hyalinous in front yellow scales, which are 1-2 lines long, sometimes denticnlated in front and free from the filaments at the very snmmit, whilst the latter becomes confluent with the scale belor and appears not prominent towards the base. Free part of filaments intensely yellow. Anthers ahout $\frac{3}{4}$ line long, attached to the filament below their middle dorsal part, ovate or oblong-ovate, with emarginate base. Style simple by the concrescence of five, hardly 1 line long, subulate, green, long persistent. Stigmas exceedingly small, united. Hypogynous ring very narrow, glabrous ontside, with eight folds, which correspond to the exterior insertion of the filaments. Capsule 4-5 occasionally only 3 lines long, measuring across the vertex nearly $\frac{1}{2}$ inch, romnded blunt at the base. Sarcocarp thin, net-veined. Endocarp polished, nerreless, pale-yellow, in age slowly seceding and breaking into two incurved valves. Colnmn angular-filiform, persistent. Seeds pendent, oblique-obovate, slightly compressed, rather shining, indistinctly wrinkled, $1 \frac{1}{2}-2$ lines long; obscurely grey-brown, at the apex attenuated. Funicles very short. Raphe hivid, prominent, stretching from below the apex to the base of the seed. Chalazn inconspicuons. Testa when macerated exuding a copious tenacious mucilage. Albumen not quite equal in thickness to the embryo, which is yellowish-green. Radicle cylindrical, half as long as the ovate plane-convex cotyledons.

Zygophyllum glaucum, F.II. in Transact. of the Vict. Inst. i. 29.

Herbaceous, prostrate, diffuse, ascending or erect, glabrous; branches compressed-terete; stipules interpetiolar, deltoid; leaflets geminate, fleshy, oblique- or cuneate-obovate, blint, perfectly entire, at least three times as long as the margined petiole; terminal appendage of the leafstalk semilanceolate; pedicels solitary, as long as or longer than the leafstalk, shorter than the flowers; sepals 4 , broad-ovate or lanceolate, persistent, sereral times shorter than the obcordate-ovate or obovate yellow petals ; stamens 8, trice as long as the sepals, half as long as the petals; scale cuneate, half as long as the filament, acutely bidentate at the apex, teethless at the sides; hypogynous disk very narrow, repand, slightly velvety at the margin; style short; stigma minute, four-lobed; ovary glabrous, with 7-9 ovules along each cell; capsule drooping, almost obovate-tetragonous, wingless, rounded blunt at the base and apex, with loculicidal dehiscence; seeds 3-5 in each cell; raphe adnate.

In the subsaline desert-plains along the Murray River, the Wimmera and the Avoca; in South Australia on the foot of the Barossa Ranges, on St. Vincent's and Spencer's Gulf, and on Venus Bay; in New Sonth Wales on the Darling River. Root probably annulal, subcylindrical, flexuose, simple or producing a few distant fibrils. Stems several
from each root, from a span to $1 \frac{1}{2}$ foot long, generally rather stout, fleshy, divided into more or less spreading
branches, which are maroined with tho ding branches, which are margined with two decurrent lines. Petioles 1-4 lines long, semiterete, stont, wingless, somewhat margined at the edge, terminated by a membranous stipellar semilanceolate appendage, which is acuminate, persistent, slightly fringed, about 1 line long and placed externally at the base of the pair of leaflets. Stipules nerreless, bifid or bidentate in age, very imperfectly fringed at the margin, about 1 line long, more or less membranous at the edge, herbaceous towards the base. Leatlets glaucous or when young bright green and then shining, $\frac{1}{2}-1$ inch long, $\frac{1-\frac{2}{3}}{4}$ inch broad, terminated by a minute apiculum, which vanishes in age, more or less distinctly one-nerved, with hardly externally visible veins. Pedicels in the axis of one of the interpetiolar stipules, terete, glabrons, 2-4 lines long, somewhat thickened towards the apex, bent downward in age, spreading when flower-bearing. Flowers inodorous, cernuous. Sepals blunt or acute or acuminate, 2-3 lines long, glabrous, greenish or red-brown, with membranous edge, at first appressed, soon after the collapse of the petals divergent, in age reflexed. Petals spreading, about $\frac{1}{2}$ inch long; lamina 
bright-yellow, nearly 4 lines long, finely striped with dark-yellow veins, generally somewhat tinged with red towards the base, yet not decidedly spotted, tapcring gradually into the pale unguis. Filaments inserted outside the hypogynous disk, all of about equal length, externally adnate to the tender scale, which is about 2 lines long, smooth, yellow towards the top, hyalinous below, and occasionally slightly denticulated at the truncate apex, where it is wholly adnate to the filament and projects on both corners. Free part of filaments yellow, glabrous, capillary-setaceous. Anthers versatile, ovate, nearly 1 line long, affixed at the back a little below the middle, slightly bilobed at the base. Pollen-grains ellipsoid, smooth, longitudinally slit. Style subulate, finely four-streaked, formed by the coalescence of four, about 1 line long, persistent, greenish. Lobes of stigma or disjointed stigmas minute, spreading, very short, often conglutinated. Ovary quadrangular-ovate, blunt, with four shining-green prominent angles. Hypogynous disk at first green, plicate, repand-four-lobed, $\frac{1}{2}$ line ligh, covered with a faint velvet at the margin, glabrous outside, each sinus opposite to an ovary-edge. Ovules oblique-pendent, occupying in two rows nearly the whole length of the cells. Capsule 6-9 lines long, generally about 5 lines broad, very blunt particularly at the apex, occasionally almost truncate, yet always rounded at the corners, when short with dimidiate subcordate cells, when long. with dimidiate subovate divisions. Sarcocarp densely net-veined, when dry almost membranous, in age irregularly separating from the yellowish smooth polished nerveless nearly pergamentaceous endocarp. Funicles very short. Seeds $1 \frac{1}{3}-1 \frac{3}{4}$ line long, slightly or hardly compressed, oblique ellipsoid or ovate, brownish. Raphe drawing from below the apex to the base of the seed, prominent. Chalaza inconspicious. Testa when macerated mucilaginous. Endopleura brown, almost membranous. Layer of albumen, which surrounds the embryo, rather thin. Cotyledons plane-convex, ovate, twice as long as the cylindrical radicle.

Zygophyllum crenatum, $F$. MI. in Linnaa, xxv. 374.

Annual, glabrous, procumbent or ascendent, rarely erect; stipules deltoid, interpetiolar; leaflets geminate, fleshy, oblique cuneate, crenate at the apex, longer than the winged petiolc or some nearly as long; terminal appendage of the petiole subulate-lanceolate; pedicels solitary, shorter than the flower; sepals 4, ovate or ovate-lanceolate, persistent, at least half as long as the jellow obovate-cuneate spotless petals; stamens 8 , nearly half as long as the corolla; scale cuneate, extending scarcely beyond the middle of the filament, jagged-fringed towards the bifid apex; anthers yellow; hypogynous disk divided into four short nearly semiorbicular lobes; style short; stigma minute, four-lobed; ovary glabrous, with 7-9 orules along each cell; capsule drooping, subovate-tetragonous, margined with exceedingly narrow wings, rounded at the base and at the apex, with loculicidal dehiscence; seeds 4-8 in each cell; raphe adnate.

On the sandy or subsaline depressions along the Murray River downward from its junction with the Murrumbidgee to the western boundaries of the Colony of Victoria. In South Australia towards Spencer's Gulf, Lake Torrens and the Flinders Ranges.

A carnulent herb, with stems from a few inches to fully 1 foot long. Branches semiterete. Petiole margined with broader or narrower leafy wings, which are dilated towards the rounded or truncate base. Stipules deltoid or sometimes semilanceolate, rarely longer than 1 line. Leaflets $\frac{1}{2}-1$ inch long, $\frac{1}{2}-5$ lines broad, with a few blunt teeth at and near the apex. Pedicels cylindrical, 2-4 lines long, bent downward in age. Sepals about 2 lines long, or in age somewhat longer. and then reflexed, acute, greenish. Petals tapering into a claw, very blunt or slightly emarginate at the apex. Filament about 2 lines long, adnate to the very tender scale, setaceous at the apex. Anthers nearly ellipsoid, dorsifixed, yellow, about $\frac{1}{2}$ line long. Pollen-grains ellipsoid, smooth, bursting lengthwise. Style shorter than 1 line. Capsules 7-9 lines long, about 5 lines broad, prominently quadrangular. Sarcocarp thin, reticulate-veined. Endocarp tardily and very incompletely secedent, yellowish, very shining. Seeds $1 \frac{1}{2}-2$ lines long, ovate, somewhat compressed, toward the apex attenuated, dull brown on account of the indurated mucilaginous testa concealing the dark-brown endopleura. Raphe, albumen and embryo not essentially different from those of the preceding species, which bears to it a close relationship. 
Plate VI. 1 , flower; 2, petals and stamens; 3 , a single petal; 4 , back view of stamens; 5 , pollengrains; 6 , style; 7 , capsule, with one cell laid open; 8 , transverse section of capsule; 9 and 10 , seeds; 11 , 12 and 13, sections of the same: all figures variously magnified.

Zygophyllum Billardierii, Cand. Prodr. i. 705; Rœpera Billardierii, Adr. de Juss. in Mém. du Muséum d'Hist. Natur. xii. 454; J. Hook. Fl. Tasm. i. 60.

Herbaceous, diffuse or procumbent, glabrous ; stipules interpetiolar, often herbaceous; leaflets geminate, fleshy, oblique-oblong or linear-oblong or linear, entire, as long as or longer than the margined wingless petiole; terminal appendage of the leafstalk semilanceolate, acuminate; pedicels solitary, about as long' as the petiole; sepals 4, persistent, lanceolate, acuminate, generally at least of half the length of the ovate-cuneate yellow spotless petals; stamens 8, about half as long as the corolla; filaments without appendages; anthers yellow; style rather short; stigma undivided; hypogynous disk divided into four semiorbicular lobes; ovary glabrous, with few ovules in each cell; eapsule aeute-quadrangular, semiovateobpyramidate, wingless, drooping, truncate at the vertex; seeds solitary, rarely 2 in ench cell, nearly three times shorter than the cavity; raple adnate.

On coast-rocks or drift-sand, dispersed from Port Phillip to the entrance of the Glenelg River; thence westward on many parts of the southern shores of Australia, extending, according to Mrr. Oldfield, on the west coast at least as far north as the Murchison River; occuring also on the islands of Bass's Straits; spread again inland over sandy desert-tracts from the Murray and its lower tributaries to Lake Torrens and Cooper's Creek, being found on the latter locality by Mr. A. Gregory.

A singularly variable plant. Root in younger plants cylindrical, branched, livid and apparently annual, although when on coast cliffs the plant becomes very robust and may be perennial. Stems branched, when spreading over sand seldom more than 2 feet long and frequently shorter; when pendent fiom coastrocks often several feet long, the plant thus assuming a most graceful appearance. Branches semiterete, margined with two decurrent lines, streaked at least in a dried state. Stipules 1-1 $\frac{1}{2}$ lines long, persistent, seldom membranous, roundish or deltoid or semilanceolate, with a ninute or elongate sometimes linearsubulate always tender acumen. Petioles sometimes divided into several secondary leafstalks, each of which is provided with a pair of leaflets. Leaflets of the coast-variety generally about 1 inch long and $3-5$ lines broad, of the desert-variety often shorter, reduced occasionally to less than $\frac{1}{4}$ incli length, about as long as the petiole or in various degrees shorter, generally opaque and blunt, sometimes, however, quite acute, rarely confluent with the petiole into a furcate leaf. Stipellar appendage more or less herbaceous or membranous, verging either into a more ovate $0 r^{\prime}$ into a more subulate form, at times almost obliterated. Pedicels, according to the manifold influences which the plant is capable to endure, varying from 1-10 lines in length, bent downward when fruit-bearing: Sepals 1-3 lines long, green, reflexed and more pointed in age, when the edges, as in other species, roll inward, occasionally less than half as long as the corolla. Petals bright. yellow, often retuse with a minute terminal apiculum, 3-6 lines long, rarely reduced to only $1 \frac{1}{2}$ line length. Filaments subulate, glabrous, jellow. Anthers nearly ovate, $\frac{1}{6} \frac{1}{3}$ line long. Hypogynous disk slightly papillose-velvety at the margin. Style $\frac{1}{2}-1 \frac{1}{2}$ line long, setaceous, not rarely twisted. Ovary-cells with 2 or sonetimes with several ovules. Stigmas not disintegrated. Capsules attaining a length of $\frac{1}{2}$ inch, and measuring scarcely less at the vertex, often, however, considerably sinaller, occasionally in meagre specimens when ripe only 2 lines long, very slightly elevated at the vertex, more or less acute at the terminal angles, where not rarely a faint herbaceous appendage decurs. Endocarp scarious-parchmentous, separable from the closely net-veined sarcocarp, yellowish, inside polished. Seeds brown, considerably compressed, oblique-

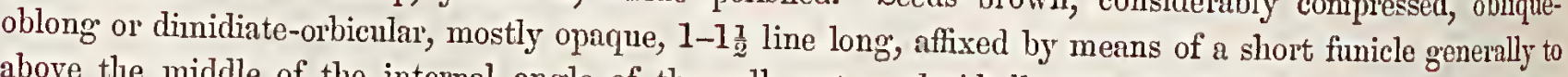
above the middle of the internal angle of the cell, not so decidedly attenuated at the apex as any other species, the hilum being placed almost at the terminal extremity, and thus the raphe extends along the whole inner side of the seed. Testa, when macerated, exuding a large mass of tough mucus, similar to that 
of many Cruciferons seeds. Embryo yellowish, thinly smrrounded by albumen. Cotyledons elliptical, planeconvex, half as long as the cylindrical indicle.

In flower throughout the greater part of the year.

Zygophyllum iodocarpum, $F$. M. in Linnce, xxv. 372.

Annual, diffuse, glabrous; stipules interpetiolar, almost deltoid; leaflets fleshy, g'eminate, oblong-cuneate, as long' as or longer' or shorter than the wing'ed petiole, notched at the apex; terminal appendage of the petiole semilanceolate; pedicels generally geminate, slightly papillose, about as long as the flowers; sepals 5, persistent, ovate-lanceolate, more than half as long as the small oblong-spathulate yellow spotless petals; stamens 10, about as long as the calyx; scales linear-cuneate, less than half as long as the filanents, entire; anthers yellow; hypogynons disk repand-undulated; ovary smooth, with two orules in each cell; style rery short; stigma lobed; capsule small, subglobose-pentagonous, drooping, wingless, with loculicidal dehiscence; seeds compressed, solitary in each cell, nearly as long as its cavity; · raphe adnate; cotyledons broad-ovate.

On dry subsaline desert-plains and on low barren ridges towards the Murray River below its junction witl the Murrumbidgee; extending along the Darling into New Soutl Wales; found also in the neighborhood of Lake Torrens and of the Flinders Ranges.

Root almost cylindrical, tortuous, simple. Stems generally several, branched, from a few inches to fully 1 foot long. Branches almost semicylindrical. Stipules nearly 1 line long, formed by the concrescence of those two opposite to each other, membranons and often somewhat finged at the margin. Petioles conspicuously dilated by the partially reflexed herbaceous margin, terminated by an acuminate appendage, which measures $\frac{1}{2}-1$ line in length. Leaflets 3-6 lines rarely 1 inch long, 1-3 mirely 5 lines broad, sometimes rounded blunt and without notch at the apex, occasionally reflexed at the margin. Pedicels 1-3 lines

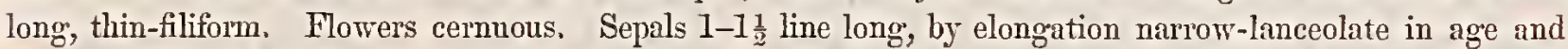
then reflexed. Petals only about $1_{\frac{1}{2}}$ line long, tapering into a conspicuous unguis. Filanents capillary, dilated below the middle by concrescence with the appendicular scale. Anthers ellipsoid or ovate, dorsifixed, about $\frac{1}{5}$ line long: Style capillary, not longer than from $\frac{1}{4}-\frac{2}{3}$ line, with five disconnected ninute stigmas. Capsule 2-3 lines long, exceeding often its height a little in breadth; when fresh somewhat carnulent and then only with slightly protruding angles; when dry angular with five acute sutural ridges, and then prominently net-veined, green or often assuming with many of the branchlets and leaves a violet hue. Endocarp nerve- and reinless, yellowish, polished at the inner side, separating easily from the sarcocarp and splitting into two regular valves. Funicles very short, generally originating not much above the middle of the cells. Seeds inore compressed than in most other species, oblique-ovate, smooth, brown, shining, tapering torards the apex, about $1_{\frac{1}{2}}$ line long, emitting, immersed into water, from the testa a copious tough gelatine. Hilum lateral above the middle. Raphe narrow. Chalaza small, basilar. Albumen forming a very thin layer. Embryo hardly shorter than the albumen, yellowish. Radicle filiform, half as long as the outward slightly convex cotyledons.

At Champion Bay and the Murclison River a plant without fruit was gathered by Mr. Aug. Oldfield, very similar to the species above described, of which it may be only a variety, differing in having externally a sinall basal lobe protruding firom most of the leaflets and also one or the other terminal teeth, and in producing solitary pedicels about $\frac{1}{2}$ inch long or even longer.

In flower during the spring.

Zygophyllum fructiculosum, Cand. Prodr. i. 705; Ropera fabagifolia, Adr. de Juse. in Mém. du Mreséum d'Hist. Nat. xii. pl. 15, 3; Deless. Icon. Select. iii. t. 42; Roepera aurantiaca, Lindl. in Mitch. Three Exped. ii. p. 70.

Shrubby, diffuse, glabrous ; stipules,flcshy, interpetiolar; leaflets geminate, carnulent, oblique, ovate- or oblong-lanceolate or quite linear, entire, of the length of the wingless petiole, or greater in length; terminal 
appendage of the leafstalk semilanceolate, membranous; pedicels solitary, about as long as the flowers or longer; sepals 4, persistent, ovate-lanceolate, acuminate, at least half as long as the corolla; petals yellow; spotless, with obovate lamina; filaments 8 , without appendages, about as long as the sepals; anthers yellow; style rather short; stigma hardly divided; hypogynous disk four-lobed, slightitly velvet-downy at the margin; ovules 2, suspended from near above the middle of the cell; capsule with septicidal dchiscencc; valves broudly and scariously winged from the summit to the base, navicular-semiorbiculate; seeds solitary in the cell; raphe adnate; cotyledons oblong.

In the Murray desert from the entrance of the Murrumbidgee at least as far as Mount Beevor; also known to exist on the Darling River, in the vicinty of Lake Torrens, on the Flinders Ranges, the Light and Elizabeth Rivers, and according to Preiss and Oldfield near Champion Bay, the Murchison and Swan River, probably therefore extending throngh a great part of the intervening desert-country.

A shrub of lax growth, accumbent to the ground or to surrounding plants, generally of dwarf growth, sometimes attaining a height of several feet. Branches terete. Branchlets somewhat angular, streaked when dry. Stipules varied in form, oblong, ovate or nearly round, quite green and fleshy like the leaves, unless tipped with an undivided or bifid membrane, scarcely with any furrow to indicate the coalescence of its two constituent parts. Petiole 2-6 lines long, fleshy, a little narrower seldom broader than 1 line, with a hardly perceptible superficial furrow. Leaflets in the coast-variety often $\frac{1}{2}-1$ inch long and $1 \frac{1}{2}$ to a few lines broad, flat, showing in exsiccation the midnerve and the veins; in meagre desert-specimens 2-6 lines long, hinear, confluent with the compressed-filiform fleshy petiole and not articulated at the base, forming thus, as it were, a simple furcate leaf. Pedicels thin-filiform, $2-4$ lines long, smooth. Sepals $I_{\frac{1}{2}}-4$ lines long, green, reflexed in age. Petals rather suddenly contracted into the claw, more or less blunt. Filaments setaceous or linearfiliform. Anthers ellipsoid or ovate, with cordate base, according to the size of the flowers exceedingly inconstant in length, measuring from $\frac{1}{5}-\frac{1}{2}$ line, yellow. Style $\frac{3-1}{4}-1 \frac{1}{4}$ line long, evidently formed by the often twisted coalescence of four. Lobes of the disk reniform-semiorbicular. Capsule resembling those of some Dodonæx, 5-10 lines long, round in outline, separable into its constituent carpels, of which sometimes 1-3 are abortive. Wings finely net-veined, always considerably broader than the cells, extending particularly at the apex long beyond them, $2-4$ lines broad, rounded-blunt at both extremities, either free at the summit and forming a narrow sinus at the apex of the fruit, or concrete beyond the valves. Endocarp yellow, polished inside, not readily separable. Funicles arising from above or near the middle of the angle, very short. Seeds grey-brown, about $1 \frac{1}{2}$ line long, slightly attenuated at the summits. Cotyledons yellowish, about 1 line long, plane-convex, twice as long as the cylindrical radicle.

The identification of Ropera aurantiaca with $R$. fabagifolia is based on circumstantial eridence; for although the Western and Southern Australian plants agree in every respect except the leaves, we have seen no intermediate forms of the latter. Yet there are before us varieties of $\mathrm{Z}$. Billardierii with leares precisely corresponding to those of $\mathrm{Z}$. aurantiacum and $\mathrm{Z}$. finticulosum respectively, and in this instance all intermediate gradations are clearly known. One of these species seeins to be alluded to by All. Cunningham, in the appendix to King's Surrey of the Coast of Australia, p. 23, as observed on an island of Sharks Bay.

\section{ORDER RUTACE无.}

Juss. Gen. 297.

Flowers hermaphrodite rarely unisexual. Calyx consisting of 3-5 very rarely 10 free or connate in restivation imbricate or valvate sepals, rarely monophyllous and undivided, very seldom wanting. Petals equal in number to the divisions of the calyx, distinct or coherent, imbricate or valvate in æestivation, rarely undeveloped. Stamens 
of equal or double rarely threefold, in Huegelia manifold, number with the petals, sometimcs alternately sterile, inserted on the outer side of a hypogynous rarely perigynous disk, free or rarely coherent or adnate to the base of the petals. Anthers tro-celled, with introrse longitudinal dehiscence. Styles united into one or rarely from below the apex free. Stigma simple or several united into one. Ovaries $2-5$, coherent, one-celled. Ovules 2 in juxtaposition or one above the other, rarely 1,4 or more. Carpels 2-5, bivalved. Endocarp cartilaginous, separating from the sarcocarp, rarely permanently adnate. Seeds with or without albumen. Testa crustaceous rarely bony. Cotyledons various. Radicle superior.

Odorous shrubs, rarely trees or suffruticose plants, dotted with oil-glands, often exuding resinous secretions, very seldom climbing or thorny, abundant in South Africa and extratropical Australia, less common in tropical America, rare in the warmer parts of Asia, North Africa, tropical Australia and South Europe. Leaves without stipules, alternate or opposite, simple or compound. Disposition of flowers various. Petals white, yellow, purple or red, seldom blue, very rarely purplish-black. Endocarp bivalved.-Lindl. Veg. Kingd. 469.

The relationship of Rutacex to Xanthoxyleæ, Aurantiaceæ and Zygophyllex is close in the extreme.

The lovely plants constituting this order are, wherever they occur, an ornament of the flora. Beauty and rarity are in an unusual degree blended in this family, many species having a very circumscribed range of distribution. In addition to the genera mentioned in the subsequent pages Huegelia and Empleurosma are to be regarded as Australian Rutacex, on the authority of Robcrt Brown and Bartling. Huegelia transgresses far the usually assumed boundaries of the order by producing ten sepals, ten petals and indefinite perigynous stamens, the latter note suggesting an approach to Myrtaceæ. Empleurosma is not less abnormal in declinous apetalous flowers, notes which may draw this plant perhaps into the vicinity of Dodonæa. Anthoderris, indicated by A. Cunningham in the appendix to the Narrative of King's Survey, pp. 22 and 23, and named in Hooker's Journal, is referable to Verticordia, an opinion confirmed by Mr. Robert Heward. An habitual resemblance exists in some Australian Rutaceæ, for instance, Chorilæna to Buettneriaceæ through Corethrostylis and Seringea, whilst no less a similarity is manifest to Tremandreæ.

Most valuable information on the Rutaceous plants may be sought in a learned essay promulgated by Adrien de Jussieu, in volume xii. of the Mémoires du Muséum d'Histoire Naturelle, in 1825. Since that period, however, the access of species to the order, gained by later discoveries, has been so great as to subject some of the generic limits then adopted to considerable alteration. Many of the indigenous Rutaceæ possess diuretic and diaphoretic properties alike to those of the South African Bucco bush. 


\section{GEIJERA.}

Schott, Rutac. 7, t. iv.

Calyx short, five-cleft, persistent ; its lobes imbricate in æstivation. Petals 5 , sessile, induplicatevalvate in præflorescence, deciduous. Stamens 5, opposite to the lobes of the calyx. Filaments subulate. Anthers without appendage. Ovaries 5, surrounded by the slightly five-lobed disk, with a solitary pendulous ovule attached near the summit of the internal angle of the carity. Style short. Stigma capitate. Carpels blunt. Endocarp very imperfectly separating from the coriaceous sarcocarp. Seeds ovate-globose. Testa bony.

Evergreen shrubs and trees of extratropical and eastern tropical Australia. Branchlets unarmed. Leaves alternate, simple, coriaceous, entire. Panicles terminal. Pedicels minutely bracteolate. Flowers small, hermaphrodite. Petals almost white. Seeds shining-black.-Endl.Gen. 1154.

Geijera effects the transit from Euodia to Xanthoxylon and Blackburnia; from the former it is chiefly distinguished in simple alternate leaves and in but slightly seceding endocarp. From Blackburnia, of which one species (B. xanthoxyloides, F. MI.) occurs near Moreton Bay, Geijera is easily recognized in having neither monœcious flowers, nor pinnate leaves, nor solitary ovaries; it agrees, however, more with this genus than with any other amongst Xanthoxyleæ, in the normally one-ovuled germens and the valvate præflorescence of the corolla. Xanthoxylum, which numbers at least one legitimate representative in Eastern Australia (X. brachyacanthum, F. MI.) differs in its pinnate leaves, imbricative præflorescence of corolla, polygamous flowers and biovulate germens. Adr. de Jussieu mentions in the Mémoires du Muséum d'Histoire Naturelle, xii. 503 and 504, a West Australian Xanthoxylum, under the name of X. Australasicum, to which as indentical Eriostemon linearifolius (Cand. Prodr. i. 720) is quoted. This plant, notwithstanding it is stated to have biovulate carpels, which is an exceptional character in Geijera, belongs probably to this genus if not even to the Victorian species; because the fruit of Geijera, as far as hitherto ascertained, is not generically different from that of Xanthoxylon, and Jussieu's examination of the former plant did not extend over perfectly developed flowers. Moreover, some of the desert-shrubs, formerly thought to be restricted to the more eastern part of the Australian continent, have recently been brought from the vicinity of Sharks Bay, to which in all probability G. parviflora, along with Nitraria, Heterodendron, \&c., will be found to extend, and from which locality, probably through Baudin's expedition, the plant was available to Jussieu and Candolle.

Ceijera parviflora, Lindl. in Mitch. Trop. Austr. 102; G. pendula, Lindl. l. c. 251.

Leuves broad-linear, rarely oblong- or lanceolate-linenr, vcinless, tapering in to a generally short petiole, on both pages of almost or quite equal color'; panicle few-flowered; carpels ronnded-blunt.

On barren sandy or stony ridges or plains in the Murray desert. Thence advancing along the Darling and its tributaries to the waters of the Burdekin and also to the desert around Lake Torrens.

A tall bush or small tree of strong odor, in aspect iresembling a Myoporum. Branchlets glabrous or when young scantily appresscd-downy, almost terete, conspersed with more or less prominent glandular dots. Lcaves blunt or acute, flat, 1-6 inches long, 1-3 lines broad, not often broader, dottcd with oil-grands, glabrous, one-nerved, not articulated with the leafstalk. Peduncles and pedicels slightly grey-downy, stont, angular; the latter generally shorter than the flowers and often upwards thickened. Bracts at the base of the pedicels solitary, deltoid, ciliolate, about $\frac{1}{2}$ line long. Bracteoles roundish, coriaceous, appressed, seldom longer often shorter than $\frac{1}{2}$ line. Lobes of calyx roundish and very finely fringed. Petals spreading, glabrous, semilanceolate-ovate, yellowisl 1 -white, truncate at the base, about 1 line long, with an inside faintly prominent 
midrib, minutely inflexed-pointed at the apex. Filaments glabrous, inserted to the faint bends of the annular glabrous disk, generally twice or thrice shorter than the petals, occasionally only one-third shorter. Anthers didymous- or cordate-r'oundish, pale, dorsifixed, $\frac{1}{4-\frac{1}{5}}$ line long, two-celled, with introrse deliscence. Pollengrains ellipsoid, smootl, with longitudinal fissure. Style very short, five-furrowed, glabrous. Stigma depressed, roundisl, indistinctly fire-angular. Ovaries in exceptional cases with two collateral ovules. Carpels often only in part developed, ovate-globose, turgid, seldom longer than 2 lines, bivalved. Sarcocarp dotted with oil-glands. Endocarp parchmentous, livid, nerveless, remaining with the exception of the margin attaclied to the sarocarp. Seeds ovate-globose, quite smootl, carrying with them the nearly linear placentar membrane, filling almost completely the cavity of the carpel. Exterior part of the testa thin and brittle, interior one hard and thick. Albumen present according to Schott. Einbryonic structure remaining unknown, none of the many seeds, examined on this occasion, having the nucleus developed.

In flower during the spring.

This species resembles in erery respect, as regards flowers and fruit, G. salicifolia, which merely by the generally ovate or broad-lanceolate long-stalked veined and beneath paler leaves and often larger and copiously Howered panicle can be distinguished from G. parviflora. As G. latifolia, which is intermixed with G. parviHora in the Brigalow scrubs of East Australia, mediates the transit fiom our plant to G. salicifolia, it becomes very doubtful whether all are not merely forms of one species, holding the same relation to each other as Dodonæa Preissii to D. viscosa ; for it can well be imagined what effect the dry deser't climate would exercise on a plant, capable to bear it, whilst it adapts itself also to our humid jungle-clime.

G. salicifolia occurs southward at least as far as Cabranatta, according to Mr. W. Woolls, and northward as far as Rockhampton, according to Mr. Anthelme Thozet. The wood was exhibited by Mr. C. MLore under N. 78 in the Paris Exhibition. Mr. Thozet prepared an excellent ink from the bark. A donbtfil species, with almost rhomboid short-rostrate carpels, has been noticed near Moreton Bay; no others are known.

\section{BORONIA.}

Smith, in Transact. Iinn. Soc. viii. 285.

Sepals 4, valvate in æstivation, persistent, rarely deciduous. Petals 4, sessile or subsessile, valvate or imbricate in præflorescence, persistent or tardily dropping. Stamens 4, opposite the sepals or 8 ; those opposite the sepals longer than the rest and sometimes bearing barren anthers, very rarely those opposite petals sterile. Filaments free, linear-subulate or filiform or subclavate, generally inflexed at the apex. Fertile anthers dorsifixed, with introrse longitudinal dehiscence. Ovaries 4 , inserted on a sinuate or undivided disk. Ovules 2, affixed at the interior angle of the ovary; the upper one ascendent, the lower one descendent. Styles united into one or wanting. Stigma simple or four-lobed. Carpels normally 4, oblique-oblong or ovate, bivalved, 1-2-seeded. Endocarp cartilaginous, bivalved, operculate towards the base by the placental membrane. Seeds subovate. Testa crustaceous. Embryo cylindrical, straight, in the axis of the copious albumen. Radicle longer than the plane-convex cotyledons or nearly as long.

Odorous slirubby rarely suffiuticose or arborescent plants, inhabitants of extratropical and subtropical Australia and of Tasmania, rare within the tropics and towards the centre of the Australian continent. Leaves opposite, simple or impari-pinnate or with ternate or biternate leaflets even sometimes in the same species, very rarely some alternate or fasciculate or verticillate. Flowers solitary, geminate, ternate, cymose or paniculate. Pedicels at or above the base jointed, and almost aways at the joint provided with two opposite bracteoles, often incrassate at the apex. Petals generally longer than the calyx and the stamens, pink, sometimes crimson, blue or whitish, very seldom 
(in B. megastigma) purplish-black outside and yellow inside, spreading, rarely subcampanulateconnivent. Filaments often hairy and at the apex glandulous-tumescent. Fertile anthers generally subcordate and terminated by a white appendage; the barren ones, when formed, often far the largest. Carpels generally very blunt. Placental membrane attached by the very short funicle to the seed, ovate or lanceolate, acuminate, white, seldom purplish. Seeds black. Raphe sometimes tumid towards the base.-Zieria, Smith, in Transact. Linn. Soc. iv. 216; Cyanathamnus, Lindl. Swan Riv. Bot. 18.

The species of Boronia are much more copious in South-Western and South-Eastern Australia than in the intervening parts of the country, being comparatively rare in the territory of South Australia; they are also more copious in the litoral districts than far inland; many prefer stony mountainous tracts; some ascend to alpine regions. The number of species has been generally over-estimated. None extend from the east coast to the western shores; none with barren anthers are yet found beyond Western Australia; whilst Zieria, which differs principally in the number of stamens, and may be retained as a genus, if this note is deemed sufficiently important for distinction, is foreign to the western part of the continent. The number of floral parts is singularly invariable, unless in monstrose flowers. Only in B. elatior occur, according to Bartling (Plant. Preiss. i. 170), barren petaline stamens. B. grandisepala (Fragm. Phyt. Austr. i..66), of which B. artemisifolia constitutes the pinnate-leaved form, is singular for the size of its sepals, which considerably excel that of the corolla. The carpological characters of all these plants are congruous. The præflorescence of the corolla is unusually variable, not only in the genus but even in some of the species; thus B. megastigma shows, as in many other species, two outer and two inner petals, but the same species produces also flowers with regular imbricative æstivation. The species with alternately fertile and sterile stamens may be separated sectionally under the appellation Dimorphanthera. R. Sweet describes (in Don's Gen. Syst. i. 794) a Zieria octandra, which, it is presumed, combines the disk of Zieria with the number of stamens of Boronia. Only one Boronia of the subgenus Zieria produces constantly simple leaves, B. veronicea, F. M., of Kangaroo Island and Encounter Bay, this being moreover the only species of the section Zieria which occurs in South Australia.

Boronia is in its affinity nearest approaching to Eriostemon, whilst through B. arborescens it is not less in habit than in most otleer characters connected with Euodia, which scarcely differs from it in any other points than in the large ovate or suborbicular cotyledons and the short radicle. Thereby a close contact again is established with Acronychia, which genus completes the link between Rutacex and Aurantiacex. Discussing the affinities of these genera, it may be appropriate to observe, that Euodia ternata (Melicope ternata, Forst. Gen. 28) differs as a genus solely in octandrous flowers from Euodia, according to an analytical comparison of the former, confirming the perfect exactness of the figure furnished in Hooker's Icones Plantarum, t. 603, with Euodia micrococca of Eastern Australia. The integument of the seeds is bony in both with a friable outer layer, the radicle superior and about half as long as the broad-ovate foliaceous cotyledons, wlich are placed across the copious albumen. Thus Melicope holds the same position to Euodia as Boronia to Zieria. Singular appears the frequent development of a fifth and occasionally even a sixth carpel both in Enodia ternata and E. micrococca, an irregularity not obvious in Boronia, but parallel to that in Acradenia, a Tasmanian genus, as far as can be judged without knowledge of its embryonic characters very allied to Euodia, from which only the permanently adnate endocarp seems to distinguish it. The three hitherto known Australian species of Euodia have a considerable range over the eastern coast-tracts, and are well marked, besides by many other characters in their seeds. Those of $\mathrm{E}$. micrococca are brownish-black; those 
of E. erythrococca beautifully blue, a note of the rarest occurrence in any tribe of the vegetable empire.

\section{Sect. I. Zieria.}

Sepaline stamens fertile, opposite to the turgid lobes of the deeply divided disk; petaline stamens wanting.

Boronia lævigata, F.M. Fragm. Phytogr. Austr. i. 101; Zieria lævigata, Smith, in Rees' Cycl. 11; Adr. de Juss. in Drus. d'Hist. Nat. xii. t. 22; Delcssert. Icon. iii. 49; Manun's Botanist, iv. 185; Paxt. Magaz. ix. 77; Spach, Suites à Buffon, 13.

Shrubby; branchlets angular; leaves slort-petiolate, trifoliolate or a few simple; leaflets lanccolate or lanceolate-linear or narron-linear, acutc, revolutc at the margin, paler beneath, coriaceons, glabrous or generally very short velvety below; flowers axillary and terminal, ternate or cymose, rarely solitary; pedicels as long as or shorter rarely longer than the flowers; bracteoles lanceolate or lanceolate-subulate, persistent; sepals ovate- or lanceolate-deltoid, generally about three times shorter than the whitish thin-velvety obovate slort-unguiculate petals and about as long as the stamens, outside glabrous rarely downy; petaline stamens none; sepaline ones smooth; anthers minutely apiculate; style extremely short, as well as the ovary glabrous ; stigma minute, depressed, four-lobed; disk deeply four-cleft; carpels rlomboid-ovate; valves of the endocarp protracted at the junction into a deltoid tooth; seeds opaque.

On barren ridges near the Goulburn River. Known besides fiom the southern parts of New South Wales.

A shrub of variable height, in habit quite similar to the generality of Boroniæ. Branchlets opposite, quite glabrous or much less commonly grey-downy. Petioles stout, $\frac{1}{2}-3$ rarely 6 lines long, somewhat channelled. Leaflets $\frac{1}{4}-1 \frac{1}{2}$ inch long, 1-3 lines broad, without special petioles. Simple leaves, if present, corresponding in form to single leaflets. Peduncles in various degrees shorter than the leaves, occasionally also longer. Bracts at the division of the peduncles opposite, either of the shape of the bracteoles or more alike in form to the leaves. Bracteoles placed near the middle of the pedicels, $\frac{3}{4}-1 \frac{1}{2}$ line long, subcoriaceous, semilanceolate-cymbiform, rarely lobed, or even showing in exceptional cases the metamorphosis into leaves. Calyx deeply cleft, seldom longer than 1 line, often tinged with black. Petals deciduous, indistinctly imbricate in preflorescence, $2-2 \frac{1}{2}$ lines long, in a small-flowered variety only about $1 \frac{1}{3}$ line long, terminated by a minute point. Filaments filiform, affixed to the back of a half-round lobe of the disk. Anthers generally less than $\frac{1}{2}$ line long, occasionally much smaller. Pollen orange. Style with few exceptions of extreme shortness. Stigma tetragonous-capitate, four-furrowed, about $\frac{1}{6}$ line broad. Carpels $1 \frac{1}{2}-2 \frac{1}{2}$ lines long, smootl, oblique broad-ovate, very blunt, with a minute apiculum. Epicarp with inside prominent net-veins. Endocarp shining, pale-yellowish, nerveless; its valves coherent at the concave base. Placental membrane half as long as the seed, semilanceolate-cymbiform, whitish. Seeds scarcely longer than 1 line, slightly tubercled. Chalaza thin. Embryo thin-filiform, nearly as long as the albumen. Cotyledons semiterete, half as long as the radicle.

Z. microplyylla (Bonpl. Nav. 64), Z. pauciflora (Sm. in Rees' Cycl. 3) and Z. revolute (A. Cunn. in Field's New South Wales, i. 330) are, as far as can be judged from the brief respective diagnosis, referable to Z. lævigata.

Boronia arborescens, F. M. Fragm. Phytogr. Austr. i. 100; Zieria lanceolata, R. Br. in Rees' Cycl. 1; Loddig. Cab.t. 878; J. Hook. Flora Tasm. i. 65; Z. Smithii, Andr. Bot. Rep.t. 606 ; Bonpl. Plant. cultiv. à MIalmais. i. t. 24; Bot. Mag. t. 1395; Z. arborescens, Sims' Bot. Mag. p. 1395; Z. macroplyylla, Bonpl. Malmais.p. 64; Deless. Icon. iii. 48; Bot. MIag.t. 4451.

Arborescent; branchlets terete; leaves trifoliolate or a few simple, twice or several times longer than the petiole; leaflets lanceolate, subherbaceous, generally large, rarely coriaceous or linear-lanceolate, flat or 
recurved at the margin, smooth or frequently beneath thin-velvety, strongly veined; cymes axillary, generally trichotomous-paniculate and velntinous; bracts and bracteoles lanceolate or lanceolate-subulate, sepals twice to four times shorter than the whitish subvelutinous corolla, semilanceolate or subdeltoid; petaline stamens wanting; sepaline filaments as long as the calyx or somewluat longer; almost smooth; anthers without appendage; style short; stigma depressed, slightly four-lobed; dish deeply four-cleft; carpels quadrate-ovate; endocarp protracted at the junction of the valves into a deltoid tooth; seeds shining; finely wrinkled.

From the Grampians and the Cape Otway Ranges eastward, scattered along the humid forest-ralleys of Victoria, thus occur'ring on MIount Disappointment, in the Dandenong Ranges, at Wilson's Promontory, and in various parts of Gipps Land, ascending to high mountain ravines; not rare in Tasmania; dispersed over Eastern Australia as far north as Moreton Bay.

A shrubby plant, becoming under favorable circumstances arborescent, when it is found to attain a height of 30 feet, exhaling a strong not agreeable odor. Bark grey. Wood pale-yellowish, close-grained. Branchlets often thinly grey-velvety, sometimes from the beginning glabrous, occasionally glandulartuberculate. Petioles semiterete, narrow-margined, sometimes cliannelled, often obscurely velvety, generally between $\frac{3}{4}$ and $1 \frac{1}{4}$ inch long, extending occasionally to the length of 2 inches, whilst in small-leared varieties it becomes much shortened. Leaflets generally from $1 \frac{1}{2}-3$ inches long, attaining, however, the length of 6 inches in luxurious specimens, shortened to a length of less than $\frac{1}{2}$ inch in stunted specimens grown in exposed highland situations, dotted with more or less pellncid oil-glands, occasionally also somewhat tuberculated, glabrous and somewhat shining rarely thin-velvety above, fiequently covered with an exceedingly thin grey velvet beneatl, although occasionally on both sides quite glabrous, keeled with a somewhat prominent midrib, producing very divergent towards the margin anastamosing veins. Primary peduncles in most cases not much longer than the petioles, cylindrical, bearing a decompound cyme generally fiom 1 to a few inches long with numerous flowers, occasionally, however, in meagre specimens furnishing a simple ferflowered cyme. Pedicels more frequently shorter than longer than the flowers. Bracts lanceolate or linearlanceolate or canaliculate-linear, acute, 1-4 lines long, in one variety early dropping, in another rnther long persistent. Bracteoles $\frac{1}{2}-2$ lines long. Sepals $\frac{1}{2}-1 \frac{1}{4}$ line long. Petals brond lanceolate-suborate, verr shortunguiculate, terminated with a minute point, one-nerved, valvate in præeflorescence. Filanents white or pale-pink, filiform, minutely glandulous at the apex, rarely scantily puberulous. Anther's pale, cordateroundish, in large-flowered varieties nearly $\frac{1}{2}$ line long, in small-flowered varieties only $\frac{1}{4}$ line or even less long. Pollen-grains orange-colored, orate, smooth. Style green, filiform, $\frac{1}{4}-\frac{1}{2}$ line long. Stigma broader than the style, smooth, greenish. Disk divided to the base into four half-round smootll purplish or pink fleshy turgid lobes, from which at the back the filaments arise. Carpels $11-2$ lines long, truncate, hardly apicnlate, one or the other frequently tabescent. Endocarp pale-yellowish, somewhat shinilig, nerveless. Seeds brown-black, oblique ovate, $2-1$ line long, one in eacli cell; if rarely two occur, then angular from mutual pressure. Placental membrane tender, whitish, triangular, closing the opening, which whilst the valves cohere is formed near the base of the internal angle of the endocarp. Albumen copions. Embryo very slender, cylindrical, nearly as long as the albumen.

The forms which, under varied circumstances, this plant is capable of assuming are singularly discrepant, but become confluent by numerous mediating stages of the species. A small-leaved ererywhere downy variety, to be found near Port Jackson, accords witl the clefinition of Z. cytisoides. A few-flowered variety is known fiom various parts of Eastern Australia, in which state the calyx is very small and the petals are reduced to the length of 1 line, whilst the narrow bracts remain long pcrsistent. Another singrular variety, with dense velvety indument in all parts, even in the fruit, with a more agreeable strong aromatic scent and densely tuberculate branches, was bronght fiom the forest-gullies of the Hastings River by $\mathrm{D}_{1}$. Beckler. Even B. granulata seems to be only an extreme state of this plant with linear leaves, which are prominently dotted, whilst the branchlets bear copiously a glandular grannlate secretion. Another variety collected on 
the Upper Clarence River and on the highlands of New England bears great similarity to B. hirsuta, and agrees closely with Sir Will. Hooker's note on Z. Fraseri in Sir Th. Mitchell's Tropical Australia, p. 339. The true B. hirsuta (Zieria hirsuta, Cand. Prodr. i. 723) differs from the small-leaved few-flowered variety of B. arborescens in sepals much pointed and nearly as long as the corolla, and in carpels broad-ovate, almost roundish.

\section{Sect. II. OCTARRHENA.}

Sepaline and petaline stamens fertile; disk undivided.

Boronia parviflora, Smith, Tracts rclating to Nat. Hist.t. 5 ; Thansact. Linn. Soc. viii. 285; B. pilonema, Labill. Nov. Holl. Plant. Specim. i. 98, t. 126 ; Lam. Encycl. t. 944; J. Hook. Fl. Tasm. i. 66.

Suffruticose, small; leaves narrow- or oblong- or obovate-lanceolate, flat, subsessile, entire or indistinctly crenulated, as well as branches, pedicels and bracteoles glabrous, opaque; pedicels terminal and axillary, frequently solitary, occasionally two or three together, as long as or often shorter than the flower, much thickened towards the apex, generally provided near the base with two lanceolate or linear foliaceous bracteoles; sepals ovate-lanceolate, ncarly as long as the small outside glabrous corolla, seldom longer, inward shightly downy; filaments glabrous or slightly hairy, less than half as long as the petals, all fertile, hardly or distinctly glandulous and tumescent at the apex; anthers without appendage, glabrous, subcordate; style very short, as well as the ovary glabrous; stigma minute, subcapitate; disk short, undivided; carpels nearly as long as the sepals; endocarp at the junction of the valves without prominent tooth; seeds small, shining-black, smooth; cotyledons shorter than the radicle.

In heathy and sandy moors at Port Albert, towards Wilson's Promontory and near Cape Liptrap; extends also to Tasmania and to New South Wales, northward at least as far as the Hastings River, where it was collected by Dr. Beckler.

One of the smallest species of the genus, from a few inches to about 1 foot long, erect, diffuse or quite prostrate, already hearing flowers in the first year of growth, then having the appearance of an annual plant. Root subcylindrical, tortuous, emitting more or less stout or slender fibres. Stems terete, simply or repeatedly almost dichotomously branched. Leaves somewhat fleshy, green or not rarely tinged with purple, very faintly one-nerved, not conspicuously veined, $\frac{1}{3}-1$ inch long, tapering generally into a very short petiole. Bracteoles quite foliaceous or at the margin membranous, $1 \frac{1}{2}-6$ lines long, $\frac{1}{2}-1$ line broad, in some instances not discernible from leaves. Pedicels $1 \frac{1}{2}-6$ lines long, when short assuming a clavate shape and forming almost an attenuated base to the calyx. Sepals $2-2 \frac{1}{2}$ lines long, often obscure-purplish, valvate in restivation, persistent, slightly spreading, neither ciliate nor at the margin truly membranous, sometimes broad-ovate, always pointed. Petals slowly dropping, imbricate in restivation, subovate; generally short-acumináte, whitish or pink, inside very finely but imperfectly downy, tapering into a very short unguis, tinged along the middle with green purple or even orange color. Sepaline stamens not much longer than the rest. Filaments all linear-subulate, white or pink, scabrous towards the summit with minute glands, or through the copious increase of glands swelling near the top, or in rare instances quite devoid of glands, bearing the anther at the inward-bent short pointed apex, inserted outside the very low glabrous slightly repand hypogynous ring. Anthers $\frac{1}{4}-\frac{1}{5}$ line long, yellow at first orange, dorsifixed below the middle, terminated by a scarcely perceptible white point. Pollen-grains smooth, ellipsoid, with longitudinal slits. Stigma hardly broader than the style, with no very distinct furrows, convex. Carpels $1 \frac{1}{2}-2$ lines long, subtruncate, oblique-ovate, with a very minute point. Endocarp whitish, veinless, thin-cartilaginous. Seeds about $\frac{2}{3}$ line long, broad-subovate, slightly compressed. Raphe to about one-third of the length of the seed turgid and brownish. Testa brittle. Embryo almost as long as the albumen. Radicle at least twice as long as the cotyledons, straight. 
The examination of a considerable series of Tasmanian, Victorian and New South Wales specimens of this plant proves the characteristics pointed out by Labillardière as distinguishing B. pilonema from B. parviflora to be of no permanent avail. Nevertheless, the stamens are in general lairless and the petals white in the Tasmanian and Victorian plant, whereas in the East Australian specimens the filaments appear frequently scantily hairy, whilst the petals attain a pink color. The great length of the sepals in proportion to the petals render's B. parviflora from most others at once discernible, although that note cannot implicitly be relied on, being; for instance, variable in B. rhomboidea, a plant from the Alps of Tasmania, very closely allied to our here described species, although habitually very distinct.

Boronia polygalifolia, Smith, Tracts relating to Nat. Hist. t. 7; Transact. Linn. Soc. viii. 285; Rcom. Archiv. iii. t. 3; B. tetrathecoides, Cand. Prodr. i. 722; B. anemonifolia, All. Cunn. in Field's Nen South Wales, 330 (not Paxt. Magaz. ix. 123); B. hyssopifolia, Sieber, according to Spreng. Syst. Veg. cur. post. 148; J. Hook. Flor. Tasm. i. 66; B. nana, Hook. Icon. Plant. t. 270; B. bipinnata, Lindl. in Mitch. Trop. Austr. 225; B. dentigera, F. MI. in Transact. Vict. Inst. i. 32.

Suffiuticose or shrubby; leaves simple, linear- or oblong-lanceolate, rarely subovate or linear, entire, almost flat, subsessile, or ternate or biternate and petiolate, with oblong- or linear-lanceolate entire or cuneate or linear-cuneate frequently upwards three-toothed or trifid rarely obovate rhomboid or linear teethless leaflets, rarely impari-pinnate bijugate; pedicels axillary rarely terminal, solitary rarely geminate or ternate, shorter seldom longer than the leaves, very rarely cymose, near or below the middle provided with two semilanceolate bracteoles; sepals rhomboid- or semilanceolate-ovate, half as long as the pint glabrous or outsicle slightly downy corolla or twice or thrce times shorter; filaments all fertile, ciliate, minutelyglandulous at the summit; anthers small, glabrous, appendiculate; style short; stigma small, at last quadrifid; disk repand; carpels about three times longer than the calyx; valves of endocarp protracted at the junction into a deltoid tooth; seeds rather large, opaque, rongh; cotyledons nearly as long as the radicle.

As well in moist moory swamps or alpine localities as in dry forest land or on arid stony or scrubby ranges or on sandy ridges not rare; for instance, on Mount Korong, the Grampians, the Pentland Hills, the Buffalo Ranges, the Ovens River, Mayday Hills, Broken River, Delatite, the subalpine summit of Mount Ligar, the Avon Ranges, La Trobe River, McCrae's Island. In South Australia as yet only found in the Stringybark Forest, between Mount Lofty and the Onkaparinga River. In East Australia noticed near Botany Bay, in the Blue Mountains, on the higher elevations of New England, on Mount Mitchell, the Hastings River, near Moreton Bay, on the Burnett River and in $18^{\circ}$ S.L. on the Newcastle Range, and according' to Sir 'Th. Mitchell on the Salvator River. In Tasmania and on some of the islands of Bass's Straits rather abundant.

One of the most variable species of the vegetable kingdom, being equally able to endure the frosts of the Alps and the sirocco of the lowland, equally adapted to the insular cool climate of Tasmania and the tropical climate of North-Eastern Australia. A neat plant, erect or ascendent or prostrate, glabrous or downy, from a few inches to several feet high, producing generally from each root many more or less stout or slender stems. Branches few or copious, slightly angular. Leaves generally shining, sometimes prominently dotted, affording notes for subdividing the species into three varieties; those of the simple-leared variety deroid of a distinct petiole, $2-15$ lines long, $2-3$ lines broad, coriaceous or subcoriaceous, not much paler sometimes of cqual color beneath, flat or recurved at the margin, almost constantly acute. Leares of the trifoliolatc variety consisting of three leaflets similar to single leaves, borne on a common petiole, which is generally about lialf sometimes fully as long' as the leaflets, channelled, linear, rarely wedge-shaped; they are generally less than $\frac{1}{2}$ inch long, sometimes reduced to $\frac{1}{8}$ inch in length, sometimes thick coriaceous, sometimes more chartaceous, flat or concave above, hardly ever recurved at the margin unless in age. All gradations between this variety and the preceding one are perceptible on specimens collected at the Delatite, 
the different forms of leaves not only of these but also of the following variety occurring occasionally on the same stems. Leaflets of the variety with bi-ternate leaves alike to those of the trifoliolate variety, provided with a common and with special petioles of nearly equal length; tlie lateral petioles become, however, occasionally suppressed and then their leaflets single, by which means impari-pinnate bijugate leaves are formed. In rare instances the biternate leaves become still further enlarged by ulterior divisions, rendering the leaf decompound. Pedicels 1-7 lines long, generally axillary, in the foliolate varieties terminating occasionally the branchlets, when the ternate and often diminutive leaves may be regarded as bracts, bearing their bracteoles, which are $\frac{1}{2}-1$ line long, seldom above the middle sometimes close to the base, generally rather stout and thickened towards the calyx, when ternate borne on a short peduncle, which is at the apex bibracteate, when alar very rarely disposed by the suppression of the floral leaves in a regular cyme. Sepals $\frac{2}{3}-1 \frac{1}{4}$ line long, participating in the smoothness or to some extent in the hairiness of the leaves, however, inside glabrous, acute or short-acuminate, but slightly membranous at the margin. Petals imbricate in restivation, sessile, broad- or lanceolate-ovate, inside always glabrous, generally $2-3$ lines long, in a smallflowered variety hardly exceeding 1 line. Filaments linear-filiform, 1-1 $\frac{1}{2}$ line long, in the small-flowered for'm only $\frac{1}{2}$ line long, bearing the anther at the inner face of the blunt more or less incrassate yet not clubshaped apex, not drawn out into a distinct lateral bristle, neither in any instance quite glabrous, although their white and generally dense downs are occasionally confined to the lower portion. Anthers ovate-cordate, $\frac{1}{6}-\frac{1}{3}$ line long, blackish or dark brown at the back, terminated into a minute small point or a more or less straight or recurved beak, which even occasionally bears one or more very minute bristles or a minute beard; the appendage never entirely imperceptible. Pollen yellow. Style glabrous or less commonly clothed with dense spreading downs, four-furrowed, twisted in age. Stigmas minute, coherent into one, or more or less separated from each other. Ovary almost constantly glabrous. Carpels oblique-ovate, rounded-blunt, $1 \frac{1}{2}-3$ lines long. Endocarp pale straw-colored, veinless; its tooth at the sinus sometimes almost obliterated. Placental membrane white, very tender, deltoid- or lanceolate-ovate, pointed, often 1 line long. Funicles 2 , very short, in juxtaposition. Seeds oblique-ovate, hardly or slightly compressed, with more or less prominent

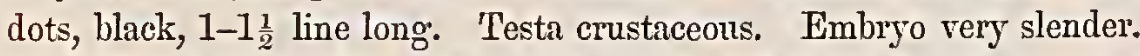

The characteristic of this species as offered in the foregoing pages rests on the examination of about 60 specimens from different localities and in varied stages of development. The suffruticose variety resembles B. parviflora.

Boronia pinnata, Smith, Traets relating to Natural History, p. 290, t. 4 ; Andr. Bot. Repos. $t$. 58; Venten. Malmais. t. 38; Loddig. Bot. Cabin. t. 473; Rom. Arehiv. iii. 3; Adr. de Juss. in Mém. du Musérm, xii. t. 22, f. 26; Bot. Mag.t. 1763; Maund's Botanist, ii. t. 99; B. pilosa, Labill. Nov. Holl. Plant. Specim. i. 97, t. 124; B. variabilis, Hook. Joum. Bot. i. 255; Compan. to the Bot. Mag. i. 277 ; B. tetrandra, J. Hook. Journ. of Bot. i. 118; Iindl. \& Paxt. Flower Garden, t. 8; B. anemonifolia, Paxt. Mag. of Bot. ix. 123; B. Fraseri, Hook. Bot. Mag. t. 4052; B. Gunnii, J. Hook. Fl. Tasm. i. 68; B. citriodora, Gunn, in Fl. Tasm. i. 68.

Shrubby, leaves impari-pinnate, petiolate, with from 2-6 rarely 1 pair of entire narrow- or ovate- or linear-lanceolate or linear, rarely ovate, flat, seldom linear-subulate leaflets; rachis channelled, wingless; pedicels axillary and terminal, solitary, twin, ternate or cymose, about as long as or longer rarely shorter than the flowers, bibracteolate; petals several or many times longer than the deltoid- rarely subulatesemilanceolate glabrous sepals, rarely less than double as long, finely downy inside and at the outer margin; stamens 8, all fertile; filaments ciliated, very rarely hairless, always glandulous, verrucose at the apex; anther's without appendage, glabrous, cordate or oblong-ovate, borne on a very short stipes ; ovary pyramidateor globose-orate, glabrous; style short, seldom obliterated; stigma minute, undivided; carpels shorter than the petals, oblique-ovate; endocarp at the junction of the valves toothless; seeds. shining-blaek, smooth; embryo shorter than the albumen; radicle twice as long as the cotyledons. 
In deep forest ravines at the sources of the Bunyip River, in the Grampians ascending to the subalpine summit of Mount William, also in heath ground near Portland Bay and towards the mouth of the Glenelo River. Also known as indigenous to the south-eastern parts of New South Wales; dispersed over the whole of 'Tasmania and some of the isles of Bass's Straits.

A glabrous or spreading-downy generally robust slnub, often several feet high, exceeding occasionally the height of 6 feet, sometimes quite diminutive only $\frac{1}{2}$ foot high, and diffuse or even prostrate, flowering already in the second year of growth. Branchlets angular, often tinged with red, sometines slightly warted. Petioles from $\frac{2}{3}$ line to $\frac{2}{3}$ inch long. Rachis varying, according to the number of leaflets, in length from a very few lines to $1 \frac{1}{2}$ inch, with joints $\frac{2}{3}-4$ lines long. Leaflets $\frac{1}{4}-1$ inch long, $\frac{3}{4}-4$ lines broad, hardly paler beneath, acute, not rarely a little recurved at the margin, shining, one-nerved, generally coriaceous, but when the plant grows in damp shaded valleys chartaceous, the glands then very pellucid, and in heath ground on exposed places sometimes very narrow, assuming a linear-subulate shape. Peduncles 1 inch long or shorter as well as the pedicels brown-red, angular, provided at the summit -with two semilanceolatesubulate bracts, which are about 1 line long. Pedicels thickened upwards, provided at the base of the upper joint witl two bracteoles similar to but often much smaller than the bracts, their lower joint, which in many instances is undeveloped, forming a secondary peduncle. Flowers sweet-scented. Sepals $\frac{2}{3}-1$ rarely $1 \frac{1}{2}$ line long, appressed as in most species. Petals slightly imbricate in restivation, with generally broad base, sessile, blunt or acute or even sliort-acuminate, $2 \frac{1}{2}-4$ rarely only $1 \frac{1}{2}$ lines long, lanceolate- or broad-ovate or' exactly lanceolate, seldom white, finally deciduous. Sepaline stamens scarcely longer than the petaline ones. Filaments $I_{\frac{1}{2}}-2 \frac{1}{2}$ rarely only $\frac{3}{4}$ lines long, hear-filiform, often densely sometimes scantily hairy; very seidom quite devoid of hair, but always in their whole length dispersed with glands. Anthers $\frac{1}{5}-\frac{1}{2}$ line long, sulphur-colored, glabrous. Pollen-grains smooth, ovate. Ovary pyramidate-ovate, tapering into a very short and stout style, or globose-ovate and suddenly terminated by an often longer and more slender filiform style, which is accasionally hairy or undeveloped, never exceeding the length of $\frac{2}{3}$ line. Stigna truncate or depressed capitate, hardly or distinctly broader than the style. Disk short, entire, convex. Carpels about $1 \frac{1}{2}-2 \frac{1}{2}$ lines long, cuneate- or quadrate-ovate, rather compressed, sometimes minutely rostrate. Endocarp slining, nerveless, livid. Placental membrane navicular-lanceolate. Seeds hardly 1 line long, oblique-ovate, often two contained in each carpel. Embryo somewhat shorter than the albumen, according to Fitch's figure in Flora Tasm. sometimes less than half as long:

B. citriodora (Gunn, in J. Hook. Fl. Tasm. i. 68) seems, notwithstanding its strong almost lemon-like scent, to belong, as far as can be ascertained from diagnosis, to this species.

If only the end forms of this polymorphous species are noticed, it will be deemed highly improbable that they should not form distinct species; yet the review of a long series of specimens on this occasion rendered the attempt vain to segregate them under specific distinctions. The ordinary variety, alike to the Port Jackson plant, occurs on the Bunyip and Genoa River. Forms, exactly resembling the B. pilosa, are to be found in the Grampians, particularly on the higher parts of Mount William. A variety with small narrow crowded almost subulate leaflets occurs on the heatls near Portland and at the entrance of the Glenelg. River. Trifoliolate leaves of this species, interspersed with the pinnate ones, are formed merely by the want of more than one pair of lateral leaflets, whilst pinnate bijugate leaves of B. polygralifolia are formed by the suppression of certain leaflets and secondary petioles of a normally biternate leaf. The anthers of B. Fraseri are according to the figure above quoted occasionally appendiculate. Boronia algida (F.M. in Transact. Phil. Soc. Vict. i.100), occurring on the bushy declivities of Mount La Trobe, Nount Hotham, Mount Cosciusko, and other high ranges, may be only an alpine state of B. pinnata; its fruit is unknown; the leaflets are very small, obovate- or obcordate-cuneate, the flowers provided with but very short pedicels, and the filanents are hairless. B. microplyylla (Sieber, in Sprengel cur. post. 148), from the Blue Mountains, stands in close relationship to $\mathbf{B}$. algida, from which it only differs in leaves witl several pair of leaflets, in hairy filaments, and possibly in fruit. 
Boronia clavellifolia, F. M. in Transact. Phil. Soc. Vict. i. 12; Fragm. Phytogr. Austr. i. 99.

Shrubby, glabrous, seldom finely downy; branchlets generally tuberculate, almost cylindrical; leaves short-stalked, impari-pinnate, with one rarcly two pair of very small blunt clubshaped-filiform or nearly cylindrical leaflets; pedicels axillary and terminal, solitary, binate or ternate, shorter than the flowers, bracteolate; petals less than twice as long or several times longer than the ovate-rhomboid ciliate sepals, nearly glabrous; stamens 8 , all fertile; filaments hairless, glandulous, thickened at the apex; anthers apiculate, pale, borne on a short stipes; style short, slender, glabrous ; stigma minute, undivided; carpels somewhat shorter than the petals; endocarp at the junction of the valves almost toothless; seeds smooth, dark-brown, opaque.

In the sandy desert towards Lake Lalbert; in various localities in the Mallee Scrub of South Australia near the Mrurray River; in Western Australia around Middle Mount Barren, near the Phillips Ranges, and on the Gardiner River, extending probably also through the intervening desert country.

A low shrub witl many spreading branches. Petioles $\frac{1}{2}-1 \frac{1}{2}$ line long, as well as the rachis when developed channelled-semicylindrical. Leaflets shining, 1-3 rarely 4-5 lines long, about $\frac{1}{2}$ line thick, beneath towards the base often with an indistinct furrow. Pedicels $\frac{1}{2}-1 \frac{1}{2}$ line long, not only provided with two ciliolate complicated subovate bracteoles of about $\frac{3}{4}$ line length, but often also at or near the base with similar bracts. Sepals $\frac{2}{3}-1$ hine long, greenish, glabrous or slightly downy at the back. Petals $2-4$ lines long, rose-colored, lanceolate-ovate, rather acute, imbricative in preflorescence, slightly or imperfectly downy inside and at the margin, with broad base, sessile, long persistent. Filaments about 1 line long, alternately somewhat shorter, smootl towards the base, beset with minute whitish papillæ towards the top. Anthers about $\frac{1}{4}$ line long, cordate, protracted into a pale straight blunt or acutish apex. 'Pollen-grains yellow. Ovaries smooth, soon disconnected. Style terminated by a depressed-capitate stigma. Disk short, entire. Carpels $1 \frac{1}{2}-2 \frac{1}{2}$ lines long, oblique-ovate, pointed by a very minute rostellum. Endocarp shining; nerveless, pale-yellow. Placental membrane minute, ovate, acuminate, very tender. Seeds oblique-ellipsoid, generally rather longer than 1 line, one or two in each carpel. Testa brittle, thin. Embryo in the few seeds available for examination not well developed.

B. brachyphylla (F. M. Fragm. Phyt. i. 99) bears in habit and appearance a complete resemblance to B. clavellifolia, and may indeed be only a variety; it differs in subsessile leaves, lanceolate-subulate sepals, fringed filaments, cornute anthers, a thin-conical puberulous style, and perhaps in fruit. Its identity with B. oxyantha (Turcz. in Bullet. de Moscou, 1852) can according to diagnosis scarcely be doubted. Both B. leptophylla and B. inornata (Turcz. 1. c.) may be the same as B. clavellifolia, but are not clearly to be recognized from published descriptions. If identical they may be combined under the name here adopted.

Boronia coerulescens, F.M. in Transact. Phil. Soc. Victor. i.p.11; Cyanothamnus tenuis, Lindl. Swan River Botany, 78.

Suffruticose; branchlets cylindrical; leaves simple, small, sessile, linear- or oblong-semicylindrical, channelled, blunt, entire, rarely rhomboid- or ovate-cuneate, often beneath tuberculate, sometimes threetoothed or oleft into three linear-oblong lobes; pedicels axillary and terminal, solitary, as long as or shorter than the flowers, bibracteolate; petals bluish, rarely white, veined, nearly twice or thrice as long as the rhomboid-or ovate- or narrow-semilanceolate sepals; stamens 8, all fertile; filaments linear-subulate, ciliated, straight at the apex; anthers conspicuously terminated with a white ellipsoid or ovate appendage; style short, filiform; stigma minute, quadrate-hemispherical; disk very depressed, entire; carpels at least onethird shorter than the corolla; endocarp at the junction of the valves protracted into a deltoid tooth; seeds opaque, black, rough; radicle as long as the cotyledons.

In the desert tracts along the Murray River and its lower tributaries, chiefly in sandy soil, also on sterile plains at the foot of the Grampians; in South Austrakia on the sandy coast of Guichen Bay and Cape Jaffa, and near St. Vincent's and Spencer's Gulf; in Western Australia, according to Oldfield, near the South 
Hutt River, and thence known to exist eastward as far as East Mount Barren; but most probably also scattered over the country inland along the Great Australian Bight.

A singular species, like all those of wide distribution, subject to multifarious variations, producing flowers already in the first and second year of growth, and thus assuming the appearance of an herbaceous plant, resembling more an Eriostemon than any of its congeners. Root livid, perpendicular, after some years' growth stout, flexuose, in seedling specimens filiform and generally undivided. Stems erect or ascending, from a few inclies to a few feet long, generally slender and towards the base quickly denuded of leaves, opposite-branched, unless simple in smaller specimens, not less frequently, together witl the leares, pedicels and calyces, velvet-downy than glabrous. Leaves of thick more herbaceous than coriaceous consistence, from $1 \frac{1}{2}-8$ lines long, generally from $\frac{1}{2}-1$ line broad, occasionally more dilated, often erect, never very much spreading; the lobes, when produced, similar to diminutive leaves. Pedicels 1-3 lines long; with two bracteoles, which resemble small leares, and are generally oblong or oval and $\frac{3}{4}-2$ lines long. Sepals 1-2 lines in length, oftener blunt than acute, appressed as in most species. Petals membranous, long persistent, convolute-imbricate in estivation, not so much spreading as those of many other species, downy along the outside prominent midrib or perfectly smooth, broad- or rhomboid- or orbicular-ovate, $2-4 \frac{1}{2}$ lines long, blunt and generally apiculate, throughout or partially tinged with blue of a dark or pale shade, often greenish towards the midrid, slightly attennated yet hardly unguiculate at the base. Filaments $\frac{3}{4}-1 \frac{1}{2}$ line long, more or less glandulous at the apex; the sepaline ones a little longer than the rest. Anthers pale, $\frac{1}{3}-\frac{1}{2}$ line long, ovate-cordate, fixed above the base; their white appendage somewhat turgid, blunt and rather variable in size. Pollen yellow. Ovary glabrous. Style $\frac{1}{2}-1$ line long, glabrous or towards the base downy, split into its four component parts after anthesis. Stigma somewhat broader than the style, depressed. Carpels 2-3 lines long; oblique-ovate, blunt. Endocarp yellowish, nerveless, with a small basal tooth. Placental membrane cordate-deltoid. Seeds $\frac{4}{5}-1 \frac{1}{2}$ line long, black, opaque, subreticulate-asperous, as in most species more turgid towards the base. Testa crustaceous. Embryo cylindrical, generally nearly as long as the albumen, in rare instances only half as long.

Cyanothamnus ramosus (Ldl. Swan Riv. Bot. 78), from which C. anethifolius and C. tridactylites appear not to be specifically distinct, seems according to its brief diagnostic note only to be a state of $B$. cortulescens with biternate leares, analogous to the corresponding variety of $B$. polygalifolia.

\section{ERIOSTEMON.}

Smith, in Transact. Linn. Soc. viii. 285.

Calyx five-toothed or five-cleft or consisting of five sepals, very rarely four- or six-cleft, imbricate in rstivation, persistent, rarely obliterated. Petals 5 , rarely 6 or 4 , sessile or short-unguiculate, imbricate or valvate in præflorescence, persistent or deciduous. Stamens 10 , very rarely 12 or more, all fertile, those opposite the petals shorter. Filaments free or seldom coherent, linear- or lanceolatesubulate or filiform, very rarely subclavate, generally straight at the apex. Anthers dorsifixed or basifixed, with longitudinal dehiscence. Ovaries 5, rarely 3 or 2 , inserted on an undivided disk. Ovules affixed to the interior angle of the ovary; the upper one ascendent, the lower one descendent. Styles united into one. Stigmas entirely or partially connate, rarely free. Carpels 5 or seldom normally 2 or 3, bursting along the internal edge, 1- or 2-seeded. Endocarp cartilaginous, biralved, operculate towards the base by the placental membrane. Seeds oblique-ellipsoid or subovate. Testa crustaceous. Embryo cylindrical, placed in the axis of the copious albumen. Radicle longer than the plane-convex cotyledons or nearly as long.

Strong-scented shrubby rarely suffruticose or arborescent plants, rather numerous in extratropical Australia, not rare in Tasmania, scarce in tropical Australia and New Zealand, glabrous or lepidate or 
clothed with starry hair, sometimes rough from prominent glands; the indument not very variable in the species. Leaves all alternate or fasciculate, constantly simple. Pedicels variously bracteolate, solitary, geminate, ternate, corymbose or umbellate, rarely racemose or (in Chorilæna) cymose. Petals generally longer than the calyx, white, pink, yellow, rarely blue or dark-red or green, spreading, sometimes connivent. Filaments smooth or hairy, seldom glandulous-tumescent at the apex, longer or shorter than the corolla. Anthers usually subcordate, with or without an appendage. Carpels blunt or rostrate. Placental membrane usually ovate, acuminate. Seeds frequently black-Crowea, Sm. in Transact. Linn. Soc. iv. 220; Phebalium, Venten. Malm. n. 102 ; Chorilæna, Endl. Enum. Pl. Hueg. 17; Microcybe, Turcz. in Bullet. ILosc. 1852; Geleznovia, Turcz. l. c. vol. xxii. 2, 12 ; Asterolasia, F. MI. in Transact. Phil. Soc. Vict. i. 9 ; Sandfordia, S. Drumm. in Hook. Kcw. Misc. vii. 53 ; Urocarpus, S. Drumm. l.c. 54.

It has been a subject of much enquiry and reflection of the author, in what manner the beautiful plants constituting the genera Eriostemon, Phebalium, Philotheca, Crowea, Urocarpus, Microcybe, Chorilæna, Asterolasia, Geleznovia, Sandfordia, Drummondita, should find their most natural arrangement; for they are linked together by so close affinity that only a solitary character or the combination of few uncertain notes distinguish them, the formerly adopted limitations having in most instances by the access of novel species been annihilated. It has been regarded therefore on this occasion as advisable to congregate the whole under Eriostemon, although this generic name agrees only with part of the species. The distinction from Boronia is through the Tasmanian E. virgatus, which produces flowers with four-cleft calyx, four petals, and eight stamens, reduced solely to the disposition of leaves, which are in Eriostemon never opposite, and in Boronia never all alternate, although, particularly in the division Zieria, some of the upper leaves are alternate. The subgenus Cyanochlamys, adopted by Bartl. (Lehm. Pl. Preiss. i. 171), comprises only a few South-West Australian species remarkable for blue flowers, including E. spicatus, Rich. (E. effusus, Turcz.).

Whether E. corymbosus (Lab. Sert. 58, t. 58), from New Caledonia, really belongs to this genus remains, although it shows considerable resemblance to E. squameus, to be ascertained, since in the otherwise excellent figure and description quoted neither mention is made of the embryo nor of the nature of the endocarp. Beyond the cymose inflorescence and the curious foliage, which reminds of Lasiopetalaceous plants, nothing remains to separate Chorilæna from Eriostemon, inasmuch as the large sepals of Eriostemon phylioides render the analogous character in Chorilæna of no avail.

Diplolæna differs from Eriostemon chiefly in the inflorescence, in its scale-like petals, and in the development of a floral involucre consisting of bracts and bracteoles; by the suppression of the calyx it is not distinguished, since the subgenus Asterolasia is likewise devoid of the calycine envelope. The D. Dampierii, of which D. grandiflora seems a mere variety, was brought from the vicinity of the Murchison River by Mr. Aug. Oldfield.

Sect. I. Crowea.

Leaves glabrous. Pedicels axillary, solitary. Sepals small, blunt. Petals persistent, generally red or white, convolute-imbricate in æstivation. Stamens shorter than the corolla. Filaments fringed, free or coherent. Anthers terminated by a bearded long appendage. Stigma simple.

تriostemon Growei.-Crowea saligna, Smith, in Transact. Linn. Soc. iv. 220; Andr. Bot. Rep. ii. t. 79 ; Loddig. Bot.Cabin.t. 310 ; Bot. MLagaz.t.989; Ventenat, ILalmais. t. 7; Adr. de Juss. in Mém. du Mus. xii.t. 21; Trattin. Thesaur. Botan. t. 70; Reichenb. Flor. Exotic.t.152 ; C. latifolia, Paxt. Mag. xiv. t. 22; Morren, Annales de Gand, 1848, t. 10; C. exalata, F. M. in Transact. Phil. Soc. Vict.i. 11. 
Branchlets acutangular; leaves subcoriaceous, glabrous, broad- or oblong-linear or lanceolate, rarely ovate, entire, flat or narrowly recurved at the margin; pedicels axillary, solitary, robust, shorter than the flower, minutely bracteolate at the base; sepals broad-or orbicular-ovate, ciliate, many times shorter than the glabrous usually red corolla; filaments coherent, ciliated, shorter than the petals; anthers terminated by a long densely bearded appendage, erect; style downy, exceedingly short; stigma undivided, broader than the style; ovary glabrous; carpels hardly half as long as the sessile persistent petals, oblique-ovate, blunt; valves of the endocarp dilated above the middle; seeds black, somewhat shining, imperfectly wrinkledtuberculate; cotyledons barely half as long as the radicle.

On the subalpine summit of Mount McFarlane, near Omeo; on the gravelly banks of the Mitta Mitta, the Livingstone and Genoa River, and on the Boggy Creek towards Lake King; thence extending into New South Wales, where it is observed at the Womboyn and Yowaka River and in the vicinity of Botany Bay.

A slurub varying in height from 1-6 feet, erect or somewhat spreading, many branched, resembling certain Boronias. Branches terete. Branchlets indistinctly or prominently acutangular, slender or robust, sometimes with decurrent wing-like edges, quite glabrous or seriate-downy. Leaves tapering gradually into the sessile or short-stalked base, alternate or under imperfect development of branchlets almost fasciculate, shining on both pages, blunt or acute, minutely apiculate, paler beneatl, $\frac{1}{2}-2 \frac{1}{2}$ inches long, $\frac{3}{4}-6$ lines rarely 1 inch broad. Pedicels 1-4 lines long, thickened towards the apex, five-furrowed, at the base provided not only with a pair of bracteoles but also often with a pair of very minute almost ovate bracts. Bracteoles linearoblong" or ovate or even roundish, generally less than 1 line long, sometimes $1 \frac{1}{2}$ line in length, tender, puberulous. Sepals ovate or round-ovate, very blunt, appressed as is usually the case with those of Eriostemons, from $\frac{3}{4}-1 \frac{1}{2}$ line long. Petals sessile, oblong- rarely broad-oval, 3-7 lines long, saturate or sometimes pale red, or partially, rarely entirely, green or whitish, far less spreading than those of most species of Eriostemon, indeed almost connivent into a cylindrical-campanulate corolla, glabrous, of rather firm consistence, faintly nerved and veined. Stamens less variable in size than the corolla, thus sometimes in small-flowered varieties more than half as long as the petals, in large-flowered varieties contrary often considerably less than half as long as the corolla. Filaments linear, narrower upwards, usually red, 1-1 $\frac{1}{2}$ line long. Anthers with introrse dehiscence, yellow, about $\frac{1}{2}$ line long; protracted into a linear-subulate inward and at the margin whitebearded appendage, which varies in length from $\frac{1}{2}-1$ line, and is finally recurved. Pollen-grains egg-shaped, smooth, bursting witl a longitudinal fissure. Disk very depressed, entire, surrounding the base of the orary. Stigma dark, hemispherical or semiovate, with five longitudinal furrows. Carpels generally measuring 2-3 lines in length. Valves of the endocarp yellowish, ribbed by transverse arcuate nerres, connate at the concare toothless base. Placental membrane broadly cymbiform- or 'rhomboid-ovate, nearly $I$ line long, white. Seeds oblique-ovate, turgid, generally about $1 \frac{1}{2}$ line long. Testa thin-crustaceous. Embryo very slender.

Three varieties of this species may be distinguished, of which only the one with narrow blunt leares, slender faintly angular branchlets, and generally smaller flowers, formerly distinguished as C. exalata, has as yet been found in Victoria. The normal variety, C. saligna, with lanceolate leaves and acutely edged branchlets, occurs as well as the former near Port Jackson; the broad-leaved rariety, C. latifolia, has been collected by W. Woolls, Esq., at Manly Beach.

After the reduction of $\mathrm{C}$. exalata and C. Iatifolia to $\mathrm{C}$. saligna, only one species, partaking of the characters of Crowea, remains left, namely, the Eriostemon Thurczaninovii (Crowea angustifolia, Turcz. in Bullet. de Moscou, xxii. 2, 13), which is not less variable in the shape of its leaves. We possess it from the Franklin River and a few other localities of South-Western Australia. It differs widely from Eriostemon Crowei in either faintly or argutely dentate leaves, which vary from a narrow-linear to a lanceolate-orate form and are of thinner consistence, in less distinctly ciliate sepals, in inside white, outside purplish thinner petals, in fiee generally longer filaments, in almost hastate versatile anthers, which are terninated by a broader less densely bearded and less acute appendage, in a long style and possibly in carpological characters. 
Already Adr. de Jussieu expressed his inclination to transfer Crowea to Eriostemon, its only distinction consisting in the long-bearded anthers.

The species nearest in affinity to $\mathbf{E}$. Crowei is unquestionably $\mathbf{E}$. salicifolius. It is not unlike it in stature, and occurs also both with narrow and broad leaves; the appendix of the anthers, although smooth and small in comparison to that of $\mathbf{E}$. Crowei, is nevertheless larger than in most congeners. The most marked character of this plant consists, however, in the imbricate bracts and bracteoles of the pedicels. Possibly this plant may yet be found in the eastern parts of Gipps Land. In Dr. Beckler's collection of plants from the Clarence River occurs a Rutaceons plant without fruits and well-developed flowers; the latter are terminal, crowded and seemingly umbellate, the leaves are oborate-cuneate, glabrous, minutely bilobed by a terminal notch, gnawed in front and from $\frac{7}{2}-\frac{3}{4}$ inch long; the branches are covered with a starry velvet. If this plant should prove referable to Eriostemon it may receive the name E. erosus.

The Eriostemon lanceolatus, Jos. Gærtn. Carpol. Suppl. 154, t. 210, fig. 6, seems almost with certainty referable to $\mathrm{E}$. salicifolius, the very characteristic imbricate bracts being well expressed in the plate above quoted.

\section{Sect. II. ERIonemia.}

Treaves often glandulous-rough, destitute of hair or scales. Flowers in most cases solitary. Segments of the calyx small. Petals usually deciduous, white, often tinged with pink, convoluteimbricate in æstivation. Stamens shorter than the corolla. Filaments fringed. Anthers terminated by a small glabrous appendage. Stigmas minute, coherent. Carpels generally rostrate.

Eriostemon trachyphyllus, F. M. in Transact. Phil. Soc. Vict. i. 99.

Tall, glabrous, dotted with prominent glands; leaves chartaceous, lanceolate- or cuneate-oblong, entire, flat, mucronulate, sessile, veined, paler beneath; pedicels, axillary and terminal, solitary, rarely twin and ternate, shorter than the leares, about as long as or longer than the flowers, minutely bracteolate at the base; segments of the calyx minute, roundish-ovate, ciliolated, many times shorter than the white outside glabrous deciduous petals; filaments ciliated, more than half or nearly as long as the corolla, glabrous at the base and apex; anthers minutely appendiculate; style capillary, glabrous; stigma minute, five-lobed; carpels blunt, Tongitudinally semiconnate into a roundish five-angular capsule, turgid, rhomboid-ovate, bursting along the inner and the upper part of the dorsal suture; valves of the endocarp deeply excised at the inner edge; placental membrane subcordate; seeds very shining, black and brown variegated; cotyledons shorter than the radicle.

On rocky declivities at the Snowy River near the Pinch River. In New South Wales on forest-rivulets amongst granite rocks near the sources of the Yowaka River.

A tall shrub, occasionally arborescent and then 12-15 feet high, pervaded by a strong somewhat aromatic scent. Branches numerous, more or less spreading, cylindrical. Branchlets somewhat angular, densely tuberculated. Leaves generally from $1 \frac{1}{3}-2 \frac{1}{2}$ inches long, from 3-5 lines broad, tapering from near the middle into an almost cuneate base, more blunt than acute, dark-green and somewhat shining above, considerably or not much paler beneath, with glands more prominent on the lower than on the upper page, the dots bearing rarely a minute tuft of stellate hair. Peduncles none. Pedicels from a few lines to nearly 1 inch long, comparatively slender, not so much thickened at the apex as in many other species, at the base provided with very small blunt ciliolated bracts and bracteoles, which vary considerably in shape. Segments of the calyx only about $\frac{1}{2}$ line long. Petals imbricate in æstivation, spreading, $2 \frac{1}{2}-3$ lines long, oblong-ovate, sessile, inside hardly visibly downy. Petaline filaments somewhat shorter than the others, $1 \frac{1}{2}-2$ lines long, all conspicuously downy, particularly towards the middle, narrowly linear-subulate. Anthers $\frac{1}{3}-\frac{1}{2}$ line long, ovate-cordate, oscillating, affixed between the lobes, terminated by a white blunt glabrous apex, and benring a gland below the tip. Pollen scarlet, consisting of ovate smooth longitudinally dehiscent 
granules. Style at least 1 line long, greenish, formed by the twisted coalescence of five. Stigma lobedcapitellate. Germen globular, consisting of five ovaries. Disk narrow, slightly repand. Carpels 5 rarely 6 in number, 3-4 lines long, glandulous-dotted, acnte at the back, remarkably blunt at the base, in age, with exception of the lower portion, which remains permanently concrete, separating from each other, the commissural part being livid, the fiee dorsal part brownish-green, splitting not only in their entire length along the inner angle, but also across the vertex. Endocarp pale-yellow, shining, nerveless, curled up as usual after ejecting the seeds, assuming, however, as in all congeners, its valvate shape when moistened, the base of both valves forming a saccate toothless cavity. Placental membrane very acute, about 1 line long and broad. Seeds abont 2 lines long, oblique-ovate, rather turgid. Embryo very slender, nearly as long as the albunen.

The coalition of the carpels distinguishes this plant from the following, to which it ranks next, and perhaps from every other species.

Bears flowers early in the spring:

Eriostemon myoporoides, Cand. Prodr. i. 720; E. cuspidatus, All. Cunn. in Field's New South Wales, 331 ; E. neriifolius, Sieb. in Spreng. Syst. cur. post. 164; E. lancifolius, Fr. M. in Transact. Vict. Inst. i. 32 .

Glabrous, dotted with prominent glands, glaucous, leaves large, narron- or oblong- rarely broadlanceolate, entire, flat, inucronulate, subcoriaceons, sessile; peduncles compressed, axillary and terminal, solitary, rarely twin, much shorter than the leaves, sometinies obliterated; pediecls stout, generally umbellate or one or a few lateral or basal, about as long as the flowers, minutely bracteolate at the base; segments of the calyx minute, deltoid-roundish, ciliolated, many times shorter than the corolla; petals white or ontside partially red, glabrous outward, deciduous; filaments ciliated, hardly half as long as the petals; anthers minutely appendiculate; style rather short, filiform, glabrous; stigma minute, lobed; ovary glabrous, conical; carpels fiee, compressed, ovate, rostrate; valves of the endocarp obliqne-cuneate; placental membrane linearlanceolate; seeds grey-brown, smooth, somewhat shining.

In the upper valleys of the Mitta Mitta; in ravines on Mount Hotham and Mount La Trobe; on the rocky subalpine summit of Mount Tambo and Mount Macfarlane, near Omeo; thence extending through a great part of eastern extratropical Australia, eastward at least as far as New England, and northward as far as the Glasshouse Mountains near Moreton Bay.

A beatiful odorous shinub of robust habit, not dissimilar to certain Myopormms, obtaining occasionally a height of 6 feet, frequently, however, more dwarf, possibly hardy in England. Branches after the lapse of the leaves thickly cicatrisate. Leaves mostly from 2-4 inches long, from 4-9 lines broad, more or less acute, rarely rounded-blunt at the apex, strongly one-nerved, faintly or indistinctly veined, nearly of equal paleness on both sides, opaque or pruinose. Peduncles generally considerably shorter rarely longer than 1 inch. Pedicels obtusangular, $3-9$ in each umbel. Bracteoles ciliolated, mostly semiovate or deltoid, about $\frac{1}{2}$ rarely 1 line long, forming a sort of small involucre at the base of the umbel. Segments of the calyx about $\frac{1}{2}$ line long, imbricate in astivation. Petals spreading, oblong-ovate, sessile, 3-4 lines long, of rather firm consistence, with exceedingly faint pubescence inside, imbricate in astivation. Filaments $1 \frac{1}{2}-2$ lines long, free, white, linear and short-fringed in their lower part, subulate-attenuated and longer-fringed upwards; the petaline ones somewhat shorter than the rest, also less pointed and their anthers later shedding the pollen, all bent inward over the ovary, which by their mutual close proxinity they conceal, divergent towards the summit. Authers ovate-cordate, with introlse dehiscence, fixed between their basal lobes, at first erect, later somewhat oscillating; their acumen narrow, white, glabrous; the cells abont $\frac{1}{2}$ line long. Pollen orangecolored; its grains ellipsoid, longitudinally slit. Style glabrous, about 1 line long, green, partly concealed by the pointed tops of the ovaries. Stigma formed by the coalescence of five, which are minute and blunt. Disk low and narrow, slightly undulate. Carpels $2 \frac{1}{2}-3$ lines long, attenuated into a hardly divergent subu- 
late beak, only bursting along the inner suture. Endocarp pale-yellow, nerveless, shining; in age entirely separating into its valves. Placental membrane white, tender, cymbiform, coinparatively narrow, but unusually long, measuring often nearly 2 lines. Seeds oblique ovate-ellipsoid, 2-21 lines long, much more slining at the black base than in other parts. Embryo not perfected in any of the seeds before us on this occasion.

The affinity of this species tends evidently to $E$. buxifolius, which shares with it the glaucescence, the dotted roughness, the structure of flowers and ovaries. The fruit of the latter we lad no opportunity as yet to compare; the chief distinctions of $\mathrm{E}$. buxifolius rest in its pubescent branches, the smallness and particularly shortness of leaves, and in the always solitary and constantly short pedicels. Throngh E. intermedius, collected by Mr. W. Vernon near Port Jackson, it passes seemingly into E. myoporoides. E. lineare, A. Cunn. (E. scaber, Paxt. Mag. xiii. t.' 127), appears to offer no furtler distinctions than the extreme narrowness of the leaves, unless such should be discerned in the fruit.

In flower during the earlier part of the spring.

Erlostemon verrucosus, Ach. Richard. in Voyago d'Astrolube, ii. 74, t. 26; J. Hook. Fl. Tasm. i. 64; E. obcordatus, All. Cunn. in Hook. Journ. of Bot. i. 254; Tcon. Plant. t. 60.

Glabrous, opaque, glandulous-tuberculate; lcarcs thick, obcordatc-cuneate, blunt, complicate, subsessile, beneath verruculose; peduncles very short or obliterated, solitary; pedicels axillary.and terminal, solitary or rarely twin, shorter than the leaves, minutely bracteolate at the base; segments of the calyx minute, rlomboid or roundish-deltoid, scarcely ciliolated, many times shorter than the white or partially pink outside glabrous deciduous corolla; filaments ciliated, about half as long as the petals; anthers minutely appendiculate; style short, filiform, glabrous; stigma minute, faintly lobed; ovaries smooth, pointed.

On barren ranges and forest-land not common; near Forest Creek, C. J. La Trobe ; on Mount Korong; B. Ross; on the summit of MLount Arapiles, J. Dallachy; on Mount Zero, C. Wilhelmi ; in the Black Forest, F. II. ; less rare in Tasmania.

A shrub from 1 to a few feet high. Branches terete, very densely corered with glandular tubercles. Leaves without lustre, green or more frequently glaucous, rather fleshy, more or less folded together, 2-8 lines long, almost even above, from tumescent perforated glands rough beneatl, with hardly perceptible midrib. Peduncles $1 \frac{1}{2}$ line long or often shorter. Bracteoles deciduous, very minute, roundish, smootl. Pedicels stout, angular, from $\frac{1}{2}-2$ lines long, upwards thickened. Calyx less than 1 line long; its segments in rstivation imbricate. Petals 2-3 lines long, in præflorescence imbricate, sessile, obovate- or ellipticaloblong; inside clothed with barely perceptible downs. Filaments linear-subulate, white, variable in degree of hairiness; the terminal ciliæ the longest. Anthers pale, subcordate, hardly $\frac{1}{2}$ line long, erect, somewlat oscillating in age ; the apex white, very small, glabrous. Style about 1 line in lengtll. Disk narrow, entire. Ovaries attenuated and disconnected at the apex, indicating rostrate fruits. The carpels, which may exhibit marked distinctions from those of $\mathbf{E}$. buxifolius, $\mathbf{E}$. gracilis and other allied species, have not been available for description.

In flower during the spring.

Eriostemon difformis, All. Cunn. in Hueg. Enum. Plant. Nov. Holl. Austr. Occ. 15 ; E. brevifolius, A. Cunn. l.c.; E. rhombeus, Lindl. in Mitch. Trop. Austr. 293; E. lalmaturorum, F. M. in Linncea, 1852,377 .

Branchlets numerous, generally downy, glandulous-tuberculate; leaves small, blunt, cuneate- or rlomboid-oblong or subovate or irregularly club-shaped, flat or thickened at the margin or almost semiterete or subcylindrical, grossly glandulous and thinly repand or crenulate, on short petioles; pedicels terninal, solitary, seldom axillary or geminate or ternate, often downy, about as long as or longer than the leaves; sepals small, subovate, sometimes rhomboid, generally tuberculate, many times shorter than the corolla; 
petals white or partially pink, downy; stamens nearly as long as the corolla; filaments woolly; anthers minutely appendiculate; style cylindrical, glabrous; stigma minute, five-lobed; ovaries donny at the summit; carpels ovate-rhomboid, rostrate; endocar'p saccate at the base, with almost renate or cuneate valves; placental membrane cordate-orbicular; seeds grey-black, not or slightly shining.

As well in arid rocky ranges as in barren scrub land; thus in the Murray desert and in the Grampians; in South Australia, near Lake Torrens, towards the Gawler River, and on the cataracts near Mount Lofty; in Western Australia near the Fitzgerald River; in New South Wales on the Macleay, Hastings, Darling and Lachlan River, on Mount Murchison, on Peel's Range ; in Queensland, near Warwick, according to Dr. Beckler, near the Burnett and Dawson River; further, according to Sir Th. Mitchell, close to the Mantua Downs; found also by Mr. W. Hill near Wide Bay.

A numerously almost dichotomously branched shrub, singular for its copious granular exudations, a few seldom many feet high. Branchlets almost cylindrical, slender. Petioles generally less than $\frac{1}{2}$ line long, narrow, usually accompanied at the base with two very minute either more scarious or more glandular stipular organs of black-brown color. Leaves, when fully grown, from $1 \frac{1}{2}-8$ lines long; of a vivid green, often shining, excessively variable in form, either somewhat club-shaped and concave above and convex below, or subovate or oblong and perfectly flat, or by reduced width merely cylindrical with a slight furrow below, or when small assuming by great glandular turgescence a somewhat rhomboid form, not rarely by having the margin tumid becoming concave beneath, the glandular protuberances at the edge forming blunt teeth, the midrib only faintly visible in the flat-leaved variety. Peduncles none. Pedicels rather slender, upwards not much thickened, 1-6 lines long; usually short-downy. Sepals measuring about 1 line, not so much concrete at the base as in many other species. Petals ovate-lanceolate, somewhat keeled, acute, almost velvet-downy with exception of the dorsal part, not much spreading, imbricate in restivation, white, often with rose-colored back and margin, 2-3 lines long, sometimes outside entirely glabrous, sessile. Filaments linear-subulate, white, clothed densely at the margin with crisp downs, which are longer in its upper than lower part. Anthers $\frac{1}{3}-\frac{1}{2}$ line long, subcordate, with a white blunt turgid glabrous apex, oscillating in age. Pollen orange-colored. Style about 1 line long, five-furrowed, concealed by the wool and within the apex of the connected ovaries. Stigma five-lobed by the imperfect coherence of its constituent parts, free in age, glabrous, spreading, $\frac{1}{8}-\frac{1}{6}$ line long. Disk narrow, depressed, smooth, crenulated. Ovaries alwayss bearded at the top. Carpels $1_{\frac{1}{2}}-2 \frac{1}{2}$ lines long and not much less broad, rather turgid, somewhat dotted, faintly ribbed, terminated suddenly into a subulate more or less erect or divergent rostrum, which is nearly 1 line in length or in various degrees shorter. Endocarp livid or pale greenish-yellow, toothless at the concave base. Placental membrane about half as long as the seed; of the latter one or two contained in each cell; if solitary of renate-ovate shape, if two assuming an oblique-truncate form by mutual pressure, one placed above the other. Testa fragile, crustaceous. Endopleura livid, membranous. Embryo very slender. Cotyledons shorter than the radicle.

Authentically named specimens of E. rhombens have been compared in Sir Tl. Mitchell's collection; the E. brevifolius, found by All. Cunningham at the base of Peel's Range, seems, according to Endlicher's short phrase of this species (in Hueg. Enum. 16), only anotler form of this singularly inconstant plant, remarkable for having the leaves downy beneath.

The narrow-leaved variety of $\mathrm{E}$. difformis bears great resemblance to Philotheca Austrahis, a plant which has, as pointed well out by A. Cunningham already (conf. Field's New South Wales, p. 330), but slight claims to generic distinctions on account of its stamens being downward permanently connate, and which. indeed has been described by Graham (in the New Edinb. Phil. Jour. xvi. 175) as Eriostemon gracilis. Contrasting the latter as a species, it will be found, that its leaves are always semicylindrical and very slightly scabrous-downy, that the flowers are constantly very short-stalked and oftener a few arising from one point, that the petals are purplish-pink, short unguiculate and frequently larger, that the filaments are below the middle glabrous and concrete into an hyalinous turgid tube, that the style attains a greater 
length and is clothed towards the middle with downs, that the rostium of the carpels is less pointed and less long, and lastly that the seeds are larger, polished and pure black.

Philotheca longifolia (Thrcz. in Bullet. de la Soc. Impér. des Natur. de Moscou, xxii. 2, 16) seems to differ only from $P$. australis, in oblong anthers terminated by a larger and bearded appendage, a note probably of uncertain value; still we are hitherto unacquainted with its fruit. But under any considerations this diversity of the projection of the anthers tends to confirm the correctness of the view adopted in this work, that Crowea might be transferred to Eriostemon, its sole distinction depending on a similar apparently invalid mark. Philotheca has been especially referred to on this occasion, because this beautiful plant will probably yet be found in the eastern parts of this colony.

The exclusively Tasmanian Eriostemon virgatus may be inserted into the series Erionema of the genus, unless it is kept apart on account of the number of its floral and fruit divisions, which are analagous to those of Boronia. In the Flora Tasmanica (vol. ii. p. 358) E. Oldfieldii (Fragm. Phytogr. Austr. i. 3) is combined with the above species. In specimens of the former, gathered on the hills beyond Flight Bay by Mr. Oldfield, we find the branchlets glabrous and tuberculate, the leaves tapering into a sessile base, often mucronulate, never retuse, and generally somewhat rough beneath from prominulous glands, whilst the flowers are principally axillary with quaternary number of floral- and fruit-parts and often solitary, and the carpels, to judge from their unripe state, terminated by a conspicuous acute rostrum. In E. Oldfieldii, on the contrary, the branchlets are soniewhat downy and always destitute of tubercles; the petioles are distinctly developed, the leaves never mucronulate but not seldom retıse, neither rough but often shining beneatli; the flowers are terminal and umbellate with the normal number of flower- and fruit-parts, whilst the carpels are small and terminated by a short and blunt rostrum. The plant is besides characterized by a balsamic scent, strongly retained even in the dried plant. The flowers, as yet in a developed state unknown, are likely to prove that $\mathrm{E}$. Oldfieldii belongs to the following section.

\section{Sect. III. LEIONEMA.}

Leaves often glabrous, always destitute of scales. Flowers in most cases umbellate. Segments of the calyx small. Petals deciduous, white rarely yellow, often tinged with red, valvate in æstivation. Stamens nearly as long as or longer than the corolla. Filaments glabrous. Anthers without a distinct terminal appendage. Stigmas minute, coherent. Carpels generally rostrate.

Eriostemon pungens, Lindl. in Mitchell's three Exped. ii. 156.

Dwarf; branchlets angular, often downy; leaves lanceolate- or channelled-linear, acute, mucronate, coriaceous, margined, almost or entirely glabrous, on very short petioles, rarely sessile; pedicels slender, axillary, solitary, rarely geminate, of less or almost the same length as the flower, with minute and acute bracts and bracteoles at the base; segments of the calyx nearly rhomboid, minute ciliolated, several times shorter than the small whitish outside glabrous deciduous petals; filaments suddenly terminated into a subulate apex, very scantily hairy, dotted, more than half as long as the petals; anthers tumid at the apex; style very short, glabrous, cylindrical; stigma minute, obscurely five-lobed; carpels oblique-ovate, acute, short-rostrate; valves of the endocarp oblique-cuneate, toothless at their junction; placental membrane navicular-ovate; seeds opaque, black, somewhat wrinkled.

On stony ranges and in sandy desert-tracts not frequent; towards Mount Hope, Sir Th. Mitchell ; near the Murray River and its lower tributaries; in the Grampians; in South Australia towards Mount Lofty and Glen Osmond.

A singular little bush, in external appearance more imitating an epacrideous or leptospermaceous plant than of any of its congeners, oftener of diffuse or even prostrate growth than erect, producing flowers already in its second year. Indument of the branchlets almost hirtellous, spreading, in rare cases wanting. 
Leaves rigid, 3-8 lines long, $\frac{3-2}{4}-2$ lines broad, somewhat blunt at the base, vividly gireen, rather shining particularly above, often shightly carinate by the beneath prominent middle-nerve, with a smooth marginal nerve and a mucro of $\frac{1}{3}-1$ line length, occasionally somewliat scabrous-downy. Bracts and bracteoles about $\frac{1}{2}$ line long, frequently rigidulous, cuspidate, ovate-cymbiform. Pedicels 1-4 lines long, upwards slightly thickened. Sepals imbricate in præflorescence, greenish, $\frac{1}{2}-\frac{2}{3}$ line long. Petals lanceolate, acute, $1 \frac{3}{4}-3$ lines long, covered with exceedingly minute velvet-downs on the inner side, outside dotted with immersed glands, valvate in æastivation, hence not more tender towards the margin than in its other part. Filaments white, linear, $1 \frac{1}{4}-1 \frac{3}{4}$ lines long, sometimes broader upwards; the petaline ones a little shorter than the rest; all truncate or blunt below the apex, thence projecting into a very short subulate apex, which carries the anther. The latter subeordate, brownish, about $\frac{1}{4}$ line long, glabrous, dorsifixed, terminated by a blunt white glabrous broad apicular turgid enlargement of the connective. Style filiform, 1 line or less long; half concealed by the perfectly disconnected glabrous ovaries. Stigma depressed, glabrous. Disk short, entire, glabrous, slighlitly waved. Carpels free, about $2 \frac{1}{2}$ lines long, scarcely more than 1 line broad, with a short and pointed but also occasionally blunt rostrum, transversely veined. Endocarp livid, nerveless; its valves connected finally only near the base and therefore hardly forming a cavity. Placental membrane cuspidate, about $1 \frac{1}{3}$ line long. Seeds slightly rough from longitudinal prominulous irregular lines, throughout orer their surface of pure black color, destitute of any lustre, orate-kidneyshaped, about $1 \frac{1}{2}$ line long. Albumen copious. Embryo almost straight, cylindrical, very slender. Cotyledons nearly as long as the radicle.

The prickly-cuspidate small leaves, together with the singular form of the filaments, which bear only some remote comparison to E. salicifolins, mark this kind of Eriostemon one of the most curious of the genus. In the latter notes it approaches to the main species of Boronia.

Eriostemon lamprophyllus, F. M. in Journ. of Pharmac. Soc. of Vict. ii. 43.

Branchlets tubercled, slightly downy; leares small, crowded, thin-coriaceous, lanceolate or oborate- or oblong-lanceolate, acute, glabrous, flat, entire or in front slightly repand-crenulate, shining on both pages, short-petiolate; peduncles short or obliterated; pedicels principally terminal, solitary or a few umbellate; bracteoles at or towards the base of the pedicels very small, nearly subulate; segments of the minute calyx deltoid, somewhat acuminate and ciliolated; petals deciduous; style capillary, glabrous; stigma capitellate, very minute; carpels ovate-rhomboid, rostrate; valves of the endocarp forming above their base a deltoid tooth; placental membrane broad ovate-navicular; seeds olive-black, polished; radicle very much longer than the cotyledons.

On the rocky subalpine summit of MLount Ligar towards the sources of the McAllister River.

A widely spreading dense shrub of a few feet high. Branches terete. Branchlets glabrescent, numerous, more or less patent, rather angular. Leaves somewhat or considerably spreading, 3-6 lines long, 1-1 $\frac{1}{2}$ line broad, generally rather broader above the middle, one-nerved, not much paler beneath, transparently dotted. Pedicels 2-3 lines long, slender, glabrous, but dotted with resinous glands, sliglitly thickened at the upper extremity. Calyx hardly more than $\frac{1}{2}$ line long. Petals and stamens as yet unknown, early dropping. Oraries smooth, acute, disconnected. Disk very narrow, undivided. Carpels hardly 2 lines long, terminated by a conspicuous slender beak, which, as in all instances of this order, forms the continuation of the dorsal "part of the pericarp, transversely lined by somewhat arcuate veins. Endocarp pale-yellow, somewhat shining. Placental membrane scarcely 1 line long, sometimes dilated into an almost orbicular form. Seeds about $1 \frac{1}{4}$ line long, oblique ellipsoid-ovate, not very turgid, of a paler or darker shade. Embryo almost straight, nearly as long as the albumen, very slender, cylindrical; radicle blunt, four times as long as the somewhat attenuated and unequal cotyledons.

No other species shows cousiderable sinilarity to E. lamprophyllus than the E. elatior (F. M. Fragm. Phytogr. Austr. i. 181) from New England. The generally blunt and longer leaves of the latter, the short blunt and coherent ovaries, which, moreover, by the elongation of the gynophorous 'disk, are raised rery 
visibly on a stipes, and the beakless carpels, offer obvious distinctions, which may possibly be strengthened when we are acquainted with the flowers of E. lamprophyllus. The cotyledons prove to be. very short in either species. The New Zealand E. nudus (Phebalium nudum, Hook. Icon. 568) stands in very close relation to E. elatior; indeed, their distinctions are as yet not clearly ascertained.

Zriostemon Fillebrandii, F. M. in Transact. Phil. Soc. Vict. i. 10; Phebalium bilobum, Lindl. in Mitch. Three Exped. ii. 178 (not of Bartling, in Lehm. Pl. Preiss. i. 172); P. truncatum, J. Hook. Fl. Tasmanice, i. 64, t. 9, \& ii. 358 .

Branchlets downy; leaves petiolate, irregularly lanceolate, oblong, ovate or quadrate-ovate, truncate or short-bilobcd at the apex, generally sermlated, rarely entire, glabrous, seldom scantily pubescent or scabiousdowny, flat or recurved at the margin, shining on both pages; pedicels terminal, corymbose or subumbellate, longer than the peduncle, rarely solitary or axillary in the axis of the upper leares, generally with two very minute narrow alternate bracteoles towards the middle, scantily downy or subglabrous; segments of the minute calyx deltoid; petals glabrous, white, tinged with pink, deciduous; filaments as long as the corolla and.somewhat longer, smooth, setaceous; anthers exappendiculate; style capillary; ovaries tro or threc, seldom four, smooth, colherent, raised on a short stipes; carpels broad oblique-ovate, rostrate; valves of the endocarp forming at the junction a deltoid tooth; placental membrane carnulent; seeds smooth, brownish, shining; cotyledons about half as long as the radicle.

On cataracts and rocky rivulets in the Victoria Ranges and Grampians; on the snbalpine summit of Mount William; in South Australia, on stony declivities towards Mount Lofty, and in rocky glens at the sources of the Gawler River.

A charming bush, subject to many alterations in habit, according to the localities which it occupies; in drier ground dwarf and very spreading, in irrigated valleys straight and attaining a height of fully 6 feet. Branches terete. Branchlets generally brown-red, clothed densely or scantily with grey often starry downs, occasionally perfectly glabrous. Leares always conspicuously stalked, thin-coriaceous or of rigid firmness, from 2-12 lines long, singularly aberrant in form, sometimes considerably dilated towards the base, and there then very blunt or even subcordate, sometimes (in young specimens chiefly) very narrow, almost linear, either excised or dilated-bilobed at the apex or simply truncate, or by laving the frontal margin rolled back retuse, rarely some rounded-blunt, in small-leaved varieties not or but slightly denticulated, in the large-leaved varieties from the summit fully to the base or nearly to it sharply and callously toothed, paler beneath, usually deprived of any indument, with a sometimes faintly sometimes strongly prominent midnerve. Peduncles downy, generally but very few lines long or even obliterated. Pedicels 2-6 lines long, frequently saturatedred, slender, but slightly thickened towards the summit, glabrous or scantily downy, somewhat angular, at the base often provided with a linear- or oblong- or ovate-canaliculate downy bract, which measures about 1 line or less in length, towards the middle in most cases furnished with two exceedingly small and especially narrow long-persistent bracteoles, not jointed. Calyx glabrous or slightly hairy, often reddish, only about $\frac{1}{2}$ line long. Petals about 2 lines long, narrow-lanceolate, often considerably tinged with red in the upper portion of their outer face, acute, sessile. Sepaline filaments a little longer than the corolla; petaline ones of about the same length as the petals, usnally white, gradually pointed, simultaneously with the corolla dropping. Anthers $\frac{1}{4}-\frac{1}{3}$ line long, versatile, resting on the filament at their dorsal cavity, bursting with more marginal than frontal fissures, yellow or at first red, destitute of an apiculum, but bearing a small dorsal gland just above the point of insertion. Dry pollen-grains smooth, yellowish-white, subovate, slit lengthwise. Styles perfectly united into one, glabrous, seldom conspersed with hardly perceptible downs, about 1 line long. Stigmas conglutinated into one, very minute, scarcely expanding beyond the apex of the style. Gynophor glabrous, cylindrical, about $\frac{1}{3}$ line long. Carpels $1 \frac{1}{2}-2$ lines long, broad towards the summit, yet hardly truncate, but rather rounded-blunt, alunost laterally rostrate in consequence of the turoidity of its sutural face, in an irregular manner transversely lined by curved veins; the rostrum about $\frac{1}{2}$ line long. Endocarp livid or 
pale-yellow, more or less shining; upwards considerably dilated, nerveless. Placenta rhomboid-ovate, somewhat fleshy, or membranous at the margin, resembling the strophiole of many seeds, often only about $\frac{2}{3}$ line long, livid, bearing two ovules. Seeds about $1 \frac{1}{4}$ line long; obliqne-ovate, turgid, sometimes a little dotted. Testa crustaceous. Endopleura membranous, pale. Embryo slender, as long as the albumen.

In flowel during the spring.

In close proximity of this plant is to be placed the Eriostemon serrulatus (F. MI. Fragm. Phytogr. Austr. i. 4), found in dense forest vallies at the upper tributaries of the Buneep River. It differs chiefly in its greater length of leaves and in the oblique-ovate acute carpels, which are larger and terminated by a long straight rostrum. Notwithstanding these discrepancies, which can be accounted for by the influence which a particularly wet locality may exercise on the plant, it would have been united on this occasion with $E$. Hillebrandii, if its flowers and seeds were known. It attains a height of fully 10 feet.

All the flowers of E. Hillebrandii examined by us have the usual number of floral parts; but Dr. J. Hooker observed the calyx to be in some instances four-cleft, the number of petals then to be four, and that of the stamens eight. In its reduced number of ovaries this species imitates E. grandiflorus and E. Drum. mondi, from Western Australia.

The species received its name in appreciation of many services rendered by Dr. Will. Hillebrand, for promoting the investigation of the South Australian flora.

Eriostemon umbellatus, Turc. in Bullet. de la Soc. Impér. des Nat. de Moscou, xxii. 2, 15; F. M. Fragm. Phytogr. Austr. i. 104; Phebalium salicifolium, Adr. de Juss. Mém. Soc. Hist. Natur. ii. t. 12, f. 1 ; P. plyylicifolium, F. M. in Transact. Vict. Inst. i. 32.

Branchlets downy; leaves lanceolate- or oblong- or elongate-linear or oblong or linear, coriaceous, blunt or l'etuse, entire or remotely denticulated, beneath very thinly grey velvet-downy, rcrolute at the margin, decurrent into the petiole; flowers axillary, pedunculate, corymbose or umbellate, rarely solitary; pedicels about as long: as the flowers, bracteolate at the base; teeth of the minute calyx deltoid; petals yellow, glabrous, glandulously dotted; filaments setaceous, longer than the corolla, glabrous ; anthers inappendiculate; style long, smooth, capillary; stigmas united, very minute; carpels subrhomboid, short-rostrate; valves of the endocarp forming at the junction a deltoid tootlı; placenta often several times sloorter than the seed, fleshy; seeds brown-black, polished; cotyledons nearly as long as the radicle.

On Mount Willinm, on the Munyang mountains, on the highest rocks of the Cobboras, on Mount Wellington, on the mountains at the sources of the Mitta Mitta monntains, at an elevation from 4000 to 6000 feet; in New South Wales along rocky gullies near Botany Bay.

A shrub, very tall and erect in lowland localities, dwarf and diffused, yet robust in alpine situations. Branches terete. Branchlets clothed with starry downs. Leaves in the lowland variety generally from $1 \frac{1}{2}-2 \frac{1}{2}$ inches long, in the alpine form from $\frac{1}{3}-1$ inch long; shining above, ashy-grey beneath on account of its tegument, or in age fully glabrescent. Corymbs or umbels simple or compound. Peduncles angular, 1 inch long or oftener shorter, in various degrees starry-downy. Pedicels somewhat lepidote or downy, or, particularly in age, glabrous, angular, hardly upwards thickened, provided at or near the base, and sometimes also towards the summit, with partially puberulous lanceolate-ovate or linear fugacious bracteoles. Calyx not so deeply cleft as in most other species. Petals narrow-lanceolate, about 2 lines long, valvate in restivation, saturate- or pale-yellow, subsessile. Sepaline filaments considerably, petaline ones slightly longer than the corolla. Anthers yellow, ovate-cordate, versatile, abont $\frac{1}{3}$ line long, with introrse dehiscence. Style about $1_{\frac{1}{2}}$ line long. Stigmas hardly expanding. Gynophor exceedingly short. Ovaries 5 , coherent, smooth, or in the alpine variety velvety. Carpels hardly 2 lines loug, seldom all developed, one- rarely two-seeded, having their beak quite lateral in consequence of the broad expansion of the vertex forming a prominent inner angle, transversely veined, sometimes downy, rarely without rostrum. Endocarp pale-yellow, shining; its valves more renate than cuneate. Placenta abont $\frac{1}{3}$ line long, roundish, somewhat fleshy, livid, or at 
times also membranous, and expanding to $\frac{2}{3}$ line length. Seeds hardly exceeding in length 1 line, renateovate. Embryo slender, nearly as long as the albumen.

This plant accords in many respects with the foregoing one.

In flower during the spring:

To the section Leionema belong further E. montanus (Phebalium montanum, Hook. Icon. 59) and E. microphyllus (F'. M. Transact. Phil. Soc. Vict. i. 99).

\section{Sect. IV. Phebalium.}

Leaves generally underneath lepidote. Flowers solitary, corymbose or umbellate. Calyx small. Petals yellow or white. Filaments usually glabrous, Anthers erect or versatile. Stigmas coherent.

Driostemon squameus, Labill. Nov. Holl. Plant. Spccim. i. p.111, t.141; F. Ir. Fragm. Phytogr. Austr. i. 104 ; Phebalium Billardierii, Adr. Tuss. Mrém. Soc. d Hist. Nat. Paris, ii. 12; J. Hook. Fl. Tasm. i. 63 ; P. elatum, A. Cunn. in Field's New South Wales, 331 ; P. retusum, Hook. Comp. Bot. Mag. i. 254; Icon. Plant. t. 57.

Arborescent; branchlets angular; leaves large, usually acute, chartaceous, rarely coriaceous, lanceolate or oval- or oblong- or linear-lanceolate, entire, flat, short-stalked, above glabrous, beneath, as well as the branchlets, peduncles and pedicels, lepidote; corymbs simple or compound; petals white, scalcless, much longer than the minute deeply and acutely toothed calyx, about as long as the stamens, deciduous; filaments fringed towards the base or almost smootli; anthers versatile; style long and ovaries smooth; stigmas coherent; carpels small, rhomboid, with a minute lateral point; valves of the endocarp forming at the junction a short deltoid tooth; placental membrane subcordate; seeds black, smooth, shining; cotyledons scarcely half as long as the radicle.

In damp forest-valleys amongst fern-trees near to Apollo Bay, towards Cape Otway and near the sources of the Barwon. Rather frequent in Tasmania; much rarer in New South Wales, where it has been found near Springwood by Allan Cunningham, near the River Grose by Miss Atkinson, near Parramatta by Will. Woolls, near Lane Cove River by Messis. Sheplerd, along the Hastings River and Cloud's Creek by Dr. Beckler.

A tall, scented, beautiful bush, finally attaining in farorable spots the form of a small or even middlesized tree, having been noticed fully 30 feet high in this colony. Branchlets covered with usually brownish scales, occasionally also warted. Leares usually from 2-4 inches long and from $\frac{1}{2}-1$ inch broad, in Tasmanian specimens of $\mathrm{Ph}$. retusum coriaceous, only about 1 inch long and 2-3 lines broad, in subtropical East Australian specimens occasionally $\frac{1}{2}$ foot long and $1_{\frac{1}{2}}$ inch broad, usually rather acute, although not nucronate, sometimes, however, quite blunt, always beautifully silvery beneath by closely appressed scales, often lightly waved at the margin, above dark-green, dotted with often slightly prominent and almost pellucid glands and usually furrowed by the impression of the midnerre. Inflorescence axillary, rarely terminal, Common peduncle 1 inch or less long, bearing a simple, double, or even several paniculate corymbs. Pedicels $\frac{1}{8}-\frac{3}{4}$ inch long, angnlar, with minute and deciduous acute bracteoles at or near the base. Calyx $\frac{1}{2}-\frac{2}{3}$ line long; with deltoid lobes. Petals orate-lanceolate, 2-21 lines long;, sometimes quite sessile, sometimes contracted into a short claw, shightly imbricate in præflorescence, rather membranous. Filaments white, linear-subulate, usually short-hairy along their lower part, in specimens from the Hastings River, however, remarkably longdowny. Anthers yellow, about $\frac{1}{3}$ line long. Pollen-grains ovate, smooth. Style formed by the twisted coalescence of 5 into 1, capillary, abont 2 lines long. Carpels for the size of the plant remarkably small, measuring usually not fully $1 \frac{1}{2}$ line, broad and truncate at the vertex. Placental membrane about $\frac{1}{2}$ line long and broad. Seeds renate-eggshaped, about $\frac{2}{3}$ line long. Embryo somewhat shorter than the albumen; its cotyledons tapering at the extremity; radicle cylindrical, slightly clavate. 
The species nearest in affinity is the following, although the habitual resemblance places E. squameus nearer to E. anceps, from S. W. Australia. That species is, however, almost entirely devoid of the silvery covering of the underpage of the leaves, whilst the petals and ovaries are outward lepidote.

Eriostemon Iepidotus, Spreng. Syst. Veg. ii. 322; F. M. Fragm. Phytogr. Austr. i. 104; E. alpinus, F. MI. l.e.; Phebalium squamulosum, Vent. ILalmais. t. 102 ; P. aureum, A. Cunn. in Field's Nen South Wales, p. 331, with plate; P. elragnifolium, Adr. Juss. Mém. Soe. d'Hist. Nat. Paris, ii. t. 11, fig. 2; P. podocarpoides, F. II. in Transaet. Tiet. Inst. i. 31.

Shrubby; branchlets hardly angular; leaves coriaceous, short-stalked, linear- or elliptical=oblong, rarely linear, blunt or retuse, entire or repand-denticulate, flat or revolute at the margin, above glabrous, beneath as well as the whole infloresecnee lepidote; umbels sessile or subsessile, terminal; petals persistent, yellow, outside scaly, much longer than the minute indistinctly toothed calyx, shorter than the stamens; filaments capillary, glabrous; anthers erect, terminated by a minute gland; style long, glabrous; stigmas minute, coherent; ovaries lepidote; carpels rhomboid-orbicular; valves of the endocarp forming at their junction a deltoid tooth; placental membrane orbicular-cordate; cotyledons scarcely half as long as the radicle.

On the rocky summit and declivities of Genoa Peak; along the periodically overflowed gravelly banks of the Genoa River; on the alpine summits of Mount Buller, the Bogong. Ranges and Munyang Mountains; in the desert of the Tattiara country and towards the Murray River; on the Grampians; through New South Wales as far nortlı as the Clarence River, ascending to the elevated country of New England.

A handsome shrubby plant, variable in height, never arborescent. Branchlets rusty and silvery lepidote; their indument changing in age to a brown- or black-grey scaly tomentum. Leaves conspersed with prominent or immersed pellucid glands, in their ordinary state 1-2 inches long; $1 \frac{1}{2}-4$ lines broad; in the alpine variety $\frac{1}{3}-\frac{1}{2}$ inch long, 1-2 lines broad; in the desert variety $\frac{1}{4}-\frac{1}{2}$ inch long, only about 1 line broad and (on account of their margins being perfectly revolute) almost cylindrical. Umbels terminating the branchlets. Pedicels as long as or little longer than the flowers. Calyx $\frac{1}{2}-\frac{2}{3}$ line long. Petals oratelanceolate, about 2 lines long, rather acute, valvate in praflorescence, sessile. Filaments yellow; the longer ones extending about one-third of their length beyond the corolla. Anthers yellow, broad-ovate, $\frac{1}{3}-\frac{1}{2}$ line long, bilobed at the base. Style twisted, hardly 2 lines long. Carpels measuring: about 2 lines, clothed with finally seceding scales. Placental membrane $\frac{2}{3}$ line long; acuminate. Seeds a little longer than 1 line, renate-ellipsoid, brown-black, slightly shining:

Eriostemon sediflorus (Fragm. Phyt. Austr. i. 30; Phebalium glandulosum, Hook. in Mitch. Trop. Austr. 199; Ph. sediflorum, F. MI. in Transact. Vict. Inst. i. 30) seems merely to differ from E. lepidotus in almost wedge-shaped leaves, which are bluntly denticulated and as well as the branchlets conspicuously tubercled by prominent copious glands. Its leaves are in some instances almost channelled, in others quite revolute at the margin. This species inhabits the granitic detritus along the banks of the Snowy River near the Pinch Mountains and the north-western desert of this colony, extending thence to Lake Torrens and Lake Alexandrina. Tasmania possesses (in Phebahum Dariesii) a plant rery closely allied to E. sediflorus, distinguishable only, according to Dr. Hooker's notes (Flor. Tasm. ii. 358), by still narower leaves, white petals and smooth ovaries. South-Western Australia again furnishes an almost conspecific representatire in Eriostemon tuberculosus, covered like E. sediflorus with granular glands, but seemingly not specifically identical on account of showing leaves quite revolute without upward dilatation, an acutely-tootled calyx, shorter stamens and scarcely any manifest terminal gland of the anthers. Eriostemon ozothamnoides (F. M. Fragm. Phyt. Austr. i. 103; Pliebalium ozothamnoides, F. MI. in T'ransact. Vict. Inst. i. 31), from the Mitta Mitta, Cabongra and Livingstone River, seems to represent a subalpine variety with obovate-cuneate leares, which change their silvery coat soon into a velvet-like tomentum. The specific and perhaps untenable boundaries of all these plants have yet to be further traced. 
Iriostemon ovatifolius, F. M. Fragm. Phytogr. Austr. i. 103; Phebalium ovatifolium, F. Mr. in Transact. Phil. Society of Victoria, i. 99.

Shrubby; branchlets somewhat angular; lcaves thickly coriaceous, ovate, blunt, entire, flat, shortstalked, above smooth, beneath together with the branchlets peduncles and pedicels lepidote; peduncles axillary, one-flowered or bearing a few-flowered corymb, considerably shorter than the leares; bracts ovatc, foliaccons; petals whitc, scalelcss, much longer than the triangular glabrous lobes of the calyx, little longer than the glabrous filaments, deciduous; anthers blunt, versatile; style rather long, glabrous; stigmas coherent; ovaries lepidote; carpels small, calvescent, rhomboid, with a very minute lateral beak; valves of the endocarp forming at the junction a small deltoid tooth; placental membrane subcordate; seeds brownblack, shining, slightly tuberculed; radicle three times as long as the cotyledons.

In some of the alpine regions of the Munyang MLountains abundant; forming also isolated patches of scrub amongst quartz rocks between Mount Wellington and Haidinger Range towards the sources of the Macallister River.

A good-sized, wide, compact bush of pretty appearance, towards the glacier region dwarf, with a foliage a good deal like English Box. Leaves $\frac{1}{3}-\frac{2}{3}$ occasionally 1 inch long, sometimes slightly retuse, sometimes a little pointed, dark-green and very shining, and showing subtile oildots abore but no superficial veins, beneath bearing silvery scales, which at first exhibit a rusty hue, but become grey in age. Bracts usually alternating, 1-2 hnes long, forming diminutive leaves. Bracteoles deciduous. Pedicels, when present, about as long as the flowers. Calyx hardly 1 line long; its lobes usually devoid of scales, deltoid-lanceolate.

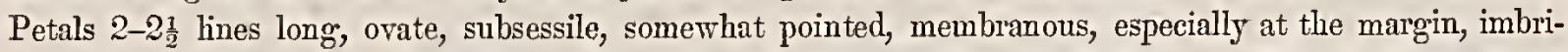
cative in præflorescence, outside tinged with red. Filaments linear-subulate. Anthers $\frac{1}{3}-\frac{1}{2}$ line long. Pollen-grains oval, smooth, bursting lengthwise. Style about $1_{\frac{1}{2}}$ hine long, filiform, consisting of the twisted coalescence of five: Carpels $1 \frac{1}{2}-2$ lines long, when old quite denuded of their scales. Endocarp livid. Seeds about 1 line long, oblique-ovate. Embryo as long as the albunen, cylindrical and straight.

This plant stands in close relation to Eriostemon lepidotus and E. squameus.

In flower towards the latter part of spring and in the beginning of summer, according to elevation.

\section{Sect. V. Chorilimopsis,}

Leaves scabrous-hairy. Umbels head-like. Segments of the calyx linear. Petals yellow, valvate in æstivation. Filaments glabrous, longer than the corolla. Anthers versatile, without terminal gland or appendage. Stigmas minute, coalescent. Carpels long-rostrate.

Driostemon phylicoides, F. M. Fragm. Phytogr. Austr. i. 107; Phebalium diosmeum, Adr. de Juss. in Mém. Soc. ¿ Hist. Nat. Paris, ii. t. 11, fig. 3; P. phylicoides, Sieb. in Spreng. Syst. Veg. cur. post. p. 164; Chorilrena angustifolia, F. Mr. in Transact. Phil. Soc. Tict. i. 10.

Branchlets downy; lcaves hispidulous, linear or oblong-linear, blunt, almost sessile, revolute at the margin ; flowers crowded into terminal head-like sessile umbcls; bracteoles linear-filiform; calyx-segments of half or one-third the length of the corolla, semilanceolate or subulate-linear, about as long as the pedicel, downy; petals yellow, almost glabrous, lanceolate, tapering at the base; filaments capillary, conspicuously exserted, glabrous; anthers exappendiculate, versatile; style setaceous, glabrous; stigmas very minute, coherent; ovaries terminated by a long narrow downy appendage.

On low sandy heath-ridges near Mount Imlay here and there abundant; also in New South Wales in the Argyle county.

An erect, showy, usually strict-growing bush, a few feet high, hardly ever exceeding 5 feet in height, with rather slender terete stems and branches. The latter less densely covered with white spreading hair than the branchlets. Leaves copious, usually from $\frac{1}{3}-\frac{2}{3}$ inch long, and in consequence of the revolute margin 
only $\frac{1}{2}-1$ hine broad, in age occasionally attaining a somewhat greater length and width, hispidulous br either short and stellate or by longer scattered deciduous hairs on both pages, scabrous on the surface, hardly paler beneath, entire at the margin, unless apparently denticulated by minute protuberances; their consistence more herbaceous than coriaceous. Umbels with several or many flowers, now and then by shortened terminal branchlets spuriously compound. Pedicels often about 1 line long, hairy, bearing a basal linear bract and two opposite likewise downy bracteoles, which are from 1-2 lines Iong. Length of the calyx-segments also 1-2 lines. Flowers but shightly fragrant. Petals 3-4 lines long, about 1 line broad, one-nerved, somewhat dotted, not rarely tinged red at the back, carrying also a few scattered dorsal hairs. Petaline filaments shorter than the sepaline ones, all yellow, deciduous; the latter attaining a length of $4 \frac{1}{2}$ lines. Anthers saturated-yellow, about 1 line long, almost ellipsoid, with a slight basal and terminal emarginature and with longitudinal introrse dehiscence. Pollen-grains smooth, ellipsoid, bursting lengthwise. Style shorter than the filaments, formed by the twisted coalescence of five, narrowed at the apex. Ovaries bearing a subilate-cylindrical rostrum, which is rather more than 1 line long, and clothed with white soft spreading hair. Ovules geminate. Carpels as yet unknown.

This species is in many respects allied to Eriostemon capitatus, which, however, belongs to the following section. It has been identified with Sieber's plant by Sir Will. Hooker (Conf, Kew. Misc. viii. 3r). Chorilæna forms a section of Eriostemon intermediate between Chorilænopsis and Asterolasia. The foliage and the arrangement of flowers of $\mathrm{E}$. quercifolius, the only species referable to Chorilæna, cannot be deemed of sufficient importance to vindicate the generic distinction of that plant, both characters being unsupported by floral differences and exhibit only extrene aberration from the variable types of the genus. The inforescence of Chorikena reminds of certain Lasiopetala (for instance, L. dasyplyyllum and I. confertiflorum), and the value of this note is invalidated by the diversity of inflorescence in Lasiopetalum itself, But this inflorescence and the habitual resemblance of Chorilæna with Thomasia, Corethrostylis and other lasiopetaleous genera induced the author of this work to assign in the First General Report on the Plants of Victoria, 1853, p. 10, to Tremandrex a place intermediate between Rutaces and Buettneriacex, and the correctness of this view, as far as the alliance of Lasiopetalese and Tremandrex is concerned, has been simultaneously borne out by Steetz in his excellent memoir on the affinities of the former tribe of plants. In its ordinary states Eriostemon quercifolius shows rather coriaceous leares; but specimens gathered in moist valleys, where the plant attains the height of 25 and 30 feet, show, analogous to those of Correa, herbaceous leaves, whilst we observe the flowers to be almost green.

\section{Sect. VI. Asterolasia.}

Leaves generally star-hairy. Flowers solitary, sessile or capitate or umbellate. Calyx very small or obliterated. Petals yellow, rarely white, valvate in æstivation. Filaments usually smooth. Anthers erect. Stigmas free and filiform or clavate, or coalescent. Carpels oftener blunt than rostrate.

ariostemon corræifolius, Fr. MI. Fragm. Phytogr. Austr. i. 105; Phebalium correifolium, Adr. de Juss. in Mém. Soc. d Hist. Nat. Paris, ii. t. 10; Ph. asteriscophorum, F. M. in Transact. Vict. Inst. i. p. 31.

Branchlets terete, toinentose; leaves herbaceous, lanceolate- or obovate-oblong, toothless, conspicuously stalked, above scantily hairy or nearly smooth, beneath pale and starry tomentose, at the margin flat; umbels axillary and terminal, sessile, quite tomentose, few-flowered, rarely reduced to one flower; pedicels as long as or longer than the flower; calyx exceedingly small, acutely toothed; pctals outsidc tomentose, inside yellow or white, longer than the glabrous filaments; anthers exappendiculate; style short, glabrous; stigmas stout, united into a head; carpels tomentose, rostrate; seeds rather shining, smooth. 
In deep valleys and ravines of the Buffalo MLountains, in the gravelly diluvium on the Buffalo River; on the forest slopes of Mount Disappointment. In New South Wales near Parramatta, according to Mr. Woolls, and in some other localities.

A shrub from 1 to a few feet high, of a strict or roundish habit, with the aspect of an Hibbertia. Tomentum of the branchlets usually brown, often grey-black in age. Leaves variable in size, from a few lines to $I_{2}$ inch long and fiom 2 lines to 1 inch broad, with a cuneate base contracted into the petiole, above dark-green and somewhat shining, and less densely than beneath scattered witl starry hair. Pedicels from 2-8 lines long; as well as the flowers rusty tomentose. Bracts and 'bracteoles, if any, obliterated in the tomentum of the flowerstalk. Calyx only about $\frac{1}{2}$ line long. Petals lanceolate-orate, rather acute, sessile, smooth inside, usually sulphur-yellow, about $2 \frac{1}{2}$ lines long, valvate in astivation. Petaline filaments visibly shorter than the sepaline ones; all capillary, yellow. Anthers didymous- or quadrate-ovate, bright-yellow or vitellinous, basifixed, about $\frac{2}{3}$ line long, with lateral deliscence, terminated by a very minute gland. Style pale, capillary, about 1 line long. Stigma green, much thicker than the style, about $\frac{1}{2}$ line long, somewhat capitate, with 5 light furrows and a slightly and irregularly lobed base. Ovaries green. Carpels 5 or by abortion less, free, rather compressed, almost rhomboid, upward dilated, beaked by a broad spreading acumen, $1 \frac{1}{2}$ line long. Placental membrane $\frac{2}{3}$ line long, quadrate, with a minute acumen. Valves of the endocarp remarkably dilated at the apex, producing at their junction a minute deltoid ascending tooth. Seeds black, oblique-ellipsoid, 1 line long.

This plant bears close affinity not only to the following species, but also to the rare South-Western Australian Eriostemon grandifiorus, which according' to Hooker's excellent plate (Icon. Plant. 724) is recognized fiom this and every other species of the genus by a double number of stamens; the style is moreover longer than in E. correifolius; the stigma is less capitate and more lobed; the petals are larger and blunt, whilst the young fruit consists seemingly only of three carpels, which are not benked. In the remarkable minuteness of the calyx both agree with Eriostemon Hookerii (Fragm. Phytogr Austr. i. 104) and establish a transit to the following congener, in which the calyx becomes quite obliterated.

Eriostemon pleurandroides, F. M. Fragm. Phytogr. Austr. i. 106; Asterolasia phebalioides, F. M. in Transact. Phil. Soc. Vict. i. 10.

Quite starry-tomentose; leaves herbaceous, chiefly fasciculate-cronded, sessile, oblong-or obcordatecuneate, notched at the apex, flat at the margin; flowers rather large, terminal, solitary, sessile; calyx oblitcratcd; petals golden-jellow, outside short-tomentose, hardly longer than the sepaline stamens; filaments glabrous; anthers exappendiculate, twice as long as broad, style below pubescent; stigmus frce, elongatcd, fliform, papillose, recurved; carpels tomentose, blunt, twice or three times shorter than the petals; valves of the endocarp toothless; placental membrane renate-cordate, more than half as long as the seed; testa of the seed but little shining.

On arid stony slopes of the Serra and Victoria Ranges, especially on Mount Sturgeon and Mount Abrupt.

A rather dwarf bush, greatly resembling certain Hibbertiæ and Pleurandræ, never above 3 feet high and usually lower, sometimes with simple stem, usually simply branded, less fiequently with repeated ramifications. Branches as well as the usually short branchlets clothed with a dense brownish-grey finally blackish tomentum. Leaves closely scattered along the branches, but forming tufts at the summits of the ramifications, and thus a spurious involucre to the terminal flowers, uswally from 3-6 lines long; above the middle 2-3 lines broad, densely tomentose on both pages, at last calvescent on the surface, and then somewhat tuberculate-scabrous, flat or by somewhat connivent upper edges concave, sometimes one or the other diminutive leaf forming bracts. Bracteoles oblong-linear or rarely linear-subulate, in most cases wanting. Petals 5 rarely 6 , longer than the floral leaves, usually from 4-6 lines long, ovate-lanceolate, minutely acuminate, of tender substance, in preflorescence valvate, soon dropping. Filaments yellow, 10 
rarely 9 or 12, linear-capillary; the petaline ones considerably shorter than the rest. Anthers about $\frac{3}{4}$ line long, quadrate-oval, with light terminal and basal emarginature, erect, outside bright- inside pale-yellow, with marginal dehiscence. Pollen-grains oval, smooth, with longitudinal slit. Ovaries greyish-tomentose. Styles 5 rarely 6, yellowish, about 2 lines long, united into one except at the apex, whence they pass into more or less uncinate above and at the margin papilliferous stigmas of about 1-1 $\frac{1}{2}$ line length. Carpels obovate-rhomboid, considerably compressed, at the commissural angle denuded of indument, $1 \frac{1}{2}-2$ lines long. Valves of the endocarp pale-yellow, united into a concave base, not so deeply excised at their margin as in many other species. Placental membrane rerging somewhat into a crescent, nearly 1 line broad, pale. Seeds

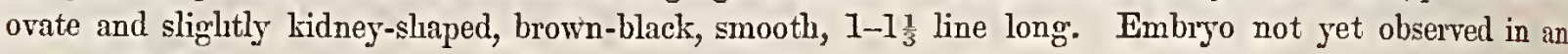
unshrivelled state.

Comparison of diagnosis and description will point out the distinction of this fine and well-marked plant from Eriostemon correifolius, to which it bears some external resemblance.

In flower during the spring.

Eriostemon trymalioides, F. M. Fragm. Phytogr. Austr. i. 106 ; Asterolasia trymalioides, $F . M$. in Transact. Phil. Soc. Vist. i. 10.

Branches numerous, starry-tomentose; leaves rather small, thick-coriaceous, mostly crowded, stalked, blunt, ovate or orbicular-or oblong-ovate, revolute at the margin, above hairy-scabrous and calvescent, beneath tomentose; flowers terminal, solitary, sessile; calyx deeply and acutely toothed, membranous or imperfectly developed; petals yellow, outside partially tomentellous, hardly as long as the sepaline stamens; filanents glabrous; anthers exappendiculate, less than twice as long as broad; style glabrous; stigmas clavate, free, reflexed; carpels tomentellous, blunt; valves of the endocarp toothless; placental membrane cordate, half as long as the seed; testa of the seed shining.

In the higher tracts of the Australian Alps by no means rare, not descending to an elevation below 5000 feet, extending from the Munyang Mountains to the Baw Baw Ranges. In New South Wales on Mount Kosciusko.

A stout amply branched bush of low stature, occasionslly several feet high, resembling when out of flower some Trymalia. Branches and branchlets terete, clothed with a brown-grey at first ferruginous at last secedent tomentum. Leaves at the extremities of the branchlets most crowded and here but short-stalked, at the lower and lowest part of the branchlets and especially at the division of the latter often much longer stalked, all blunt, usually from $2-4$ hes long and from $1 \frac{1}{4}-2$ lines broad, above in age shining, beneath covered with grey-ferruginous star-hair; the inner floral leaves passing into bracts. Bracteoles membranous, almost scarious, of irregular form and position, ovate or lanceolate, or semiovate or oblong, 1-2 lines long, more or less hairy at the back, sometimes foliaceous at the tip. Flowers half buried in leaves. Calys about 1 line long, membranous, usually almost glabrous, deeply divided into 5 rather unequal deltoid teeth, of which occasionally one or the other is transformed into a bracteole or obliterated. Petals about 3 lines long, lanceolate-ovate, acutish, with a hightly prominent middle-nerve, valvate in restivation, finally deciduous. Filaments yellow, capillar-subulate. Anthers $\frac{1}{2}-\frac{3}{4}$ line long, at first cordate-roundish and saturated yellow, bursting at the margin, more oval in age and pallescent. Style 1 line, finally $1 \frac{1}{2}-2$ lines, long. Stigmas first green, then yellow, hardly longer than $\frac{1}{2}$ line, quite turned downward, forming a peltate head, outward papillose, beneath smooth. Carpels 2 lines long, considerably compressed, rhombeo-deltoid. Valves of the endocarp pale-yellow, united into a basal cavity, upwards much dilated. Placental membranc with a deep notch. Seeds hardly longer than 1 line, brown-black, oblique ellipsoid, smooth.

The definition of the genus Asterolasia, offered in the Phil. Transactions, was founded on an analysis of imperfect flowers, whence the floral envelopes receiverl a wrong interpretation.

In flower late in the spring. 


\section{CORREA.}

Smith, in Transact. Linn. Soc. iv. 219.

Calyx monophyllous, cup-shaped, truncate and toothless or 4-8-toothed or 4-8-lobed. Petals 4, sessile, valvate in æstivation, deciduous, free or usually with exception of the apex connate into a tube. Stamens 8, all fertile. Filamcnts free, straight. Anthers ellipsoid or ovate, erect, with introrse longitudinal dehiscence, exappendiculate. Ovaries 4, inserted on a short slightly sinuate and prominently 8-ridged disk. Ovules 2, affixed at the interior angle of the ovary; the upper one ascendent; the lower one descendent. Styles 4, united into 1. Stigmas coherent or rarely divergent. Carpels normally 4, bivalved, 1-2- rarely 3-seeded. Endocarp seceding, cartilaginous, bivalved, operculate towards the base by the placental membrane. Seeds oblique-ovate. Testa crustaceous. Embryo cylindrical, straight, in the axis of a copious albumen. Radicle longer than the plane-convex cotyledons.

Showy, strong-scented, mostly starry-tomentose, rather robust shrubby rarely arborescent plants, which occur spontaneously and copiously in South Australia, Tasmania, Victoria and New South Wales, rarely in Queensland and very rarely in South-Western Australia, extending neither to Central Australia nor to the western, northern or north-eastern coast of this continent, ascending partially to subalpine elevations. Branches and leaves opposite, rarely ternate; the lattcr herbaceous or coriaceous, usually broad, constantly simple. Pedicels terminal or axillary, solitary, geminate or ternate, rarely cymose, usually short, provided with 2 narrow deciduous bracteoles. Corolla frequently elongated, varied in color, although never purely blue. Stamens usually exserted. Filaments smooth, subulate-filiform; the petaline ones often dilated at the base. Carpels always blunt and tomentose. Seeds dark-colored.-Mazeutoxeron, Labill. Relat. du Voy. à la Recherche de la Pérouse, vol. ii. 11 ; Antomarchia, Colla, Hort. Ripul. App. ii. 345 ; Didymeria, Lindl. in Mitch. Three Exped. ii. 197.

The genera nearest allied to Correa are Boronia and Nematolepis (Symphyopetalum).

Correa alba, Andrew's Botanist's Repository, t. 18 ; Vent. Malmais. $t .13$; Bot. Regist. t. 515 ; Lodd. Cabinet, t. 152; Lam. Encyclop. MLéthodiq. t. 945; Adr. de Juss. in Mém. du Muséum d Hist. Nat. xii. t. 21, fig. 22; C. rufa, Vont. Ifalm.t.13; Cand. Prodr. i. 719; J. Hook. Fl. Tasm. i. 61; C. cotinifolia, Salisb. Paradis. Lond. t. 100; Mazeutoxeron rufum, Labill. Voy. ii. 11, t.17.

Leaves coriaceous, spreading, ovate, orbicular-ovate or orbicnlar, clothed beneath with an usually grey and thin tomentum; flowers erect or patent, solitary or geminate; calyx subcoriaceous, toothless or indistinctly 4-toothed, somewhat broader than long; petals short, white, entirely free; filaments shorter or nearly as long as the corolla, white, scarcely dilated towards the base; anthers red, twice as long as broad; style smooth; stigmas coherent; carpels ovate-rhomboid, glabrescent; valves of the endocarp upwards gradually dilated; seeds scabrous; cotyledons about half as long as the radicle.

On the sandy or rocky sea-shores, frequent from St. Vincent's Gulf to New South Wales; also in Tasmania.

A compact more or less ample bush, absolutely restricted to the coast, from a few to 6 feet higll. Branchlets cylindrical, covered witl a starry grey-brown in age nigrescent tomentum. Leaves provided with a tomentose conspicuous petiole, $\frac{2}{3}-1 \frac{1}{2}$ rarely 2 inches long, entire, flat or lightly waved at the margin, above scantily or thinly star-hairy and finally often glabrescent, beneath clothed with a thin grey velvet of likewise starry hair. Pedicels terminating very short peduncle-like branchlets, arising in most cases solitary from the axes of a pair of small deciduous leaves, thus geminate, 1-2 lines long, bearing two opposite small linear caducous bracteoles. Calyx cup-shaped, outward grey-brown tomentose, about $1 \frac{1}{2}$ line long, broader 
than long, with 4 more or less minute sharp teeth, which alternate with the petals. Petals lanceolate, 4-6 lines long, sessile, free already whilst expanding, elevated at the inner margin, outward thinly velvet-downy, inside smooth. Filaments subulate; those opposite to the petals about 4 lines long, and at the base flatter than those alternating with the petals, which measure nearly 5 lines. Anthers broad-oval, about $\frac{3}{4}$ line long, finally somewhat versatile. Style white, subulate, about 3 lines long. Stigmas very minute, not divergent unless imperfectly at the apex. Disk green, 8-waved, smootl, forming a base to the ovaries. The latter white-tomentose. Carpels considerably excelling the length of the calyx, bearded at the apex, $3-1$ lines long. Valves of the endocarp forming a saccate toothless base, truncate and slightly emarginate at the apex. Seeds broad- and oblique-ovate. Cotyledons half as long as the radicle.

In flower throughout the year.

Correa speciosa, Andr. Bot. Repos.t.653; Bot.Reg.t.26; Bot. Mag. t.1746; Lodd. Cabinet, t.112; Mazeutoxeron reflexum, Labill. Voy. ii. p. 11, t. 19; Correa rubra, Sm. Exot. Bot. ii. 26; C. virens, Sm.l.c.t.72; Bot.Reg.t. 3; Bot. Mag.t. 1901; Lodd.Cab. 336; C. viridiflora, Andr. Repos. t. 436; Bonpl. Malm. t. 12 ; C. reflexa, Pers. Syn. Plant. i. 419 ; Gertn. Suppl. Carpol. p. 155; C. rufa, Gertn. Suppl. Carpal. t. 210,f.7; C. pulchella, Mackay, in Sneet's Hort. Brit. S9; Sneet, Flor. Austr. t. 1; Bot.Reg.t.1224; Maund's Botanist, t. 152; Lodd. Cabt. 1684; Reichenb. Flor. Exot. t. 345; Bot.Maga . t. 4029; Antomarchia rubra, Calla, Hort. Ripul. App. ii. 345 ; C. glabra, Lindl. in IIitch. Three Exp. ii. 48; C. leucoclada, Lindl. l.c. ii. 30 ; C. rotundifolia, Lindl. l.c.・ii. 217; C. cordifolia, Lindl. l. c. ii. 231; C. Backhousiana, Itook. Ic. Pl. 2, t.2; C. Schlechtendalii, Bchr, in Limnaa, xx. 630; C. cardinalis, F.M. in Bot. Mag. t. 4912.

Leaves coriaceous or subherbnceous, spreading or reflexed, verging in to a cordate or orbicular or ovate or elliptic or oblong form, even or bullate; pediçels stout, usually short and solitary; flowers generally pendulous; calyx subcoriaceous, toothless or minutely 4-toothed, frequently twice as broad as long; petals elongated, only at the base and apex free; tube of the corolla crimson, pink, purplisl- or white- or yellowish green; filaments usually short- sometimes long-exserted; the petaline filaments dilatcd tonards the base; anthers yellow, generally about thrice as long as broad; style below the middle downy, more rarely glabrous; stigmas colerent or somewhat divergent; carpels glabrescent, oblique dimidiate-round or rhomboid-orate; valves of the endocarp at the inner edge usually deeply excised; seeds brown-black, shining; cotyledons nearly as long as the radicle.

Not rare in heatl-ground or in barren rocky localities as well along the const as over the inland tracts, equally on low ridg'es as in mountainous regions, yet not ascending to alpine elevations, extending from the Great Australian Bight to Lake Torrens and to the northern boundaries of New South Wales, disappearing towards Central Australia; not rare in Tasinania.

A usually niddle sized, sometimes dwarf bush, with spreading branches, seldom above 8 feet high; the red-flowering variety particularly of charming aspect. Younger branches and branchlets starry-tomentose, with longer and shorter at first brown later nigrescent liair. Leaves short-stalked, oftener bent downward than upward, usually from $\frac{3}{4}-\frac{1}{2}$ inch long, and from $\frac{1}{2}-1$ inch broad, in a certain variety (restricted to the desert) only about $\frac{1}{2}$ incl long, sometimes in meagre specincns only a few lines broad, in luxuriant specimens occasionally 2 inches long and more than 1 inch broad, with a beneath prominent midrid and lateral divergent nerves, above more or less scantily star-hairy and by secession of the indument finally scabrous, beneatl denscly clothed with an at first pale-brown or grey or fulvous finally darker tomentum, rarely on both pages quite glabrous, towards the margin mol'e or less recurved or rarely quite flat, cntire or lightly waved or minutely denticulated. Leares of snuall seedlings of this and otler Correas alternate. Flowers not fragrant, terminating singly or in pairs or ternately lateral sloort branchlets, provided usually only with short pedicels, occasionally howerer (particularly those of a certain variety peculiar to the desert) producing stalks fully $\frac{1}{2}$ inch long. Bracteoles seated at or near the middle of the flowerstalks, linear-filiform, rarely 
oblong or spathulate, opposite, 1-3 lines long, tomentose, rery caducous. Calyx semiovate- or hemisphericalcupsliaped, $1 \frac{1}{\mathfrak{l}}-3$ lines rarely 4 lines long, truncate, persistent, usually outward brown-sometimes greytomentose, rarely glabrous, seldom as long as broad, with 4 minute teeth, which if present alternate with the petals, rarely 8 -toothed. Petals usually 2 lines broad and 1-1 $\frac{1}{2}$ inch long, narrow-lanceolate, in a variety inhabiting the desert and in another variety occurring in coast-tracts reduced to the length of $\frac{2}{3}$ inch, in the variety designated C. cardinalis fully 2 inches long, connate into a cylindrical tube, divergent at the apex, when reduced in length exhibiting an almost bell-shaped form, inside below the apex and at the very base whitish; their terminal portion on both pages green or tinged somewhat with red or brown, or rarely yellowish white, or quite white, outside all over pulverulent-tomentose with very short starry downs, never smooth, inside quite glabrous, finally deciduous, more or less secedent in age. Filaments white or slightly tinged with green or red, smooth, deciduous; those opposite the petals either suddenly or gradually but always conspicuously dilated just above the base; their dilatation about 1 line rarely only $\frac{1}{2}$ line broad, outward concave, inward convex, always tapering to the bottom, retaining a nectarfluid; the four filaments alternating with the petals all around equally but only comparatively little thickened towards the base, also pointed at the bottom. Anthers 1-12 line long, yellow, finally dark red-brown at the back, ellipsoid, with truncate base and apex and introrse dehiscence. Pollen-grains yellow, smooth, at first spherical, when shedding ellipsoid, bursting with three longitudinal fissures. Style about as long as the filaments or somewhat longer, thinfiliform, long-persistent, rery gently attenuated towards the summit; its upper portion pale-green, and always smooth; its lower portion white and much less frequently glabrous than clothed with tender white radiate downs, which are scantily or densely distributed. Stigmas so minute as not or little to exceed the thickness of the style, rarely short-divergent. Hypogynous disk only about $\frac{1}{2}$ line high, greenish-yellow, consisting of 4 smooth almost renate confluent glands, which in being outward bent form 8 longitudinal ridges. Carpels usually half or more than half emerging beyond the calyx, rarely in diminutive desert-grown specimens nearly concealed in the calyx, in their ordinary state 3-4 lines long, in diminutive specimens shorter. Their valves of rather firm thin-coriaceous consistence, livid or brownish, with curved transverse anastomosing lines, rounded or truncate or eren dilated at the apex, 1- or more frequently 2-seeded, entirely smooth or usually in part laxly tomentose. Valves of the endocarp parchment-like, livid, sometimes only lightly excised nitl toothless cup-like base. Placental membrane about 1 line long. Seeds brown-black or dark-brown, sometimes rariegated, smooth, 1-2 lines long, by mutual pressure truncate on one extremity when geninate, otherwise oblique-orate. Radicle thicker than the cotyledons.

In flower throughout the year.

Colonists have not appropriately given the nane "Native Fuclisia" to this plant. The flowers, although usually pendent, are also, perhaps according to the action of light, patent or even erect, as well expressed in the Bot. Mag. t. 1746, and in the Bot. Reg. t. 26, such difference in the direction of the flowers being ascertained to exist also in C. Lawrenciana. C. magnifica appears to be rather a variety of C. speciosa than a hybrid nroduction; its leaves are small, almost flat and of so thick a texture as to conceal the lateral nerres and the veins, which render the foliage of the ordinary state of C. speciosa almost wrinkled. What is cultivated in gardens under the name of C. rosea and C. Grevillei is clearly conspecific with C. speciosa. Nor are any characters apparent by which C. longiflora (Paxt. Mag. vii. 195), C. Harrisii (Paxt. Mag. rii. 79) and C. bicolor (Paxt. Mag. ix. 267), could be withdrawn from the other numerous varieties of C. speciosa, a plant which in the wide range of its distribution encounters such varied influences by climate and soil as to render its playforms readily enough understood when studied in free nature. The above garden-plants can be regarded only as the result of cross-impregnation not of species but of varieties, and forms analogous to them may be met with in the fields of Australia. C. decumbens (F. M. in Transact. Phil. Soc. Vict. i. 30) is nearly related to $\mathrm{C}$. speciosa. It occurs on the cataracts of the Mount Lofty Ranges and on the Onkaparinga in South Australia, also according to Mr. F. Waterhouse's collections in Kangaroo Island. From the redflowering variety of $\mathrm{C}$. speciosa it differs in having a distinctly 8-toothed calyx, the teeth opposite the petals 
being deltoid, those alternating with the petals elongated, linear-subulate or filiform; the stigmas are cruciate-divergent and longer than in any other species; less important distinctive characters rest in the depressed growth of this plant, in the always erect flowers and in the long-exserted stamens. Still considerable discrepancies in the dentation of the calyx may be noted also in C. Lawrenciana. C. decumbens may perhaps successfully be sought for in our Grampians and in the adjacent ranges.

Correa Iawrenciana, Hook. Journ. of Bot. i. 254 and ii. 417 ; Correa fernginea, Backhouse, in Ross's Hobarton Almanac, 1835, p. 80; Hook. Compan. to the Bot. Mag. i. 276; Hook. Ic. Pl.t. 3; Hook. Jonimal of Bot. ii. 417.

Shrubby, arborescent; leaves coriaceous, usually large, ovate or oblong-ovate, flat, spreading; above smooth; pedicels stout, usually short; flowers solitary, twin, ternate or several cymose; calyx minutely rarely long 4-toothed, usually as long as broad; petals free only at the apex; tube of the corolla pale greenish-yellow; filaments long-exserted, scarcely dilated at the base; anthers yellowish-green, about thrice. as long as broad; style smooth; stigmas coherent; cnrpels tomentose, finally glabrescent, ovate-rhomboid; valves of the endocarp upwards dilated; seeds dark-brown, somewhat shining; cotyledons nearly as long as the radicle.

Descending from subalpine elevations along torrents and rivulets and over humid jungle-declivities to sheltered umbrageous valleys as low as $\mathbf{1 0 0 0}$ feet above the level of the sea, although never to lowlandplains; observed on the summit of Mount William, in the ravines between Apollo Bay and Cape Otway, on the Upper Barwon, on the Upper Yarra, towards the sources of the Buneep River, the Tarwan, the Tyres, the Tangil, the King River, on the Buffalo River, the Delatite, the Mitta Mitta, Cabongra, Ingegobba, Snowy River, Hume River and on the Upper Genoa River. In Tasmania south as far as Southport.

A tall shrub, assuming in favorable places an arborescent growth, noticed fully 30 feet high in the deep morassy forest-glens between Cape Otway and Apollo Bay, always consociated with types of the Tasmanian vegetation, but hardly with any exclusive companions of $\mathrm{C}$. speciosa. Branchlets densely tomentose. Leaves conspicuously stalked, quite entire, in their ordinary state $2-3$ inches long and about 1 inch broad, in subalpine forms only of lalf the above dimensions; in luxuriant specimens sometimes 4-5 inches long, and proportionately broad, glabrous on both pages or more frequently clothed beneath witl a thin grey or pale fulvous tomentum, which but in rare instances secedes. Peduncles tomentose, rather short, or $\frac{1}{2}-1$ inch long or sometimes scarcely developed, axillary. Pedicels very short or a few lines long, tomentose. Bracteoles 1-3 lines long, linenr-filiform, caducous. Calyx usually 3 lines long and in proportion to its diameter much longer than that of the preceding species, usually also remarkably blunt at the base, there even frequently impressed-truncate, sometimes remarkably turgid and hence upward contracted, sometimes again in certain varieties (restricted to frequently flooded river-banks) cylindrical-campanulate and then outward green and smooth, and protracted into 4 deltoid-subulate teeth of 1-2 lines length, which alternate with the petals; in most instances, however, clothed with a dense pale- or dark-brown tomentum, accasionally in subalpine specinens hemispherical-cupshaped as in the nomal state of C. speciosa; thus the calyx varying in length between $1 \frac{1}{2}$ and 6 lines. Corolla varying between 8 and 18 lines in length, usually less spreading at the apex than in any other species, pale greenish-yellow with sometimes brownish tips, outward clothed with a more or less velvet-like or pulverulent indumontum, inside smooth. Filaments pale-mreenisl, finally blackpurplish, linear-setaceous, glabrous, short- or long-exserted. Anthers almost ellipsoid, witl short-bilobed base, yellow in front, more green at the back, 1-1 $\frac{1}{2}$ line long. Pollen-grains ellipsoid, smooth, yellow, with three longitudinal slits. Style setaceous, about as long as the longer filaments, pallid-oreen. Stigmas very minute. Hypogynous disk short, smooth, greenish, with eight undulations. Carpels covered with a finally seceding tomentum, livid, 4-5 lines long, truncated-blunt, otherwise oblique-ovate, longer than the calyx. Endocarp pale-yellow; its valves united into a hollow toothless base. Seeds oblique- or truncate-ellipsoid, 
olivaceous-black, 1-2 lines long, shining; smooth or partially tubercled, usually twice as long as the subovate colorless placental membrane. Cotyledons hardly thinner than the radicle.

C. Lawrenciana forms the smooth-leaved variety of this species, C. ferruginea the variety with tomentose leaves. In the "Flora Tasmanica" C. glabra and C. Schlechtendalii are referred to C. Lawrenciana, while undoubtedly they represent glabrous-leared varieties of $\mathrm{C}$. speciosa; nor can C. leucoclada, which we possess from the locality indicated by Sir Th. Mitchell, be drawn to any other species than C. speciosa. C. Lawrenciana is, like numerous other plants common to this colony and Tasmania, not indigenous to South Australia; hence it is more likely that also.the South-Western Australian species, indicated by Dr. Hooker (conf. Fl. Tasm. i. 62) as probably belonging to C. Lawrenciana, should be referred to C. speciosa, which indecd we possess from Major Warburton's collection as far west as Streaky Bay and Venus Bay. Nevertheless it must be admitted that the differences between $C$. alba, C. remula and C. speciosa are greater and more positive than between C. speciosa, C. decumbens and C. Lawrenciana; but whilst amongst extensive sets of specimens of the latter three plants all middle forms are wanting, we have to regard them as really specifically distinct.

Correa æmula, F. M. First Gen. Report on the Veget. of the Colony Vict. p. 10; Fragm. Phytogr. Austr. i. 3; Didymeria æmula, Lindl. in Mitch. Three Exped. ii. 197.

Leaves herbaceous, cordate or orbicular- or lanceolate- or cordate-ovate; pedicels solitary, geminate or ternate, slender-filiform, clongated, scantily hairy, jointed, much thickened towards the apex; flowers pendulous; calyx lax, herbaceous, seantily hairy, cleft beyond the middle into 4 deltoid or scmilanceolate long-acuminated lobes; petals long-persistent, membranous, during anthesis only free at the apex, finally separating from each other; tube of the corolla greenish or purphish; filaments short-exserted; those opposite the petals broadly dilated towards the base; anthers yellow, nearly thrice as long as broad; style smooth; stigmas coherent or slightly divergent; carpels as long as the calyx, oblique-ovate.

On stony shady and irrigated declivities of the Serra and Victoria Ranges; beyond this colony known only from deep rocky well-watered glens of the Barossa Ranges and from the mountains near Encounter Bay.

A remarkable shrub, several feet sometimes up to 10 feet high, with ustally patent branches, which are thickly hispidulous-tomentose. Leaves provided with short or moderately long petioles, conspersed on both pages with scattered stellate hair, usually from 1-1 $\frac{1}{2}$ inch long, occasionally fully $2 \frac{1}{2}$ inches in length, often rather acute, undulated and frequently denticulated at the margin, somewhat paler beneath. Pedicels $\frac{1}{3}-1$ inch long, terminating short axillary peduncles, which are provided at the apex with a pair of opposite sanceolate, ovate or cordate, always acuminate, foliaceous bracts of $2-4$ lines length." Bracteoles placed variedly more towards the apex or iniddle or base of the pedicels, lanceolate- or linear-subulate, 1-2 lines long, scattered-hairy. Calyx dark-green, about 4 lines long, scantily clothed with dispersed star-hair; its lobes alternate with the petals, divergent. Corolla always of a more or less sordid color, bluish- or purplishgrey or pale yellowish-green, more tender in substance than that of its congeners, 1-1 $\frac{1}{3}$ inch long, outside covered with minute downs, inside glabrous, partially or often totally separating from each other in age and involving a pair of filanents. Filaments greenish-white, finally yellowish, smooth. Anthers yellow, little longer than 1 line, almost ellipsoid, with bilobed base. Pollen-grains golden-yellow, ellipsoid, bursting with longitudinal slits. Style white-green. Stigmas very minute. Disk short, pale green-yellow, smooth, with 8 prominent ridges. Carpels livid, about 3 lines long; rounded-blunt, bearded at the summit. Endocarp pale-yellowish. Seeds and placental membrane similar to those of its congeners. Embryo as yet unknown.

This plant is in flower almost throughout the whole year, and may be readily multiplied by cuttings.

PLATE VII. 1, hair ; 2, flowers laid open; 3, stamens ; 4, dry pollen-grains ; 5, moist pollen-grains; 6 , ovary; 7 , the same with the style and with downward-bent filaments ; 8 , carpels ; 9 , vertical section of the fruit; 10, diagram of Hower; 11, valves of the endocarp separated; 12, seed; 13, longitudinal section of the seed; 14, transverse section of seed: figurcs 1, 3, 4, 5, 7, 12, 13 and 14 more or less magnificd; the remainder of natural size. 


\section{VI.-COLUMNIFERA.}

Calyx in præflorescence valvate. Corolla in bud usually imbricated or twisted, rarely wanting. Placentre axil. Albumen more frequently small or absent than copiously developed.

\section{ORDER BUETTNERIACEÆ. \\ R. Br. in Flinders's Voyage, ii. 540.}

Flowers symmetrical, hermaphrodite, rarely declinous. Caly $x$ with 4 or 5 lobes or sepals, valvate in preflorescence. Petals 4-5, alternate with the lobes of the calyx, twisted or induplicated-valvate in restivation, persistent or deciduous, sometimes wanting. Fertile stamens 5, and then opposite to the petals or numerous. Staminodia opposite to the divisions of the calyx or wanting, frequently connate with the stamina. Anthers terminal, two-celled rarely three-celled, extrorse or introrse, with longitudinal or terminal dehiscence. Pollen-grains smooth. Ovary free, compound and with central columna or simple. Ovules geminate or sereral or many. Styles consolidated, rarely free. Stigmas divergent or coalescent. Fruit consisting either of a capsule with loculicidal dehiscence or of one or more carpels. Albumen, if present, mucilaginous or carnulent. Embryo varied in form. Radicle usually inferior.

Trees or shrubs or rarely herbs, dispersed over the tropical and warm temperate zones, frequently clothed with stellate or ramified hair. Leaves alternate, very rarely opposite, always simple. Stipules deciduous, sometimes persistent, seldom wanting. Inflorescence and color of petals various.-Endl. Gen. Plant. 995 ; Lindl. Teg. Kingd. third ed. 363 .

This order includes a considerable number of Australian plants, referable to the following genera ; amongst the tribe Lasiopetalex : to Guichenotia, Thomasia, Rhynclostemon, Leucothamnus, Lasiopetalum, Asterochiton, Corethrostylis, Lysioscpalum, Sarotes, Kerandrenia, Seringia ; amongst the tribe Buettneriaceæ : to Rulingia, Commersonia, Hannafordia, Achilleopsis and Abroma; amongst the tribe Hermanniex: to Waltheria, Dicarpidium, Melochia, Ridleya; amongst Dombeyacese : to Melhania and seemingly also to Pterospermum.

Affinity brings this order in near contact with Malvacese and Sterculiacex, and also, as well pointed out by Dr. Steetz, with 'lremandrex.

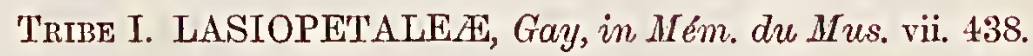

Calyx corollaceous. Petals scale-like or wanting. Filaments free or at the base connate. Staminodia 5, narrow or wanting. Antlicr-cells often contiguous. 


\section{LASIOPETALUM.}

Sm. in Transact. Linn. Soc. iv. 216.

Calyx corollaceous, subcoriaceous, persistent, five-cleft, supported by a solitary trisected persistent bracteole. Petals 5, minute, scale-like, alternate with the lobes of the calyx, rarely wanting. Stamens 5, opposite to the petals, free. Filaments short, linear-subulate. Anthers affixed at the inner side, ovate or oblong, upwards attenuated and truncate, opening by two terminal pores, rarely also by lateral slits. Staminodia wanting. Ovary 3 - rarely 4- or 5-celled, with 2 sometimes 3 ovules in each cell. Style short, subulate, at or above the base articulated. Stigmas 3 rarely 4 or 5 , very minute. Capsule enclosed in the calyx, 3-rarely 4- or 5-celled, with loculicidal dehiscence. Seeds 1 or 2 in each cell, ascendent, subovate. Testa downy. Mesosperm subcrustaceous. Strophiole lobed. Embryo straight, placed in the axis of the fleshy albumen. Cotyledons almost orbicular, flat. Radicle cylindrical, inferior.

Shrubs, scattered over many tracts of extratropical Australia, clothed with an usually starry tomentum. Leaves coriaceous, alternate, rarely opposite, simple, almost always entire, above glabrous or glabrescent. Stipules wanting. Cymes opposite to the leaves, bracteate. Bracteole unilateral, calycine or rarely petaloid; its middle lobe the longest. Flowers not vividly colored. Anthers usually purplish-black. Capsule comparatively small. Seeds almost black.-Gay, in Mém. du MIus. vii. 445, t. 18 et 19 ; Endl. Gen. 996 ; Steetz, in Lelım. Pl. Preiss. ii. 317.

Lysiosepalum (F. MI. Fragm. i. 142), Corethrostylis and Thomasia are the genera, which in the cyclus of affinity approach nearest to Lasiopetalum. The former differs in free sepals and manyovuled cells of the ovary. The differences of the latter genera are pointed out in the following pages.

Iasiopetalum ferrugineum, Smith, in Andr. Bot. Rep.t. 208; Vent. Malmais. i. t. 59 ; Bot. Mag. t. 1766 ; Reiehenb. Magaz. der Rssthet. Botan. t. 37; L. Sieberi, Stectz, in Lehm. Pl. Preiss. ii. 338.

Leaves alternate, short-stalked, ovate- or linear-oblong, entire, repand or at the blunt or cordate base irregularly lobed, flat or slightly recurved at the margin, beneath thinly velvet-hainy; cymes short-pedunculate; flowers rather large, subsessile or short-stalked; segments of the bracteole semilanceolate- or linearsubnlate; the lateral segments shorter than the calyx; lobes of the ealyx inside grey-tomentose, outside rusty-tomentose, semilanceolate-deltoid; petals glabrous; anthers about as long as the filaments, opening by terminal pores; style shorter than the anthers, below the middle or near the base velutinous; ovary densely covered with a short white tomentum, often short-rostellate; capsule three-celled, outside starry velutinous, inside glabrous; longer lobes of the strophiole about half as long as the seed.

On granitic ridges near Mount Imlay; thence throngh New South Wales at least as far nortli as Botany Bay.

A pretty bush, a few or many feet in height. Branchlets terete, tomentose by starry at first rustbrown afterwards blackish-grey hair. Leares $1 \frac{1}{2}-5$ inches long, 4-10 lines broad, sometimes snbhastate, above scantily star-hainy and soon glabrescent, beneath densely clothed with short more or less grey or ferruginous rarely white star-hair, one-nerved, somewhat wrinkled at the surface by the inpressed lateral nerves. Primary peduncles opposite to the leaves, measuring less than $\frac{1}{2}$ inch. Cymes consisting usually of two branches, which are variedly shorter than $\frac{1}{2}$ inch, and as well as the peduncle, bracts and bracteoles rusty-tomentose. Bracts linear-subulate, 2 or several lines long. Lateral segments of the bracteoles about 2 lines long, middle one usually 3 lines long. Length of calyx $3-4$ lines; its lobes flat or slightly reflexed at the margin. Petals spathulate- or orbicular-rhomboid, membranous, veined, entire, $\frac{1}{3}-\frac{1}{2}$ line long, at first purple-brownish, afterwards dark-purple, inserted as well as the stamens on a very narrow black-purple 
hypogynous ring. Filaments fiee, linear-filiform, glabrous, about 1 line long. Anthers elliptic-ovate, erect, affixed below the middle of the inner side, at first pale-yellow, soon brown, finally black-purple. Pollengrains ovate, smooth, bursting lengthwise. Style $\frac{1}{2}-\frac{3}{4}$ line long; at the base or up to the middle densely covered with short white stiff spreading fascicnlate hair; its upper joint glabrous, setaceons, usually earlier dropping than the lower joint, which forms a mucro to the young capsule. Orary clothed with an indument similar to that of the lower joint of the style, trigonous-globular, with three slight longitudinal impressions. Capsule of the size of a pea or somewhat longer. Seeds ovate, about 1 line long, nearly black, scantily covered with downs. Strophiole digitate, livid, somewhat carnulent and transparent; its lobes linear-filiform, blunt; the two inner ones longer than the three exterior ones. Cotyledons roundish, lightly emarginate, about as long as the radicle.

In flower during the spring.

The description and plate of Lasiopetahum ferrugineum, published in the Mémoires du Muséum d'Histoire Naturelle, tom. vii. p. 446, tab. 18, accord sufficiently with our South-Eastern Australian plant, although Gay states, that the definition and figure given in the Mémoires were founded on West Australian specimens. But amongst the numerous plants, which our herbarium possesses through Mr. Oldfield's collections from the vicinity of the Murchison River, where most of the plants noticed at the Baie des Chiens-marins reappear, no species exist corresponding to that of Gay; and since neither in any other part of West and South-West Australia a Lasiopetalum at all resembling I. ferrugineum occurs, and since further, the otherwise accurate Gay unhesitatingly quotes the illustration of the truly East Australian plant given in the Bot. Mag. t. 1766, as belonging to his plant, it becomes evident that all the quotations in reference to the West Australian localities, admitted also by $\mathrm{Dr}$. Steetz in his excellent memoir of Lasiopetalex as correct, are resting on errors. Sir Jam. Smith's definition of the genus was certainly based on our species, when enumerating it together with many of its East Australian consociates in the Transactions of the Linnean Society (vol. iv. p. 216).

Iasiopetalum parviflorum, Rudge, in Transact. Linn. Soc. x. 297, t. 19, fig. 2; Gay, in Mém. the Musérum, vii. p. 447, tab. 19; Steetz, in Lelm. Pl. Preiss. ii. 339.

Leares alternate, short-stalked, oblong- or broad-linear, entire, flat or at the margin slightly recurved, beneath thinly grey-velrethairy; cymes short-pedunculate; flowers small, subsessile or short-stalled; segments of the bracteole almost linear, all shorter than the calyx; lobes of the calyx inside almost glabrons, deltoidsemilanceolate, outside clothed with grey-brown star-hair; petals glabrous; an thers longer than the filaments, opening by terminal pores; style tomentose at the base; capsule three-celled, outsidc star-hairy, inside smooth.

On the granitic banks of watercourses at the eastern frontier of Gipps Land; thence extending into New Sonth Wales at least as far northward as Botany Bay.

A shrub from a few to 8 feet high. Leaves $1 \frac{1}{3}-5$ inches long, 3-5 lines broad. Calyx usually about 2 lines long, occasionally, however, $3-4$ lines in length, and then with more aciminate lobes. Anthers $\frac{1}{2}-\frac{2}{3}$ line long. Capsule of the size of a small pea.

The distinctions of this from the preceding species are so trifling as to render a detailed description superfluons. The leaves are usually narrower and the flowers smaller, characters which prove, however, not to be permanent; nor appears the style to offer any important notes of discrimination. Thus the principal difference which characterized this from the foregoing congener must be songht in the inside smooth calyx, unless the seeds, which were unavailable for comparison on this occasion, should exhibit further reliable peculiarities.

Iasiopetalum Baueri, Stcetz, in Lelim. Pl. Preiss. ii. 339.

Leaves alternate, short-stalked, oblong- or broad-linear, entire, recurved or revolute at the margin, beneath thinly grey-velutinous; cymes racomose, on conspicutous slender pedrencles, fow-flowered; Howers small; pedicels as long as or shorter than the flower's; segments of the small bracteole ovate- or oblong-or 
linear-lanceolate, all considerably shorter than the calyx; lobes of the calyx inside slightly tomentose, semilanceolate-deltoid, outside clothed with brown-grey star-hair; petals glabrous; anthers longer than the filaments, opening by terminal pores; style glabrous or below scantily downy, nearly as long as the anthers; ovary grey-tomentose; capsule three-celled, outside glabrescent, inside at the axis downy; longer lobes of strophiole half or less than half as long as the seed.

In the Murray desert; also although rarely in the sandy scrub at the cliff beyond Brighton. In South Australia not rare in sandy ridges from the Murray to St. Vincent's Gulf, Kangaroo Island and Spencer's Gulf. In New South Wales along the Lower Darling and Murrumbidgee.

An amply expanding shrub, a few feet in height. Leaves usually from 1-2 $\frac{1}{2}$ inches long; $1 \frac{1}{2}-4$ lines broad, above very thinly grey-downy, glabrescent, blunt at the base and apex; the tomentum of the lower page sometimes rust-brown. Peduncles decurved, measuring from the base to the commencenent of pedicels $\frac{1}{3}-\frac{2}{3}$ inch, together with the latter very thinly grey-downy. Cymes occasionally reduced to two flowers, somewhat fragrant. Bracts linear, scattered, about 1 line sometimes 2 lines long. Lateral lobes of the bracteoles about 1 line long, middle one about $1 \frac{1}{2}$ line. Calyx about $2 \frac{1}{2}$ lines long, clothed outside with longer or shorter more or less gland-bearing hair, of more grey than brown color, inside when fresh of a whitish or purplish color. Petals minute, black-purple. Anthers brown-red, about $\frac{2}{3}$ line long, with white apex, somewhat oblong and connivent. Style subulate, often bearded at the base. Capsule of the size of a pea, trigastrous, outward scattered or imperfectly star-hairy. Valves almost crustaceous. Seeds hardly 1 line long. Strophiole fulvous at the base; its lobes pale; the outer ones very short or obliterated.

L. stelligerum (Turcz. in Bullet. de la Société Impériale des Natural. de Moscou, 1852), a Western Australian plant, seems, to judge by its description, closely allied to I. Baueri.

Iasiopetalum Eehri, F. M. in Transact. Phil. Soc. Vict. i. p. 36.

Leaves alternate, elliptical- or narrow-oblong; entire, flat or lightly recurved at the margin, beneath thinly velutinous; cymes few-flowered, on peduncles of moderate length; flowers rather large, on conspicuous pedicels; segments of the bracteole linear- or lanceolate-oblong, considerably shorter than the calyx; lobes of the calyx inside glabrons, semilanceolate-ovate, outside grey-velutinous; petals smooth; anthers longer than the filaments, opening by terminal pores; style hardly as long as the anthers, glabrous; ovary densely covered with a short white tomentum; capsule three-celled, outside starry grey-velutinous, inside at the axis scantily hairy; longer lobes of the strophiole less than half as long as the seeds.

In the north-western desert-tract of the Colony of Victoria; thence extending to Kangaroo Island, to the eastern part of the Great Australian Bight, to Lake Torrens, to the Darling River and to the Murrumbidgee.

An erect or diffused shrub, a few or several feet high. Branchlets and the lower page of the leaves covered with dense very short star-hair, which change their color from rust-brown to grey. Petioles mostly from 3-6 lines long. Leares thick-coriaceous, usually $1 \frac{1}{2}-3$ inches long, $3-6$ lines broad, often blunt as well at the apex as at the base, casually ovate or much elongated, always with a stout beneath prominent midrib, somewhat wrinkled above by the spreading lateral nerves, often bent downward, at the surface quickly glabrescent. General peduncle measuring usually $\frac{3}{4}-1$ inch; the pedicels $1 \frac{1}{2}-4$ lines long. Segments of the bracteole $1 \frac{1}{2}-2$ lines long. Flowers cernuous or pendent, slightly fragrant. Calyx 4 lines long, inside whitish when fresh, but greenish at the base. Petals orbicular- or cuneate-obcordate, $\frac{1}{3}-\frac{1}{2}$ line long. Anthers linearoblong, attenuated towards the apex, purplish-black, somewhat shining, about 1 line long. Filaments but little extending beyond the base of the anther. Style nearly of the length of the anthers, setaceous, with exception of the base smooth. Capsule measuring about $2 \frac{1}{2}$ lines, sphæroid, three-furrowed. Seeds 1 or 2 in each cell, ovate, dark-brown, finally almost black, 1 line long, slightly downy.

Plate III. 1, back view of a flower; 2, front view of flower; 3 , side view of flower ; 4, fruit; 5 , petals ; 6 , stamens; 7 , pollen-grains, dry; 8 , pollen-grains, moist; 9 , seeds; 10,11 and 12 , sections of seeds. 
Iasiopetalum dasyphyllum, Sieb. in Hook. Journ. of Bot. ii. 414 (exclus. var. a) ; I. Gunnii, Steetz, in Lehm. Enum. Plant. Austral. ii. 342; J. Hook. Flor. Tasman. i. 51; L. Wilhelmii, $F . M$. in Transact. Phil. Inst. Tict. ii. 65.

Leaves alteinate, often large, lanceolate- or cordate-ovate, rarely oblong-lanceolate or linear-oblong or cordate, entire, flat, beneath finally pale- and short-velutinous; floners cronded into an almost eapitate cyme, rather numerous, covered with an usually dark- or rust-brown rarely grey-brown tomentum; peduncles shorter than the cyme; segments of the bracteole ovate-lanceolate, shorter than the ealyx, rarely about as long as the calyx; lobes of the calyx inside glabrous or slightly downy, many-nerved, semilanceolatedeltoid; anthers suborate, hardly as long as the filaments, finally bursting lengthwise; style glabrous or frequently the lower portion velutinous; ovary tomentose; capsule 3-4-celled, rarely 5-celled, outside starhairy; longer lobes of the strophiole less than lialf as long as the seed.

On the lighliest declivities of the Grampians near Rose's Gap, C. Wilhelmi ; on the granitic ridges near Corner Inlet, on Mount Hunter, at Shady and Monkey Creek; more frequent towards tlie eastern boundary line of Gipps Land; thence extending to the Blue Mountains of New South Wales, to the Islands of Bass's Straits and to the north-western coast of Tasmania.

A slirub from a few to 12 feet high, often simply branched. Young branches densely covered with starry dark- or rust-brown hair. Leaves usually $2-4$ rarely to 6 occasionally only about $1 \frac{1}{2}$ inches long, from a broad rounded or cordate base protracted gradually into an acute rarely obtuse apex, in respective varieties rednced to the width of $\frac{1}{2}$ inch or widened fully to 3 inches, always penninerved, distinctly reined, above somewhat wrinkled and early glabrescent, sometimes yellow-variegated, clothed beneath with at first partially rust-brown at last grey or whitish star-hair. Cymes oftener many-flowered than few-flowered, opposite to the leaves, with 2-4 divergent short rays, at first by the curvature of the peduncle drooping, at last somewhat expanding, yet letaining the flowers much more crowded than in the antecedent species. Flowers sessile or on very short stalks. Biacts subulate-linear, 2-4 rarely 1 line long, laxly grey- and brownish-tomentose. Bracteoles rather variable in form, jet. not radiating, nor (as stated in the Plant. Preiss.), as far as inspection of our specimens teaches, linear, always on botlı sides velutinous-tomentose, but on the inner side paler. Flowers always hermaphrodite. Calyx about 4 lines long; its lobes not rarely inside bearded by a line of starry tomentum, which extends parallel to the margin. Petals spathulate- or orbicularorate, black-purple or brownish, $\frac{1}{3}-\frac{1}{2}$ line long, usually glabrous, but occasionally (as remarked by Dr. Steetz) beset with a fer hairs, sometimes a little pointed. Filaments linear-setaceous, somewhat rarely considerably excelling the length of the anther, which measures usually $\frac{2}{3}$ line, is purplish-black or dark-brown, not manifestly contracted towards the apex, rather truncate-oblong, with lightly emarginate base, and splits often in age partially or perfectly at its longitudinal sutures. Style about $\frac{3}{4}$ line long, towards the middle or near the base articulated; its lower joint white-tomentose; both .joints long persistent. Stigmas 3-5, rery minute. Capsule of the size of a large pea, nearly as often three-celled as four-celled, but much less fiequently five-celled, either sparingly downy or quite glabrous inside. Seeds ellipsoid, about 1 line long, slightly downy, black. Strophiole somewhat cupular, either fulvous or whitish, with 2 sometimes 3 narrow lacinise.

Lasiopetalum confertiflorum (F. M. in Linniea, 1852, p. 377), from Spencer"s Gulf and Kangaroo Island, accords well in form of leaves and arrangement of flowers with L. dasyphyllum, but may at once be recognized by the purplish radiating bracteoles, which exceed considerably the length of the calyx. How far L. confertiflorum is in its notes congruous with L. discolor (Hook. in Compan. to Bot. Magr. 1. 2r6) the author has at present no means of ascertaining, although from Dr. Jos. Hooker's remarks (in Flor. 'Tasun. i. 50) it mould appear that both share in those characteristic involucre-like bracteoles. Amongst West Australian plants $L$. capitellatum (Turcz. l. c.) will be found comparable with L. dasyphyllnm; and the affinity to $\mathrm{I}_{\text {. }}$ quinquenerviun ('Iurcz. 1. c.) is perhaps still closer, the calyx of the latter is, howerer, inside tomentose outside grey liairy, the cyme expanded and the bracteole divided into linear-filiform seg'ments. 
In its tendency to a longitudinal dehiscence of the anthers $L$. dasyphyllum agrees with I. micranthum (J. Hook. F. Tasm. i. 51). This character, which perhaps in aged states of other species may also be observed, breaks the main barrier by which Rhynchostemon was separated from Lasiopetalum, which two genera consequently should be combined. The presence or absence of petals in species of the allied genus Thomasia renders the distinction of Rhynchostemon and Lasiopetalum on these grounds inadmissible. 'It may be worthy of record that the. length of the strophiole in species of this genus is subject to considerable fluctuations; thus specimens of a Lasiopetalum from S.W. Australia, seemingly referable to L. indutum, show lacinia of the strophiole longer than the seeds.

\section{CORETHROSTYLIS.}

Endl. in Nov. Stirp. MLus. Tindob. Decad. p. 1.

Calyx ebracteolate or provided with a simple rarely double bracteole, corollaceous, membranous, persistent, five-cleft. Petals 5, minute, scale-like, opposite to the stamens, or wanting. Stamens 5, alternate with the lobes of the calyx, free. Filaments short, linear-subulate. Anthers affixed at the inner side, ovate or oblong, opening by two terminal pores. Staminodia none. Ovary three-celled. Ovules usually 2 in each cell, collateral, ascending from near the base of the central angle. Style setaceous, retro-hispid by fasciculate deciduous hair. Stigmas 3, very minute. Capsule enclosed in the calyx, three-celled, bursting by loculicidal dehiscence. Seeds 1 or 2 in each cell, ascendent, subovate. Testa downy. Mesocarp subcrustaceous. Strophiole lobed. Embryo straight, placed in the axis of the fleshy albumen. Cotyledons almost orbicular, flat, as long as the cylindrical inferior radicle.

Star-hairy shrubs, very sparingly dispersed over the southern litoral but rather frequently over the south-western tracts of Australia. Stipules wanting. Leaves coriaceous or herbaceous, flat, alternate or rarely almost opposite, entire, repand or sinuated. Cymes simple or compound, usually racemose, opposite to the leaves, with solitary bracts and entire sometimes petaloid bracteoles. Flowers white or pink. Capsule comparatively small, with one or the other cell sometimes vacuons. Seeds black.-Endl. Gen. 997 ; Steetz, in Lehm. Plant. Preiss. ii. 317.

Asterochiton (Turcz. in Bulletin de la Société Impériale des Naturalistes de MLscou, 1852) is probably referable to this genus, differing according to the quoted description in a five-celled ovary and smooth style, notes which are of no avail for generic discrimination in the closely allied genus Lasiopetalum. The inflorescence is, however, reduced to solitary flowers, and the fruit, which as yet remains umknown, may possibly exhibit generic distinctions. The ambiguous Corethrostylis cordifolia (Steetz, in Lehm. Pl. Preiss. ii. 344 ; Lasiopetalum cordifolium, Endl. in Enum. Plant. Hueg. p. 10) obliterates the line of demarcation between this and the preceding genus. It seems, however, notwithstanding the absence of petals, best consociated with Lasiopetalum, on account of a less petaloid calyx and of the development of an hypocalycine bracteole, although the latter not always exhibits the normal trisected form. C. microphylla (Turcz. in Bullet. Mosc. 1852) seems a variety of C. cordifolia.

Corethrostylis Schulzenii, F. BI. in Transact. Phil. Soc. Vict. i. 36.

Leaves herbaceous, repand or entire, usually broad-cordate, on both pages star-hairy; cyme starry tomentose, mostly compound; bracteoles close under or near to the calyx, as well as the bracts linear-filiform; calyx large, whitish or pale pink, longer than the pedicel; its lobes ovate-semilanceolate, inside almost glabrous; petals existing; ovary glandless, white-tomentose; style except at the apex copiously conspersed with retroversed fasciculate hair; capsule outside thinly star-hairy; strophiole hardly half as long as' the seed. 
On Cape Nelson, W. Allitt; near the entrance of the Glenelg River, Rev. Jul. Edm. Woods; beyond Victoria on Mount Benson near Cape Bernouilli, and near the Saltflat of Guichen Bay, Schulzen; in Kangaroo Island, Waterhouse.

A shony slurub of a few to 6 feet high. Branchlets terete, as well as the petioles and peduncles covered with grey-brown starry tomentum. Petioles $\frac{1}{2}-1$ inch long, cylindrical. Leaves usually $2-3$ inches long and broad, sometimes slightly sinuated, above not glabrescent, although particularly in age much thinner star-hairy than beneath, with a not very strong midrib, with straight divergent lateral distant nerves and anastomosing not very conspicuous veins; the apex acnte, less frequently obtuse; the basal lobes rounded, sometimes overlapping: Primary peduncle $\frac{1}{2}-1$ inch long, cylindrical, rather stout. Branches of the cyme usually several, often flexuose, mostly $\frac{3}{4}-1 \frac{1}{2}$ inch long. Bracts and bracteoles long persistent, 1-2 lines long, or the lower biacts sereral lines long, very narrow, star-downy; the former at the base of the pedicel; the latter hypocalycine or slightly lemote from the calyx, much less frequently geminate than solitary. Pedicels commonly 2-4 lines long, upwards somewlint thickened. Calyx about 4 lines long, deeply five-cleft, casually six-cleft, almost membranous; the lobes somewhat keeled by the prominent midrib, long and almost gradually protracted from a broad-ovate base to the apex, streaked by secondary nerves, tender veined. Petals resembling those of Lasiopetalum, rhomboid-orbicular, only about $\frac{1}{3}$ line long, pale fulvous or purplish, with broad hardly unguiculate base sessile. Filaments glabrous, linear-setaceous, about half as long as the anther, which is about $\frac{3}{4}$ line long, narrow-ellipsoid, fulvous or purplish-black, with shight terminal and basal emargination; each cell opening with an introrse terminal very short pore-like slit. Pollen-grains globular, smooth. Style hardly longer than I line, glabrous at or towards the apex, longer bearded towards the middle than towards the base. Stigmas extremely minute. Capsule spherical, trifurrowed, of the size of a pea, inside, except-at the very slightly pilose axis, glabrous. Seeds about 1'line long, subovate, slightly trigonous, imperfectly clothed with short white down. Strophiole pale livid, somewhat fleshy at the base, with sereral narrow lobes, of which the anterior ones are the longest. Albumen anygdaloid, white. Embryo yellowish. Cotyledons slightly emarginate at the base.

C. bracteata differs, according to the figure in Bot. Reg. t. 47 , in less broad leares, often only greminate and longer branches of the cyme, petaloid bracteoles, smaller rose-colored flowers, absence of petals, a glandulous-hairy ovary. C. membranacea has less hairy leaves, long slender peduncles, which as well as the pedicels are clothed with spreading septate often glandulous hair, and differs further in most of the characters pointed out under $\mathrm{C}$. bracteata, also in its more densely tomentose style and narrow lobes of the calyx. C. oppositifolia constitutes a variety of the latter species. C. parviflora (Turcz. Bullet. Mosc. xx. 172) has very small flowers on extremely short pedicels, whilst the whole inflorescence is densely star-hairy. Ours is the only species as yet noticed beyoud the precincts of Western Australia.

\section{THOMASIA.}

Gay, in Mém. due Mus. d'Hrst. Nat. vii. 450.

Calyx corollaceous, submembranous, persistent, five-cleft, supported by a solitary trisected persistent bracteole. Petals 5 , minute, scale-like, opposite to the fertile stamens, or wanting. Stamens 5 , alternate with the lobes of the calyx, with or without interjacent minute staminodia. Filaments short, linear-subulate. Anthers affixed at the inner side, ovate or oblong, opening by lateral slits rarely by pores. Ovary 3-5-celled. Ovule 2-14 in each cell, ascendent, affixed to the interior angle of the cell. Style setaceous. Stigmas very minute. Capsule enclosed in the calyx, 3 -5-celled, bursting with loculicidal dehiscence. Seeds subovate. Testa downy. Mesocarp subcrustaceous. Strophiole crenate or laciniate. Embryo straight, placed in the axis of the fleshy albumen. Cotyledons almost orbicular, flat, as long as the cylindrical inferior radicle. 
Star-hairy shrubs, rare in the southern rather frequent in the south-western tracts of Australia. Stipules foliaceous, usually large. Leaves often chartaceous or herbaceous, varied in form, always alternate, not rarely waved or sinuated. Inflorescence racemose, seldom cymose, opposite to the leaves. Bracteole unilateral, calycine. Flowers usually purplish. Stamens free or connate at the base. Style usually smooth. Capsule comparatively small. Seeds black-Endl. Gen. Plant. 997; Steetz, in Lehm. Pl. Preiss. ii. 317 ; Ditomostrophe, T'urcz. in Bullet. Moscou, xix. 498.

Thomasia petalocalyz, F. M. in Transact. of the Philos. Soc. of Viet. i. 35; T. macrocalyx, Schlechtend. in Linncea, xx. 633.

Hispid-tomentose; petioles shorter than the stipules; leaves almost herbaceous, oblong or ovate-oblong; repand or entire, at the margin recurved; stipules large, oblique cordate-ovate or rhomboid-or dimidiatecordate; racemes simple, few-flowered; pedicels nearly as long as the flower; segments of the bracteole lanceolate-oxate or lanceolate, almost as long as the calyx ; petals obcordate- or cuneate-orbicular, smooth or rarely slightly downy, sometimes absent; anthers oblong-linear, opening torards the apex by short terminal slits; filaments extending not far beyond the base of the anthers; staminodia linear-subulate, often wanting; style glabrous, about as long as the anthers; ovary short-downy; capsule subsessile, glabrescent, three-celled, minutely apiculated; longer lobes of the strophiole several times shorter than the seeds.

On stony coast-ridges near Yanake at Wilson's Promontory. In South Australia near the Rivers Light and Gawler in pine-scrubs, Dr. Behr; on scrubby declivities of the Barossa and Bugle Ranges, F. M.; in Kangaroo Island, F. Waterhouse. In Western Australia between the Great Australian Bight and King George's Sound.

A diffusely ramified shrub, 1-3 feet high. Tomentum star-hairy, brown and dense on the younger branches, less copious on the leaves. Stipules almost sessile, quite foliaceous, $\frac{1}{3}-1$ inch long, inequilateral, one-nerved; the broader outer lialf sometimes lobed. Petioles 2-4 lines long. Leaves measuring in length 1-2 inches, in width $\frac{1}{3}-\frac{1}{2}$ inch, usually rounded at the base, blunt at the apex, not much paler beneath, somewhat wrinkled and shining above, with an above impressed beneath prominent midrib, with several lateral nerves and copious netted veins. Peduncles rather slender, with addition of the rachis often $2-3 \frac{1}{2}$ inches long, rarely less than 1 inch long, clothed with grey star-downs of unequal length, producing the pedicels only unilaterally at its upper portion, bearing usually 2-5, rarely but one flower. Pedicels distant, more or less grey or brown star-downy; the lowermost usually bractless; the others frequently supported at the base by a foliaceous ovate- or narrow-lanceolnte acute bract of 2-3 lines length; the uppermost bracts sometimes geminate. Segments of the bracteole herbaceous, reflexed, inside thinner star-hairy than outside. Calyx of a squalid lilac color, abont 4 lines long, cleft rather beyond the middle into 5 accidentally 6 ovate or orbicular-ovate inside scantily downy lobes; the midnerve of the divisions yellowish-green, prominent, from which diverge lateral nerves, which again are united by net-veins. Petals almost of the color of the anthers, seldom longer sometimes even sloorter than $\frac{1}{2}$ line. Anthers hardly 1 line long, finally blackpurplisl, somewhat bronder towards the slightly bilobed base, pallescent and extravergent towards the apex, where alone the cells are bursting during anthesis. Pollen-orains whitish, ovate, smooth, longitudinally dehiscent. Styles 3, connate into a solitary setaceous one. Stigmas exceedingly minute. Orules often 5-6 in each cell of the ovary. Capsule almost sessile, pointed by a very short apex, covered with almost invisible downs, globose or ovate-globose, with 3 longitudinal furrows, $2-2 \frac{1}{2}$ lines long, inside glabrous. Seeds 1-4 ripening in ench cell, sparingly clothed with short white downs, broad ovate, black-brown. Strophiole livid, somewhat carnulent, rerging into either a hippocrepic or cupular form; its lobes bent to the raphe. Radicle cylindrical, hardly longer than the broad-orbicular cotyledons.

The principal and possibly not specific differences of Thomasia macrocalyx (Steud. in Lehm. Pl. Preiss. i. 230 ; Steetz, l. c. ii. 319 ) must be sought in the narrower segments of the hypocalycine bracteole, the usually larger calyces, the longer filaments and style, the longitudinal dehiscence of the anther-cells and the 
granular indument of the ovary. T. purpurea (Gay, in Mém. Mus. vii. 452, tab. xxi. figs. 8-13) seems only distinguishable by the also narrower lobes of the bracteole, by the not densely downy ovary and the stipitate capsule; the degree of dehiscence of the anthers being modified by age and possibly also by other circumstances. The specific limits of this species has therefore yet further to be traced in its various states. The otherwise also closely allied T. undulata (Steetz, l. c. ii. 320) differs particularly in the harshness of its leaves. T. pauciflora (Lindl. in Append. to Bot. Reg. p. 18) and T. cognata (Steud. l. c. i. p. 232), although in habit similar to our plant, are more widely different in the characters of their floral organs. T. petalocalyx is the only species as yet known beyond the territory of Western Australia.

It flowers almost throughout the year.

\section{TRTBE II. BUETTNERIE \&, Cand. Prodr. i. 484.}

Petals conspicuous. Stamina and Staminodia connate near or towards the base. Anthers often didymous.

\section{COMIMERSONIA.}

Forst. Charact. Gener. 43, t. 22.

Calyx five-cleft, valvate in rstivation, ebracteolate. Petals sessile, dilated and inflexed at the base, ligulate at the summit, disconnected with the staminal tube. Staminodia ternately interjacent between the fertile filaments, the middle one ligulate. Fertile filaments 5 , very short, opposite to the petals, bearing a solitary anther with divergent cells, which opens by extrorse longitudinal dehiscence. Ovary sessile, five-celled. Ovules $3-6$ in each cell, ascending in two rows along the inner angle of the cell, anatropal. Styles short, setaceous, coherent, finally secedent. Stigmas very minute. Capsule echinate with slender fasciculate-hispidulous bristles, five-valved, opening by loculicidal dehiscence. Seeds 1-4 in each cell, strophiolate. Embryo straight, in the axis of a fleshy albumen. Cotyledons flat. Radicle cylindrical, inferior.

Shrubs and trees of East and West Australia, Oceania and India, more or less tomentose. Leaves alternate, broad, variously toothed, sometimes short-lobed. Stipules narrow, deciduous. Flowers in simple or paniculate cymes. Petals small, white, pink or rarely bluish.-Gcertn. de Fruct. et Semin. ii. 79, t. 94; Endl. Gen. Plant. 997.

This genus differs from Rulingia principally in the number of staminodia, from Hannafordia chiefly in the absence of a hypocalycine bracteole, in divergent anther-cells and in a five-celled bristlebearing capsule.

Commersonia Eraseri, Gay, in Mém. đun ILuséum d’ Histoire Nat.x. 215, t. 15; Steetz, in Lehm. Plant. Preiss. ii. 359 .

Shrubby, arborescent; leaves verging into a cordate, orbicular, ovate or ovate-lanceolate form, serrateor repand-crenate, lobeless or short-lobed, usually acuminate, slightly oblique at the base; panicles cymose, many-flowered; calyx inside smootlı or glabrescent; petals glabrous; their ligule longer than the clasping basal portion; staminodin glabrous, as long as or longer than the calyx, all cuneate-spathulate, long-and narrow-unguiculate, the middle ones the largest and deltoid at the base; capsule elothed with hispid bristles, imperfectly, five-ninged torards the vertex; valves at the axis hairy; seeds black, ovatc-globose; strophiole minute, obverse pyramidal, livid, hardly lobed; cotyledons orbicular, as long as the radicle.

On the banks of the Genoa River, also along watercourses towards Mount Imlay. In various parts of New South Wales, extending northward as far as the Hastings River, descending to the vicinity of the const near Twofold Bay. 
A tall shrub or small tree. Branchlets terete, tomentose. Petioles cylindrical, $\frac{1}{3}-2$ inches long, tomentigerous. Stipules ovate- or subulate-lanceolate, sometimes linear-subulate, velvet-downy, $2-4$ lines long. Leaves herbaceous, flat, variable in size and form and indument, 2-6 inches long, above scantily star-hairy and soon glabrescent, beneath paler or even whitish by a very short and close vestiment, over which (in the tomentose variety) copious star-hairs are distributed; middle nerve and straightly divergent lateral nerves beneath prominent; veins anastomosing between the nerves. Panicle usually opposite to the leaves, sometimes, however, terminal or axillary, tomentose with brown-grey hair. Primary peduncle usually $\frac{1}{2}-1$ inch long. Pedicels very short, or a few lines long, sometimes extended to the length of nearly a inch, provided with a solitary lanceolate- or subulate-linear herbaceous velutinous bracteole of 1 to a few lines length. Calyx persistent, deeply five-cleft, with ovate-lanceolate spreading somewhat acuminate lobes of about 2 lines length. Petals white, glabrous, membranous, from a broad subcordate or deltoid inflexed base prolonged into an oblong-spatluulate finely 5-7-nerved slightly veined ligule. Tube of the stamens less than 1 line long; staminodia opposite to the lobes of the calyx; fertile filaments very short, glabrous. Anthers purplish, bent outward ; the cells ovate-globose, about $\frac{1}{4}$ line long, bursting by a frontal longitudinal fissure, the dehiscence in consequence of the divergence of the cells appenring to be transverse. Pollen whitish, consisting of globular smooth granules. Ovary globular, with five prominent ridges, outward at first only minutely papillose. Styles hardly $\frac{1}{2}$ line long, glabrous, capillary, coherent, separating in age. Stigmas hardly thicker than the apices of the styles. Capsule according to extra-Victorian specimens tardily dehiscent, almost spherical, measuring (the bristles added) nearly $l$ inch, a number of the bristles connate or coherent towards the vertex of the valves, so as to form 5 apical-dorsal somewhat horn-shaped wings. Valves rather hard, about 4 lines long, imperfectly separable into two layers, slit along the middle from the summit towards the base, inside, with exception of the axis, glabrous, outside very densely covered by innumerable bristles, which are hispidulous by copious bundles of short rigid grey hair. Seeds in each cell usually 1-2 developed, pure-black, without polish, glabrous, although often slightly rough, nearly 1 line long. Testa coriaceous. Embryo lodged in a white rather fleshy indurating albumen, yellowish, about $\frac{3}{4}$ line long.

In contrasting this species with specimens of Commersonia echinata, collected in subtropical East Australia on the Clarence, Brisbane and Pine Rivers, we find the leaves only small-toothed and hardly ever lobed, with a predominant cordate-ovate not much acuminated form; the calyx smaller and inside thinly velutinous, the petals still smaller and inside slightly downy, the staminodia vclutinous; the middle one of each three of these lanceolate, about half as long as the calyx; the lateral oncs much smaller, setaceous, only about as long as the fertile stamens; the anthers smaller; the orary less conspicuously ridged; the stigmas more conspicnous; the capsule smaller, wingless, covered with shorter bristles, which are less rigidly hispidulous; the seeds ovate and dark-brown, provided with a yellowish somewhat longer and more evidently lobed strophiole. The embryo shows no appreciable differences. According to Forster's figure and Gay's description the fruit of C. echinata, grown in the South Sea Islands, is by no means smaller than that of C. Fraseri.

The only remaining Commersonia litherto known, C. Gaudichaudii (Gay, 1. c. x. 213, t. 14), which occurs not only at Sharks Bay, but according. to Mr. Oldfield's collections also at the Miurchison River, shows the following marks of distinction. That species is never arborescent; the leaves are comparatively small, remarkably obliquc, dceply and bluntly crenated, not acuminate; the cymes consist usually of few flowers; the lobes of the calyx are less acute, sometimes quite blunt, inside slightly downy; the ligule of the petals is shorter or as long as the clasping base; the staminodia are all decidedly shorter than the calyx; the lateral staminodia uncinate, high-connate nith the fertile filament, the middle one semielliptical; the stigmas. minutely.capitellate; the capsule is, according to Gay's description and illustration, wingless, beset with seemingly tender and shorter bristles; the seeds are ovate and number 4-5 in each cell, are provided with a long trisected strophiole, whilst the oblong-hinear cotyledons are stated to be (at least in hardly matured seeds) longer than the radicle. Should future investigations confirm the latter notes, then a subgeneric 
separate position may be assigned to $\mathrm{C}$. Gaudichaudii, which moreover in habit differs so much from the two other species. All the other described Australian Commersoniæ are referable to Rulingia. C. platyphylla (D. C. Prodr. i. 486; Asa Gray, in Bot. of Unit. Stat. Explor. Exped. p. 188) seems only a variety of C. echinata.

\section{RULINGIA.}

R. Br. in Bot. Mag. 2191.

Calyx five-cleft, valvate in æstivation, ebracteolate. Petals sessile, dilated and inflexed or saccate at the base, ligulate at the summit, disconnected with the staminal tube. Staminodia dilated, singly interjacent between the fertile filaments. The latter opposite to the petals, 5 , bearing a solitary didymous anther with extrorse longitudinal dehiscence. Ovary sessile, five-celled. Ovules nsually 2 in each cell, ascending from its inner angle. Styles coherent or rarely obliterated. Stigmas minute. Capsule densely armed with thorns or acute tubercles or bristles, opening by loculicidal dehiscence, five-valved. Seeds strophiolate. Embryo straight, in the axis of a fleshy albumen. Cotyledons flat. Radicle cylindrical, inferior.

Shrubs, dispersed over the eastern and western extremities of extratropical Australia, very rare in the tropical desert portion of the Australian Continent. Leaves altemate,- various in form, almost always toothed. Stipules small, secedent. Flowers often small, collected in axillary or lateral cymes. Calyx inside white, pink, rarely yellow. Capsule nsually star-hairy.-Endl.Gen.Plant. 997 ; Steetz, in Lehn. Pl. Preiss. ii. 351.

The Indian, Madagascar, and inore particularly tropical American genus Buettneria, with which Rulingia was formerly confused, differs (as well pointed ont by Dr. Steetz) in unguiculate petals, which with their cucullate portion adhere to the staminal tube, in the septicidal dehiscence of the fruit, in the absence of the strophiole and of the albumen and further in spirally coiled cotyledons.

Some Rulingiæ bear considerable resemblance to certain rhamnaceous plants of the genera Trymalium and Pomaderris.

Rulingia pannosa, R. Br. in Bot. Mrag. 2191; R. rugosa, Steetz, in Lelm. Pl. Preiss. ii. 352; Buettneria dasyphylla, Gay, in Mém. du Mnus. d'Hist. Nat. x. 200, t. 12; B. inodora, Gay, in Dict. des Scienc. Nat. t. 140; Commersonia dasyphylla, Andr. Bot. Rep. t. 603.

Leaves large, either ovate- and oblong-lanceolate and lobeless or in circumscription subcordate with 3-5 acute lobes, always rounded or cordate at the base, upwards long contracted, irregularly toothed or crenulated, rarely some quite entire, above less densely hairy than beneath; stipules and bracteoles subulateand lanceolate-linear; calyx and corolla white; lobes of the former deltoid-ovate; ligule blunt, one-nerved, hardly as long as the inferior part of the petal; staminodia downy towards the apex; bristles of the capsule elongated, scattered-hairy.

Amongst granite boulders of the Buffalo Range, also in the vicinity of Mlount Imlay; thence distributed over granite tracts of New South Wales as far north as the Clarence River, and westward as far as New England.

A shrub from $1 \frac{1}{2}-6$ feet ligh. Root divided into many fibrilligerous branches, outside pale-brown. Stem-bark brown or blackish, tough, finally glabrous. Branches clothed with a tomentum of spreading fasciculate grey-fulvous hair. Stipules brown, membranous, hairy, $2-4$ lines long, rarely bifid, deciduous. Leaves more herbaceous than coriaceous; the lower ones on longer the upper ones on shorter stalks; those of plants which are one to two years old more or less deeply cleft; the lobes approaching to a semilanceolate or deltoid form, the terminal lobe the longest; the leaves of the slirub when morre advanced in age lobeless, $1 \frac{1}{2}-5$ inches long; all spreading-nerved, copiously veined, wrinkled above, clothed on both pages, but more 
densely on the paler underpage, with fasciculate or stellate grey-fulvous hair. Cymes usually many-flowered, sometimes producing but few flowers, densely pubescent, always opposite to the leaves. General peduncles usually rather short, sometimes, however, elongated. Special peduncles mostly a few lines long. The alar pedicel varying in length from a few to 9 lines; the other pedicels shortened in various degrees, all bearing solitary finally deciduous bracteoles of 2-4 lines length. Flowers without fragrance; those of the young plant usually larger than those of the older plants. Calyx corollaceous, persistent, beyond the middle fivecleft, inside as well as outside pubescent, witli exception of the greenish base white; its lobes $1 \frac{1}{4}-2 \frac{1}{2}$ lines long, sometimes acute, sometimes obtuse, one-nerved, finely net-veined. Petals rhomboid-obcordate, cucullate-compressed and thus almost keeled, glabrous, ${ }_{3}^{2-1}$ line long, clasping the fertile stamen; the ligule of the petal oblong- or spathulate-linear, above slightly or partially bearded. Stamens and staminodia only towards the base connate into a very short tube. Filaments glabrous, capillary, less than 1 line long, pale. Anthers round- or renate-cordate, turned outward, brown-red, about $\frac{2}{2}$ line broad, bursting with lateral fissures. Pollen-grains pallid, ovate-globose, smooth, longitudinally dehiscent. Staminodia opposite to the lobes of the calyx, alternate with the petals, linear-lanceolate, $1 \frac{1}{3}-2$ lines long, towards the basis glabrous, towards the soon reflexed apex downy on both sides, valvate in restivation, sometimes, according to Gay, bearing small fugacious terminal anthers similar in form to those of the fertile stamens (Conf. Gay, l. c. pl. 12, fig. 7). Styles glabrous, about $\frac{3}{4}$ line long, coherent, but easily separable. Stigmas 5, very minute, roundish, also coherent. Ovary sphæroid, asperulous. Ovules $3-4$, affixed to the axil angle of the ovary. Capsule spherical, hard; valves measuring usually about 3 lines, outside black-brown and covered with subulate thorms of 1-2 lines. length, which have radiating hair at the apex and scattered gland-topped hair along their sides; inner side of the capsule livid, shining, smooth. Seeds $2-4$ in each cell, ascendent, broad-ovate, brown-black, $\frac{2}{3}-1$ line long, slightly wrinkled-rough, provided with a subcordate-cupular pale carnulent strophiole of about $\frac{1}{4}$ line length. Testa subcrustaceous. Embryo axil, as long as the fleshy albumen. Cotyledons flat, orbicular, hardly as long as the cylindrical inferior radicle.

Dr. Steetz compares this plant to Seringia corollata. Rulingia hermannifolia, of which R. oblongifolia seems only a variety, differs chiefly in the shortness of the fruit-thorns, which, however, is not improportionate to the smallness of the whole fruit, for which reason this characteristic as a specific one will require further investigation. R. cistifolia seems to mediate the transit of both to R. pannosa. The form of the petals of $R$. corylifolia shows no essential distinction from that of the rest of the species, the petals being open to the base and not truly saccnte, as illustrated in the Bot. Mag. t. 3182, at least in specimens examined on this occasion. Several of the Rulingire described by Turczaninow in the Bullet. de Moscou, 1852, are evidently referable to previously described species.

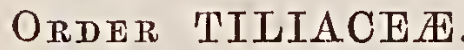

Juss. Gen. 290.

Flowers symmetrical, mostly hermaplirodite. Sepals usually 4-5, free, rarely connate, valvate or rarely imbricate in preflorescence, deciduous. Petals mostly 4-5, in bud imbricate, sometimes wanting. Stamens frequently indefinite in number, sometimes twice as many as the petals, free or united into bundles, the outer ones sometimes barren. Anthers terminal, two-celled, turned inwards, opening with longitudinal or terminal dehiscence. Pollen-grains smooth. Ovary free, consisting of two or more cells or carpellary parts. Ovules 2 or several, rarely but 1 , attached to the inner angle of the cell. Styles consolidated, sometimes not formed. Stigmas diver- 
gent or coalescent. Fruit dry or succulent, indehiscent, or with loculicidal rarely with septicidal dehiscence, sometimes apocarpous. Seeds frequently albuminous. Embryo straight or bent. Cotyledons leafy, rarely amygdaloid. Radicle next to the hilum.

Trees or shrubs or rarely herbaceous plants, much more frequent in the warmer than in the temperate zones, not advancing to arctic or antarctic latitudes, restricted in Australia to the tropical and eastern extratropical tracts of the Continent and the Tasmanian Island. Leaves alternate, rarely opposite, simple, usually toothed or lobed. Stipules mostly small, rarely persistent or wanting. Disposition and colors of flowers various.-Endl. Gen. Plant. 1004; Iindl. Veg. Kingd. third edit. 371.

This order of plants is very closely related as well to the preceding as to the two following ones. Continental Australia possesses, as far as known, five species of Elæocarpus and one of Aristotelia amongst the plants of the Elæocarpeous section of the order. Tasmania but one Aristotelia. The section Grewiex is rather extensively represented in the warmer parts of Australia by species of Corchorus, Triumfetta and Grewia, some of these identical with Indian plants.

\section{ELEOCARPUS.}

Linné, Gen. Plant. 553.

Sepals 4-5. Petals 4-5, alternate with the sepals, subcuneate, usually $3-5$-cleft, with toothed or fimbriated rarely entire lobes. Stamens indefinite, inserted on a hypogynous disk. Filaments short, capillary. Anthers usually linear, with introrse bivalvular terminal dehiscence, rarely bursting by imperfect lateral slits. Ovary sessile, 2-5-celled. Ovules 2 or more in each cell, pendulous, anatropal. Style subulate. Stigmas coherent. Fruit drupaceous. Putamen usually rough, 1-5celled. Seeds solitary in the cells. Embryo placed in the axis of fleshy albumen. Cotyledons flat, longer than the superior radicle.

Trees rather numerous in tropical Asia, rarer in Mauritius, in Eastern and Northern Australia and New Zealand, very rare in the Pacific Islands Leaves alternate, usually oval or lanceolate, crenulated or serrulated, seldom entire. Stipules deciduous. Racemes axillary. Anthers often at the apex bristle-bearing. Drupes frequently blue.-Dicera, Forst. Char. Gen. t. 40; Ganitrus, Gertn. de Fruct. et Semin. ii, 271; Monocera, Jack, in Hook. Bot. Miscell. ii. 85; Beythea, Endl. Gen. 1011.

Elæocarpus stands in close relationship to Friesia, which offers in its opposite leaves and in its baccate fruit the principal marks for discrimination.

mlaocarpus cyaneus, Ait. Epit. Hort. Kow addend. 367; Sims, Bot. MLag. 1737; Lodd. Cabin. 1055; Turp. Diet. des Sciene. Nat. t. 148; Loisel. Herbier de l'Amateur, iv. 237; E. reticulatus, Smith, in Rees's Cyelop. ; Kor; in Edw. Bot. Regist. $65 \%$.

Branchlets almost glabrous; leaves conspicuously stalked, lanceolate, acuminate, copionsly serrulated, densely net-veined, almost glabrous; racemes simple; flowers bisexual; sepals acute, longer than the pedicels, slightly velvet-hairy at the margin; petals bearded inside at the base, downy at the lower margins, otherwise glabrous, cleft into fimbriated lobes; stamens fire or six times as numerous as the petals, shightly downy; anthers linear, short-nucronate, opening only at the apex; their terminal valves almost of equal length; 
ovary bi-celled as well as the style glabrous; drupe one-secded or rarely two-seeded, small, globular or ovate-globular; cotyledons arcuate.

In the forest-gullies of Wilson's Promontory and in wooded ranges from the Tambo River to the eastern boundary of Gipps Land; not rare in East Australia, extending there to the Blue Mountains, to New England and to Moreton Bay.

A tree usually of small size, attaining, however, in favorable localities, for instance in the damp glens of Sealers' Cove, a height of 60 feet. Branchlets almost cylindrical, somewhat glutinous at the apex. Stipules linear-subulate, about 1 line long, deciduous. Petioles $\frac{1}{3}-1$ inch long: Leaves coriaceous, usually from 2-4 inches long and from $\frac{2}{3}-1 \frac{1}{3}$ inch broad, less vividly green and less shining beneath than above, and there along the nerves and veins very slightly downy, serrulated by minute callous teeth. Racemes on rather short peduncles, axillary, solitary, by the fall of the leares lateral, sometimes with fer sometimes with nany flowers. Rachis $\frac{3}{4}-3$ inches long, somewhat glutinous. Pedicels stout, when flower-bearing 1-3 lines long; when fruit-bearing 3-5 lines long, furnished witl three approximated viscous minute lanceolate-subulate bracteoles, of which the middle one is the longest. Sepals 5 rarely 6 , narrow-semilanceolate, about 3 lines long, inside prominently onc-ridged. Petals not much longer than the sepals, divided to about one-third of their length into a fer long-fringed lobes, cuneate torards the often red-colored base, broader than the sepals. Outer filaments very short; inner ones attaining partially the length of $\frac{2}{3}$ line, all short-hairy. Anthers palefulvons, varying in length between $\frac{2}{3}$ and $1 \frac{1}{3}$ line, clothed with exceedingly short downs; their outer terminal valre armed witl a lightly curred puberulous bistle, which measures only about $\frac{1}{4}-\frac{1}{3}$ line. Pollen-grains rery minute, pale, smootl, oral, with very blunt extremities and longitudinal fissures. Style subulate, 1-2 lines long:. Stigma rery minute. Hypogynous ring yellowish, glabrous. Sereral ovules in each cell of the orary. Drupes beautifully blue, shining, 4-5 lines long, sometimes yellowish-dotted. Pulp scanty, brownish, granular, of astringent, acidulous taste. Putamen sphæroid. Seeds about 2 lines long; when solitary in the putamen renate-pearshaped, resembling those of certain salsolaceous genera; their bend so close as to conceal the more or less deep sinus; the seeds when two in each putamen more plane-convex and less turned. Testa thin, brittle, shining-brown, smooth. Embryo surrounded by oily-fleshy albumen. Cotyledons about 3 lines long, very flat, oblique- and narrow-oblong. Radicle cylindrical, varying in length from $\frac{1}{2}-1$ linc, much narrower than the cotyledons.

Spccimens of an Illawarra Elæocarpus with more sharply and deeply serrated leaves of fully 8 inches length, of which tree flowers and fruit remain unknown, appear to belong to this species. Cattle and sheep are fond of the leaves of E. cyaneus. Our plant comes perhaps nearest to the East Australian E. obovatus (Don, Gen. Syst. i. 559, non Arn.), which is identical with E. parviflorus (Ach. Ricl. Voy. l'Astrolabe Botaniq. 67, t. 24) and very similar to the equally small-flowered E. Hookeri (Raoul, Choix de Plantes de la Nouv. Zélande, 26, t. 25). E. obovatus differs from E. cyaneus chiefly in less densely net-veined and more remotely crenulated leaves, in smaller flowers witl less dissected petals and in awnless anthers.

Elæocarpus holopetalus, F. M. Fragm. Phytogr. Austr. ii. 143.

Branchlets woolly-tomentose; leaves short-stalked, obovate-rarely long-lanceolate, acute or acuminate, repand-serrate, copiously veined, above glabrous, beneath velvet-hairy and pale fulvous; racemes brownishtomentose, bracteoles large; flowers bisexual; sepals acute, little shorter than the pedicels; petals glabrous, undivided, in front slightly crenulated; stamens twice or thrice as numerous as the petals, slightly downy; anthers oblong, armless, opening only at the short-bearded apex; their terminal ralves almost of equal length; ovary two-celled, as well as the lower portion of the style silky-downy; drupe one-seeded or rarely two-seeded, subovate.

In Eastern Gipps Land, along valleys of the Nungatta Mountains, at an elevation from 2000-4000 fcet; Weatlierhead, F. M.; also on the Terra River, between the Genoa and Snowy River, J. Alexander; not yet found elsewhere. 
A noble tree, rising to the height of 80 feet. Bark grey-brown, somewhat wrinkled. Branchlets cylindrical, riscid in a young state. Stipules short, lanceolate-subulate, black-brown, clammy. Leaves when fully developed $2-6$ inches long with many spreading nerves, rather coriaceous than chartaceous. Racemes simple, solitary, in the scanty number of specimens hitherto found few-flowered. Bracteoles herbaceous, solitary at the base of the pedicels, nearly lanceolate, inflexed at the margin, 3-5 lines long, outside velvethairy, soon dropping. Sepals narrow-lanceolate, $2 \frac{1}{2}-3$ lines long, outward clothed witl a thin grey-brown tomentum, inside smooth and prominently one-nerred. Petals little exceeding the length of the calyx, obovate-cuneate, not fimbriated nor even laciniated, crimson townrds the base, otherwise white. Outer filaments the shortest; the other nearly as long as the anthers, which hardly exceed the length of $\frac{1}{2}$ line. Style thin-subulate, about $1 \frac{1}{2}$ line long. Annular disk crentlated, with exception of the vertex smooth. Ovary ovate-globose, containing but few orules. The perfect finit hitherto unknown; the putamen, according to the remnants of old drupes, 3-5 lines long, deeply wrinkled; one cell seed-bearing, the other usually empty.

This species shows considerable resemblance to the New Zeelandian Elæocarpus dentatus (Vahi, Symb. iii. 6r), of which E. strictus (Lamb. in Don Gen. Syst. i. 559), E. Hinau (A. Cunn. in Annal. of Nat. Hist. iv. 23; Hook. Icon. 602), and E. Cunninghami (Rooul, Choix, p. 25) are synonyms. This New Zealand species shows, however, longer petioles, a thinner more silky indument on the lower page of the leaves, and there also conspicuous foveoles in the axis of the lateral nerres of the lenves, and short-lobed although also not fringed petals and not large foliaceous bracteoles. Both E. holopetalus and E. dentatus approach to $\mathrm{E}$. bifidus of the Sandwich Group, in regard to the inconsiderable division of the petals, a character on which the untenable genus Beythea is principally founded.

\section{ORDER STERCULIACER.}

Vent. Jard. Malmais. ii. 91.

Flowers bi- or unisexual. Calyx monophyllous, 5- rarely 4- or 6-cleft, or consisting of 5 sepals, or irregularly torn, often valvate in restivation. Pctals 5, convolute or imbricate in bud, not rarely wanting. Stamens in number definite or indefinite. Filaments united into a column. Anthers two-celled, turned outward, bursting by longitudinal slits. Pollen-grains smooth. Staminodia none. Ovary consisting of 5 rarely 3 very rarely 10-12 cells or carpellary portions, sessile or borne on a cylindrical torus. Orules many, several, fcw or rarely 1, attached to the inner angle of the orary. Styles coherent or distinct, seldom undereloped. Stigmas free or coalescent. Fruit capsular, loculicidal five-valved, sometimes drupaceous or baccate or formed by free follicular rarely mut-like carpels. Seeds morc frequently albuminous than without albumen. Form of the cotylcdons and seat of the radicle various.

Shrubs or oftener trees, rarcly suffruticose plants, usually star-hairy and mucusyielding, noticed only in warmer latitudes, the Sterculean tribe preponderant in the eastern hemispherc, the Bombacere in the western, attaining in this colony the remotest southern position (lat. $37^{\circ} \mathrm{S}$.), of very rarc occurrence in Soutl Africa. Wood frequently soft. Bark tough. Leaves alternate, compound or simple, usually deciduous. Stipules almost always quickly dropping. Disposition and color of flowers 
varied. Seeds often ovate, without umbilical appendages.-Endl.Gen.987; Lindl. Veg. Kingd. ed. iii. 360 ; Bombaceæ, Kunth, Dissert. Iralv. p. 5.

A comparison of the ordinal notes of Sterculiacer with those of Malvaceæ, Buettneriaceæ and Tiliaceæ will evince how nearly all these orders are related to eaeh other.

Sterculiacer present several trees and shrubs in tropical and Eastern Australia, extending in one single species (Brachychiton Gregorii, F. M.) to the Murchison River and Sharks Bay in Western Australia. As a form of extreme interest in Australia we regard the Adansonia Gregorii, the Gouty-stem tree, alluded to by Allan Cunningham and Capt. Stokes, and of which an illustration, showing the remarkable features of this tree contypic to those of the Boabab of tropical Africa, may be compared in "Bennett's Gatherings of a Naturalist in Australia," pl. v. The order comprises in Continental Australia, as far as known, the Helicteres Ixora, two species of Methorium, Sterculia fœtida, St. quadrifida, at least ten well marked species of Brachychiton, Argyrodendron trifoliolatum, the above-mentioned Adansonia, and, according to Rob. Brown and Jos. Hooker, Lheritiera litoralis. The allied family Cochleospermex numbers two endemic species in tropical Australia.

\section{BRACHYCHITON}

R. Br. in Horsf. Plant. Javan. rarior. 234.

Flowers monœcious. Calyx monophyllous, bell-shaped, corollaceous, five-cleft, deciduous, with valvate rarely induplicate æstivation. Corolla wanting. Male flowers: Stamens connate into a slender column. Anthers rather numerous, crowded into five very short bundles, connivent into a globular head, concealing a rudimentary ovary; cells distinct, ellipsoid, parallel, bursting externally with longitudinal slits. Female flowers: Styles 5, coherent, filiform, fimally seceding. Stigmas short, simple. Ovaries 5 , seated on an elevated torus, surrounded at the base by many anthers. Ovules numerous, biseriate along the ventral suture. Follicles hard, wingless, stalked, few- or many-seeded, bursting finally lengthwise. Seeds ovate, by their outer densely star-hairy brittle integument mutually coherent. Middle integument hard, separated from the exterior layer of the testa by a powdery pulp, terminated by a large orbicular chalaza. Cotyledons flat, straight, ovate, in the axis of the adnate albumen. Radicle small, egg-shaped, placed next to the hitum, centripetal. Plumule minute.

Australian trees or rarely shrubs, dispersed over the northern and eastern tracts of the country, but of very rare occurrence on the west coast. Petioles long, cylindrical. Leaves alternate, evergreen or decidnous, herbaceous or coriaceous, undivided or lobed, rarely radiate- or digitate-compound. Stipules linear-subulate, as well as the bracteoles fugacious. Flowers paniculate, less frequently collected into clusters. Pedicels articulated at or below the apex. Calyx often red or variegated, rarely provided at the bottom with an inflexed annular plate, seceding into scale-like lobules. Staminal column enclosed within the calyx. Superior part of the outer cover of the seeds retained as an almost alveolar stratum within the follicle, by its transverse derupture liberating the seed.-Brachychiton, Pœcilodermis and Trichosiphon, Schatt \& Endl. Meletem. 33. 
Brachychiton is well separated by Rob. Brown from the near-related Sterculia, on account of the hairy testa being half-retained within the follicle, and principally in consequence of the radicle being not situated on that extremity of the seed remotest from the hilum; to which characters may be added that of the expression of a large orbicular chalaza and the faint indication of a longitudinal raphe.

Brachychiton populneum, R.Br. in Horsfeld's Plant. Jaran. rarior. 234; Sterculia hetero. phylla, All. Cunn. in Garden Catalog. not Beauv.; S. diversifolia, Don, Gen. Syst. i. 516.

Evergreen; leaves simple, glabrous, thin-coriaceous; those of the adult tree verging into an ovate or rhomboid form, long-and narrow-acuminate, entire or acutely three-lobed; flowers paniculate; peduncles and pedicels glabrous; calyx rather small, brọad-bellshaped, outside sparingly short-downy, inside red-and yellow-variegated, glabrous and without appendages at the bottom; its lobes nerveless, short-tomentose at the margin; staminal column smooth, ovaries inserted on a very short stipes, star-lnairy; follicles rather large, coriaceous-lignous, many-seeded, longer than the stipes, outside glabrous.

- Amongst granite rocks and in granitic drift on the Snowy River near the Pinch Range, and on the tributaries Ingegobba and Freestone River, also on the River Hume. In East Australia from Twofold Bay to the Mackenzie River.

A monœcious tree, attaining a height of 60 feet, well adapted for lining walks, on account of its singularly beautiful evergreen umbrageous folinge. Stem often more or less turgid, remarkably so when growing from betwixt granite rocks, whence the appellation "Bottle-tree" has been given as well to this species as to Brachychiton Delabechei ; in exceptional instances young stems, emerging from the fissures of rocks, attain a width of $2 \frac{1}{2}$ feet by a length of only about 5 fcet. Bark smooth, of a bluish-grey or finally grey-brown and slightly wrinklcd exterior, tough, worked into textile fabrics by the aborigines, called, with other textile barks, such as that of Sida pulchella, Commersonin Fraseri, Pimelea axiflora, \&\&.., "Curryong."

- Branches divaricate or considerably spreading, thus forming a beautiful dense wide crown to the tree. The form of the leaves in the juvenile plant remarkably subject to variation, as expressed in the accompanying plate; thus entire, or in various degrees cleft into $2-5$ obtnse, acute or acuminate broad or narrow lobes, passing by all possible internediate modifications into the more normal broad- or lanceolate- or rhomboidovate long-acuminate form of those of the aged tree, which measure usually from $2-4$ inches in length, are shining, of an almost equal color on both pages, dark-green, provided with 1-3 rarely 4-5 primary nerves, with many secondary spreading nerves and net-veins, stalked by a slender long petiole. Stipules fast dropping, free, 1-3 lines long, often semilanceolate. Panicle axillary, with several, sometimes but fer, rarely very many flowers. Pedicels solitary or twin, variable in length, but shorter than the flowers, articulated below the summit or near the middle. Bracteoles lanceolate or linear, acute, 1- $1 \frac{1}{2}$ line long. Male flowers usually prevalent in number and larger than the female blossoms. Calyx when fully expanded from $\frac{1}{2}-1$ inch long, to near the middle rarely still deeper five-cleft, in abnormal cases six-cleft, with more or less semilanceolate or deltoid lobes, outside white- or green-yellowish. Staminal columu of the male flowers $1 \frac{1}{2}-3$ lines long, bearing at the top a small globule, consisting of five very short connivent phrlanges with extrorsely adnate anthers, surrounding and concealing fire minute barren ovaries, which are terminated by vcry short connate styles. Anthers $\frac{1}{2}-\frac{2}{3}$ line long, yellow or finally brownish, arranged in an irregular series around the phalanges; their cells through mutual pressure of the anthers often so much distorted and misplaced as to assume the appearance of one-celled anther's. Pollen-grains palc-yellow, elliptical, smooth, with three longitudinal slits, spherical when moistened. Oraries of the female flower 5 , colering into a globe, seated on a very short alnost obliterated staminal column, surrounded at the base with many polliniferous and seemingly fertile anthers, which are not unlike those of the strictly male flowers, and indistinctly arranged in bundles. Styles 5, glabrous or somewhat downy towards the base, capillary, about $1 \frac{1}{2}$ liue long, lengthwise connate or more or less twisted, at last partially free from below. Stigmas very short, free. Ovules 15-18, arrayed in a double row along the suture. Follicles usually $2-3$ inches long, subovate, rostrate, 
provided with stalks of about 1 inch length, inside densely clothed with grey-fulvous branched or stellate hair. Seeds 6-16, hardly $\frac{1}{2}$ inch long, obovate, tapering towards the base. Outer testa thin, yellowish, shining, laxly adherent to the inner integument, from which it is separated by a Jellow when moistened pastelike powder, bursting by transverse irregular mupture; the seed when thus free from the outer cover exactly egg-shaped and 3-4 lines long. 'Inner integument or mesosperm of the seed bony, black, brown, smooth, 3-4 lines long. Chalaza black, orbicular, measuring nearly $1 \frac{1}{2}$ line. Endopleura whitish, closely adherent to the albumen, not to the mesosperm. Albumen amygdaloid. Radicle lardly 1 line long, lodged in the snall sinus of the cotyledons. The latter inseparable from the albumen, although readily from each other, dividing the albumen into two parts, giving it the deceptive appearance of amygdaloid cotyledons.

Supplemental Plate V. 1, side view of stamens of male flowers; 2, moistened terminal portion of the stamens, bent outward to show the barren pistil; 3 , fiont view of a staminal phalanx; 4 , back view of the same; 5 , anthers; 6 , dry pollen-grains; 7 , moist pollen-grains ; 8 , pistils, surrounded by stamina ; 9 , three pistils separated; 10 , transverse section of ovaries; 11 , side view of a seed; 12 , seed viewed fiom the base; 13, superior part of ruptured testr; 14, seed, showing the hilum; 15, seed, showing the chalaza; 16, seed, showing the raphe; 17 , longitudinal section of seed, showing radicle and face of cotyledons; 18 , longitudinal section of seed, showing albumen and edges of longitudinally cut cotyledons; 19 , transverse section of seed; 20, ramified hair: figs. 1-10 and 20 variously magnificd; figs. 11-19 natural sizc.

Our plant bears to B. diversifolium from Arnhem's Land the closest alliance. The latter is distinguished by a black more wrinkled and rimose bark, by always lobeless generally cordate-ovate and long-acuminate more deciduous leares, by somewhat smaller outside velvet-hairy flowers, by the conspicuous hairiness of the base of the staminal colunn, by usually less numerous anthers and by densely tomentose oraries with shorter styles. In consistence of leares and color of flowers both species are similar. Brachychiton acerifolium lias irrespective of many other characters a somewhat thinner tomentum of the inner sides of the follicles and of the onter integument of the seeds. The carpological characters are very similar in both. The foliage of $\mathrm{B}$. huridum is nearly deciduous. B. ramiflorum, distributed over a great part of tropical Australia, resembles more a Hibiscus, than any of its congeners. It is deciduous-leared, and oftener shrubby than arborescent and never attaining any great height. The large sometimes brilliant sometimes dull-red flowers stand occasionally singly. Its follicles are outside velvet-hispid, inside densely starry-tomentose. Brachychiton discolor is a large-flowered species, allied to B. ramiflorum. It attains, howerer, the height of 80 feet, and forms thus one of the noblest trees of East Australia; the bristles covering the inner sides of the follicles are again less long than in B. populneum. B. platanoides, a species which was noticed by the autlor of this work not only on the Abel Tasman River at the Gulf of Carpentaria, but also on the Rivers Burdekin and Dawson, has larger never undivided leaves. Brachychiton Delabechei (Delabechea rupestris, Mitch. Trop. Austr. 154) has leaves promiscuously simple and compound; the former and the leaflets of the latter are broad-linear, lanceolate or orate-lanceolate, acute and mucronulate, the leaflets sometimes confluent at the base, but there usually orerlapping each other; the follicles are only $1-1 \frac{1}{2}$ inch long, hardly longer than their stipes, conspicuously rostrate, 6-8-seeded, inside clothed with a short hispidulous toment. The seeds are in shape alike to those of its congeners, but measure after the removal of the outer coating only about $2 \frac{1}{2}$ lines. B. Gregorii (F. M. in Hook. Journ. 1857, 199) has always simple leaves, deeply cleft into 3-5 lanceolate-linear acute or acuminate lobes, the basal lobes usually short; the leaves are rarely lobeless and then narrow-lanceolate; the follicles are very similar to those of B. Delabechei, rather shorter rostrate and inside clothed witl somewhat longer hair; the seeds after removal of the exterior coating are only 3 lines long; their embryonic structure is exactly that of Brachychiton. The B. pubescens, from the dry ranges beyond Ipswich, is, according to its discoverer, Mr. C. Moore, of Sydney, at once recognized by downy trilobed leares and a pink calyx only $\frac{1}{3}$ inch long.

It is not improbable that the tragacantli-like mucilage obtainable from this tree might be turned to profitable account. The roasted seeds have been occasionally used by travellers for food. 


\section{ORDER MALVACE无.}

Juss. Gen. 271.

Flowers hermaphrodite, rarely unisexual. Calyx 5- very rarely 3- or 4- or 6 cleft, or seldom spathaceous; its lobes valvate in æstivation. Petals as many as lobes of the calyx, twisted in bud, connate at the base with the staminal tube. Stamens indefinite, rarely definite in number, very seldom reduced to 5. Filaments united into a column, almost always free towards the summit. Anthers kidney-shaped, one-celled, bivalved. Pollen-grains globose, asperous. Staminodia none. Ovary with five or more seldom less cells, sessile. Orules affixed to the inner angle of the cells. Styles as many as ovary-cells, free or connate. Stigmas free, rarely coalescent. Fruit consisting of free or coherent carpels, arranged around a central column or forming a loculicidal or septicidal capsule; carpels or cells 5 or more, rarely less. Albumen usually scanty, fleshy-mucilaginous. Embryo arcuate. Cotyledons foliaceous, plicate. Radicle cylindrical.

Herbs or shrubs, seldom trees, frequently star-hairy and mucilaginous, abundant in hotter regions of the world, gradually declining in number towards the colder regions of the globe, but not extending to the polar zone. Leaves alternate, simple, usually herbaceous, often lobed, stipulate. Inflorescence various, mostly axillary with a solitary flower. Calyx usually persistent, not unfrequently surrounded by an involucre, very rarely (in a certain species of Paronia) not expanded during anthesis. Petals prevailingly yellow or red, exceptionally (in some Paronia) never expanding. Base of staminal tube dilated and covering the ovaries.-Fndl. Gen.978; Lindl. Veg. Kingd. ed. iii. 368.

Malracex touch in their affinity not only on the other columniferous families, but verge also to Geraniaceæ and Phytolaccex.

The Australian genera, with which we are acquainted, are Lavatera, Malva (Malvastrum), Pavonia, Hibiscus (including Fugosia), Abelmoschus, Paritium, Thespesia, Sturtia, Gossypium, Sida (including Abutilon, Abutiliea, Fleischeria, Hohcria, Lawrencia), Halothamnus and Hlowittia. Of these Sida and Hibiscus are far the richest in species; the latter genus seems, however, not to advance to our colony, although a few species occur southward as far as the Lower Darling River and at Port Lincoln.

\section{HALOTHAMNUS}

F. M. Second Gen. Rep. on the Veg. of Vict. p. 10.

Flowers diocious. Calyx almost bell-shaped, plicate, short 5 -or 6-toothed, without an involucre. Male flowers : Petals 5 rarely 6 , unguiculate, spathulate, connate at the base with the slender staminal tube. Stamens 14-20; the free parts of the filaments arising fasciculate from the summit of the 
cylinder. Anthers renate, bivalved, one-celled. Ovary minute, barren, with conglutinated styles. Female flowers: Petals oblique ovate, connected by the very short staminal tube into an almost urceolar-bellshaped corolla. Anthers minute, subsessile around the top of the cylinder. Ovary one, with 3-6 cells. Ovules solitary in each cell, suspended from a minute soon obliterated column. Styles 3-6, connate at the base, inside longitudinally stigmatose. Capsule membranous, one-celled, utricular, at the summit short-5-6-valved, one-seeded, irregularly bursting. Seed smooth. Albumen scanty. Cotyledons folded, roundish, flat. Radicle ascending, cylindrical, as long as the cotyledons.

Lepidote, shrubby plants, restricted to the southern and south-western parts of the Australian continent. Branchlets often spinescent. Leaves mostly fasciculate, small, entire, or near the apex toothed. Stipules adnate at the base. Flowers small, axillary, sessile or short-pedicellate, solitary or a few together. Petals yellowish or towards the summit purplish.

The relationship of this genus is nearer to Plagianthus than to Lawrencia, to which it was referred in the Flora Tasmanica. From the former Halothamnus is easily distinguished by the 5- or 6celled ovary, by the early suppression of the columella, and by the peculiar texture and dehiscence of the pericarp. From the typical form of Plagianthus (P. divaricatus) it differs moreover in longer and narrower stigmas and, according to the illustration of the former in the Bot. Mag. t. 3271, in very scanty albumen. Free, almost indehiscent carpels distinguish Lawrencia. The salsolaceous genus Falothamnus, established by Jaubert and Spach, is reduced by Moquin Tandon (conf. D. C. Prodr. xiii. ii. 172) to Caroxylon.

Falothamnus microphylius, F. M. Second Gen.Rep.p. 10; Plagianthus microphyllus, $F . M$. Fragm. Phytogr. Austr. i. 29.

In the inland-tracts of the Colony of Victoria, on sandy but especially on subsaline localities, or in the so-called "saltbush country;" for instance in the vicinity of Lake Hindmarsh (Dallachy), and thence extending. through many parts of the Murray Desert; in South Australia occurring also in the litoral tracts, for instance on the Coorong, on Lake Albert, on Lake Alexandrinæ, at Port Adelaide, Port Gawler, Port Pirie and other places on Spencer's Gulf.

A low rigid bush, usually much branched, oftener divergent than strict-growing, quite of the aspect of a salsolaceous plant. Branches and branchlets terete, lepidote-downy, glabrescent. Leares carnulent, linearor broad-lanceolate, or linear- or oborate-cuneate, channelled or flat or slightly revolnte at the margin, varying in length from $1 \frac{1}{2}-6$ lines, rarely filly to 1 inch long, usually from $\frac{3}{4}-3$ lines broad, sessile or tapering into an indistinct petiole, not unfrequently provided with three acute tecth at the apex, which are from $\frac{1}{4}-1$ line long. Stipules about $\frac{1}{2}$ line long, senilanceolate- or linear-subulate. Calyx more or less distinctly fivefolded, $1 \frac{1}{2}-2$ hines long; obconical- or cupular-campanulate, with small deltoid teeth. Petals glabrous or nearly so, transparent, finely veined; those of the male flower $2-2 \frac{1}{2}$ lines long; bidentate at the apex; those of the female flowers shorter and more connected. Staminal tube of male flowers 1-1 $1 \frac{1}{2}$ line long, glabrous, dissolved at the summit into slort filaments, which bear yellow anthers with a very imperfect longitudinal septum; the valves of the antlers, as normal in Mralvacex, revolute at the extremities, thus giving to the short septum-like ridge an apparent transverse position. Ovary of male flower 1 , abortive, bearing short permanently connected styles. Staminal tube of the female flower very short, with very minute yellowish anthers. Styles about $1 \frac{1}{3}$ line long, almost capillary, recurved, outside glabrous. Columella of the ovary central, only $\frac{1}{2}$ line long, subulate. Septa of the ovary extremely tender and early perishing. Capsule globose-ovate, $1 \frac{1}{4}-1 \frac{1}{2}$ hine long. One seed only developed in each fiuit, about 1 line long, renate-sphreroid. Testa brown, smooth.

Lawrencia squamata (Nees, in Lehm. PI. Preiss. i. 242) is referable to this genus. 
SIDA.

Limné, Gen. 837.

Flowers hermaphrodite, rarely diœcious or polygamous. Calyx five-cleft, persistent, without an involucre. Petals 5, unguiculate, at the base connate with the staminal tube. Stamens numerous; free parts of the filaments terminating the cylinder. Anthers renate, bivalred, one-celled. Ovaries 5 or more, attached to a columella. Orules 1 or more in each cell, suspended. Styles 5 or more, connate towards the base, free towards the summit, terminated by a capitellate stigma, seldom along the inner side stigmatose. Carpels 5 or more, connate or secedent, usually bursting towards the summit. Seeds with scanty albumen. Cotyledons folded, roundish, flat. Radicle ascending.

Herbs or shrubs, rarely trees, copiously distributed through all tropical and subtropical countries, extending, however, in the northern hemisphere to the United States of America and very sparingly also to the south of Europe, and in the southern hemisphere to Tasmania and New Zealand. Leares raried in form, frequently soft and toothed, seldom narrow. Stipules free and deciduous, rarely towards the base adnate to the petiole. Pedicels articulated, variously arranged. Petals more or less oblique; generally obovate or obcordate, prevailingly yellow or red, sometimes white-Abutilon, Gortn. de Fruct. et Semin. ii. 251, t. 135 ; Hoheria, All. Cunn. in Annal. Nat. Hist. iii. 319 ; Lawrencia, Hook. Icon. Plant. 261 ; Fleischeria, Steud. in Lehm. Plant.Preiss. i. 236; Abutilæa, F.M. in Linncea, xxv. 379.

It seems preferable to consociate the above quoted genera all under Sida, than to group their respective species under separate generic descriptions. The carpological characters become confluent by many intermediate forms; and the nature of the stigmas, which remains the principal point on which their distinction could be based, cannot be regarded of higher value in Sida than in Drosera, whose differences are in this respect still greater. Limited, as proposed on this occasion, the genus Sida will be most readily distinguished from all other Australian genera.

\section{Sect. I. Notho-Plagianthus.}

Stipules free. Flowers dicecious, rarely polygamous. Petals of male flowers exserted, of female almost enclosed. Anthers of the female flower sessile around the top of their staminal tube. Orules solitary in each cell. Styles along the inner side stigmatose. Carpels coherent, finally secedent.

Through Sida pulchella and Plagianthus (or Asterotrichion) sidoides the transit is established from Sida to Plagianthus. The latter species exlibits often two, sometimes eren three developed carpels, attached to a somewhat dilated septum-like columella. Its styles are distinct to near the base and similar to those of Sida pulchella. The habit of both plants is similar. Asterotrichion (Klotzsch, Icon. Plant. Rar. Hort. Berol. t. S) is identical, as already pointed out by Dr. Jos. Hooker, with Blepharanthemum, the illustration of the latter, referred to by Klotzsch, representing the female plant

Sida pulchella, Bonpland, Plantes cultivées à Malmaison, t. 2; Bot. Magaz. t. 2753; Loddig. Cabinet, t. 1841 ; S. Tasmanica, J. Hook. in Journ. of Bot. ii. 412; Abutilon pulchellum, G. Dor, Gen. Syst. of Diehlam. Plants, i. 501 ; Sneet's Flower Garden, ii. $t .287$; Plagianthus pulchellus, Gray, Botany of the U. S. Explor. Exped. i. 181; J. Hook. Fl. Tasm. i. 49.

Tall-shrubby or arborescent; leaves long-stalked, cordate-ovate, gradually and long contracted to the summit, glabrous or sparingly hairy or closely tomentellons, unequally crenate, lobeless or some short-lobed; stipules subulate-linear, deciduous; racemes diacions, compound or paniculate; pedicels about as long as the 
flowers or frequently shorter; lobes of the calyx semilanceolate-deltoid, nearly as long as the tube; petals small, white, ovate-spathulate, outside glabrous; free part of the filaments arising from the summit of an almost glabrous tube; styles 5, glabrous, free, upwarls inside stigmatose; ovaries usually 5 , with single orules; carpels normally 5 , longer than the calyx, trigonous-ovate, rather acute, awnless, at the back downy; seeds glabrous.

Not rare along the banks of rivers and rivulets in the soutlern and middle parts of this colony; exteuding into New South Wales northward, according to All. Cunningham, as far as the Macquarie River; also widely distributed over the Tasmanian Isle.

A tall somewhat graveolent shrub, attaining the height of about 30 feet and then assuning an arborescent labit. Bark of the branches tough, outside brown, worked up by the aborigines into cordage, that of the stems of older trees black-brown and wrinkled. Petioles semicylindrical, often between 1 and 2 inches long. Stipules only $1 \frac{1}{2}-2$ lines long. Fully developed leaves varying usually in length from $2-4$ inches, always cordate at the base, but variable in width, sometimes coarsely, sometimes but lightly crenated, when star-lairy paler beneatl. Inflorescence smooth or less commonly velvet-tomentose, mostly axillary and by the lapse of leaves often lateral, measuring usually from $1 \frac{1}{2}$ to several inches in length. Secondary peduncles oftener short than long, sometimes quite abbreviated. Pedicels solitary, twin, or a few together, generally above the base articulated, supported at the base by a small lanceolate- or subulate-linear rarely ovatelanceolate caducous bract. Bracteoles linear-subulate, about 1 line long, situated near the basis of the pedicel, deciduous. Flowers fragrant. Calyx almost bell-sliaped, about $1 \frac{1}{2}$ line long. Male flowers: Petals spreading, oblique rhomboid-ovate, short-ungtuiculate, very tender, abont 2 lines long, with an oblique small excisure at the summit, faintly three-nerved, white-bearded at the lower margin and inside towards the base of the lamina, also at the inner upper part of the unguis, when fading retained by the long persistent styles. Filaments white, numerons. Column of filaments nearly $1 \frac{1}{2}$ line long; slightly downy towards the base. Free parts of filaments at an average 1 line long, 11 sually connate in pairs. Anther yellowish-white, kidney-shaped, $\frac{1}{2}-\frac{2}{3}$ line long, bursting on a longitudinal suture externally into two valves, showing the mere rudiment of a longitudinal septum. Pollen-grains yellow, spherical, echinulate-asperous. Ovaries 5, barren, very small, connate into a five-furrowed pyramid, slightly downy, under exceptional circumstances fecundated, whereby the plant is rendered polygamous. Styles 5, filiform, free, hardly 1 line long, thickened and internally stignatose towards the summit. Female flowers: Petals only about $1 \frac{1}{2}$ line long, seldom excised at the apex, often less distinctly bcarded, also proportionately narrower. Staminal column almost pyramidal, undivided, terminated with many sessile crowded whitish sometimes hispidulous anthers, which are smaller than those of the male flowers. Styles 5 rarely 6-7, free, $1 \frac{1}{2}-2$ lines long, filiform, upwards exserted, slightly thickened and inward stigmatose. Ovaries with exception of the apex glabrous, pyramidally concrete. Fruit consisting of 5 rarely 6 or 7 carpels, which are $1 \frac{1}{2}-2 \frac{1}{2}$ lines long;, coliere into a depressed-globular capsule, and secede in age from the five-angular at the apex five-toothed column. One or more of the carpels occasionally abortive. Valves almost membranous, tardily opening from the apex along the inner suture and also towards the middle along the outer suture, hardly rough on the commissural faces. Seed suspended from the apex of the cell, brown-black, slightly shining and wrinkled, about 1 line long, somerrhat gibbose. Albumen scanty, mucilaginous-carnose. Cotyledons incumbent, subcordate, foliaceous, unequally towards thc summit crenulated, plicate and towards the radicle incurved, about 1 line long. Radicle ascendent, cylindrical, of the length of the cotyledons.

This plant bears manifold comparison with the North American Sida dioica and S. Napæa. Sprengel erroneously combined it with the widely different S. ranosa from the Senegal (vid. Syst. Veg. iii. 115). Garcke (conf. Bonplandia, 1860, 366) refers Sida pulchella to Hoheria. The bark of aged stems is brownblack and wrinkled. The fruit-axis is slender.

Sida leucopetala from Ánhlem's Land is the only other white-flowering indigenous Australian species, with which we are hitherto acquainted. 


\section{Sect. II. LAWRENCIA.}

Stipules of the upper leaves adnate. Flowers bisexual. Calyx angular. Petals short-exserted. Ovules solitary in each cell. Styles at the inner side stigmatose. Carpels secedent.

Sida Iawrencia._Lawrencia spicata, Hook. Icon. Plant. 261; L. glomerata, Hook. l.e. 417.

Herbaceous, smooth or grey velvet-downy; leaves, fleshy; lower ones lanceolate- or cuneate- or roundish. ovate, long-stalked, serrulate or crenulate or towards the base entire; floral leaves connate with the stipules, bract-like, subsessile or short-stalked, orate- or cuneate- or linear-lanceolate, entire or towards the apes toothed; flovers sessile, colleeted into a simple or glomerate leafy spike; lobes of the calyx almost deltoid, nearly as long as the tube; petals oblique-oblong, truncate or indented at the apex, always glabrous, short exserted, broad at the base; free parts of filaments very short, arising fiom the summit of a short glabrows tube; number of anthers not exceeding 20 ; styles 5 , connate only near the base, acute, stigmatose along the inner side; ovaries 5, with single ovules; carpels 5, glabrous, shorter than the calyx, gibbose, acutangular, short-rostrate; pericarp reticulated; seeds glabrous.

In salt-marshes scattered along the coast; also in dry salt-lagoons and in subsaline places of the northwestern desert of the colony; the glabrous erect variety with simple spikes: on Lake Victoria; at the entrance of the Yarra; at Port Fairy (Gunn.); at the noonth of the Glenelg River (Allitt); beyond the Colony of Victoria at Guichen Bay ; at Holdfast Bay; at Coffin Bay (Wilhelmi); at Trial Bay (Warburton); at Hamden in Westcrn Australia (Clarke); in the Sussex district (Preiss.); at Port Gregory (Oldfield); at Kelvedon in Tasmania (Backhouse, according to Hooker); on Flinders Island (Milligan); the procumbent or ascendent velvet-downy branched variety with glomerate spikes: on the Reedy Lake at the Irurray River; on Lake Wurringren (Dallachy); at Trial Bay (Warburton); in Western Australia (Drummond).

A fleshy plant of a grey- or yellowish-green hue. Root seemingly annual, although often thick and more or less divided into fibrilliferous branches. Stem attaining the height of fully 5 feet, although usually less high, cylindrical, in most instances between $\frac{1}{4}-\frac{1}{2}$ inch thick. Stipules from $1_{2}^{1}-3$ lines long, rarely longer, linear- or semilanceolate-subulate, sonietimes (especially in the desert variety) deltoid, the lower less than the upper ones adnate to the petioles. Leafstalks semicylindrical, slightly longitudinally furrowed; those of the radical and lower stem-leaves from 1-3 inches long. Leaves not mucl shining, flat, 3-5-nerved; the lorer ones 1-21 inches long, blunt at the base and often also at the apex; their form reminding. of those of some Saxifragre. Filoral leaves or bracts always equal in number to the flowers, unless an additional imperfect bract exists, $\frac{1}{2}-1$ inch long, appressed, sometimes patent, rarely spreading-recurved, tapering to a petiolar base, to which the stipules are half-adnate, thus constituting apparently a mere trifid or appendiculate bract. Bracteoles none. Flowers often singly arranged in a densely cylindrical at first uninternupted solitary spike of a few or many inches length, and thus more or less concealed by the appressed leaf-like bracts; less frequently many spikes arising from the leaf-axes of the stem, and producing less copious and more scattered flowers; in other instances again by the suppression of development of branchlets two or few flowers crowded in apparently the axis of one leaf, each, lowever, sustended by a spccial bract or diminutive leaf. Calyx cleft to near the middle, turbinate-campanulate, $3-4$ rarely only 2 lines long, at first more or less plicate. Petals tender-membranous, pale-yellowish, finely longitudinally veined, about 3 rarely only 2 lines long, connate at the broad somewhat inbricate base, and then adnate to the staminal tube, their lowest extremity produced into a very minute subulate lacinia. Staminal tube transparent, finely strenked, 1-1 line long, with esceedingly short linear-subulate filaments at and immediately below the summit. Anthers yellow, $\frac{1}{3}-\frac{1}{2}$ line long, with a prominent crescent-shaped but imperfect longitudinal septum; valves after dehiscence revolute at the margins. Pollen-grains globose, armed with very short points. Styles 2-4 lines long, sometimes purplish, at other times pale-colored, acute, linear- or setaceous-semicylindrical. Columella persistent, angular-subulate, 
usually about 2 lines rarely only 1 line long. Carpels grey- or pale-brown, with addition of their valvatebifid beak about $1 \frac{1}{2}$ line long, rarely reduced to the length of but 1 line, flattened at the back by the prominent and slightly crested lateral angles of the pericarp, tardily dehiscent along the inner suture, with an infra-terminal foramen at the point of their attachment to the columella. Seeds almost filling the cavity of the thin pericarp, and thus isomorphous, trigonous, gibbose at the back, pointed at the apex. Testa darkbrown, smooth, rather opaque. Albumen scantily surrounding the embryo, white, fleshy-mucilaginous. Cotyledons broad, incurved-folded, hardly longer than the ascending radicle.

Only by the careful comparison of a long series of specimina the indentity of the two Lawrencix could be ascertained.

In flower during the later part of the spring and early in the summer.

\section{Sect. III. EustDA.}

Flowers bisexual. Petals exserted. Free parts of the filaments arising from the summit of the staminal column. Ovules in each cell solitary. Stigmas terminal, capitellate. Carpels coherent, finally secedent.

Sida corrugata, Lindl. in Mitch. Threc Exped. ii. 12; S. fibulifera, Lindl.l.c. ii. 45 ; S. filformis, A. Cunn. in Mitch. Trop. Austr. 361; S. pisiformis, A. Cunn. l. c.; S. nematopoda, S. interstans, S. spodochroma, S. trichopoda, F. M. in Linnea, xxv. 382-384; S. intricata, F. MI. in Transact. Phil. Soc. Vict. i. 12; S. humillima, F. M. l. c.

Suffinutescent ; branches erect, diffused or procumbent, tomentose- or velutinous- or scattered-starhairy; leaves lobeless, cordate- or orbicular- or oblong-ovate, or narrow- or linear-oblong, densely or scantily starhairy or above glabrous, crenate or serrate or indistinctly toothed; stipules lincar-setaceons, long-persistent; pediccls thin-filform or capillary, usually solitary, jointed; lobes of the calyx deltoid; petals small, yellow, oblique-obcordate, longer than the calyx, slightly downy at the unguis; styles 5-8, connate towards the base, terminated by capitellate stigmas ; ovaries with single ovules; fruit-column pyramidal-subulate; carpels $5-8$, as long as or somewhat longer than the calyx, cohcrcut into a dcprcssed-globose finit, ovate-trigonous, somewhat pointed, awnless, reticulated at the commissural faces, hardly bursting; seeds brown.

In desert tracts, also on basaltic downs and ridges; from Bacclius Narsh to the north-western part of the Colony of Victoria; thence through the greater part of the Colony of South Australia, through Central Australia and through almost the whole of the drier portion of tropical Australia, advancing to the Murchison River, the Victoria River, the Carpentaria Gulf and southward again to Now England.

A half-shrub, attaining the height of 2 rarely of 3 feet, often of humble growth, unusually variable in stature, hairiness (although never long-hairy), form of leaves, size of flowers and shape and markings of the fruit. Leaves usually from $\frac{1}{2}-1 \frac{1}{2}$ inch long, rarely $2 \frac{1}{2}$ inches or in the variety intricata only $2-6$ lines long, blunt or truncate at the apex, rounded and entire at the base, rarely rery short-lobed towards the lower extremity, beneath rather prominently nerved, finely or grossly, copiously or remotely, more or less bluntly or acutely toothed; the upper ones shorter stalked, the lower ones usually on long petioles. Stipules from 1-4 or even to 6 lines long; linear- or setaceous- rarely lanceolate-subulate. Peduncles rarely developed; producing, if present, a few-flowered corymb with stipule-like bracteoles. Pedicels axillary and terminal, frequently solitary, from a very few lines to fully $1 \frac{1}{2}$ rarely 2 inches long; their lower joint oftener glabrous than downy; the upper joint somewhat bent, deciduous and almost always short. Calyx campanulate-turbinate, when flower-bearing $1 \frac{1}{2}-2$ lines long, in the variety intricata only about 1 line long; when fiuit-bearing more rotate, somewhat lengthened and particularly widened. Petals 2-4 lines long, either broad- or cuneateobcordate, very tender, veined, except the base glabrous. Column of stamens pyramidal-subulate, glabrous or downy, 1-1 $\frac{1}{2}$ line long. Free portion of filaments short, glabrous. Anthers 12 or more, $\frac{1}{4}-\frac{1}{6}$ line broad. 
Styles capillary, $1 \frac{1}{2}-2 \frac{1}{2}$ lines long, connate at and near the base. Fruit-column persistent. Carpels 1-1 $\frac{1}{2}$ rarely 2 lines long, usually depressed below the bistriate apex, more or less strongly netted and often also asperous at the commissural sides, glabrous or short-downy and sometimes asperous at the back, very rarely narrow-winged at the angles, not distinctly bursting, with or without a terminal cleft. Seeds about $\frac{3}{4}$ line long, brown, slightly downy or glabrous, somewhat gibbose, ratlere pointed at the apex.

On this occasion it has been frustraneously attempted to limit the plants here consociated to more than one species, although the end-forms show such marked discrepancies, that without a careful examination of the plant, in a living and preserved state, the identity of the formerly assumed spurious species could not have been ascertained. Amongst extra-Australian plants S. grewioides from tropical Africa shows considerable resemblance to ours. Amongst Australian congeners S. corrigata will be found nearest to S. petrophila, of which S. phrotricha proves a variety. The latter is quite shrubby, grows to greater height, produces larger Howers with more pointed lobes of the calyx, which excel the length of the carpels and become somewhat scarious in age. We possess this plant from the vicinity of Sharlis Bay, where most likely Gay's Sida calyy. hymenia was procured, which according to its description seems identical with S. petrophila. Of this of of S. corrugata, it may be presumed, S. virgata will prove to be a variety. In S.W. Australia occurs, probably as an introduced plant, $\mathrm{S}$. triloba; the specimens from thence accord sufficiently with the descriptions of $\mathrm{S}$. leiophloia, S. rupestris and S. Hookeriana (Miq. in Lehm. Pl. Preiss. i. 241).

\section{Sect. IV. AnutriloN.}

Flowers bisexual. Petals exserted. Ovules more than one in each cell. Stigmas terminal, capitellate. Carpels connate into a loculicidal and partially septicidal capsule, sometimes secedent.

Sida Abutilon, Limné, Sp. Plant.963; Ahntilon Avicenna, Grevtn. de Funct. et Seminibus, ii. 2àl, t. 135 ; Abutilon Behrii, F. II. in Transact. Phit. Soc. Trct. i. 13.

Annual, velvet-hairy; stem branchless or simply bianclied, erect; leaves lobeless, cordate, acuminate, repand or slightly crenate, on long petioles; stipules linear-snbulate, deciduous; pedicels stout, axillary, solitary or several terminal, articulated near or above the middle; lobes of the calyx semilanceolate-deltoid, on both sides downy; petals rnther large, yellow, oblique-obcordate, almost perfectly glabrous, not much longer than the calyx; tube of stamens short, glabrous, very turgid; styles glabrous, 9 or more, connate towards the base, terminated by capitellate stigmas; ovaries witl few ovules in ench cell; firuit-column about twice as long as broad, attenuated towards the mildle; curpets $9 \mathrm{or}$ more, longer thun the calyx, compressed, rostrate, outward downy, to about the middle dehiscent; seeds black, somewhat scnbrous.

In dry beds of lagoons adjoining the Murray River; bejond the Colony of Victoria on the Rirer Darling and on many of its tributaries, gregarious at its localities, occurring also in the warmer parts of Asia and in South Europe.

An herb, seldon more, oftener less than $I_{\frac{1}{2}}$ fout high. Root flexuose or ulmost strighth, cylindrical, with fow fibrilles. Stem cylindrical, usually even in age not glubrescent. Stipules 2 or a few lines long, early dropping. Lenves broad-cordate, vividly green, measuring fiom $1 \frac{1}{2}-5$ inches, flat, with a nartow basal sinus, on both pages velutinous, but in age more scattered-hairy at the surface; the five prinary nerves arising from the base of the leaves, emitting divergent secondary nerves and numerous veins. Pedicels from $\frac{1}{2}-1 \frac{1}{2}$ inch long. Calys when flower-beariug 3-4 lines long, when fiut-bearing a little longer, eleft rather deeper than the middle. Petals nearly $\frac{1}{3}$ inch long; finely nerved und veined. Column of stamens downward much expanded, not attenuated into a conspicuous slender tube, only abont $1 \frac{1}{2}$ linc long, exserting fiom the sunmit free and nore or less connate filaments of nenly 1 line lengtl. Anthers numerous, yellon: Styles hardly longer than the stamens. Stigmas depressed-globose. Fruit-column stont, encircled by the carpels, nearly 3 lines long, upwards thickened und then bearing very slort funicles. Carpels in age full 
separable from each other; their valves 4-6 lines long, rhomboid-ovate, with a manifest excision and a descending subulate tooth at the inner angle, terminated by a linear-subulate beak of rather more than 1 line length, at last dark squalid-brown, diaphanous and smooth on their commissural area, inside quite hairless and very shining; outside slıort-hairy along their vertex and back. Seeds $1 \frac{1}{4}-1 \frac{1}{2}$ line long, 11sually 2 or 3 sometimes 4 ripening in each cell, pyriform-renate, somewhat compressed.

This plant is in our country consociated with several South European plants, which extend to India and Australia; for instance, Cressa Cretica, Frankenia levis, Tribulus terrestris, Euphorbia Chamæsyce, Meniocus serpillifolius, Glinus lotoides, and seemingly also Nitraria Schœberi. Besides Sida Abutilon there exist in Australia (although not in this colony) several other species identical with Indian congeners, including' Sida Indica, S. crispa, S. retusa. The latter yields an excellent fibre, according to experiments instituted by Mr. W. Hill, Director of the Brisbane Botanic Garden. The genus Hibiscus includes also several IndoAustralian species, viz., H. panduriformis, H. radiatus, H. heterophyllus, H. vitifolius, H. Trionum, H. (Paritium) tiliaceus and H. ('Thespesia) populneus.

Sida otocarpa, $F$. M. Second Syst. Index of the Plants of Vict. p. 10; Abutilon otocarpum, F. M. in Transact. Phil. Soc. Vict. i. 13.

Fruticose, erect, velvet-hairy; leaves orbicular- or ovate-cordate, unequally crenate, on long petioles; stipules linear-subulate, deciduous; pedicels axillary, solitary, articulated above the middle; calyx inflated, 5-angular, with semicymbiform long-acuminated lobes; petals rather large, yellow, oblique-obcordate, not much longer than the calyx, ciliated towards the base; styles below the middle concrete, glabrous; stigmas capitellate; ovaries 10-21, with usually three ovules; fruit column almost as thick as long; carpels shorter than the calyx, very compressed, slightly coherent, ear-shaped, beakless, outside everywhere downy, to the middle dehiscent; seeds black, rough, glabrous.

On barren places at the Murnay River, near its junction with the Darling, thence through many of the desert-tracts of Australia north-eastward as far as the Gilbert River near the Gulf of Carpentaria, and north-
westward to Sturt's Creek.

A shrub from $\frac{1}{2}-2$ feet high. Stems and branches terete. Stipules $1 \frac{1}{2}-5$ lines long. Developed leaves

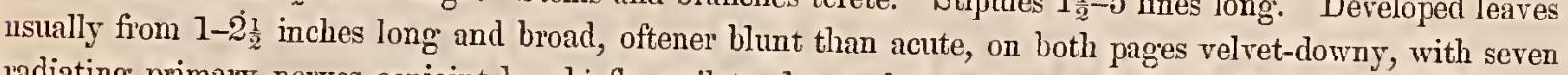
radiating primary nerves conjoint by chiefly unilateral nervelets and net-veins. Pedicels $1-1 \frac{1}{2}$ inch long, densely pubescent ; their upper joint often bent down in age. Calyx $\frac{1}{2}-\frac{2}{3}$ incll long, with five prominent winglike angles and when flower-bearing remarkably tumid, thus reminding of that of Plyysalis; its lobes at first convergent, inward slightly downy. Petals usually not longer than $\frac{1}{2}$ incli, ciliated towards the base. Staminal column glabrous, $2 \frac{1}{2}$ lines long, very turgid at the base, cylindrical at the summit, terminated with many very short filaments. Styles about 3 lines long, glabrous. Stigmas depressed-globose. Columella thick-cylindrical, furrowed, $1 \frac{1}{2}$ line long;, terminated by a short cuspis. Carpels $2 \frac{1}{2}-4$ lines long, obliqueovate, very compressed, blunt or short-acuminate, thinly covered with star-liair on the pale outer side, softdowny at the greenish back, completely seceding from each other, excised at the inner angle towards tlie base, containing sometimes only two orules and seeds; their valves in age fully separating except at the lower dorsal edge, inside polished and hairless. Seeds angular, renate-pyriform, about $\frac{3}{4}$ line long, grey- or darkbrown, wiinkled, glabrous.

Sida otocarpa shows considerable resemblance to S. halophila (F. M. in Linnæa, 1852, p. 380), a plant growing on the Lachlan, on the Barrier Range, around Lake Torrens, Spencer's Gulf and towards Sharks Bay; its leaves are more densely net-veined, and the carpels are nore cartilaginous, larger, and surpass considerably the length of the hardly tumescent calyx, whilst the seeds are downy. S. diplotricha (F. M. in Linnæa, 1852, p. 380), an interior desert-plant, is also nearly related to our plant, differs however in its indument, not laxly inflated calyx, the bigemmulate ovaries, the more rhomboid form of the carpels, which have more rigid not almost completely deliscent valves, and include usually 2 sometimes 1 downy seeds. 


\section{ILAVATERA.}

Linné, Gen. Plant. 842.

Flowers bisexual. Calyx surrounded by a monophyllous three-cleft involucre, five-lobed. Petals 5, unguiculate, at the base connate with the staminal tube. Stamens numerous. Free parts of filaments arising lateral and terminal from the cylinder. Anthers renate, bivalved, one-celled. Ovaries many attached to a columella. Ovules one in each ovary, aseendent. Styles as many as ovaries, connate towards the base, free and along the inner side stigmatose towards the summit. Carpels many, secedent, indehiscent, encircling in a single series the columella. Seeds with scanty albumen. Cotyledons folded, cordate, foliaceous. Radicle descending.

Herbs or shrubs indigenous to Middle and South Europe, Middle Asia, North Africa and extratropical Australia. Leaves broad, soft, always toothed. Stipules deciduous, sometimes foliaceous. Lobes of the involucre rarely subdivided. Corolla showy, usually rose-colored. Fruit-axis usually thick, varied in form.

This genus could be adopted as a section of Althæa, from which it solely can be distinguished by its involucre, which is cleft into only three entire or subdivided lobes. Malva, of which genus, besides Malva ovata, only introduced species exist in Australia, differs also merely by its inrolucre, it being dissected into free leaflets. The South African genus Sphæroma, established by Prof. Harvey (vide Harv. \& Sond. Flor. Capens. i. p. 158), differs in capitate stigmas and 2-3-ovuled dehiscent carpels. In Pavonia the styles are developed in a number double to that of the carpels.

Iavatera plebeja, Sims, Bot. Mag.t. 2269; Colla, Memorie di Turino, xxxi. 336, t. 14; J. Hook. Fl. Tasm. i. 47 ; I. Behriana, Schl. Linn. 1852; I. australis, A. Cunn. in Schl. Linnca, 1854, 528; Ialra Behriana, Schl. Iinn. 1847, 633.-Australian Marsh-Mallow.

Frutescent, short-starhairy; stipules minute, semilanceolate-deltoid; leaves round-cordate, with 5-i sometimes 3 short and usually blunt lobes; pedicels solitary, twin or several fasciculate, as long as or often longer than the calyx; lobes of the involucre semiovate; calyx nearly twice as long as the involucre, inside except the margin smooth, its lobes deltoid; staminal tube downy towards the iniddle; free parts of filaments short; carpels acutangular, much shorter than the calyx, larger than the pyramidate-conical apex of the columella.

Along the banks of watercourses and in occasionally inundated depressions scattered orer many parts of the Colony of Victoria, more frequent in the north-western portion; thence extending to St. Vincents Gulf, Spencer's Gulf, Lake Torrens and the country on the eastern side of the Great Australian Bight; distributed also over a great portion of the interior of New South Wales; very common townrds the Barrier Range, according to the unfortunate Mr. W. Wills.

A shrubby plant, attaining the height of about 10 feet. Stems and branches clothed with usually dense stary downs. Lower petioles 1-3 inches long; upper ones gradually shorter. Stipulcs 1-1 $\frac{1}{2}$ line long, on both sides star-hairy, enrly dropping. Leaves rather dissite, light-green, crenulated, on both pages almost equally downy, with as many ladiating nerves as lobes, also traversed by secondary norves and by fiint veins. Pedicels axillary or forming a kind of leafy interupted terminal panicle, rather stout, thinly star-hairy, from 1-4 inches long, sometimes shorter, articulated near the summit. Involucre persistent, cleft to about twothirds of its length into hardly pointed lobes, which me laxly appressed and traversed by a slightly prominent midnerve and some faint lateral longitudinal nervelets, and are on both sides star-downy and $1 \frac{1}{2}-2 \frac{1}{2}$ lines long. Calyz about 4-5 lines long, broad-campanulate, outside thinly star-downy, cleft to rather less than

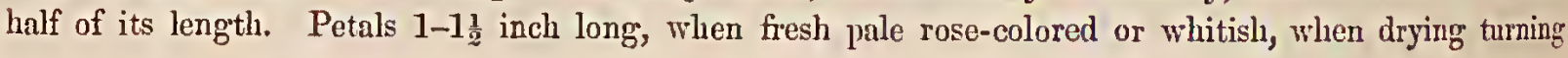


bluish, obcordate-cuneate, streaked by saturated-colored veins, connate only near the base, from the middle towards the base scantily ciliated, at the base bearded-fringed, otherwise glabrous. Staminal column slender, about 4 lines long, glabrous towards base and apex, exserting from above the middle to the summit numerous whitish capillary filaments. Anthers renate, pale yellow, about $\frac{1}{3}$ line long, internally with a narrow longitudinal ridge. Pollen-grains yellow, spherical, echinate. Styles short-exserted beyond the staminal tube, glabrous and connate to near the middle, thence setaceous-capillary, free and lightly recurved, along the inner side very thinly bearded-stigmatose. Fruit-columella about as broad as long, glabrous, measuring $1 \frac{1}{2}-2$ lines, below the apex ridged by the persistent remnants of the pericarp of the seceding carpels, terminated by a small cone. Carpels 10-16, glabrous, concealed within the more or less connivent calyx, indehiscent, hardly longer than 1 line, pallid- or black-brown, compressed-trigonons, roundish-renate, little coherent, rather acute at the dorsal edges, flat one-nerved and slightly wrinkled at the back, transversely streaked at the sides, opening at the ventral angle with an irregular aperture, caused by the rupture of the pericarp from the fruit-axis. Seeds filling the cavity of the thin pericarp, smooth, black- or fulvid-brotwn. Albumen white, mucilaginous-fleshy. Embrjo arcuate. Cotyledons yellowish, cordate, plicate, as long as the cylindrical radicle, which they partially enclose.

This species has many characters in common with Lavatera maritima, L. Africana and L. silvestris; the two former differ in subulate-linear stipules, the latter in a scattered-hairy indument, in acuminate lobes of the calyx, and in obtusangular carpels.

In our herbarium exist cultivated specimens of Lavatera hispida, raised from the seeds of plants naturalized in the islands of Bass's Straits. The root of L. plebeja is medicinally used like that of Althæa officinalis. Mr. A. Tolmer has recommended the plant as eligible for the manufacture of paper.

\section{HOWITTIA.}

F. M. in Transact. Vict. Inst. i. 116.

Flowers bisexual. Calyx 5- rarely 4- or 6-cleft, persistent, without an involucre. Petals 5, unguiculate, connate at the base with the staminal tube. Stamens numerous; free parts of filaments emerging separately along the upper portion of the tube. Anthers kidney-shaped, one-celled. Ovary one, 3-rarely 4-celled, with two collateral ascending ovules in each cell. Styles 3 rarely 4 , connate into one. Stigma clubshaped or capitate, 3-rarely 4-lobed. Capsule loculicidal, 3- rarely 4-valved. Cells containing two collateral ascending glabrous seeds. Raple lateral. Testa thinly coriaceouscrustaceous. Albumen rather scanty. Cotyledons trisected, foliaceous, curved or infracted. Radicle descending.

A starry tomentose tall shrub, restricted to South-Eastern Australia. Leaves lobeless, lanceolateovate- or broad-cordate, crenulated, denticulated or repand. Stipules obliterated or very fugacious. Pedicels axillary, usually solitary. Corolla purple, rarely white. Capsule enclosed.

In the systematic arrangement Howittia takes a place next to Lagumea, which differs in the development of stipules, in the terminal secession and in the number of the styles, in the five-celled many-seeded capsule, in the almost total absence of albumen and in the undivided cotyledons, the embryo of Lagunea showing no generic distinction from that of Sida, whereas the dissected cotyledons render the embryo of Howittia quite aberrant from that of any other hitherto described Mal.vaceous plant. In regard to the number and position of the ovules Howittia bears comparison to Serræa, in regard to the styles to Fugosia.

Irowittia trilocularis, F. M. in Transact. Vict. Inst. i. 116.

On bushy declivities of the Victoria Ranges; Wilhelmi. At Mount Arapiles; Dallachy. On scrubby ridges around Lake King; F. M. In coast-ravines towards Cape Howe; F. M. On the banks of the 
Lower Genoa River; F. M. Beyond Victoria in the valley of the River Grose; Miss Atkinson. Along the Wonboyn River and near Twofold Bay; F. M. In the Tattiara country; Rev. Jul. Edm. Woods.

An erect flexible slrub, attaining under farorable circunstances the height of fully 20 feet, when dwarf resembling Solanum stelligerum. Branches and branchlets dissite; the latter as well as the leafstalks clothed with a grey-brown finally nigrescent toment. Petioles from $\frac{1}{3}$ to $I$ incl long; the superior ones the shortest. Leaves alternate, herbaceons, usually somewhat acute, $1 \frac{1}{2}-4$ inches long, $\frac{1}{2}-3$ inches broad, above dark-green, wrinkled by netted veins, slightly scabrous from star-hair and finally glabrescent, beneath fulrous-cinereous, closely yet thinly tomentose; the stout midnerve and spreading lateral nerves benenth prominent. Stipules cynbiform, membranous, shorter than 1 line, glabrous or at the outer side hairy, apparently often not developed. Pedicels persistent, $\frac{3}{4}-2$ inches long, filiform, upwards thicker, tomentose, not distinctly articulated; sometimes 2-3 consociated and terminal on a short peduncular branchlet. Calyx cleft to or beyond the middle, outside tomentose, inside clothed with scanty or copions silk-hair, also more or less tinged with blue inside; its lobes senilanceolate-deltoid, $1 \frac{1}{2}-2 \frac{1}{2}$ lines long; one-nerved. Petals broad- or rhomboid-ovate, comparatirely short-unguiculate, $\frac{1}{2}$ to nearly 1 inch long, dark-red towards the base, faintly repand, outwards half tomentellous, above the glabrous white claw bearded-ciliate, along the outer margin thinly ciliated, inside glabrous. Staminal column glabrous, rising only to the length of about 2 lines over the basal tube of the corolla. Free portions of filaments 1 line or less long, densely aggregated from the middle to the summit of the cylinder, capillary. Anthers yellowish, $\frac{1}{2}-\frac{1}{3}$ line long; with a very narrow longitudinal septal ridge. Pollen-grains globose, echinulate-asperous. Style filiform, glabrons, excelling the length of the stamen, abont half as long as the corolla, whitish. Stigmas short, conglutinated. Capsule measuring $3-4$ lines in diameter, depressedglobose, hardly acuminate, shightly waved by sutural and dorsal contractions of the ralves, outside with exception of the base densely clotled with soft simple fulvous hair, producing at the upper part of the carities long white soft hair, which finally separate and form a small tuft of wool overlying the rertes of the seeds. Central axis, if not seceding with the valves, split into 3 rarely 4 setaceous segments. Endocarp imperfectly separating. Funicles extremely short. Seeds at least 1 line long, black, oborate, indistinctly or bluntly trigonous, very minutely verruculose. Albumen white, fleshy mncilaginous. Enibryo yellow. Cotyledons always dissected into three curved infiacted or spiral lobes; the middle segment narrow-oblong, ${ }_{3}^{-1}-1$ line long and $\frac{1}{4}-\frac{1}{3}$ line broad; the two lateral lobes falcate- or linear-oblong, about half as long as the middle one. Radicle curred-cylindrical.

PLate IV. 1, vertical section of flower; 2, petals; 3, anthers unexpanded; 4, anthers expanded; 5, pollen-grains; 6 , style; 7 and 8 , capsule; 9 , capsule laid open; 10 , seeds with the hair-tufts; 11 and 12, dissections of seeds: figs. 1, 2 and 6 , natural size; 3-5 and 7-12, magnified.

Malva rotundifolia L., the British dwarf mallow, common in many places of this country, has been omitted in this enumeration of Victorian Malvacex, since it is, as well as Malva rerticillata and MI. silrestris, unquestionably not indigenous, although now quite naturalized.

In concluding these observations on Victorian Nalvacere attention may be drawn to the circumstance, as affecting the limitation of the order, that Pavonia hastata, naturalized in the eastern warmer parts of Australia, produces here only exceptionally normal flowers. We find the calyx almost constantly remaining closed until the carpels ripen. The corolla is reduced to extreme minuteness and never expands under corer of the calys. The stamina are reduced to 5 , but the styles occur in the typical number. The ovaries of these abnormal flowers are very generally fecundated.

Some of the Hibisci of tropical Australia are useful as sorrel. The North Australian Gossypium Australe (F. MI. Fragm. Plyytogr. Austr. i. 46) is not eligible for cotton cultivation, the seeds being but scantily clothed with fibre. The plant occasionally regarded by settlers as a native cotton is Gomphocarpus arborescens, a naturalized asclepiadeous bush from South Africa, the seed-hair of which is unavailable for textile fabrics. The leaves of our malvaceons plants may serve for cataplasmata. The herb of Sida Lawrencia is useful as spinage. 


\section{VII.-GRUINALIS.}

Calyx in præflorescence imbricate. Corolla twisted in bud, very seldom wanting. Stamens definite, oftener monadelphous than disunited. Placentre axil. Albumen copious, scanty or wanting.

\section{ORDER GERANIACEE. \\ Juss. Gen. 268.}

Flowcrs bisexual. Sepals 5, persistent, unequal, imbricatcd in bud. Petals 5, alternate with the scpals, unguiculate, twisted in bud, deciduous, rarely 1 or 3 undeveloped. Stamens 10, in Monsonia 15, more or less connate, all fertile or some of thosc opposite to the petals sterile. Anthers two-celled, introrse; cells parallel, longitudinally dehiscent. Pollen-grains smooth. Ovaries fire-celled. Ovules 2 in each cell, one. above the other, affixed to the axis. Styles 5, connate into one, inwards stigmatose and free towards the summit, long-persistent. Carpcls 5, oneseeded, bursting at the inner side. Process of the pericarp much lengthened, linearsubulate, adnate to the long angular-subulate fruit-axis, at last seceding elastically from below upwards, carrying with it the carpel. Albumen wanting. Embryo conduplicate. Cotyledons convolute-plicate or channelled or flat, foliaceous. Radicle descending, vaginated by the endopleura, subulate-conical.

Hcrbaceous, less commonly suffrutescent or shiruby plants, frequent in the temperate zone of the northern hemisphere, rarer towards the polar regions, very abundant in Soutl Africa, scarce within and near tlie tropics, except in colder altitudes, raie also in Australia and extratropical America. Stems articulated.' Leaves opposite, stipulate, sometimes the upper ones very rarcly all alternate, never truly compound. Pedumcles axillary or opposite to alternating leaves, 1- or 2-flowered or bearing a simple umbel or very rarely a panicle. Petals glabrous; their color varions. Filaments persistent. Anthers fugacious. Prolongations of the pericarp, whilst connate with the fragile pentapterous fruit-axis and whilst terminated by the more or less lengthened or shortened style, forming a long beak to the fruit. Carpels small, alternate with the sepals, usually egg-shaped or club-shaped.—Endl. Gen.1166; Lindl. Veg. Kingd. ed. iii. 493.

Geraniacex form a transit from Malvaceæ to Oxalideæ. No other plants of the order than those, noted in these pages, are indigenous in Australia, where moreover the absence of very high mountains within the tropic precludes their advancing northward. If the tropical-Amcrican genera Aulacostigma and Hypsochloris are 
genuine constituents of the order, then the limits of Geraniacex, as adopted here, will require considerable extension. Of Balsaminez, an order of the gruinal series, no Australian represcntative came hitherto under notice, although the humid mountain regions of North-East Australia, clothed with virgin forest, may perhaps nourish species of Impatiens.

\section{PELARGONIUM}

L'Herit. Geran. tab.-Stork's-bill.

Posterior sepal lengthened into a descending nectar tube, which is innate-decurrent along the pedicel. Petals 5 , rarely 4 or 2 , often unequal. Stamens 10 , towards the base monadelphous, unequal. Filaments from a dilated base subulate; the five petaline filaments all or partially destitute of anthers; the sepaline filaments devoid of an anterior gland. A wn-like prolongations of the carpels spirally seceding from the lengthened fruit-axis. Cotyledons flat or slightly concave-convex, oblong or oval.

Herbaceous, suffruticose or shrubby often strong-scented plants, very numerous in South Africa, rare in Abyssinia, represented by a single species in the Taurus Mountains, the Canary Islands, Tristan d'Acunha, Australia and New Zealnuld. Leaves singularly manifold in form (but hardly ever simply linear), entire, toothed, lobed or pinnatisected or compound-dissected. Peduncles opposite to the leaves or axillary or radical. Pedicels umbellate. Bracteoles forming an involucre. Flowers often rery shons, easily hybridized, of singularly varied and often vivid colors. Carpels more or less attenuated towards the base. Carpellar prolongations at the inner side partially villose._Endl.Gen. 1168.

The embryonic notes here for the first time ascribed to the genus seen preponderant, if not universal, being manifestly the same in all the species examined on this occasion (viz, P. Australe, P. triste, P. tomentosum, P. inquinans, P. coriandrifolium, P. triangulare, P. alchemilloides, P. dasycaulon), and are particularly at variance with those of Geranium.

Pelargonium Australe, Willd. Spec. Plant. iii. 675; Jacq. Eclog. Plant. i. 149, t. 100; Sweet, Geran. t. 68; J. Hook. Flor. Tasm. i. 57; P. inodorum, Willd. Hort. Berol. t. 34; Sneet, Geraniac. t. 56 ; P. glomeratum, Jacq. Eclog. i. 146, t. 98; P. erodioides, Hook. Journ. of Bot. i. 252 ; Nees, in Lehm. Pl. Preiss. i. 163; P. Acngnaticum, J. Hook. Fl. Tasm. i. 57 ; P. litorale, Hueg. Bot. Areliv.t.5; Endl. Enum. Plant. Hueg. 14; P. crinitum, Necs, in Lehm. Plant. Preiss. i. 163.

Herbaceous, more or less downy, caulescent; root perennial; petioles jointless at the apex; leares cordate or renate- or orbicular-cordate, lobelcss or short-7obed, crenated; stipules free, membranous, semilanceolate-deltoid; umbels many-flowered, rarely few-flowered; leaflets of the invotuere membranous, small, semilanceolatc or subulate-linear, shorter than the pedicels; segments of the cnlyx herbaceous, lanceolate; neetar-tube short; petals 5, usually small, white ol pink, spathulate- and cunente-oborate, about twice as long as the calyx, entire, short-unguiculate, upper ones somewhat broader and more copiously reined; stamens connate at the base, scren generally fertile, the longest mearly half as long as the petals; filaments glabrous, linear-subulate; auther's purple; pollen orange; sterile stamens slort-subulate; style short, glabrous; carpels pubescent, obovate-ellipsoid; seeds smooth, oblique-ellipsoid; raphe about four times shorter than the seed; cotyledons oblong; flat.

Frequent in our colony, on sand-shores, licatlı-gr'ound, desert-land, river-banks, ridges and mountains. Not less common throughout the greater part of extratropical Anstralia.

An herb from a few inclies to a few feet high. Stens and branches cylindrical, sometimes red, very variable in their indument. Petioles almost cylindrical or seniteretc; the upper ones short, the rest more 
or less elongated; those of the radical leaves very long. Leaves opposite, rarely the uppermost alternate, from $\frac{2}{3}-6$ inches long and broad, traversed by radiating and ramified nerves and divergent veius, more or less undulate, sometimes crisp, blunt at the apex, usually with a deep basal sinus. Stipules downy, measuring usually from $1 \frac{1}{2}-3$ lines in length, persistent. Peduncles axillary, not opposite, 1-3 inches long, cylindrical, in various degrees downy. Leaflets of the involucre soft-downy, $1 \frac{1}{2}-2$ lines long. Pedicels oftener shorter than longer than the flower, more or less downy. Flowers rather fragrant. Segments of the calyx, with exception of the upper one, during anthesis spreading or reflexed, $1 \frac{1}{2}-4$ lines long, outside downy, inside almost glabrous, lanceolate; the upper one and the two lower ones broader than the two lateral segments; all longitudinally three-nerved and after anthesis erect. Petals white or rose-colored, glabrous, from 2-6 lines long; the lower ones only streaked by purple, violet or deep-red veins and narrow-ungruiculate; the upper ones dendritic-veined and towards the centre often somewhat spotted, tapering into a inore cuneate unguis. Lower of the fertile stamens nearly as long as the calyx, upper ones shorter. Filaments white or pink, bent somewhat downward, more or less curved. Anthers from $\frac{1}{2}-1$ line long; ellipsoid, purple, with cordate base, glabrous, dorsifixed, soon versatile. Pollen-grains broad-ovate, smootl, orange-colored. Pistil 1 $1 \frac{1}{2}-4$ lines long, dark- or pale-red or whitish; the carpellar part downy; the style rery thin and deciduous; its stigmatic lobes fron $\frac{2}{3}-1 \frac{1}{2}$ line long, red, recurved. Carpels $\frac{3}{4}-1 \frac{1}{2}$ line long, laterally open, rarely two-seeded. Carpellar prolongations from nearly $\frac{1}{2}-1$ incl long, linear-setaceous, inside villose by long white copious lygroscopic hair, above the middle short-downy, towards the base almost glabrous. Seed brownblack, opaque, nearly filling the carpellar cavity. Radicle conical-subulate, appressed to the cotyledons, which are one-third longer than the radicle, lobeless, sessile and incumbent.

This plant flourishes already as a seedling and has then the appearance of an annual plant. It is one of the most variable species amongst congeners singular for their variability. Thus the author has not even ventured to admit Pelargonium Rodneyanum (Mitch. Three Exped. ii. 144) as specifically distinct, a careful comparison of which revenling only such notes as seem to entitle it merely to the rank of a variety. The stem of P. Rodneyanum is usually short, sometimes almost obliterated, the root is often thicker and proportionately very large, the leaves are mostly rhomboid-ovate, the flowers are manifestly larger and of a deep rose-color, the sterile stamens and style longer, and the fruit, which is seldom dereloped, larger. It appears to be a variety, which adapts itself to clay pasture-land. Dr. J. Hooker is inclined to regard the Pelargonium from the isle of Tristan d'Acunha and one of the South African species identical with ours. The P. clandestinum from New Zealand differs perhaps in dotted seeds. Specimens of the latter are in our herbarium not arailable for comparison.

Supplemental Plate. I, flower, without petals; 2 , calyx; 3, posterior segment of calyx; 4, petals; 5, stamens; 6 , anthers; 7, pollen-grains; 8 , pistil; 9 , style, before expansion of the stigmatose lobes ; 10, vertical section of orary; 11, ovules : all.figures more or less magnified.

In a luxuriant monstrosity fire smaller additional petals occur; in another the petals are incised.

\section{ERODIUM.}

\section{L'Herit. Geran. tabul.-Heron's-bill.}

Calyx devoid of a nectar tube. Petals 5, equal or almost equal. Stamens 10, towards the base monadelphous or almost free, biseriate. Filaments from a dilated base subulate; the five petaline exterior flaments destitute of anthers; the sepaline filaments provided at the base with an anterior gland. Awn-like prolongations of the carpels spirally sececing from the lengthened fruit-axis. Cotyledons nearly elliptical, concave-convex, more or less replicate on one side.

Herbaceous, rarely suffruticose, usually downy plants, diffused through the temperate zones of both hemispheres, frequent in the mediterranean regions, sparingly to be found on high mountains 
within the tropies, one species only indigenous to Australia. Leaves usually longer than broad, simply or doubly pinnatisected, or cleft into 3-5 longer or shorter lobes, toothed besides. Peduncles axillary, or opposite to the leaves or alar; or radical, sometimes 1- or 2-flowered, often umbelliferous. Pedicels bibracteolate at the base, forming to the umbels an involucre. Petals pink, purple, blue or white. Carpellar prolongations inside villose, rarely glabrous. Carpels obverse subulate-conical._Endl. Gen. 1166.

Erodium cygnorum, Nees, in Lelm. Plant. Preiss. i. 162.

Annual, short-hairy; stipules deltoid- or semilanceolate-ovate; leaves trisccted, or the lower ones trifd, short- and appressed-hairy; lobes almost rhomboid, blunt, coarsely and unequally toothed, entire towards the base; the upper lobe the largest and trifid, the lateral lobes somerwhat bific ; peduncles 1-2-flowered or oftener umbellate few-flowered; sepals short-cuspidate; petals blue, ciliolate towards the base; fertile filaments glabrous, to above the midtlle ovate-lanceolate, thence lineur-setaceous, toothless, considerably longer than the pointless staminodia; pistil silky; carpellar prolongations outside short-lispidulous; carpels hispid; seeds fulvid-1'ufous; cotyledons lobeless.

As well in fertile as barren localities, not rare in many parts of the eolony; extending further orer almost the whole extratropical part of the Australian Continent, being found as far north as the Murchison River on the west coast and nortlwward to the $26^{\circ}$ S.L. on the east eoast; not observed in eitler Tasmania or New Zealand.

An lerb of erect, diffuse or procumbent habit, sometimes stemless. Root descending, cylindrical, usually with few fibrillæ. Stems, as well as the branches, petioles, pedhneles and pedicels, clothed with short grey recumbent sprending or ascendent glandless hair, Stipnles membranous, eiliate, 1-2 lines long, sometimes into interpetiolary ones concrete. Lower petioles elongated, upper ones gradually slorter. Leares measuring from 1-21 inches, benenth more densely hispidulons than above; the lobes towards the base cuneate and entire and without interjacent teeth or lohules; some of the radical leaves occasionally cordate-orate and lobeless. Peduncles from so to sereral inclies long. Bracteoles usnally deltoid-lanceolate, ciliated, acuminated, sometimes blunt. Pedicels $\frac{1}{2}-1 \frac{1}{2}$ inch long, when fruit-benringr horizontal or declinate. Calyx when flowerbearing 2-3 lines long, when fruit-bearing albout half longer; its segments three-nerved, outside dornv, inside smooth, diaphanous at the margin. Petals euneate-obovate, about as long as the calyx or half longer. Fertile filanents $1 \frac{1}{3}-2$ lines long, setaceous, prominent at the inner side of their membranous wings. Staminodia often several times shorter than the fertile stamens, scale-like, membranous, somewhat hacerons at the apex. Anthers yellowish, about $\frac{1}{3}$ line long, with ellipsoid eells. Pollen-grains yellow, spherical, smooth. Stigmas terminating the rostrum, $\frac{1}{3}-\frac{1}{2}$ liue long, glabrous. Carpels $2 \frac{1}{2}-3 \frac{1}{2}$ lines long, obverse conicalsubulate, nore densely hairy towards the base, opening longitudinally by a narrow slit, impressed with tiro

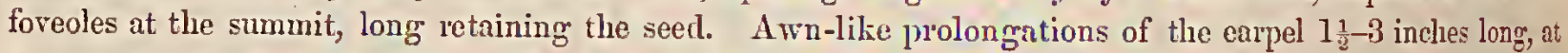
the inner side densely silky downy, towards the middle long and rather sparingly villose with pale or brown hair, spirally twisted from the base to the middle, seceding usually for some distance downward from the summit previous to their secession from the base upwrirds. Seeds clavate, $1 \frac{1}{2}-2$ lines long, smooth, opaque. Raphe hardly longer than one-third of the seed. Radicle descending, conical-subulate, appressed to the cotyledous, partially vaginated by the endopleura. Cotyledons amygrdaloid, slightly concurved, oblong, shortstipitate, bronder towards the base.

The affinity of this plant to E. gruinum is so great, that it remains doubtful whether the assumed distinetions will prove specifically valid. The distinctive charucters of $\mathrm{E}$. grruinum anomut to the following. 'The lobes of the leaves are acuminate or acnte, larger' and towards the base also toothed; the flowers are larger, the sepals longer enspidate, the wings of the fertile filaments slightly truncate at the summit. E. serotinum is perennial, has many-flowered peduncles and also largo flowers and acute leaves. In Mitchells: "Tropical Australia," p. 360, our plant is recorded as allied to E. litoreunn. E. malachoides differs in lobeless 
or short-lobed leaves, purple petals, but slight inequality of filaments, all being pointed, and in the glabrous rostrum of the firuit.

Erodium cicutarium, which in several rarieties occurs now rather frequently throughout extratropical Australia, seems to be an introduced plant, and is therefore eliminated from this diagnostic enumeration. It can readily be distinguished by the pinnatisected leaves with deeply pinnatifid segments, by pink petals with stronger bearded and more distinct unguis, by narrower and nore gradually attenuated filaments of less inequality in length, by more velvet-hairy carpels and by somewhat crenulated or lobulated cotyledons. Erodinm moschatum, which has likewise become a common Australian weed, differs from E. cicutarium only in a musky scent, usually larger stipules, less deeply divided segments of the leaves, often bidentate fertile filaments, characters on which perhaps too much dependence has been placed for specific distinction. All the accepted species of this genus have to undergo a new critical revision and limitation, their number being. evidently vastly overrated.

\section{GERANIUM.}

\section{Gen. 350.-Crane's-bill.}

Calyx devoid of a nectar tube. Petals 5, equal or almost equal. Stamens 10, towards the base monadelphous or almost free, biseriate. Filaments from a dilated base subulate, all fertile, rarely the five exterior petaline filaments destitute of anthers. Sepaline filaments provided at the base with an anterior gland. Awn-lite prolongations of the carpels circinate-seceding from the lengthened fruit-axis. Cotyledons orbicular, convolute, on one side replicate.

Herbs, rarely half-shrubs, very rarely (in species from the Sandwich Islands) shrubby plants, inhabiting the more temperate and colder regions of the globe, thus within the tropics to be met with in high mountain tracts, much more frequent in the northern than in the southern hemisphere, one species only indigenous to Australia. Leaves usually in outline cordate, renate or orbicular, often deeply cleft. Peduncles axillary or opposite to the leaves, 1-2-flowered, rarely terminal and paniculate. Pedicels at the base bibracteolate. Color of petals generally blue, purplish or pink. Carpellar prolongations on the inmer side smooth, rarely short-downy or villose.-Endl. Gen. 1167.

The cotyledons verge either into a renate- or cordate-orbicular form; they are folded back on one side only in all the species here subjected to examination (viz, G. Sibiricum, G. sanguineum, G. lucidum, G. Pjrenaicum, G. Robertianum, G. phæum, G. viscidum, G. dissectum).

Geranium dissectum, L. Sp. Plant. 956; Engl. Bot. t. 75̃3; J. Hook. Fl. Nov. Zeel. i. 39; Fl. Tasm. i. 56; G. pilosum, Forst. Prodr. 91 ; Will. Sp. Plant. iii. 706; Sneet, Geran. ii. t. 119; G. parviflorum, Willd. Enum. 716; Schleeht. Linnaa, xx. 644; G. retrorsum, L' Herit. in Cand. Prodr. i. 644; G. philonotum, Cand. Prodr. i. 639; G. potentilloides, LHer. in Cand. Prodr. i. 639; J. Hook. Fl. Nov. Zeel. i. 40; Fl. Tasm. i. 57; G. brevicaule, Hook. Joum. of Bot. ii. 252; J. Hook. Fl. Nov. Zeel. i. 40 ; Fl. Tasm. i. 57 ; G. Australe, Nees, in Lehm. Pl. Preiss. i. 163.

Diffuse or procumbent, hairy; leaves mostly long-stalked, in circumscription cordate- or renate-orbicular, deeply 5-7-cleft; their partitions cut into three or more linear- or semi-oblong or broad-linear or dilated cuneate and trifid lobes, rarely some entire; stipules and bracteoles usually small, semilanceolate- or linear-subulate, membranous; peduncles axillary, 2- or 1-flowered, rarely undeveloped; fruit-bearing pedicels declinate; petals euneate-obovate, entire or slightly emarginate, pink or pale, scantily downy at the base, as long as or longer than the short-cuspidate sepals, minutely unguiculate, withont anterior basal ridge; stamens all fertile, shorter than the calyx, usually thinly downy towards the base, short-connate; staminal glands glabrons; styles puberulous, extending but little beyond the carpellar prolongations; earpels downy, without wrinkles; testa densely reticulate. 
Frequent throughout our colony, occupying most varied places, soils and elevations, ascending to alpine altitudes; not less common in most other parts of extratropical Australia, ceasing at about the 27 parallel of S.L.; abundant in most parts of Europe; recognized as also indigenous to many parts of Asia and of America, found likewise in New Zealand and the antarctic islands; probably dispersed over many other parts of the globe.

Root in this climate perennial, generally simple and more or less napiform, sometimes divided into many cylindrical branches, outside blackish-or squalid-browu, used as food by the aboriginal natires. Stems dichotomously branched, weak and lax, usually many from each root, short or extending to various lengths, rcaching to fully 3 feet, rarely not developed, almost semicylindrical, slightly channelled along the inner side, clothed as well as the petioles, peduucles and pedicels, with longer or șhorter spreading or repressed greyish hair. Stipules 1-3 lines long, one-nerved, thinly hairy, rarely some ovate- or even deltoid-lanceolate. Lower and lowest petioles considerably longer than the leaves, middle and upper ones gradually less long. Leaves measuring from $\frac{2}{3}-2$ inches, alternately one of each pair smaller and shorter stalked, on both sides clothed more or less densely or scantily with often accumbent liair of varied length, benenth sometimes of red hue; a midnerre procurrent through each main partition and a lateral nerre through each secondary or tertiary lobe; all divisions oftener blunt than acute. Peduncles slender, often longer than the leafstalks, sometimes however quite undeveloped, again in luxurious specimens from lumid subtropical forests attaining a length of fully 7 iuches. Pedicels variable in length, occurring exceptionally as long as $2 \frac{1}{2}$ inclies, when geminate one a little shorter than the other, solitary and geminate pedicels occasionally observed on the same branch. Bracteoles 2 at the base of each pedicel. Sepals usually $2-3$ lines long, in luxurious specimens $4 \frac{1}{2}$ lines long; the two inner narrower lanceolate, the three outer broad- or ovate-lanceolate, all three-nerved, usually green, inside glabrous, at the margin with longer hair, at the outer side witl rery short down; the cuspis short or almost obliterated. Petals glabrous, membranous, in exceptional cases as long as $\frac{1}{2}$ inch. Filaments short, persistent, from a dilated base linear-subulate; the sepaline ones a little longer. Anthers at first yellowisi and cordate-orbicular, erect, dorsifixed, afterwards versatile and assuming a more oblong form, bursting with lateral slits, early dropping. Pollen-grains globular, smooth. Anterior staminal glands opposite to the sepals, roundish, carnulent, green, glabrous, faintly confluent into a five-lobed disk. Styles crowning the fruit-benk and continnous with it, yellow or red, 1-2 lines long. Carpels alternate with the sepals, usually little longer than 1 line, in gigantic forest plants however about 2 lines long, oblique-orate, not breaking fron no: articulated with the arn-like prolongations, with which they are outside short-downy, inside smooth; basis of pericarp at the inner side bearded with a tuft of white hair. Beak of the firuit long-subulate, formed by the coalescence of the carpellar prolongations with the acutely five-angular slender glabrous axis, $5-16$ lines long; the latter persistent, transient into the styles, which are connate at the base, outside slightly appressedlaairy, from which although also continuous with them the valvular prolongations finally break off. Seed varying from broad-orate to ellipsoid, often more or less trigonous and slightly renate, filling almost the cavity and long retained in the carpel after secession. Testa brown-black, opaque. Raphe nearly half as long as the seed. Cotyledons as typical cordate-orbicular, cmarginate at the summit, lobeless, slightly fleshy.

According to Elliot, as mentioned in Torley and Gray's Flora of North America, occasionnlly both orules are matured in the carpel. The description of this plant now offered is fourded solely on Australian specimens.

G. molle, found in New Zealand according to Dr. Hooker, differs in larrer stipules, in somewhat wrinkled carpels and a smooth testa. G. pusillum differs in liaving fire of its filaments deprived of anthers. But the manifold Australian varieties seem to obliterate completely the limits betreen G. dissectum and G. columbinum. The carpels of the latter are not always perfectly smooth, whilst luxuriant specimens of G. dissectum show fully as strong an exteusion of the style beyond the rostrum as is normal in G. columbinum. The midnerve of the carpel is hardly more prominent in the one than in the other, nor offers the indument of the rostrum reliable marks of discrimination. G. brevicaule, restricted to higluland plains, in 
which snow lies during the winter months, differs, as well pointed out by Dr. Hooker, solely in the suppression of stems and peduncles, by which means pedicels and petioles are all arising from the summit of the root, bracteoles and stipules being simultaneously enlarged.

In flower and fruit throughout the year.

\section{ORDER OXALIDE \\ R. Brown, Append. to Tuckey's Congo Exped. 432-433.}

Flowers bisexual, symmetrical. Sepals 5, free or towards the base connate, imbricate in bud, persistent. Petals 5, alternate with the divisions of the calyx, short-unguiculate, spirally twisted in bud, decidnous. Stamens 10, free or at the base connate, all fertile or those opposite to the petals sterile. Anthers two-celled, introrse; cells parallel, longitudinally dehiscent. Pollen-grains smooth. Ovaries five-celled. Orules 1 or more in each cell, affixed to the axis. Styles 5 , capillary, free or at the base connate, long persistent. Stigmas terminal. Fruit usucully capsular, five-celled, loculicidal-deliscent, with valves permanently connate with the axis, rarely baccate and indehiscent. Outer arillar integunent of the seed bivalved, elastically receding, very seldom wanting. Albumen copious, fleshy. Embryo straight or slightly curved. Cotyledons oval. Radicle superior.

Acid herbs, rarely lialf-shrubs or shrubs, very rarely trees, represented in all zones but the highest arctic latitudes, counting very many species in Southern Africa, tropical and subtropical America, but few in any other part of the globe. Petioles often transparent and enlarged at the base by a vaginal or stipular dilation. Leaves compound, alternate or crowded, rarely verticillate or opposite, relapsing in repose. Peduncles terminal, axillary or radical, 1-2-flowered or bearing an umbel or rarely a racemose panicle, often pellucid. Color of petals various. Petaline filaments shorter and interior. Anthers finally versatile. Capsule often five-furrowed. Seeds peindulous.-Endl. Gen. Plant. 1171; Torr. \&. Gray, Fl. of North. Amer. i. 310 ; Harv. \& Sond. Flor. Capens. i. 313.

This order, although nearest related to the grumal families, touches also on Connareæ, Balsamineæ and Zygophylleæ. It contains, as far as known, no other Australian members than the Victorian species. Beyond Oxalis no other known genus but Averrhoa can well be arrayed in this order.

OXALIS.

Lim. Gon. Plant, 582,-Wood-sorrel.

Sepals 5, free or towards the base united. Petals 5, tender-membranous. Stamens 10, all fertile or 5 sterile. Styles 5 , terminated by papillose rarely bilobed stigmas. Capsule loculicidal-fivevalved, more or less seceding into its carpellary parts. Seeds 1, 2, few or many in each cell. 
Stemless or caulescent herbaceous sometimes frutescent hardly ever truly arborescent plants, common in the warmer parts of America and in extratropical Africa, rare in Australia and elserwhere Root various in structure, often bulblike-tuberons. Leaves usually on long and pellucid petioles, circinate in vernation. Leaflets 3 or more, terminal, seldom pinnately arranged or geminate or single, always entire or at the summit notched, sometimes sensitive. Pedicels bibracteolate. Petals usually obovate-cuneate. Capsule herbaceous or membraneous. Seeds often ribbed and rugose-Jacquin Oxalis, 1-119, t. 1-81; Endl. Gen. 1172; Biophytum, Cand. Prodr. i. 689.

Oxalis Ixagellanica, Forst. Comment. Goetting. ix. 33; J. Hook. Fl. Antarctic. i. 253; Fl. of New Zeal. i. 42, t. 13; Fl. Tasm. i. 59; O. cataracte, A. Cunn. in Annal. Nat. Hist. iii. 315; Hook. Icon. Plent. 418; O. lacten, Hook. Joum. of Bot. ii. 410.

Stemless, downy; rhizome creeping; petioles very long, with oval glabrous membranous base; leares trifoliolate; leaflets broad-obcordate, minutely appendiculate beneath at the summit; pedurcles longer than the petioles, with two glabrous channelled linear-subulate bracteoles above the middle; sepuls oral, imperfectly ciliated, about three times shorter thom the corolla; petals white, glabrous; filaments longer than the calrx, smooth, short-connate at the base; styles glabrous; stigmas simple, conrex; cells of the ovary with usually three orules; capsule ovate-globose, blunt, glabrous, less than trice as long as the caljx; seeds usually solitary in each cell, turgid, irregularly wrinkled.

In lumid subalpine beech-forests, on springs, and along rirulets and torrents in the western part of Gipps Land; thus on the somrces of the Yarna, the La Trobe River, the Tyers River, the Tangil, on the Baw Baw Mrountains and in the Albert Ranges, at elevations from 2500-5000 feet. Found also in New Zealand, in Tasmania (where in the southern part of the island it descends to the lowlands), and in the most southern tracts of America.

A neat little herb, usually sparingly downy, attaining a heiglat of about 6 inches, generally dwareer, in exposed coldest localities only about an inch high. Rhizome brown, descendent or horizontal, more or less elongated, producing some slender fibres; its upper part invested with the relics of vagina and leafstalks. Stems exceedingly short or undereloped. Petioles pellucid, several or many arising from the summits of the rhizone, between $\frac{3}{4}$ and 3 incles long, dilated at the base into a concurved whitish finally brown at the apes bidentate or fornicate ragina of $1 \frac{1}{2}-6$ lines length. Leaflets from $1 \frac{1}{2}-8$ lines long, above usually glabrous, benenth and along the margin appressed- and scattered-hairy, finely nerved and reined, provided with a small roundish pale cutaneous terminal appendage, benenth often glaucous or opaque-purplish. Peduncles radical, solitnry, somewhat longer than the petioles. Bracteoles opposite or alternate, glabrous, menibranous, 1-? lines long. Sepals 2-3 lines long, green; the inner ones with a brond membranous margin, the outer ones more ciliate, all appressed-hairy at the back. Petals broad obovate-cuneate, yellow towards the base, finely anastomosing-reined, more or less ciliolate towards the sumnit, otherwise smooth. Shorter filaments not much longer than the calyx, longer filaments about half as long as the corolla and conspicuously dilated at the base ; all persistent, whitish, glabrous, capillary. Anthers deciduous, yellow, cordate-orate, $\frac{1}{3}-\frac{1}{3}$ line long. Dry pollen-grains smootl, globular, with three openingss. Styles persistent, free, dhring anthesis extending to the leiglit of the longer filaments, capillary, grabrous, about 2 lines long. Ovary glabrous or very slightly puberulous. Capsule (according to Tasmanian specimens communicated by the Hon. Will. Archer) glabrous, membranous, 2-3 lines long. Consistence of the dehiscent exterior integument of the seed betreen enrtilaginous and membranous; its color pale-yellowish. Seed after the lapse of the epidermis red-brorn, about $\frac{3}{4}$ line longr, ovate-globose, glabrous. Embryo not quite as long as the albumen. Cotyledons broadovate, flat, as long as the radicle.

But slight character's exist to separate this species from O. Acetosella, the Wood-sorrel of Europe. The latter is however recognized by no distinctly developed cutaneons concavity at the notch of the leaflets, by smaller hairy and more fleshy scales of the rhizome and of the base of the petiole, by hairy bracteoles, by 
pointed but not hairy sepals, by pointed and more ovate capsules, which are nearly twice as long as the calyx, and finally by more compressed streaked seeds, of which two usually occur in each cell.

This species, with its frequent companion Libertia Lawrencii, might be easily naturalized in the Middle and North European forests. The identification of the Australian with the antarctic American plant rests on the authority of Dr. J. Hooker.

Oxalis corniculata, L.Sp.Pl.623; Jacq. Oxal.10, t. 5; Engl. Bot.t.1726; J. Hook. Fl. Nen Zeal. i. $42 ; \mathrm{Fl}$. Tasm. i. 59; O. reptans, Forst. Prodr. 519 ; O. microphylla, Poir. Suppl. iv. 248; O. cognata, Steud. in Lehm. Pl. Preiss. i. 160.

Caulescent, downy; rhizome divided, usually creeping; petioles long, slightly dilated at the base; leaves trifoliolate; leaflets broad-obcordate, exappendiculate at the summit; peduncles mostly longer than the petioles, with single geminate or umbellate pedicels; bracteoles lanceolate- or subulate-linear; sepals less than half as long. as the corolla, oblong-lanceolate; petals yellow, glabrons; filanents smooth, not much longer than the calyx, towards the base conspicuously connate; styles short-downy; stigmas simple, convex; capsule cylindrical, rostrate, short-hairy, more than twice as long as the calyx; seeds several in each cell, compressed, transversely strong-wrinkled, longitudinally costate.

Common throughont the colony except in the alpine tracts; extending also over the other parts of extratropical Australia, and over tropical Australia to the 19 parallel of southern latitude; further distributed over a vast extent of the other parts of the globe, although regarded of American origin.

Root more or less fusiform or cylindrical or fascicnlate, emitting distant-scaly rhizomes. Stems of varied length, sometimes reduced to extreme shortness, sometimes extending to several feet and flaccidly leaning against surrounding plants, usually of moderate length, diffuse or procumbent, occasionally erect, scattered- or dense-hairy, sometimes almost glabrous. Petioles lengthened or shortened in proportion to the leaves, thus varying from $\frac{1}{2}-2 \frac{1}{2}$ inches in length, variable also as regards indument and the basal truncate stipular dilatation, the latter being more or less hairy. Leaflets $1 \frac{1}{2}-10$ lines long, green, not rarely purplisl, sometimes velvet-downy, sometimes scattered-hairy, sonetimes almost or totally glabrous, with a deep terminal incision. Peduncles $\frac{1}{2}-5$ inches long, variously hairy, slender, seldom smooth. Bracteoles $\frac{3}{4}-2$ lines long, hairy. Pedicels $1-16$ in number, slender, varying in length from a few lines to $1 \frac{1}{2}$ inch. Sepals appressedhairy, 1-3 lines long, more or less acute or obtuse. Petals oblique obovate- or obcordate-cuneate, singularly inconstant in size, thus from 2 lines to nearly 1 inch long, sometimes externally tinged with red, not rarely ciliolated towards the summit, entire or emarginate, coherent at the short unguis, deciduous. Filaments persistent, linear-setaceous, as well as the styles greenish. Anthers yellow, $\frac{1}{5}-\frac{1}{3}$ line long, cordate, deciduous. Styles $\frac{3}{4}-2$ lines long, concrete towards the base, during anthesis sonewhat longer than the stamens. Stigmas yellow, very papillose, almost penicillar. Capsule usually from $\frac{1}{2}-1$ inch long, $1 \frac{1}{2}-2$ lines in diameter, conically contracted at the summit, rarely shortened to $\frac{1}{3}$ inch length, with a much abbreviated rostrum. Seeds after dehiscence of the livid-fulvous epidermis saturated-brown, hardly shining, ovate, slightly pointed, $\frac{1}{2}-\frac{2}{3}$ line long. Cotyledons oval, as long as the radicle.

0. Preissiana (Steud. in Lehm. Plant. Preiss. i. 160), to which probably a white corolla is erroneously attributed, appears also referable to 0 . corniculata, which species we possess in manifold specimens from Western Australia. That yet several other supposed species are to be united under 0 . corniculata, from which not even the Linnean $\mathrm{O}$. stricta is specifically discernible, cannot be a subject of doubt. No other than the here described species exist in any litherto explored part of Australia.

The agreeable acidulous taste of the species of Oxalis is owing to their juice containing Binoxalate of potash. The herb is occasionally used as salad, or for preparing refrigerant beverages, but should be employed only with very great caution for such purposes, as pernicious effects are experienced from any extensive alimentary uses of these plants. 


\section{Order UINE无.}

Cand. Théorie Élémentaire de la Botanique, ed. i. 89.

Flowers bisexual, symmetrical. Sepals 5, rarely 4, imbricate in bud, persistent. Petals 5, rarely 4, alternate with the sepals, unguiculate, twisted in bud, deciduous. Stamens free or torvards the base connate; 5 opposite to the sepals, 5 opposite to the petals, all fertile or the latter either sterile or wanting. Anthers two-celled, introrse; cells parallel, longitudinally dehiscent. Pollen-grains smooth. Glands 5-10, rarely 1 or 3 or 4 , adnate to the base of the stamens. Ovary 5 -celled, rarely 3 - or 4 -celled, with two collateral axil suspended ovules in each cell, or seldom completely 10-celled and with a solitary ovule in each cell. Styles 5, rarely 3 or 4, free or connate. Stigmas free, simple. Fruit capsular, rarely drupaceous, 5-10-celled, rarely 3-4celled or by abortion 1-celled. Seeds pendulous, with very scanty rarely with copious albumen. Enbryo straight or slightly curved. Cotyledons flat. Radicle superior.

Herbs or half-shrubs, rarely shrubs or trees, dispersed over the temperate zones, rare within the tropics. Stems inarticulate. Stipules wanting or indicated by glands, seldom perfectly developed. Leaves simple, alternate, less frequently opposite, rarely verticillate, entire, seldom serrated. Pedicels paniculate, racemose, corymbose, cymose or solitary, articulated at the summit. Color of petals various.-Planchon, in Hook. Lond. Journ. vi. 588.

Lineæ, in the circumscription adopted by Dr. Planchon, bring the Gruinal orders in contact not only with Caryophylleæ, but also with many others of Thalamiflorie.

\section{LINUM.}

Iinné, Syst. Natur. edit. Gmelin. tom. ii. pars i. 313.-Flax.

Sepals 5, lobeless. Petals 5, inappendiculate, membranous. Fertile filaments 5, linear-subulate, connate and glandulose at the base; sterile stamens tooth-like or undeveloped. Styles 5 , free or connate. Stigmas capitate or elongate. Capsule formed by the concrescence of five imperfectly rarely perfectly vertical-bilocellate separable carpels, which burst internally and at the summit. Secondary septa parietal. Axis of fruit undeveloped. Seeds ovate, compressed, solitary in the secondary cells. Moistened testa mucous. Albumen very scanty. Embryo oily-fleshy.

Herls or half-shrubs, often glabrous, occurring in the more temperate and colder zones and on higher mountains within the tropics. Bast tenacions. Stipules wanting or represented by glands Leaves entire, one-nerved or longitudinally three-nerved, small, inconspicuously or finely reined, usually sessile. Flowers ebracteolate, corymbose, racemose, cynose or paniculate. Pedicels usully opposite to a leaf. Petals blue, white or yellow, rarely red. Filaments persistent. Anthers deciduous. Capsule generally globular and short-pointed.-Planchon, in Hook. Lond. Journ. vi. 593 and 597-98.

I.num marginale, All. Cunn. according to Planchon in Hook. Lond. Joum. of Bot. vii. $169 ; \mathrm{J}$. Hook. Fl. Tasm. i. 46 ; L. angustifolium, Bartl. in Lehm. Pl. Preiss. i..161. 
Glabrous, perennial; leaves alternate, lanceolate-linear or subulate-linear or the lower ones oblong; stipular glands-wanting; flowers corymbose- or racemose-paniculate; pedicels always erect, longer than the calyx; sepals ovate, acuminate or cuspidulate, entire or slightly ciliolated, membranous at the margin; petals blue rarely white, about three times longer than the calyx; their unguis smooth, short; filaments about as long as the sepals, short-connate, extending to the height of the styles; anthers narrow cordateoblong, yellow; staminodia obliterated; styles connate to byond the middle; stigmas linear-clavate, gradually passing into the styles; capsule little or half longer than the calyx, short-pointed; secondary septa imperfect, at the inner edge scantily ciliated; seeds brown.

In fertile and sterile localities throughout the greater part of the colony, ascending to the Alps; also distributed over other wide tracts of extratropical Australia.

An herb greatly varying according to the influences which soil, situation and climate must exercise on so widely diffused a plant, flowering aheady in the first year of growtl, and then having entirely the appearance of an annual. Root hard, more or less thick or slender, flexuose, tortuose or more straight, with more or less ramifications and fibrillæ. Stems cylindrical, streaked, simple or often towards the summit branched, at an average from a span to 2 feet high, occasionally, however, but from $1 \frac{1}{2}$ to a few inches long and then only one- or few-flowered, sometimes attaining the height of several feet, often many from one root. Leaves from a few lines to $1 \frac{1}{2}$ inch long, $\frac{1}{2}-2$ lines broad, usually acute, more or less green or glaucous, with a conspicuous midnerve and a less perfect lateral nerve on each side. Racemes or corymbs generally fewflowered, terminating the branchlets, often collected into a fastigiate panicle. Pedicels opposite to a diminutive bract-like leaf, 2-16 lines long, slender-filiform and slightly angular. Sepals free, 11-3 lines long, with a distinct midnerve and upwards evanescent laternl nerres, green with exception of the margin; the inner ones sometimes nearly orbicular. Petals much more frequently blue than white, broadly oborate- or obcordatecuneate, blunt or minutely acuminate, entire, finely veined. Filaments inembranous, glabrous, concrete at the base. Anthers $\frac{1}{2}-1$ hine long, basifixed, linear-oblong, with cordate base. Pollen-grains globular, smooth. Staminodia if present very minute. Style $1 \frac{1}{2}-2$ lines long; capillary, glabrous. Stigmas $\frac{2}{3}-1$ line long; semiterete, upwards thickened. Capsule 2-4 lines long, pale or fulvous and shining outside, tardily secedent into its five primary carpels, which are readily separable into their two constituent parts. Secondary septa not fully extending to the axis. Seeds brown, ovate, compressed, shining; 1-1 $\frac{1}{2}$ line long, very minutely dotted. Testa emitting when moistened a copious mucus. Albumen hardly any. Cotyledons flat, ovate, nearly thrice as long as the cylindrical radicle.

We are acquainted with no other but this species of Australian Flax. The L. surdifolium (Planch. in Hook. Lond. Journ. vii. 168) appear's to constitute one of the many varieties of L. marginale. The L. Babingtonii (Planch. in Hook. Lond. Journ. vii. 179; Cliococca tenuifoha, Babingt. in Transact. Linn. Soc. xix. 34, t. 3), originally pronounced as indigenous to Australia, seems not to differ specifically from I. selaginoides, Lam., and is most probably of South American origin. As immigrated L. Gallicum is noted in East Australia.

The Australian Flax differs, as pointed out by Dr. Planchon, from the European L. angustifolium principally in highly connate styles. L. monogynum, a $\mathrm{New}$ Zealandian species, is to be distinguished by sepals, which show hardly any membranous margin, by usually larger flowers, distinctly developed staminodia and frequently larger capsules and seeds. The bast of the Australian Flax is of considerable strength and well adapted for textile fabrics. The aborigines convert it into nets, fishing lines and other articles of great strength and neatness. The seeds may be used for mucilaginous decoctions, for expressing oil, for preparing poultices and for any other uses for which the common linseed is employed.

To the Gruinal division, as a distinct order next to Limnantheæ, may possibly be referable the singular genus Cadellia, previously alluded to under Malpighiaceæ. Professor Planchon has lucidly pointed out its affinity to Limnanthes, Biebersteinia and Suriana. Dr. Jos. Hooker observed several ovules in each of its ovaries. 


\section{VIII.-POLYGAIIN.⿻.}

Calyx in præeflorescence valvate or imbricate. Corolla in bud induplicate or im. bricate. Stamens definite. Anthers usually opening by a terminal pore. Ovary tro. celled, generally with 1 or 2 ovules in each cell. Placentation axil. Embryo straight, often surrounded by albumen.

\section{ORDER TREMANDRE王.}

R. Br. in Flind. Voyage, ii. 544.

Flowers bisexual, symmetrical. Sepals $\mathbf{4 - 5}$, free or at the base connate, valuate in restivation. Petals $4-5$, free, inchiplicate in bud, deciduous. Stamens 8-10, free, hypogynous, all fertile. Filaments short. Anthers connivent, extrorse, 2-4-celled, opening by a terminal pore. Pollen-grains smooth. Ovary two-celled, compressed. Ovules 1-3 in each cell, pendulous. Styles 2, perfectly connate, rarely free towards the summit. Stigmas minute, confluent. Capsule two-celled, compressed, bursting by loculicidal dehiscence. Seeds pendent. Hilum naked. Chalaza terminal. Embryo straight, cylindrical, placed in the axis of fleshy albumen. - Radiclc superior.

Shrubby or suffruticose ornamental often heath-like plants, restricted to extratropical Australia and Tasmania. Leaves alternate or verticillate, rarely opposite, simple, entire or toothed, sessile or' short-stalked, sometimes reduced to minute scales. Stipules wanting. Pedicels axillary, often solitary. Petals purplish, rarely white.Endl. Gen. 1076 ; Lindl. Veg. Kingd. ed. iii. 374 ; Payer, in Annal. des Scienc. Naturell. 1851, 346-359 ; Steetz, die Familie der Tremandreen, 1-111 ; Schuchh. Synops. Tremandr. 1-49; Payer, Traité d'Organogénie comparée, 133-138, tab. 29-30.

Rob. Brown indicated to Tremandrex a position in the series of natural orders next to Polygalere. Steetz in his masterly dissertation placed them lucidly next to the-lasiopetaleous tribe of Buettneriacer, from whence they establish a link to Polygalex. Simultaneous to the issue of Dr. Stcctz' memoir the Tremandrex rere placed next to Buettmeriacex by the author of this work (conf. T. M. First Gen. Report on the Vegctation of Victoria, p. 10). To retain them in that position would perhaps be most advisable.

Some alliance of this order to Pittosporese also exists, as noted by Professor Lindley. The habit of Rhytidospormm procumbens is not unlike that of some Tetrathecre and its capsule is by no means dissimilar to that of Platytheca galioidcs, although considcrablc embryonic differences between the seeds of both exist. External resem. 
blance is also manifest between certain species of Tetratheca and the Saxifrageous genus Bauera, one species of which, Bauera sessiliflora, having also the stamens usually double to the number of the petals, the anthers imperfectly dehiscent and geminate pendulous ovules, whilst the disposition of the leaves in Platytheca and some Tetrathecæ is identical with that of Bauera. The similarity to some Boroniæ is also evident. The genus Platytheca seems to comprise but a solitary species, nor can there be much doubt, that the two hitherto distinguished Tremandræ are to be combined.

\section{TETRATHECA.}

Smith, Specim. of the Bot. of New Holland, i. t. 2.

Sepals 4-5, much shorter than the corolla. Petals ${ }^{4}-5$, during præflorescence clasping around pair of stamens. Stamens 8-10, geminate in front of the petals, nearly equal, uniseriate. Anthers continuous with the filaments, 2-celled or biseriate 4-celled, confluent into a terminal cylinder. Ovary tiro-celled. Ovules in each cell 1 ; or 2 of which one above the other; or rarely 3 of which the two upper collateral. Style straight or above the base tortuose, formed by the concrescence of two. Stigma minute. Capsule chartaceous, compressed, bivalved. Seeds ellipsoid. Chalaza extended into a fungous spiral or contorted or uncinate appendage, remotest from the hilum.

Slender shrubby or suffruticose plants, scattered over extratropical Australia, ascending to the Alps, more frequent towards the south-eastern and south-western extremities of the Continent, one species only occurring from the Murray River to the Great Bight, none towards Central Australia. Branches terete or angular, rarely leafy-compressed and then minutely leaved or provided with minute scattered bracteole-like scales. Leaves short-stalked or sessile, alternate, scattered or verticillate, rarely some opposite, sometimes wanting. Pedicels filiform or capillary, minutely bibracteolate at the base. Calyx already in bud considerably shorter than the corolla. Filaments very short. Anthers usually purplish-black, suddenly or gradually contracted into a long or short tubular rostrum. Style setaceous or capillary, rather short. Capsule small, usually obovate or roundish-Endl.Gen. 1077 ; Steetz, clie Familie der Tremandreen, 30.

Tetratheca stands in habit nearer to Platytheca than to Tremandra. The former differs, as pointed out by Dr. Steetz, in a long calyx, in stamens which are not by pairs surrounded by the petals whilst in bud, but are unequal and disposed in two rows, by four uniseriate anther-cells, and by the absence of the chalazal appendage. Tremandra differs essentially in habit, in anthers articulated with the filaments and not contracted into a distinct tubular rostrum, and possibly in fruit.

Fetratheca cillata, Lindl. in Nitch. East Austr. ii. 206; Hook. Icon. Plant. 268; Schuchh. Synops. Tremandr. 32; J. Hook. Fl. Tasm. i. 34.

Branches terete; leaves scattered or ternate- or quaternate-verticillate, oborate- or orbicular-rhomboid, rarely some narrow-lanceolate, flat or at the margin slightly recurved; sepals soon reflexed, almost rhomboid, as well as the petals usually 4 ; stamens usually 8 ; anthers smooth, four-celled, black-purple, tapering into a compressed short filament and into a short tubular apex; cells of the ovary generally biovulate; capsule orbicular or obovate-orbicular.

Frequent in many parts of the Colony of Victoria in heath ground and in barren forest-ridges; extending into the south-eastern regions of the Colony of South Australia and to the northern parts of Tasmania, seemingly neither reaching East Australia nor ascending to the Alps. 
A half-slirub with the habit of a Boronia, attaining the height of 3 feet, usually, however, more dwarf, producing in most instances many erect ascending or diffused rather slender stems from the stout woody root. Branches less frequently smooth than hairy, some of the hair occasionally terminated with a gland. Leaves herbaceous or thin-coriaceous, varying in length from about 2-9 lines, quite entire or somewhat repand or seldom imperfectly crenulated, glabrons or in various degrees downy from pale hair, above dark. green, beneath paler; the midrib ratler strong; the lateral nerves and veins faint. Pedicels thin-filiform, usually black-purple, arising solitary or geminate from the axis of leaves, spreading or recurved, at the apex considerably thickened, at the base beset with two bracteoles, fiom nearly equal to double the length of the leaves, either quite glabrous, or oftener more or less short- and pale-hairy and simultaneously beset with some longer black-purple gland-bearing hair. Bracteoles less than 1 line long, subulate-linear, channelled, sometimes ciliolated, deciduous. Sepals usually black-purple, $\frac{2}{3}-1$ line long, adnate with their truncate base to the dilated summit of the pedicel, slightly acuminate, inside especially towards the margin and midnerve short-liairy, outside clothed with an indument similar to that of the pedicel. Petals oblong-oral, slightly tapering to the base, more variable in size than the sepals, thus from $2 \frac{1}{2}-8$ lines long; entire, clothed with very thin only under a lens obserrable pubescence, usually of a rosy purple, rarely white or pale-red; the midnerre tender; the veins very fine. Stamens from 1-13 line long, sometimes quite blunt, usually attenuated into a short and paler apex; the tetragonous-cylindrical anthers confluent with the filament; the pore terminal, minnte, occasionally almost lateral and large. Pollen-grains pale, ellipsoid, smooth, with longitudinal fissures. Style hardly longer than 1 line, thin-subulate, reddish towards the base, fulrous-pale towards the summit, very minutely downy below the middle. Ovary covered with very short grey and sometimes also with scattered longer dark gland-bearing hair; the cells rarely containing three ovules. Capsule 2-4 lines long; bent downward, outside covered with exceedingly short hair, amongst which sometimes a few longer gland-hairs are scattered, inside smooth. Seeds dark- or grey-brown, 1-1 $\frac{1}{4}$ line long, scantily clothed with short patent soft pale hair, when 1 in each cell ovate, when 2 truncate-ovate. Appendage of seed either spirally coiled or variously twisted, pale, especially upwards. Albumen amygdaloid. Embryo yellowish, transparent, thin-cylindrical, straight, shorter than the albumen. Radicle about as long as the cotyledons.

Tetratheca exicifolia, Sm. Exot. Bot.p. 37, t. 20; T. tlymifolia, Sm. l.e.p. 39, t. 22; Rudge, in Transact. Lim. Soe. viii. 295, tab. xi.; T. glandulosa, Sm. l. e.p. 38, t. 21; Rudge, l.e. viii. 294, t. 10; T. pilosa, Lab. Nov. Holl. Plant. Specim. i. 95, t. 122; T. glandulosa, Lab. l. e. i. 95, t. 123; T. rubioides, All. Cunn. in Field's Geograph. Memoirs on New South Wales, 336; T. denticulata, Sieb. in Spreng. Syst. Veg. vol. iv. pars ii. p. 147 ; T. bauerefolia, F. M. in Sehuehh. Syn. Trem. 29; T. calva, F. M. l.c. 25; 'I. procumbens, Gunn, in J. Hooh. Fl. Tasm. i. 35, tab. vii. A.; T. Gumnii, J. Hook. l. c. 36, tab. viii. в.

Branches terete; leares scattered or crowded or verticillate, linear or lanceolate or oblong or oute or rhomboid, often revolute at the margin, seldom wanting; sepals appressed, rhomboid- or orbicular-ovate, often acuminate, as well as the petals nsually 4, stamens usually 8 ; antliers smooth, four-celled, black-purple, tapering into a compressed short filment; their cells longer than the tubular apex; cells of the ovary 1ovulate; capsule cuneate- or orbicular-obovate.

On heatli-trnots of the mountains and ridges in many parts of this colony, ascending to alpine elevations, extending to St. Vincent's Gulf, Kangaroo Island, 'Lasmania, Flinders Island and Moreton Bay.

A suffinticose or shrubby plant, variable in aspect, attaining the height of several feet, sometimes quite dwarf, in alpine localities and much exposed barren spots occnsionally depressed. Indument variable, sometimes glandulous, sometimes deficient. Leaves from 2-10 lines long. Pedicels mensuring from 1-14 lines. Flowers so similar to the various varieties of the preceding species as to render their description here needless. Petals in alpine varieties sometimes reduced to $1 \frac{1}{2}$ line length. Fruit-capsule usually narrower than that of $T$. ciliata, otherwise as well as the seeds similar to that species. 
The direction of the sepals, a character which perhaps is not implicitly to be relied on, seems the principal note to distinguish the broad-leaved and broad-capsnled forms of T. ericifolia from T. ciliata. It proved frustraneous to limit all the plants, here drawn together under 'T. ericifolia, into distinct species. Nevertheless the varieties retain typical differences with considerable firmness. Thus the narrow-leaved original T. ericifolia, which is almost restricted to our eastern frontiers, shows mostly linear-verticillate leaves with levolute margin, long pedicels, glandulous-hairy more ovate and acuminate sepals. T. denticulata, also an eastern form, has scattered toothed leaves. T. thymifolia, which bears particular resemblance to Bauern, is as a variety recognized by also verticillate ovate or lanceolate leaves, often ovate and acuminate sepals and silky oraries. Its capsule is particularly inconstant in form. It is this variety which extends to the Glasshouse Mountains of Moreton Bay. In our mountain regions it is from Mount Disappointment eastward exceedingly frequent. The ' $T$. glandulosa produces scattered toothed orate or lanceolate or rhomboid leaves, copious gland-hairs and a broad capsule, the proportion of width of the latter being in most varieties to some extent ruled by the width of the leaves. It occurs more commonly in Tasmania than in Victoria, being' here noticed on the ranges near or towards the Avon River of Gipps Land, also on the dry scrubby hills timbered with ironbark-trees between the Ovens and Broken River. The sepals and even the petals of this variety are occasionally long persistent. The length and color of the anther-tubule is variable; but it is never contracted and extended to the great length and tenuity of that of some Western Australian species; the style is sometimes at the apex distinctly cleft into its two constituent parts.

To the main form of $T$. pilosa may be ascribed hairy narrow scattered leaves. We possess it not so frequently in our colony as it occur's towards St. Vincent's Gulf, where this variety solely occurs. In Tasmania it abounds. Specimens gathered in the Avon Ranges of Gipps Land obhiterate the distinctions between the leaves of certain broad-leaved states of T. ericifolia and narrow-leaved forms of T. ciliata. One of the most curious of all the varieties of $\mathrm{T}$. ericifolia is the var. aphylla, which occurs on scantily timbered quartz-rang'es at the sources of the Genoa River, especially on the White Peak. It is almost constantly as much devoid of leaves as T. juncea; but its ramifications are terete, often flexuose or even singularly contorted; the pedicels arise from the axis of minute lanceolate-subulate bracts, between which and the occasionally developed rarely large ovate leaves all possible metamorphic gradations may be observed. It is, lowever, to be noted that the fruit of this leafless variety remains as yet unknown.

The tubule of the anthers of all these assumed forms of $\mathrm{T}$. ericifolia exhibits no reliable notes in reference to color and length; it may be seen pale, yellowish, purple or black.

\title{
ORDER POLYGALE巴.
}

\author{
Juss. in Annal. du Mus. xiv. 386.
}

Flowers bisexual, unsymmetrical. Calyx consisting of five sepals, rarely 5- or 3-cleft, imbricate in bud; 2 or 3 sepals exterior, small; 1 or 2 of which anterior and one posterior; the two inner sepals lateral, usually large and petaloid. Petals unequal, 3-5, connected by the staminal tube, rarely free; the posterior ones approximated; the anterior one the largest, including the genitalia. Stamens 8 , rarely 3,4 or 5 . Filaments connate into a tube, which is slit in front, rarely free. Anthers one-celled, opening by a terminal pore, rarely two-celled. Ovary 2-celled, seldom 1- or 3-celled, with a single pendent rarely two superposite ovules in each cell. Styles concrete into 1. Stigma labiate or simple. Fruit capsular, compressed, bicelled, bursting with 
loculicidal dehiscence, rarely samarous or drupaceous. Seed pendulous, with fleshy albumen, rarely almost exalbuminous. Embryo axil, straight or lightly curved. Cotyledons plane-convex. Radicle short, superior.

Herbs, half-shrubs or shrubs, usually of bitter taste, distributed over the tropical and temperate zones, in Australia less frequent north than south of the circle of Capricorn. Leaves simple, alternate, very seldom opposite, undivided, without stipules. Pedicels tribracteolate. Flowers often spicate or racemose. Prevailing color of petals red or blue.-R. Br. in Append. to Flinders' Voyage, 343; Aug. de St. Hilaire and Moq. Tandon, in Mém. du Mus. xvii. 313; Endl. Gen. 1077 ; Lindl. Veg. Kingd. ed. iii. 375 .

The alliance of Polygaleæ tends as well to Tremandreæ as to Sapindacex. Australia, as far as known, possesses only the genera Polygala, Comesperma and Sala. monea.

\section{POLYGALA.}

Linné, Gen. Plant. 851. .

Sepals 5, often persistent; the outer three small; the two inner sepals large, petaloid. Petals 3 rarely 5 , conuate with the staminal tube; the anterior one large, concave, galeate, three-lobed or one-lobed and cristate ; lateral.petals very minute, often wanting; posterior two connirent. Stamens 8 , almost equal, ascendent. Tube of the filaments slit in front; their summit free. 'Anthers basifixed, one-celled, opening by a terminal aperture. Hypogynous disk unilateral or wanting. Ovary twocelled, compressed. Ovules solitary, pendent from below the apex of the narrow dissepiment. Style curved, undivided or short and unequally lobed, stigmatose at or below the summit. Capsule compressed, two-celled, opening with marginal dehiscence, rounded at the base. Seeds at the hilum strophiolate.

Herbaceous, suffruticose or frutescent plants, widely distributed over the temperate and tropical zones, but not numerous in Australia, and restricted then to the northern and eastern tracts. Leares alternate, rarely opposite or verticillate, entire. Flowers racemose, spicate, corymbose or capitate, rarely solitary. Genitalia concealed within the anterior keel-like petal. Capsule generally membranous and at the summit emarginate. Seeds frequently pubescent.-St. Hilaire \& Moquin, in Mém. du Mus. xvii. $t .27$ \& $28 ;$ Endl. Gen. 1078.

Polygala veronicea, F. M. in Transact. Vic. Inst. i. 117.

Perennial, herbaceous; stems erect or diffused, dwarf, nearly terete, as well as peduncles and pedicels short downy; leaves chartaceous, alternate, on very sliort petioles, early smootl, flat or at the margin slightly recurred, net-vcined, the loner ones orate or some roundish, the npper ones lanceolate or oratelanceolate, acute; flowers small, collected in a subsessile corymb or raceme, rarely geminate or solitary, longer than the pedicels; niddle bracteole ovate-lanceolate, longer than the mimute semilanceolate lateral bracteoles, much shorter than the pedicel; calyx persistent; exterior sepals cymbiform-lanceolate, free; interior sepals far the largest, obovate, nearly as long as the fimbriatc-erested anterior petal and the orlicular-obcordate ninged capsule; style with a stipitate terminal and a sessile lateral gland; strophiole downy, half as long as the broad-obovate seed.

In grassy or gravelly places scattered along the banks of the Goulburn, the Ovens River and their lower tributaries; thence extending through East Australia at least as far as the 26 southern parallel. 
A slightly bitter herb of the aspect of a Veronica. Rhizome in age somewhat woody. Stems several or many from the rhizome, generally less than a span long, simple or from near the base branched. Leaves copious, from 3-10 lines long, usually acute, slightly rigid, almost opaque above, paler and somewhat shining. beneath, with a strong midnerve and ascendent lateral nerves. Inflorescence axillary and terminal. Pedicels 1-2 lines long: Middle bracteole about 3 line long, lanceolate- or ovate-cymbiform, outside somewhat downy; lateral ones more or less oval- or narrow-lanceolate, about half as long. Outer sepals 1-1 $\frac{1}{3}$ line long, lanceolate- or linear-cymbiform, somewhat patent, slightly downy or almost glabrous; inner sepals smooth, slightly unguiculate, pale at the margin, otherwise almost green, broad-ovate, 2-3 lines long, traversed by a midnerve and copious veins. Aniterior petal almost obcordate-dilated, lilac-colored especially towards the summit; its crista consisting of two main partitions, about 1 line long, formed by numerous fringes. Posterior petals oblique, spathulate-oblong, somewhat shorter than the carina. Filamer ts only free at the summit, sometimes 9. Anthers truncate-ellipsoid, about $\frac{1}{4}$ line long. Pollen-grains spherical, smooth. Style about $1 \frac{1}{2}$ line long, clarate-linear, slightly ascendent, a sessile gland below and a stipitate gland above forming the stigmatic apparatus at the apex. Capsule measuring $2-3$ lines, slightly turgid, finely veined, surrounded by a wing; which tapers at the base, measures $\frac{1}{2}$ line in breadth upwards, and is cleft at the summit. Seeds rather more than 1 line long, finely pubescent. Strophiole cleft deeply into three narrow livid or fulvous lobes. Testa crust-like, black-brown. Albumen scanty. Embryo yellowisl, about $\frac{3}{4}$ line long. Cotyledons nenrly orbicular, almost flat, about five times as long as the superior radicle:

In all probability our Polygala is identical with P. Japonica, which indeed is enumerated by Dr. Hooker (Flor. Tasm. introd. p. 42) as an Indo-Australian species, it being here moreover often consociated with Salvia plebeja and other East Asiatic plants.

\section{COMESPERMA.}

Labill. Nov. Holl. Plant. Specim. ii. 21, t. 159-163.

Sepals $4-5$, deciduous; the outer 2 or 3 small ; the two inner sepals larger, petaloid. Petals 3 , rarely 5 , connate with the staminal tube; the anterior one large, concave, galeate, 3 - or 1-lobed, not crested ; lateral petals very minute, often wanting; posterior two oblong or lanceolate. Stamens 8 , almost equal, ascendent. Tube of filaments slit in front; their summit free. Anthers basifixed, onecelled, opening by a terminal aperture. Ovary two-celled, compressed. Ovules solitary, pendent from near the apex of the narrow dissepiment. Style curved, compressed, short-bilobed at the apex. Stigma terminal. Capsule compressed, two-celled, opening with marginal dehiscence, usually contracted into a stipes. Seeds uswally invested with long descending silky hair, with or without a strophiole.

Perennial-herbaceous, suffiruticose or frutescent plants, rather frequent in extratropical Australia, rare in tropical Australia, not found elsewhere. Branches straight or climbing, rarely spinescent. Leaves alternate, never very large, sometimes but scantily developed or very minute and bract-like. Flowers racemose, less frequently solitary, blue or red or yellow, seldom white. Capsule membranous or coriaceous, at the summit truncate or emarginate. Seeds frequently downy.-Endl. Gen. 1078; Steetz, in Lehm. Plant. Preiss. ii. 292-294.

Besides the indument of the seed no character is manifest by which this genus could be separated from certain sections of Polygala. Additional somewhat aberrant species obliterate also almost the generic distinctions of Catacoma, except the habitual diversity. In two species of Comesperma the seed-hair are developed solely along the margin of the seed, in some other only near the apex. The strophiole whenever formed extends in a narrow line to the chalaza, where it is expanded into a membranous plate of varied form and size. In this regard Catacoma seems not to offer sufficient marks of distinction from Comesperma. 


\section{Sect. I. Prosthenospernia.}

Leaves all or the upper ones minute, bract-like. Exterior sepals disunited, about half as long as the almost orbicular wings. Capsule devoid of a distinct stipes. Seeds short-downy. Strophiole expanded at the chalaza into a membranons appendage.

Comesperma scoparium, Steetz, in Lehm. Plant. Preiss. ii. 309; F. M. Fragm. Phytogr. Austr. i. 145 .

Shrubby, erect; branches strict, furrowed; leaves minute, snlulate, appressed, remote; pedicels stont, axillary, spuriously and distantly spicate, at the base minitely imbricate-braeteate, very short; bracteoles almost equal, tardily secedent, broad- or orbicular-ovate; exterior sepals free, about half as long as the interior ones, equal, subovate; inner sepals roundish, blue; posterior petals bearded; filaments to near the middle monadelphous, thence free; eapsule coriaceous, broadly cuncate-oborate, margined; seeds short-donny; strophiole terminated at the chalaza by a narrow-semielliptical downy membrane of more than half the length of the seed; cotyledons oval.

In the sandy desert near the Nurray River, Dallachy; found also in the Darling Desert, near the Fitzgerald Ranges, and by Mr. Oldfield near the Murchison River, probably dispersed over many of the intermediate deser't tracts.

A shrubby broom-like plant, from 1 to a few feet high. Branches striped, slightly scabrous, attenuated and occasionally pungent at the summit. Lenves about 1 hine long, rigid, very acute, flat at the inner side. Pedicels arising solitary from the axis of the leaves, short and stont or almost obliterated, at the base provided with a few minute scale-like bracts, which gradually pass into bracteoles; the latter nearly alike in form, minutely ciliolated, $\frac{1}{2}-\frac{2}{3}$ line long, lightly concurved at the margin. Exterior sepals about $1 \frac{1}{2}$ line long, green; inner sepals $2 \frac{1}{2}-3$ lines long, blunt, faintly reined, harlly shorter than the carina, tapering into a very short unguis. Anterior petal almost glabrons, indistinctly three-lobed. Posterior petals a little longer than the anterior, to which they are half adnate, bearded towards the middle inside. Filaments connate towards the base, free above the middle. Anthers about $\frac{1}{3}$ line long, yellow, narrow- and truncate-ellipsoid. Style glabrous, curved-filiform, cernnous at the apex. Stigma obliqne-terminal, with a basilar gland. Capsule not contracted into a stipes, slightly and obliquely notehed and pointed at the summit, $2 \frac{1}{2}-3$ lines long. Valves traversed by a faint impressed midnerve, coriaceous, prominently margined. Seeds ellipsoid, rather longer than 1 line, short-downy, with no longer hair either at the chalaza or at the hilum. Chalazal appendage downy, livid, compressed, at least half as long as the seed, fornied by the strophiole, which in a nnrrow line is decurrent from the hilun. Testa crust-like, black-brown. Albumen scanty. Cotyledons oral, about four times longer than the radicle.

The only other species of Comesperma, referable to the section Prosthemosperma, occurs sparingly in the sonthern part of East Australia, and is described by Dr. Steetz muder the name C. sphrerocarpum. It differs in herbaceous growtl, hnen'-lanceolate larger leaves on the lower part of the stem, longer pedicels, absence of imbricate bracts, narrower longer already before nnthesis secedent bracteoles, less concare and blunt exterior sepals, an almost orbicular slightly downy capsule, which is neither conspicnously margined nor slightly notched at the apex, and finally in longer hair around the chalaza. In external appearnece, however, C. spinosum (F. M. Fragm. Phyt. Austr. i. 144) stands much ucarer to our plant; it differs in divergent more angular pungent and less furrowed branchlets, in longer pedicels, want of imbricate bracts, less thickly margined and more towards the base attenuated stronger pointed capsules, exapplendiculate seeds clothed with the long silky hair usual amougst congeners. Under the existence of this allied and normal species, and under the consideration that also in C. virgatum and other species the stropliole extends to a chalazal membrine, it becomes unadvisable to separate the section Prosthemosperma from the genus, from which it otherwise might be regarded as distinct as Catacoma. With the latter it shares the terminal appen- 
dage of the seeds. This character seems to point additionally to the relationship of Polygalex to Tremandrex, which in most cases are also provided with a strophiolar terminal appendage, although arising from the chalaza and not from the hilum. In Catacoma, according to Bentham and Steetz, the two lateral minute scale-like petals, which also occur in one species of Comesperma, are always present; the other petals are less highly connate, the capsules carnulent and never distinctly stipitate, whilst the seeds are enveloped in long: soft hair arising from near the hilum solely and not from the testa generally or its margin or apex.

\section{Sect. II. Disepalum, Steetz, in Lehm. Plant. Preiss. ii. 309.}

Leaves conspicuous. Anterior sepals concrete into one, all much shorter than the wings. Capsule attenuated into a stipes. Seeds long-downy. Strophiole obliterated, sometimes extended to the chalaza and thence dilated.

Comesperma polygaloides, $F$. M. in Transact. Plil. Soc. Vict. i. 7.

Dwarf, smooth, erect, herbaccous; leaves oblong- or linear-lanceolate, glaucous, flat, with hardly prominent keel; racemes many-flowered, hardly pedunculate; pedicels shorter than the flower; lateral bracteoles about half as long as the middle one; anterior scpals comnate into one, all much shorter than the purplish wings; petals smooth; carina almost as long as the wings; filaments nearly to the summit diadelphous; capsule narrowly spathulate-cuneate, long attenuated in to the base, much longer than the slightly spreading pedicel; seeds ellipsoid, everywhere long-hairy; strophiole obliterated; cotyledons elliptical.

Scattered over less fertile plains and low ridges of the southern and western parts of the colony; for instance, occurring near Station Peak; near Skipton according to the Rer. W. Whan; on the Avoca and towards the Grampians. In South Australia found at Rivoli Bay and Encounter Bay, in Kangaroo Island according to $\mathrm{Mr}$. Waterhouse, and near Spencer's Gulf according to M[ajor Warburton.

A perennial erect herb, of great external resemblance to certain varieties of Comesperma calymegum and also to Polygala vulgaris, from a few inches to about $I$ foot ligh. Root often tortuose. Stems usually a few from each root, cylindrical, simple or few-branched. Leaves rather copious, flat, 3-8 lines long, $\frac{2}{3}-2$ lines broad, rather acute than blunt, one-nerved, not distinctly veined. Racemes 1-4 inches long, with but a very short distinct peduncle. Pedicels twice or thrice shorter than the expanded flower. Bracteoles very early dropping, narrow- or linear-lanceolate, somewhat cymbiform, long-pointed; the middle one of about 1 line length, nearly twice as long as the lateral bracteoles. Outer sepals roundish-rhomboid, about 1 line long; the anterior either slightly emarginate, or oftener by less complete concrescence of the two, which form it, divided from $\frac{1}{6} \frac{1}{3}$ of its length into two more or less blunt or acute lobes; posterior sepal rather acute ; inner sepals petaloid, pink, tinged with g'reen, seldom white, seemingly never blue, $2 \frac{1}{2}-3$ lines long, obovatespathulate, blunt; the lamina gradually tapering to the unguis, inflexed at the margin. Carinal petal short-trilobed; its galea blunt, slightly cleft in front, about 1 line long, yellow. Laternl petals almost narrow-spathulate, hardly longer than the carina, glabrous, very minutely denticulated, pale towards the base, purple towards the summit. Filaments lighly adnate, monadelphous to above the middle, thence divided into two bundles; the four free parts of the filaments of each bundle even shorter than the anthers, which are only about $\frac{1}{4}$ line long, yellow and truncate-cylindrical. Pollen-grains spherical. Style smooth, curved, compressed, nearly 2 lines long, upwards gradually dilated, at the almost truncate summit slightly bilobed; the upper lobe somewhat pointed; the lower bearing tle jellow spherical stigmatic gland. Capsule little more than 1 line broad, with addition of the stipes about 4 lines long; truncate at the summit and with a small projecting middle tooth, each angle of the summit protracted into a minute triangular membrane. Seeds ellipsoid, about 1 line long; their soft white silky lair arising from every part of the testa, extending long beyond the summit. Albumen rather scanty, surrounding the elliptical cotyledons and the very short radicle. 
This Comesperma is readily distingnished from the South-Western Australian C. virgatum in the not frutescent also less branched and less elated stem, in not prominently keeled thinner and often broader leares, in usually shorter and less subulate middle bracteoles, in pedicels neither when fruit-bearing very divergent, nor nearly as long as the capsule; in not fringed claws of the petals, in narrower capsules, which are gradually contracted into a much longer stipes and never assuming the almost deltoid-cnneate form characteristic of those of $\mathrm{C}$. virgatum; further,. in more copiously comose seeds, which are not provided with a distinctly developed strophiole, whilst the strophiole of $\mathrm{C}$. virgatum ascends from the hilum in a narrow line quite to the chalaza, where it is dilated to a semiorbicular membrane. Thus the transit is clearly established from the section Prosthemosperma to the other divisions of the genus. The long villi of the seeds of $\mathrm{C}$. virgatum rendily secede from the testa and are retained in the cavity of the cell, whilst the short hair remain persistent. The development of the short dorsal spur of the galea takes place not always, and its length is subject to considerable variation, sometimes exceeding $\frac{1}{2}$ line.

PlATE VIII. 1, a flower with its bracteoles and pedicel; 2, front view of a flower laid open; 3, back view of the same; 4 , a pistil; 5 , a bundle of stamens; 6 , pollen-grains; 7 , a capsule; 8 and 0 , rertical dissections of the same; 10 , horizontal section of the same; 11, a seed with the long indument; 12, a seed without its hairy indument; 13, longitudinal section of seed, exhibiting the embryo : all figures variously magnified.

Sect. III. Isocalyx, Steetz, in Lehm. Plant. Preiss. ii. 306.

Anterior sepals free, not much shorter than the wings. Capsule attenuated into a long stipes. Seeds long-downy.

Comesperma calymega, Labill. Nov. Holl. Plant. Specim. ii. 23, t. 162; Steetz, in Lehm. Plant. Preiss. ii. 306 ; Schlechtend. in Linnea, xx.635; J. Hook. Fl. Tasm. i. 32; C. isocalyx, Spreng. Syst. Veget. iii. 172.

Erect, herbaeeous; stems cylindrical; leaves flat, lanceolate or linear-lanceolate or the lowrest oborate; racemes densely many-flowered, pedunculate, usually blue; pedicels shorter than the flowers; lateral bracteoles hardly half as long as the semilanceolate middle one; anterior sepals disconnected, oblong-lanceo. late, all more than half as long as the spathulate-ovate vings; petals glabrous; filaments to about the middle monadelphous, thence free; npper lobe of the style narrow, bearded; capsules spathulate-cuneate, angular at the summit, long attenuated into the base, much longer than the pedicel; secds broad-ovate, long lanuginose-comose with villi arising from every part of the testa; strophiole obliterated; cotyledons broadoval.

On busly barren ridges and mountains and on arid heathy plains in many parts of the colony; for instance, at Port Phillip, the Wimmera, Wilson's Promontory, Port Albert and in sereral intermediate localities. Beyond Victoria known from Tasmania, also from Kangaroo Island, St. Vincent's Gulf, the Barossa Ranges, Bugle Ranges, Mount Lofty Ranges and other spots in Sonth Australia.

Root flexuose, descending, livid, distantly fibrilliferous, with a somcwhat spongy integument, sending forth several or many stems. The latter from a few inches to about $\mathbf{1}$ foot long, cylindrical, upwards somewhat angular, simple or few-branched, fincly streaked, smooth or towards the base finely subpapillose-downy. Leares of thickly consistence, glabrons, ncither distinctly nerved nor veined, varying in length mostly from 4-10 lines; the radical leaves somewhat rosulate, early lost; the lower stem-leares larger than the upper ones, which arc gradually decreasing in size, sometimes very narrow, but hardly even reduced to minute bract-like scales. Racemes 1 or a few, terminal, at first dense spikc-like and about 1 inch long, after florescence lengthened to $2-4$ inches. Pedicels $1-1 \frac{1}{2}$ line long. Niiddle bracteole cymbiform-lanceolate, about 1 line long, of fully twice the length of the narrow-lanceolate lateral bracteoles, often blue at the back, always white at the margin. Posterior sepal ovate; anterior ones oblong, all about $1 \frac{1}{2}$ line long; sessile with 
truncate base, glabrous, pale, at the back and towards the summit usually blue. Wings approximately 2 lines long; entirely cyan-bluc, rarely rose-red, beautifully reined, longer than the cariua. Posterior petals falcate-lanceolate, to the length of nearly I line free, upwards dark-blue, downward white, somewhat longer than the carina. Galen of the latter yellow, biplicate and this short-trilobed. Anthers yellow; about $\frac{1}{4}$ line

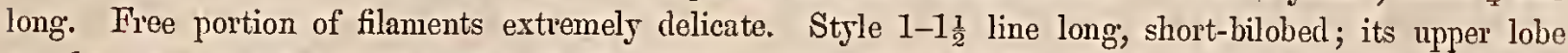
membranous; the lower one thick and stigmatose. Capsule with addition of its stalk-like portion 3-4 lines long, apiculate in the terminal oblique emarginature, at the apical angles produced into a narrow rather prominent than obtuse wing. Seed-hair, as noted already by Dr. Hooker, singularly curly, white, copious, extremely tender, not readily seceding, several times longer than the seed. Seed about $\frac{3}{4}$ line long. Albunen almost none. Cotyledons about $\frac{1}{2}$ line long; plane-convex, many tiues longer than the very minute radicle.

C. strictum, which occurs in S.W. Anstralia and has been traced nortluward by Messrs. Oldfield and Walcott as far as the Murchison River, seems not to have sufficient claim for specific distinction from C. calymega.

Comesperma defollatum.-C. nudiusculnu, Stectz, in Lchn. Pl. Preiss. ii. 308.

Frect or ascendent, herbaccous; stems extremely slender, furrowed, angular, leafless or with few lanccolate- or subulate-linear leaves; racemes remotely many-flowered, pedunculate, usially blue; pedicels shorter than the flowers; lateral bracteoles more than half as long as the ovate-lanceolate middle one; cxterior sepals oblong, disconnected, exceeding half the length of the spathulate-elliptical wings; corolla glabrous ; filaments to about the middle monadelphous, thence fiee; upper lobe of the style broad, bearded; capsule spathulate, rounded at the summit, attenuated into a very long stipes, much longer than the pedicel; seeds broad-ovate, comose with long straight villi arising from uear the chalazal extremity; cotyledons orbicular-ovate.

Scattered orel sandy-heathy ridges fiom Port Phillip to the Broadribb River. In Tasmania found near Southport; in New South Wales at Mlawarra by Mrr. Shepherd, at the Clarence River by Dr. Beckler.

A wiry herb, more slender than any of its congeners. Root tortuons, descending, externally upwards somewhat spongy. Stems simple or few-branched, usually varying in height between 1 and 2 feet, glabrous, by the early fall or imperfect development of the leaves wholly or partially leafless. Leaves remote, acute, 1-1 line broad; the lower ones fiom a few to about 9 lines long, the upper ones often reduced to the length of 2 lines. Racemes finally fiom 2-4 inches long. Niddle bracteole about 1 line long, more or less acute or blunt, somewhat cymbiform. Exterior sepals concurved, $1 \frac{1}{2}-2$ lines long, glabrous, membranous, generally tiuged with blue. Wings tender, about $2 \frac{1}{2}$ lines long, ascendent, glabrous, longer than the carina. Posterior petals also conspicuously longer than the carina, falcate-lanceolate. Galea biplicate-trilobed. Anthers about $\frac{1}{4}$ line long. Filaments extremely fine. Style about $1_{\frac{1}{3}}$ line long; its upper lobe membranous, concave, formiug almost an indusium to the lower recurred stigmatic lobe. Capsule $3 \frac{1}{2}-5$ lines long, lined with but a very narrow border at the summit. Seeds about $\frac{3}{4}$ line long, clothed with short mostly appressed hair except towards the summit, from whence descend copious extremely soft white hair of a few lines length. Albumen very scantily developed. Radicle exceedingly minute.

The dingnosis points ont the main notes which distinguish C. defoliatum from C. calymega. The habit is widely different, imitating according to Dr. Steetz that of C. ramosissimum, in which species probably the real C. nudiusculum is to be sought, since De Candolle (Prodr. i. 334) assigns King George's Sound as the native locality to that species. Our plant agrees fully with the description of his $\mathrm{C}$. nudiusculum offered by Dr. Steetz from Bauer's specimens, which were collected promiscuously with C. sphærocarpum and doubtless near Port Jackson. Comparing the description of C. ramosissimum we find, that this species differs fiom C. defoliatum in cylindrical stems, more numerous leaves, anterior connate sepals, blunt and slightly downy posterior petals, a beardless upper lobe of the style, and short-stalked roundish along the whole margin narnowly winged capsules. 


\section{Sect. IV. Eucomespernia, Steetz, in Lehm. Plant. Preiss. ii. 295.}

Leaves conspicuous. Anterior sepals free, much shorter than the wings. Capsule attenuated into a long stipes. Seeds long-downy.

Comesperma ericinum, Cand. Prodr. i. 334; J. Hook. Flor. Tasm. i. 32; C. cordifolium, All. Cunn. in Field's New South Wales, 337; C. linarifolium, All. Cunn. in Steetz Plant. Preiss. ii. 297; C. latifolium, Steetz, T. e. 295 ; C. acutifolinn, Steetz, l.c. 296.

Frutescent, erect; leaves numerons, oblong- or linear-lanceolate, rarely ovate, usually mucronulate, reflexed or revolute at the margin; racemes many-flowered; pedicels about as long as the flowers; lateral bracteoles half or less than half as long as the semilanceolate middle one; anterior sepals free, all much shorter than the generally pink broad-ovate wings; petals glabrous; filaments nearly to the summit diadelphous; capsule truncate at the apex, long-stipate; seeds brond-ellipsoid, long-comose ; strophiole protractel? into a short chalazal appendage; cotyledons elliptical.

On heathy tracts as well of the lowlands as mountains, not rare in the southern and eastern parts of the Colony of Victoria; found also in Tasmania, and northward to lat. $26^{\circ} \mathrm{S}$. in East Australin.

Stems from 1-3 feet high, downy or more frequently glabrous, usually branched towards the summit, cylindrical. Branches upwards angular. Leaves short-stalked or almost sessile, of rather thick consistence, from $2-12$ lines long, from $\frac{3}{4}-1 \frac{1}{4}$ line broad, more or less patent, terminated by a short often recurved mucro, sliglitly keeled by the beneath prominent midrib; those nearest to the flowers often small and orate. Racemes forming usually at the sumnit of the branches a corymbose panicle, comparatively short, hardly pedunculate. Bracteoles caducous; the middle one about 1 line long; the lateral ones lonceolate-subulate, $\frac{1}{3}-\frac{1}{2}$ line long'; all semilanceolate, acuminate. Exterior sepals pale-colored, membranous, glabrous, deltoidsemiovate, about $\frac{3}{4}$ line long. Inner sepals broad-obovate, hardly unguiculate, about 3 lines long, excelling a little the length of the corolla. Carina with two short folds at the galea and thins trilobulate. Posterior petals nearly as long as the carina, oblique-oblong, curved. Bundles of filaments only at the very summit divided into their constituent parts. Anthers yellow, truncate-ellipsoid, about $\frac{1}{4}$ line long. Style membranous, smooth, compressed, about 2 lines long, gently curved, upwards dilated, at the base attennated, truncate and slightly emarginate at the inclinate summit, at the termination of the upper edge swollen into a yellow stigmatic gland. Capsule 3-5 lines long, obcordate-spatlulate, upwards surrounded with a rery narrow border; the angles of the summit more or less apiculate. Seeds about 1 line long. Testa almost black, downy with short persistent hair and comose with long straight tender separable villi, which attain three or four times the length of the seed. Strophiole extended along the raphe at the inner edge of the seed in a narrow line to the chalaza, whence it is expanded into a minute semiovate or semiorbicular glabrous appendage. Albumen exceedingly scanty. Cotyledons slightly convex outward, narrow elliptical, about four times as long as the radicle.

Comesperma patentifolium seems only a variety with very spreading and towards the base remarkably dilated leaves.

Comesperma retusum, Labill. Nov. Holl. Plant. Specim. ii. 22, t. 160; Steetz, in Lelim. Plant. Preiss. ii. 295; J. Hook. Fl. Tasm. i. 32.

Shrubby, erect, tall ; leaves numerous, oblong or lanceolate- or oval-oblong, blunt, flat or inflexed at the margin; racemes many-flowered, corymbose; pedicels about as long as the flowers; lateral bracteoles half or more than half as long as the cymbiform-semilanceolate milldle one; anterior sepals fiec, all conspircuously shorter than the obovate generally purple wings; petals glabrous; filaments nearly to the summit diadelphous; capsule long-stipitate, short-bilobed at the sumnit; seeds ellipsoid-ovate, long-comose; strophiole obliterated; cotyledons elliptical. 
Abundant in the Sphagnum moors and along the rivulets and torrents of the Australian Alps, at heights from 4000-6000 feet. Frequent in Tasmania; found also on the Blne Mlountains of New South Wales.

A handsome glabrous shrub, varying in height from a ferv to 8 feet. Leaves as well as branches often opaque and pruinose; the former usually between 3 and 6 lines long, 1-2 lines broad, usually roundish-blunt, sometimes a little acute or even apiculate, the midnerve not rarely almost concealed. Racemes usually short. Middle bracteole about 1 line long, more or less blunt or acute; all semilanceolate. Onter sepals deltoidsemiovate, about 1 line long. Wings, petals and genitalia very similar to those of C. ericifolimn. Capsule t-6 lines long, upwards rather more suddenly dilated than those of most other species, the summit apiculate and retuse (hence the specific name), each terminal angle protracted into a little lobe with decurrent border. Seeds about 1 line long, short-downy and beside clothed especially at the inargin and summit with the usual long soft straight villi. Albumen exceedingly scanty. Cotyledons elliptical, four times longer than the radicle.

Comesperma silvestre, from Mount Pluto, from the Burnett Ranges and from New England, which occurs as well glabrous as short-downy, seems not specifically distinct from the southern alpine form, except in slightly pointed leaves. C. Drummondi, which extends in S.W. Avistralia from the Stirling: Ranges to E. Mount Barren, differs from C. retusum in slightly scabrid stems, branches and leaves, in a narrower. capsule, which tapers gradually into a shorter stipes, in narrow-ellipsoid seeds, with shorter villi. Its strophiole is not developed.

Comesperma volubile, Latill. Nov. Holl. Plant. Specim. ii. 24, t. 163; J. Hook. Flor. Tasm. i. p. 31 ; C. gracile, Paxt. Magaz. v. 145.

Suffruticose, climbing; stems and branches tortnous, furrowed; leaves elliptical- or linear-lanceolate or linear, distant, flat, deciduous; racemes axillary and lateral, pedunculate; pedicels remote, shorter than the flowers; lateral bracteoles nore than half as long as the ovate- or lanceolate-navicular middle one; anterior. sepals free, all much shorter than the generally blue cordate-orbicular unguiculate wing's; carina distinctly three-lobed; posterior petals blunt, ciliated; filaments to about the iniddle monadelphous, thence fiee; style geniculate; capsule oblong-cuneatc, rounded or slightly truneate at the summit, gradually tapering into the elongated stipes; seeds narrow-ellipsoid, glabrons at the sides; long-rillose at the margin; strophiole obliterated; cotyledons narrow-elliptical.

In forest- and scrub-country widely distributed not only over the Colony of Victoria, but also over many other tracts of extratropical Australia; frequent in Tasmania.

A truly elegant plant, climbing to a considerable height, glabrous in all parts, intricately and often spirally ramified. Leares often but sparingly developed, slort- or conspicuous-petiolate, flat, from a few lines to $1 \frac{1}{2}$ inch long, 1-4 lines broad, one-nerved; the lateral nerves and veins often obscured. Racemes often in great profusion developed, with addition of their peduncle generally from 2-4 inches long. Bracteoles less caducous than in most other species; the middle one nearly 1 line long. Anterior sepals semiovatedeltoid, about 1 line long, somewhat smaller than the orbicular-obovate posterior one, all incurved at the margin. Wings $2 \frac{1}{2}-4$ lines long; their unguis measuring nearly 1 line, linear-cuneate; the lamina finely veined, rarely purple. Lateral petals 2-3 lines long, pale-yellow, not beyond the middle adnate to the carina, oblique- and narrow-oblong. Carina at the galea saccate-gibbose, cyan-blue, rarely rose-colored, on each side of the latter prodncing a tooth-like semilanceolate free lobe of about $\frac{1}{2}$ line lengtl. Style about 2 lines long, less dilated and much stronger bent than in most other species, stigmatose at the inner angle of the truncate apex. Capsule 6-7 lines long, at the upper portion $1 \frac{1}{2}$ line broad, about three times longer than the pedicel. Seeds approximately $1 \frac{1}{2}$ line long, slightly rough but not costulate. Albumen hardly developed. Cotyledons narrow elliptical, slightly convex ontward, about four times as long and twice as broad as the radicle. 
Comesperma ciliatum of S.W. Australia is nearly allied to our species, but has very small and ciliated leaves, shorter capsules and seeds which are regularly and closely wrinkled near the edges, whilst the middle ridges of the testa are even. The testa is equally as in C. volubile destitute of short hair and villose at the margin only. C. integerrimum, also from S.W. Australia, the only other allied plant, will at once be recognized by its yellow flowers.

\section{IX.-GUTTIFERA.}

Calyx in præflorescence imbricate. Corolla involute or imbricate in bud. Sta. mens more frequently indefinite than-definite, often concrete into bundles. Placentation central, rarely sutural. Albumen usually wanting. Embryo mostly straight.

\section{ORDER HYPERICINEAૈ。 \\ Juss. Gen. 254.}

Flowers bisexual. Calyx consisting of 5, rarely 4, sepals or lobes, two of which exterior, all persistent, rarely calyptrate-colerent and deciduous. Petals 5, rarely 4, alternate with the sepals, equal, convolute or involute in bud. Stamens indefinite, united into 3 or 5 bundles, rarely monadelphous or free. Anthers dorsifixed, bicelled, opening with introrse longitudinal deliscence. Ovarium perfectly or incompletely 3-5-celled, very seldom 6-12-cellcd. Orules indcfinite, rarely definite. Styles 3-5, rarely $6-12$, free or imperfectly connate. Stigmas free. Truit capsular, dry or fleshy, completely or imperfectly 3-5-celled, rarely 6-12-celled, opening by septicidal rarely by loculicidal dehiscence. Seeds without strophiole. Placentæ central or attached to the edge of the septa or of the valves. Albumen none or very scanty. Embryo straight, seldom curved. Radicle next to the hilum.

Herbs, shrubs or trees, not seldom resinous, dispersed orer the temperate and warmer parts of the globe, more frequent in the temperate parts of the northern hemisphere and within the tropics of America, than in tropical Asia or Africa, rery rare in Australia. Stipules wanting. Leaves usually opposite, sometimes verticillate, always simple, often dotted with pellucid glands. Inflorescence prevailingly cymose or paniculate. Petals unequilatcral, usually yellow. Secds almost always numerous and minute, sometimes winged. Septa formed by the inflexcd valves. Choisy, Prodr. Iypericin. 1821; Lindl. Veg. Kingd. ed. iii. 405; Spach, in Suites à Buffon, v. 335, and in Nouv. Annal. Scienc. Nut. 349 ; Payer, Trcité d'Organog. comp. 1-8, tab. i.

This order, although standing in ncarcst relationship to Clusiacex, may also in many regards be compared to Linex. The Tasmanian Eucryphia is restricted to that island. Besides this and Hypericum no other genera are known from Australia. 


\section{HYPERICUM.}

Tournef. Instit. 128. - St. John's Wort.

Sepals 5 , very seldom 4 , free or at the base united, persistent. Petals 5 , rarely 4 , usually inequilateral. Stamens many, more or less connate into bundles, seldom free or few. Hypogynous scales wanting. Ovules numerous, arranged in two or more rows, seldom few. Styles 3-5, rarely 2 or 6 , filiform, entirely or upwards free. Capsule one-celled, with 3-5 parietal placentæ, or 3-5-celled by the placentæ meeting in the axis, very rarely 2 - or 6 -celled. Seeds many, rarely few, very rarely one in each cell. Testa scrobiculate or reticulate or furrowed, closely surrounding the nucleus or winglike expanded. Albumen none. Embryo cylindrical. Cotyledons shorter than the radicle.

Herbs, half-shrubs or shrubs, occurring in almost every part of the globe, especially numerous in the temperate regions of the northern hemisphere, some extending to alpine elevations although none seemingly to the polar regions. Leaves herbaceous or coriaceous, sessile or petiolate, opposite or rarely verticillate, entire or slightly toothed, often dotted with pellucid glands. Inflorescence varied. Sepals entire or at the margin glandulous or fimbriate. Petals yellow, more or less unguiculate. Stamens persistent or deciduous. Styles short or elongated. Divisions of the capsule, when carpellar by complete development of the septa, splitting along the inner edge, rarely opening only by a foramen. Valves sometimes nerved or papillose. Form of placentæ very varied.-Endl.Gen. 1032.

ב马ypericum gramineum, Forst. Prodr. 281 ; Labill. Sert.Austro-Caledon. 53, t. 53; J. Hook. Fl. Nov. Zeel. i. 36 ; Fl. Tasm. i. 53; H. Japonic1m, Thunb. Fl. Japon. 295, t. 31; Royle, Mlustr. 24; J. Hook. Fl. Tasm. i. 53; H. involutım, Choisy, Prodr. Hyp. 50; H. pusillum, Choisy, l. c.; H. pedicellare, Endl. in Enum. Plant. Hueg. p. 12; Aseyrum involutum, Labill. Nov. Holl. Plant. Specion. ii. 32, t. 174; A. pusillum, Lab. I. c. ii. 33, t. 175; Brathys Billardierii, Spach, in Annal. des Scienc. Nat. ser. ii. v. 367.

Glabrous; stem herbaceous, quadrangular; leaves sessile, verging from oval to oblong and oblonglanceolate, entire, pellucidly dotted; inflorescence leafy, more or less cymose or racemose or paniculate, or with a few or a single terminal flowers; sepals lanceolate, acute, entire, nearly equal, always appressed; petals entire; filaments persistent, almost free; styles 3 , short, disconnected; capsule oval-ellipsoid, pointed, smooth, one-celled, three-valved; placenta narrov-linear, sutural; seeds numerous, fulvous, oval-ellipsoid; testa clathrate.

In pasture land as well as in barren localities, common throughout the colony, ascending to the Australian Alps; further of rather general distribntion over the other parts of the Australian Continent, over Tasmania, New Zealand, New Caledonia, Southern and Eastern Asia.

An erect, ascendent or half-procumbent herb, attaining a height of about 2 feet, usually, however, of lower growth, sometimes reduced to extreme dwarfness. Root perennial, more or less ramified and fibrilliferous, often creeping. Stems usually below simple, upwards dichotomously branched, sometimes, however, quite simple, in other instances ramified from the base and less regularly dichotomous. Leaves opposite, opaq1e, flat or at the margin reflexed, often somewhat clasping at the base; the lower ones generally more closely approximated and shorter than the upper ones; in luxuriant specimens attaining rather more than 1 inch length and nearly $\frac{1}{2}$ inch width; in the small variety only from $1 \frac{1}{2}$ to a few lines long, never very acute, oftener blunt; the midnerve beneath slightly prominent; the veins obscured. Cyme simple or compound or rednced to a few dispersed flowers, or the pedicels partially arranged alternately along the branches into leafy racemes. Pedicels very variable in length, sometimes almost obliterated, usually longer than the floral leaf, and from a few lines to about 1 inch long, slender filiform. Sepals broad- or narrow-lanceolate, $1 \frac{1}{2}-4$ lines long; nerved. Petals orange- or deep-yellow, extremely tender, oblique-obovate, not mnch longer than 
the calyx or nearly twice as long, copiously veined, only under bright sunlight fully expanding, otherwise rolled in at the margin and collapsed, never black-dotted. Stamens varying in number from about 8-40. Filaments very tender, capillary, shorter than the corolla, free or slightly and irregularly connate. Anthers roundish, didymous, yellow, dorsifixed, $\frac{1}{8}-\frac{1}{6}$ line long, terminated with an exceedingly minute yellow gland. Pollen-grains ellipsoid, smootl, bursting lengthwise. Styles finely setaceous, yellow, divergent, but not curved, $\frac{1}{2}-1$ line long. Stigma minute, depressed-globose. Capsule in some instances hardly longer than the calyx, in others approaching to twice the length. Valves thus 2-5 lines long, finally seceding to the

base. Funicles extremely short. Seeds $\frac{1}{5}-\frac{1}{3}$ line long; almost straight, very blunt, with more prominent longitudinal streaks and finer transverse lines.

It seems that the South African H. Lalandi is very nearly allied to our plant. H. humifusum, the British trailing St. John's Wort, which has great resemblance to the dwarf forms of H. gramineum, may be recognized by its more compressed stems, by blunt sepals, which as well as the leaves are somewhat blackdotted, and in rather larger almost black seeds.

\section{ORDER ELATINE正.}

Cambessedes, in Mém. du Mruséum d’ Hist. Nat. xviii. 225.

Flowers bisexual, symmetrieal. Segments of the calyx 2-5, persistent, alternate with an usually equal number of petals; both imbrieate in bud. Stamens definite, free. Filaments filiform. Anthers introrse, dorsifixed, two-celled; the cells turgid, bursting with a longitudinal fissure. Ovary 2-5-celled. Ovules many in each cell, affixed to the axillary placentr. Styles 2-5, free, short, persistent. Stigmas simple. Capsule 2-5-celled, opening by dehiscence or rupture of the septa; its central column placentiferous and persistent. Seeds many, often eurved. Albumen none. Radicle longer than the cotyledons, next to the hilum.

Herbs or rarely suffruticose plants, dispersed in a seanty number of species orer all parts of the globe except the arctic regions, generally growing in water or occasionally inundated places. Leaves stipulate, opposite or rarely vcrticillate, simple. Flowers small, axillary, solitary or glomerate-cymose. Petals usually white or pink. Endl. Gen. 1033 ; Seubert, in Walp. Repert. Botan. Syst. i. 283, and in Nov. Act. Academ. Cees. Leop. Carol. Natur. Cur. xxi. i. 35-37; Payer, Organog. compar. 369370, t. 109, figs. 1-10.

If the genus Tetradielis is referable to this order then the limitation of Elatinex, as adopted here, will have to undergo eonsiderable cxpansion.

This order is evidently very closely allied to Hypericinex, a relationship confirmed by the very great resemblance of the seeds of Elatinc with those of Hypericum. From Caryophyllex they are much more distinct. Australia, as far as linown, possesses six species of Elatine, four tropieal and one extratropieal species bclonging to the section Bergia, and one extratropical and subtropical spceies belonging to the original genus of Elatine. 
ELATINE.

Limn. Gen. Plant. 502.-Waterwort.

Segments of the calyx 2-5. Petals 2-5, short unguiculate. Stamens either as many as the petals and alternate with them or twice as many and the inner ones opposite to the petals. Styles 2-5. Capsule nearly globose; its dissepiments formed by the introflexed valves, meeting in the axis. Seeds usually cylindrical, truncate at one extremity, rounded-blunt at the other, rarely ellipsoid. Testa clathrate or very seldom smootl.

A cosmopolitan genus of small and insignificant usually annual plants, lax and succulent when growing in water, more hard and rigid when growing in dry localities. Leaves usually flat, entire or toothed. Flowers sessile or short-stalked, seldom on long pedicels.-Fischer \& Meyer, in Linnaca, x. 69; Wight \& Arnott, Prodr. Flor. Penins. Ind. Orient. i. 41.

\section{Sect. I. HYDRopIPER.}

Glabrous lax water-plants, almost confined to extratropical countries. Leaves membranous, entire. Flowers ebracteolate, always solitary in the axils of the leaves. Capsule bursting with septifragal dehiscence.

Elatine minima, Fischer \& MLeyer, in Bullct. de la Soc. Impér. des Natur. de Mosc. and in Linnea, x. 69 ; Seubert, in Nov. Act. Acad. Caesar. Leop. Carol. Cur. Natur. xxi. 41, t. 2, figs. 9 \& 10; E. Americana, Amott, in Edinb. Journ. for Nat. and Geogr. Sciences, i.430; Gray \& Sprag. Gen. Flor. Amer. Bor. Mllustr. t. 95; Torrey, Flora of New York, i. 91; J. Hook. Flor. Nov.Zeel. i. 27; Flor. Tasm. i. 47; E. gratioloides, All. Cunn. in Annal. Nat. Hist. iv. 26 ; Peplis Americana, Pursh. Flor. Amer. Septentr. i. 238; Crypta minima, Nutt. in Journ. Acad. Philad. i. 117, t. 6, f. 1 .

Glabrous; stipules deltoid, denticulated; leaves membranous, opposite, subsessile, entire, flat, spathulate- or oblong- or orbicular-obovate, rarely linear-oblong or elongate-lanceolate; flowers sessile, alternate, very small; segments of the calyx oval, entire, as well as the roundish petals, the stamens, styles and valves of the capsule 2-4; dissepiments of the capsule evanescent; sccds slightly curved, cylindrical; testa clathrate.

On muddy places and on the margins of still fresh waters, sparingly distributed over our colony; extending over the greater part of extratropical Australia, having been found by the author of this work as far north as Moreton Bay and Lake Torrens, and by Mr. A. Oldfield on the Murchison River; found also in New Zealand and Tasmania and in North America, probably hitlerto overlooked in other parts of the globe.

Stems cylindrical, lax, fistulose, procumbent or ascendent or when submersed erect, attaining thie length of 8 inches, usually but a few inches long, sometimes exceedingly short, arising from a creeping rhizome, radicant with long capillary fibres at the lower nodes. Stipules about $\frac{1}{2}$ line long, almost delta-shaped, membranous, slightly toothed. Leaves usually a few lines long and rounded-blunt, in some instances fully 1 inch long, and more tapering to a retuse apex, varying in breadth from $\frac{1}{2}-3$ lines, distantly and tenderly penninerred and veined. Flowers very minute, alternate. Sepals greenish. Petals pink, extremely tender and evanescent, usually three in Australian specimens, but sometimes reduced to two according to observations instituted by American botanists, whilst the isomeral symmetry of the flower then would necessitate the formation of the same number of stamens, stigmas, cells of ovary and valves of capsule, although not invariably the same number of divisions of the calyx. Stamens short, opposite to the lobes of the calyx, the stigmas and the valves of the fruit. Anthers and stigmas very minute. Pollen-grains ellipsoid, smooth, bursting lengthwise. Capsule $\frac{3-1}{4}-1$ line in diameter, round, very depressed on the vertex, oftener 3 - than 4 -ralved; the valves readily separable and tender-membranous; the septa more or less destroyed during the 
advancing growth of the fruit, the latter thus at maturity one-celled. Seeds counted between 15 and 80 in Australian specimens, pale-brown or livid, shining, $\frac{1}{4}-\frac{1}{3}$ he long, when fewer in number a little larger in size.

The proportion of length of petals and calyx and the shape of the columna, which in the specimens examined on this occasion could not be absolutely defined, may, according to the beautiful figures published by Dr. Seubert in his monograph, adrantageously be drawn into the diagnoses.

R. Brown (Gen. Remarks, p. 590) refers our species doubtfully to E. Hydropiper. From the closely allied E. triandra it seems merely to differ in not somewhat crenulated leaves and possibly in not having the sepals reduced to two, whilst the flower is otherwise also trimerous.

\section{Sect. II. BERGIA.}

Rigidulous land-plants, often downy, almost confined to tropical and subtropical countries, Leaves herbaceous, usually denticulated. Flowers solitary in the axis of the leaves or cymoseglomerate or spuriously verticillate and bracteolate. Capsule bursting with septicidal dehiscence.

Elatine tripetala.-Bergia tripetala, F. M. in Tronsact. Phil. Inst. Vict. ii. 66.

Stems and branches procumbent, glandless-downy; stipules narrow-lanceolate, acuminate, incisedfimbriolate; leares chartaceous, glabrous, opposite, subsessile, lanceolate-ovate, flat, minutely and distantly serrulated; pedicels much shorter than the leaves; flowers trimerous, very small, spuriously verticillate, seldom tetramerous; segments of the calyx cymbiform-lanceolate, partially serrated; petals obovate; capsule 3- rarely 4-celled; seeds ellipsoid-ovate; testa clathrate.

On shallow water-pools (clay-pans) subject to evaporation, near the confluence of the rivers Darling and Murray.

A seemingly annual plant. Stems rigid, several from the root, distantly ramified, from a few to sereral inclies long, clothed with crisp white articulate hair. Leaves $2-5$ lines long, slightly acute, flat, on both pages equally glaucous-green. Stipules about 1 line long. Spurious rerticils many-flowered. Pedicels as long as the flowers or shorter, glabrous. Calyx smooth; its segments about $\underset{3}{2}$ line long, green at the back, white at the margiu. Petals white or pink, about as long as the calyx. Filaments linear-subulate, generally somewhat shorter than the calyx. Anthers didynous. Stigmas 3, rarely 4, very short, club-shaped. Capsule about one-third longer than the calyx; its septa very thin. Seeds ellipsoid- or renate-ovate, brown, shining, about $\frac{1}{6}$ line long.

This rare plant las as yet not been found anywhere but in the locality indicated. For future inrestigation it is left to ascertain, whether besides erect growth and the glandular pubescence of the stems and branches any other differential notes can be pointed out, by which the Indian B. trimera (Fisch. \& Mey. in Linnæa, x. 74; B. ammannioides, Hook. Botan. Miscell. 93, suppl. tab. xxviii.; Wight, Illustrat. of Ind. Bot. t. xxv.) could be specifically distinguished, a question which cannot satisfactorily be solved at present, the only small specimen of E. tripetala in our herbarium having been sacrificed in the analysis, which we owe to the skilful pencil of the late lamented Dr. Ludwig Becker. The specimens of the also closely allied E. ammannioides from Arnhem's Land (conf. F. M. Fragm. Phyt.-Austr. ii. 47) are all erect, the petals narrow-lanccolate, and the capsules more deeply impressed at the sutures. In transferring with other Bergire also B. tripetala to Elatine, it is nnecessary to alter the specific name, althongl preoccupied by Sir James Smith in the English Flora, ii. 243 , since the British plant was previously described as E. hexandra by De Candolle in the Flore Française, v. 609.

Plate IX. 1, front view of flower; 2 , back view of flower; 3 , side view of a flower; 4 , back view of a tetramerous flower; 5 , petal; 6 and 7 , stamens; 8 , pollen-grains; 9 , seed; 10 , longitudinal section of seed, showing the embryo; 11, stipules; 12 , portion of a branch, exhibiting the articulate hair; 13 , apex of leaf: all figures mainified in a lesser or greater legree. 


\section{X.-CARYOPHYLLIN $\approx$.}

Calyx in præflorescence imbricate. Corolla contorted in bud, sometimes wanting. Stamens usually definite and free. Placentæ central. Embryo cylindrical, peripherical, more or less surrounding the amylaceous albumen.

\section{ORDER PHYTOLACCEA.}

\section{R. Br. in Append. to Tuckey's Congo Expedition, p. 35.}

Flowers uni- or bisexual, usually symmetrical. Calyx divided into 4 or 5 sepals or lobes, or.shortly 4-8-toothed, persistent; the sepals or lobes imbricate in bud. Petals generally wanting, when developed free and unguiculate. Stamens as many as divisions of the calyx and atternate with them or more mumerous, free or at the base united. Anthers two-celled, bursting longitudinally with introrse dehiscence. Staminodia wanting. Ovary free, simplc or compound, usually with a single ovule in each cell or carpel. Styles continuous to the inner angle of the carpels, usually introrse-stigmatose. Fruit consisting of one or more free or connate or around a central column adnate indehiscent or bivalved carpels. Pericarp membranous, chartaceous, nucamentaceous or baccate. Seeds erect, solitary. 'Testa membranous or crustaceous. Albumen usually farinaceous, central or unilateral, seldom peripherical or fleshy or wanting. Embryo annular or arcuate, peripherical, seldom straight. Cotyledons foliaceous and convolute or flat, or semiterete. Radicle inferior.

Herbaceous, less frequently shrubby, rarely arborescent plants, rather numerous in the warmcr parts of America and in South Africa, much fewer in other parts of the globe, none penetrating to colder latitudes. Leaves alternate, very seldom almost opposite, never vaginate, always simple, entire or minutely denticulated, sometimes pellucidly dotted, with or without stipules. Flowers prevailingly racemose, spicate or glomerate, usually three-bracteolate, not showy. Calyx sometimes petaloid.Endl.Gen.975; Lindl.Veg. Kingd. edit. iii. p. 508 ; Moquin-Tandon, in Cand. Prodr. xiii. i. 2 ; Payer, Traité d'Organog. comparée, 301, pl. 63.

Had not the general divisions of Candolle's system been adhered to in this work, it would have been desirable to consociate to this order Portulaceæ, Salsolaceæ and Amaranthaceæ, with all of which the Phytolaccere are brought in close contact by manifold characters and especially by the peripheral embryo and amylaceous albumen. The Australian genera hitherto divulged are Gyrostemon, Codonocarpus, Cyclotheca, Didymotheca, Tersonia, Monococcos and perhaps Stylobasium. These with exception 
of Stylobasium and of Monococcos, which points towards Riviniex, establish a transit to Malvaceæ. Phytolacca octandra can here only be regarded as an adventitious plant.

\section{DIDYMOTHECA.}

J. Hook. in London Journ. of Bot. vi. 278.

Flowers diœcious. Calyx 4-8-toothed, persistent. Corolla wanting. MIale flowers: Anthers 6-17, uniseriate, almost sessile, basifixed, arranged around rudimentary pistils. Female flowers: Ovaries 2-8, adnate to the columella, otherwise free or mutually connate, with a single ascendent ovule affixed at the inner angle of each. Styles 2-8, continuous to the fruit-axis, subulate, persistent, inward stigmatose. Carpels 2-8, compressed, bivalved, free or partially comnate, bursting along the back, adnate to a central persistent column. Seeds ascendant, wrinkled, strophiolate. Testa crustaceous. Albumen very scanty, fleshy or undeveloped. Embryo uncinate-annular, cylindrical. Radicle hardly longer than the cotyledons.

Suffruticose or frutescent glabrous plants, peculiar to the Australian continent and to Tasmania. Leaves scattered, fleshy, linear or semicylindrical. Flowers of both sexes axillary, solitary, shortpedicellate. Valves of the fruit more or less coriaceous.-MLoq. in Cand. Prodr. xiii. 1,36; J. Hook, Fl. Tasm. i. 309 ; Cyclotheca, Moq. l. c. 37.

The exclusively West Australian genus Gyrostemon, contrasted with Didymotheca, is chiefly characterized by pluriseriate stamens, and more numerous stronger compressed and membranous carpels. The only genuine species, G. ramulosus, has longer pedicels than the species of Didymotheca But in its pluriseriate stamens Gyrostemon seems to differ from all other genera of the Gyromerous group, since also Tersonia, according to our specimens gathered in as well the northern as southern parts of Western Australia, shows only single circles of anthers. The male flowers of Tersonia, as described by Moquin, belong probably to Gyrostemon ramulosus, both plants growing promiscuously and exhibiting considerable external resemblance.

Didymotheca pleiococca, F. Mr. Fragm. Phyt. Aust. i. 202 (adnot.); Cyclotheca Australis, Moq. in Cand. Prodr. xiii. i. 37; Gyrostemon ramulosus, Schlechtend. Linnaea, xx. 632.

Branches hardly angular; calyx almost flat expanded, with more than four teeth; styles and carpels three or more; valves partially connate towards the axis.

In the MIallee scrub from the Wimmera through the north-western part of this colony, growing specially on sandhills; thence extending to St. Vincent's Gulf, Kangaroo Island, Spencer's Gulf; occurring also, according to Moqquin-Tandon, in South-Western Australia; extending seemingly also over Central Australia.

An erect glabrous opaque shrub, attaining a few feet height. Branches usually but little dirergent, slightly streaked, in age distantly or remotely cicatrisate, rarely scabrous. Stipules less than $\frac{1}{2}$ line long, subulate. Leaves variable in size, from a few lines to $2 \frac{1}{2}$ inches long; from $\frac{1}{2}-2$ lines broad, carnulent, semicylindrical or linear, flat or often channelled, usually divergent, and at the summit more or less pointed and recurved; the midrib more or less distinctly visible. Pedicels recurved, frequently less, seldom more than 1 line long. Calyx about 1 line in diameter, its teeth more or less deltoid or semiovate, and of various and irregular length. Anthers 8-17, cuneate- and almost tetragonous-obovate, $\frac{1}{2}-1$ line long, pale-yellow, furrowed along the connective on both sides, pressed in to a circle, leaving the central somewhat elevated space of the male calyx vacant; its cells bursting lengthwise. Pollen-grains yellow, ellipsoid, opening with three longitudinal fissures. Styles united at the base, radiating, narrow- or lanceolate-subulate, 1-13 line long, stigmatose at the surface. Fruit formed by the coalescence of the carpels towards their inner edge, in outline 
globular. Valves $1 \frac{1}{2}-4$ lines long, verging from a rhomboid or dimidiate-orbicular into an ovate form, almost cartilaginous, outside, except the margin, greenish, inside shining, connate sometimes only near the inner edge, sometimes to nearly the outer margin, the concrescence not rarely so pernanent as to render the fruit loculicidal-capsular, then one valve of two adjoining carpels seceding from the fruit-axis without mutual dissolution. Central column conical towards the base, stout- or slender-cylindrical upwards, persistent, always angular. Seeds $\frac{1}{2}-\frac{2}{3}$ line long, ovate-roundish, with an imperfect narrow sinus from the base upwards, rough through elevated transverse lines, glabrous. Strophiole $\frac{1}{4}-\frac{1}{2}$ line long, pallid, cellular, somewhat fleshy, obconical with faint lobes. Testa finally dark-brown. Embryo almost annular in an elliptic line. Albumen, if developed, lying solely in tlie sinus of the embryo.

The specimens collected in North-Western Australia, on Sturt's Creek, show only male flowers, and are remarkably narrow-leaved and slightly viscid, the plant thus assuming the appearance of a Dodonæa. D. thesioides, from which D. Drummondi, according to Moquin's description, seems not distinct, differs principally in a four-cleft calyx and in a dicarpellar fruit. At an average its anthers are neither so numerous as in D. pleiococca.

Supplemental Plate IX. 1, portion of a branch with leaves; 2, undeveloped flower with leaves; 3 , fiont view of a male flower; 4 , back view of a male flower; 5 , anthers; 6 , transverse section of an anther; 7, pollen-grains; 8 , female flower; 9 , young fruit with styles and calyx; 10, vertical section of fruit with a separate valve; 11 , transverse section of fruit; 12 , longitudinal section of fruit; 13 , seeds; 14 , transverse section of seed; 15, longitudinal section of seed; 16 , embryo.

\section{CODONOCARPUS.}

All. Cunningh. in Hook. Bot. Misc. i. 244.

Flowers diœcious. Calyx meniscoid, repand or few-toothed. Corolla wanting. Male flowers: Anthers 14-20, uniseriate, subsessile, basifixed, arranged around rudimentary pistils. Female flowers: Ovaries numerous, concrete around a central column. Ovules solitary, ascendent from the inner angle of the ovary. Styles numerous, continuous to the placental edges of the fruit-axis, subulate, stigmatose, persistent. Carpels numerous, completely coherent into a campanulate-obconical fruit; those of the outer series fertile, secedent, membranous, flat, bursting at the inner edge. Column towards the summit much dilated and at the vertex concave and stigmatose by the indurated coalescence of imperfectly developed inner series of carpels. Seeds affixed near the summit of the column, strophiolate. Testa crustaceous. Embryo uncinate-annular, cylindrical, surrounded by very seanty fleshy albumen. Radicle hardly longer than the cotyledons.

Small trees, peculiar to extratropical and subtropical Australia. Leaves carnulent, opaque, entire. Stipules exceedingly minute. Male flowers collected into leafless racemes. Female flowers solitary or racemose. Bracteoles exceedingly minute, geminate at the base of the pedicels.-Endl. Gen. Plant. 978; Hymenotheca, F. M. Fragm. Phytogr. Austr. i. 201.

Gyrostemon, reduced on this occasion to the earliest published species (G. ramulosus, Desf. in Mém. du Mus. vi. 17, t. 6.) differs generically from Codonocarpus in axillary solitary male flowers, in pluriseriate anthers, occupying the whole bottom of the calyx, thus not admitting of the development of rudimentary pistils, in a single whorl of carpels, tlie column being consequently neither thickened into a large turbinate nor at the vertex stigmatose summit, in bivalved completely dehiscent carpels, in which the seed is lodged near the bottom of the cavity. The indistinct formation of inner pistils is not peculiar to Codonocarpus, traces of the same organization being manifest in Tersonia, in which genus moreover the arrangement of the fertile styles and their form is akin to Codonocarpus. 
Codonocarpus cotinifolius.-Gyrostemon cotinifolius, Desf. in Mém. du Mrus. viii. 116, t. 10; Moq. in Cand. Prodr. xiii. 1, 39 ; G. pungens, Lindl. in IItch. Eastern. Austr. ii. 120; G. (Codonocarpus) acaciformis, $F$. MI. in Iinnaea, xxv. 439; Hymenotheca acaciformis, F. M. Fragm. Phyt. Austr. i. 202, ii. 181.

Leaves lanceolate or obovatc or rhomboid, blunt or acute, slender-stalked; fruit-pedicels about twice as long as the fruit; seeds wrinhled.

Rare on the pine-plains near Lake Hindmarsh, more numerous in the sandy Mallee scrub, back of Kulkyne, at the Murray River, J. Dallachy; beyond the Victorian territory towards the junction of the rivers Murray and Darling near Golgol, and in the bushy desert along the Darling, Sir Th. Mitchell; near the Barrier Ranges, Dr. Beckler; on Cooper's Creek, A. C. Gregory; between the Flinders Ranges and Lake Torrens, F. M.; on the Murchison River, A. Oldfield; Baie des Chiens-marins, Gaudichand.

$A$ tall shub or more frequently a small tree, occasionally, however, attaining a height of about 40 feet; in its narrow-lenved form resembling some phyllodineous Acacix. The stem sometimes partially procumbent under ground, attaining often fully 1 foot in diameter. Wood light, pale, slightly fragrant. Alburnum greenish. Bark at first fulvous, in age almost black, as well longitudinally as transversely rimose. Branches stout, more or less twisted, rather smooth, grey-fulvid. Branchlets moderately or very spreading, red-or yellow-brownish; the younger ones cylindrical, pruinous-or glaucous-grey and pendent. Lenves bitter and nauseous to the taste, reminding of that of horse-radish according to an enrly discoverer, rather carnulent,

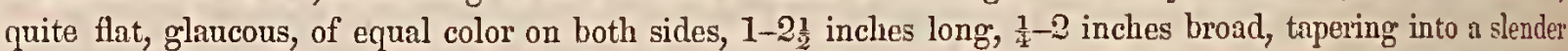
petiole; their midnerve much more conspicuous than the spreading lateral nerves; their veins not distinct. Stipules only about $\frac{1}{4}$ line long, subulate. Racemes of male flowers, according to specinens discovered by Dr. Beckler during the Victorian Expedition, axillary and terminal, with few or several solitary pedicels, attaining with added comparatively short peduncle a length of $1 \frac{1}{2}-2 \frac{1}{2}$ inches. Rachis slender. Pedicels hardly 1 line long, with two lateral extremely small readily overlooked subulate or gland-like bracteoles, and a deltoid- or ovate-lanceolate deciduons bract at the base. Calyx only about I line in diameter, waved at the margin and ninutely 7-9-toothed. Stameus surrounding a circular elerated at the vertex broadimpressed barren ovary. Antlers 15-20 in number, about 1 line long, tetragonous- and clarate-ellipsoid, yellow, bursting longitudinally at the margin, with a very narrow connective. Pollen-grains smooth, sulplum-colored, ovate-globose, trifissured. Female flowers either few or several, forming axillary racemes of 2-3 inclies length, or their pedicels arising singly from the axis of the leaves, after the lapse of which constituting infir-terminal racemes. Pedicels when flower-bearing about $\frac{1}{2}$ inch, when fruit-bearing about 1 inch long; rather dissite, slightly thickened towards the sununit. Calyx 2-21 lines in diameter, laxly surrounding the oraries, shightly waved and bluntly or acutely denticulated. Frnit-column slender and cylindrical towards the base, by the perfect coalescence of rudimentary carpels turbinately widened at the summit and there about 3 lines thick and rough from longitudinal alternately higher and lower placental elerations, after the lapse of the carpels surrounded at the base within the persistent calyx by a radiating and ascending-fringed disk, which is formed by the persistence of the lower portion of the repla, concave and stigmatose-papillose at the rertex, where some papillæe arise often in almost a concentric disposition within the marginal stigma series, thus indicating the existence of wore or less verticillate suppressed pistils. Styles or ratlier stigmas fulrous, by close nutual approach brought into a circle, only $\frac{1}{4}-\frac{1}{2}$ hine long; bluntly and rather rigidly subulate. Young fruit pear-slinped, older one nore bell-slinped. Carpels in number 30-40, mensuring $4-5$ lines in length, 1-1 $\frac{1}{2}$ line in breadtl, very compressed; the dorsal line extremely narrow, green and herbnceous; the valres otherwise delicatc-membranous, oblique cuneatc-oblong, gently excised towards the summit at the inner angle, at first colherent, at last secedent, bursting along the whole inner edge and finally at the basc, but not along the dorsal suture. Seeds dark-brown, opaque, 1-1 $\frac{1}{2}$ line long, placed in ench alternate carpel at and below the summit (since their turgidity would not admit of being arrayed in a single cyclus within the fruit), ronndish-orate, with an imperfect simus from the point of insertion towards the middle, copiously transverse- 
lined. Strophiole about four times shorter than the seed, pale, fleshy when fresh, oblique semiovate, very faintly lobed. Embryo greenish, slender, almost horseshoe-curved. Albumen scantily or scarcely developed.

Codonocarpus pyramidalis (F. M. in Linnea, xxv. 438) agrees generically well witl C. cotinifolius, but is specifically fully marked by its pyramidal growth, by linear leaves, by longer although still very small stipules, by pedicels hardly of greater length than the fruit, by somewhat larger carpels, and by not rugose seeds with a comparatively smaller strophiole. Its male flowers accord fully with those of C. cotinifolius. In some specimens of the latter the female inflorescence is terminated by male flowers. The original C. Australis is characterized by lanceolate leaves extending into a very long acumen, by a seemingly still more suddenly and broadly expanded column, by the slightly rough-pulverulent dorsal lines of the carpels and probably in other notes, which our very imperfect knowledge of that very local plant not admits of pointing out at present. Should the male flowers of C. Australis, which as yet are unlsnown, prove distinct from those of the here assumed congeners, then it would be necessary to restore the genus Hymenotheca for the reception of C. pyramidalis and cotinifolius. Dissecting the half-matured but somewhat defect fruit of C. Australis, from Cunninghamian specimens, which we owe to the liberality of the venerable $\mathbf{R}$. Heward, Esq., the writer observes the existence of the minute subulate styles as described in C. cotinifolius. Nor seem more than one orule contained in each carpel, as previously mentioned by Endlicher in Hueg. Enum. p. 10. The same authority ascribes inner whorls of seminiferous carpels to this plant. The young seeds and their strophiole exhibit nothing distinct in their characteristic. The shape of leaves proving very variable in a congener, it remains yet further to be ascertained how far the long-acuminate leaves of C. Australis afford means of specific discrimination.

\section{ORDER MOLLUGINE无.}

Benth. in Procced. Linn. Soc. 1861.

Flowers bisexual. Sepals 5, free, persistent, imbricate in bud. Petals 5, seldom more, often wanting. Stamens definite or indefinite. Filaments free or towards the base connate or colherent, all fertile or some sterile. Anthers two-celled, bursting longitudinally. Ovary free, 3-5-celled. Ovules several or many in each cell, attached to its inner angle. Styles 3-5, free, inward stigmatose. Capsule completely or incompletely 3-5-celled, bursting with loculicidal dehiscence. Albumen central-unilateral, farinaceous. Embryo peripherical, imperfectly annular.

Herbaceous or suffruticose plants, dispersed in the eastern hemisphere through the warmer parts of the temperate and through the tropical zone, rare in the western hemisphere. Leaves scattered or spuriously verticillate, very seldom reduced to minute scales. Stipules developed or wanting. Flowers variously disposed, often cymose.

The small order of Molluginex, according to the limits recently assigned to it by $\mathrm{Mr}$. G. Bentham, comprises amongst Australian plants three species of Glinus, Mollugo Cerviana, Mollugo trigastrotheca (Trigastrotheca molluginea, F. M. in Hook. Kew. Misc. ix. 16), and two species of Macarthuria (conf. Fragm. Phytogr. Austr. i. 11). Gunnia septicida (F. M. Report on Plants of Babbage's Exped. p. 9) is probably rather more congruous with Molluginese than with the recently recorded characters of Portulaceæ and Ficoideæ, differing from all in the septicidal dehiscence. The seed 
vessels of Mollugo trigastrotheca burst only under maceration; but since they are truly valvate and since the seeds of Mollugo stricta are neither numerous in each cell, it seems advisable to unite Trigastrotheca with Mollugo, although its singularly shaped capsule entitles it to subgeneric distinction. Some additional Indian species of Mollugo are likely yet to be discovered in tropical Australia.

\section{GLINUS.}

\section{Loffing, Iter Hispanic. 145.}

Sepals 5. Petals wanting. Staminodia linear-subulate or furcate, indefinite in number or wanting. Stamens 3-24, free or coherent. Filaments linear-setaceous, membranous. Anther-cells bursting with extrorse longitudinal dehiscence. Ovary free, 3-5-celled, with numerous ovules. Styles 3-5, stigmatose. Capsule membranous, completely 3-5-celled. Septa separating from the columella, permanently connate with the valves. Seeds several or numerous. Funicles very short. Strophiole more or less extended into a bristly process. Testa crustaceous. Embryo semiannular.

Glabrous or downy procumbent herbs, in very few species distributed over most of the warmer parts of the globe. Leaves flat, entire or denticulated, without stipules. Flowers axillary, collected into sessile fascicles or umbels, seldom solitary.-Gcertn. de Fruct. et Seminib. ii. 236, t. 130; Fenal, in den Annalen des Wiener MIuseums, i. 355.

The closely allied genus Orygia, for which in North Australia may be sought, is recognized by its scattered leaves, by its paniculate leafless inflorescence, by its filiform wingless filaments, by its scale-like petals (or staminodia), by its chartaceous or pergamentaceous capsule, by the almost perfect rupture of the septa from the valves but not from the columna, and by the absence of any longer or shorter bristly process of the strophiole. The embryo of both genera shows no appreciable differences, The genus Mollugo stands still nearer to Glinus; it is demarked merely on account of the alsence of a distinct strophiole, which note must be declared of doubtful value, when we see the strophiole not entirely suppressed in Mollugo nudicaulis. Hence Achilles Richard's opinion, that Glinus should be transferred to Mollugo, is deserving of every attention.

Glinus lotoides, Loefl. Iter Hisp. 145; Burm. Flor. Indic. 112, t. 36; Sibthorp \& Smith, Flora Grecea, t. 472; Fenzl, in Amnal. Wien. Mrus. i. 357; G. dictamnoides, Lamark, Encyclop. MYéthod. ii. 729, t. 413; Mollugo Glinus, Aeh. Rieh. Tent. Flor. Abyss. i. 48.

Stellate-downy; leaves obovate- or spathulate- or orbicular-cunente; sepals large, acute; staminodia furcate, developed in uncertain number or rarely wanting; stamens $5-20$; stigmas 5 , rarely 4 or 3 ; placentax nearly as long as the cell; capsule usually five-valved; seeds very numerous; strophiole spongiose, of about half the size of the small and very numcrous sced; testa seriate-granular; bristly process of the strophiole laxly encircling the seed.

On the sandy occasionally inundated banks of the River Mrurray and there also at the margins of lagoons and in shallow depressions after the recess of water, reaching here in latitude about $35^{\circ} \mathrm{S}$. its southern limit; oxtending over many parts of subtropical and tropical Australia, Asia and America, also from the south to tho north of Africa and likewise over South Europe.

An annual herb, with several or many expanded dichotomous stenis, which attain a length from a ferr inches to about 1 foot, and are seldom erect. Leaves herbaceous, usually approximated by four into irregular whorls, unequal-sized, exclusive of the petiole from a few lines to about 1 inch long, tapering with cuneate base into a petiole of about half their length, somewhat penninerved, downy on both pnges. Pedicels as long 
as the flowers or mostly in various degrees shorter, congregated into axillary umbels or fascicles, provided at the base with linear-subulate externally and along the margin star-downy bracteoles of 1-2 lines length. Sepals 3-5 lines long, more or less acuminate; the two outer ones lanceolate, quite herbaceous and outside star-hairy; the third one unilateral-membranous; the two inner ones more concurved, membranous and glabrous on both edges, broader than the outer ones; all with a distinct midnerve and fainter lateral nerve, inside glabrous. Staminodia exterior to the fertile filaments, about two lines long, linear, furcate to near the middle, membranous, glabrous, one-nerved; the nerve divided for continuing its course to the summit of the two narrow pointed lobes. Filaments linear-setaceous, very tender, membranous, one-nerved, about as long' as the staminodia. Anthers nearly $\frac{1}{3}$ line long; yellow, versatile; its cells narrow-ellipsoid, bursting: extrorse longitudinally. Pollen-grains spherical, smooth. Stigmas 5, about $\frac{1}{3}$ line long, recurved, clavatespathulate. Capsule sessile, free, glabrous, tender-membranous, 2-3 lines long, many seeded. Septa 4-5, breaking from the fruit-axis, permanently connate with the valves. Columella 4-5 angled, subulate, rough from the cicatrices of the finicles. Seeds attached in two close rows to the angle of the fruit-axis in each cell, attached to a funicle of about $\frac{1}{3}$ line length, which is almost entirely enclosed within the strophiole, which is somewhat cupular and almost white. Seeds oblique-kidneyshaped, about $\frac{1}{4}$ line long, dark-brown, somewhat shining, beautifully seriate-granular, encircled by a free setaceous pallid process, which arises from the funicle at the hilum, and bends irregularly around the back of the seed so as to touch almost the chalaza. The latter closely approxinated to the hilum. Albumen mealy, scanty, lying near the hilum. Embryo semiannular. Cotyledons almost as long as the radicle.

A variety with leaves glabrous at the surface is of rare occurrence.

Glinus orygioides, F. M., brought by Dr. Beckler from the desert-plains east of Grey Range and by Ir. Wright from Cooper's Creek, agrees in size of flowers and leaves, and in its numerous stamens (16-24) with G. lotoides; it is however widely distinct in its almost perfect glabrescence (only the nodes and young branches being crisp-hairy), in carnulent leaves, in blunt broad- 01 orbicular-ovate inner sepals, which in consequence of their very broad white margin appear almost petaloid, in larger anthers, in but very few linear-subulate not forked staminodia, which are placed amongst the exterior fertile stamens, in 3-4 somewhat longer styles, which are stigmatose torards the summit, in a 3-rarely 4-celled fruit, in much less copious seeds of larger size arrayed nlong shorter placentre, in a furrowed and slightly foveolated testa, and in a linear-subulate strophiole, the bristly apex of which reaching less than half around the seed. This rare and interesting species is of stout habit and may be of perennial growth; it mediates somewhat the transit from Glinus to Orygia, inasmuch as it shows but a short bristly process of the strophiole, contrasted with the setaceous prolongation, which surrounds almost completely the seed of Glinus lotoides and G. MIollugo.

Glinus Mollugo, Fenzl, in Annal. des Wien. MIus. i. 359; Mollugo Spergula, Linn. Spec. Plant. i. 131 ; M. erecta, Burm. Flor. Indic. p. 31 ; MI. verticillata, Roxb. Fl. Ind. i. 360 ; M. Novo-Hollandica, F. IT. in Transact. Ph. Soc. Vict. i. 14; Pharnaceum Mollugo, Linn. Mant. p. 651.

Stems almost unilateral crisp-downy; leaves nearly glabrous, obovate- or oblong- or linear-cuneate; sepals small, obtuse, nearly glabrous; staminodia undivided or furcate, often wanting; stamens 3-10; stigmas 3; capsulc three-valved; testa seriate-granular; seeds very numerous and exceedingly small; placentæ nearly as long as the cell; strophiole oval, much smaller than the seed; setaceous process of the strophiole laxly encircling the seed.

On the sandy periodically inundated banks of the Murray River and its back-waters; extending thence to tropical Australia, tropical Asia and to various parts of Africa and perhaps of America.

Root nnnual, slender. Stems generally prostrate and numerous, fiom a few inches to about 1 foot long, compressed, striolated, alternately or dichotomously branched; at the side directed to the ground almost glabrous. Leaves with inclusion of the petiole from a few lines to about 1 inch long, of unequal size, collected at the nodes in fascicular verticils; slightly carnulent, tapering gradually into the petiole, towards 
the summit often slightly repand or faintly denticulated; the midnerve conspicuous; the lateral nerres faint: Pedicels capillary, axillary and terminal, consociated into spurious and usually few-flowered umbels, scantily woolly-downy, in age more glabrous, promiscuously longer or shorter than the calyx. Bracteoles at the base of the pedicels, membranous, usually less than 1 line long, lanceolate- or linear-subulate, ciliolated. Sepals about $1 \frac{1}{2}$ line long, one-nerved; the two outer oblong- or lanceolate-cymbiform, herbaceous, the three inner sepals ovate-lanceolate; two on both sides, one on the inner side membranous. Stamens frequently 3 and then opposite to the septa of the capsule, or in Indian specimens often increased in number. Filaments linear-setaceous, one-nerved, membranous, glabrous, free, about 1 line long. Anthers yellow, about $\frac{1}{6}$ line long, consisting of two narrow-ellipsoid towards the middle connate cells. Stigmas very minute, roundish, depressed, in Indian specimens more erect and slightly elongated. Capsule broad egr-shaped, abont $1 \frac{1}{2}$ line long, sessile, membranous. Column subulate, narrow-tripterous. Seeds numerous, seriate along the placentr, pressed into three irregular rows, placed almost horizontally, pyriform-renate, glittering, dark-brown, about $\frac{1}{6}$ line long, rough from seriate dots, affixed to a very short funicle, which is adnate to the strophiole. The latter oval or oblong, whitish. Bristly appendage extending laxly and in a more or less flexuose line around the back of the seed, reaching nearly the chalaza.

The specimens from the Murray River, examined on this occasion, are devoid of the forked staminoid petals, which are usually present in Indian specimens; we find here moreover the flowers seldom otherwise than triandrous, whilst the whole plant occurs more downy with shorter pedicels. But Professor Fenzl has traced varieties similar to the Australian plant into the petaliferous and pleiostemonous Indian forms, leaving little doubt of our plant being justly referred to G. Mollugo. Some specimens from Arnhem's Land are almost glabrous, but are like those from the Murray River apetalous.

\section{ORDER CARYOPHYLLE $\mathrm{E}$.}

Juss. Gen. 299.

Flowers bisexual, usually symmetrical. Sepals 5, rarely 4, free or connate, persistent, imbricate in bud. Petals 5, rarely 4, alternate witli the sepals, free, in bud contorted, rarely wanting. Stamens as many as the sepals and opposite or rarely alternate to them, or double their number, rery seldom less, those opposite the petals shorter and sometimes barren. Filaments free or at the basc connate. Anthers two-celled, bursting longitudinally. Ovary free, one-celled. Ovules usually numerous. Funicles arising from the base of the ovary, free or joined into a columella. Styles 2-5, free or towards the base united, inwards longitudinally stigmatose. Capsule perfectly or imperfectly valvate, detriscent from the summit. Albumen central-unilateral, farinaceons. Embryo peripherical, incompletely annular.

Herbaceous or suffruticosc, seldom frutescent plants, of vast exuberance in the temperate zone of the northern hemispherc, elsewhere except in South Africa comparatively rare. Stems often dichotomously branched. Leaves opposite, often connate at the base, sometimes spuriously verticillatc, simple, never lobed or grossly-toothed. Stipules oftener wanting than developed. Inflorcscence various. Petals prevailingly white or various shades of red.-Fenzl, in Endl. Gen. Plant. 955. 
The order of Caryophyllea is adopted here in the circumscription recently assigned to it by Mr. G. Bentham. It contains, as far as known, no other native Continental-Australian plants, than those enumerated on this occasion, except various species of Polycarpæa (conf. F. M. Report on Plants of Babbag. Exped. pp. 8-9), ranging over tropical and subtropical Australia. Several Caryophyllex have found their way from Europe and other parts of the globe into our colony, amongst which Agrostemma Githago, Spergula arvensis, Arenaria serpillifolia, Cerastium vulgatum, and Silene Gallica are to be counted. It is beyond possibility to ascertain now after lengthened colonization of Australia, whether Sagina apetala, S. procumbens, Polycarpon tetraphyllum, Gypsophila tubulosa, Stellaria glauca and Spergularia rubra originally belonged to our flora; these therefore are here adopted doubtfully as indigenous members.

\section{POLYCARPON.}

Lafing, in Linn. Gen. 105.-Allseed.

Sepals 5, keeled, connivent. Petals 5, minute, entire or bidentate. Stamens 3-5, opposite to the sepals. Ovary one-celled, with numerous ovules. Funicles arising from the basal placentæ. Style three-cleft, exceedingly short. Capsule membranous, trivalved. Seeds several or many, estrophiolate. T'esta granular.

Annual or perennial herbs, scattered over the warmer temperate parts of the globe. Leaves opposite or spuriously verticillate, scariously stipulate. Bracts and bracteoles scarious. Flowers cymose, small. Stamens extremely short. Capsule minute.-Endl. Gen. 960.

Polycarpon tetraphyllum, Linn. Syst. Veg. edit. xiii. 111; Mollugo tetraphylla, Linn. Spec. Plant. i. 89 ;. Suppl. 116; Engl. Bot.t. 1031.

Glabrous, annual; leares spathulate-obovate, opposite or quaternate; sepals mucronnlate; stamens 3.

In light soil widely dispersed over the Colony of Victoria; noticed also in many parts of New South Wales, South Australia, Tasmania and Western Australia; known also from Sonth and North Africa, South and Middle Europe and some parts of Asia and North America; perhaps in this and some other parts of the globe to be regarded as an introduced species.

An annual, decumbent or ascendent herb. Root pallid, more or less branched and fibrous. Stems from a few inches to a span long, as well as the patent dichotomous branches almost cylindrical and finely streaked, somewhat turgent on the nodes, seldom branchless and singly from the root. Leaves herbaceous, flat, opposite in a single or double pair, tapering into a short or conspicuous petiole, usually between 3 and 6 lines long, one-nerved, indistinctly veined, often tinged with a reddisl hue, one in each pair alternately somewhat larger and smaller. Stipules persistent, lanceolate-subulate, $\frac{1}{2}-1 \frac{1}{2}$ line long, entire or somewhat laciniated, not rarely concrete into single interpetiolar acuminate-deltoid ones. Cymes terminal, short-pedunculate, dichotomously more or less compound, with several or numerous crowded flowers. Bracts and bracteoles similar to the stipules, opposite at the base of the peduncles and pedicels, persistent. Pedicels usually shorter, seldom longer than the calyx, articulated at the base, upwards thickened. Sepals connivent, 1-1 $\frac{1}{2}$ line long, greenish or reddish except at the pale membranous margin, lanceolate-cymbiform, unequal in length. Petals membranous, white, oblong; entire, only from $\frac{1}{4}-\frac{1}{2}$ line long. Filaments in all here examined specimens 3 , opposite to the three larger sepals and to the three fruit-valves, about half as long as the petals. Anthers didymous-round, only about $\frac{1}{8}$ of a line long, consisting of two ellipsoid cells, which burst with longitudinal 
introrse dehiscence: Pollen bright-yellow; its grains spherical, bursting longitndinally. Orary spherical, seated on a very short stipes, containing from about a dozen to many ovules. Style only about $\frac{1}{12}$ line long, capillary, with three ratler short stigmatose hardly divergent lobes. Capsule enclosed in the never expanding calyx, globose-ovate, completely threc-valved, $\frac{1}{2}-\frac{2}{3}$ line long; the valves entire and nerveless, after dehiscence rolled inward with their margins. Funicles forming a bundle at the bottom of the cavity, short. Seeds about $\frac{1}{4}$ line long, oblique renate-ovate, scabrid from subtile seriate gramules, more or less fulvous or grcy. Albumen amylaceous.

In Candolle's prodromus (i. 376) the Sonth Enropean P. alsinifolium stands recorded also as an Australian and South African plant. In Dr. Sonder's excellent review of South African Caryophyllex only P. tetraphylluin is admitted. It seems therefore likely, that this plant is merely a pentandrous form of P. tetraphyllum, although the specimens from many parts of Australia, subjected to analysis, exhibit only triandrous flowers.

\section{GYPSOPHILA.}

Linn. Gerr. 768.

Sepals concrete into a five-lobed ebracteolate calyx. Petals 5, exappendiculate, entire or emarginate or bidentate, contracted into a cuneate base. Stamens 10, all fertile, or the petrline ones rarely sterile. Ovary one-celled, short-stipitate, with many ovules. Funicles very short, attached to a central columella. Styles 2, very seldom 3, longitudinally inward stigmatose. Capsule cleft into 4 rarely 6 valves. Seeds estrophiolate, many or few. Testa wrinkled or granular.

Herbs or half-shrubs indigenous to the warmer temperate zones of Europe, Asia and Africa, one species doubtfully regarded as belonging also to the Australian flora. Leaves opposite, exstipulate. Flowers cymose or scattered-solitary, usually small. Petals white or pink.-Endl. Gen. Plant. 971; Dichoglottis, Fisch. et Mleyer, Index Sem. Hort. Petropol. 1835, i. 25.

Gypsophila tubulosa, Boissier Diagn. Plant. Orient. i. 11 ; Jos. Hook. Flor. Nov. Zeel. ii. 325; Dichoglottis tubulosa, Jaub. \& Spach, Mlustr. Plant. Orient. i. p. 14,f.6; D. Australis, Schlechtend. Linnea, xx. 631 .

Small, annual, glandulous-pubescent, erect; leaves narrow-linear, almost blunt; flowers axillars, alar and terminal, solitary; pedicels longer than the flowers; calyx short-and bluntly-fire-lobed, campanulatecylindrical, appressed; petals spathulate- or oblong- or linear-cunente, less than half exserted, retuse; stamens considerably shorter than the corolla, all fertile; styles 2; eapsulc cgg-shaped; funicular column raised to the middle of the crpsule; seeds numerous, small; testa seriate-granulated.

In sandy localities by no means very rare in the Colony of Victoria; for instance, near Forest Creek, on the subalpine summit of Mount Timbertop near Monnt Buller, on the Orens River, in the Murray desert; found also in various parts of South Australia, Western Anstralia, Tasmania and New Zealand; indigenous in the northern hemisphere to Asia Mrinor.

A branched or simple-stemmed herb, usually less than a span high. Root slender, flexuose, descending with some capillary tortuous fibres. Stems and branches slender, cylindrical. Leares from a few lines to nearly 1 inch long; $3-\frac{1}{3}$ line broad, convex and somewhat keeled beneath at the base, membranously dilated, and thus the leaves of each pair comnate at thc base. Pedicels from little to sevcral times louger than the calyx, more or less spreading. Calyx about 2 lines long, consisting of 5, for the greater part concrete, at the margin pellucidly membranous, and at tlic back green aurl prominent scpals. Petals usually only shortexserted, finely membranous, white or pink, lined with 3 red subtle nerres, also somewhat red-veined, generally from $2 \frac{1}{2}-3$ lines long, and $\frac{1}{3}-\frac{2}{3}$ line broad. Filaments setaceous-linear, about half as long as the corolla, finely one-nerved. Anthers didymous-roundish, dorsifixed, only abont $\frac{1}{12}$ line long; cells ellipsoid, 
bursting introrse longitudinally. Styles 2, fiee, $\frac{1}{2}-\frac{3}{4}$ line long; longitudinally stigmatose, very narrow. Ovary on a very short stipes, emarginate at the summit. Capsule four-valved, sometimes a little shorter than the calyx, sometimes short exserted; its valves finally seceding to near the base. Funicles of the columella exceedingly short. Seeds from rufous turning black-brown, roundisli-renate, rostellate, $\frac{1}{6}-\frac{1}{4}$ line long. Albumen starchy, rather copious, unilateral-central, half surrounded by the semicircular embryo. Cotyledons somewhat longer than the radicle.

Seemingly this species has but slight clains for being held specifically distinct from G. muralis, a plant not rare in Middle and South Europe, which differs merely in being smooth, in producing rather broader leaves, somewhat larger petals, less rostellate seeds and a more clathrate testa; none of these characters being of absolute validity. Notwithstanding its wide distribution over Australia, G. tubulosa is probably not an indigenous species.

\section{SPERGULARIA.}

Pers. Synops. Plant. i. 504.

Sepals 5. Petals undivided, 5, seldom 4 or none. Stamens 10, sometimes less, free. Exterior filaments biglandulose at the base. Ovary one-celled. Ovules many, attached to a central columella. Styles 3-5, rarely 2. Valves of the capsule as many as styles, when 5 alternate with the sepals. Seeds numerous, wingless or winged. Embryo imperfectly annular.

Annual, biennial or perennial herbs, dispersed over many parts of the globe. Leaves free, opposite or pseudo-rerticillate, narrow, usually carnulent. Stipules scarious, persistent, solitary between the leaves, connate at the base. Pedicels axillary or in racemose cymes. Petals pink, sometimes white-Endl. Gen. Plant. 962 ; Lepigonum, Fries, Addend. Flor. Malland. 159 ; Koch, Synops. Flor. Germ. \& Helvet. i. 120; Kindl. Synops. Lepigon. 1-12; Stipularia, Haw. Synops. Plant. Succul. 10 t.

This genus differs from Alsine, as defined by Professor Fenzl, chiefly in stipulate leaves, a character it has in common with but few other genera of Caryophylleæ. Of these Spergula stands nearest to Spergularia, being however mainly recognized by the position of its five valves opposite to the sepals.

Spergularia rubra, Cambess. in St. Hil. Flor. Brasil. Mcrid. ii. 179; J. Hook. Fl. Tasm. i. 41; S. salina, Presl. Cech. 93; S. marginata; Kitt. Flor. Dentschl. ii. 1004; S. rupestris, Camb. l. c.; Fenzl, in Plant. Hueg. 9; Schlechtend. Linncea, xx. 632; Arenaria rubra, Linn. Sp. Plant. 606; A. media, L. l.c.; A. campestris, Allioni, Flor. Pedemont.; A. salina, Seringe, in Cand. Prodr. i. 401; A. marina, Roth. Fl. Germ. i. 189; Engl. Bot.t. 938; A. Canadensis, Pers. Syn. i. 504; A. marginata, Cand. Flor. Franc. iv. 793; Stipularia rubra, Haw. Syn. 104; Alsine marina, Wahlenb. Fl. Suec. 281; Lepigonum rubrum, Wahlenb. For. Gathob. p. 45; L. medium, Wahlenb. l. c.; L. marinum, Wahlenb. l. c.; L. marginatum, Koch, Syn. Fl. Germ. \& Helv. ed. 2, vol. i. 121; L. brevifolium, Bartl. in Lehm. Pl. Preiss. i. 243; L. anceps, Bartl. l.c.; L. laxiflorum, Bartl. l. c. 244; Spergula purpurea, Raj. Syn.351; S. rubra, Tom. S.Gray, Fl.of North Amer. i. 175.

Leaves linear-filiform; stipules entire, seldom bifid; pedicels rather stout, as well as the sepals usually glandulous-downy; flowers generally large; herbaceons dorsal part of the outer sepals broader than the membranous margin; styles and valves of the capsule 3; seeds winged or wingless.

On coast meadows and in subsaline tracts of the interior, or on clayey or sandy plains not unfrequent in this colony, ascending occasionally mountainous tracts, thus found 1000 feet high on Ben Lomond. Widely dispersed over the subtropical, temperate and subarctic zones of the globe. 
An erect, ascendent or decumbent herb, from a few inches to about one foot high. Root in age often perennial, stout, sometimes of several inches length and quite woody, producing usually many stems; in seedling plants slender, the plant then assuming the appearance of an anuual, in colder climates often only of one year's duration. Branches almost cylindrical or compressed, tumid at the nodes, glabrous or oftener and especially upwards glandulous-downy. Leaves attaining the length of $2 \frac{1}{2}$ inches, although usually shorter, and often the floral ones reduced by degrees to extreme shortness and bract-like appearance, glandulous-downy, or the lower ones or all glabrous, acnte or short-mucronulate. Stipules semilanceolate or deltoid, acuminate, $3^{-3}$ lines long, glabrous, nerveless, seldom denticulated, never jagged, sometimes imbricately crowded: Pedicels constituting a terminal, often somewhat leafy biracemose cyme, 1-6 lines long, filiform, seldom

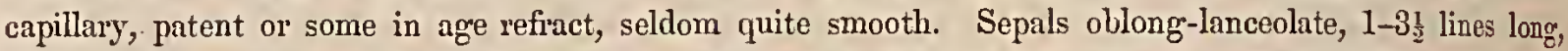
glandulous-downy at the back, the inner broader margined than the outer ones, their middle-field green. Petals glabrous, lanceolate-ovate, as long as or somewhat shorter than the calyx, pale- or deep-pink, or white. Stamens 10. Filaments linear-setaceous, about half as long as the corolla. Antlers yellow, dorsifixed, ovate; the narrow-ellipsoid cells introrsely dehiscent, $\frac{1}{3}$ line or less long. Styles free, $\frac{1}{6}-\frac{1}{3}$ line long, filiform, inward stigmatose. Capsule broad-ovate, somewhat longer sometimes rather shorter than the calyz. Columella reaching hardly beyond the middle of the cavity, stout, bearing from the base to the summit exceedingly short funicles. Seeds scabrous or smooth, pyriform- or orbicular-renate, $\frac{1}{5}-\frac{3}{5}$ line long, perfectly wingless or surrounded by a broader or narrower membranous pale striolated wing, impressed seldom turgid at the sides, more or less shining or opaque, dark-brown or black. Albumen rather scanty. Embryo semiannular or horseshoe-shaped, cylindrical. Radicle almost as long as the cotyledons.

The description here offered is derived exçlusively from Australian specimens, between which all the principal forms occurring in the northern hemisphere exist, and which do not appear to have clear claims for specific distinction.

\section{SAGINA.}

Linn. Gen. Plant. 176.-Pearlwort.

Sepals 4-5. Petals as many as sepals or wanting. Stamens 4-5, opposite to the sepals, or 10 , all fertile. Filaments free. Ovary sessile, one-celled, free. Ovules numerous, inserted to the basal columella. Styles 4-5, short, alternate with the sepals. Capsule membranous, one-celled, 4-5-ralved, the valves entive, opposite to the sepals. Seeds numerous, very small, without strophiole. Embryo imperfectly annular.

Annual or perennial minute herbs, seemingly transmigrated from the temperate zone of the northern hemisphere to other parts of the globe. Leaves opposite, narrow, without stipules. Flowers minute, on capillary pedicels, axillary or terminal, cymose or solitary.-Fenzl, in den Annal. des Fien. Museums, i. 43; Bartl. Ord. Natur. p. 305; Spergella, Reichenb. Flor. Germ. 110.

Sagina procumbens, Linné, Spee. Plant. 185; Engl. Bot.t. 880; Schluhhr, Botan. Handbuch, t. 27; Gertn. de Fruct. \& Semin.t. 129; Kocle, Synops. Fl. Germ. \&. Helvet. ed. 2, rol. i. 118 \& 119; Torrey S. Gray, Fl. of North Amer. i. 177.

Perennial; stems mostly procumbent, much branclied; leaves linear, acute; pedicels after florescence usually curred at the summit, finally again erect; flowers tetvamerous, seldom pentamerous; sepals blunt, ovate-orbicular; petals laalf or less than half as long as the calyx, seldom wanting; styles recurred; capsule somewhat longer than the calyx.

In morassy mossy valleys between Mount Linster and the Limestone River, at an elevation of about 4000 feet; not yet found in any other part of Australia. Distribnted over a great part of the temperate northern zone. 
Root fibrous. Stems from 1 to several inches long, with the branches almost capillary. Leaves 2-6 lines long, $\frac{1}{4}-\frac{3}{4}$ line broad, spreading; each pair at the base confluent into a very short cylindrical vagina; the radical leaves the longest and usually tufted. Pedicels axillary and terminal, solitary, capillary, from a few lines to nearly 1 inch long, often curved at the summit. Sepals $\frac{1}{2}-1$ line long, almost nerveless. Petals obovate-cuneate, blunt, entire, white, alternate with the sepals. Stamens 4 , seldom 5 , shorter than the calyx. Filaments linear-subulate, opposite to the sepals. Anthers roundish, very minute, yellow, introrsely dehiscent. Ovary nearly globose. Styles 4 , about $\frac{1}{6}$ line long. Capsule thin-cartilaginous, to about the middle fourvalved, ovate-globose, usually about half-exserted. Funicles fasciculate, of unequal length; the longest reaching hardly to lalf the heiglit of the cavity. Seeds renate-ovate, turgid, $\frac{1}{6}$ line long, at first brown, when ripe black, rather shining, slight tly dotted. Embryo semiannular.

Sagina apetala, Limné, Mantissa Plant, p. 559; S. stricta, Fries, Novit. Flor. Suec. ed.2, 58 ; S. maritima, Don, in Engl. Bot. 2195.

Anmual; stems mostly erect or ascendent; leaves linear or semicylindrical, pointed; pedicels usually permanently erect; flowers tetramerous; petals much shorter than the calyx or wanting; capsule somewhat longer than the calyx.

On low meadows around Port Phillip. Found in Australia also on St. Vincent's Gulf. Not unfrequent in the temperate zone of the northern hemisphere.

The similarity of this to the preceding species renders a detailed description unnecessary. It is usually of smaller size. The strand variety is often purplish-tinged, like other litoral plant somewhat carnulent, and usually devoid of petals. The inland variety has its leaves mostly longer pointed and the lower part not raxely fringed; its pedicels and sometimes also its stems and branches are slightly puberulous; its exterior sepals are generally slightly pointed; the petals are often developed, althougli exceedingly small. Mr. G. Bentham (Handbook of the British Flora, 120) is not inclined to assign to this plant specific distinction, but combines it with the foregoing.

\section{STELLAREA.}

Linn. Gen. Plant. 568.-Stitcliwort.

Sepals 4-5. Petals 4-5, more or less deeply bifid, seldom jagged or wanting. Stamens twice the number of the sepals, seldom fewer, all fertile. Styles usìally 3, rarely 2, 4 or 5 . Ovary sessile, one-celled. Orules few or many. Funicles inserted to the basal or columnar placenta. Capsule cleft beyond the middle; its valves twice the number of the styles. Seeds many or few, rarely 1 . Strophiole wanting. Embryo imperfectly annular.

Annual or perennial herbs, occurring in the temperate and colder parts of the globe, rare or absent within the tropics unless in cooler elevations, extending neither to Western Australia. Stems angular. Leaves opposite, exstipulate. Flowers usually long-pedicellate, cymose or solitary. Petals white.-Fenzl, in Endl. Gen. Plant. 969.

Stellaria pungens, Brogniart, in Duperrey, Voy. autour du Monde Bot.t. 78; J. Hook. Fl. Tasm. i. 44; S. squarrosa, Hook. Journ. of Botany, i. 250.

Perennial; branchlets morc or less lanuginous; leaves complicate, rigid, ovate- or lanceolate-subulate, pungent, sessile, towards the base scantily fringed, otherwise glabrous, shining; pedicels axillary and terminal, solitary, usually downy; sepals lanceolate-subulate, three-nerved; petals somewhat or hardly longer than the calyx, bipartite; capsule ovate, six-valved; columella very short.

In rocky, stony or sandy places not unfrequent throughout the greater part of the colony, ascending to the Australian Alps, not extending into the desert nor north-eastward and westward beyond Australia Felix; abundant, however, in Tasmania. 
A laxly decumbent, ascendent, erect or somewhat climbing herb, more or less dwarf or elongated, in favorable places when leaning over other plants attaining a height of several feet, often copionsly branched. Root ramified; the cylindrical branches emitting many tender fibres. Branches more or less strict or spreading, quadrangular, clothed densely or scantily with soft crisp pale jointed hair, sometimes glabrous. Leaves copious, opposite or by innovation fasciculate, in younger branches imbricate or crowded, strongly or slightly arcuate or straight, often squarrose, sometimes erect, 2-6 lines long, somewhat clasping, shining on both pages, with a beneath prominent midnerve. Pedicels shorter than the leaves or usually longer, attaining occasionally the length of $1 \frac{1}{2}$ inch, angular or compressed, rather stout, upwards thickened. Sepals somewhat cymbiform, blunt at the base, $2-4$ lines long, shining, glabrous or imperfectly ciliated; the inner ones with broad membranous margin. Petals sessile, white, tender-membranous, quickly collapsing, cleft to about three-fourths their length into two narrow- and oblique-oblong lobes, finely veined. Stamens 10. Filaments linear-setaceons, about as long as the sepals or somewhat shorter. Anthers dorsifixed, versatile, almost ovate, $\frac{1}{4}-\frac{1}{2}$ line long, consisting of two narrow-ellipsoid cells, bursting with introrse-marginal dehiscence. Pollen-grains yellow, spherical, smooth. Styles 3, free, glabrous, 1-2 lines long, capillary, white, stigmatose towards the summit inward. Ovary subglobose, glabrous, sessile, with many ovules. Capsule orate, about as long as the calyx. Valves coherent in pairs. Funicles unequal, mostly short. Seeds few or sereral in each capsule, only seen in an unripe state, when they are nearly globose, about $\frac{1}{2}$ line long, somewhat wrinkled and dark-brown.

Certain states of this plant bear great similitude to some varieties of the following species.

Stellaria glauca, Withering, Bot. Arrang. i. 420 ; Engl. Bot.t. 825; J. Hook. Fl. Tasm. i. 44; S. angustifolia, Hook. Journ. of Bot. i. 250.

Perennial, smooth or slightly scabrous; leaves linear, aeute; pedicels axillary and terminal, solitary; sepals lanceolate, very acnte, three-nerved; petals little longer than the calyx, bipartite; anthers red; capsule ovate, attenuated at the base, six-valred; columella very short; seeds brown, papillose-rough.

On moist rocky, grassy or sandy localities scattered over a considerable extent of the colony; adrancing beyond Victoria to St. Vincent's Gulf and to 'Tasmania and New Sonth Wales.

Stems variable in height, erect, strict or flaccid, sometimes intricate, tctragonous, usunlly distantly branched, smooth or slightly scabrid, emitting often from the lower joints capillary fibres. Leaves $\frac{3}{4}-1 \frac{1}{2}$ inch long, $\frac{1}{2}-1 \frac{1}{2}$ line broad, vividly green or opaque, one-nerved, slightly thickened and often a little scabrous at the margin, sessile, broadest towards the base. Pedicels from $2 \frac{1}{2}$ inches length rarionsly slorter, angular, more or less spreading. Sepals 2-4 lines long, smooth or imperfectly ciliolated; the inner ones with a broader, the outer with a narrower membranous margin. Petals white, with oblique- and narrow-oblong lobes. Filaments rather more than half or nearly as long as the sepals, linear-setaceous. Anthers oral, $1-\frac{1}{2}$ line long: Styles 3, capillary, about 2 lines long. Capsule nearly as long as the calyx or short exserted, somewhat attenuated at the base. Funicles of unequal length, capillary. Seeds in each capsule sereral or few, deep-brown, opaque, approximately $\frac{1}{2}$ line long, turgid, almost globose, rostellate. Enbryo uncinateannular, slender, almost entirely surrounding the albumen. Cotyledons abont as long as the rndicle.

The European Stellaria graminea, of which S. Frieseann, S. longipes and S. longifolia appear to be merely varieties, is distinct, as far as our limited material hcre admits of judging, in producing scarious bracts at the base of the pedicels, whilst the flower-stalls of $\mathrm{S}$. glauca arise from the axis of leares. It requires thereforc further investigntions to learn whether this cliaracter, which impresses on both plants quite a different habit, is validated by other collateral notes, or whether the floral lcaves are occasionally transformed into bracts. No transit exists in our specimens of St. graminifolia from Europe and North America to those of St. glanca. Excluded from the liere furnished description is the dwarf almost mossy Stellaria cxespitosa (J. Hook. in London Journ. of Botany, ii. 411), although very probably constituting only a variety of St. glauca. In this not only leares and flowers are reduced to a remarkable smallness, but also its stems 
and branches are quite interwoven and radicant, whilst the sepals are blunt. It grows along the banks of the Murray River and its tributaries, and on the adjoining lagoons in humid sandy soil, and resembles externally the Himalaian St. decumbens (Edgeworth, in Transact. Linn. Soc. xx. 35), which is, however, already recognized by its smaller petals and downy branches. States of St. cæspitosa exist, in which the filaments excel in length the sepals. The flowers of St. pungens and St. glanca bear the greatest resemblance to each other.

Stellaria media, Withering, Bot. Arrang. i. 418; Villars, Flor. Delph. ii. 615; Engl. Bot. 537; Sm. Engl. Flor. ii. 301 ; Wight, Icon. Plant. Ind. Orient. iii. 947; J. Hook. Flor. Tasman. i. 43; S. Hlaccida, Hook. Compan. to Bot. MIag. ii. 275; J. Hook. in Journ. of Bot. ii. 411; Alsine media, Linné, Spee. plant. 389.

Annual; stems weak, glabrous or imperfectly downy; leaves ovate, acuminate, or sometimes cordate or rhomboid or lanceolate, stalked or subsessile, glabrous or imperfectly ciliated; pedicels axillary and terminal, solitary or forming a leafy terminal cyme, often elongated; sepals lanceolate-ovate, one-nerved or indistinctly three-nerved; petals bipartite, seldom wanting; stamens 3-10; anthers purple, finally black; capsule deeply six-ralved; columella short; seeds brown, tuberculate-rough.

In shady humid places, on cultivated ground, in forest valleys, on the gravelly banks of rivers from the lowlands to the highest alps of Australia, perhaps indigenous. Frequent in the cooler parts of the northern hemisphere, transmigrated to most parts of the globe.

A flaccid, decumbent, laxly diffused or ascendent herb, very variable in size. Stems and branches almost cylindrical or quadrangular, conspersed with pale articulated soft short hair, or from joint to joint alternately unilateral-downy. Petioles broad, channelled, about as long as the leaf or shorter or almost obliterated, somewhat dilated towards the base, glabrous or ciliated. Leaves from 2 lines to about 1 inch long, opaque, saturated-green, of uniform color on both sides, flat, of tender herbaceous consistence, with a conspicuous midnerve and a faint intramarginal and spreading latcral nerves, finely and immersedly netveined, usually very slightly dotted-scabrous. Pedicels slender, almost capillary, about as long as or often longer than the leaves, attaining sometimes the length of $2 \frac{1}{2}$ inches, seldom quite glabrous, often scattered. hairy or lined on the inner side with soft whitish downs, in age usually bent downward. Sepals $1 \frac{1}{2}-2 \frac{1}{2}$ lines long, obtuse or acute or even occasionally acuminate, more or less conspersed with articulate hair, sometimes, however, quite glabrous; the inner oues transparent towards the margin; the midnerve more or less strongly developed or even evanescent towards the summit; the lateral nerves often only towards the base perceptible. Petals white, tender-membranous, from 1-4 lines long; deeply cleft into narrow-oblong lobes, finely veined; the undivided portion forming a short somewhat yellowish unguis. Filaments linear-setaceous, persistent, glabrous, about as long as the petals or somewhat shorter, externally at the base glandulous-tumescent. Anthers $\frac{1}{8}-\frac{1}{4}$ line long, versatile, consisting of two oblique-ovate or ellipsoid cells, bursting with introrsemarginal dehiscence; those of the normal variety at least verging from red through purple into black. Pollen-grains yellowish. Styles $\frac{1}{2}-1 \frac{1}{2}$ line long, recurved, internally stigmatose. Capsule ovate, hardly or considerably longer than the calyx, membranous, deeply cleft. Funicles arising fiom a short basal columna, mostly not so long as the seeds. Seeds in each capsule several, almost opaque or a little shining;, renateglobose, dark- or black-brown, about $\frac{1}{2}$ line long, seriate-tuberculate, slightly compressed. Embryo horseshoe-shaped, slender, cylindrical. Albumen conspicuous. Cotyledons about as long but a little broader than the radicle.

The plant, which inhabits our forests and alps, constitutes a race somewhat different to the ordinary form, which occurs here also as a common garden weed. The stems and branches are more quadrangular and rather scattered- than unilateral-downy; the leaves are usually sessile and somewhat ciliated; the sepals are often more acute and less indistinctly nerved; the petals and even the stamens are almost always longer than the calyx, and the styles are also more extended. It seems, however, as pointed out by Dr. Hooker, 
that we have to adopt these distinctions only as characteristic of a luxuriant variety, but not as those of a distinct species.

Stellaria multiliora, Hook. Compan. to the Bot. Mag. i. 275; J. Hook. in Journ. of Bot. ii. 411; Flor. Tasman. i. 43.

Annual, smooth; leaves narron-lanceolate, small, sessile; pedicels axillary and terminal, solitary, oftener shorter than longer than the leaves; sepals subulate-lanceolate, three-nerved; petals wanting; stamens 5-10, much shorter than the sepals; anthers jellow; capsule ovate or ellipsoid, six-valved; columella almost obliterated; seeds brown, minutely tubercled.

In sandy, grassy and rocky localities not uncommon within our territory, as well in the lowlands as in the mountain regions, ascending to the alps. Distributed also over the southern and eastern parts of the Colony of South Australia and over the whole of Tasmania.

Root producing many tender fibres. Stems usually many from each root, from 1 inch to about $I$ foot long, quadrangular, shining, weak, erect or ascending, sometimes radicant at the lower nodes. Leaves 2-6 lines long; acute, one-nerved, opaque, flat. Pedicels emerging solitary from almost every node, seldom I inch long, not rarely shorter than the calyx. Sepals $1 \frac{1}{2}-2 \frac{1}{2}$ lines long, with narrow membranous margin, smooth. Petals rarely present and then incomplete in number and developed in a diminutive rudimentary state, 1 line or less long, entire, roundish, one-nerved or nerveless, blunt or mucronulate, white, membranous, undivided ; their position normal. Filaments linear-subulate, only $\frac{1}{2}-\frac{2}{3}$ line long, confluent at the base into a narrow disk, some occasionally barren. Anthers very minute. Styles 3 , filiform, blunt, about $\frac{1}{8}$ line long. Capsule usually of the length of the calyx, ovate, occasionally longer than the calys and narrow-ellipsoid, deeply dehiscent; its valves mostly revolute at the apex, sometimes, however, quite straight. Seeds several or few in each capsule, renate-globose, $\frac{1}{3}-\frac{1}{2}$ line long. Embryo cylindrical, horseshoe-shaped. Cotyledons about as long as the radicle.

\section{COLOBANTHUS.}

Bartling, Reliq. Honk. ii. 13, t. 49.

Sepals 4-5. Corolla wanting. Stamens 4-5, alternate with the sepals. Ovary one-celled. Ovules numerous, inserted with long funicles to the basal or columnar placentæ. Styles 4-5, stigmatose at the summit, opposite to the sepals. Capsule membranous or chartaceous, perfectly or im. perfectly 4-5-valved; the valves alternate with the sepals. Seeds many, without a strophiole. Embryo semiannular.

Small usually tuft-growing or moss-like perennial plants, observed in the colder regions of South America, Australia, Tasmania, New Zealand, the Island of Amsterdam and the antaretic islands. Stems vaginate by the opposite leaves. Stipules wanting. Flowers very small, usually solitary.Fenzl, in Endl. Atakta, t. 4.9; Annalen des Wien. Mus. i. 48 ; ii. 273 ; Jos. Hook. Flor. Antarct. i. 248.

The relative position of sepals and stamens, in which regard Colobanthus approaches to many Portulaceæ, distinguish it from all other Australian genera of the order.

Colobanthus Billardieri, Fenzl, Amal. des Wiener MIuseums, i. 48; J. Hook. F. Antarctic. i. 14; Fl. N. Zeeland, i. 27; Fl. Tasm. i. 45; C. affinis, J. Hook. Fl. Tasm. i. 45; Spergula apetala; Labill. Nov. Holl. Plant. Spccim. i. 112, t. 142 ; S. affinis, J. Hook. in Joum. of Bot. ii. 410 ; Hook. Icon. Plant. t. 266.

Alnost stemless; leaves long, linear, very acute, Hat; flowers pentamcrous, on scape-like pedicels; sepals ovate or lanceolate, at the summit acute or subulate, longer than the stamens; capsule globose-ovate, about as long as or longer than the calyx; seeds numerous. 
On rocky hills near Warrnambool; Sam. Hannaford. Found also in Tasmania, where it extends from the northern to the southern extremity, from the shores to the alps; observed also in New Zealand and in some of the antarctic islands.

Root at first filiform and branched, later forming stout upwards fastigiate rhizomes, each terminated with a tuft of leaves and covered with the residues of vagina of former year's' growth. 'Stems very short, concealed within the tufts of leaves. Leaves rigidulous; the radical ones often curved, from $\frac{3}{4}-1 \frac{3}{4}$ inches long, less than 1 line broad, one-nerved, gradually upwards pointed, conspicuously thickened as well as slightly scabrous and often scantily ciliolated at the margin, dilated at the base into a clasping membranous vagina. Stem-leaves few, opposite, very short, concrete into a vagina. Pedicels smooth, stiff, especially towards the summit furrowed, terminating the short stems, long persistent, comparatively stout. Sepals of firm consistence, greenish, mucronulate, 1-1 $\frac{1}{2}$ line.long, slightly membranous at the margin. Stamens often only half as long as the sepals. Filaments linear-subulate. Anthers very minute. Styles 5, very short, longitudinally stigmatose. Capsule of firm consistence, 1-1 $\frac{1}{2}$ line long, ovate-globose, somewhat pentagonous. Valves after dehiscence often at the apex involute. Funicles penicillar, arising from the bottom of the capsule. Seeds many, brown, shining, almost egg-pearshaped, $\frac{1}{6}-\frac{1}{4}$ line long, very minutely areolated, with a darkel narrow line at the back. Embryo uncinate-hemicyclical.

Colobanthus pulvinatus, F. M. in Transactions Philosoph. Society Victor. i, 101 ; Hook. Kew Miscellany, viii. $7-8$.

Glabrous, stems moss-like, tufted; leaves crowded, rigid, squarrose, broadly triquetrous-subulate, channelled, short, pungent; vaginæ close; flowers pentamerous, on very short pedicels; sepals from a broad base lanceolate-subulate, nearly twice as long as the stamens, hardly longer than the broad-eggshaped capsule; seeds numerous.

On the barest gravelly sumnits of the Munyang Mountains, buried the greater part of the year under snow, not occurring below an elevation of 6000 feet. Seemingly the same species found by Dr. Hooker in Campbell's Island.

Stems very numerous, depressed and condensed into close mossy tufts, which sometimes extend over a considerable space of ground, Root ramified, descending. Leaves 2-4 lines long, smooth, sometimes less channelled, sometimes more trigonous, mucronate, dilated at the base into a membranous vagina, thickened

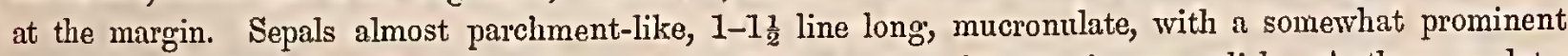
dorsal nerve. Filaments linear-subulate, connate into a very short perigynous disk. Anthers cordate, yellow, $\frac{1}{8}-\frac{1}{6}$ line long, bursting with introrse longitudinal dehiscence. Pollen-grains smooth, splerical. Styles extremely short, longitudinally stigmatose. Capsule about 1 line long, blunt at the base, cleft to about the middle into five valves. Funicles capillary, arising brush-like from the bottom of the capsule, partially.much longer than the seed. Seeds brown, shining, about $\frac{1}{4}$ line long, pyriform-ovate, slightly rough at the back. Albumen lateral-central. Cotyledons nearly half as long as the radicle.

This plant is perhaps not otherwise distinguishable from Colobanthus Benthami (Fenzl, in Endl. Atakta, t. 49; C. subulatus, J. Hook. Fl. Antarctic. ii. 247, t. 93), a Fuegian and Falkland Islands plant, than in its quinary floral parts.

Notwithstanding the great discrepancy in habit, we must regard C. pulvinatus as very closely allied to C. Billardierii, the flowers and fruits of both species exhibiting hardly any discrepancies.

Plate XI, 1, flower with its bracteal leaves; 2 , flower viewed from above; 3 , capsule; 4, vertical section of a capsule; 5 , transverse section of a capsule; 6 , valves; 7 , stamens, showing their relative position; 8 , front view of a stamen; 9 , back view of a stamen; 10 , pollen-grains; 11 , seed with funicle; 12 , longitudinal section of a seed; 13 , transverse section of a seed; 14 , leaves seen in their decussate position; 15 , a separate leaf; 16, a branch; 17 , a solitary stem, separated from the tuft: all figures variously magnified. 


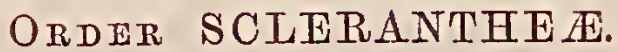

Link. Hort. Bot. Berol, i. $41 \%$.

Flowers bisexual. Calyx 4-5-cleft, its lobes imbricate in bud. Petals wanting. Stamens inserted to the orifice of the caly $x, 1-5$ fertile, opposite to its lobes, or 10. Anthers two-celled, rarely one-celled, bursting with introrse longitudinal dehiscence. Staminodia setaceous or scale-like, alternate with the fertile stamens or ranting. Ovary free, one-celled. Ovules 1 or 2 , suspended from the summit of a slender columella. Styles 2, free, introrse or at the summit stigmatose, rarely 1. Fruit utricular, valveless, enclosed within the tube of the calyx, one-seeded. Albumen unilateral-central, farinaceous. Embryo peripherical, incompletely annular.

Small herbaceous plants, distributed in a few species over the temperate regions of Europe, Asia, North America, Australia and New Zealand, represented by Guilleminia in the Andes of South America. Leaves opposite, exstipulate, connate at the base. Flowers small, cymose, glomerate, geminate or solitary. Calyx articulate at the base.-Lindl. Veg. Kingd. edit. iii. 528; Koch, Synops. Flor. Germ. \& Helvet. edit. ii. vol. i. 281; Tomey, Flor. of the State of New York, i. 107.

The series of thalamiflorous orders, comprised in this volume, terminates here with Scleranther, although these are strictly referable to the perigynous Curvembryonatx, bearing amongst them very close affinity to Paronychieæ. Since, howerer, of the latter family, no species are known from Australia, we prefer to array our Scleranthi with Caryophylleæ. The alliance of Sclerantheæ to Salsolacer is intimate.

\section{SCLERANTHUS.}

Linn. Gen. Plant. 562.

Calyx 4-5-cleft. Corolla none. Stamens 1-10. Anthers two-celled. Staminodia present or wanting. Ovary free, with one rarely two ovules. Styles two. Fruit utricular, enclosed within the tube of the calyx and dropping with the latter.

Anmual or perennial herbs, known from the extratropical parts of the northern hemisphere and of Australia, also from New Zealand. Leaves opposite, connate at the base, linear or subulate. Flowers small. Bracteoles geminate, persistent. Calyx usually indurated and the tube at the summit contracted.-Gortn. de Fruct. \& Sem. t. 126; Endl. Gen. 963; Gray \& Sprag. Gen. Flor. Bor. Amer. t. 102 ; Mniarum, Forst. Char. Gen. i. t. 1 ; Ditoca, Banks \& Solander, in Gortn. Carpolog. t. 126.

Scleranthus biflorus, J. Hook. Flor. Nov. Zeal.i. 74 ; MIniarum biflorum, Forst. Gen. 1.t.i.; Comment. Goetting. 9, t. 1; Lam. Eneycl. Method. t. 6 ; M. pedunculatum, Labill. Nov. Holl. Plant. Specim. i. 8, t. 2; Poir. Encycl.t. 901 ; MI. fasciculatum, R. Br. Prodr. i. 412; Hook. Tcon. Plant.t. 283; Ditoce muscosa, Banks \& Soland. in Gertn. Carpolog. ii. 196, t. 126. 
Densely tufted, pereunial; leaves linear-subulate; pecluncles solitary, bearing at the summit a pair of flowers and four decussate semilanceolate-cymbiform bracteoles; lobes of the ealyx 4, convergent or erect, shorter than the tube; stamen 1 , about half as long as the limb of the calyx ; staminodia none.

Abundant on the alpine and subalpine plateaus and ralleys through all the clains of our snowy mountains, seldom, and only in the vicinity of the alps, descending to about 3000 feet, seen very rarely (for instance at the foot of the Nungatta Mountains) as low as 2000 feet; in the cooler climate of Tasmania descending. from the higher ranges quite to the lowlands; found in the elevated regions of the Blue Mountains by Miss L. Atkinson, on Ben Lomond and Mount Mitchell in New England, and on the sources of the Clarence River by Dr. H. Beckler. Originally gathered by Banks and Solander and by R. and G. Forster in New Zealand.

A remarkable plant, forming dense moss-like patehes of various sizes, often expanding into large cushionlike masses. Stems very numerous, procumbent, densely intricate, more or less branched, almost semicylindrical or nearly terete, slightly scabrous-downy or smooth, emitting rootlets fiom the lower nodes. Root in age woody, upwards ramified. Leaves opposite or by innovation fasciculate, usually between 2 and 8 lines long; concrete at the base into a very short vagina, slightly keeled, more or less spreading or recurved, somewhat scabrous at the edges or smooth, acute or short mucronulate, more or less channelled. Peduncles variable in length, sometimes very short and concealed between the leaves, sometimes extended to nearly one inch length, compressed-filiform or semicylindrical, glabrous or slightly scabrous at the edges, occasionally faintly thickened upwards. Bracteoles 4 at the summit of each peduncle, decussate; those of the outer pair cymbiform-connate and about $\frac{1}{2}$ line long; those of the inner pair smaller. Flowers geminate, quite or almost sessile. Calyx ribless or indistinctly ribbed, smooth, about $I$ line long, of rather thick somewhat pergamentaceous consistence, urceolate-ovate; the tube soon livid and turgid; the lobes 4 rarely 5 in number, semiovate or semilanceolate; the fruit-bearing calyx readily secedent. Filaments glabrous, linear-setaceous, $\frac{1}{4}-\frac{1}{3}$ line long. Anthers yellow, about $\frac{1}{8}$ line long, consisting of two ellipsoid cells, which dehisce at the margin. Pollengrains egg-shaped, smooth, with longitudinal fissures. Styles $\frac{1}{4}-\frac{1}{2}$ line long, sometimes short exserted, capillary-setaceous, longitudinally stigmatose. Carpel broad- or globose-ovate, rostellate, pale, about $\frac{1}{2}$ line long, except the apex membranous. Seed alike to those of all other Scleranthi perfectly filling the cavity, pale-yellowish, smooth, apiculate, borne on a very narrow and tender funicular columella. Hilum infraterminal. Embryo incompletely annular. Cotyledons about as long as the superior radicle.

Scleranthus mniaroides.-Mniarum singuliflorum, R. M. in Transaet. Phil. Soe. of Victor. i. 13. Tufted, perennial; leaves linear-subulate; peduneles solitary, bearing at the summit a single flonor and two orbicular-rhomboid incompletely confluent bracteoles; lobes of the ealyx 5, convergent or ereet, shorter than the tube; stamen 1 , about half as long' as the limb of the calyx; staminodia none.

In the glacier-regions of the Anstralian Alps, not descending to an elevation of less than 5000 feet.

This species requires no detailed description, being, except in the notes pointed out, but very slightly different from $\mathrm{S}$. biflorus. The stems are less closely tufted; the bracteoles, which are closely appressed, disunite to some extent by an interjacent sinus. The utricular carpel is lagenar-globose.

PLATE XII. 1, leaves and peduncles with and without fruit; 2, terminal portion of a leaf; 3, calyx during anthesis; 4 , calyz past anthesis; 5 , flower laid open ; 6 , the same seen from above; 7, fruit-bearing calyx; 8 , part of -calyx with the stamen; 9 , stamen; 10 , pollen-grains; 11 , carpel, partially laid open; 12 , styles with part of calyx and fruit; 13 , fruit; separated; 14, seed; 15, vertical section of the seed; 16 , transverse section of a seed: all figures to various extent magnified.

Scleranthus diander, R. Br. Prodr. i. 412; J. Hook. Fl. Tasm. i. 42.

Perennial, erect or ascendent; leaves trigonous-subulate, mucronulate; flowers in sessile clusters, lobes of the ealyx 5, as long as the tube or longer, aeute; stamens 2 , much shorter than the limb of the calyx; perigynous ring: entire or slightly denticulated. 
On subalpine meadows through most ramifications of the Australian Alps; extends to the Tasmanian island.

A perennial herb, from a few to many inches long. Root woody, emitting numerous flexuose often tastigiate-branched stems. Branches cylindrical or semicylindrical or somewhat compressed, glabrous or very finely downy. Leaves $2-6$ lines long, towards the base along the edges somewhat scabrous and ciliolated; the floral leaves sometimes very small. Vagina very short. Clusters of few or several flowers at the summit of the branches or in the axils of the upper leaves. "Bracteoles $\frac{2}{3}-1$ line long, lanceolate, halfmembranous, quite glabrous, connate at the base, persistent. Flowers sessile or on very short pedicels, glabrous, 5- rarely 4-cleft, 1-11 line long; the tube broad-obconical, indistinctly ribbed; the lobes lanceolate. or deltoid-orate, towards the margin pale-membranous, erect or somewhat spreading in age. Filaments linear-setaceous, hardly or little longer than the anthers. The latter roundish-cordate, yellow, about $\frac{1}{8}$ line long; the ellipsoid cells bursting with marginal dehiscence. Pollen-grains almost globular, smooth. Staminodia not distinctly developed in those specimens subjected here to examination, scale-like according to $\mathrm{R}$. Brown, filamentous according to Jos. Hooker. Styles free, capillary, reaching to near the summit of the caljx, inward stigmatose. Utricular caryopsis nearly globose, cylindrical-rostrate, membranous. Seed paleyellow, hardly $\frac{1}{2}$ line long, smooth, almost spherical, slightly pointed. Albumen rather copious, anylaceous. Embryo imperfectly annular.

By some intermediate forms from the upper granitic valley of the Snowy River this species seems to pass into a desert plant, which extends along the Murray to the Wimmera and Lake Alexandrina. This desert variety bears flowers already in the first year of growth, thus assuming the appearance of an annul plant; its flowers are nsually more distinctly pedicellate and occasionally scattered; the tube of the calys is generally campanulate; the lobes of the latter are often remarkably narrow, subulate-semilanceolate and thus but slightly membranous at the margin, but considerably longer than the tube and singularly dirergent; the styles are shorter than in the alpine variety; the seed is almost pear-shaped, fulvid, with infiaterminal hilum. This desert variety may in some points be compared to the British Scleranthus annuus.

Scleranthus pungens, R. Br. Prod. Flor. Nov. Holl. 412.

Ascending; leaves trigonous- or linear-subulate, mucronulate; flowers in sessilc clusters; calyx deeply five-cleft; the lobes membranous, spreading, orbicular- or lanceolate-ovate, usually acuminate, contracted at the base; stamens 5, as long as the calyx or longer; staminodia 5, linear-setaceous.

On barren ridges and plains of the north-western desert. Extending through part of the Mrurray scrub of South Australia; found also on the desert near Spencer's Gulf and the Flinders Ranges.

A seemingly perennial plant. Stems laxly tufted, flexuose, of several inches length, branched, smooth or slightly scabrous, terete or upwards semicylindrical, occasionally emitting rootlets from the nodes. Leares united at the base into a very short vagina, smooth or at the edges partially scabrous, by innovation often fasciculate, 3-8 lines long, somewhat broader than in any other species, with stems and brancles yellowishpallescent in age. Flowers several or many, sessile, forming terminal and towards the summit axillary clusters, surrounded by leaves. Bracteoles lanceolate- or linear-cymbiform, about 1 line long. Lobes of the calyx 1-1 $\frac{1}{2}$ line long, with exception of the often faint dorsal line quite membranous, during anthesis mucl longer than the tube. Staminodia shorter than the stamens and alternate with them, occasionally very short. Fertile stamens opposite to the sepals, linear-setrceous, glabrous, sometimes stretching considerably beyond the calyx. Anthers cordate- or ovate-round, about $\frac{1}{4}$ line long, consisting of two parallel ellipsoid cells, which burst with marginal dehiscence. Ovary short-stipitate, glabrous, upwards gradually contracted, Styles 2 , about $\frac{1}{4}$ line long, capillary, longitudinally stigmatose. Fruit as yet unknown.

The European Scleranthus perenuis shows filnments nearly ns long as the calyx, and thus far approaches nearest to the short-filamentose state of $\mathrm{S}$. pungens, from which, however, the narrow leaves, cymose info. rescence, small flowers and semipetaloid lobes of the calyx render it already very distinct. 


\section{AD D ITIONS.}

\section{Caltha INTROLOBA-p. 10.}

Found recently also on ooggy moors of the Baw Baw Mountains and of the Albert Ranges, and also on the Haidinger Ranges at the sources of the Macallister River. Noticed also in the alpine western mountains of Tasmania by Mr. W. Archer.

The petioles attain sometimes the length of 6 inches; the peduncles are occasionally still longer. Filaments about 2 lines long, linear-setaceous. Anthers ellipsoid, yellowish, about $\frac{1}{2}$ line long. Carpels extending sometimes to the length of $2 \frac{1}{2}$ lines. Seeds about $\frac{2}{3}$ line long, shining, smooth, fulvous. The Veronica, with which this plant is consociated on the Munyang Mountains, is V. densifolia (F. Mr. Fragm. ii. 137).

\section{Brasenia peltata-p. 12.}

The occurrence of this plant in Khasia and Bhotan (conf. Hook. \& Thoms. Fl. Indic. i. 246) and in Japan (conf. A. Gray, Bot. Statist. of Unit. States) renders the distribution of this plant less isolated and singular than previously supposed.

\section{Hibbertia Billardierit-p. 14.}

The locality of Spencer's Gulf, assigned to this plant, must be regarded as doubtful.

Jribbertia dentata, R. Br. in Cand. Regn. Veg. Syst. Nat. i. 426 ; Bot. Mag. 2338; Bot.Reg. 282; Loddig. Cabinet, 347; Loisl. Herbier Gén. de l'Amateur, t. 306; Spach, Hist.Nat. des Végét. t. 59.

Steins creeping or scandent; leaves large, long-stalked, ovate, repand, crenate or serrate, glabrescent, rather acute; the teeth remote, short-mucronulate; peduncles bracteate at the base, solitary, as long as or longer than the ebracteolate calyx; sepals cuspidate, roundish, or the outer ones broad-ovate; the inner alnost membranous; petals cuneate-obcordate, cuspidulate; stamens very numerous; anthers ovate, much shorter than the filaments; ovaries usually 3, glabrous; carpels 3-5-seeded; seeds black, minutely reticulated; arillus jagged-fringed, glutinons, longer or somewhat shorter than the seed.

In stony forest-declivities near the Genoa River, on the Genoa Peak and in other localities at the south-eastern limit of Gipps Land; thence extending through New South Wales to the MacLeay River.

A beautiful climber or trailer, extending to the length of several or many feet. Branchlets brown, at first soft-liairy, soon glabrescent. Petioles channelled, rather broad, slightly and gradually dilated and clasping at the articulated base, finally from $\frac{1}{2}-1$ inch long. Leares $1 \frac{1}{2}-3$ inches long, scantily hispidulous on both pages when young, calrescent in age, or from the beginning hairless; much paler beneath, conspicuously one-nerved, traversed by ascending secondary nerves; the teeth or crenatures terminated by a short mucro- Peduncles arising from lateral short or alnost undeveloped branchlets, from $\frac{1}{2}-1$ inch long, usually downy with soft brown-grey pubescence, sometimes smooth, provided at or near the base with a membranous brown lanceolate- or linear-subulate bract, which measures $2-3$ lines, and is outside appressedhairy. Sepals varying. from ' $3-6$ lines in length, outside clothed with more or less copious or scattered 
appressed hair, inside smooth, at the margin ciliate, terminated with a longer or shorter cuspis; the outer ones foliaceous. Petals about one-third longer than the calyx, bright-yellow, smooth, penninerved, reined. Stamens much shorter than the calyx. Filaments thickened at the summit. Anthers about $\frac{1}{2}$ line long; yellow, opening with marginal dehiscence. Styles excelling a little the length of the stamens, setaceous, glabrous, with minute depressed stigma. Carpels $2-3$ lines long, inside and outside smootl. Seeds hardly longer than 1 line, slining, from dark-brown turning black, renate-globose, with a whitish or livid membranous nore or less clammy aril.

The species nearest related are $H$. grossularifolia and $H$. volubilis. The former is a smaller not climbing plant, restricted to South-West Australia, with almost orbicular leaves, and with 10-15 ovaries, which are hairy at the summit. $H$. volubilis, which may possibly occur in our eastern territory, differs in toothless lanceolate leaves tapering into the petiole, in larger sessile or short-stalked flowers, in longer acuminate outside silky sepals, in larger linear anthers, which are about as long as the filaments, in 5-8 ovaries and styles, and in seeds deprived of an aril.

Drims aromatica-p. 20.

On the alpine summits of the Baw Baw Ranges, where this species as a small shrub very copiously occurs, tetrogynous flowers were not unfrequently noticed, developing all four carpels to maturity.

\section{Order. ANONACE E.}

Juss. Gen. 283.

Flowers bisexual, rarely unisexual. Sepals usually 3 , and valvate in æstiration, or the calyx rarely valveless and circumcised. Petals 6 in two rows, valvate or less frequently imbricate in xstivation, sometimes 3 , seldom wanting. Stamens almost constantly indefinite and multiseriate. Anthers two-celled, bursting with lateral or extrorse dehiscence. Ovaries indefinite, rarely definite, free or coherent or concrete, with one or more orules in each. Carpels scssile or stalked, free or into a many. celled fruit united, dry or pulpose. Albumen large, ruminated. Enbryo small, lodged at the base of the albumen.

Aromatic trees or shrubs, not rarely scandent, ratlier frequent within the tropical and subtropical zones of Asia, Africa and Amcrica, rare in Australia, rare also or absent in the temperate zone, entirely wanting in colder regions. Leares alternate, entire. Stipules veanting. Arrangement of flowers various. Filaments usually rery short. Connective of antlicrs generally broad.-Dunal, ITonogr. des Anon. 1817; Alph. de Cand. in ILém. Soc. Phys. Genèv. v. 177; Endl. Gen. 830; J. Hook. \&. Thoms. Flor. Indic. i, 86-91.

Eupomatia is herc admitted, not without reluctance, as a genus of Anonacex, according to the views cnunciated by R. Brown and supported by most phytologists. Nevertheless the anomalies in the structure of the flowers and fruit of this plant are so great, as to entitle it pcrlaps to ordinal distinction, and to a place in the vicinity of Laurineæ. 


\section{EUPOMATIA.}

R. Br. in Flind. Voy. ii. 597.

Calyx ovate or globose-ovate, valveless, circumcised near the base. Petals none. Stamens exterior, perigynous, bent outward. Filaments conspicuous, dilated towards the connate base. Anthers pointed. Staminodia petaloid, interior, numerous, imbricate, connivent. Ovar'y inferior, inordinateand indefinite-manycelled, with several ovules inserted to the inner angle of each cell. Stigmas minute, sessile, very depressed. Fruit baccate, concrete with the calyx, flat and areolate at the summit, many-seeded.

An arborescent shrub, ranging over extratropical and subtropical Eastern Australia, assigning to Anonex its most southerly geographical extension. Leaves large, very shining. Peduncles axillary, one-flowered.-Endl. Gen. 834 .

Eupomatia laurina, R. Br. in Flind. Voy. ii. 597, t. 2.

In forest-glens along rivulets near the south-eastern boundary of Gipps Land. Thence extending to Moreton Bay.

A large evergreen shrub or small tree, attaining however in deep irrigated forest-ravines the height of 40 feet, in all parts glabrous. Branchlets terete, striolate, more or less flexuose. Leaves chartaceous or thincoriaceons, alternate, almost distichous, from 2-8 inches long, ovate-lanceolate or ovate, more or less aciminate, flat, entire, shining on both pages with a beautiful histre, occasionally particularly the young ones with a purplish shade, dark-green abore, with a prominent midrib and thin-netted veins, secedent with the petrole, which is somewhat curred and only from $1 \frac{1}{2}$ to a few lines long. Flowers solitary, terminal in short axillary brancllets or on mere peduncles arising from the axis of the leaves. The proper peduncle but a ferr lines long, gradually upwards thickened. Flowers of a strong macis-scent and taste. Calyx palegreen, opaque, finally brownisl, before dehiscence globose-ovate and about $\frac{1}{2}$ inch long, circumcised below the niddle; the opercular portion without distinct sutures, but traversed by subtle nerves and veins. Fertile stamens inserted in several rows below the margin of the persistent part of the caly $x$, connate at the base. Filaments flat, broad, dilated towards the base, glabrous, $1 \frac{1}{2}-2$ lines long. Anthers erect, linear, from $1 \frac{1}{2}-2$ lines long; the connective protracted into a terminal cuspis; the cell bursting along the outer margin. Staminodia as well as the stamens connate at the base into a flat ring, which is adnate to the inner margin of the calyx-tube, from which this portion of the flower wholly and simultaneously secedes. Staminodia forming sereral rows, bent inward, petaloid, ovate; the outer ones from 2-3 lines long; the inner ones shorter; all glabrons, slightly cartilaginous at the margin, entire or faintly crenulated. Ovary turbinate, with several orules affixed to the inner angle of the numerous and irregularly distributed cells. The vertex of the ovary flat, orbicular, with as many areoles as cells, each terminated with a small depressed stigma. Fruit baccate, often pruinose, turbinate- or urceolar-hemispherical, $\frac{1}{2}-\frac{3}{4}$ inch long, green and soft when fresh and ripe, of strong aromatic odor and taste, edged around the summit by the narrow slightly expanded margin. Seeds 1 or 2 rarely 3 ripening. in many of the cells, surrounded by a slight quantity of tough pale pulp, more or less egg-shaped, about 2 lines long, by mutual pressure variously angulate, slightly wrinkled and foreolate. Chalaza terminal. Testa livid or pale-brown, shining. Endopleura extremely thin. Albumen fleshy, deeply wrinkled, particularly a narrow fold penetrating into the albumen along the raphe. Embryo several times shorter than the albumen, lodged at its base. Cotyledons oval, flat, about as long as the cylindrical radicle.

It remains ạs yet doubtful, whether E. Bennettii (F. M. Fragm. Phytogr. Austr. i. 45), on account of glandulous and tufted-downy staminodia and some other as yet imperfectly compared characters, can be distinguished from E. lanrina. 


\section{Hedycarya Pseudonorus-p. 23.}

Under this name $\mathbf{H}$. Cunninghami, lately receired from extratropical and subtropical Eastern Australia, seems combinable with $H$. racemosa. Carpels drupaceous, when fresh sometimes 2 lines long. Putamen finally almost black. Integument of the seed very thin, membranous, pallid, smooth. Embryo hardly half a line long, as well as the albumen whitislı; the former considerably shorter than the latter. Cotyledons broad. ovate. Radicle obconic-cylindrical, about as long as the cotyledons.

\section{Atherosperma soschatum-p. 24.}

Branchlets almost silky; leaves thich-coriaceous, imperfectly sharp-serrate, rarely entire, lanceolate or ovate, rather blunt at the base, acute at the apex, corered beneath with a glaucous exceedingly short indu. ment; peduncles one-flowered; bracteoles at the apex of the peduncles large, ovate, outside velret-downy, inside silky; flowers large, declinous; calyx outside silhy, eight-cleft; the female calyx with cup-shaped tube; staminodia lanceolate- or linear-subulate, silky; fruit-calyx truncate, almost cup-shaped, ralveless, indeliscent.

Atherosperma micrantlum (Tulasne, in Archives du Mus. d'Hist. Natur. p. 421, t. 34), which occurs in the forests from the Hastings River to Moreton Bay, has an obverse clarate-cylindrical outside glabrous fruit-calyx, which bursts with a longitudinal fissure, being besides imperfectly divided into a few ralves and measuring about $\frac{2}{3}$ inch in length. The inner walls of the calyx as well as the style are covered with long soft hair of grey-brown color. The apex of the style is white-silky; the limb of the fruit-calys is short, almost glabrous, long persistent and membranous. From the above notes it will be evident that this plant slould be placed into the subgenus Laurelia of Atlerosperma.

The bark of A. moschatum has lately been subjected to a careful chemical analysis by Dr. Wittstein of Munich. For remarks on the Atherospermin, the essential oil and the other substances of the bark and their medicinal value, refer to Dr. Wittstein's memoir, and to the report of the jurors of the Victorian Exhibition of 1862. A pharmacological description of the bark is recently offered by Dr. O. Berg.

\section{STEPHANIA.}

Loureiro, Flor. Cochinchin. 747.

Flowers diøcious. Male: Sepals free, 6-10, biseriate. Petals 3-5, minute, fleshy. Connective disk-like, raised on the staminal column, girded by 6-8 horizontal one-celled anthers. Female: Sepals free, 3-5. Petals as many, fleshy. Stigmas 3-6, subulate, unequal, finally by inversion basilar. Carpel solitary, drupaceous. Putamen tuberculate and turgid at the back, impressed at the sides, without vacous cells. Seed horseshoe-formed. Albumen scanty, homogenous. Cotyledons apposite. Radicle inferior.

Scandent shrubs, indigenous to the tropical and subtropical regions of chiefly the eastern hemisphere, seldom far extratropical. Leaves generally peitate. Umbellules paniculate or umbellate. Flowers minute.-Endl. Gen. 827 ; J. Hook. \& Thoms. Flor. Indic. i. 195 ; Clypea, Blume Bijaragen tot de Fl. vans Nederl. Indie, 26.

Stephania hernandifolia, Walp. Repert. Bot. Syst. i. 96; J. Hook. \& Thoms. Fl. Indic. i. 195́; S. discolor, Walp. l. c.; Hassl. Pl. Javan. Rarior. 168; S. Abyssinica, Walp. 1. c.; A. Rich. Flor. Abyss. t. iv. fide J. Hook.; S. venosa, Walp. l. e.; S. glaucescens, Walp. l. c.; S. Australis, Miers, in Amal. and Mag. of Nat. Hist. 1851 ; S. Forsteri, Asa Gray, in Wilk. Unit. Stat. Explor. Exped. Bot. i. 36; S. Gau- 
dichandii,-A. Gray, l.c. 37 ; Cissampelos hernandifolia, Willd. Spec. Plant.iv. 861 ; Clypea hernandifolia, Wight \& Amott, Prodr. i. 14; Wight, Icon. Plant. Ind. Orient. t. 939; Spicileg. Neilg.t. 7 ; Cocculus Forsteri, Cand. Syst. i. 517.

Leaves peltate, cordate-orbicular, acute or acuminate, entire; umbellules capitate.

In forest-glens on the south-eastern frontiers of Gipps Land; thence through the woods of the whole eastern coast-tracts of Australia, ascending in New England to the height of 3000 feet; scattered over North Australia, extending westward at least as far as the Victoria River'; frequent in tropical Asia and also in some parts of tropical Africa, also in several of the South Sea Islands.

A dicecious shrnb with winding branches, ascending to considerable height. Branches terete, slightly furrowed. Petioles from $\frac{1}{2}-3$ inches long, less frequently longer, cylindrical, slightly channelled, near the base more or less tristed, soon glabrous, streaked. Leares chartaceous, flat, $1 \frac{1}{2}-4$ inches long, radiatingnerved, net-reined, above slining, glabrous and dark-green, beneatl paler and clothed more or less copiously or scantily with short grey jointed hair, affixed to the petiole usually $\frac{1}{2}$ or $\frac{3}{1}$ of an inch above the basal margin, rouuded-truncate or slightly simuted at the base, rarely with deep basal sinus. Umbels axillary, decompound or proliferous-paniculate. Universal peduncle cylindrical, glabrons or from articulated spreading hair downy, at the base minutely bracteate, $\frac{1}{3}-1$ inch long. Secondary peduncles few or many, shorter than the general one, sometimes again divided, longer than the narrow-linear bracts. Umbellules depressed, little longer than the linear-subulate bracteoles. Male flowers: Sepals 6-8 in two rows, nnequal, abont $\frac{1}{2}$ line long; green, papillose, puberulous, ovate- or orbicular-cuneate, in front repand. Petals $3-4$, renate or rhomboid, carnulent, green, depressed, shorter than the sepals, clasping the staminal column. The latter cylindrical, green, hardly as long as the calyx, at the summit expanded into a disk-like connective. Anthers 6-8, one-celled, whitish, encircling horizontally the periphery of the connective, bursting lengthwise, confluent into a continous ring. Pollen white, consisting of smooth globules. Female flowers : Sepals rather more than $\frac{1}{2}$ line long, slightly downy, cuneate-oborate, deciduous. Petals glabrous, rhomboid- or orbicula1obovate, about as long as the calyx and as well decidnous. Ovaries glabrous, uncinate-obpyriform, free, terminated, with 3-6 very minute subulate or dentiform divergent stigmas. Carpels orauge-red, in exsiccation nigresceut, round, with oblique contracted base, compressed when dry, glabrons, around the margin wrinkled and turgid, at both sides impressed, 2-3 lines long, somewhat larger when fresh. Pericarp succulent. Endocarp or putamen crust-like, transversely tuberculate-costate. Embryo three-fourths annular, cylindrical, white, surrounded by scanty albumen, $\frac{1}{3}$ line thick. Cotyledons rather shorter than the radicle.

According to the new arrangement of Menispermer by Miers, the hitherto known Cocculi of tropical Australia are to be placed into the genera Tinospora and Pericampylus (conf. Benth. in Proceed. Linn. Soc. v. Second Suppl. p. 52). To these, as Australian, Pachygone should be added, and also an. undetermined genus from the nortll-east coast. It may be anticipated that the members of this order will receive yet. additions from the litoral tracts of tropical Australia.

\section{Sarcopetalum Harveyainum- -27.}

Petals pale-yellowish. Stamens 2-4. Recent fruit, received from W. Woolls, Esq., almost pear-shaped, 3-4 lines long. Embryo semiannular, cylindrical, lying within copious albumen. Cotyledons nearly as long: as the radicle, opposite.

\section{Turritis Glabra-p. 33.}

Occurs also in New England, perhaps as an indigenous species. This plant has as yet never been found in Australian lowlands.

Cardauine dictyosperma-p. 35 .

Extends to New England and the Clarence River. 


\section{MENKEA.}

Lehmann, Index Sem. Hort. Hamburg. 1843, p. 8.

Sepals equal at the base. Petals oblong-obovate, entire. Stamens free, without teeth. Stigmas united, subsessile. Silicles orbicular- or obovate-elliptical, flat or slightly turgid. Valves one-nerved, deciduous. Septuriv obliterated. Funicles mostly elongated. Replum persistent. Seeds numerous, almost quadriseriate, without a border. Cotyledons incumbent.

Annual herbs, restricted to the extratropical desert-tracts of Continental Australia, Leares entire or the lower ones toothed. Pedicels racemose, bractless. Flowers very small. Petals white-Bunge, in Lehm. Plant. Preiss. i. 259.

A genus allied to Stenopetalum and more particularly to Capsella.

Irenkea procumbens, F. AT. Fragn. Phytogr. Austr. ii. 142; Stenopetalum procumbens, Hook. Icon. Plant. 610.

Leaves spathulate- or cuneate-oblong; silicles shorter than the pedicel or hardly as long, orate or elliptical, slightly turgid.

In the Murray desert. Found also near the Darling River and in South-Western Australia.

A small glabrous herb of great resemblance to Capsella elliptica. Root pallid, slender, filiform, descending, flexuose, almost simple. Stems filiform, from 2 inclies to nearly a span long, several from each root, spreading. Lenves 2-6 lines long, the lower ones occasionally with a few teetl. Pedicels when flowerbearing very short, when fruit-bearing $2-4$ lines long, capillary. Sepals oblong, somewhat shorter than the corolla, about $\frac{1}{2}$ line long, reddish. Petals white, lather narrow. Anthers very minute, yellowish. Stigmas exceedingly small. Silicle usually ovate, about 2 lines long, strongly compressed. Valves membranous, finely veined. Funicles extremely tender, $\frac{1}{8}-\frac{1}{3}$ line long. Seeds numerous, roundish, fulvous, about $\frac{1}{8}$ line long.

Menkea Australis (Lehm. l. c.; Stenopetalum draboides, Hook. Icon. 617) differs principally in the shortness of the pedicels, which are in length much exceeded by the silicles, the latter being moreorer larger and of a more oblong form.

\section{CAPSELLA ANTIPODA-p. 44.}

Found on the plains near Carisbrook by the Rev. W. Whan.

\section{LEPIDIUM RUDERALE-p. 45.}

A variety with spinescent branches was discovered near Skipton by the Rev. W. Whan.

LEPIDIUM PAPILLOSUM-p. 46.

Radical leaves pinmatifid. MIr. A. Oldfield brought from the vicinity of the Murchison River, in $\mathrm{W}$. Australia, a downy variety, further remarkable for the wide terminal sinus of the capsule.

LEPIDIUM MONOPLOCOIDES-p. 47.

Noticed also-in the Darling Desert.

LEPIDIUM LEPTOPETALUM- $p .48$.

From this species the Iberis linearifolia proves distinct, forming only a variety of Lepidium rotundum (Cand. Syst. ii. 537; Hook. Icon. 609), standing therefore nearer to L. phlebopetalum. 


\section{STENOPETALUMI VELUTINUM-p. 49.}

Extends to the upper tributaries of the Darling River.

In summing up the Cruciferous plants of Australia (conf. p. 51) we have to add the Western Australian Geococcus pusillus (Harvey, in Hook. Kew Misc. vii. 52), also Lepidium strongyloplyllum and Thlaspi ochranthum from the Darling Desert, the two latter as yet imperfectly known.

On the heath near Portland. W. Allitt.

$$
\text { Drosera Pygurea-p. } 56 .
$$

Drosera Arcturi-p. 57.

On the Baw Baw Momntains and on the sources of the Yarra Yarra.

On the Murchison River. A. Oldfield.

$$
\text { Drosera Indica-p. } 58 \text {. }
$$

On the Buneep Creek.

$$
\text { Drosera spatulata-p. } 60 .
$$

Drosera auriculata.-p. 61.

In East Australia at least as far north as the Clarence River.

Ionidium Vernonli.-Herbaceous, glabrous, stem simple or not much branched, angular; leaves all alternate, lanceolate- or broad- or narrow-linear, entire; stipules extremely minute, clavate-filiform; peduncles axillary, one-flowered, about as long as the pedicel, many times shorter than the flower, bibracteolate at the summit; sepals semilanceolate, acuminate; paired petals blunt, scarcely longer than the calyx, the upper ones one-nerved, all several times shorter than the blue orbicular or broad-ovate unguiculate labellum; anterior filaments with a globular gland; anthers terminated with two exceedingly minute teeth.

On barren plains and ridges near the Genoa River; also near Twofold Bay, and according to Mr. W. Woolls and Mr. W. Vernon likewise to be found near Port Jackson.

Root perennial, cylindrical, pallid, finally divided into flexuose branches. Stems generally numerous, sometimes few or one, especially upwards as well as the branches remarkably angular, occasionally somewhat scabrous, already flowering during the first $y^{2}$ ear of growth. Leaves $\frac{2}{3}-1 \frac{1}{3}$ incli long; $\frac{1}{2}-2$ lines broad, sessile, one-nerved, tapering into the base and the apex, very faintly veined, flat or very slightly at the margin revolute; rarely some cuneate-obovate; the lower ones early falling; the floral leaves sometimes nuch reduced in size. Stipules almost gland-like, only about $\frac{1}{4}$ line long. Flowers constituting along the summit of the

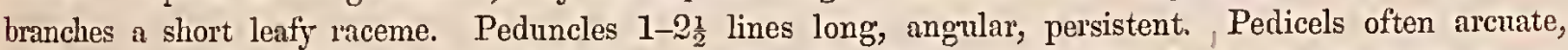
furrowed, deciduous. Bracteoles membranous, semilanceolate, finely one-nerved, about $\frac{1}{2}$ line long; persistent, glabrous, Sepals about $1 \frac{1}{2}$ line long, finely three-nerved, broader and narrower semilanceolate. Lower pair of petals quadrate-ovate, $1 \frac{1}{2}-2$ lines long; finely five-nerved; upper pair about 1 line long; nearly ovate. Labellum finely fabellate-reined, about $\frac{1}{2}$ inch long; tapering into an unguis and short saccate base, there bicarinulate and slightly bearded. Staminal glands greenish, smooth. Filaments extremely short, marrow, flat, glabrous. Terminal appendage of the anthers orange-colored, membranous, glabrous, semiovate; cells of the anthers elliptical; connective outside slightly downy. Style glabrous, about $\frac{2}{3}$ line long, clavatefiliform, geniculate at the base. Stigma truncate. Ovary almost spherical, smooth. Fruit as yet unknown.

Gingins' short diagnosis of Pigea filiformis responds fully to the plant here described. But since all subsequent writers on these plants, except Don (Gen. Syst. of Dichl. Plant. i. 336), combine I. filiforme with 
I. monopetalum, it was found requisite to distinguish our plant under a new appellation. In choosing that here adopted the author wishes to express a mark of acknowledgment for much aid, which in forming collections of plants in the classical fields around Port Jackson, he experienced from Mr. W. Vernon of Sydney.

I. monopetalum may readily be recognized by the notes early offered by Roemer and Schultes (Syst. $r$. 400), but which have not been sufficiently recorded by Gingins (in Cand. Prodr. i. 307). These notes consist in terete stems, (partially) opposite leaves and two-flowered long peduncles, and these point solely to the plant, which at page 66 of this volume has been referred to I. filiforme, in accordance with the riews of D. Dietrich (Synops. Plant. i. 838), of Steudel (Nomenclator Botanic. i. 814) and of Asa Gray (Botany of Unit. Stat. Explor. Exped. i. 87), although it must be admitted, that only by comparison of authentic specimens it can be ascertained, whether $I$. filiforme is not rather to be sought in the here described new species. If I. filiforme should prove identical with.I. monopetalum, the former name would remain preferable, since Schultes' designation conveys an erroneous idea of the structure of the flower. As pointed out at page 68 of this work, our new Ionidium has many notes in common with I. enmeaspernum (Vent. Malm. p. 27), of which I. suffiuticosum (Roth, in Roem. \& Schult. Syst. Veg. v. 394) forms a variety, as pointed out by Sprengel (Syst. Veg. i. 804). An excellent description of I. suffiuticosum is furnislied by Roxburgh (Flora Indica, ii. 447), in which particularly is alluded to the rosy petals and the hornlets of the lower filaments. To these marks may be added, that I. enneaspermum is often downy, that the stipules are more conspicuous, that the peduncles excol the pedicel in length, that the labellum is never blue although not rarely brickcolored, that the lower pair of petals is moro inequilateral and long-acuminate, that the upper petals are oblong, three-nerved and abrubtly short-acuminate, and that the filaments are longer. A comparison of the fruits will hereafter probably render these distinctions still ampler. Referring to our description of the assumed I. filiforme it will be seen, that it is easily recognized by almost terete branches, larger stipules, of which the upper ones are membranous, by partially opposite leaves, by long peduncles, by leafless racemes, by acuminate laternl petals and more distinctly bidentate anthers.

I. calycinum (Steudel, Nomencl. Bot. i. 813; Pigen calycina, Cand. Prodr. i. 307 ; P. glauca, Endl. in Hueg. Enum. p. 5), a strictly Western Australian plant, is still less likely than ${ }^{\circ}$. monopetalum to be confused with our plant.

Ripe seeds brown-black.

$$
\text { IONIDIUM FILIFORNE-p. } 66 .
$$

\section{Hyunantuera BaxksiI-p. 69}

Observed in the valleys of the remotest eastern tracts of the colony to attain the height of fully 20 feet. Flowers very fiagrant.

\section{Pittosporua undulatum-p. 71 .}

At Corner Inlet, where, according to Mr. Wilhelni's remarks, it attains a height of 60 feet; on Phillip Island; in the fern-tree gullies near the Tarwan; on the lower Genon River.

\section{Pittosporuar Bicolor-p.72.}

To this species is in all probability to be rcduced P. discolor (Regel, Gartenfiora, i. 133, t. 15), according to the dingnosis republished by Dr. C. Mueller (in Walp. Annal. Bot. Syst. iv. 242).

Pittosporum rovolutum, Dryander, in Ait. Hort. Ken. edit. 2, vol. ii. 27; Loddig. Bot. Cabinet, 506; Bot.Reg. iii. 186; P. tomentosum, Bonpt. Matmais. i. 57, t. 21; Dict. Sciene. Nat.t. 129; Lodd. Cab. 1441; Sweet, Flor. Austral. 33; P. fulrum, Rudge, in Transact. Linn. Soc. x. 298, t. 20; Sweet, Flor. Austral. 25; P. rubiginosum, R. Cunn. in Annal. of Nat. Hist. ir. 10 S. 
Leaves on short petioles, lanceolate- or broad-ovate, seldom narrow-lanceolate, entire, often acuminate, spreading-nerved, conspicnously veined, flat or revolute at the margin, above glabrous, bencath as well as the branchlets and pedicels rusty-downy or tomontose, seldom quite smootli ; umbels or corymbs terminal, usually simple; sepals slightly glandulous-dornny, free, together with the bracteoles very acute; potals yellow, narrow oblong-spatlulate, blunt, high-coherent; anthers about half ns long as the filaments; ovary tomentose; capsule turgid, 2-3-valved; valves lignous-coriaceous, ontside brown-black and imperfectly rusty-downy, inside yellow; funicles partially as long the garnet-colored seeds.

On lightly-tinbered undulations and ridges along the soutl-eastern boundary line of Gipps Land; thence penetrating northward to the ricinity of Moreton Bay, ascending to the Blue Mountains.

A shrıb from several to many feet high, attaining in favorable sheltered forest-ravines the size of a small tree. Branches and brancllets cylindrical, usually only towards the summit leafy, bearing often along: their lower part some scattered linear-subulate bract-like scales of a few lines length. Lenves varying, according to the locality of the plant, much in texture and size, sometimes more chartaceous, sometimes thickly coriaceous, from 2-7 inches long, from 1-21 inches broad, not rarely at the margin undulate, above by the impression of the nerves and veins somewhat wrinkled, dark-green and when fresh shining, beneath paler and clothed with more or less brown or grey secedent crisp downs. Umbels sliort- seldom long-pedunculate or sessile, consisting of few or many, never however very numerous, flowers. Peduncles provided with several scattered lanceolate- or linear-subulate finally delapsing outside tomentose bracts of a few lines length. Pedicels 4-8 lines long, appressed- and soft-hairy. Bracteoles solitary at the base of the pedicels, keeled, short- and somewhat glandulous-downy, 2-5 lines long, deciduons. Flowers at least before expansion nodding or cernuous. Sepals remarkably variable in size, from $1 \frac{1}{2}-3 \frac{1}{2}$ lines long, brownish, from a gradually dilated and imbricate base lanceolate or subulate-lanceolate, strongly one-nerved, sparingly or hardly longdowny, but always conspersed with minute gland-bearing hair. Petals glabrous, finely three-nerved, from 4-8 lines long, coherent to at least two-thirds their length into a broad- or campanulate-cylindrical tube,

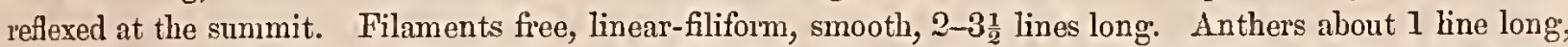
narrow oblong-sagittate, golden-yellow. Pollen-grains smooth, ellipsoid, bursting lengthwise, pale-yellow. Ovary closely inrested with soft accumbent grey-brown hair. Style glabrous, shorter than the filaments, $1 \frac{1}{2}-2 \frac{1}{2}$ lines long. Stigma depressed, almost orbicular, finally $\frac{1}{2}$ a line broad. Capsules on stout pedicels, $\frac{1}{2}-1$ inch long, verging into a more globular or more ovate form, pointed at the summit by the persistent style. Valves in age fully expanding, outside rough, inside with a bright yellow lustre. Placental ridge

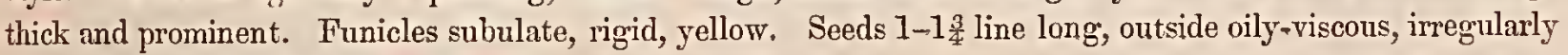
coherent, angular-globose, numerous.

\section{RHYTIDOSPORUM PROCUMBENS-p. 75.}

Ascending to the alpine summits of the Bogong Range; frequent towards Cape Howe and Mount Imlay.

\section{Cheiranthera linearis-p. 76 .}

Near the River Severn in New England. A curious variety with twisted climbing stems, more mucronate almost semiterete leaves and solitary flowers, was discovered by Mr. F. Waterhouse in Kangaroo Island. This last-mentioned plant may possibly be a distinct species, its fruit not being known.

\section{Billardiera longtplora-p. 78.}

On the Baw Baw Mountains. Advancing at least as far as Twofold Bay.

The author has failed to identify the Campylanthera ericoides (Lindl. in Mitchell's Eastern Australia, ii, 275), found Sept. 1836, by Sir Th. Mritchell during his discovery-journey through our territory. According to the brief record in Mitchell's Journal it was collected on the basaltic plains near Mount Greenock, at the 
Victorian Pyrenees. It is described as a smooth little bush of heath-like habit and of erect growth, with leaves oblong-cuneate, mucronulate, at the margin revolute, with solitary polypetalous erect and terminal flowers, resembling those of Sollya, and with almost round anthers.

Dodonæa triquetra, Wendland, Botanische Beobachtumgcn, 44; Andr. Bot. Repos. t. 230; Trattin. Archiv. t. 396; F. M. Fragm. Phytograph. Austral. i. 73; D. laurina, Sieber, in Spreng. Syst. Tegetabil. iv. pars ii. 152.

'Tall, hardly viscid; branchlets compressed-angular; leaves lanccolate, or ovate- or oblong-lanceolate, petiolate, cliartaceous, flat, entire; flowers dicecious, corymbose-paniculate; sepals acuminate; stamens 8-10; anthers slender, several times longer than the minute calyx, glabrous, acuminate; filaments finnlly as long as the sepals; capsules three-valved, winged from the summit to the base; sides of the ralres broadly dimidiate-ovate; wings hardly as broad as the valves, at the extremities rounded-blunt; dissepiments persistent with the columna; seeds very shining; strophiole wanting.

On barren declivities and granite rocks of Genoa Peak and elsewhere in the vicinity of the Genoa River; extending over Eastern Australia as far nortl as Moreton Bay.

A good-sized bush, becoming on farorable spots arborescent and then attaining a height of about 20 feet. Leaves from 2-5 inches long, $\frac{1}{2}-1 \frac{1}{2}$ inch broad, more or less acuminate, one-nelved, finely featherveined, somewhat paler beneath, gradually tapering into a short petiole. Male corymbs decompound, terminal and axillary. Sepals 4-5, green, ovate, apiculate, only about $\frac{1}{2}$ line long, early dropping. Filanents rery short, capillary, glabrous. Anthers slender, yellow, about $1 \frac{1}{2}$ line long, linear-tetrngonous. Female cormbs also axillary and terminal, compound, short pedunculate. Pedicels very slender, upwards thickened, much longer than those of the male flowers. Sepals occasionally enlarged to the length of $1 \frac{1}{2}$ line and a longer while persistent. Style early secedent, setaceous-filiform, $\frac{1}{3}-\frac{2}{3}$ inch long, at the summit short-lobed. Valres of the capsule 3-5 lines long. Wings about as broad as the ralves, but longer, upwards somerhat dilated, veined. Seeds measuring about 1 line, oblique- and turgid-lenticular, polished-smootl, black, margined by a crisp diaphanous white pellicle.

This Dodonæa approaches in its characters to D. platyptera and to D. procumbens. D. Ianceolata from Arnhem's Land is perhaps from it not specifically different.

Dodonæa truncatiales, F. M. Fragm. Phytogr. Austr. ii. 143.

Tall, hardly viscid; branchlets compressed-angular, almost winged towards the summit; leates narronlanceolate, glabrous, entire or slightly denticulate-repand; flowers simple- or paniculate-corymbose; sepals 4 , orate, acute, little longer than the tetragonous-orate at the summit bearderl anthers; filaments very short; capsule four-valved, sometimes three-ralved; valves upreards dilatcd, almost broader than long, torards the base wingless, towards the summit expanded into a truncate and very broad wing; septa persistent with the columna.

On the wooded banks of the Genoa Rivel. In New South Wales along the rivers Towamba and Towaka and on rivulets in the Blue Mountains.

An erect shrub, attaining the height of abont 12 feet, dicecious or occasionally monocious. Leares 2-8 inches long, $\frac{1}{4-1}$ incl broad, almost opaque, beneath slightly paler, generally tapering by degrees into the base and apex, strongly one-nerved, thinly featler-veined, by exsiccation somewlint revolute at the margin. The female corymb usually less compound than the unalo inflorescence. Bracts linear, clunnelled, solitary, $\frac{1}{2}-1 \frac{1}{2}$ line long, deciduous. Sepals hardly longer than 1 line, ciliolated. Fruit-pedicels $\frac{1}{2}-1$ inch long, slender, upwards thickened. Valves $1_{2}-2$ lines high. Wings sometimes dimidinte-lanceolate, sometimes ovate-semilanceolate, $2-4$ lines broad, green or reddish. Well matnred seeds as yet unknown.

In habit and foliage not dissimilar to D. triquetra; in male flowers and fruit widely distinct; in regard to its capsules closely allied to D. platyptera (F. M. Fragment. Phytograph. Austral. i. 73) from 
Arnhem's Land, which species, however, produces terete branchlets, thicker leaves, and exudes a viscid secretion.

The aborigines employ the wood, which is very liard, for the manufacture of their spears.

\section{DODONEA HIRTELLA-p. 89}

Specimens, gathered in the Blue Mountains by Miss Atkinson, show leaves with as many as 15 pairs of leaflets. The staminiferous flowers form the terminal and axillary compound corymbs usual iu Dodonæa. Sepals 4, semilanceolate, acuminate, $1 \frac{1}{2}-2$ lines long. Stamens 8. Filaments extremely short. Anthcrs rather longer than 1 line, narrow-tetragonous, yellow, hispidulous towards the summit. The peduncle of the female corymb is sometimes fully an inch long, bearing few or several flowers. The capsule occurs also three-valved.

It seems very likely that this species represents the original D. pinnata.

\section{SPANOGHEA.}

Bhume, Rumphia, iii. 172 .

Calyx cupular, 4-5-toothed, valvate in præflorescence. Petals 5, equal or wanting. Stamens 8 , inserted on the inner side of a hypogynous perfect disk. Filaments free, filiform. Anthers basifixed. Ovary central, 2-4-celled. Ovules single in each cell, ascending from its inner angle. Styles concrete, at the summit stigmatose. Campels 2-4, connate, valveless, bursting by irregular ruptures or not opening. Seeds provided with a grumular-fleshy arillus. Testa crustaceous. Embryo curved. Cotyledons thick, incumbent. Radicle short, inferior.

Trees peculiar to litoral India and East Australia. Tendrils and stipules wanting. Leaves pinnate, alternate. Leaflets large, coriaceous. Flowers racemose or paniculate. Carpels not rarely in part suppressed, coriaceous- or lignous-crustaceous, usually turgid.

This Sapindaceous genus, is separated from Nephelium on account of not corticate carpels, of an arillus not completely enclosing the seed and of curved and unequal cotyledons. From Aryteria it differs in the valveless carpels, but hardly in any other character, from Cupania in its not locucidalvalvate fruit. Closely allied to Heterodendron.

Spanoghea nephelioides, $F$. M. in Transact. Phit. Inst. Vict. iii. 25; Nephelium leiocarpum, F. M. T. c.

Branchlets, petioles and peduncles slightly downy; rachis of leaves two-edged; leaflets coriaceous, lanceolate or ovate-lanceolate or ovate, entire or distantly serrated, mostly acuminate, beneatl very scantily dorrny and usually paler and opaque; flowers petaliferous, anply paniculate; anthers yellow; styles concrete to the summit; carpels 2-4, almost globose, outside and inside glabrous, disjointed at or towards the summit, breaking transversely; seeds large, depressed-spherical.

On the south-eastern boundary line of the colony near Mount Imlay; thence extending as far north as the Richmond River.

A tall beautiful tree. Bark grey, usually white-spotted, more or less rimous or quite smootll. Branchlets cylindrical, glabrescent, towards the summit furrowed and slightly velvet-downy. Petioles and rachis almost semicylindrical, the latter upwards compressed. Leaflets 2-6, alternate or scattered or subopposite, tapering into an extremely short special leafstalk, strongly ribbed, conspicuously and densely net-veined, perfectly or towards the base entire, above glabrous and shining, varying in length between 2 and 5 inches. Panicles axillar, lateral and terminal, from a few to many inches long, consisting of short-stalked few-flowered corymbs intermixed with single flower's. Ramifications of panicle angular-compressed, short-downy, straight, patent. 
Pedicels slender, about as long as the flowers or somewhat longer. Bracts and bracteoles solitary, downy, more or less lanceolate linear or subulate, $\frac{1}{2}-1$ line long. Flowers all bisexual, but only partially fertile. Calyx patellar; persistent, 1 line or less long, hardly enlarged in age, with deltoid or semilanceolate teeth. Petals alternate with the teeth of the calyx, deciduous, hardly 1 line long, rather variable in shape, renatesemiorbicular or verging into a cordate-orbicular form, minutely acuminate, usually short-ungtuiculate, often by infraction of the lower angles apparently rhomboid, membranous, imperfectly downy, at the back almost smootl. Disk repand. Filaments $1-1$ line long, filiform, glabrous. Anthers oblong-ovate, nearly 1 line long, glabrous, basifixed, emarginate at the base; the cells bursting with introrse longitudinal dehiscence. Pollen-grains smooth, almost spherical, three-porose. Ovary usually obcordate and tro-celled, sometimes 3-4-lobed, appressed grey-downy. Style stout, filiform, about 1 line long, slighlitly pubescent, less frequently exserted than immersed in the terminal sinus of the fruit. Frnit-pedicel finally a few lines long, stout, almost glabrous, cylindrical. Carpels globose, lalf- or ligh-connate, usually 2 , of which one not unfrequently abortive, or sometimes 3 rarely 4 developed, brown, smootl, $3-5$ lines long, short-contracted into a narrow base. Pericarp between coriaceous and crust-like, breaking irregularly across the middle. Seed hight enclosed within an acidulous scarlet aril, depressed-globose, $2 \frac{1}{2}-3 \frac{1}{2}$ lines in diameter, polished-black, perfectly smooth, livid along the aril. Testa thin-crustlike. Endopleura fulvid, membranous. Cotyledons concurved aud slightly plicate. Radicle pointing to the hilum.

A second Australian species, S. connata, produces also petals; a third one, S. tomentosa, as well as the two Indian species, S. ferruginea and S. glabra, are devoid of petals. Several Australian Sapindaceous trees bear in foliage great resemblance to S. nephelioides; none of these, however, forms the rachis of the leares so sharp-edged as our species.

\section{Heterodendron oleifolium-p.90.}

Found on the Lachlan by Mr. Lockh. Morton; on Cooper's Creek by Mr. Wright, and in rarious intermediate localities.

Carpels sometimes thinly velvet-downy. Seeds measuring 2-3 lines. Testa brown-black, smooth. Cotyledons tlick, incurved, ovate or roundish; the outer one rather acute. Radicle less than 1 line long, curved, subulate-conical.

At Cape Nelson. W. Allitt.

$$
\text { Nitraria Billandierii-p. } 92 .
$$

ACronychia LAURina-p. 97.

In the forests towards Cape Howe.

\section{ZYGOPHYLUM GLAUCUM- $p$. 102.}

The specific name of this plant is to be altered in Z. glaucescens, since Prof. E. Meyer pre-employed the above name for a South African species (conf. Flora, Botanische Zeitung, 1843; Harrey \& Sonder, Flora Capensis, i. 362). Sprengel already (Syst. Veg. cur. poster. 164) combined Roepera with Zygophyllum.

\section{Zygophylum chenatum-p. 103.}

On the Lachlan River. Mr. Lockll. Morton.

Boronia veronicea, F. M. in Transact. Phil. Soc. Vict. i. 11.; Zieria veronicen, F. M. l.c.

Velutinous; branches terete; leaves simple, opposite and alternate, ovate or oblong, subsessile, revolute at the margin, herbaceous; pcdicels axillary, solitary, shorter than the flower, with two narrow bracteoles at the base; sepals narrow-semilanceolate, half or more than half as long as the thinly relvet-downy petals 
petaline stamens none; sepaline ones and style scantily-downy; anthers without appendage; stigma minute, depressed, four-lobed; disk deeply four-cleft; carpels velvet-downy, oval-elliptical; valves of the endocarp protracted at the junction in to a deltoid tooth.

In the sandy MIallee scrub along' the Lower Wimmera, Dallachy; beyond Victoria found at Encounter Bay and in Kangaroo Island at Antichambre Bay.

A pretty little bush, everywhere velvet-downy. Branches oftener opposite than alternate. Leares crowded, sessile or on very short petioles, blunt, 3-6 lines long, 1-3 lines broad, one-nerved, paler beneatl. Flowers constituting a leafy raceme towards the sumnit of the branches. Pedicels $1-1 \frac{1}{2}$ line long. Bracteoles $\frac{1}{2}-1 \frac{1}{2}$ line long, narrow-linear. Lobes of the calyx about $1 \frac{1}{2}$ line long, ontside and inside downy. Petals white or pale-pink, orbicular-ovate, provided with an exceedingly short unguis, shightly pointed, one-nerved, indistinctly veined, deciduous. Lobes of the hypogynous disk semiovate, turgid, slightly margined, glabrous. Filaments about 1 line long, filiform. Anthers ovate-cordate, pallid, near the base dorsifixed, somewhat contracted at the summit, deliscent introrsely. Pollen orange-colored. Style deciduous, about 1 line long. Stigna glabrous, about twice as broad as the style, with blunt lobes. Carpels nearly twice as long as the calys, considerably compressed, minutely apiculate, sometimes short-rostellulate. Endocarp yellowish, shining, smooth, excised below the niddle. Placental membrane deltoid-semicymbiform. Seed ovate, not seen in a ripe state.

\section{Boronia ARBorescens-p. 111.}

The variety illustrated at tab. 1395 in the Botanical Magazine occurs not unfrequently on the Genoa River and elsewhere in East Gipps Land. Zieria cytisoides is to be found on sandstone cliffs along the coast towards Cape Howe and at Twofold Bay. It forms rery ample bushes, with obovate leaflets revolute at the margin, with ovate bracts, with sepals half or more than half as long as the petals and with velvety carpels. It is to be regarded as a coast-form of Boronia arborescens, unless the fruit sliould prove it to be distinct as a species.

BORONIA PARVIFLORA-p. 113.

On heath-ground near Portland; W. Allitt; also on the Bunyip River.

\section{Boronia pinNata-p. 115.}

On the Upper Tarwan. In New England; on the Upper Clarence River.

B. filifolia (F. M. Fragm. Plyyt. Austr. i. 3) has been found by the Rev. Jul. Edw. Woods in the Tattiar country within the Victorian boundary, and in Kangaroo Island by Mr. F. Waterhouse. Occurring there promiscuously with simple and trifoliate leaves, it seems to exhibit merely another of the extreme forms of B. pinnata, one with cylindrical leaflets. Specinıens of Boronia clavellifolia, gathered in the vicinity of Lake Hindmarsh, obliterate almost the distinctions between that species and the narrow-leaved varieties of B. pinnata.

\section{Eniostranon verrucosus-p. 123.}

On the White Hill near Bendigo, Dr. Beckler; in the Tattiara country, Rev. Jul. Edw. Woods.

Allied to this species is the E. obovale (All. Cunn. in Field's New South Wales, p. 331). E. buxifolius, next to $\mathrm{E}$. verrucosus, may-yet be found in our eastern territory. According to specimens, transmitted by Miss L. Atkinson, from the Blue MLountains, 10 specific distinction can apparently be drawn between E. buxifolius and E. hispidulus (Sieber, in Spreng. cur. post. p. 164).

\section{ERIostemon DifFormis-p. 123.}

This widely distributed and consequently variable species has recently been brought from the Phillips River in South-Western Australia and also from the vicinity of Broad Sound. The stamens are occasionally considerably shorter than the petals. 


\section{ERiostemon uMbellatus- $p$. 128.}

Haidinger Range and elsewhere in the Australian Alps.

Phebalium lachnæoides (A. Cunn. in Field's New South Wales, p. 322) belongs to the alpine variety of this species, according to a specinen communicated by Mr. Rob. Heward, the possessor of Cunningham's herbarium. Eriostemon Ralstoni (F. M. Fragm. Plyytogr. Austr. ii. 101, tab. 14) will most probably yet be found on the granite tracts of Eastern Gipps Land.

On Lake King.

\section{LASIOPETALUM DASYPHYLLUM-p. 144 .}

\section{MaLvacex-p. 158.}

To the series of Australian Malvaceous genera, enumerated in this work, is to be added Lagunaria, the only true species of that genus, L. Patersonii, formerly only known from Norfolk Island, having been recently discovered in the vicinity of Port Denison in eastern tropical Australia.

\section{TETRATHECA-p. 181.}

The fiuit of Tremandra shows no generic discrepancies from that of Tetratheca, unless in the embryo, which remains as yet unknown. The capsule of Tremandra stelligera is cordate-orbicular, slightly turgid, bivalved, about 2 lines long. Seed singly ripening in each cell, almost globose, slightly compressed, about 1 line long; short grey-downy. Testa brown-black. Strophiole semicircular, livid, fleshy, extending from the chalaza in a narrow line half down the raphe. Hilum near the summit lateral. 


\section{N D E X.}

[The classes, orders, tribes, genera and species described are distinguished by capitals, small capitals or italics; the synonyms and quotations refer solely - to Australian plants and are printed in Roman letters.]

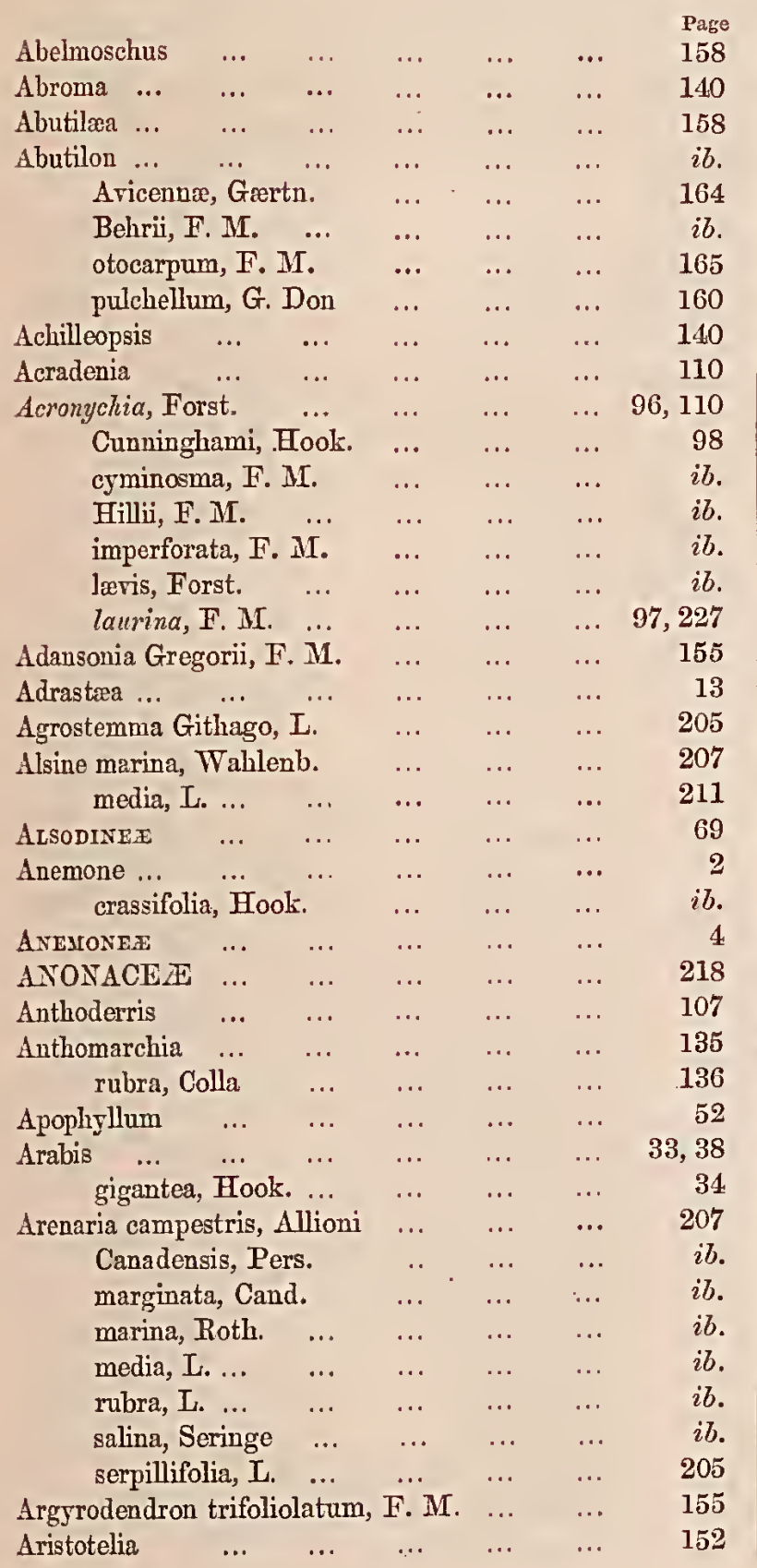

$\begin{array}{lllllll}\text { Aryteria } & \ldots & \ldots & \ldots & \ldots & \ldots & \ldots\end{array}$

Ascyrum involutum, Lab. $\quad \ldots \quad \ldots . \quad \ldots$. $\begin{array}{llllll}\text { pusillum, Lab. } & \ldots & \ldots & \ldots & \ldots & i b .\end{array}$

$\begin{array}{lllllll}\text { Asterocliton } & \ldots & \ldots & \ldots & \ldots & \ldots & 140,145\end{array}$

$\begin{array}{lllllll}\text { Asterolasia } & \ldots & \ldots & \ldots & \ldots & \ldots & 119\end{array}$

phebalioides, F. M. $\quad \ldots \quad \ldots \quad \ldots \quad 133$

trymalioides, F. M. $\quad \ldots . \quad \ldots \quad \ldots . \quad 134$

$\begin{array}{llllllll}\text { Atalaya } & \ldots & \ldots & \ldots & \ldots & \ldots & \ldots & 84\end{array}$

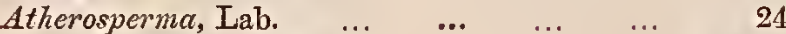
$\begin{array}{lllll}\text { micranthum, Tul. } & \ldots & \ldots & \ldots & 24,220\end{array}$

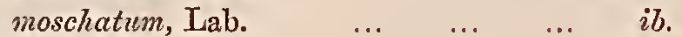

$\begin{array}{llllll}\text { AURANTIACEA } & \ldots & \ldots & \ldots & \ldots & 96\end{array}$

Barbarea, R. Br.

Australis, J. Hook. $\quad \ldots \quad$... $\quad \ldots . \quad$ ib.

stricta, Andrz. $\quad \ldots \quad$... $\quad \ldots \quad$...

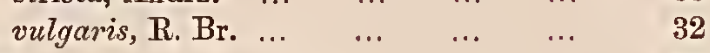

$\begin{array}{lllllll}\text { Beatsonia ... } & \ldots & \ldots & \ldots & \ldots & \ldots & 82\end{array}$

$\begin{array}{llllllll}\text { Bergia } & \ldots & \ldots & \ldots & \ldots & \ldots & \ldots & 194\end{array}$

ammannioides, Hook. $\quad \ldots \quad \ldots \quad \ldots . \quad \ldots \quad 196$

$\begin{array}{lllll}\text { trimera, F. \& M. } & \ldots & \ldots & \ldots & i b .\end{array}$

tripetala, F. M. $\ldots . \quad \ldots \quad$... $\quad \ldots \quad$ ib.

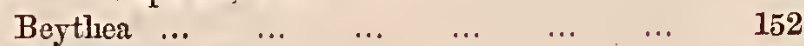

$\begin{array}{lllllll}\text { Billardiera, Sm. } & \ldots & \ldots & \ldots & \ldots & 78\end{array}$

$\begin{array}{lllll}\text { augustifolia, Cand. } & \ldots & \ldots & \ldots & 79\end{array}$

$\begin{array}{lllll}\text { braclyantha, F. M. } & \ldots & \ldots & \ldots & i b .\end{array}$

Canariensis, Wendl. $\quad . . \quad \ldots \quad \ldots \quad$...

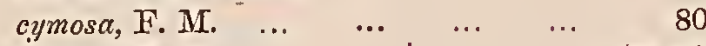

$\begin{array}{lllllll}\text { elegans, F. M. } & \ldots & \ldots & \ldots & \ldots & 78,81\end{array}$

$\begin{array}{lllll}\text { grandiflora, Putt. } & \ldots & \ldots & \ldots & 79\end{array}$

$\begin{array}{lllll}\text { Huegeliana, F. M. } & \ldots & \ldots & \ldots & 78\end{array}$

$\begin{array}{llllll}\text { latifolia, Klatt } & \ldots & \ldots & \ldots & \ldots & 77,79\end{array}$

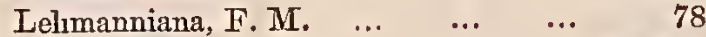

$\begin{array}{lllll}\text { longiflora, Lab. ... } & \ldots & \ldots & \ldots & \mathbf{7 8 , 2 2 5}\end{array}$

macrantha, J. Hook. $\quad \ldots \quad \quad \ldots \quad \ldots . \quad 78$

$\begin{array}{lllll}\text { mutabilis, Salisb. } & \ldots & \ldots & \ldots & 79\end{array}$

$\begin{array}{llllll}\text { ovalis, Lindl. } & \ldots & \ldots & \ldots & \ldots & 78\end{array}$

$\begin{array}{lllll}\text { parriflora, Cand.... } & \ldots & \ldots & \ldots & 80\end{array}$

pseudocymosa, Klatt $\quad \ldots \quad \ldots \cdots \quad \ldots \quad i b$.

$\begin{array}{llllll}\text { scandens, } \mathrm{Sm} . & \ldots & \ldots & \ldots & \ldots & 79\end{array}$

$\begin{array}{lllll}\text { sericophora, F. } \stackrel{M}{\mathrm{M}} . & \ldots & \ldots & \ldots & \\ & \ldots & \ldots & \ldots & 80\end{array}$

speciosa, F. M. ... $\quad \ldots . \quad \ldots \quad$... $\quad 78$

$\begin{array}{lllll}\text { rersicolor, F. M. } & \ldots & \ldots & \ldots & \\ & & & & \end{array}$ 
Blackburnia xanthoxyloides, F. MI

Blennodia, R. Br. alpestris, F. M. . brevipes, F. M. ... canescens, $\mathrm{Br}$. curvipes, F. M. . lasiocarpa, F. M. Pl. II

Boronia, Sm. algida, F, MI $-\cdots, \quad \ldots, \ldots, \ldots$ anemonifolia, A. Cunn. ... anemonifolia, Paxt. arborescens, F. MI. artemisifolia, F. M. bipinnata, Lindi brachyphylla, F. II. citriodora, Gunn. clavellifolia, F. MI. corulescens, F. M. dentigera, F. MI. elatior, F. M. filifolia, F. M.

Fraseri, Hook. ... grandisepala, F. M. granulata, F. M. . Guunii, J. Hook. hirsuta, F. MI. hyssopifolia, Sieb. inornata, Turcz. . lavigata, F. II. leptophylla, F. MI megastigma, Nees microphylla, Sieb. nana, Hook. oxyantha, Turcz. parviflora, Sm. .. pilonema, Lab. ... pilosa, Lab. pinnata, Sm. polygalifolia, Sm. rhomboidea, Hook. tetrandra, J. Hook. tetrathecoides, Cand. variabilis, Hook. . veronicea, T. MI. . Brachychiton, R. Br. accrifolium, F. M. Delabechei, F. M. discolor, F. M diversifolium, R. Br. Gregorii, F. M. ... luridum, C. Moore

platanoides, R. Br. populneum, R. Br. Suppl. Pl. Y. pubescens, C. Moore ramiflorum, R. Br.
Brasenia, Schreb. Hydropeltis, Raf.

$\begin{array}{lllll}\text { Brathys Billiardierii, Spach } & \ldots & \ldots & \ldots & 12,217\end{array}$

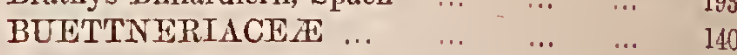

$\begin{array}{lllllll}\text { Buettreriex } & \ldots & \ldots & \ldots & \ldots & \ldots & 145\end{array}$

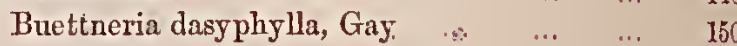
inodora, Gay $\quad \ldots \quad$... $\quad \ldots . \quad \ldots \quad$ ib.

$\begin{array}{llllll}\text { Bursaria, Cavan. } & \ldots & \ldots & \ldots & \ldots & \text { i3 }\end{array}$ diosmoides, Putt. $\quad$... $\quad \ldots . \quad \ldots \quad$ is incana, Lindl. $\quad \ldots \quad \ldots \quad \ldots \quad \ldots \quad$ is procumbens, Putt. $\quad$... $\quad \ldots \quad$... $\begin{array}{llllll}\text { spinosa, Car. } & \ldots & \ldots & \ldots & \ldots & \text { i1 }\end{array}$ Stuartiana, Klatt $\quad \ldots \quad \ldots \quad \ldots \quad$... $\begin{array}{llllll}\text { Busbeckia, Endl. } & \ldots & \ldots & \ldots & \ldots & 52\end{array}$

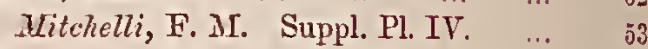
$\begin{array}{llllllll}\text { Byblis } \quad . . & \ldots & \ldots & \ldots & \ldots & \ldots & j\end{array}$

$\begin{array}{lllllll}\text { CABOMBE } & \ldots & \ldots & \ldots & \ldots & \ldots & 11\end{array}$

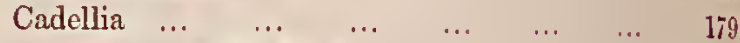
$\begin{array}{lllllr}\ldots & \ldots & \ldots & \ldots & \\ \text { pentastylis, F. M. } & \ldots & \ldots & \ldots & 179 \\ & \ldots & \ldots & \ldots & 92\end{array}$

Caltha, L. introloba, F. II. ... $\quad \ldots \quad$... $\quad \ldots \quad$ 10,217

Noræ Zelandix, J. Hook. $\quad$... $\quad \ldots . \quad$, 11

Campylanthera Frazeri, Hook. $\quad$... $\quad \ldots \quad$ is

$\begin{array}{llllll}\text { Candollea, Lab. } \ldots & \ldots & \ldots & \ldots & \ldots & 13\end{array}$

$\begin{array}{llllll}\text { CAPPARIDE } & \ldots & \ldots & \ldots & \ldots & 51\end{array}$

$\begin{array}{llllll}\text { Capparis Mitchelli, Lindl. } & \ldots & \ldots & \ldots & \\ \end{array}$ nummularia, Cand. $\quad \ldots \quad \ldots \quad \ldots \quad \ldots \quad 52$

$\begin{array}{llllll}\text { Capsella, Moench } & \ldots & \ldots & \ldots & \ldots & \pm 2,222\end{array}$ antipoda, F. M. ... $\quad \ldots \quad \ldots \quad \ldots \quad 44,51,222$ blennodina, F. MI. $\quad \ldots \quad$... $\quad \ldots \quad$ t? $\begin{array}{lllll}\text { bursa pastoris, Mœench } \ldots & \ldots & \ldots & \ldots & \text {... } \\ & & \ldots & \end{array}$ elliptica, C. A. Meyer ... $\quad \ldots \quad$... 43,51 $\begin{array}{lllll}\text { pauciflora, Koch ... } & \ldots & \ldots & \ldots & 41\end{array}$ pilosula, F. M. $\ldots . \quad \ldots \quad \ldots \quad \ldots, \quad$ ib. $\begin{array}{lllll}\text { procumbens, Fries } & \ldots & \ldots & \ldots & 43\end{array}$

$\begin{array}{llllll}\text { Cardamine, Tournef. } & \ldots & \ldots & \ldots & \ldots & 34\end{array}$ corymbosa, J. Hook. $\quad \ldots \quad \ldots . \quad \ldots .36$ debilis, B. \& S. $\quad \ldots \quad$... $\quad \ldots \quad$... $\quad$ ib. depressa, J. Hook. $\quad \ldots . \quad \ldots \quad \ldots . \quad 37$ dictyosperma, Hook. . .. $\quad \ldots \quad$... 30ّ, 221 divaricata, J. Hook. $\quad \ldots . \quad \ldots, \quad \ldots \quad 35$ $\begin{array}{llllll}\text { eustylis, T. MI. } & \ldots & \ldots & \ldots & \ldots & \\ \text { l... } & \ldots & 37\end{array}$ heterophylla, Hook. $\quad$... $\quad$... $\quad \ldots .36$ $\begin{array}{lllll}\text { hirsuta, } \mathbf{L} . \quad \ldots & \ldots & \ldots & \ldots & 33,36,138\end{array}$ intermedia, Hook. $\quad$... $\quad \ldots \quad$... 30 $\begin{array}{lllll}\text { laciniata, F. M. ... } & \ldots & \ldots & \ldots & 35\end{array}$ $\begin{array}{llllll}\text { lilacina, Hook. } & \ldots & \ldots & \ldots & \ldots & 36\end{array}$

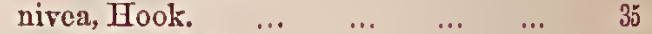
parviflora, L. $\quad \ldots \quad \ldots \quad \ldots \quad \ldots \quad \ldots, \quad 36$ $\begin{array}{llllll}\text { pratensis, } \mathbf{L} . & \ldots & \ldots & \ldots & \ldots & 36,37\end{array}$ $\begin{array}{lllll}\text { radicata, J. Hook. } & \ldots & \ldots & \ldots & 34 \\ \end{array}$ $\begin{array}{llllll}\text { resedifolia, L. } & \ldots & \ldots & \ldots & \ldots & 37\end{array}$ $\begin{array}{llllll}\text { silvatica, Link. } & \ldots & \ldots & \ldots & \ldots & \\ & & & & & \end{array}$ 
INDEX.

Cardamine stellata, J. Hook

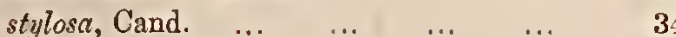
$\begin{array}{lllll}\text { tenuifolia, Hook. } & \ldots & \ldots & \ldots & \mathbf{3 6}\end{array}$

$\begin{array}{llllll}\text { CARYOPHYLLE } \mathbb{E} & \ldots & \ldots & \ldots & \ldots & 204\end{array}$

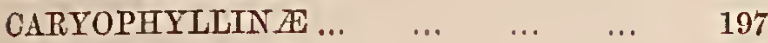

$\begin{array}{lllll}\text { Cerastium rulgatum, } \mathrm{L} . & \ldots & \ldots & \ldots & 205\end{array}$

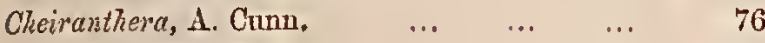
brevifolia, F. M. ... $\quad \ldots \quad$... $\quad . . \quad$ ib. cyanea, Brogn. $\quad$,.. $\quad \ldots \quad$... $\quad \ldots \quad$ ib. linearis, A. Cunn. $\quad \ldots \quad \ldots \quad \ldots, 76,225$

Preissiana, Putt. $\quad$.. $\quad \ldots . \quad \ldots . \quad \% 6$

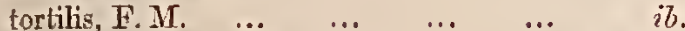

Chorilæna angustifolia, F. M. ... ... ... 119, 131

$\begin{array}{lllllll}\text { Chorilknopsis } & \ldots & \ldots & \ldots & \ldots & \ldots & 132\end{array}$

Cissampelos hernandifolia, W. $\quad \ldots . \quad \ldots \quad 221$

$\begin{array}{llllll}\text { Cissus acetosa, F. M. } & \ldots & \ldots & \ldots & \ldots & 94\end{array}$ Australasica, F. M. $\quad \ldots . \quad \ldots \quad \ldots . \quad$ ib. hypoglauca, A. Gray $\quad \ldots \quad \ldots \quad \ldots \quad$... 94,95

$\begin{array}{lllllll}\text { Citriobatus } & \ldots & \ldots & \ldots & \ldots & \ldots & 63,70\end{array}$

$\begin{array}{llllllll}\text { Citrus } & \ldots & \ldots & \ldots & \ldots & \ldots & \ldots & 96\end{array}$

$\begin{array}{lllllll}\text { Chematides } & \ldots & \ldots & \ldots & \ldots & \ldots & \end{array}$

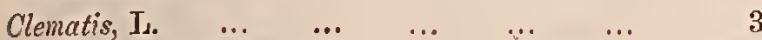

aristata, $\mathrm{R} . \mathrm{Br}, \quad \ldots \quad \ldots \quad \ldots \quad \ldots, \quad \ldots \quad$ ib.

blanda, Hook. $\quad \ldots \quad$...$\quad \ldots \quad \ldots \quad \ldots \quad$ ib.

$\begin{array}{llllll}\text { cognata, Steud. } & \ldots & \ldots & \ldots & \ldots & \ldots\end{array}$

coriacea, Cand. $\ldots . \quad \ldots . \quad \ldots \quad$... $\quad i b$.

discolor, Steud. $\ldots . \quad \ldots \quad \ldots \quad \ldots \quad \ldots \quad$ ib.

gentianoides, Cand. $\quad \ldots . \quad \ldots \quad \ldots . \quad$ ib.

glycinoides, Cand. $\quad \ldots \quad \ldots \quad \ldots . \quad$... $\quad$ ib.

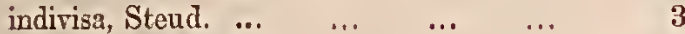

linearifolia, Steud. $\quad \ldots \quad$... $\quad \ldots \quad$ 4

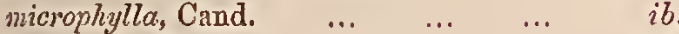

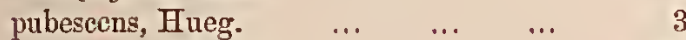

stenosepala, Caud. $\quad \ldots . \quad \ldots \quad \ldots . \quad \ldots \quad i b$.

$\begin{array}{llllll}\text { Cleome flava, Banks } & \ldots & \ldots & \ldots & \ldots & 52\end{array}$

$\begin{array}{lllll}\text { Cliococca tenuifolia, Babingt. ... } & \ldots & \ldots & 179\end{array}$

Clyper hernandifolia, W. \& A. $\quad$... $\quad \ldots . \quad 221$

Cocculus Forsterii, Cand. $\quad \ldots . \quad \ldots \quad \ldots . \quad \ldots \quad i b$.

Harveyanus, F. M. $\quad \ldots . \quad \ldots \quad \ldots . \quad 27$

$\begin{array}{lllll}\text { Codonocarpus, } 4 \text {. Cunn. } & \ldots & \ldots & \ldots & 199\end{array}$ acaciformis, F. M. $\quad$... $\quad \ldots \quad$... 200

Australis, A. Cunn. $\quad$... $\quad \ldots \quad \ldots . \quad 201$

$\begin{array}{lllll}\text { cotinifolius, F. M. } & \ldots & \ldots & \ldots & 200 \\ \end{array}$

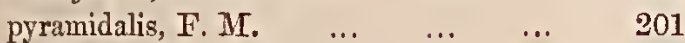

$\begin{array}{llllll}\text { Colobanthus, Bartl. } & \ldots & \ldots & \ldots & \ldots & 212\end{array}$

affinis, J. Hook, ... $\quad \ldots \quad \ldots . \quad \ldots, \quad i b$.

Billardierii, Fenzl $\quad \ldots \quad$... $\quad \ldots . \quad$ ib.

Benthanii, Fenzl $\quad \ldots . \quad \ldots \quad \ldots . \quad \ldots \quad 213$

pulvinatus, F. M. Pl. XI. $\quad \ldots \quad \ldots . \quad i b$.

$\begin{array}{llllll}\text { COLUNINIFER } \mathbb{E} & \ldots & \ldots & \ldots & \ldots & 140\end{array}$

$\begin{array}{llllll}\text { Comesperma, Lab. } & \ldots & \ldots & \ldots & \ldots & 185\end{array}$

$\begin{array}{lllll}\text { acutifolium, Steetz } & \ldots & \ldots & \ldots & 140\end{array}$

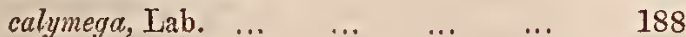

$\begin{array}{lllll}\text { ciliatum, Steetz } & \ldots & \ldots & \ldots & 192\end{array}$

coridifolium, A. Cunn. ... $\quad \ldots \quad \ldots . \quad \ldots \quad 190$

defoliatum, F. M.
Comesperma Drummondi, Stectz Page

ericinum, Cand.

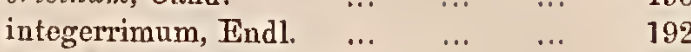

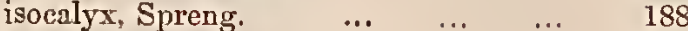

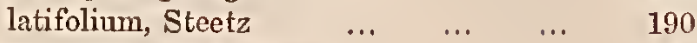

lincarifolium, A. Cunn.... ... ...

nudiusculum, Cand. $\quad \ldots . \quad \ldots \quad \ldots . \quad 189$

nudiusculum, Steetz $\quad \ldots \quad \ldots . \quad \ldots, \quad i b$

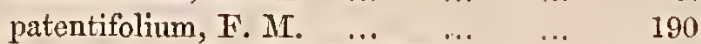

polygaloides, F. M. Pl. VIII. _.. 187

$\begin{array}{lllll}\text { ramosissimum, Steud. } & \ldots & \ldots & \ldots & 189\end{array}$

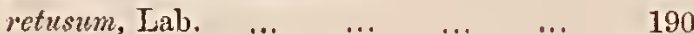

$\begin{array}{lllll}\text { scoparizm, Steetz } & \ldots & \ldots & \ldots & 180\end{array}$

silvestre, Lindl. ... $\quad \ldots \quad$... $\quad \ldots . \quad 19$ I

sphærocarpum, Steetz $\ldots . \quad \ldots \quad \ldots \quad 186,189$

$\begin{array}{lllll}\text { spinosum, F. M. ... } & \ldots & \ldots & \ldots & 186\end{array}$

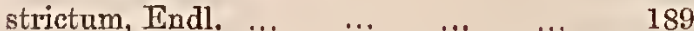

virgatum, Lab. $\quad \ldots \quad \ldots \quad \ldots \quad \ldots \quad \ldots 186,188$

volubile, Lab. ... $\quad \ldots \quad$...

Commersonia, Forst. $\quad \ldots \quad \ldots . \quad \ldots . \quad \ldots \quad$ 140, 148

dasyphylla, Andr. $\quad$... $\quad \ldots \quad$... 150

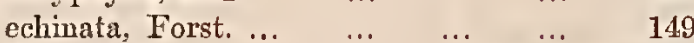

Froseri, Gay $\quad \ldots \quad \ldots \quad \ldots \quad 148,149,156$

Gaudichandii, Gay $\quad \ldots \quad \ldots . . .149$

$\begin{array}{lllll}\text { platyphylla, Cand. } & \ldots & \ldots & \ldots & 150 \\ \text { Cookin } & & & & \end{array}$

$\begin{array}{rrrrrrr}\text { Corchorus ... } & \ldots & \ldots & \ldots & \ldots & \ldots & 95 \\ & \ldots & \ldots & \ldots & \ldots & \ldots & 152\end{array}$

$\begin{array}{llllll}\text { Corethrostylis, Endl. } & \ldots & \ldots & \ldots & \ldots & 145\end{array}$

bracteata, Endl. ... $\quad \ldots \quad$... $\quad \ldots \quad 146$

$\begin{array}{lllll}\text { cordifolia, Steetz } & \ldots & \ldots & \ldots & 145\end{array}$

membranacea, Steud. $\quad \ldots \quad \ldots . \quad \ldots \quad \ldots .146$

microphylla, Turez. $\quad \ldots \quad \ldots . \quad \ldots \quad 145$

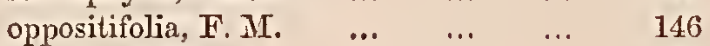

$\begin{array}{lllll}\text { parviflora, Turcz. } & \ldots & \ldots & \ldots & i b .\end{array}$

$\begin{array}{lllll}\text { Schulzenii, F. M. } & \ldots & \ldots & \ldots & 145\end{array}$

$\begin{array}{lllllll}\text { Correa, Smith } & \ldots & \ldots & \ldots & \ldots & \ldots & 135\end{array}$

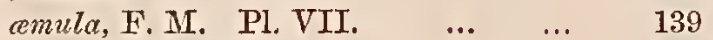

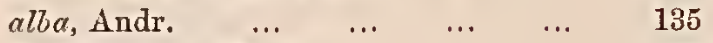

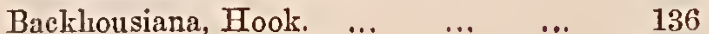

$\begin{array}{llllll}\text { bicolor, Paxt. } & \ldots & \ldots & \ldots & \ldots & 137\end{array}$

$\begin{array}{lllll}\text { cardinalis, F. M. } & \ldots & \ldots & \ldots & 136\end{array}$

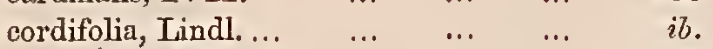

$\begin{array}{lllll}\text { cotinifolia, Salisb. } & \ldots & \ldots & \ldots & 135\end{array}$

$\begin{array}{lllll}\text { decumbens, F. M. } & \ldots & \ldots & \ldots & 137\end{array}$

$\begin{array}{lllll}\text { ferruginen, Backl. } & \ldots & \ldots & \ldots & 138\end{array}$

glabra, Lindl. $\quad \ldots \quad \ldots \quad \ldots \quad \ldots \quad 136,139$

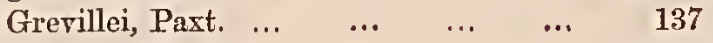

Harrisii, Paxt. - ... $\quad \ldots . \quad \ldots \quad \ldots . \quad \ldots \quad i b$.

Lawrenciana, Hook. ... $\quad \ldots \quad$... 136

leucoclada, Lindl. $\quad \ldots \quad \ldots \quad \ldots \quad$ 136, 139

$\begin{array}{lllll}\text { longiflora, Paxt. ... } & \ldots & \ldots & \ldots & 136,139 \\ & & \ldots & \ldots & 137\end{array}$

magnifica, Paxt. ... $\quad \ldots \quad \ldots . \quad \ldots \quad$ ib.

$\begin{array}{lllll}\text { pulchella, Mackay } & \ldots & \ldots & \ldots & \\ & \ldots & & \ldots & 136\end{array}$

$\begin{array}{llllll}\text { reflexa, Pers. } & \ldots & \ldots & \ldots & \ldots & i b .\end{array}$

$\begin{array}{llllll}\text { rosea, Paxt. } & \ldots & \ldots & \ldots & \ldots & 137\end{array}$

rotundifolia, Lindl. $\quad \ldots \quad \ldots \quad \ldots . \quad 136$ 


\begin{tabular}{|c|c|c|c|c|c|}
\hline \multirow{6}{*}{\multicolumn{2}{|c|}{$\begin{array}{ll}\text { Correa rubra, Sm. } & \ldots \\
\text { rufa, Gærtn. } & \ldots \\
\text { Schlechtendaliu, } & \text { Behr } \\
\text { speciosa, Andr. } & \ldots \\
\text { virens, Sm. } & \ldots \\
\text { viridiflora, Andr. } & \end{array}$}} & & & & $\begin{array}{l}\text { Page } \\
136\end{array}$ \\
\hline & & $\ldots$ & $\cdots$ & $\ldots$ & $i b$. \\
\hline & & ... & $\ldots$ & $\ldots$ & 136,139 \\
\hline & & $\ldots$ & $\ldots$ & $\ldots$ & 136 \\
\hline & & $\ldots$ & $\ldots$ & $\ldots$ & $i b$. \\
\hline & & $\ldots$ & $\ldots$ & $\ldots$ & $i b$. \\
\hline \multicolumn{2}{|c|}{$\begin{array}{c}\text { Crowea ... } \\
\text { angustifolia, Turcz. }\end{array}$} & $\ldots$ & $\ldots$ & $\ldots$ & 119 \\
\hline \multirow{2}{*}{\multicolumn{2}{|c|}{$\begin{array}{l}\text { angustifolia, Turcz. } \\
\text { exalata, F. } M I . \quad \ldots\end{array}$}} & $\ldots$ & $\ldots$ & $\ldots$ & 120 \\
\hline & & $\ldots$ & $\ldots$ & $\ldots 1$ & 119,120 \\
\hline \multirow{2}{*}{$\begin{array}{l}\text { latifolia, } \mathrm{Paxt} \text {. } \\
\text { saligna, Sm. }\end{array}$} & ... & .. & ... & $\ldots$ & $i b$. \\
\hline & ... & $\ldots$ & ... & $\ldots$ & 119 \\
\hline \multicolumn{2}{|l|}{ CRUCIFER $\approx$... } & $\ldots$ & ... & $\ldots$ & 30 \\
\hline Crypta minima, Nutt. & ... & $\ldots$ & $\ldots$ & $\ldots$ & 195 \\
\hline Cupania ... ... & ... & $\cdots$ & $\ldots$ & $\ldots$ & 84,227 \\
\hline \multicolumn{2}{|l|}{ Cyanochlamys ... } & $\ldots$ & $\ldots$ & $\ldots$ & 119 \\
\hline \multirow{2}{*}{\multicolumn{2}{|c|}{$\begin{array}{c}\text { Cyanothamnus ... ... } \\
\text { anethifolius, Cunn. }\end{array}$}} & $\ldots$ & $\ldots$ & $\ldots$ & 110 \\
\hline \multirow{2}{*}{\multicolumn{2}{|c|}{$\begin{array}{l}\text { anethifolius, Cumn. } \\
\text { ramosus, Lindl. ... }\end{array}$}} & $\cdots$ & $\cdots$ & $\cdots$ & 118 \\
\hline & & $\cdots$ & $\ldots$ & $\ldots$ & $i b$. \\
\hline \multicolumn{2}{|c|}{ tenuis, Lindl. $\quad \ldots$} & $\cdots$ & ... & ... & 117 \\
\hline \multicolumn{2}{|l|}{ tridactylites, Bartl. } & ... & ... & $\ldots$ & 118 \\
\hline \multicolumn{2}{|l|}{ Cyclotheca $\quad \ldots \quad \ldots$} & $\cdots$ & .. & $\ldots$ & 197 \\
\hline \multicolumn{2}{|c|}{ Australis, Moqu. } & $\ldots$ & .. & $\ldots$ & 198 \\
\hline \multicolumn{3}{|c|}{ Cyminosma oblongifolia, A. Cunn. } & $\ldots$ & $\cdots$ & 97 \\
\hline \multicolumn{2}{|c|}{$\begin{array}{l}\text { pedunculata, Cand. } \\
\text { Cyrilla spinosa, Spreng. }\end{array}$} & $\ldots$ & ... & $\ldots$ & 98 \\
\hline \multicolumn{2}{|l|}{ Cyrilla spinosa, Spreng. } & $\cdots$ & ... & $\ldots$ & 74 \\
\hline \multicolumn{2}{|c|}{$\begin{array}{l}\text { Delabechea rupestris, Jlitch. } \\
\text { Dicarpidium } \quad . .\end{array}$} & .. & $\ldots$ & $\ldots$ & 157 \\
\hline \multicolumn{2}{|c|}{ 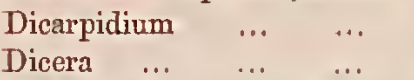 } & $\ldots$ & ... & $\ldots$ & 140 \\
\hline Dicera $\quad \ldots \quad \ldots \quad$. & $\cdots$ & $\cdots$ & .. & $\ldots$ & 152 \\
\hline Dichoglottis Australis, S & Schlect & & $\ldots$ & $\ldots$ & 206 \\
\hline tubulosa, Jaub. \& & Spac & & $\ldots$ & ... & $i b$ \\
\hline Didymeria $\quad \ldots$. . & ... & $\cdots$ & ... & $\cdots$ & 135 \\
\hline æmula, Lindl. & ... & ... & $\cdots$ & $\ldots$ & 139 \\
\hline Didynotheca, J. Hook. . & & $\cdots$ & $\cdots$ & $\ldots$ & 197,198 \\
\hline Drummondü, Mo & oqu. & $\ldots$ & $\ldots$ & $\ldots$ & 199 \\
\hline pleiococca, F. M. & Sup & pl. Pl & IX. & $\ldots$ & 198 \\
\hline thesioides, J. Hoc & ols. & $\ldots$ & $\ldots$ & $\ldots$ & 199 \\
\hline Dillenia procumbens, $\mathrm{La}$ & & $\ldots$ & $\ldots$ & $\ldots$ & 18 \\
\hline Diluenee & ... & $\ldots$ & $\ldots$ & $\ldots$ & 13 \\
\hline DILLENIACE & ... & $\ldots$ & $\ldots$ & $\ldots$ & $i b$. \\
\hline Dimorphanthera ... . & $\ldots$ & $\ldots$ & $\ldots$ & $\ldots$ & 110 \\
\hline Diplolæna Dampierii, D & esf. & $\ldots$ & $\ldots$ & $\ldots$ & 119 \\
\hline grandiflora, Desf. & & $\cdots$ & $\ldots$ & ... & $i b$. \\
\hline Diplopeltis $\quad \ldots$. & ... & ... & $\ldots$ & $\ldots$ & 84 \\
\hline Huegelii, Fndl. 。 & ... & $\ldots$ & $\ldots$ & $\ldots$ & $i b$. \\
\hline Diplotaxis $\quad \ldots \quad$. & .. & $\ldots$ & $\ldots$ & $\ldots$ & 40 \\
\hline Distichostemon ... . & & $\ldots$ & $\ldots$ & $\ldots$ & 84 \\
\hline Ditoca muscosa, B. \& S. & & $\ldots$ & $\ldots$ & $\ldots$ & 214 \\
\hline Dodoncea, I. ... & ... & $\ldots$ & $\ldots$ & $\ldots$ & 84 \\
\hline accrosa, Lindl. & ... & ... & $\ldots$ & $\ldots$ & 85,88 \\
\hline adenophora, Miq. & & ... & ... & ... & $i b$. \\
\hline asplenifolia, Rudg & & ... & ... & $\ldots$ & 85 \\
\hline attenuata, A. Cun & & ... & $\cdots$ & $\ldots$ & $i b$. \\
\hline Baueri, Fndl. & ... & $\cdots$ & ... & ... & 87 \\
\hline boronifolia, Don & & $\ldots$ & ... & $\ldots$ & 89 \\
\hline Burmanniana, $\mathrm{C} n$ & & $\ldots$ & $\ldots$ & $\ldots$ & 86 \\
\hline
\end{tabular}

Dodonca bursarifolia, B. \& M. Pl. V. ... $\quad 85,87$

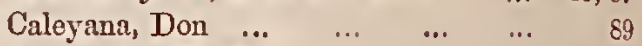
\begin{tabular}{lllll} 
ceratocarpa, Endl. & $\ldots$ & $\ldots$ & $\ldots$ & \\
\hline 5
\end{tabular} $\begin{array}{llllll}\text { conferta, Don } & \ldots & \ldots & \ldots & \ldots & i b .\end{array}$

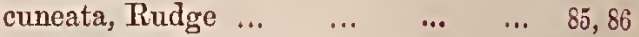

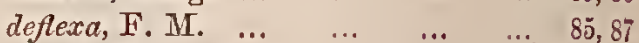
$\begin{array}{llllll}\text { filifolia, Hook. } & \ldots & \ldots & \ldots & \ldots & 88\end{array}$ foliolosa, F. M. $\ldots . \quad \ldots \quad \ldots . \quad \ldots \quad$... hexandra, F. M... $\quad \ldots \quad \ldots \quad \ldots \quad 85,89$ livitella, Miq. $\quad \ldots \quad$... $\quad \ldots \quad$ 85, 89,227 hispidula, Endl. ... $\quad \ldots \quad \ldots \quad \ldots \quad 81$ humilis, Endl. $\quad \ldots \quad \ldots \quad \ldots \quad$... $84,85,89$ $\begin{array}{llllll}\text { Kingii, Don } \quad \ldots & \ldots & \ldots & \ldots & 85\end{array}$ lanceolata, F. M. $\quad \ldots \quad \ldots, \quad \ldots \quad 226$ $\begin{array}{llllll}\text { laurina, Sieb. } & \ldots & \ldots & \ldots & \ldots & 87,226\end{array}$

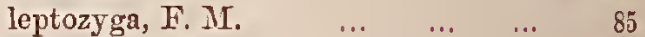

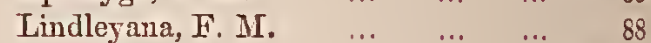
lobulata, F, M. . .. $\quad \ldots \quad \ldots \quad \ldots \quad \ldots \quad 85,86$ longipes, Don $\ldots . \quad \ldots \quad \ldots \quad \ldots$ $\begin{array}{lllll}\text { megazyga, F. M. } \quad \ldots & \ldots & \ldots & 86\end{array}$ $\begin{array}{llllll}\text { mollis, Lindl. } & \ldots & \ldots & \ldots & \ldots & 88\end{array}$ $\begin{array}{lllll}\text { multijuga, F. MT.... } & \ldots & \ldots & \ldots & 85,89\end{array}$ oblongifolia, Link. ... ... ... 85 $\begin{array}{lllll}\text { oxyptera, F. M. ... } & \ldots & \ldots & \ldots & i b .\end{array}$ $\begin{array}{lllll}\text { physocarpa, F. M. } & \ldots & \ldots & \ldots & i b .\end{array}$ $\begin{array}{llllll}\text { pinifolia, Miq. } & \ldots & \ldots & \ldots & \ldots & i b .\end{array}$ $\begin{array}{llllll}\text { pinnata, } \mathrm{Sm} . & \ldots & \ldots & \ldots & \ldots & 89\end{array}$ $\begin{array}{lllll}\text { platyptera, F. M. M. } & \ldots & \ldots & \ldots & 85,226\end{array}$ polyzyga, F. II. $\quad \ldots . \quad \ldots \quad \ldots \quad$... 80 Preissiana, Miq. ... ... .... ib. procumbcns, F. MI. $\quad \ldots \quad \ldots \quad \ldots 86,226$ $\begin{array}{llllll}\text { stenophylla, F. M. } & \ldots & \ldots & \ldots & 85\end{array}$ $\begin{array}{lllll}\text { stenozyga, F. M. } \quad \ldots & \ldots & \ldots & \delta 50,8 s\end{array}$ $\begin{array}{lllll}\text { tenuifolia, Lindl. } & \ldots & \ldots & \ldots & 88\end{array}$ $\begin{array}{lllll}\text { triangularis, Lindl. } \quad \ldots & \ldots & \ldots & 85,88\end{array}$ trigona, Lindl. ... triquetra, Wendl. $\quad \ldots \quad \ldots 85,86,87,226$ $\begin{array}{lllll}\text { truncatiales, F. M[. } & \ldots & \ldots & \ldots & 226\end{array}$

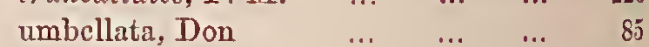
$\begin{array}{llllll}\text { vestita, Hook. } & \ldots & \ldots & \ldots & \ldots & i b .\end{array}$

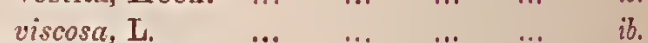

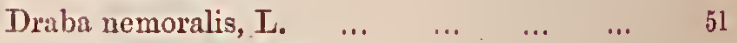
Pumilio, R. Br. ... $\quad \ldots \quad \ldots . \quad \ldots \quad$ ib.

$\begin{array}{lllllll}\text { Drosera, } \mathrm{L} . & \ldots & \ldots & \ldots & \ldots & \ldots & 51\end{array}$ Arcturi, Hook. $\ldots \quad \ldots \quad \ldots \quad 11,57,223$ $\begin{array}{lllll}\text { angustifolia, F. M. } & \ldots & \ldots & \ldots & \text { os }\end{array}$ $\begin{array}{lllll}\text { auriculata, Backh. } & \ldots & \ldots & \ldots & 61,223\end{array}$ $\begin{array}{llllll}\text { binata, Lab. } & \ldots & \ldots & \ldots & \ldots & 59\end{array}$

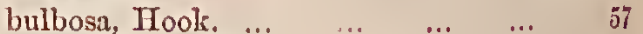
$\begin{array}{lllll}\text { Burmannï, Vahl. } & \ldots & \ldots & \ldots & 60\end{array}$ $\begin{array}{lllll}\text { glanduligera, Lchm. } & \ldots & \ldots & \ldots & 55\end{array}$ filicaulis, Endl.

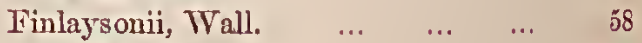
foliosa, J. Hook. gracilis, J. Hook. $\quad \ldots . \quad \ldots . \quad \ldots \quad$ ib. $\begin{array}{lllll}\text { hexagyna, Blanco } & \ldots & \ldots & \ldots & \text { อs }\end{array}$ 


\begin{tabular}{|c|c|c|c|c|c|c|c|c|c|}
\hline Diosera Indica, L. $\quad \ldots$ & $\ldots$ & $\ldots$ & ... & $\begin{aligned} \text { Pago } & \\
58, & 223\end{aligned}$ & Eriostcmon Crowei, F. M. & $\ldots$ & $\ldots$ & 119,120, & $\begin{array}{l}\text { Page } \\
121\end{array}$ \\
\hline intermedia, A, Cunn. & $\ldots$ & $\ldots$ & $\ldots$ & 59 & cuspidatus, $A$. Cunn. & $\ldots$ & $\cdots$ & ... & 122 \\
\hline lunata, Hook. ... & $\ldots$ & $\ldots$ & $\ldots$ & 60 & difformis, A. Cunn. & $\cdots$ & $\cdots$ & $\ldots 123,1$ & 128 \\
\hline Menziesü, Hook. & $\ldots$ & $\ldots$ & $\ldots$ & 62 & Drummondii, F. M. & $\cdots$ & $\cdots$ & $\ldots \quad 1$ & 128 \\
\hline pedata, Pers. ... & ... & ... & $\ldots$ & 59 & effusus, Turcz。 ... & $\cdots$ & $\cdots$ & $\cdots$ & 119 \\
\hline peltata, Sm. $\quad \ldots$ & $\ldots$ & $\ldots$ & $\ldots$ & 60,61 & elatior, F.MI. ... & $\ldots$ & $\ldots$ & $\ldots$ & 126 \\
\hline Planchonii, J. Hook. & $\ldots$ & $\ldots$ & $\ldots$ & 62 & erosus, F. Ir. $\quad \ldots$ & $\ldots$ & $\ldots$ & $\ldots$ & 121 \\
\hline porrecta, Lehm. ... & $\ldots$ & $\ldots$ & $\ldots$ & 57 & gracilis, Grah. ... & $\ldots$ & $\ldots$ & 124,133 & 134 \\
\hline propinqua, A. Cunn. & $\ldots$ & ... & $\ldots$ & 60 & grandiflorus, F. M. & ... & $\ldots$ & $\ldots 128,1$ & 133 \\
\hline pygmea, Cand. ... & $\ldots$ & $\ldots$ & $\ldots$ & 56,223 & halmaturorum, F. M. & $\ldots$ & $\ldots$ & ... & 123 \\
\hline rosulata, Behr ... & $\ldots$ & $\ldots$ & $\ldots$ & 56 & Hillebrandi, F.M. & $\ldots$ & $\ldots$ & $\ldots$ & 127 \\
\hline rosulata, Lehm. ... & $\ldots$ & $\ldots$ & -.. & 57 & hispidulus, Sieb. & ... & $\ldots$ & $\ldots$ & 228 \\
\hline serpens, Planch. ... & $\ldots$ & ... & $\ldots$ & 58 & Hookerii, F. M. & $\ldots$ & $\ldots$ & $\ldots$ & 133 \\
\hline spatulata, Lab. ... & $\ldots$ & $\ldots$ & $\ldots$ & 60,223 & intermedius, Irook. & $\ldots$ & $\ldots$ & $\ldots$ & 123 \\
\hline stenopetala, J. Hook. & $\ldots$ & $\ldots$ & ... & 55,58 & lanccolatus, J. Gærtn. & $\ldots$ & $\ldots$ & $\ldots$ & 121 \\
\hline sulphurea, Behr ... & $\ldots$ & $\ldots$ & $\ldots$ & 60 & lamprophyllus, F. M. & $\ldots$ & $\ldots$ & $\ldots$ & 126 \\
\hline Whittakerii, Planch. & Suppl. & PJ. & VI. & 56 & lepidotus, Spr. & $\ldots$ & $\ldots$ & $\ldots 130$ & 131 \\
\hline DROSERACE $Z$ E & $\ldots$ & $\therefore$ & $\ldots$ & 54 & linearifolius, Cand. & $\ldots$ & $\ldots$ & $\ldots$ & 108 \\
\hline Droseres $\quad \ldots$ & $\ldots$ & $\ldots$ & $\ldots$ & $i b$. & linearis, A. Cunn. & $\ldots$ & $\ldots$ & $\ldots$ & 123 \\
\hline Drummondita ... & $\ldots$ & ... & $\ldots$ & 119 & montanus, F. M. & $\ldots$ & $\ldots$ & $\ldots$ & 129 \\
\hline Drimys, Forst. ... ... & $\ldots$ & .. & $\ldots$ & 20 & myoporoides, Cand. & $\ldots$ & $\ldots$ & $\ldots 122]$, & 123 \\
\hline aromatica, F.M. & $\ldots$ & $\ldots$ & $\ldots$ & 20,218 & nerïfolius, Sieb. & $\ldots$ & $\ldots$ & $\ldots$ & 122 \\
\hline arillaris, Forst. ... & $\ldots$ & $\ldots$ & $\ldots$ & 21 & mudus, F. M. ... & $\ldots$ & $\ldots$ & $\ldots$ & 127 \\
\hline dipetala, F. M. ... & $\ldots$ & $\ldots$ & $\ldots$ & $i b$. & obcordatus, A. Cunn. & $\ldots$ & $\ldots$ & $\ldots$ & 123 \\
\hline & & & & & oboratus, A. Cunn. & $\ldots$ & $\ldots$ & $\ldots$ & 228 \\
\hline Elcoocarpus, L. ... _.. & $\ldots$ & $\ldots$ & $\ldots$ & 152 & Oldfieldii, F. M. & $\ldots$ & $\ldots$ & $\ldots$ & 125 \\
\hline Cunninghami, Raoul & $\ldots$ & $\ldots$ & $\ldots$ & 154 & ovatifolius, F. M. & $\ldots$ & $\ldots$ & $\ldots$ & 131 \\
\hline cyaneus, Ait. $\quad$... & $\ldots$ & $\ldots$ & $\ldots$ & 152 & ozothamnoides, F. M. & $\ldots$ & $\ldots$ & $\ldots \quad 1$ & 130 \\
\hline dentatus, Vahl. & $\ldots$ & $\ldots$ & $\ldots$ & 154 & phylicoides, F. M. & $\ldots$ & $\ldots$ & ... 119, ] & 131 \\
\hline Hinau, A. Cunn. & $\ldots$ & $\ldots$ & $\ldots$ & $i b$. & pleurandroides, F. M. & $\ldots$ & $\ldots$ & ... & 133 \\
\hline holopetalus, F. M. & $\ldots$ & $\ldots$ & $\ldots$ & 153 & pungens, Lindl. & $\ldots$ & $\ldots$ & $\ldots$ & 125 \\
\hline Hookeri, Raoul & $\ldots$ & $\ldots$ & $\ldots$ & $i b$. & quercifolius, F. M. & $\ldots$ & $\ldots$ & $\ldots$ & 132 \\
\hline oboratus, Don ... & $\ldots$ & $\ldots$ & $\ldots$ & $i b$. & Ralstonii, F. M. ... & $\ldots$ & $\ldots$ & $\ldots$ & 228 \\
\hline parviflorus, A. Rich. & $\ldots$ & $\ldots$ & $\ldots$ & $i b$. & Lindl. & $\ldots$ & $\ldots$ & ... 123, & 124 \\
\hline reticulatus, Sm. ... & $\ldots$ & $\ldots$ & $\ldots$ & 152 & salicifolius, Sm. & $\ldots$ & $\ldots$ & $\ldots$ & 121 \\
\hline strictus, Lamb. ... & $\ldots$ & $\ldots$ & $\ldots$ & 154 & Paxt. ... & $\ldots$ & $\ldots$ & $\ldots$ & 123 \\
\hline ELATINEE & $\ldots$ & $\ldots$ & $\ldots$ & 194 & sediflorus, F. M. & $\ldots$ & $\ldots$ & $\ldots$ & 130 \\
\hline Elatine, L. $\quad \ldots \quad \ldots$ & $\ldots$ & $\ldots$ & $\ldots$ & 195 & scrrulatus, F. M. & $\ldots$ & $\ldots$ & ... & 128 \\
\hline Americana, Arn... & $\cdots$ & $\cdots$ & $\cdots$ & $i b$. & spicatus, Rich. ... & $\ldots$ & $\ldots$ & $\ldots$ & 119 \\
\hline gratioloides, A. Cunn. & $\cdots$ & $\cdots$ & $\cdots$ & $i b$. & squancus, Lab. ... & ... & $\ldots$ & 119,129 & 131 \\
\hline hexandra, Cand. ... & $\cdots$ & $\cdots$ & $\ldots$ & 196 & trachyphyllus, F. M. & $\ldots$ & ... & $\ldots$ & 121 \\
\hline Hydropiper, I. ... & $\cdots$ & $\cdots$ & $\ldots$ & $i b$. & trymalioides, I. M. & $\ldots$ & ... & $\ldots$ & 134 \\
\hline $\operatorname{minima}, \mathrm{F}, \& \mathrm{M}$. & $\cdots$ & $\cdots$ & $\cdots$ & 195 & Turczaninovii, F. M. & ... & ... & $\ldots$ & 120 \\
\hline triandra, Schk. ... & & $\cdots$ & $\cdots$ & 196 & unbellatus, Turcz. & $\ldots$ & ... & $\ldots 128$ & 228 \\
\hline tripetala, F. M. $\mathrm{Pl}, \mathrm{I}$ & & $\ldots$ & $\cdots$ & $i b$. & verpucosus, A. Rich. & $\ldots$ & $\ldots$ & $\ldots 123$ & 228 \\
\hline Emblingia $\quad \ldots \quad \ldots$ & $\ldots$ & $\ldots$ & $\ldots$ & 52 & virgatus, $A$. Cunn. & $\ldots$ & $\cdots$ & .. 119, & 125 \\
\hline Empleurosma ... & $\ldots$ & $\ldots$ & $\ldots$ & 107 & Erodium, L'Her. $\quad$... & $\ldots$ & ... & $\ldots$ & 171 \\
\hline Erioglossum $\quad \ldots$ & $\ldots$ & $\ldots$ & $\ldots$ & 84 & cicutarium, L'Her. & $\ldots$ & ... & ... & 173 \\
\hline Eriostemon, Smitli & $\cdots$ & $\cdots$ & $\cdots$ & 118 & cygnom, Nces & $\ldots$ & $\ldots$ & $\ldots$ & 172 \\
\hline alpinus, F. M. ... & $\cdots$ & $\cdots$ & $\ldots$ & 130 & grainum, L'Her. & $\therefore$ & $\ldots$ & $\ldots$ & $i b$. \\
\hline anceps, F. MI. ... & $\begin{array}{l}\cdots \\
\cdots\end{array}$ & $\ldots$ & & $i b$. & Jitoreum, Leman & ... & $\ldots$ & ... & $i b$. \\
\hline brerifolius, A. Cunn. & $\ldots$ & ... & $\ldots 1$ & 123,124 & Erpetion hederaceum, Cand. & ... & ... & ... & 65 \\
\hline buxifolins, Sm. ... & $\ldots$ & $\ldots$ & $\ldots 1$ & 123,128 & petiolare, Don & $\ldots$ & $\ldots$ & ... & $i$ i. \\
\hline capitatus, F. M. ... & $\cdots$ & $\cdots$ & $\cdots$ & 132 & reniforme, Sweet & $\ldots$ & $\ldots$ & $\because \cdots$ & $i b$. \\
\hline corraifolius, F. M. & $\ldots$ & $\ldots$ & 132,1 & 133,134 & spathulatum, Don & $\ldots$ & $\ldots$ & $\ldots$ & $i b$. \\
\hline corymbosus, Lab. & $\begin{array}{l}\cdots \\
\cdots\end{array}$ & $\begin{array}{l}\cdots \\
\cdots\end{array}$ & $\ldots$ & 119 & Erysimum $\quad \ldots \quad \ldots$ & $\ldots$ & $\ldots$ & $\ddot{2}$ & 38 \\
\hline
\end{tabular}




$\begin{array}{ccccr}\text { Erysimum blennodes, F. M. } & \ldots & \ldots & \ldots & 40 \\ \text { breripes, F. M. ... } & \ldots & \ldots & \ldots & 41 \\ \text { curvipes, F. M. ... } & \ldots & \ldots & \ldots & 42 \\ \text { filifolium, F. M. .. } & \ldots & \ldots & \ldots & 40 \\ \text { Nasturtium, F. M. } & \ldots & \ldots & \ldots & 39 \\ \text { Eucryphia .. ... } & \ldots & \ldots & \ldots & 192 \\ \text { Eunomia cochlearina, F. M. } & \ldots & \ldots & \ldots & 51 \\ \text { Euodia .. ... ... } & \ldots & \ldots & \ldots & 108,110 \\ \text { erythrococca, F. M. } & \ldots & \ldots & \ldots & 111 \\ \text { micrococca, F. M. } & \ldots & \ldots & \ldots & 110 \\ \text { ternata, Forst. ... } & \ldots & \ldots & \ldots & i b . \\ \text { Euphorbia Chanæsyce, L. } & \ldots & \ldots & \ldots & 165 \\ \text { Eupomatia, R. Br. ... } & \ldots & \ldots & \ldots & 219 \\ \text { Bennettii, F. M. ... } & \ldots & \ldots & \ldots & i b . \\ \text { laurina, R. Br. ... } & \ldots & \ldots & \ldots & i b .\end{array}$

Fleischeria 158 fruticulosa, Cand. lavis, L. $\ldots \quad \ldots \quad \ldots \quad \ldots \quad \ldots \quad \quad 82,83,165$ pauciflora, Cand. scabra, Lindl. scrpillifolia, Lindl. $\quad \ldots . \quad \ldots \quad \ldots . \quad$ ib. tetrapetala, Lab.

$\begin{array}{llllll}\text { FIRANKENIACEE } & \ldots & \ldots & \ldots & \ldots & 81\end{array}$

$\begin{array}{lllllllr}\text { Friesia } & \ldots & \ldots & \ldots & \ldots & \ldots & \ldots & 152\end{array}$

$\begin{array}{lllllll}\text { Fugosia } & \ldots & \ldots & \ldots & \ldots & \ldots & \ldots \\ \end{array}$

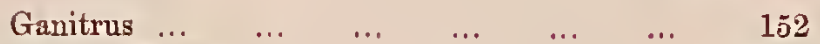

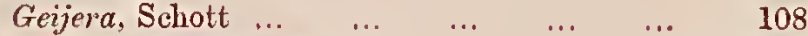
latifolia, Lindl. $\ldots . \quad \ldots \quad \ldots \quad \ldots \quad 109$ parviflora, Lindl. $\quad \ldots \quad \ldots \quad \ldots 108,109$ pendula, Jindl. ... ... ... ... 108

Geleznovi

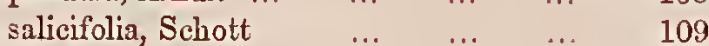

Geococcus pusillus, Harr. $\begin{array}{llllll}\text { GERANLACE } \mathbb{E} & \ldots & \ldots & \ldots & \ldots & 169\end{array}$ Geranium, L. ... $\quad \ldots \quad \ldots . . .173$

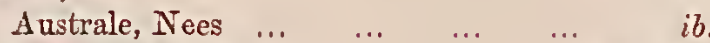
brevicaule, Hook. $\quad \ldots \quad \ldots . \quad \ldots \quad 173,174$ columbinum, I. ... $\quad \ldots \quad \ldots . \quad \ldots \quad \ldots \quad 174$ dissectum, L. $\quad \ldots \quad \ldots \quad \ldots \quad \ldots, 173,174$

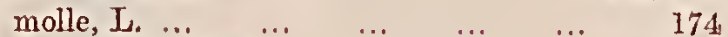

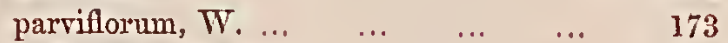
philonotum, Cand. $\quad \ldots . \quad \ldots . \quad \ldots, \quad i b$. pilosum, Forst. ... $\quad \ldots \quad$... $\quad \ldots . \quad$ ib. potentilloides, L'Her, $\quad \ldots \quad \ldots . \quad \ldots \quad$ ib.

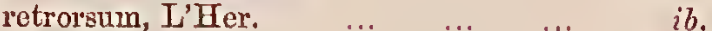

Glines, Iœfl. dictamanoides, Gly cosmis oryoles, F Gossypium $-\cdots, \ldots$ $\begin{array}{llllll}\text { Australc, F. M. } . . . & \ldots & \ldots & \ldots & 158 \\ & \ldots & \ldots & \ldots & 168\end{array}$
Page

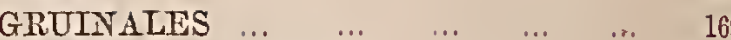

$\begin{array}{lllllll}\text { Guichenotia } & \ldots & \ldots & \ldots & \ldots & \ldots & 140\end{array}$

Gunnia septicida, F. MI. ...

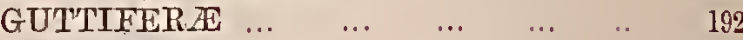

$\begin{array}{lllllll}\text { Gynaudropsis } & \ldots & \ldots & \ldots & \ldots & \ldots & 5\end{array}$

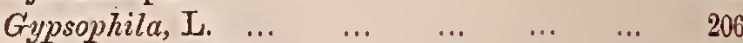

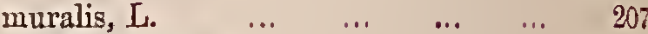
tubulosu, Boiss. ... $\quad \ldots \quad \ldots \quad \ldots \quad 206$

$\begin{array}{llllllll}\text { Gyrostemon } & \ldots & \ldots & \ldots & \ldots & \ldots & 197\end{array}$ acaciformis, F. MI. $\quad \ldots \quad \ldots, \quad \ldots, \quad 200$ cotinifolius, Desf. $\quad \ldots \quad \ldots \quad \ldots \quad$ ib. pungens, Lindl. ... $\quad \ldots \quad$... $\quad \ldots \quad$ ib. ramulosus, Desf. ... $\quad$... $\quad \ldots \quad \ldots \quad$... 198

Halothamnus, F. MI. $\quad \ldots \quad$.. $\quad \ldots \quad \ldots \quad \ldots \quad 158$ $\begin{array}{lllll}\text { mierophyllus, F. II. } \quad \ldots & \ldots & \ldots & 159\end{array}$

$\begin{array}{lllllll}\text { Hannafordia } & \ldots & \ldots & \ldots & \ldots & \ldots & 140\end{array}$

$\begin{array}{llllllll}\text { Harpulia } & \ldots & \ldots & \ldots & \ldots & \ldots & \ldots & 84\end{array}$

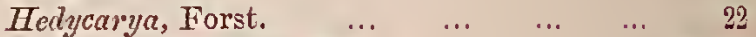
$\begin{array}{lllll}\text { Cunninghami, Tul. } & \ldots & \ldots & \ldots & 23,220\end{array}$ dentata, Forst. $\quad \ldots \quad \quad \ldots \quad \ldots \quad \ldots . \quad 23$ macrophylla, A. Cunn. ... ... ... ib. Psendomorus, F. M. Suppl. Pl. II. ... 23, 220 $\begin{array}{llllll}\text { racemosa, Tul. } & \ldots & \ldots & \ldots & \ldots & \ldots \\ \end{array}$

$\begin{array}{llllll}\text { Helicteres Ixora, } L . & \ldots & \ldots & \ldots & \ldots & 1005\end{array}$

$\begin{array}{lllllll}\text { HILLEBOREE } & \ldots & \ldots & \ldots & \ldots & \ldots & 10\end{array}$

$\begin{array}{lllllll}\text { Hemistemma } & \ldots & \ldots & \ldots & \ldots & \ldots & 14\end{array}$

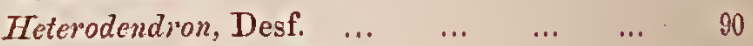
dirersifolium, F. M. oleifolium, Desf. ... $\quad \ldots \quad \ldots \quad \ldots \quad$... 90,227

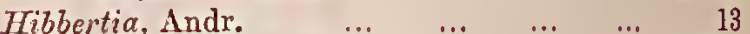
$\begin{array}{lllll}\text { acicularis, F. M. } & \ldots & \ldots & \ldots & 17\end{array}$ $\begin{array}{lllll}\text { angustifolia, Salisb. } \quad \ldots & \ldots & \ldots & 19,18\end{array}$ $\begin{array}{llllll}\text { aspera, Cand. } & \ldots & \ldots & \ldots & \ldots & 18\end{array}$ Billardierii, F. M. $\quad$... $\quad \ldots \quad$... 14,217

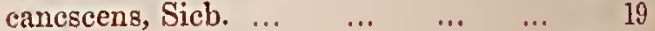
densiftora, F, M.

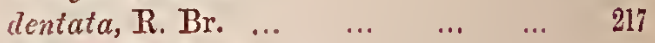
$\begin{array}{llllll}\text { diffusa, R. Br. } & \ldots & \ldots & \ldots & \ldots & 18\end{array}$ $\begin{array}{lllll}\text { ericifolia, J. Hook. } & \ldots & \ldots & \ldots & 17\end{array}$ fasciculata, R. Br. $\begin{array}{lllll}\text { glandulosa, Schlecht. } & \ldots & \ldots & \ldots & 18\end{array}$ $\begin{array}{lllll}\text { grossularifolia, Salisb. } \ldots & \ldots & \ldots & 218\end{array}$ Inmifusa, F. M. Suppl. Pl. I. _.. 16 $\begin{array}{llllll}\text { linearis, } \mathrm{R} . \mathrm{Br} . & \ldots & \ldots & \ldots & \ldots & 19\end{array}$ monogyna, $\mathrm{R}$. Br. $\quad \ldots \quad \ldots \quad \ldots \quad \ldots \quad 18$ $\begin{array}{lllll}\text { obtusifolia, Cand. } & \ldots & \ldots & \ldots & 19\end{array}$ pedunculata, R. Br. $\quad \ldots \quad$... $\quad \ldots \quad$ is procumbens, Cand. $\quad \ldots . \quad \ldots . \quad \ldots \quad$ ib. prostrata, Hook. ... $\quad \ldots \quad \ldots \quad \ldots \quad \ldots \quad i b$. scrpillifolia, R. Br. $\quad \cdots \quad \ldots \quad \ldots \quad \ldots \quad$ ib. $\begin{array}{llllll}\text { stricta, } \mathrm{R} . \mathrm{Br}, & \ldots & \ldots & \ldots & \ldots & 15,16\end{array}$ $\begin{array}{llllll}\text { virgata, } \mathbf{R} . \mathrm{Br} . & \ldots & \ldots & \ldots & \ldots & 11,19\end{array}$ $\begin{array}{lllll}\text { volubilis, Andr, ... } & \ldots & \ldots & \ldots & 218\end{array}$

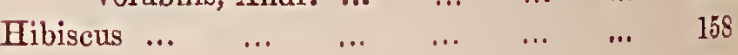


Hibiscus heterophyllus, Vent. ... $\quad \ldots \quad \ldots \quad \ldots \quad 165$ pandurifolius, Burm. ... $\quad \ldots \quad \ldots . \quad$... populneus, L. $\quad \ldots \quad \ldots \quad \ldots \quad \ldots, \quad i b$. radiatus, Cav. $\quad \ldots \quad-\quad \ldots \quad \ldots \quad \ldots, \quad i b$. $\begin{array}{llllll}\text { tiliaceus, } \mathrm{I} . & \ldots & \ldots & \ldots & \ldots & \text { ib. }\end{array}$ $\begin{array}{llllll}\text { Trionum, } \mathrm{L} . & \ldots & \ldots & \ldots & \ldots & i b .\end{array}$ ritifolius, L.

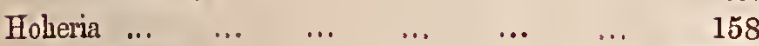

$\begin{array}{lllllll}\text { Homalosporum } & \ldots & \ldots & \ldots & \ldots & \ldots & 70,77\end{array}$

Howittia, F. II. ... ... ... ... . . 158, 167 trilocularis, F. M. Pl. IV. $\quad \ldots \quad \ldots \quad 167$

Huegelia

$\begin{array}{lllllll}\text { Hutchinsia } & \ldots & \ldots & \ldots & \ldots & \ldots & 42 \\ & & \end{array}$

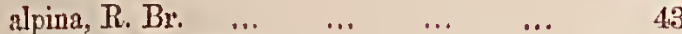
Australis, J. Hook. $\quad \ldots \quad \ldots \quad \quad \ldots \quad$ 4 procumbens, Desv. $\quad \ldots \quad$... $\quad \ldots \quad 43$

Hrdropeltis purpurea, L. C. Rich. $\quad \ldots \quad$...

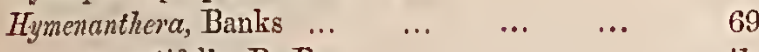
angustifolia, R. Br. $\quad \ldots \quad \ldots, \quad \ldots . \quad$ ib. Banksii, F. II. ... $\quad \ldots \quad$... $\quad \ldots, 69,224$ crassifolia, J. Hook. $\quad \ldots \quad \ldots \quad \ldots, \quad \ldots \quad 70$

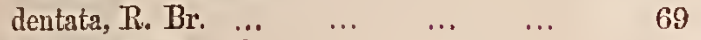

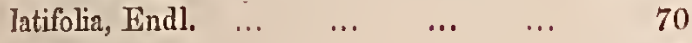

$\begin{array}{lllllll}\text { Hymenolobus } & \ldots & \ldots & \ldots & \ldots & \ldots & 42\end{array}$ diraricatus, Nutt. $\quad$... $\quad \ldots \quad$... 43

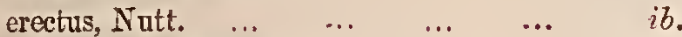
procumbens, Nutt. $\quad \ldots \quad$... $\quad \ldots . \quad$ ib.

$\begin{array}{lllllll}\text { Hymenosporum... } & \ldots & \ldots & \ldots & \ldots & 70\end{array}$

Hymenotheca acaciformis, F. MI. $\quad \ldots . \quad \ldots \quad 200$

$\begin{array}{llllll}\text { HYPERTCIN } E & \ldots & \ldots & \ldots & \ldots & 192\end{array}$

$\begin{array}{llllll}\text { Hypericum, Toumef. } & \ldots & \ldots & \ldots & \ldots & 198\end{array}$ gramineum, Forst. $\quad \ldots . \quad \ldots \quad \ldots b^{2}$ inrolutum, Choisy $\quad \ldots \quad \ldots . \quad \ldots . \quad i b$. Japonicum, Thunb. $\quad \ldots . \quad \ldots \quad \ldots . \quad$ ib. pedicellare, Lindl. $\quad \ldots \quad \ldots \quad \ldots . \quad i b$. pusillum, Choisy

Iberis linearifolia, Cand.

Ionidium, Vent.

Australasix, Behr

calycinum, Steud.

enneaspermum, Ven

filiforme, Endl. ...

foribundum, Lindl. Suppl. Pl. VIII. glaucum, Endl.

linaroides, Pres].

monopetalum, R. \& S. . .

ramosissimum, Thwait. ...

suffruticosum, Ging.

Vernonii, F. MI.

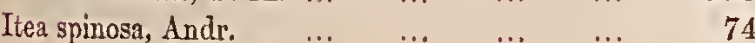

Keraudrenia

Lagunaria Pattersonii, Don
Lasiopetalum, Sin.

..... 140, 14

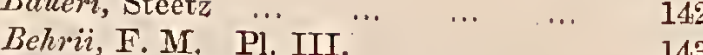

capitellatum, Turez. $\quad$... $\quad \ldots . .6143$

confertiflorum, F. M. $\quad \ldots \quad \ldots \quad \ldots, 132,144$

cordifolium, Endl. $\quad \ldots . \quad \ldots . \quad \ldots \quad 145$

dasyphyllum, Sieb. $\quad \ldots \quad$... $\quad 132,144,228$

discolor, Hook. $\quad \ldots \quad \ldots \quad \ldots \quad \ldots \quad \ldots .144$

$\begin{array}{lllll}\text { ferrergineum, } \mathrm{Sm} . & \ldots & \ldots & \ldots & 141 \\ & & \ldots & \ldots & 141\end{array}$

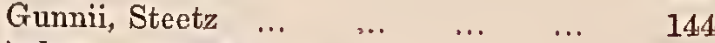

indutum, Steud. ... $\quad \ldots \quad \ldots \quad \ldots \quad \ldots . \quad 145$

micranthum, J. Hook. ... $\quad \ldots \quad \ldots . \quad$...

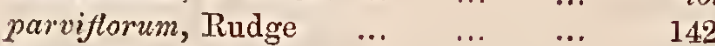

quinquenervium, Turez. $\quad$... $\quad \ldots \quad \quad 144$

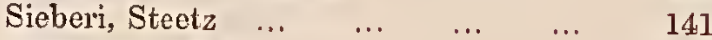

stelligerum, Turcz. $\quad \ldots . \quad \ldots \quad \ldots . \quad 143$

Wilhelmii, F: M. $\quad \ldots \quad \ldots . \quad \ldots, \quad 144$

$\begin{array}{llllllll}\text { Laurelia } & \ldots & \ldots & \ldots & \ldots & \ldots & \ldots & 24\end{array}$

Lavatera, L. $\quad \ldots \quad \ldots . \quad \ldots \quad \ldots \quad \ldots 158,166$

Australis, A, Cunn. $\quad$... $\quad \ldots \quad \ldots \quad 166$

Behriana, Schlecht. $\quad \ldots \quad$... $\quad \ldots . \quad i b$.

$\begin{array}{llllll}\text { hispida, Desf. } & \ldots & \ldots & \ldots & \ldots & 167\end{array}$

$\begin{array}{llllll}\text { plebeja, } \operatorname{Sim} s \quad \ldots & \ldots & \ldots & \ldots & 166\end{array}$

Lawrencia $\quad \ldots \quad \ldots . \quad \ldots \quad \ldots \quad \ldots 158,159$

glomerata, Hook. $\quad$... $\quad \ldots \quad \ldots \quad \ldots \quad 162$

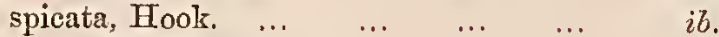

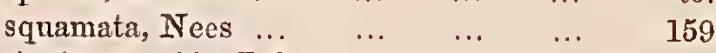

Lawsonia Acronychia, Lab. $\quad \ldots \quad \ldots \quad \ldots \quad \ldots \quad 98$

$\begin{array}{llllllll}\text { Learosa } & \ldots & \ldots & \ldots & \ldots & \ldots & \ldots & 24\end{array}$

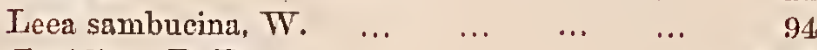

Lepidium, R. Br. $\quad \ldots \quad \ldots \quad \ldots \quad \ldots \quad \ldots \quad 42,45$

amıbiguum, F. M. $\quad$... $\quad \ldots \quad \ldots . \quad \ldots \quad 45$

$\begin{array}{lllll}\text { cuneifolium, Cand. } & \ldots & \ldots & \ldots & 46\end{array}$

foliosum, Desv. ... $\quad \ldots \quad \ldots \quad \ldots . \quad \ldots \quad i b$.

hyssopifolium, Desv. ... $\quad \ldots \quad \ldots, \quad 45$

leptopetalum, F. MT. $\quad \ldots \quad \ldots \quad 48,51,222$

monoploeoides, F. M. ... $\quad \ldots \quad \ldots \quad 47,222$

Nove Hollandiæ, Desv. $\quad$... ... 46

papillosum, F. M. $\quad$... $\quad \ldots \quad$... 46,222

phlebopetalum, F. M. .. $\quad \ldots \quad$... 47,51

$\begin{array}{lllll}\text { piscidium, Forst. } & \ldots & \ldots & \ldots & 46\end{array}$

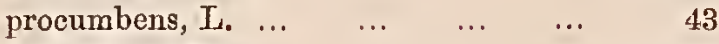

puberulum, Bunge $\quad \ldots \quad \ldots \quad \ldots, \quad 46$

rotundum, Cand.... $\quad \ldots \quad \ldots \quad \ldots \quad 47,224$

mederale, L. $\quad \ldots \quad \ldots . \quad \ldots \quad 45,46,222$

strongylopliyllum, F. M. $\quad$.. $\quad$... 223

Lepigonum, Fries $\quad$... $\quad \ldots \quad$... $\quad \ldots . \quad 207$

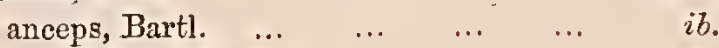

brevifolium, Bartl. $\quad \ldots \quad \ldots . \quad \ldots \quad$ ib.

$\begin{array}{lllll}\text { laxiflorum, Bartl. } & \ldots & \ldots & \ldots & i b .\end{array}$

marinum, Wahl... $\quad \ldots \quad \ldots \quad \ldots . \quad$ ib.

marginatum, Koch $\quad \ldots \quad \ldots . \quad \ldots \quad$ ib.

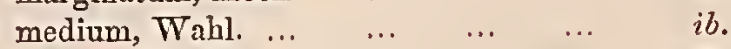

rubrum, Wahl. $\ldots . \quad \ldots \quad$... $\quad \ldots \quad$ ib.

$\begin{array}{lllllll}\text { Leucothammus } & \ldots & \ldots & \ldots & \ldots & \ldots & 140\end{array}$

$\begin{array}{lllll}\text { L'Heritiera litoralis, Ait. } \quad \ldots & \ldots & \ldots & 155\end{array}$ 
LINE $\mathbb{A}$

Limum, L.

Babingtonii, Planch.

Gallicum, L.

marginale, A. Cunu. monogynum, Forst.

selaginoides, Lam.

suxdifolium, Planch.

Lysiosepalum

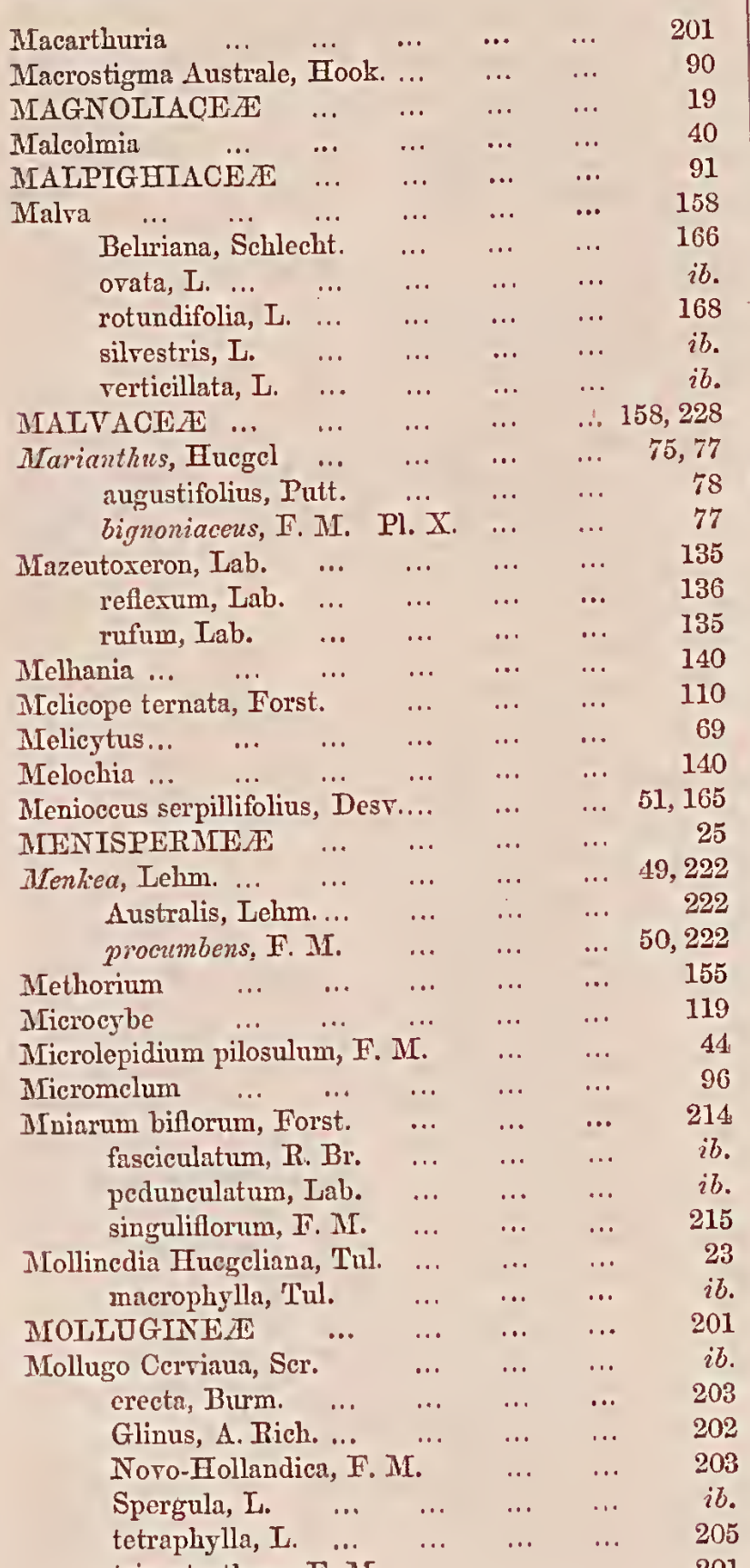

$\begin{array}{lllll}\text { Mollugo rerticillata, Roxb. } & \ldots & & & \\ \text { Page }\end{array}$ $\begin{array}{llllll}\text { MONIMUACE } 2 \mathrm{E} & \ldots & \ldots & \ldots & \ldots & 22\end{array}$

$\begin{array}{lllllll}\text { Monimine } & \ldots & \ldots & \ldots & \ldots & \ldots & i b .\end{array}$

$\begin{array}{llllllll}\text { Mounocera } & \ldots & \ldots & \ldots & \ldots & \ldots & 152\end{array}$

$\begin{array}{lllllll}\text { Monococcus } & \ldots & \ldots & \ldots & \ldots & \ldots & 197\end{array}$

$\begin{array}{llll}\text { Monoploca leptopetala, F. M. ... } & \ldots & \ldots & 48\end{array}$ linifolia, Bunge $\ldots \quad \ldots \quad \ldots \quad \ldots \quad$... phlebopetala, F. M. $\quad \ldots \quad$... $\quad \ldots .4 \quad 47$

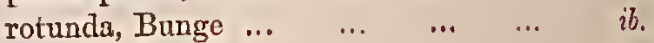

$\begin{array}{lllllll}\text { Moricandia } & \ldots & \ldots & \ldots & \ldots & \ldots & 40\end{array}$

$\begin{array}{llllllll}\text { Miurraya } & \ldots & \ldots & \ldots & \ldots & \ldots & 96\end{array}$

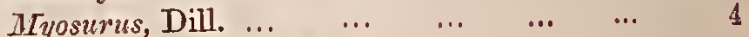
aristatus, Benth. $\quad$.. $\quad \ldots \quad \ldots \quad$... $\begin{array}{lllll}\text { Australis, F. M. } & \ldots & \ldots & \ldots & 4\end{array}$ $\begin{array}{llllll}\text { minimus, L. } & \ldots & \ldots & \ldots & \ldots & i b .\end{array}$

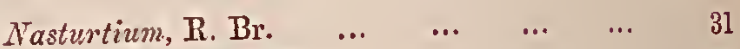
amphibium, $\mathrm{Br} . \ldots \quad \ldots \quad \ldots \quad \ldots \quad$... 32 $\begin{array}{llllll}\text { officinale, Br. } & \ldots & \ldots & \ldots & \ldots & i b .\end{array}$

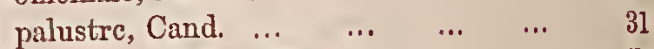
semipinvatifidum, Fook. $\quad \ldots \quad \ldots \quad$ ib.

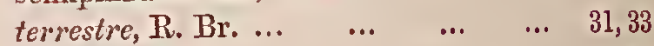
$\begin{array}{llllll}\text { silvestre, } \mathrm{Br} . & \ldots & \ldots & \ldots & \ldots & 32\end{array}$

$\begin{array}{lllllll}\text { Nematolepis } & \ldots & \ldots & \ldots & \ldots & \ldots & 135\end{array}$

$\begin{array}{lllllll}\text { Fiephelium } & \ldots & \ldots & \ldots & \ldots & \ldots & 22 i\end{array}$ $\begin{array}{lllll}\text { leiocarpum, F. M. } & \ldots & \ldots & \ldots & i b .\end{array}$

$\begin{array}{lllllll}\text { Nitraria, L. } & \ldots & \ldots & \ldots & \ldots & \ldots & 92\end{array}$ Billardicrii, Cand. Suppl. Pl. VII. 92, 227 Schœberi, L. $\quad \ldots \quad \ldots \quad \ldots \quad \ldots \quad \ldots 9,165$ $\begin{array}{lllllll}\text { NotorRHIZE } & \ldots & \ldots & \ldots & \ldots & \ldots & 38\end{array}$

$\begin{array}{lllllll}\text { Ochrolasia } & \ldots & \ldots & \ldots & \ldots & \ldots & 14\end{array}$

$\begin{array}{lllllll}\text { Oncosporum } & \ldots & \ldots & \ldots & \ldots & \ldots & 75\end{array}$

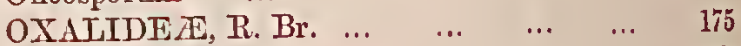

$\begin{array}{lllllll}\text { Oxalis, I. } & \ldots & \ldots & \ldots & \ldots & \ldots & i b .\end{array}$ cataractæ, A. Cunn. $\quad \ldots \quad$... $\quad \ldots \quad 176$ $\begin{array}{llllll}\text { cognata, Steud. } & \ldots & \ldots & \ldots & \ldots & 177\end{array}$ $\begin{array}{llllll}\text { corniculata, } \mathrm{L} . & \ldots & \ldots & \ldots & \ldots & \ldots\end{array}$

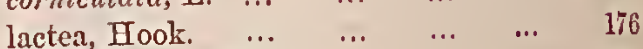
Magellanica, Forst. $\quad \ldots \quad \ldots \quad \ldots \quad$... $\quad$ b. microphylla, Poir. $\quad \ldots \quad \ldots \quad \ldots \quad$... 177 $\begin{array}{lllll}\text { Preissiana, Steud. } & \ldots & \ldots & \ldots & i b .\end{array}$ reptans, Forst. $\quad \ldots \quad \ldots \quad \ldots \quad \ldots \quad \ldots \quad i b$. $\begin{array}{llllll}\text { stricta, L... } & \ldots & \ldots & \ldots & \ldots & i b .\end{array}$

$\begin{array}{lllllll}\text { Pachygone } & \ldots & \ldots & \ldots & \ldots & \ldots & 221\end{array}$

$\begin{array}{lllllll}\text { Pacliynema } & \ldots & \ldots & \ldots & \ldots & \ldots & 14\end{array}$

$\begin{array}{llllll}\text { Papaver, Tournef. } & \ldots & \ldots & \ldots & \ldots & 29\end{array}$ horridum, Cand.... $\quad \ldots \quad \ldots \quad \ldots \quad$ ib. $\begin{array}{llllll}\text { Rhoeas, L. } & \ldots & \ldots & \ldots & \ldots & 29,30\end{array}$

$\begin{array}{llllll}\text { PAPAVERACE } E & \ldots & \ldots & \ldots & \ldots & 26\end{array}$

$\begin{array}{lllllll}\text { Paritium } & \ldots & \ldots & \ldots & \ldots & \ldots & 168\end{array}$ tiliaceum, A. Juss. $\quad \ldots \quad \ldots . \quad \ldots \quad 165$

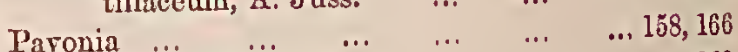
$\begin{array}{llllll}\text { hastata, } \mathrm{L} . & \ldots & \ldots & \ldots & \ldots & 168\end{array}$

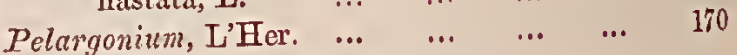


INDEX.

Pelargonium Acugnaticum, J. Hook. .. Australe, W. Suppl. Pl. XI. clandestinum, L'Her. ... $\quad \ldots-17$ orodioides, Hook. $\quad \ldots . \quad \ldots . \quad \ldots, \quad$ ib. glomeratum, Jacq. $\quad \ldots \quad \ldots, \quad \ldots, \quad i b$, inodorum, $\mathrm{W} . \quad \ldots \quad \ldots \quad \ldots \quad \ldots \quad$ ib.

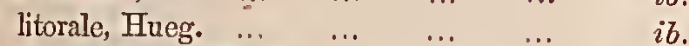
Rodneyanum, Mitch. $\quad \ldots \quad \ldots \quad \ldots \quad \ldots \quad 171$

$\begin{array}{lllll}\text { Peplis Americana, Purslı. } \quad \ldots & \ldots & \ldots & 195\end{array}$

$\begin{array}{lllllll}\text { Pericampylus } & \ldots & \ldots & \ldots & \ldots & \ldots & 27,221\end{array}$

$\begin{array}{lllll}\text { Pharnaccum Mollugo, } \mathrm{L} . \quad \ldots & \ldots & \ldots & 203\end{array}$

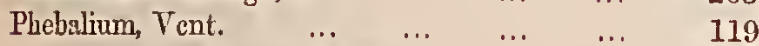
asteriscophorum, F. M. ... $\quad \ldots . \quad \ldots . \quad 132$ $\begin{array}{lllll}\text { aureum, A. Cunn. } & \ldots & \ldots & \ldots & 130\end{array}$

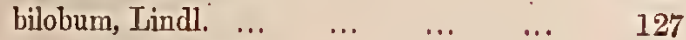
Billardierii, A. Juss. $\quad \ldots \quad$... $\quad \ldots \quad 129$ corræifolium, A. Juss, $\quad \ldots \quad \ldots \quad \ldots \quad \ldots \quad 132$

$\begin{array}{lllll}\text { Dariesii, J. Hook. } & \ldots & \ldots & \ldots & 132 \\ & \ldots & \ldots & 130\end{array}$

diosmeum, A. Juss. $\quad \ldots \quad \ldots, \quad \ldots, \quad 131$

cleagnifolium, A. Juss. ... $\quad \ldots, \quad \ldots . \quad 130$

$\begin{array}{lllll}\text { elatum, A. Cunn. } \quad \text {... } & \text {... } & \text {... } & 129\end{array}$

glandulosum, Hook. $\quad \ldots \quad \ldots \quad \ldots \quad \ldots \quad 130$

$\begin{array}{llll}\text { lachnæoides, A. Cunn, } & \ldots & \ldots & 228\end{array}$

montanum, Hook. $\quad$... $\quad \ldots . \quad \ldots . \quad 129$

$\begin{array}{llllll}\text { nudum, Hook. } & \ldots & \ldots & \ldots & \ldots & 127\end{array}$

$\begin{array}{lllll}\text { oratifolium, F. M. } & \ldots & \ldots & \ldots & 131\end{array}$

$\begin{array}{lllll}\text { ozothamnoides, F. M. } & \ldots & \ldots & \ldots & 130\end{array}$

$\begin{array}{lllll}\text { phylicifolium, F. M. } & \text {... } & \ldots & \ldots & 128\end{array}$

$\begin{array}{lllll}\text { phylicoides, Sieb. } & \ldots & \ldots & \ldots & 131\end{array}$

podocarpoides, F. M. $\ldots . \quad \ldots, \quad \ldots, \quad 130$

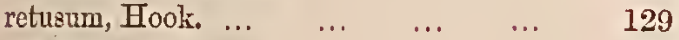

$\begin{array}{lllll}\text { salicifolium, A. Juss. } & \ldots & \ldots & \ldots & 128\end{array}$

$\begin{array}{lllll}\text { sediflorum, F. M. } & \ldots & \ldots & \ldots & 130\end{array}$

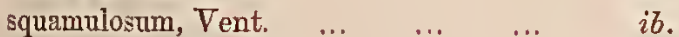

truncatum, J. Hook. $\quad \ldots \quad \quad \ldots \quad \ldots \quad 127$

. ... 130

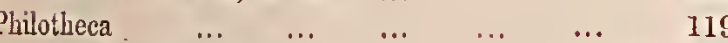

dustralis, Rudge... $\quad \ldots \quad \ldots \quad \ldots \quad 124,125$

$\begin{array}{lllll}\text { longifolia, Turcz. } & \ldots & \ldots & \ldots & 125\end{array}$

$\begin{array}{llllll}\text { PHYTOLACCE } 1 \text { E } & \ldots & \ldots & \ldots & \ldots & 197\end{array}$

$\begin{array}{lllll}\text { Pigea Banksiana, Ging. ... } & \ldots & \ldots & \ldots & 67\end{array}$

calycina, Cand. ... $\quad \ldots \quad \ldots \quad \ldots 67,224$

filiformis, Cand. ... $\quad \ldots \quad \ldots \quad \ldots \quad 66,223$

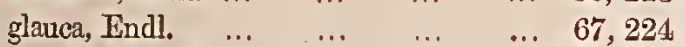

monopetala, Ging. $\quad \ldots . \quad \ldots \quad \ldots .67$

$\begin{array}{llllll}\text { PITTOSPORE } 2 \mathrm{E} & \ldots & \ldots & \ldots & \ldots & 70\end{array}$

$\begin{array}{llllll}\text { Pittosporum, B. \& S. } & \ldots & \ldots & \ldots & \ldots & \text { 7I }\end{array}$

acacioides, A. Cunn. $\quad \ldots \quad \ldots \quad \ldots .72$

angustifolium, Lodd. $\quad \ldots \quad \ldots \quad \ldots \quad \ldots \quad 73$

bicolor, Hook. $\quad \ldots \quad \ldots \quad \ldots \quad \ldots \quad$... 72,224

discolor, Regel $\ldots . \quad \ldots \quad \ldots \quad \ldots \quad \ldots \quad$ 224

$\begin{array}{llllll}\text { flarum, Hook. } & \ldots & \ldots & \ldots & \ldots & 73\end{array}$

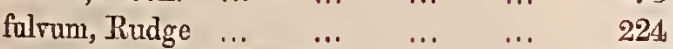

$\begin{array}{llll}\text { ligustrifolium, A. Cunn. } & \ldots & \ldots & 72\end{array}$

longifolium, Putt.
Pittos por'um melarospermum, F. M.

nanum, Hook.

73

oleafolium, A. Cunn. $\quad \ldots \quad \ldots \quad \ldots . \quad \ldots \quad 72$

ovatifolium, F. M. $\quad \ldots . \quad \ldots \quad \ldots . \quad 73$

$\begin{array}{lllll}\text { parviflorum, Putt. } & \ldots & \ldots & \ldots & \text {... }\end{array}$

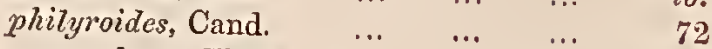

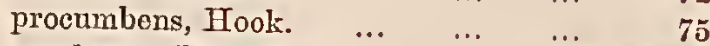

revolutum, Dryand. $\quad . . \quad \ldots \quad 71,73,224$

rhombifolium, A. Cunn. $\quad \ldots . \quad \ldots \quad 73$

$\begin{array}{lllll}\text { Rœanum, Putt. ... } & \ldots & \ldots & \ldots & 73 \\ \end{array}$

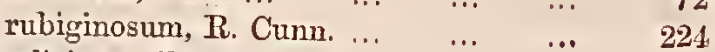

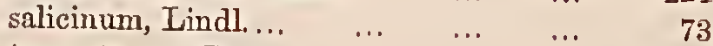

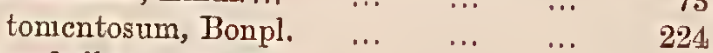

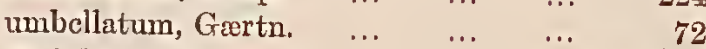

undulatum, Vent. $\quad \ldots \quad \ldots . \quad \ldots \quad 71,224$

$\begin{array}{lllllll}\text { Plagianthus } & \ldots & \ldots & \ldots & \ldots & \ldots & 71,224 \\ & & \ldots & \ldots & 159\end{array}$

divaricatus, Forst. $\quad \ldots \quad \ldots . \quad \ldots \quad \ldots, \quad i b$.

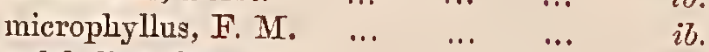

$\begin{array}{lllll}\text { pulchellus, Gray } & \ldots & \ldots & \ldots & 160\end{array}$

$\begin{array}{lllllll}\text { PLATrGones } & \ldots & \ldots & \ldots & \ldots & \ldots & 26\end{array}$

$\begin{array}{lllllll}\text { Platyphragma } & \ldots & \ldots & \ldots & \ldots & \ldots & 34\end{array}$

$\begin{array}{lllll}\text { Platy theca galioides, Steetz } & \ldots & \ldots & \ldots & \\ & & \ldots & & \end{array}$

$\begin{array}{rrrrr}\text { Pleurandra acerosa, } \mathrm{Br} . & \ldots & \ldots & \ldots & 180 \\ \end{array}$

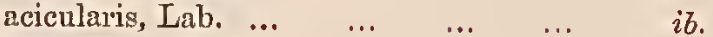

$\begin{array}{lllll}\text { astrotricha, Sicb. } & \ldots & \ldots & \ldots & 14\end{array}$

calycina, Cand. ... $\quad \ldots . \quad \ldots \quad \ldots . \quad 15$

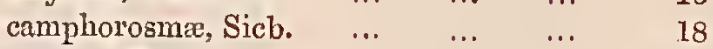

$\begin{array}{llllll}\text { cinerea, } \mathrm{Br} . & \ldots & \ldots & \ldots & \ldots & 15\end{array}$

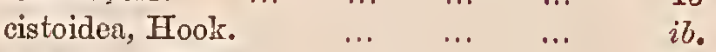

densiflora, Hook. $\quad \ldots \quad \ldots \quad \ldots . \quad i b$.

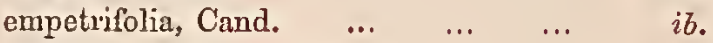

enervia, Cand. ... ... ... ... $\quad i b$.

cricifolia, Cand. ... $\quad \ldots \quad \ldots \quad \ldots \quad \ldots \quad i b$.

humifusa, F. M. ... $\quad \ldots \quad \ldots . \quad \ldots \quad 16$

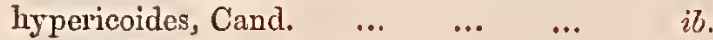

$\begin{array}{llllll}\text { incana, Lindl. } & \ldots & \ldots & \ldots & \ldots & 15\end{array}$

intermedia, Cand. $\quad \ldots \quad \ldots . \quad \ldots \quad$ ib.

juniperina, Turez. $\quad \ldots . \quad \ldots \quad \ldots . \quad \ldots \quad 17$

mucronata, Turcz. $\quad \ldots \quad$... $\quad \ldots \quad$ ib.

$\begin{array}{llllll}\text { nitida, } \mathrm{Br} . & \ldots & \ldots & \ldots & \ldots & 15\end{array}$

$\begin{array}{llllll}\text { ovata, Lab. } & \ldots & \ldots & \ldots & \ldots & 14,15\end{array}$

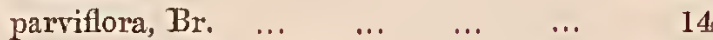

$\begin{array}{llllll}\text { riparia, } \mathrm{Br}, & \ldots & \ldots & \ldots & \ldots & 15\end{array}$

$\begin{array}{llllll}\text { scabra, } \mathrm{Bl} . & \ldots & \ldots & \ldots & \ldots & 14\end{array}$

$\begin{array}{llllll}\text { sericea, } \mathrm{Br} . & \ldots & \ldots & \ldots & \ldots & 15\end{array}$

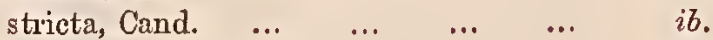

$\begin{array}{llllll}\text { Pledrorrhize.... } & \ldots & \ldots & \ldots & \ldots & 31\end{array}$

$\begin{array}{lllllll}\text { Pœcilodermis } & \ldots & \ldots & \ldots & \ldots & \ldots & 155\end{array}$

$\begin{array}{lllllll}\text { Polanisia } & \ldots & \ldots & \ldots & \ldots & \ldots & 52\end{array}$

$\begin{array}{lllllll}\text { Polycarpæa } & \ldots & \ldots & \ldots & \ldots & \ldots & 205\end{array}$

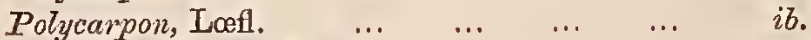

$\begin{array}{lllll}\text { alsinifolium, Cand. } & \ldots & \ldots & \ldots & 206\end{array}$

$\begin{array}{lllll}\text { tetraphyllum, I. ... } & \ldots & \ldots & \ldots & 205\end{array}$

$\begin{array}{lllllll}\text { Polygala, L. } & \ldots & \ldots & \ldots & \ldots & \ldots & 184\end{array}$

Japonica, Thunb. $\quad \ldots . \quad \ldots \quad \ldots . \quad 185$

veronicec, F. M. ... $\quad \ldots . \quad \ldots \quad$... 
INDEX.

\begin{tabular}{|c|c|c|c|c|}
\hline POLYGALE正 & & $\ldots$ & & $\begin{array}{l}\text { Pirge } \\
183\end{array}$ \\
\hline POLYGALTNEIE & $\ldots$ & $\ldots$ & $\ldots$ & 180 \\
\hline $\begin{array}{lll}\text { Pomaderris } & \ldots & \ldots\end{array}$ & ... & $\ldots$ & $\ldots$ & 150 \\
\hline Pringlea antiscorbutica, R. Br. & &.. & $\ldots$ & 52 \\
\hline Pronaya angustifolia, Lehm. . & $\cdots$ & .. & $\cdots$ & 78 \\
\hline elegans, Hueg. . ... & $\cdots$ & $\cdots$ & $\cdots$ & $i b$. \\
\hline ericoides, Lindl. ... & ... & $\cdots$ & $\ldots$ & 75 \\
\hline Huegeliana, Putt. & $\cdots$ & $\cdots$ & $\ldots$ & 78 \\
\hline speciosa, Endl. $\ldots$ & $\cdots$ & $\cdots$ & $\ldots$ & $i b$. \\
\hline Pterospermum $\quad \ldots \quad \ldots$ & $\cdots$ & $\cdots$ & $\cdots$ & 140 \\
\hline RANUNCULACE $A \quad \ldots$ & $\cdots$ & $\cdots$ & $\ldots$ & 2 \\
\hline RAXUNCULEE $\ldots, \quad \ldots$ & $\ldots$ & $\cdots$ & $\cdots$ & ร \\
\hline Ranuneulus, C. Bauh. ... & $\cdots$ & $\cdots$ & $\cdots$ & $i b$. \\
\hline acaulis, B. \& S. ... & $\ldots$ & $\cdots$ & $\cdots$ & 8 \\
\hline anemoneus, F. M. Pl. I & I. & $\cdots$ & $\cdots$ & 78 \\
\hline aquatilis, $\mathrm{L} . \quad \ldots \quad$ & $\cdots$ & $\cdots$ & $\cdots$ & 7,8 \\
\hline biternatus, Sm. ... & $\cdots$ & $\cdots$ & $\cdots$ & 8 \\
\hline circinatus, Sibth. & $\cdots$ & $\cdots$ & $\cdots$ & $\begin{array}{r}6 \\
-8\end{array}$ \\
\hline colonorum, Endl. & $\cdots$ & $\cdots$ & $\cdots$ & 7,8 \\
\hline crassipes, J. Hook. & $\cdots$ & $\ldots$ & $\cdots$ & 8 \\
\hline cuneatus, Hook. ... & $\cdots$ & $\cdots$ & $\cdots$ & 7 \\
\hline discolor, Steud. ... & $\ldots$ & $\ldots$ & $\cdots$ & 8 \\
\hline geraniifolius, J. Hook. & $\cdots$ & $\cdots$ & $\cdots$ & $i b$. \\
\hline glabrifolius, Hook. & $\ldots$ & $\ldots$ & $\cdots$ & $i b$. \\
\hline Gunnianus, Hook. & $\cdots$ & $\cdots$ & $\cdots$ & 9 \\
\hline hirtus, B. \& S. ... & $\cdots$ & $\cdots$ & $\cdots$ & 8 \\
\hline incisus, J. Hook. & $\ldots$ & $\cdots$ & $\cdots$ & $i b$. \\
\hline inconspicuus, $\mathrm{J}$. Hook. & $\ldots$ & $\cdots$ & $\cdots$ & $i b$. \\
\hline inundatus, $\mathrm{R} . \mathrm{Br}$. & $\cdots$ & $\cdots$ & $\cdots$ & 8 \\
\hline lappaceus, Sm. ... & $\ldots$ & $\ldots$ & $\cdots$ & 7,8 \\
\hline leptocaulis, Hook. & $\cdots$ & $\cdots$ & $\cdots$ & 9 \\
\hline macropus, J. Hook. & $\cdots$ & $\cdots$ & $\cdots$ & 8 \\
\hline Millani, F.M. ... & $\cdots$ & $\cdots$ & $\cdots$ & 6 \\
\hline multiscapus, J. Hook. & $\ldots$ & $\cdots$ & $\cdots$ & 7 \\
\hline muricatus, I. $\quad \ldots$ & $\cdots$ & $\cdots$ & $\cdots$ & 9 \\
\hline nanus, Hook. $\quad$... & $\cdots$ & $\cdots$ & $\cdots$ & $T$ \\
\hline nivicola, Hook. . .. & $\cdots$ & $\cdots$ & $\cdots$ & $i b$. \\
\hline parviflorus, L. ... & $\cdots$ & $\cdots$ & $\cdots$ & 9 \\
\hline pilulifer, Hook. ... & $\ldots$ & $\ldots$ & $\ldots$ & $i b$. \\
\hline pimpinellifolius, Hook. & $\ldots$ & $\cdots$ & ... & 7 \\
\hline plebejus, R. Br. & $\ldots$ & $\cdots$ & $\ldots$ & 8 \\
\hline Pumilio, Br. $\quad \ldots$ & $\ldots$ & $\ldots$ & $\ldots$ & 9 \\
\hline repens, I. $\quad \ldots$ & ... & $\ldots$ & $\ldots$ & 8 \\
\hline rivularis, B. \& S. & ... & $\cdots$ & $\ldots$ & $i b$. \\
\hline scapigcrus, J. Hook. & $\ldots$ & $\ldots$ & $\ldots$ & $\tau, 8$ \\
\hline sessiliflorus, R. Br. & $\ldots$ & ... & $\ldots$ & 9 \\
\hline stenopetalus, Hook. & ... & $\ldots$ & $\ldots$ & 8 \\
\hline RHCEADES $\quad \ldots \quad \ldots$ & ... & $\ldots$ & $\ldots$ & 28 \\
\hline Thyuchostemon $\quad .$. & ... & $\ldots$ & $\ldots$ & 140 \\
\hline Rhytidosporum, F. M. ... & $\ldots$ & $\ldots$ & $\ldots$ & 74,75 \\
\hline procumbens, F. М. & $\ldots$ & $\ldots$ & 75,1 & 80,225 \\
\hline Riedlea $\quad \ldots \quad \ldots \quad \ldots$ & $\ldots$ & $\ldots$ & $\ldots$ & 140 \\
\hline $\begin{array}{llll}\text { Ropera } & \ldots & \ldots & \ldots\end{array}$ & $\ldots$ & $\ldots$ & $\ldots$ & 52 \\
\hline aurantiaca, Lindl. & & $\ldots$ & $\cdots$ & 105 \\
\hline Billardierii, A. Juss. & $\ldots$ & $\ldots$ & $\ldots$ & 104 \\
\hline
\end{tabular}

$\begin{array}{llllll}\text { Ropera fabagifolia, A. Juss. } & \ldots & \ldots & \ldots & \text { Page } \\ & & \ldots & & & \end{array}$ latifolia, J. Hook. $\quad \ldots \quad \ldots . \quad \ldots \quad 101$

Rulingia, R. Br. ... $\quad \ldots \quad \ldots \quad \ldots \quad \ldots 140,150$ cistifolia, A. Cunn. $\quad$... $\quad \ldots . \quad \ldots . \quad 151$ $\begin{array}{lllll}\text { corylifolia, Grah. } & \ldots & \ldots & \ldots & i b .\end{array}$ hermannifolia, Steetz $\quad \ldots \quad \ldots . \quad \ldots \quad$ ib. $\begin{array}{lllll}\text { oblongifolia, Steetz } & \ldots & \ldots & \ldots & i b .\end{array}$ pannosa, R. Br. ... $\quad \ldots \quad \ldots \quad \ldots \quad$... 150

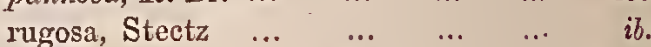

$\begin{array}{lllllll}\text { RUTACEE } & \ldots & \ldots & \ldots & \ldots & \ldots & 100\end{array}$ $\begin{array}{lllllll}\text { RUTINE正 } & \ldots & \ldots & \ldots & \ldots & \ldots & 96\end{array}$ $\begin{array}{lllllll}\text { Ryssopteris } & \ldots & \ldots & \ldots & \ldots & \ldots & 92\end{array}$

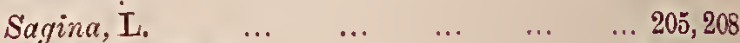
apetala, L. $\quad \ldots . \quad \ldots \quad \ldots \quad \ldots 205,209$ $\begin{array}{llllll}\text { maritima, Don } & \ldots & \ldots & \ldots & \ldots & 209\end{array}$ prooumbens, L. ... ... $\quad \ldots \quad \ldots 200,208$ stricta, Fries $\quad \ldots \quad \ldots \quad \ldots . \quad \ldots \quad 209$ $\begin{array}{lllllll}\text { Sandfordia } & \ldots & \ldots & \ldots & \ldots & \ldots & 119\end{array}$ $\begin{array}{llllll}\text { SAPINDACE } & \ldots & \ldots & \ldots & \ldots & 83\end{array}$ $\begin{array}{lllllll}\text { SAPINDIN } 2 & \ldots & \ldots & \ldots & \ldots & \ldots & i b .\end{array}$

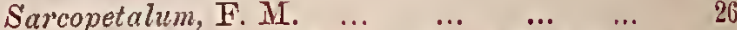
Harveyamim, F. M. Suppl. Pl. III.... 27, 221

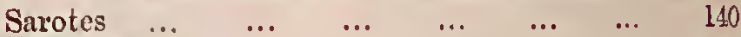

$\begin{array}{lllllll}\text { Schmiedelia } & \ldots & \ldots & \ldots & \ldots & \ldots & 84\end{array}$

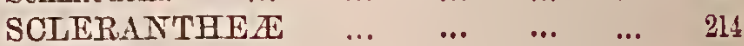

$\begin{array}{lllllll}\text { Scleranthus, L. } & \ldots & \ldots & \ldots & \ldots & \ldots & i b\end{array}$ bifloms, J. Hook. $\quad \ldots \quad$... $\quad \ldots$. ib. diander, R. Br. ... ... $\ldots$. mniaroides, F. M. Pl. XII. $\quad \ldots . \quad \ldots . \quad$ ib. pungens, R. Br. ... $\quad \ldots \quad$... $\quad \ldots \quad 216$

Senebiera Coronopus, Poir. $\quad \ldots \quad$... $\begin{array}{llllll}\text { didyma, Pers. } & \ldots & \ldots & \ldots & \ldots & i b .\end{array}$

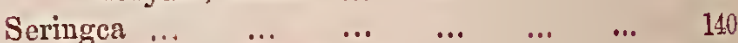

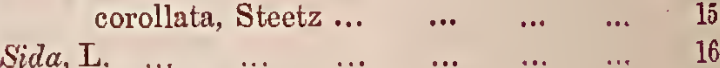
$\begin{array}{llllll}\text { Abutilon, L. } \quad \ldots & \ldots & \ldots & \ldots & 164\end{array}$ calyxhymenia, Gray $\quad$... $\quad \ldots \quad$... ib corrugata, Lindl. $\quad \ldots . \quad \ldots \quad \ldots 163,104$ crispa, L. ... $\begin{array}{lllll}\text { diplotricha, F. M. } & \ldots & \ldots & \ldots & \text { i } \\ \end{array}$ $\begin{array}{lllll}\text { fibulifera, Lindl, ... } & \ldots & \ldots & \ldots & 163\end{array}$ filiformis, A. Cunn. $\quad \ldots \quad \ldots . \quad \ldots \quad i b$. halophila, F. M... $\quad \ldots \quad$... $\quad \ldots \quad 165$ Hookeriana, Miq. $\quad$... . ... ... 164 $\begin{array}{lllll}\text { liumillima, F. M. } & \ldots & \ldots & \ldots & 163\end{array}$ $\begin{array}{llllll}\text { Indica, } \mathrm{L} & \ldots & \ldots & \ldots & \ldots & 165\end{array}$ interstans, F. Mr... $\quad \ldots \quad \ldots \quad \ldots \quad 163$ intricata, F, M. ... $\quad \ldots \quad$... $\ldots$. ib. Lawencia, F. MI. $\quad \ldots . \quad \ldots . \quad \ldots$ 162, 168

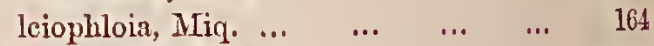
$\begin{array}{lllll}\text { leucopetala, F. M. } & \ldots & \ldots & \ldots & 161\end{array}$ $\begin{array}{lllll}\text { nematopoda, F. IF. } & \ldots & \ldots & \ldots & 163\end{array}$ $\begin{array}{lllll}\text { otocarpa, F. М.... } & \ldots & \ldots & \ldots & 160\end{array}$ $\begin{array}{lllll}\text { petrophila, F. M. } & \ldots & \ldots & \ldots & 164\end{array}$ phrotricha, F. Mr. ․ $\quad$... $\quad \ldots \quad$ ib. 


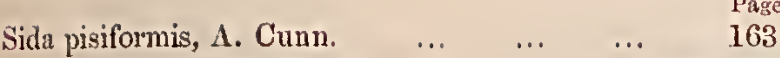
pulchella, Bonpl. $\quad \ldots \quad \ldots \quad \ldots 156,160$ ramosa, Spreng. ... $\quad \ldots \quad \ldots \quad \ldots \quad \ldots \quad 161$ $\begin{array}{lllllll}\text { retusa. } I . & \ldots & \ldots & \ldots & \ldots & 165\end{array}$ $\begin{array}{llllll}\text { rupestris, Miq. } & \ldots & \ldots & \ldots & \ldots & 164\end{array}$ spodochroma, F. M. $\quad \ldots \quad \ldots, \quad \ldots .163$ Tasmanica, J. Hook. $\quad \ldots . \quad \ldots . \quad \ldots .160$ $\begin{array}{lllll}\text { trichopoda, F. M. } & \ldots & \ldots & \ldots & 163\end{array}$ $\begin{array}{llllll}\text { triloba, Car. } & \ldots & \ldots & \ldots & \ldots & 164\end{array}$ rirgata, Hook. … ...

Silene Gallica, I. $\quad \ldots \quad \ldots . \quad \ldots \quad \ldots \quad \ldots$

Sinapis hastata, Desf. ... ...

$\begin{array}{llllll}\text { Sisymbrium, L. } & \ldots & \ldots & \ldots & \ldots & 38\end{array}$ cardaminoides, F. M. $\quad \ldots . \quad \ldots . \quad \ldots .40$ filifolium, F. M. ... $\quad \ldots \quad \ldots . \quad \ldots \quad$ ib. $\begin{array}{lllll}\text { nasturtioides, F. M. } & \ldots & \ldots & \ldots & 39\end{array}$ officinale, Scop. ... $\quad \ldots \quad \ldots \quad \ldots \quad \ldots 4,51$

$\begin{array}{lllll}\text { Thalianum, Gaudinı } \quad \ldots & \ldots & \ldots & 39\end{array}$ trisectum, F. M.

Solea calycina, Spr.

Sollya monopetala, Spr.

Spanoghea, Blume connata, F. M. nephelioides, F. M. tomentosa, F. M.

Spergula affinis, J. Hook. apetala, Lab. ... arrensis, $I$. purpurea, Ray $\ldots .$.
rubra, Torr. \& Gray

Spergularia, Pers. marginata, Kitt. ... nubra, Cambess. ... rupestris, Cambess. salicina, Presl.

Stellaria, I. angustifolia, Hook. caspitosa, J. Hook. flaccida, Hook. ... glauca, Wither. media, Wither. multiflora, Hook. pungens, Brogn. ..

- squarrosa, Hook.

Stenopetalum, R. Br.

croceum, Bunge

draboides, Hook. gracile, Bunge ... incisifolium, J. Hook. lineare, $\mathrm{R}$. Br. minus, Bunge procumbens, Hook. robustum, Endl. ... spherocarpum, F, M.

70,76

90,227

227
Stenopelalum velutinum, F. MI.

Page

$\begin{array}{llll}\text { Abyssinica. Walp. } & \ldots & \ldots & 26,220 \\ & & & \end{array}$

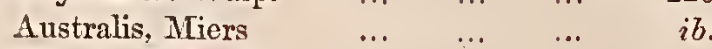

discolor, Walp. ... $\quad \ldots . \quad \ldots . \quad \ldots . \quad$ ib.

Forsterii, Asa Gray - ... $\quad \ldots \quad \ldots \quad \quad i b$.

Gaudichaudii, Asa Gray $\quad \ldots, \ldots, 221$

glaucescens, Walp. $\quad \ldots \quad \ldots \quad \ldots \quad \ldots \quad 220$

hernandifolia, Walp. ... $\quad \ldots \quad$... 26,220

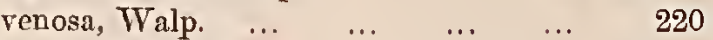

$\begin{array}{llllll}\text { Sterculia diversifolia, Don } & \ldots & \ldots & \ldots & 156\end{array}$

$\begin{array}{llllll}\text { fotida, } \mathrm{L} . . . & \ldots & \ldots & \ldots & \ldots & 155\end{array}$

heterophylla, A. Cunn. ... $\quad \ldots \quad \ldots . \quad 156$

$\begin{array}{llllll}\text { quadrifida, } \mathrm{Br}, & \ldots & \ldots & \ldots & \ldots & 155\end{array}$

$\begin{array}{llllll}\text { STERCULTACE } 2 E & \ldots & \ldots & \ldots & \ldots & 154\end{array}$

$\begin{array}{llllll}\text { Stipularia, Haw. } & \ldots & \ldots & \ldots & \ldots & 207\end{array}$

$\begin{array}{llllll}\text { rubra, Haw. } & \ldots & \ldots & \ldots & \ldots & i b .\end{array}$

$\begin{array}{llllllll}\text { Sturtia } & \ldots & \ldots & \ldots & \ldots & \ldots & \ldots & 158\end{array}$

$\begin{array}{lllllll}\text { Stylobasium } & \ldots & \ldots & \ldots & \ldots & \ldots & 90,197\end{array}$

lineare, Nees $\quad \ldots \quad \ldots \quad \ldots \quad \ldots \quad \ldots 0$

spathulatum, Desf. $\quad \ldots \quad \quad \ldots \quad \ldots \quad$...

$\begin{array}{llllllll}\text { Suriana } & \ldots & \ldots & \ldots & \ldots & \ldots & \ldots & 179\end{array}$

$\begin{array}{llllll}\text { Symphyopetalum } & \ldots & \ldots & \ldots & \ldots & 135\end{array}$

$\begin{array}{lllll}\text { Tasmania aromatica, } \mathrm{R} . \mathrm{Br} . & \ldots & \ldots & \ldots & 20\end{array}$ $\begin{array}{llllll}\text { dipetala, } \mathrm{R} . \mathrm{Br}, & \ldots & \ldots & \ldots & \ldots & 21\end{array}$ insipida, $\mathrm{R}, \mathrm{Br} . \quad \ldots \quad \ldots \quad \ldots . \quad \ldots, \quad i b$.

$\begin{array}{lrrrrr}\text { Tersonia } & \ldots & \ldots & \ldots & \ldots & 19 \\ \end{array}$

Tetratheca, Sm. ... $\quad \ldots \quad \ldots \quad \ldots \quad \ldots, 181,228$

baueræfolia, F. M. $\quad$... $\quad \ldots \quad$... 182

$\begin{array}{llllll}\text { calra, F. M. } & \ldots & \ldots & \ldots & \ldots & i b .\end{array}$

$\begin{array}{llllll}\text { ciliata, Lindl. } & \ldots & \ldots & \ldots & \ldots & 181\end{array}$

denticulata, Sieb. $\quad \ldots . \quad \ldots \quad \ldots \quad 182$

ericifolic, Sm. $\ldots \quad \ldots \quad \ldots, \quad \ldots, \quad, i b$.

glandulosa, Sm. ... $\quad \ldots . \quad \ldots \quad \ldots . \quad i b$.

Gunnii, J. Hook. $\quad \ldots \quad$... $\quad . . \quad$ ib.

$\begin{array}{llllll}\text { juncea, Sm. } & \ldots & \ldots & \ldots & \ldots & 183\end{array}$

$\begin{array}{llllll}\text { pilosa, Lab. } \quad \ldots & \ldots & \ldots & \ldots & 182\end{array}$

procumbens, Gunn. $\quad$.. $\quad \ldots \quad \quad \therefore \quad i b$.

rubioides, A. Cunı. $\quad \ldots \quad \ldots . \quad \ldots . \quad i b$.

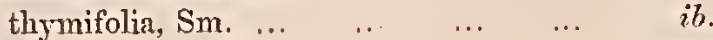

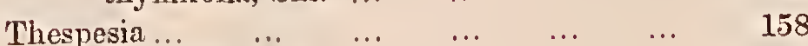

populnea, Corr. ... $\quad \ldots \quad$... $\quad \ldots \quad 165$

$\begin{array}{llllllll}\text { Thlaspi } & \ldots & \ldots & \ldots & \ldots & \ldots & \ldots & 42\end{array}$

cochlearinum, F. M. $\quad \ldots . \quad \ldots \quad \ldots . \quad \ldots 1$

ochranthum, F. M. $\quad$... $\quad \ldots . \quad \ldots . \quad 223$

Tasmanicum, J. Hook. ... $\quad \ldots \quad \ldots . \quad 51$

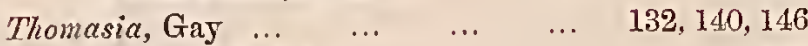

$\begin{array}{llllll}\text { cognata, Stoud. } & \ldots & \ldots & \ldots & \ldots & 148\end{array}$

macrocalyx, Schlecht. $\ldots \quad \ldots \quad \ldots \quad 147$

macrocalyx, Steud. $\quad \ldots \quad \ldots \quad \ldots \quad \ldots$ ib.

pauciflora, Lindl. $\quad$... $\quad$... $\quad \ldots \quad 148$

petalocaly $x, \mathrm{~F} . \mathrm{M}$. $\quad \ldots \quad \ldots \quad \ldots 147,148$

$\begin{array}{llllll}\text { purpurea, Gay } & \ldots & \ldots & \ldots & \ldots & 148\end{array}$

undulata, Steetz ... $\quad \ldots \quad \ldots \quad \ldots \quad$ i. 
Thouinia adenophora, Miq

\section{TILIACE $A$}

Tinospora..

Tremandra stelligera, $\mathrm{R} . \mathrm{Br}$.

TREMANDRE $A$

Tribulopsis augustifolia, $\mathrm{R}$. Br. bicolor, F. MT. pentandra, $\mathrm{R}$. Br. Solandri, $R, B r$.

Tribulus, Tournef. acanthococcus, F. M. bicolor, F. M.

Brownii, F. M. cistoides, $\mathrm{L}$

Hystrix, R. Br. lanatus, Walp. ... lanuginosus, L. ... $\quad \ldots \quad \ldots \quad \ldots$ ranunculiflorus, F. M. Solandri, F. M. terrestris, $\mathrm{L}$.

Trichosiphon

Trigastrotheca molluginea, F. M

Triphasia

Tristellateia Australasica, A. Ric

Triumfetta

Turritis, Dill. glabra, I.

Urocarpus

VINIFER.A

Viola, Tournef. . betonicifolia, $\mathrm{Sm}$ Caleyana, Don Cunninghami, J. Hook. hederacea, Lab. .. longiscapa, Cand. phyteumifolia, Cand. Sieberiana, Spr.

VIOLACE 70

VIOLEX

Titis, L.

$\begin{array}{cccr} & & & \text { Page } \\ \ldots & \ldots & \ldots & 88 \\ \ldots & \ldots & \ldots & 151 \\ \ldots & \ldots & \ldots & 221 \\ \ldots & \ldots & \ldots & 228 \\ \ldots & \ldots & \ldots & i b . \\ \ldots & \ldots & \ldots & 180 \\ \mathrm{Br} . & \ldots & \ldots & 99 \\ \ldots & \ldots & \ldots & i b . \\ \ldots & \ldots & \ldots & i b . \\ \ldots & \ldots & \ldots & i b . \\ \ldots & \ldots & \ldots & i b . \\ \ldots & \ldots & \ldots & i b . \\ \ldots & \ldots & \ldots & i b . \\ \ldots & \ldots & \ldots & i b . \\ \ldots & \ldots & \ldots & i b . \\ \ldots & \ldots & \ldots & 100 \\ \ldots & \ldots & \ldots & i b . \\ \ldots & \ldots & \ldots & 99 \\ \ldots & \ldots & \ldots & i b . \\ \ldots & \ldots & \ldots & i b . \\ \ldots & \ldots & \ldots & 99,165 \\ \ldots & \ldots & \ldots & 155 \\ \mathrm{M} . & \ldots & \ldots & 201 \\ \ldots & \ldots & \ldots & 96 \\ \mathrm{Rich} & \ldots & \ldots & 92 \\ \ldots & \ldots & \ldots & 152 \\ \ldots & \ldots & \ldots & 33 \\ \ldots & \ldots & \ldots & 33,221 \\ & & & \end{array}$

119

93

63

64

$i b$.

66 angustissima, F. MT. $\quad \ldots \quad \ldots . \quad \ldots, \quad$ ib. clematidea, F. M. $\quad \ldots . \quad \ldots . \quad \ldots \quad$ ib. h.ypoglauea, A. Gray. Suppl. Pl. X. $\quad 94,95$

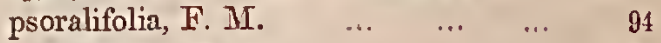
stcrculifolia, F. M.

Vlamingia Australasica, Vries. $\quad \ldots \quad \ldots .67$

$\begin{array}{lllllll}\text { Waltheria... } & \ldots & \ldots & \ldots & \ldots & \ldots & 140\end{array}$

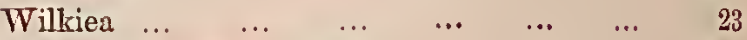

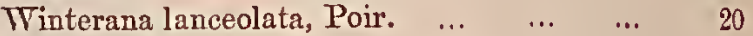

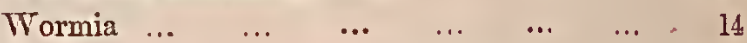

Xanthoxylon Australasicum, A. Juss. $\quad$... 108 brachyacanthum, F. M. $\quad \ldots \quad \ldots . \quad$...

$\begin{array}{lllllll}\text { Zieria, Smith } & \ldots & \ldots & \ldots & \ldots & \ldots & 110\end{array}$ arborescens, Sims $\quad \ldots \quad \ldots \quad \ldots \quad 111$ cytisoides, $\mathrm{Sm} . \quad \ldots \quad \ldots \quad \ldots \quad \ldots, \quad \ldots 112,223$ $\begin{array}{llllll}\text { Fraseri, Hook. } & \ldots & \ldots & \ldots & \ldots & 113\end{array}$ hirsuta, Cand. $\quad \ldots \quad \ldots \quad \ldots \quad \ldots \quad \ldots \quad$ ib. $\begin{array}{llllll}\text { lævigata, } \mathrm{Sm} . & \ldots & \ldots & \ldots & \ldots & 111\end{array}$ lanceolata, R. Br. $\quad \ldots \quad \ldots \quad \ldots \quad$ ib. macrophylla, Bonpl, $\quad \ldots \quad \ldots . \quad \ldots \quad i b$. microphylla, Bonpl. $\quad \ldots \quad \ldots \quad \ldots \quad$ ib. $\begin{array}{llllll}\text { pauciflora, Sm. } & \ldots & \ldots & \ldots & \ldots & i b .\end{array}$ $\begin{array}{lllll}\text { octandra, Sweet } \ldots & \ldots & \ldots & \ldots & 110\end{array}$ $\begin{array}{lllll}\text { revoluta, A. Cunn. } & \ldots & \ldots & \ldots & 111\end{array}$ Smithii, Andr. $\quad \ldots \quad \ldots \quad \ldots . \quad \ldots \quad$ ib. $\begin{array}{lllll}\text { Teronicea, F. M. } & \ldots & \ldots & \ldots & 228\end{array}$ $\begin{array}{llllll}\text { ZYGOPHYLLEX } & \ldots & \ldots & \ldots & \ldots & 98\end{array}$

$\begin{array}{lllllll}\text { Zygophyllum, I. ... } & \ldots & \ldots & \ldots & \ldots & 100\end{array}$ $\begin{array}{lllll}\text { apiculatum, F. M. } & \ldots & \ldots & \ldots & 101\end{array}$ aurantiacum, F. MI. $\quad \ldots \quad \ldots . \ldots .106$ Australasicum, Miq. $\quad \ldots \quad \ldots \quad \ldots \quad 101$ Billardierii, Cand. ... $\ldots . . .104,106$ crenatum, F. MI. Pl. VI. ... ... 103, 227 fruticulosum, Cand. ... ... ... 105, 100 glaucescens, F. M. $\quad \ldots \quad \ldots \quad \ldots 102,227$ $\begin{array}{llllll}\text { glaucum, F. M. ... } & \ldots & \ldots & \ldots & 22 \pi\end{array}$ $\begin{array}{lllll}\text { iodocarpum, F. M. } & \ldots & \ldots & \ldots & 105\end{array}$ $\begin{array}{llll}\text { prismatothecum, F. M. ... } & \ldots & \ldots & 101\end{array}$ 
PI.1.

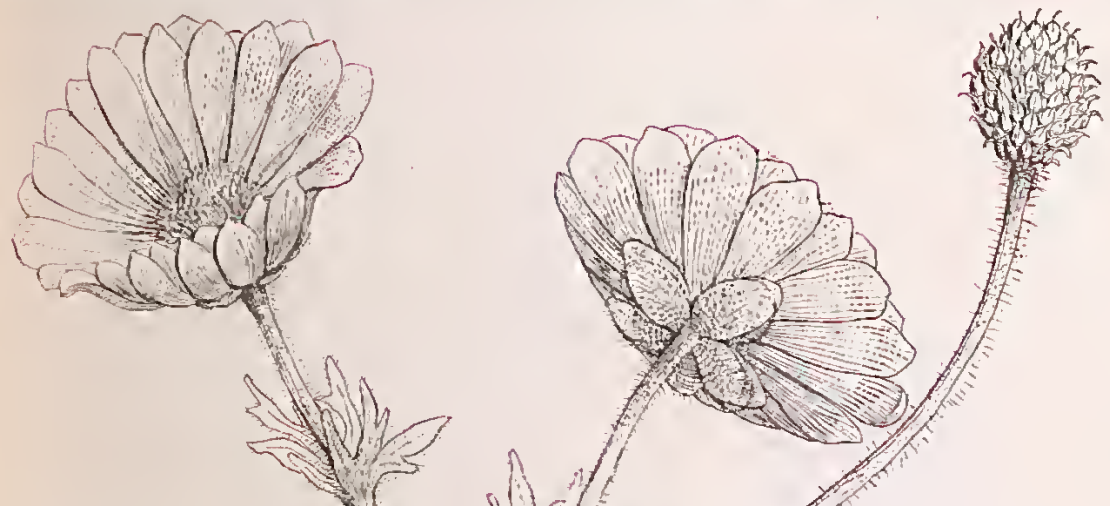

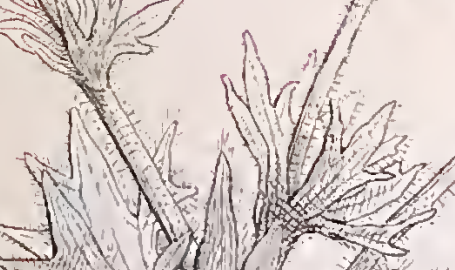
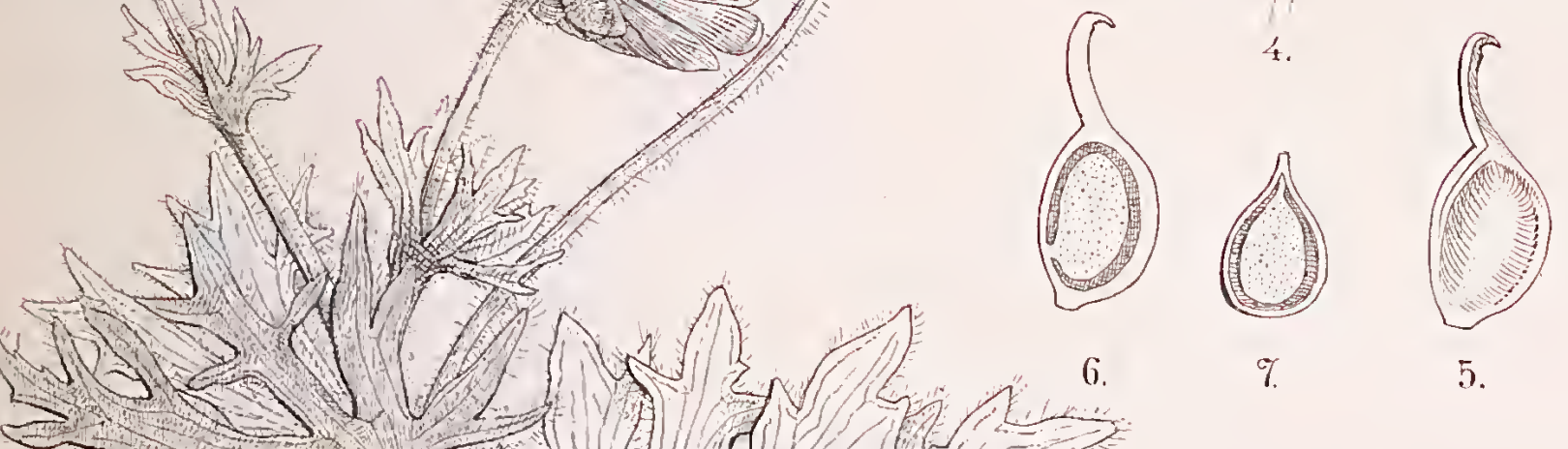

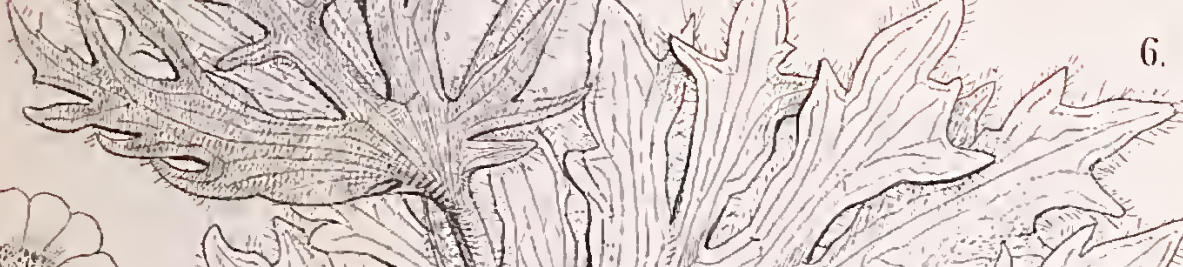

COS

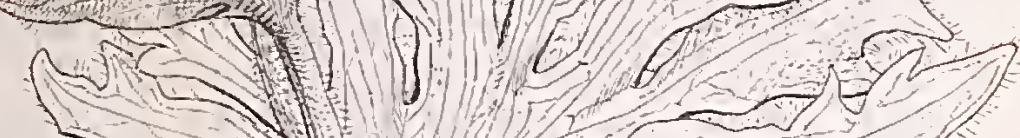

7

5.

sond num

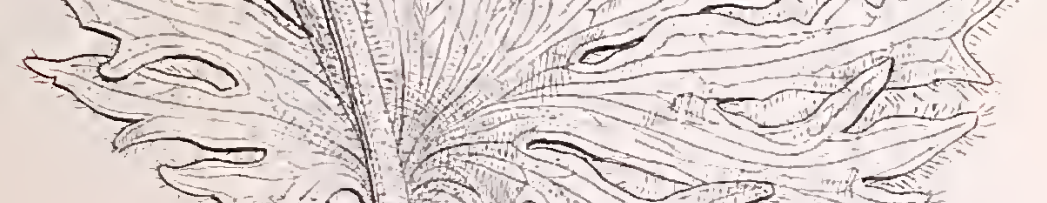

Hon
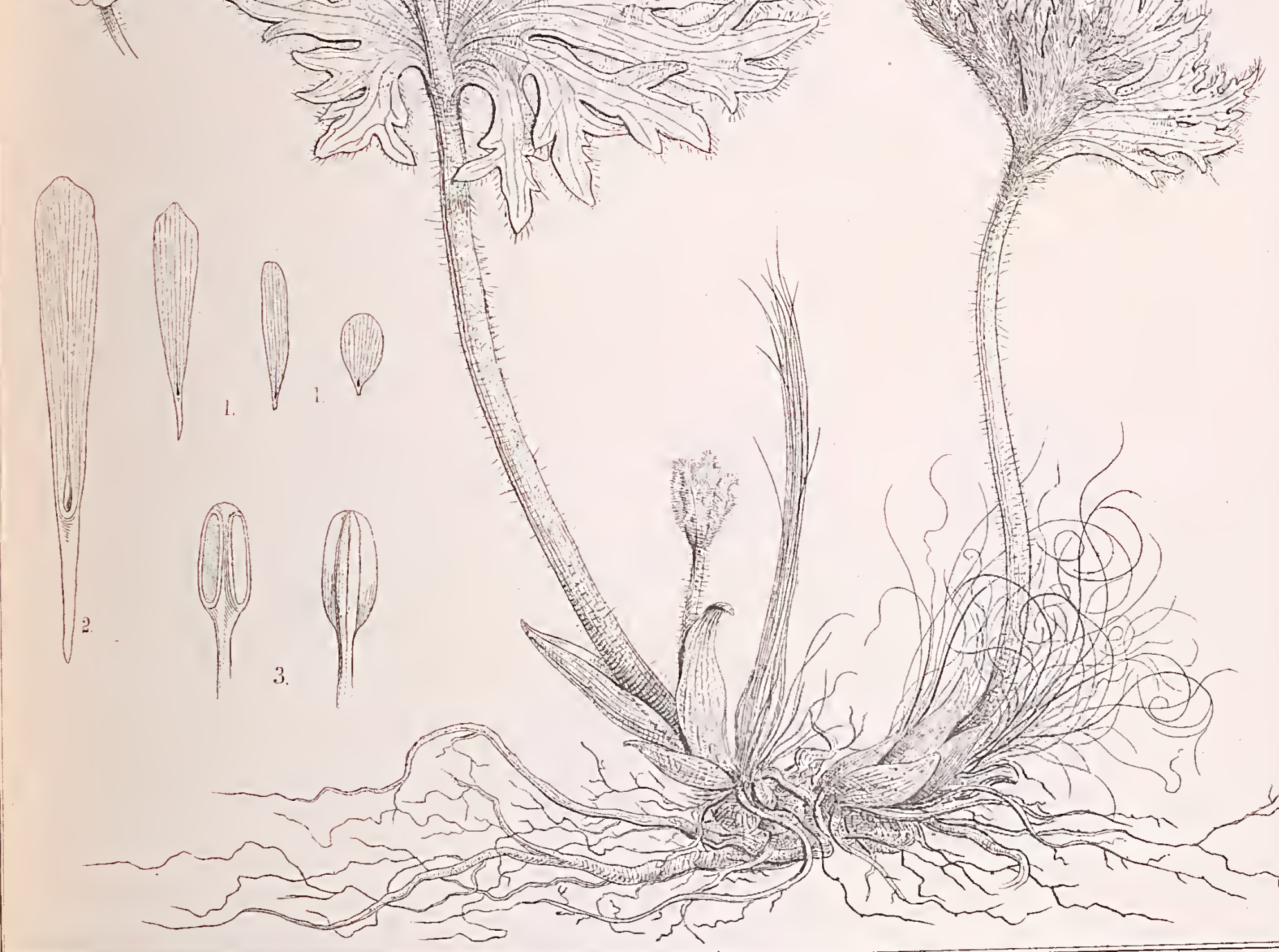



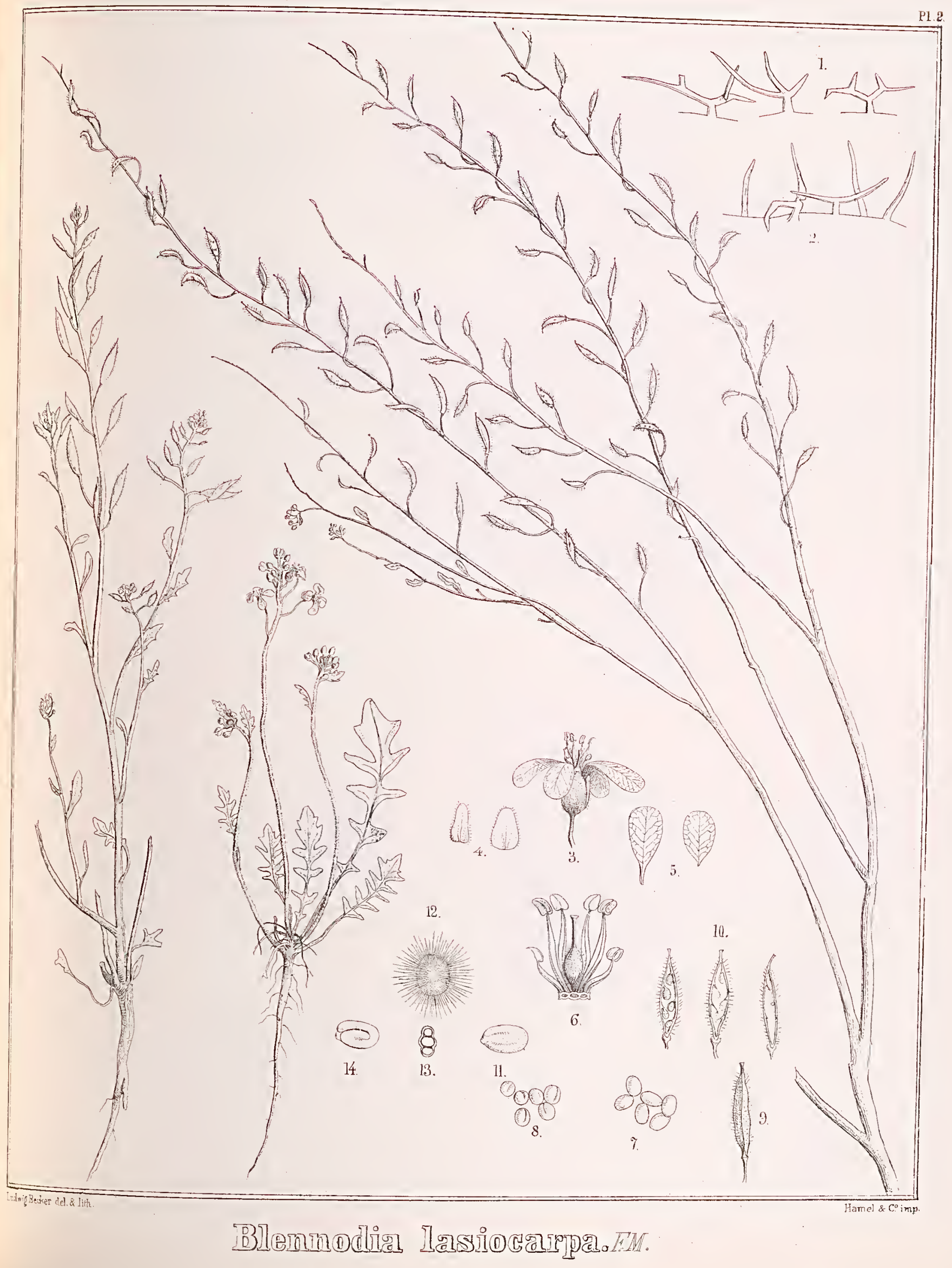





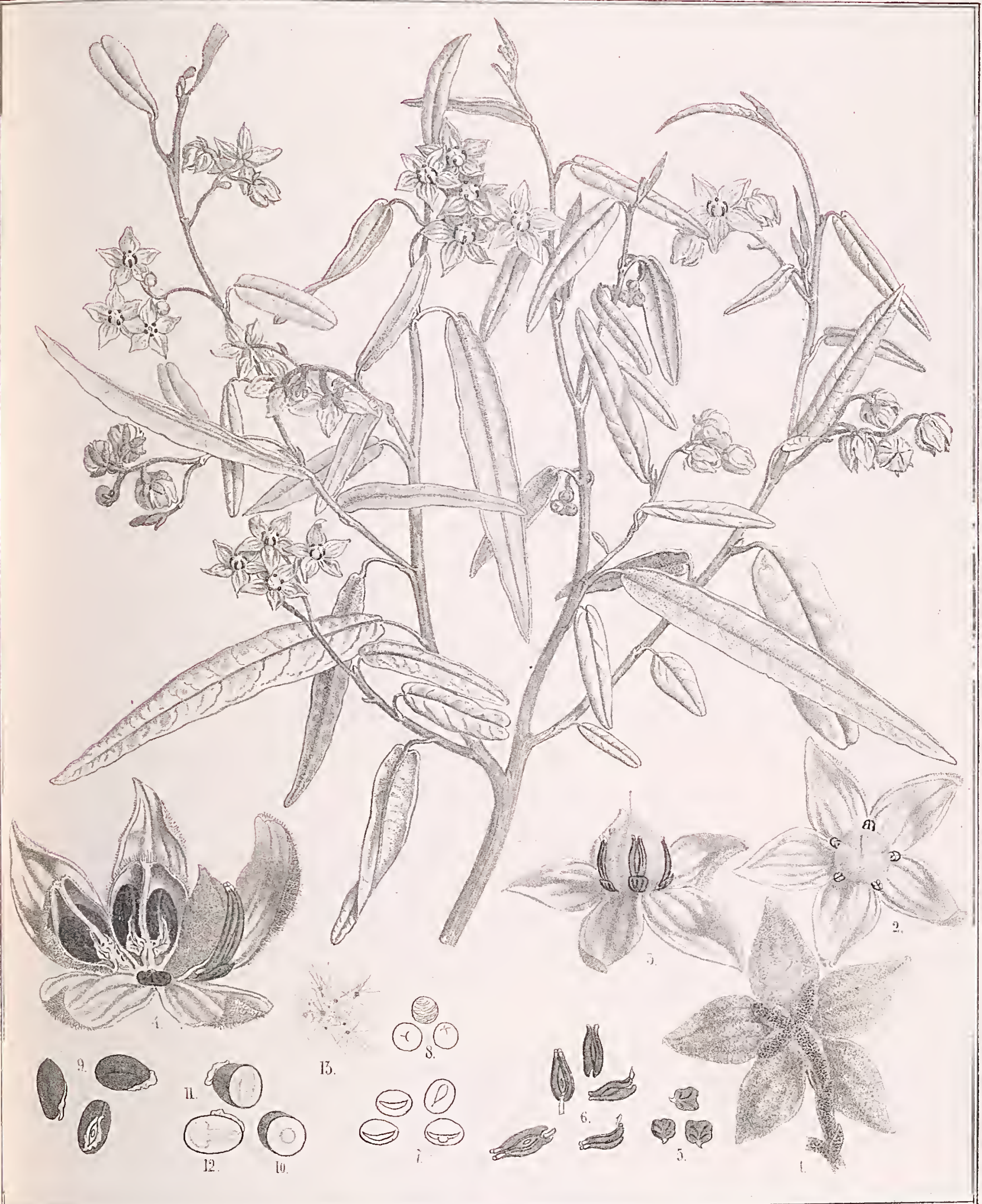






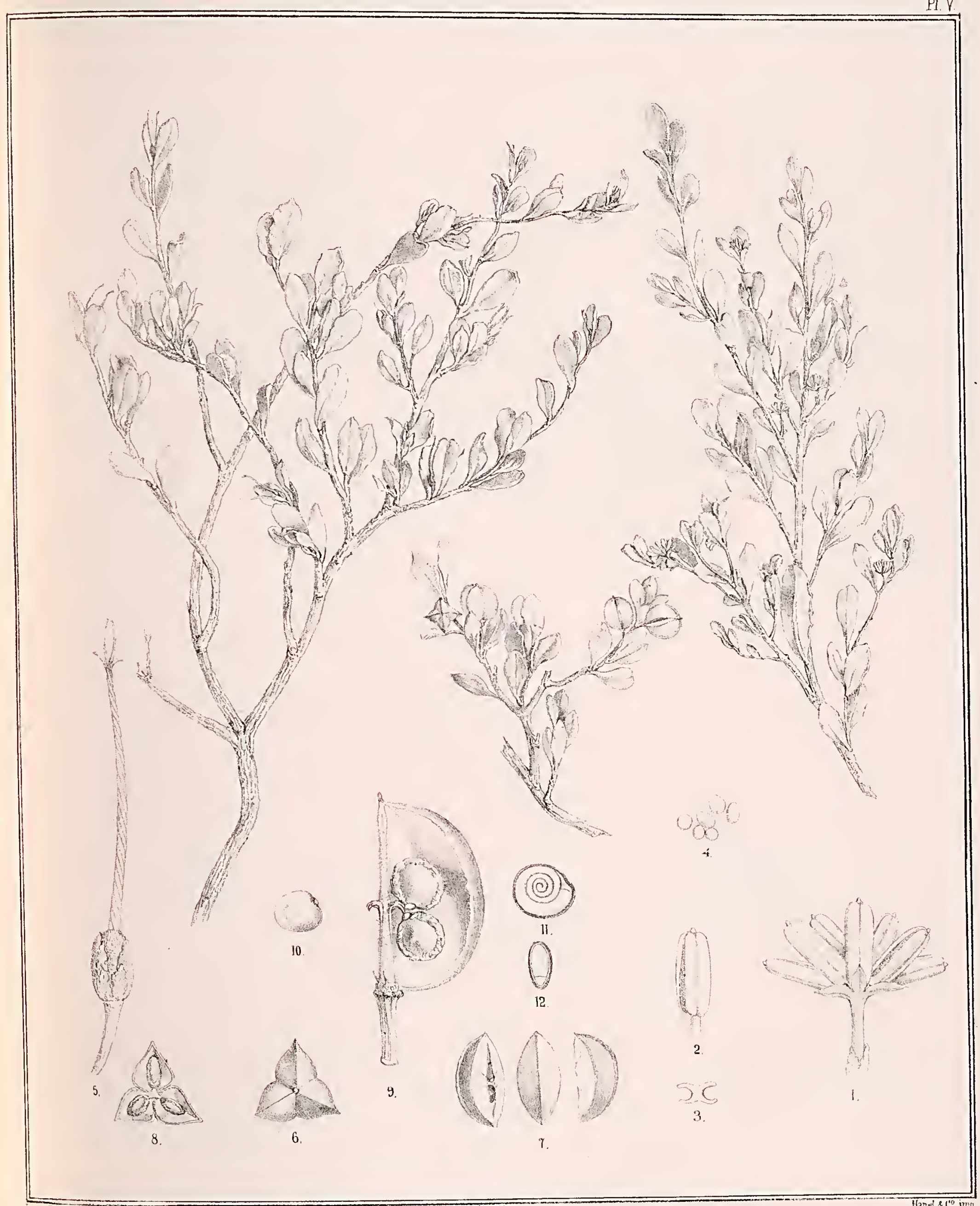

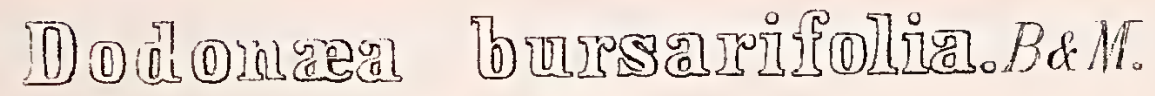





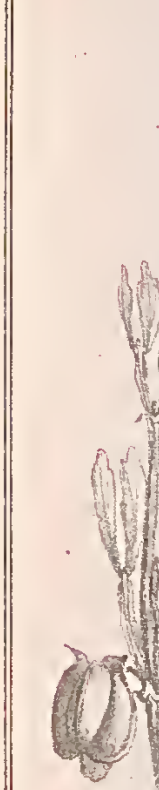

सin की

mingon $\quad 0$

Wo 10 Wh

(1)

Why

What

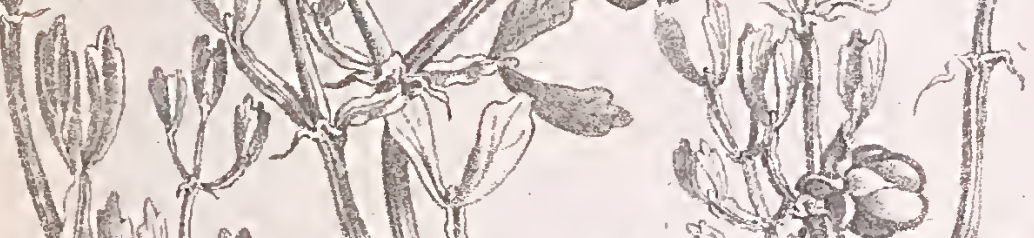

(1)
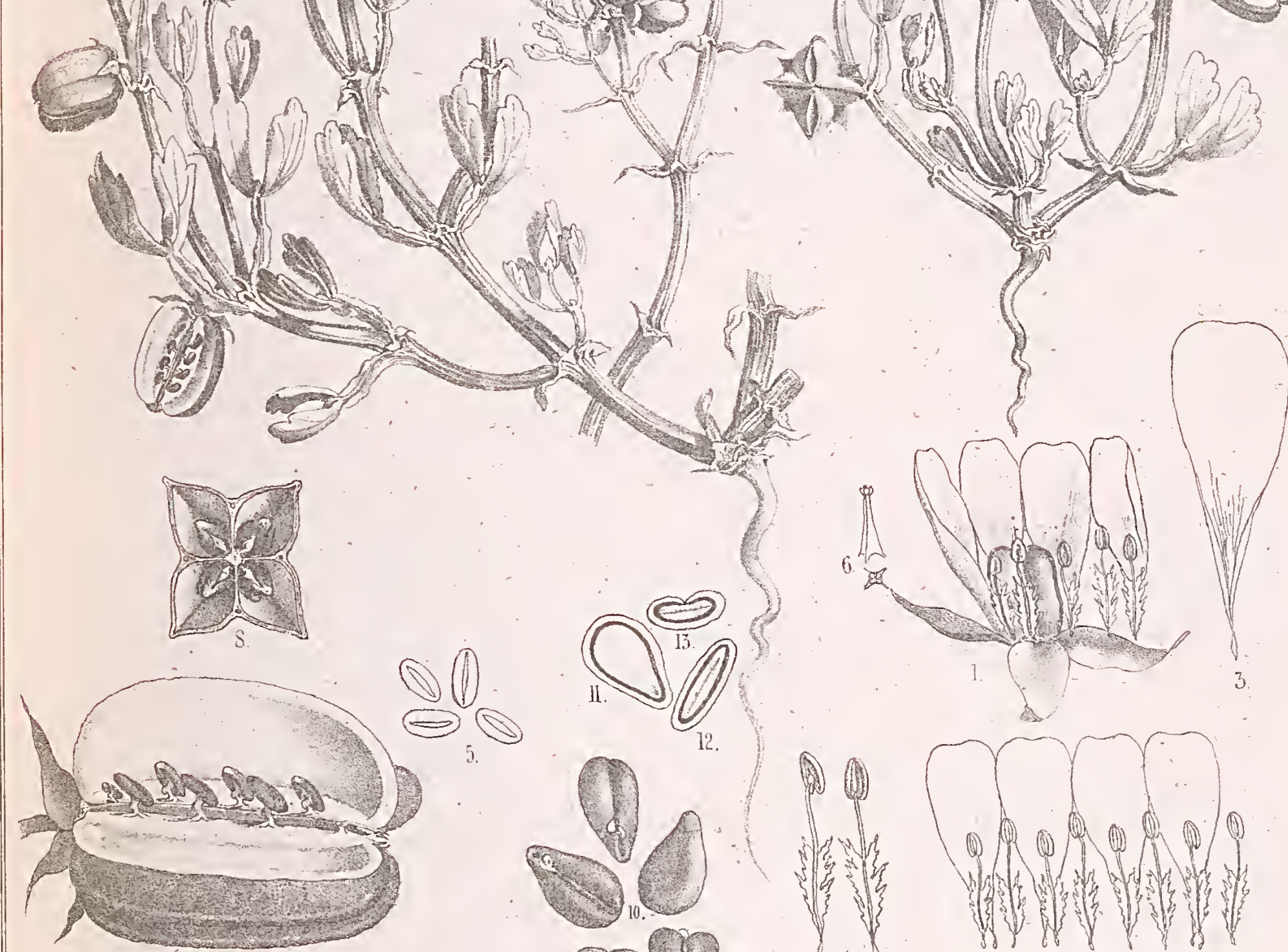

7

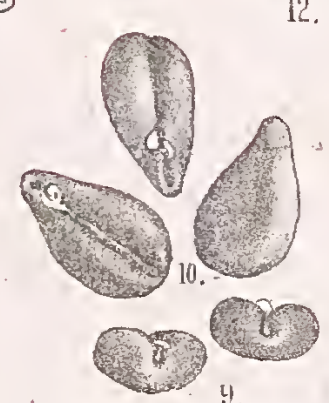

$\sqrt[3]{4}$
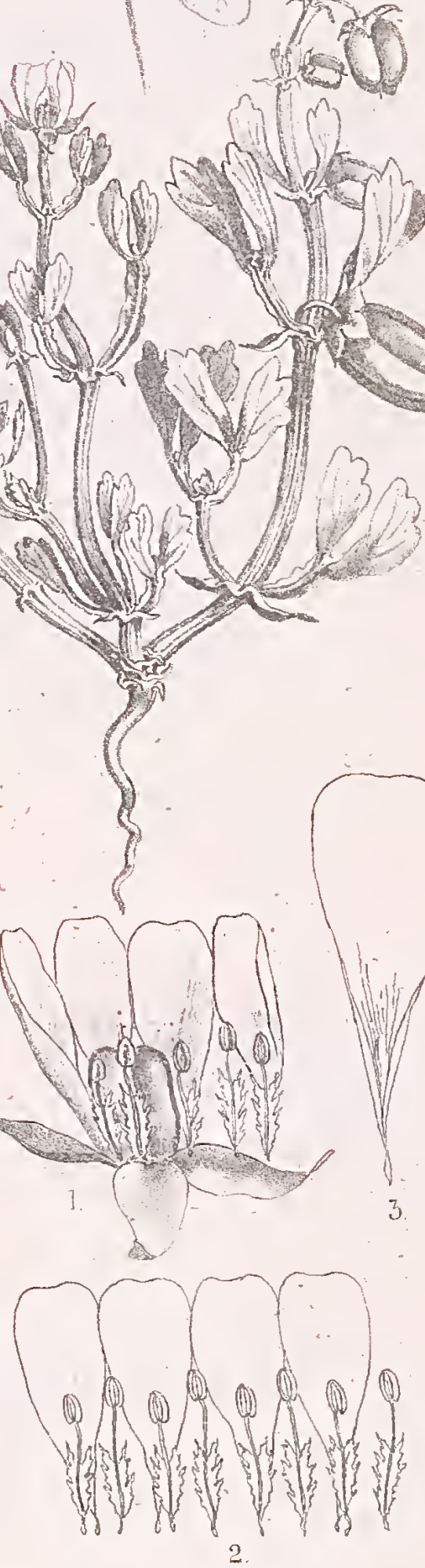
Hon 14

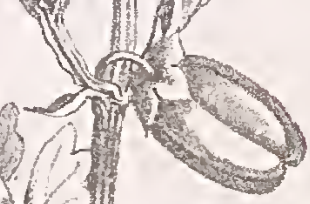
1) W $M$

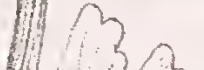




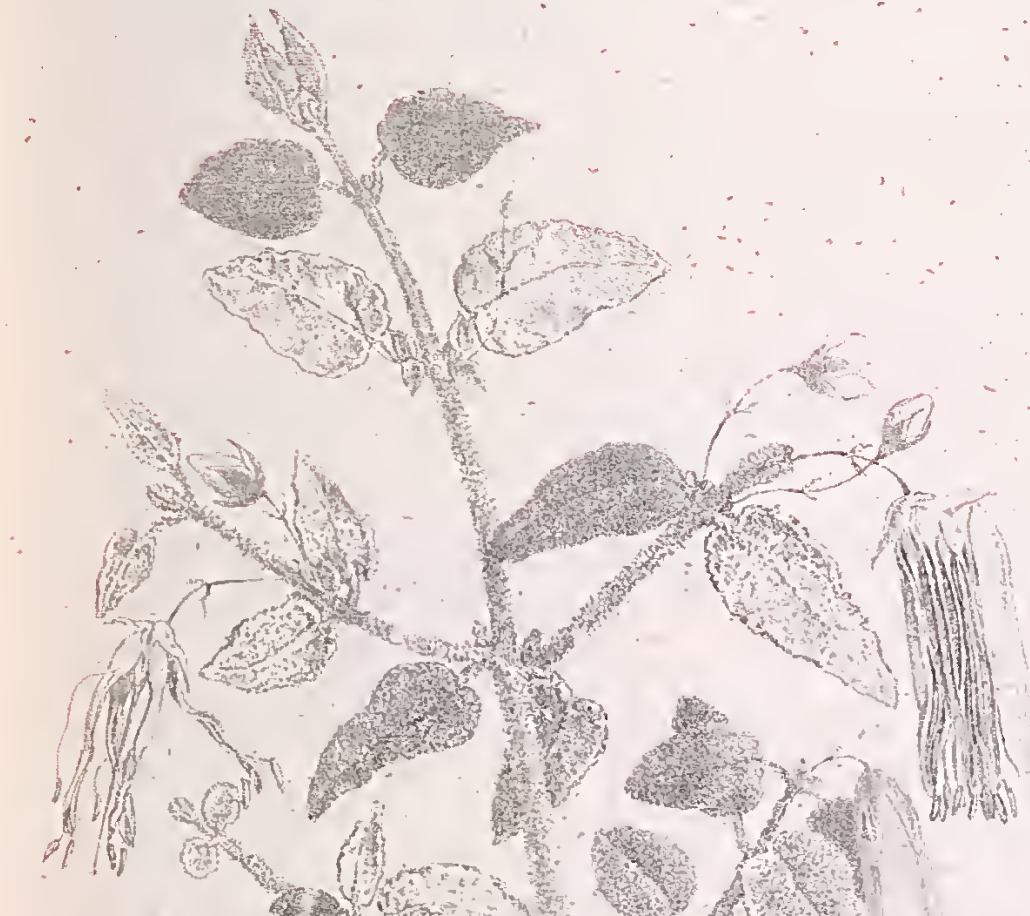


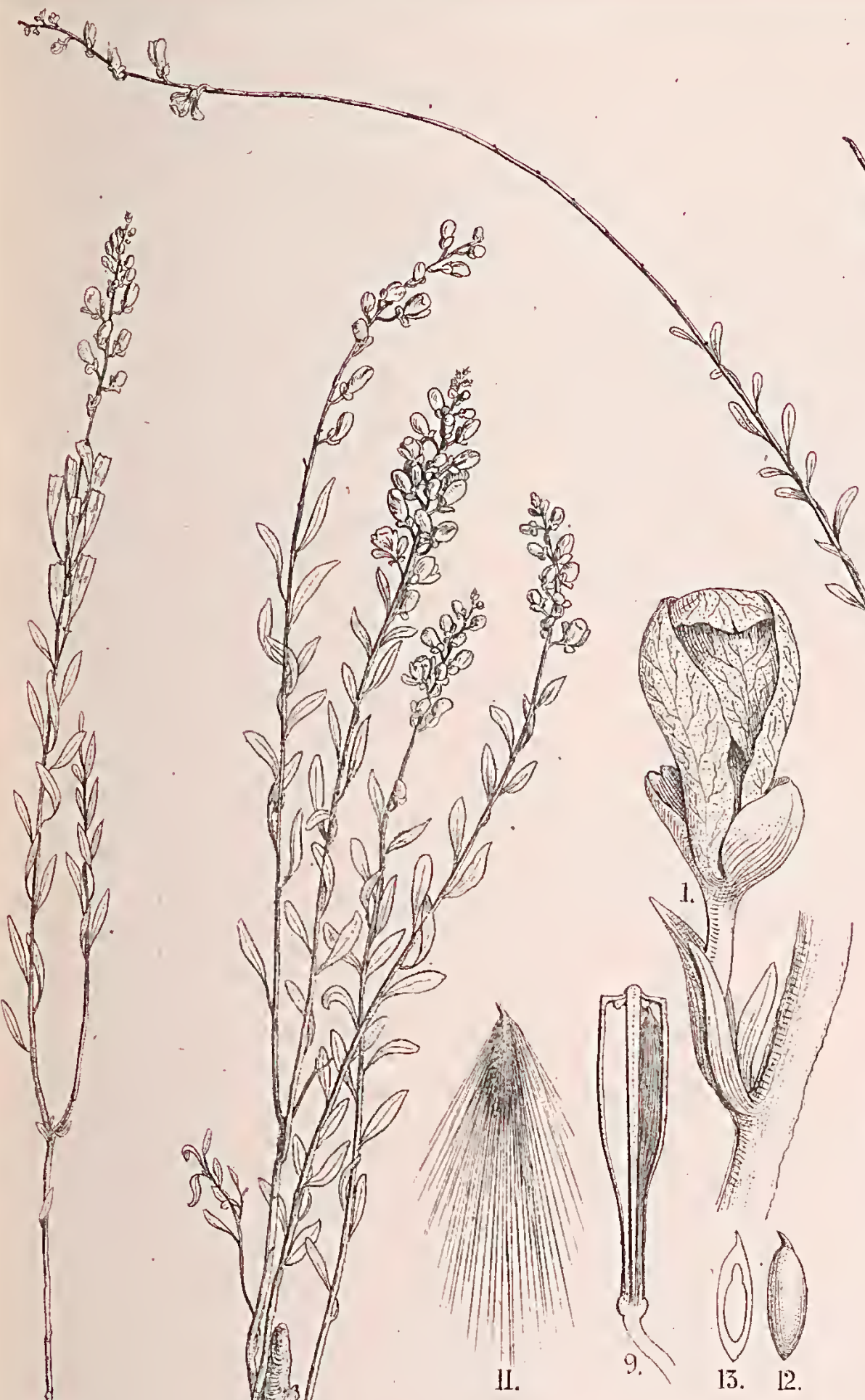

II.

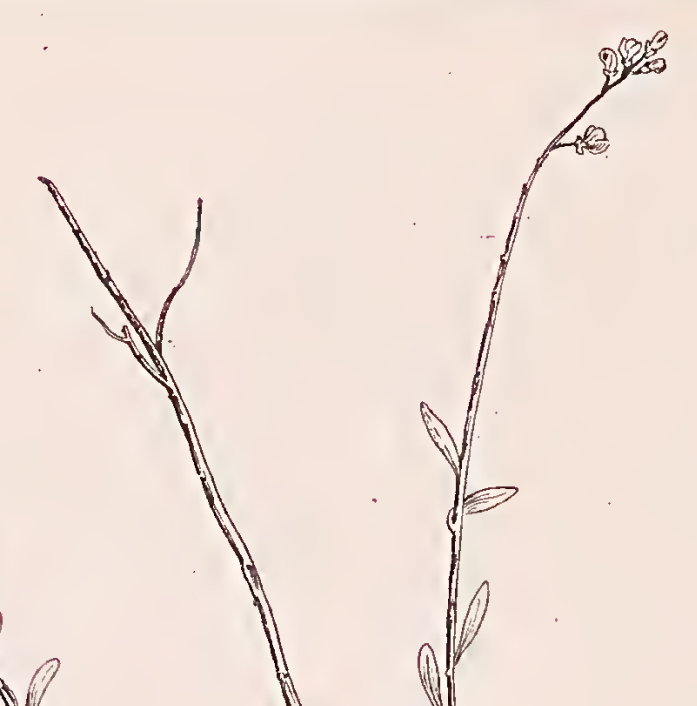





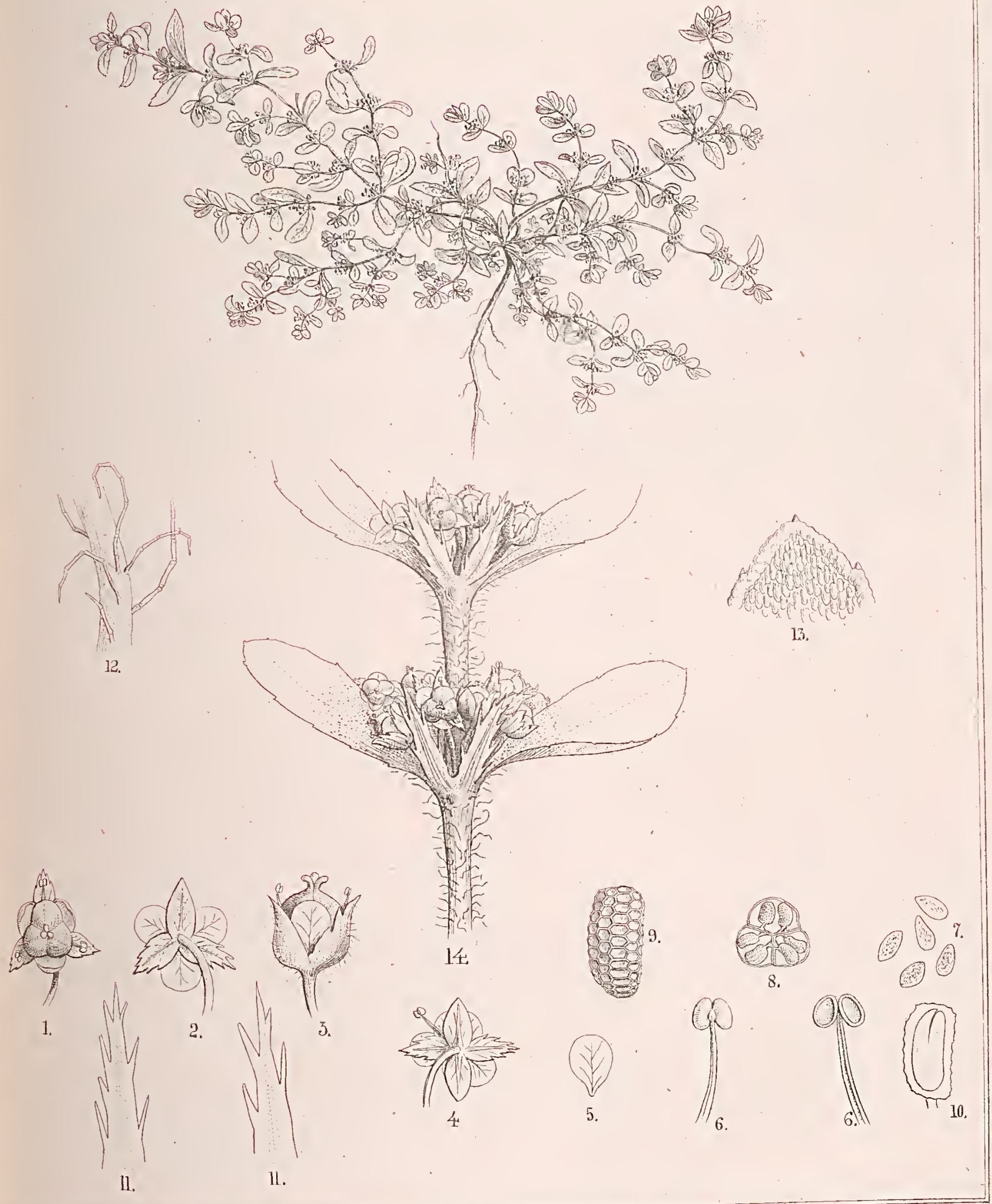

II.

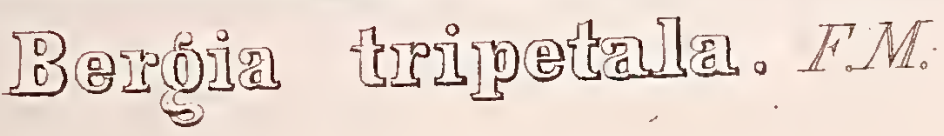



PIX

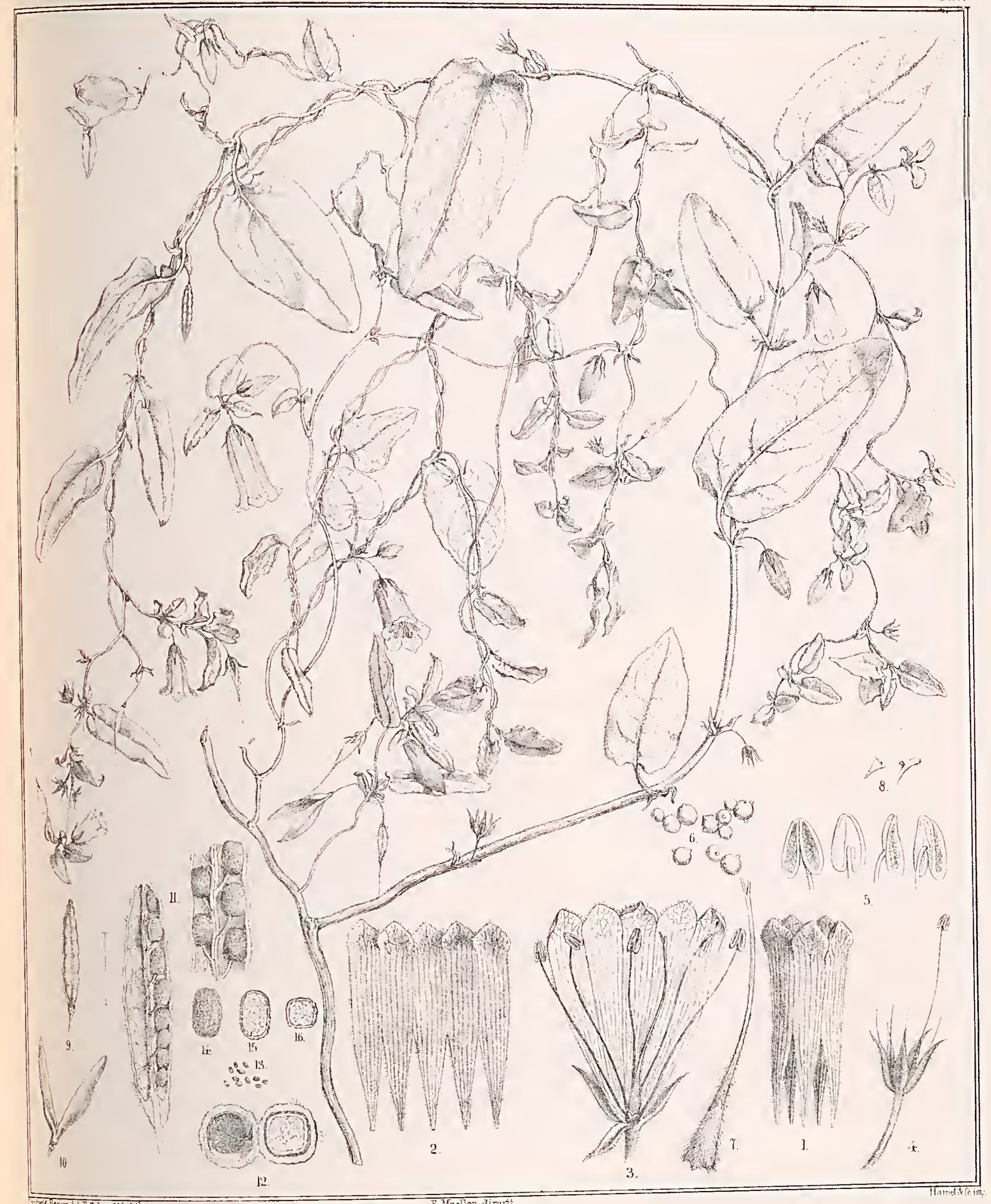

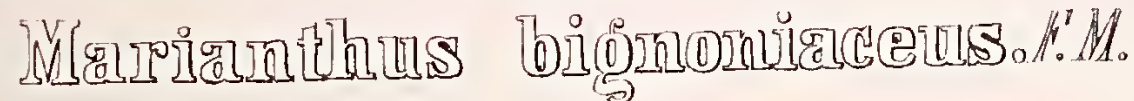




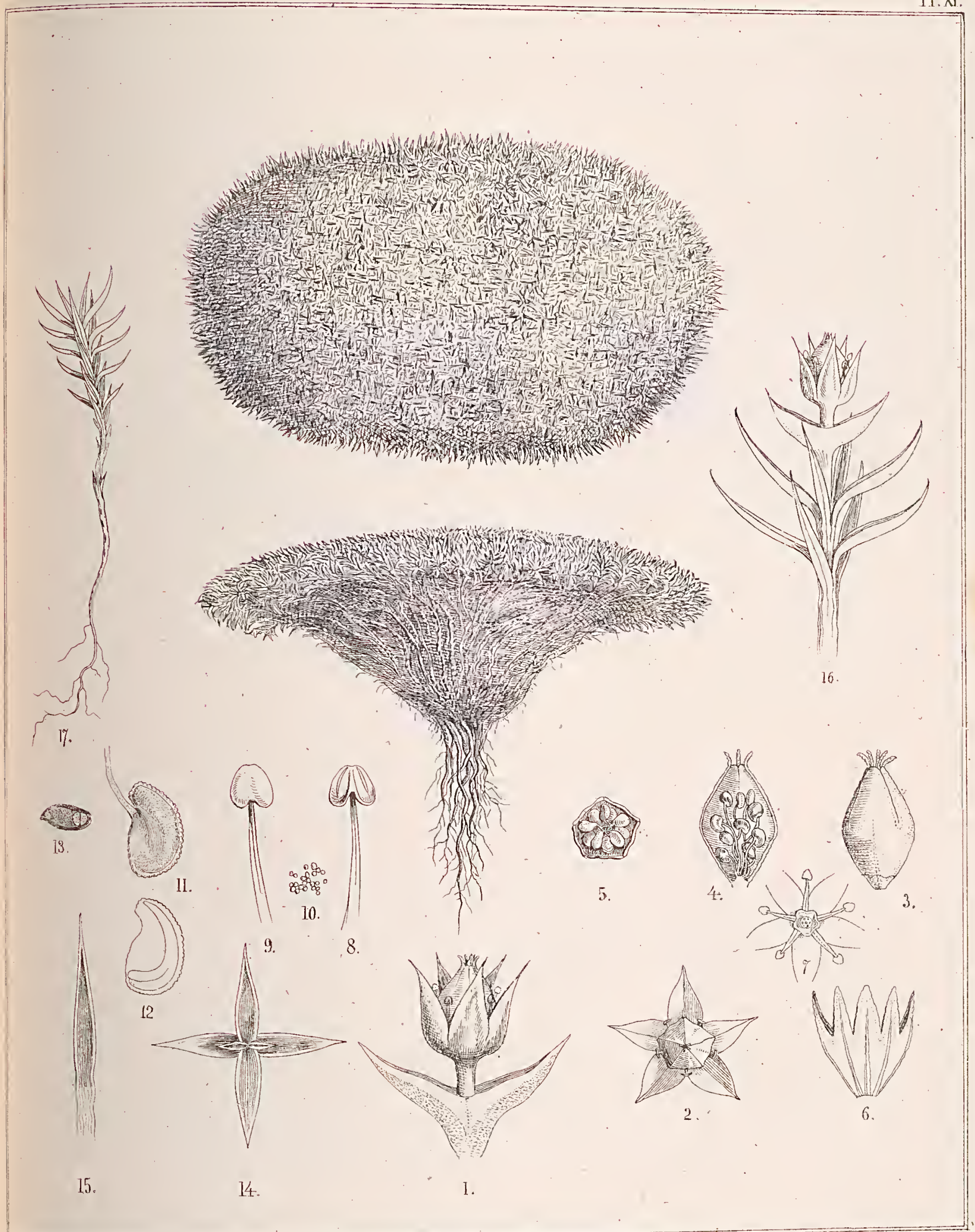

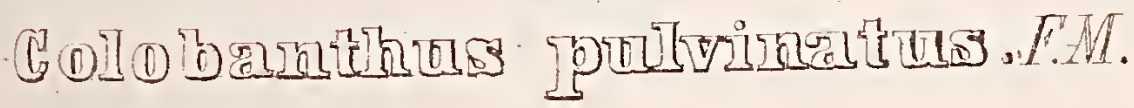



Plate XII

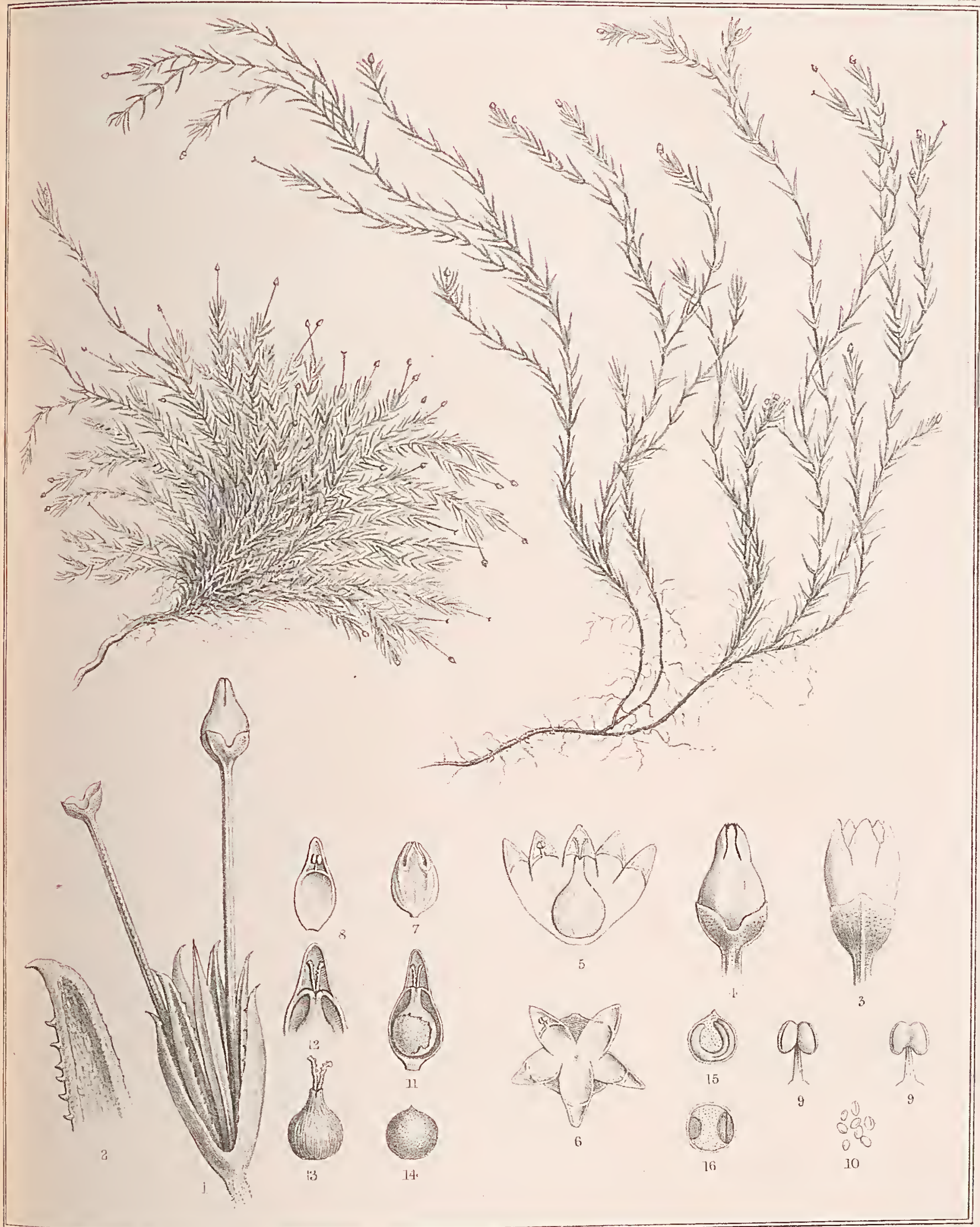

Inimig Decker, del s Iith

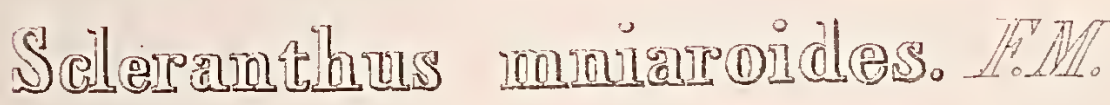





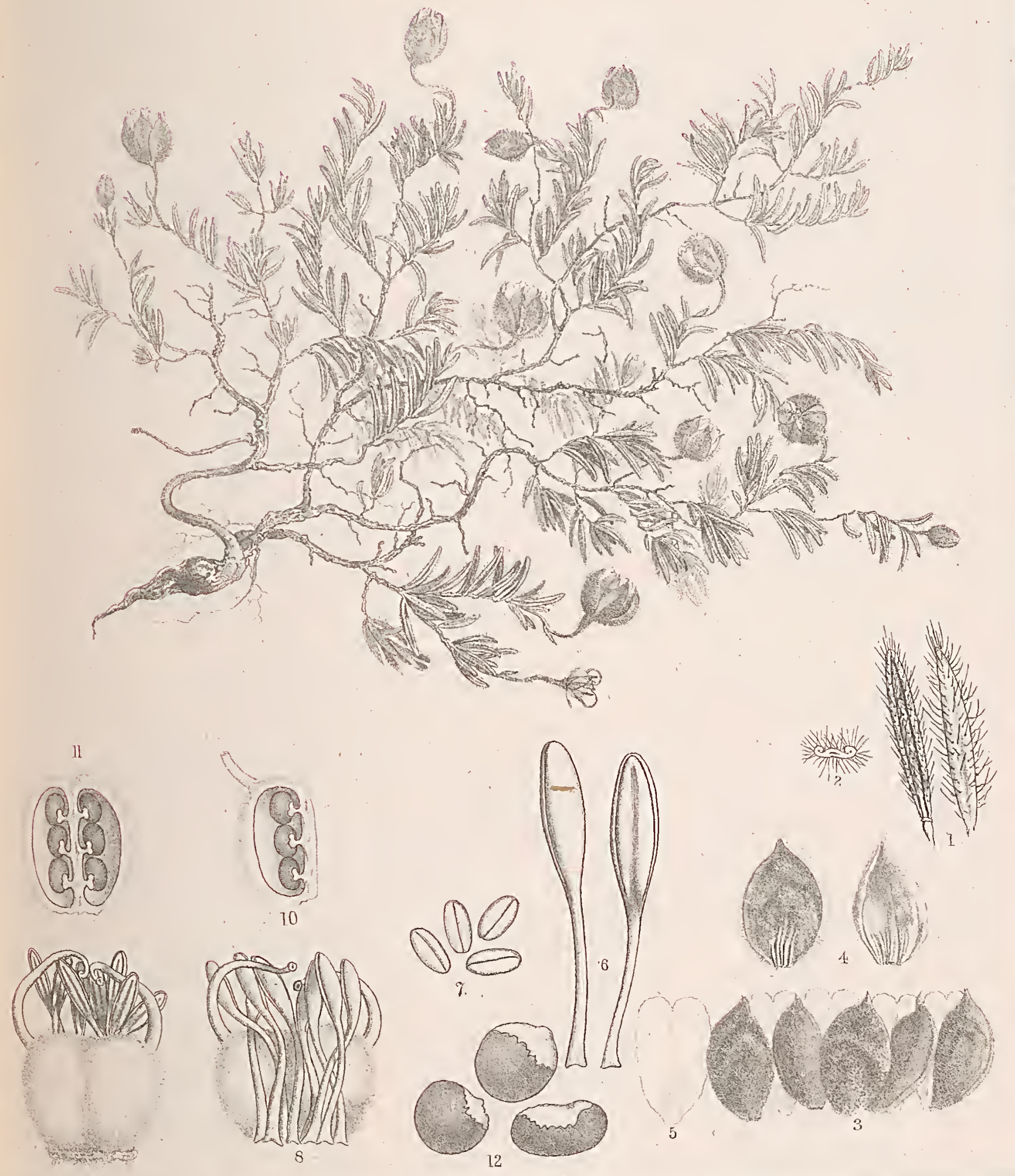




Supplentental PI. III.

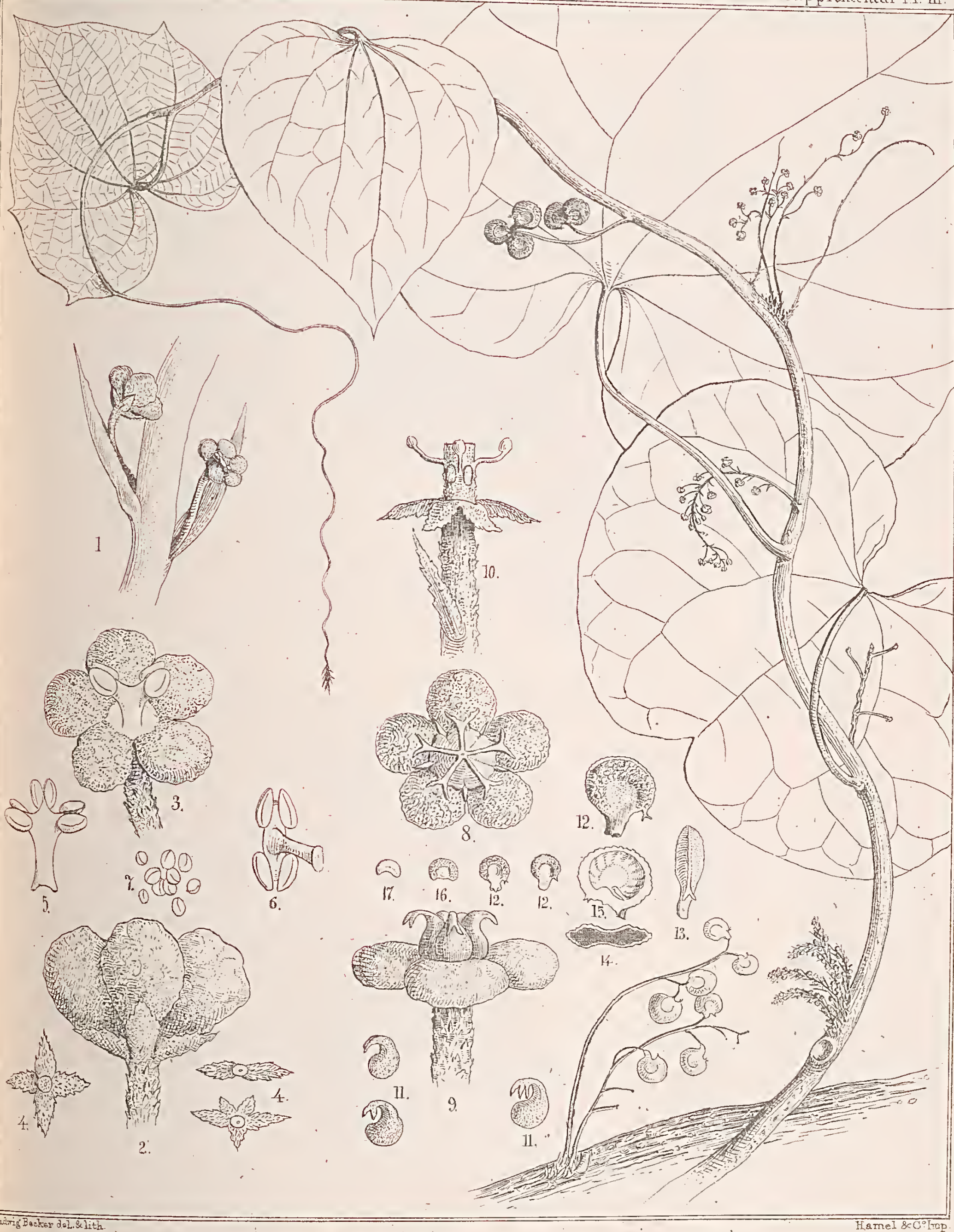

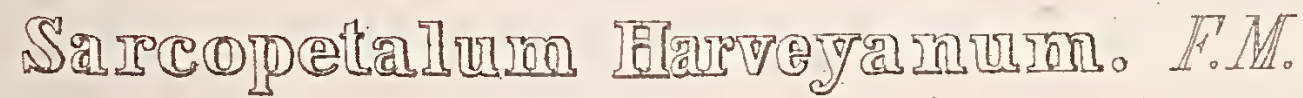


Suplemental Plate.V.



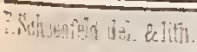

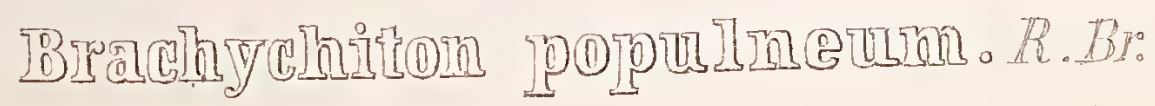





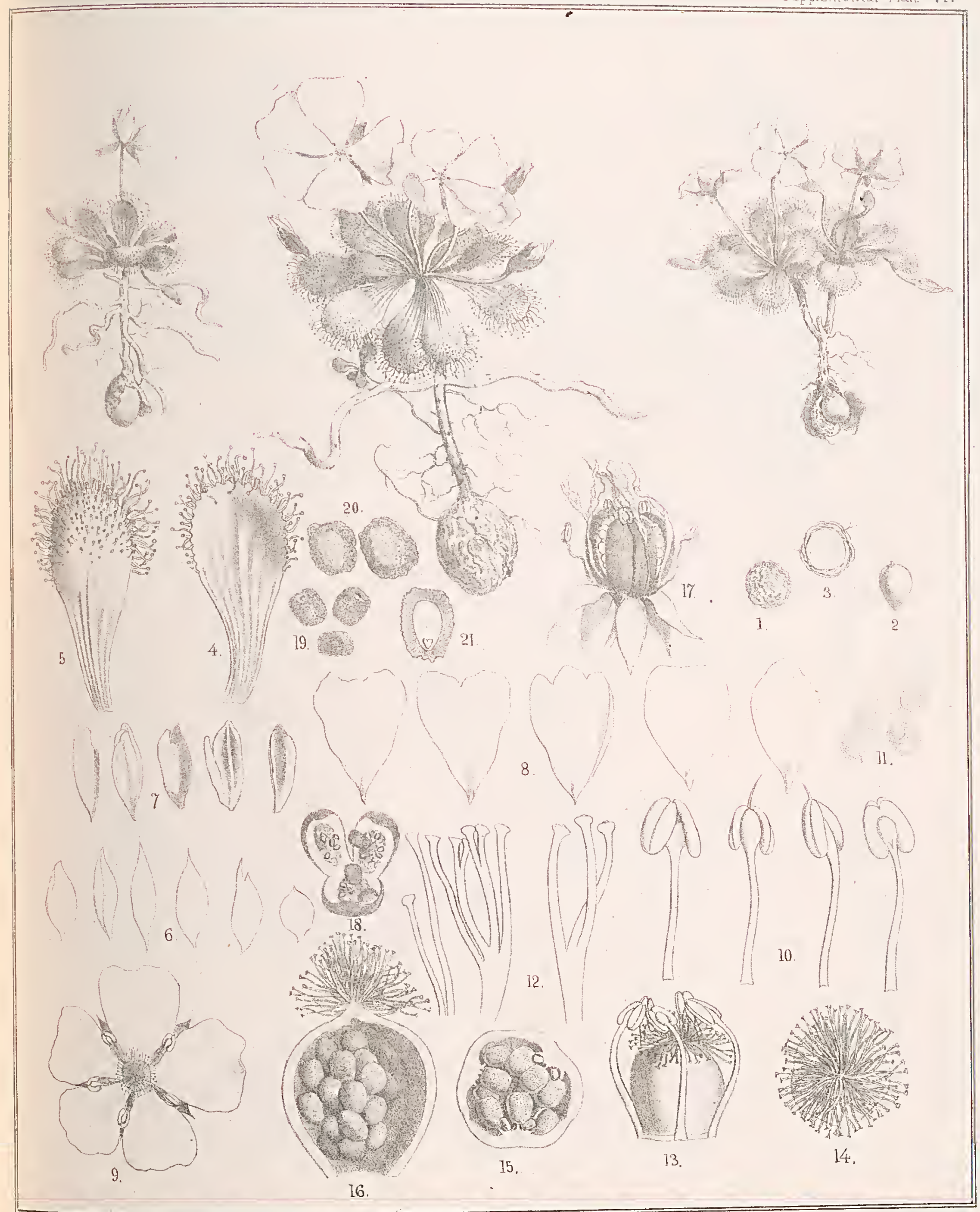

Fincrefeld del \& lith.

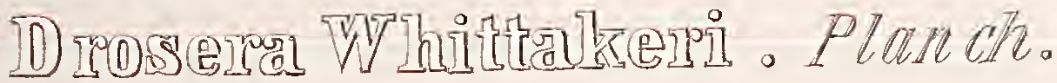





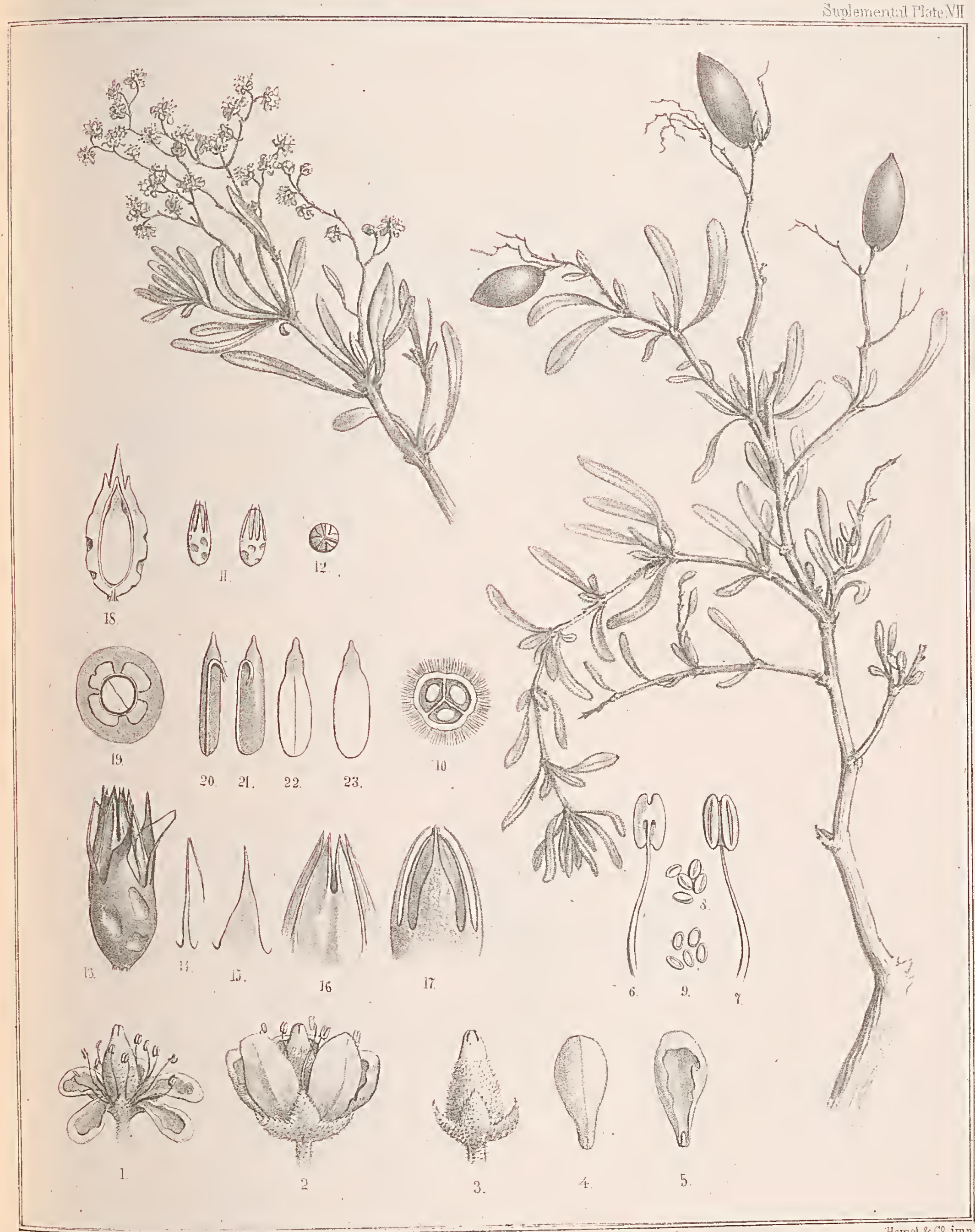

Hamel \& $C^{\circ} \mathrm{O}$ imp

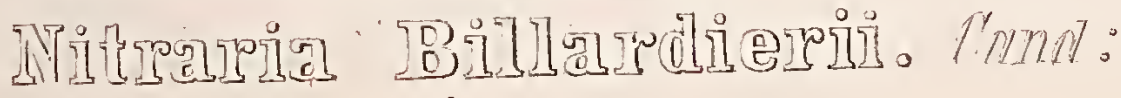





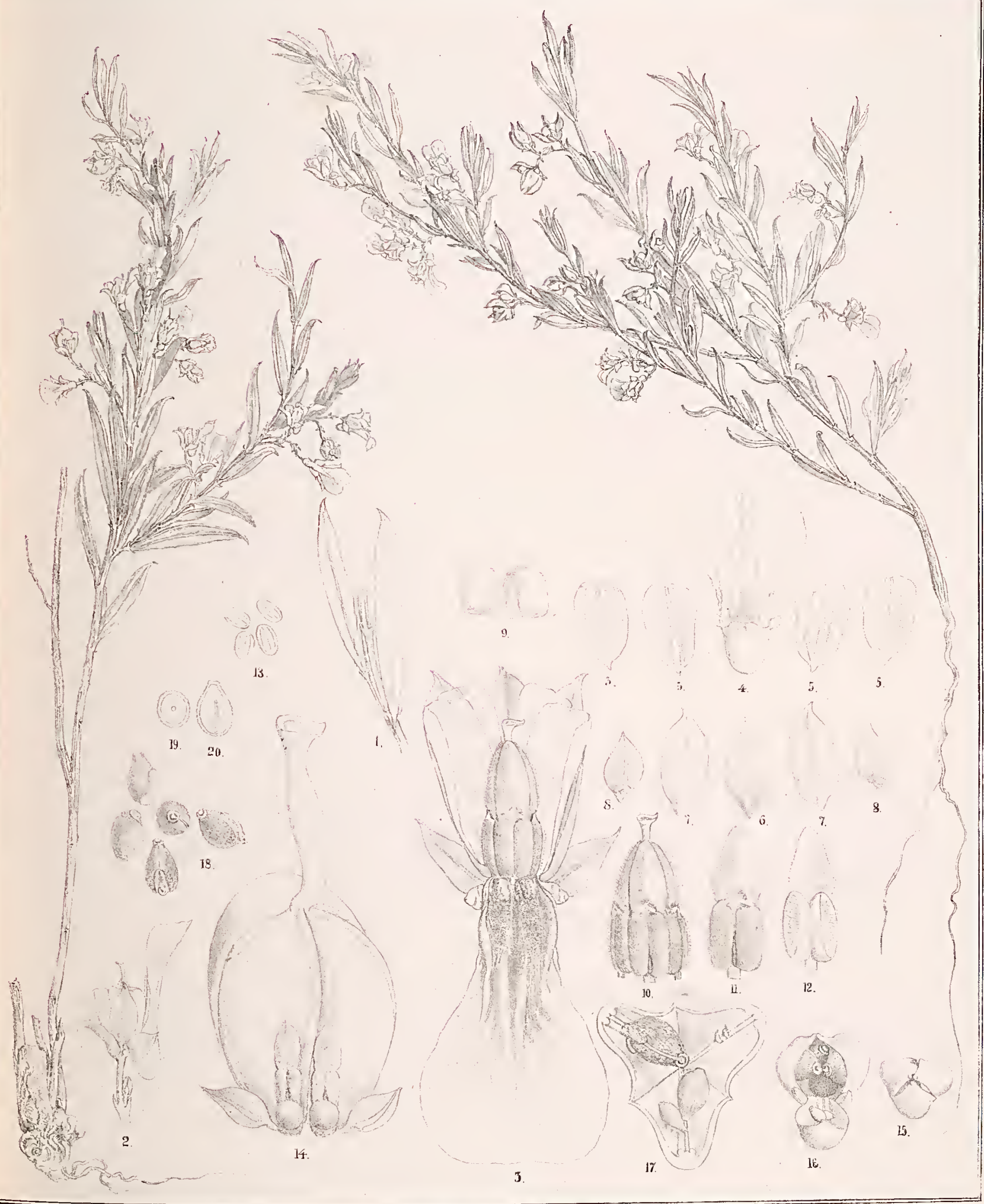





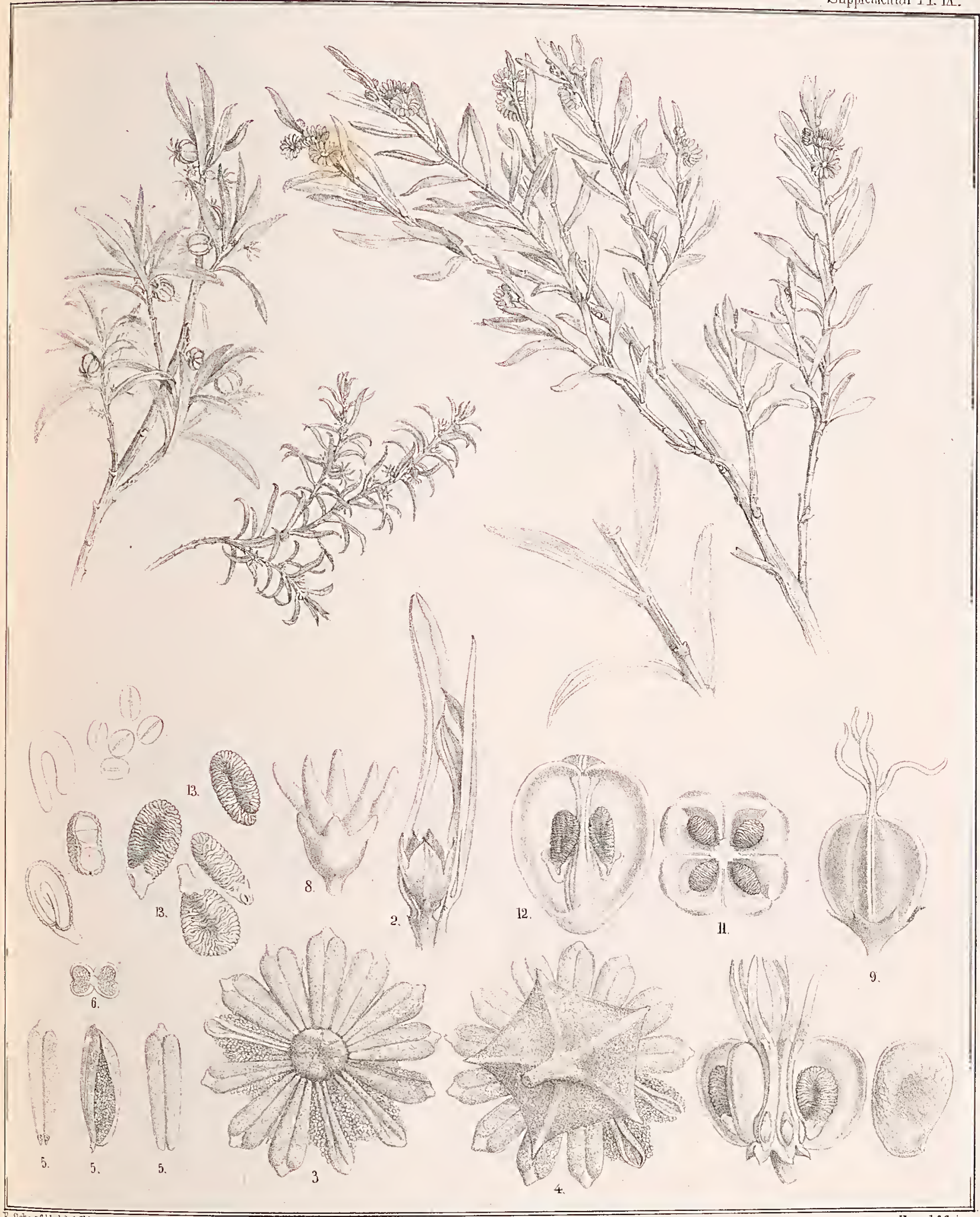

T. Mueller direx!

Hame? \& Co.im

(C) 


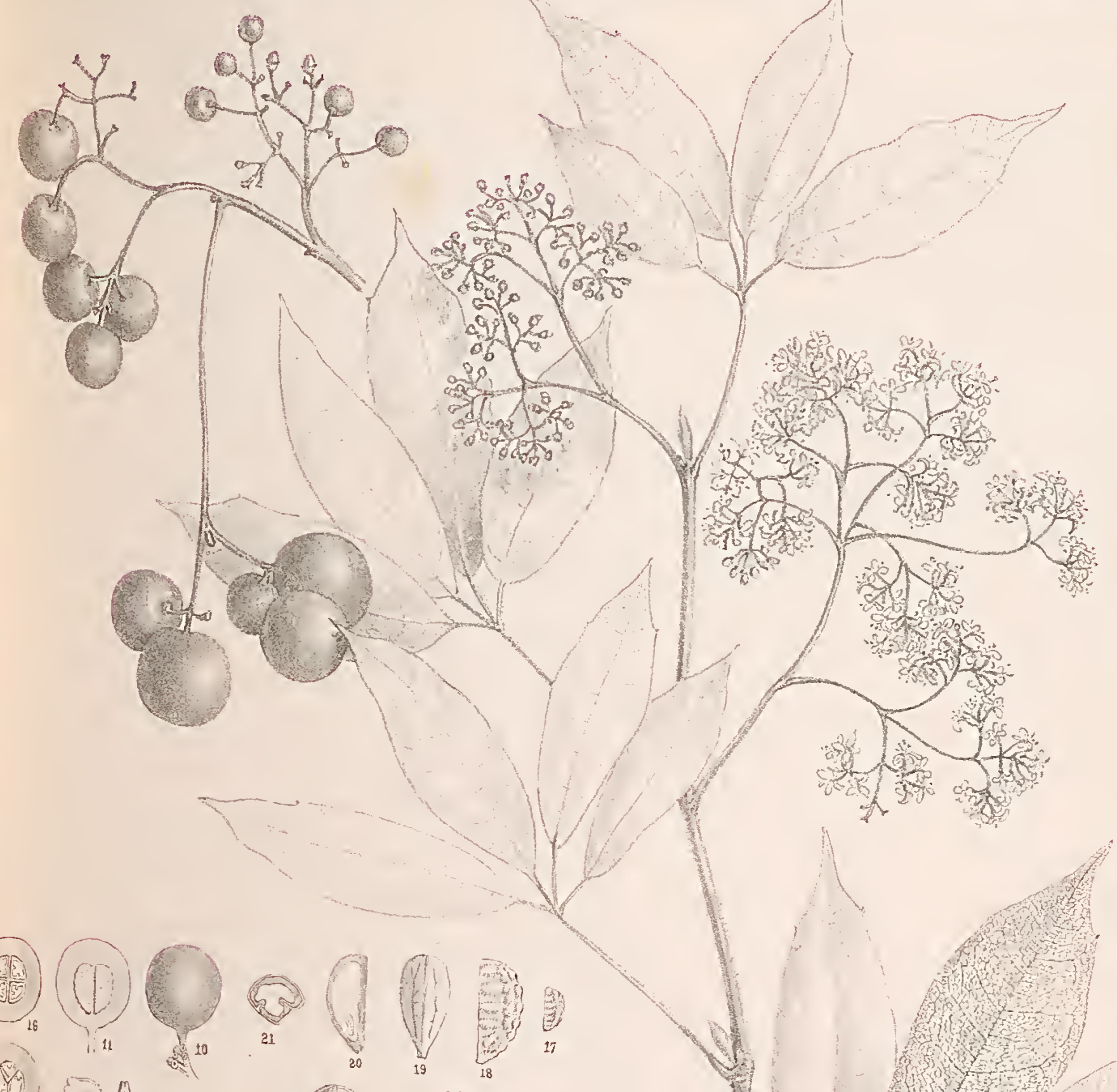

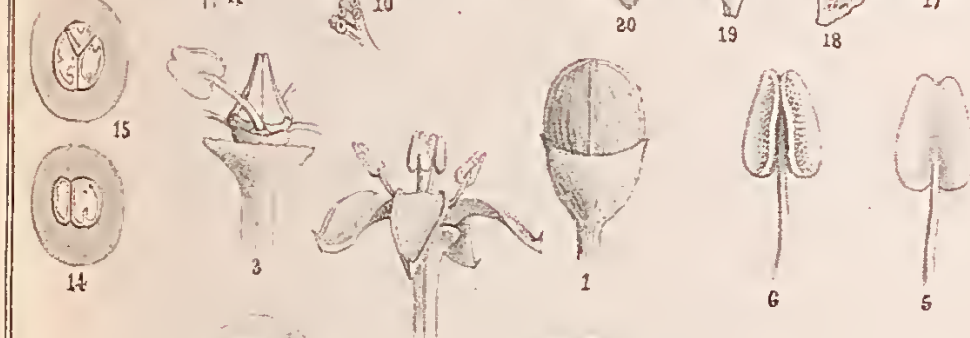
9 ?
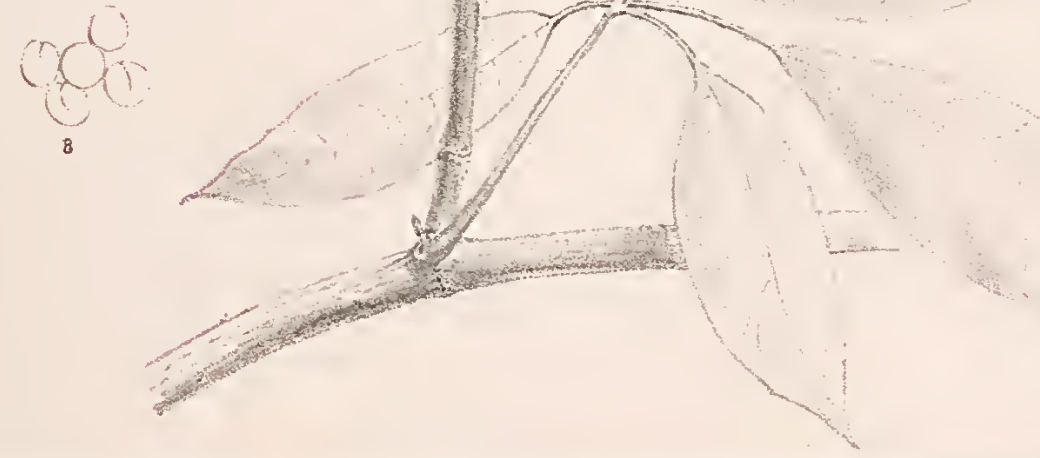

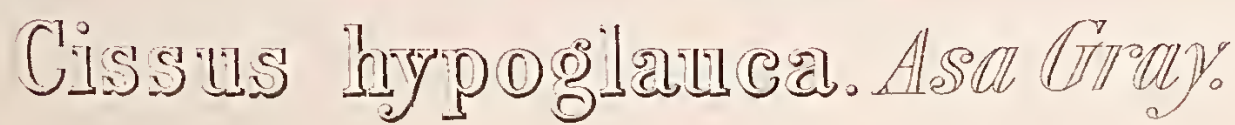





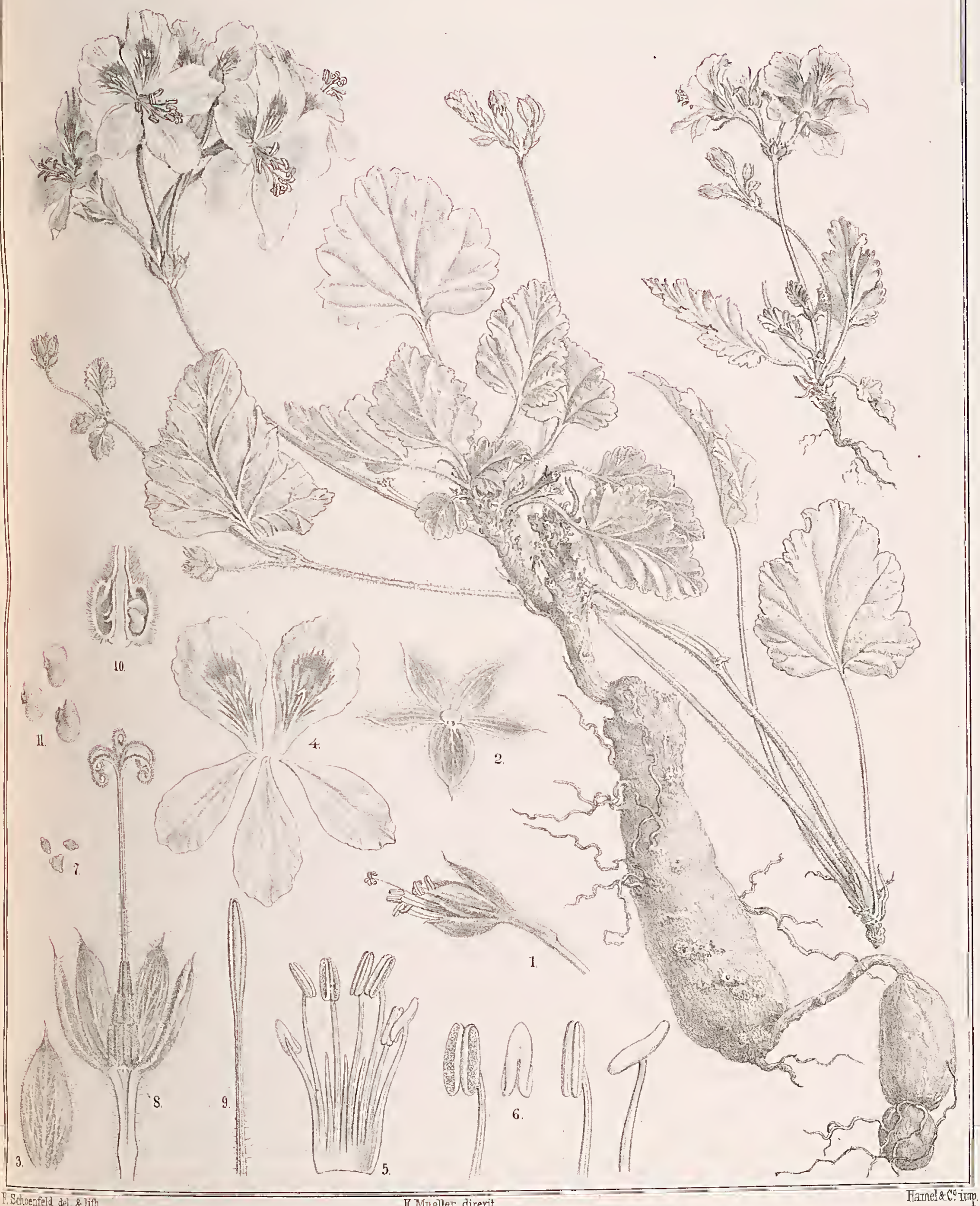

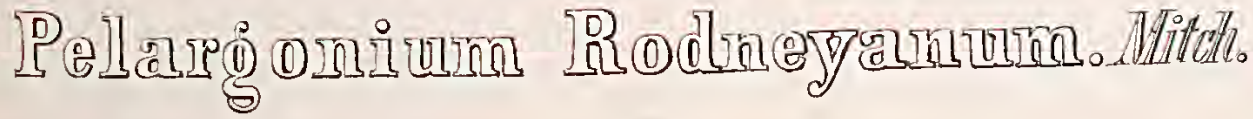




RARE BOOL

581.9945

$M \cdot 946 p$ 




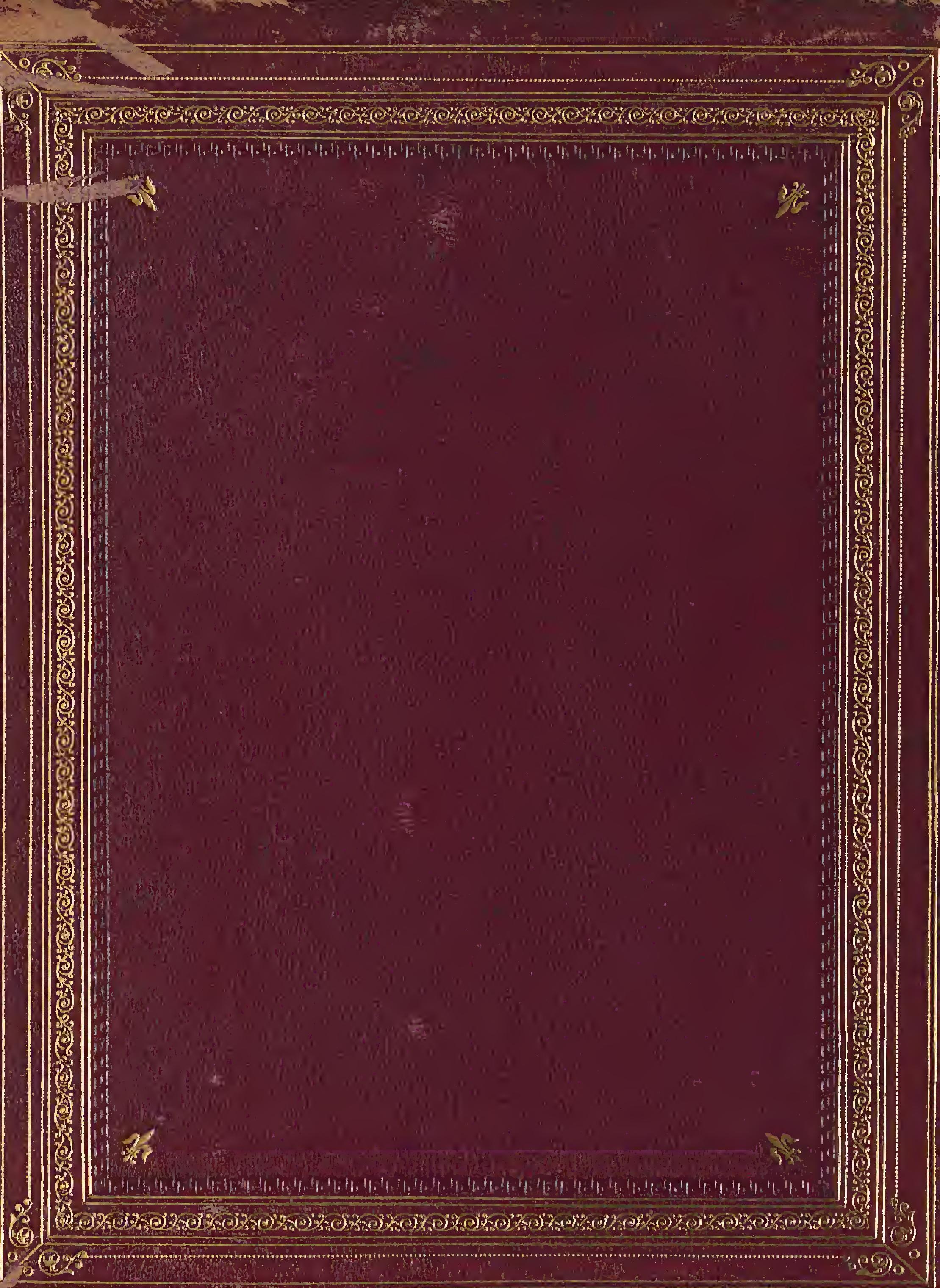

